\title{
Mississippi River and Tributaries Flowline Assessment Hydraulics Report
}

MRG\&P Report No. 24; Volume 3 • December 2018

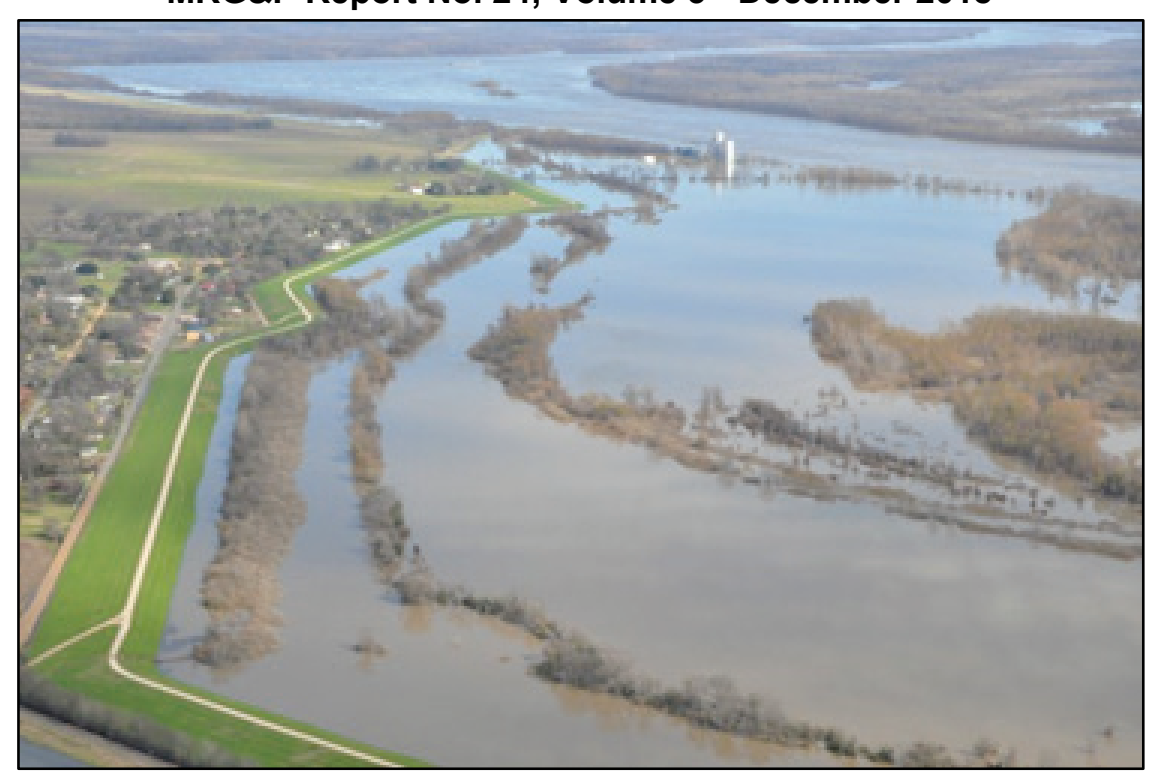

MRG\&P

Mississippi River Geomorphology \& Potamology Program 


\section{Mississippi River and Tributaries Flowline Assessment Hydraulics Report}

James Lewis

Coastal and Hydraulics Laboratory

U.S. Army Engineer Research and Development Center

3909 Halls Ferry Road

Vicksburg, MS 39180-6199

Edmund Howe

U.S. Army Engineer District, Little Rock

700 West Capitol Avenue

Little Rock, AR 72201-3221

Coral A. Cruz, Malcolm L. Dove, and Wesley A. Crosby

U.S. Army Engineer District, Vicksburg

4155 Clay Street

Vicksburg, MS 39183

Ron J. Taylor, David A. Ramirez, and Matthew S. Dircksen

U.S. Army Engineer District, New Orleans

7400 Leake Avenue

New Orleans, LA 70118

Robert Gambill

U.S. Army Engineer District, Memphis

167 North Main Street

Memphis, TN 38103-1894

Report 3 of a series

Approved for public release; distribution is unlimited.

Prepared for U.S. Army Corps of Engineers, Mississippi Valley Division 1400 Walnut Street

Vicksburg, MS 39180

Under Project 449963, “Mississippi River and Tributaries Flowline Assessment” 


\section{Abstract}

This report documents the development of the model for the Mississippi River and Tributaries Flowline Assessment using the Hydrologic Engineering Center - River Analysis System model (unsteady, version 5.0.1) completed by the U.S. Army Engineer District, Memphis; the U.S. Army Engineer District, Vicksburg; the U.S. Army Engineer District, New Orleans; and the U.S. Army Engineer Research and Development Center, Vicksburg, MS. The 2011 Mississippi River flood was chosen as the primary event for calibration, and the model performance was checked for 2002 and 2008, two other recent high-flow events. The model from this effort was used for two simulations of historic project design flows (PDFs), here labeled "Historic PDF - Existing Yazoo" and "Historic PDF - Authorized Yazoo." The combined model was also used for 10 new hypothetical project design flows. Additionally, the model was used for one alternative scenario, labeled "Concept Plan." Future sea level rise was also implemented with the Concept Plan and the New Hypo 58A-R PDF simulations.

DISCLAIMER: The contents of this report are not to be used for advertising, publication, or promotional purposes. Citation of trade names does not constitute an official endorsement or approval of the use of such commercial products. All product names and trademarks cited are the property of their respective owners. The findings of this report are not to be construed as an official Department of the Army position unless so designated by other authorized documents. DESTROY THIS REPORT WHEN NO LONGER NEEDED. DO NOT RETURN IT TO THE ORIGINATOR. 


\section{Contents}

Abstract....................................................................................................................................... if

Figures and Tables....................................................................................................................................

Preface .............................................................................................................................................. xili

Unit Conversion Factors.................................................................................................................. xiv

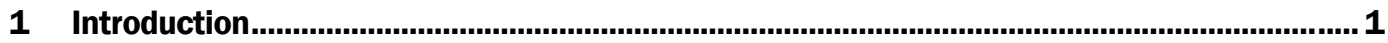

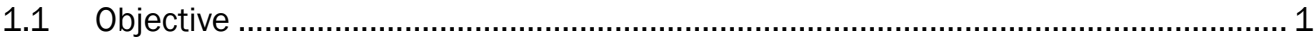

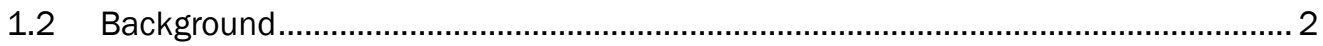

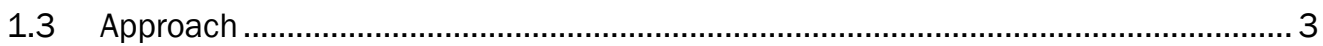

2 Model Development and Validation .................................................................................... 4

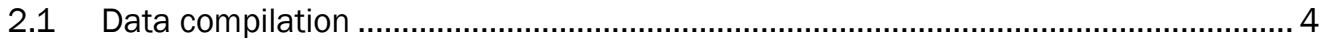

2.2 Model setup and calibration ............................................................................. 5

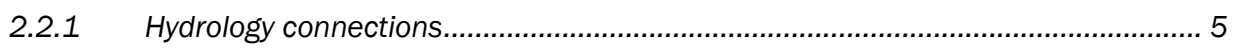

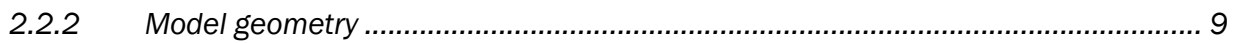

2.3 Model combination............................................................................................ 15

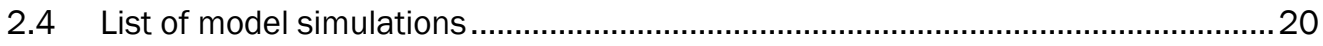

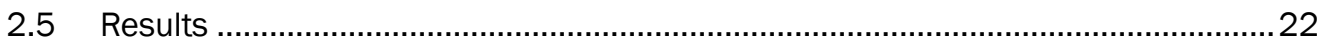

3 Simulations Using the 1955 Historical Project Design Flood (PDF) Flows........................30

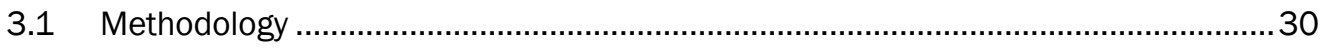

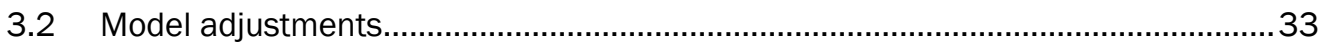

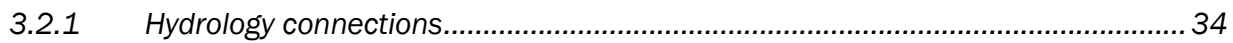

3.2.2 Merriwether-Cherokee Levee and Sheep's Ridge road elevations

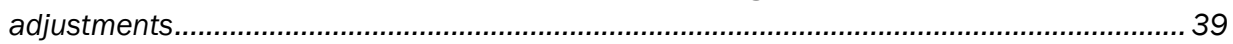

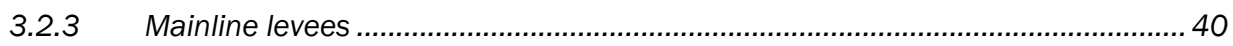

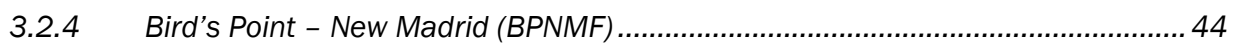

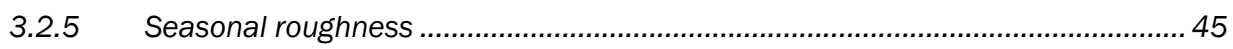

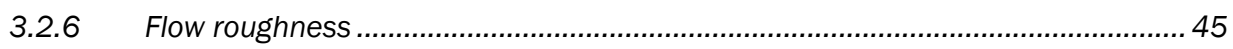

3.2.7 Yazoo Backwater Levee........................................................................................ 46

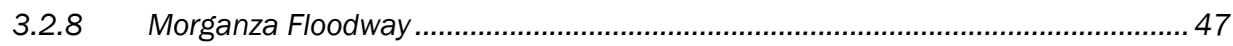

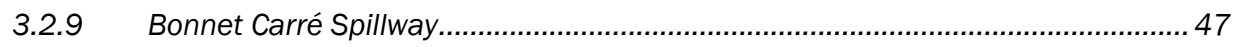

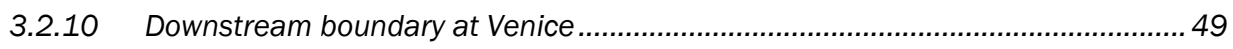

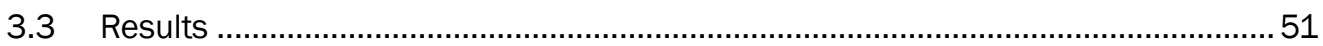

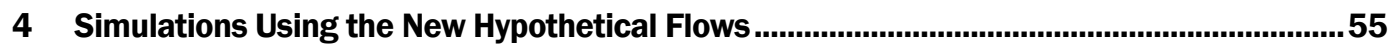

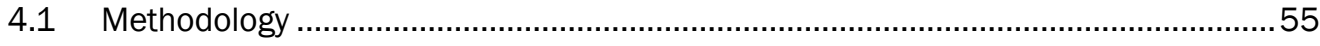

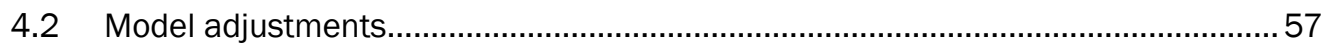

4.2.1 Flow adjustments from National Weather Service (NWS) model ..........................57

4.2.2 Old River Control Complex (ORCC) ..................................................................... 61

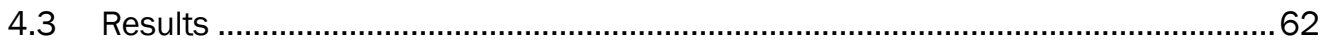

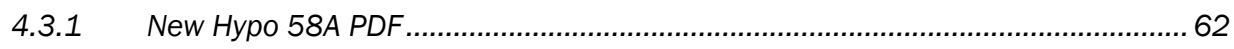


4.3.2 Other new hypo PDF simulations .................................................................... 74

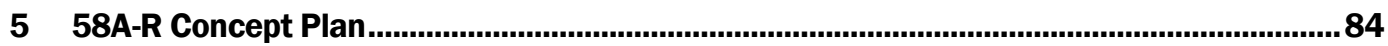

5.1 St. Francis Backwater Area optimization.............................................................. 85

5.2 White River Backwater Area optimization ...............................................................8 87

5.3 Yazoo Backwater Levee optimization ....................................................................... 91

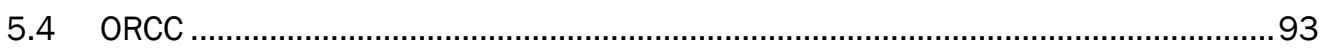

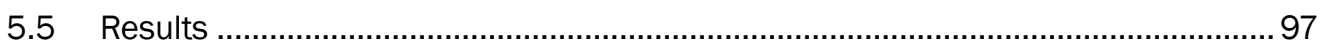

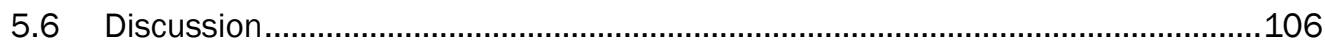

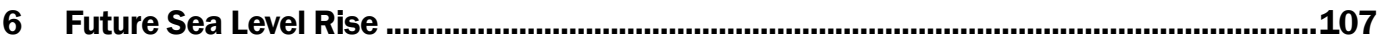

7 Atchafalaya River ............................................................................................................. 114

7.1 HEC-RAS geometry ................................................................................... 115

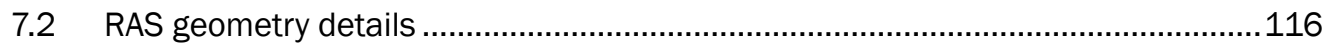

7.3 Boundary conditions .............................................................................. 117

7.4 Flow stage calibration and validation ...........................................................120

Simulation of hypothetical design events ................................................... 137

7.5.1 Existing condition simulations........................................................................ 137

7.5.2 Downstream boundary sensitivity test...........................................................142

7.5.3 Future condition geometry ....................................................................... 143

7.5.4 Future condition simulations............................................................................. 144

7.6 Comparison to 2010 flowline analysis .............................................................. 151

$7.7 \quad$ Summary and path forward ............................................................................153

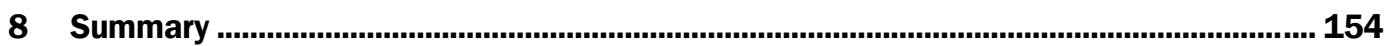

References.......................................................................................................................... 156

Appendix A: Memphis District (MVM) Model.......................................................................... 159

Appendix B: Vicksburg District (MVK) Model ........................................................................... 186

Appendix C: New Orleans District (MVN) Model....................................................................... 198

Report Documentation Page 


\section{Figures and Tables}

\section{Figures}

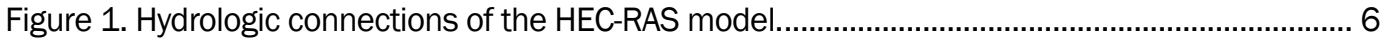

Figure 2. Labeled hydrologic connection points for model calibration simulation. ............................ 7

Figure 3. MR\&T Flowline HEC-RAS model domain...................................................................... 10

Figure 4. Stage hydrograph at Helena, AR (RAS station 676.42, 1962 River Mile [RM]

663.1), for 2002 ……................................................................................................................ 11

Figure 5. Stage hydrograph at Helena, AR (RAS station 676.42, 1962 RM 663.1), for 2008 .

Figure 6. Stage hydrograph at Helena, AR (RAS station 676.42, 1962 RM 663.1),

for 2011

Figure 7. Stage hydrograph at Natchez, MS (RAS station 368.44, 1962 RM 363.3).

for 2002.

Figure 8. Stage hydrograph at Natchez, MS (RAS station 368.44, 1962 RM 363.3),

for 2008

Figure 9. Stage hydrograph at Natchez, MS (RAS station 368.44, 1962 RM 363.3).

for 2011. 13

Figure 10. 2011 stage hydrograph at RAS station 588.4 ............................................................ 16

Figure 11. 2011 flow hydrograph at RAS station 588.4 ............................................................ 16

Figure 12. 2011 stage hydrograph at RAS station 562.18........................................................... 17

Figure 13. 2011 flow hydrograph at RAS station 562.18 ........................................................... 17

Figure 14. 2011 stage hydrograph at RAS station 325.46 ........................................................ 18

Figure 15. 2011 flow hydrograph at RAS station 325.46........................................................ 19

Figure 16. 2011 stage hydrograph at RAS station 265.00.......................................................... 19

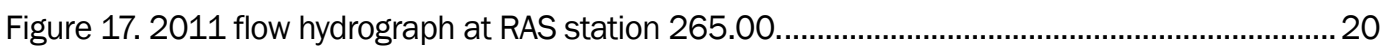

Figure 18. 2011 simulated and observed stages for Helena, AR (RAS station 676.42), ................. 23

Figure 19. 2011 simulated and observed stages for Natchez, MS (RAS station 368.44)............... 23

Figure 20. 2011 simulated and observed stages for Baton Rouge, LA (RAS station 232.49).

Figure 21. 2011 simulated and observed flows for Baton Rouge, LA (RAS station 232.49).......... 24

Figure 22. 2002 simulated and observed stages for Helena, AR ................................................. 25

Figure 23. 2002 simulated and observed stages for Natchez, MS. ................................................2

Figure 24. 2002 simulated and observed stages for Baton Rouge, LA.......................................... 26

Figure 25. 2002 simulated and observed flows for Baton Rouge, LA (gaps indicate data

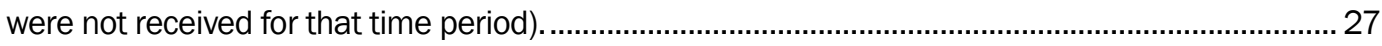

Figure 26. 2008 simulated and observed stages for Helena, AR ................................................ 27

Figure 27. 2008 simulated and observed stages for Natchez, MS................................................... 28

Figure 28. 2008 simulated and observed stages for Baton Rouge, LA. ....................................... 28

Figure 29. 2008 simulated and observed flows for Baton Rouge, LA...........................................29

Figure 30. Historic PDF flows within the MR\&T system (flow in 1000 cfs)....................................... 31 
Figure 31. Subbasins with available historic hydrographs of flow data.........................................35

Figure 32. Labeled hydrologic connection points for historic model simulations.............................36

Figure 33. Differences in the Merriwether-Cherokee levee profile, pre/post-2011.........................40

Figure 34. Plot of the existing Yazoo Backwater Levee profile..........................................................46

Figure 35. Plot of the authorized (112.8ft) Yazoo Backwater Levee profile..................................... 47

Figure 36. Comparison using the Bonnet Carré rating curve instead of observations for 2011.

Figure 37. The model downstream boundary is located at Venice, LA, pinpointed in figure.

Figure 38. New Hypo PDF 58A-R flow hydrograph at the Below Cairo location (the flows are the same at this location for the "Existing Yazoo" and "Authorized Yazoo" runs since it is relatively far upstream).

Figure 39. New Hypo PDF 58A-R flow hydrograph at the Memphis location (the flows are the same at this location for the "Existing Yazoo" and "Authorized Yazoo" runs since it is relatively far upstream)

Figure 40. New Hypo PDF 58A-R flow hydrograph at the Helena location (the flows are the same at this location for the "Existing Yazoo" and "Authorized Yazoo" runs since it is relatively far upstream).

Figure 41. New Hypo PDF 58A-R flow hydrograph at the Arkansas City location (the flows are the same at this location for the "Existing Yazoo" and "Authorized Yazoo" runs since it is relatively far upstream).

Figure 42. New Hypo PDF 58A-R flow hydrograph at the RRL location.

Figure 43. New Hypo 58A-R water surface profile for RMs 910 - 953 (Refined 1973

Computed Flowline is without loop, sediment, and freeboard effects).

Figure 44. New Hypo 58A-R water surface profile for RMs 810 - 910 (Refined 1973

Computed Flowline is without loop, sediment, and freeboard effects). 69

Figure 45. New Hypo 58A-R water surface profile for RMs 710 - 810 (Refined 1973

Computed Flowline is without loop, sediment, and freeboard effects).

Figure 46. New Hypo 58A-R water surface profile for RMs 610 - 710 (Refined 1973

Computed Flowline is without loop, sediment, and freeboard effects). 70

Figure 47. New Hypo 58A-R water surface profile for RMs 511 - 611 (Refined 1973 Computed Flowline is without loop, sediment, and freeboard effects).

Figure 48. New Hypo 58A-R water surface profile for RMs 410 - 510 (Refined 1973

Computed Flowline is without loop, sediment, and freeboard effects). 71

Figure 49. New Hypo 58A-R water surface profile for RMs 310 - 410 (Refined 1973

Computed Flowline is without loop, sediment, and freeboard effects).

Figure 50. New Hypo 58A-R water surface profile for RMs 210 - 310 (Refined 1973

Computed Flowline is without loop, sediment, and freeboard effects.)

Figure 51. New Hypo 58A-R water surface profile for RMs 110 - 210 (Refined 1973

Computed Flowline is without loop, sediment, and freeboard effects).

Figure 52. New Hypo 58A-R water surface profile for RMs 11 - 110 (Refined 1973

Computed Flowline is without loop, sediment, and freeboard effects).

Figure 53. Other New Hypo PDF's water surface profile for RMs 910 - 953 (Refined 1973

Computed Flowline is without loop, sediment, and freeboard effects).

Figure 54. Other New Hypo PDF's water surface profile for RMs 810 - 910 (Refined 1973

Computed Flowline is without loop, sediment, and freeboard effects). 
Figure 55. Other New Hypo PDF's water surface profile for RMs 710 - 810 (Refined 1973 Computed Flowline is without loop, sediment, and freeboard effects).

Figure 56. Other New Hypo PDF's water surface profile for RMs 610 - 710 (Refined 1973

Computed Flowline is without loop, sediment, and freeboard effects).

Figure 57. Other New Hypo PDF's water surface profile for RMs 510 - 610 (Refined 1973

Computed Flowline is without loop, sediment, and freeboard effects).

Figure 58. Other New Hypo PDF's water surface profile for RMs 410 - 510 (Refined 1973

Computed Flowline is without loop, sediment, and freeboard effects).

Figure 59. Other New Hypo PDF's water surface profile for RMs 310 - 410 (Refined 1973

Computed Flowline is without loop, sediment, and freeboard effects).

Figure 60. Other New Hypo PDF's water surface profile for RMs 210 - 310 (Refined 1973

Computed Flowline is without loop, sediment, and freeboard effects).

Figure 61. Other New Hypo PDF's water surface profile for RMs 110 - 210 (Refined 1973

Computed Flowline is without loop, sediment, and freeboard effects).

Figure 62. Other New Hypo PDF's water surface profile for RMs 11 - 110 (Refined 1973

Computed Flowline is without loop, sediment, and freeboard effects).

Figure 63. Map of St. Francis Backwater Area.

Figure 64. St. Francis Backwater Levee optimization..................................................................... 87

Figure 65. Map of White River Backwater Area. ...................................................................... 89

Figure 66. Upper White Backwater Levee optimization. …….....................................................90

Figure 67. Lower White Backwater Levee optimization................................................................90

Figure 68. Map of Yazoo Backwater Area..............................................................................92

Figure 69. Yazoo Backwater optimization.................................................................................93

Figure 70. Map of Tensas Cocodrie Backwater Area.....................................................................95

Figure 71. Concept Plan flow hydrograph at the Below Cairo location (the flows are the same at this location for the "Authorized Yazoo" and "Concept" runs since it is relatively far upstream).

Figure 72. Concept Plan flow hydrograph at the Memphis location (the flows are the same at this location for the "Authorized Yazoo" and "Concept" runs since it is relatively far upstream).

Figure 73. Concept Plan flow hydrograph at the Helena location. ...................................................100

Figure 74. Concept Plan flow hydrograph at the Arkansas City location.........................................100

Figure 75. Concept Plan flow hydrograph at the RRL location. ..........................................................

Figure 76. Concept Plan water surface profile for RMs 910 - 953 (Refined 1973

Computed Flowline is without loop, sediment, and freeboard effects. The Concept results are on top of the Authorized Yazoo results in this figure).

Figure 77. Concept Plan water surface profile for RMs 810 - 910 (Refined 1973

Computed Flowline is without loop, sediment, and freeboard effects. The Concept results

are on top of the Authorized Yazoo results in this figure).

Figure 78. Concept Plan water surface profile for RMs 710 - 810 (Refined 1973

Computed Flowline is without loop, sediment, and freeboard effects).

Figure 79. Concept Plan water surface profile for RMs 610 - 710 (Refined 1973

Computed Flowline is without loop, sediment, and freeboard effects).

Figure 80. Concept Plan water surface profile for RMs 510 - 610 (Refined 1973

Computed Flowline is without loop, sediment, and freeboard effects). 
Figure 81. Concept Plan water surface profile for RMs 410 - 510.(Refined 1973

Computed Flowline is without loop, sediment, and freeboard effects).

Figure 82. Concept Plan water surface profile for RMs 310 - 410 (Refined 1973

Computed Flowline is without loop, sediment, and freeboard effects). 104

Figure 83. Concept Plan water surface profile for RMs 210 - 310 (Refined 1973 Computed Flowline is without loop, sediment, and freeboard effects). 105

Figure 84. Concept Plan water surface profile for RMs 110 - 210 (Refined 1973

Computed Flowline is without loop, sediment, and freeboard effects). 105

Figure 85. Concept Plan water surface profile for RMs 11 - 110 (Refined 1973 Computed Flowline is without loop, sediment, and freeboard effects). 106

Figure 86. Sea level rise adjustment to the Venice rating curve. ..................................................108

Figure 87. Future sea level rise water surface profiles for RMs 310 - 410....................................112

Figure 88. Future sea level rise water surface profiles for RMs 210 - 310................................112

Figure 89. Future sea level rise water surface profiles for RMs 110-210...................................113

Figure 90. Future sea level rise water surface profiles for RMs 11 - 110.....................................113

Figure 91. Map of federal levees of the Atchafalaya basin...............................................................114

Figure 92. ORCC to Morgan City, LA (MVN), hydraulic model schematic......................................118

Figure 93. Terrain data sources of the Atchafalaya model. ...........................................................119

Figure 94. Zoomed view of 1D/2D RAS geometry..................................................................120

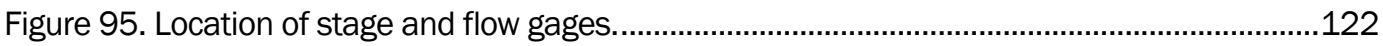

Figure 96. Maximum inundation depth for 2011 calibration event...............................................123

Figure 97. Modeled vs. observed stages at Simmesport, LA.......................................................124

Figure 98. Modeled vs. observed flows at Simmesport, LA...........................................................124

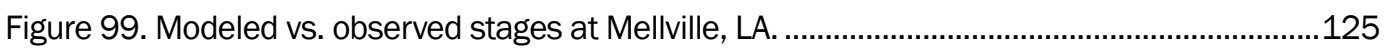

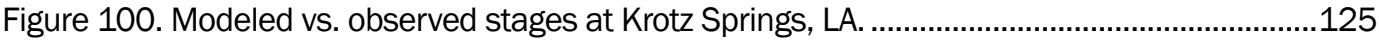

Figure 101. Modeled vs. observed stages at Chicot Pass near Myette Point. ................................126

Figure 102. Modeled vs. observed stages at Morgan City, LA.........................................................126

Figure 103. Modeled vs. observed flows at Morgan City, LA. ......................................................127

Figure 104. Modeled vs. observed stages at Avoca Island Cutoff. .............................................127

Figure 105. Modeled vs. observed stages at Whiskey Bay Pilot Channel.....................................128

Figure 106. Modeled vs. observed stages at Butte La Rose. ........................................................128

Figure 107. Modeled vs. observed stages at Six Mile Lake. .............................................................129

Figure 108. Modeled vs. observed stages at Calumet...............................................................129

Figure 109. Modeled vs. observed flows at Calumet. ……............................................................130

Figure 110. Modeled vs. observed stages at Crewboat Channel.................................................130

Figure 111. Maximum water surface elevation for the 2002 flood. .............................................134

Figure 112. Maximum water surface elevation for the 2008 flood.............................................135

Figure 113. Maximum water surface elevation for the 2011 flood. .............................................136

Figure 114. Maximum water surface elevation of the 2016 58A-R Authorized Yazoo Plan...........139

Figure 115. Maximum water surface elevation of the 2016 58A-R Existing Yazoo Plan................140

Figure 116. Maximum water surface elevation of the 2016 Concept Plan. ................................... 141 
Figure 117. Comparison of existing condition Concept Plan with downstream boundary set to 0.9 and $3.3 \mathrm{ft}$ NAVD88.

Figure 118. Future condition cross section with accretion. .......................................................145

Figure 119. Future condition cross section with scour..............................................................146

Figure 120. Comparison of existing and future condition bed change and peak water surface for the 58 A-R Authorized Yazoo Plan.

Figure 121. Comparison of existing and future condition bed change and peak water surface for the 58 A-R Existing Yazoo Plan

Figure 122. Comparison of existing and future condition bed change and peak water surface for the Concept Plan. 148

Figure 123. 58A-R modeled stages at Simmesport, LA 148

Figure 124. 58A-R modeled stages at Mellville, LA. 149

Figure 125. 58A-R modeled stages at Krotz Springs, LA...........................................................149

Figure 126. 58A-R modeled stages at Butte La Rose...............................................................150

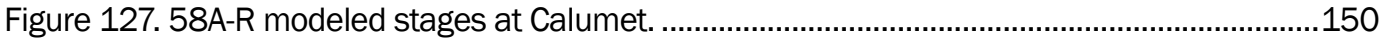

Figure 128. Difference between 2010 and 2016 peak flood profiles..........................................153

Figure 129. Chester, IL/Smithland, KY, to Vicksburg, MS (MVM) hydraulic model schematic. 160

Figure 130. BPNMF breach activation progression................................................................ 174

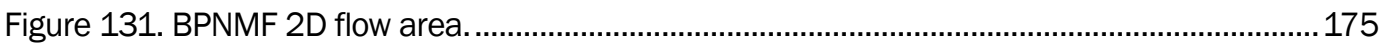

Figure 132. Arkansas, White, and Mississippi Rivers confluence 2D flow area............................. 176

Figure 133. BPNMF breach locations. ................................................................................ 181

Figure 134. USGS gage locations during 2011 activation............................................................182

Figure 135. Elevation hydrograph near Inflow Crevasse..........................................................183

Figure 136. Elevation hydrograph near Inflow/Outflow \#1 Crevasse. .............................................183

Figure 137. Elevation hydrograph near Inflow/Outflow \#2 Crevasse.............................................184

Figure 138. Elevation hydrograph near center of floodway...........................................................184

Figure 139. Rosedale, MS, to St. Francisville, LA, (MVK) hydraulic model schematic. ...................187

Figure 140. 2011 Vicksburg gage calibration, (a) without seasonal roughness and

(b) with seasonal roughness. .... 192

Figure 141. 2011 Arkansas City gage calibration, (a) without seasonal roughness and

(b) with seasonal roughness. 193

Figure 142. 2011 Greenville gage calibration, (a) without seasonal roughness and (b) with seasonal roughness. .194

Figure 143. 2011 Lake Providence gage calibration, (a) without seasonal roughness and (b) with seasonal roughness. 195

Figure 144. Tarbert Landing, LA, to Venice, LA (MVN), hydraulic model schematic.......................199

Figure 145. Subsidence rates in South Louisiana....................................................................20

Figure 146. Diversions and outlets (in blue) - lower river..........................................................205

Figure 147. 2011 RRL gage calibration. ..................................................................................2 210

Figure 148. 2011 Baton Rouge gage calibration...................................................................210

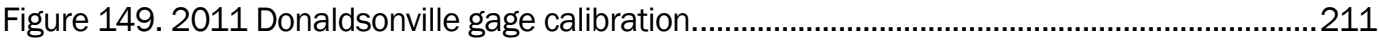

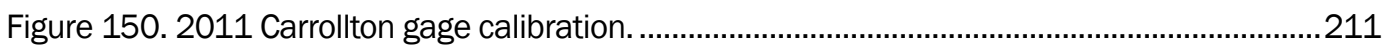


Figure 151. 2011 Pointe a la Hache gage calibration.

Figure 152. 2011 Venice stage comparisons with actual gage data vs. rating curve used for Venice boundary.

Figure 153. 2011 Empire stage comparisons with actual gage data vs. rating curve used for Venice boundary.

Figure 154. 2011 Carrollton stage comparisons with actual gage data vs. rating curve used for Venice boundary.

Figure 155. 2011 Baton Rouge stage comparisons with actual gage data vs. rating curve used for Venice boundary.

Figure 156. 2008 Venice stage comparisons with actual gage data vs. rating curve used for Venice boundary.

Figure 157. 2008 Carrollton stage comparisons with actual gage data vs. rating curve used for Venice boundary.

Figure 158. 2008 Baton Rouge stage comparisons with actual gage data vs. rating curve used for Venice boundary.

Figure 159. 2002 Venice stage comparisons with actual gage data vs. rating curve used for Venice boundary.

Figure 160. Influence of Mississippi River discharge on stage at Southwest Pass.......................218

Figure 161. Venice stage vs. Southwest Pass stage during high river flow conditions.

\section{Tables}

Table 1. List of reports included in the overall project.................................................................... 1

Table 2. Extents of the individual district models.

Table 3. Inflow boundary conditions (N/A means that point is not applicable to this set of simulations; those points are used for other simulations [e.g., the historic hydrology simulations]).

Table 4. List of simulations of the HEC-RAS model described in this report.

Table 5. Inflow boundary conditions for historic simulations (N/A means that a multiplier was not required for that inflow point).

Table 6. Mainline levees modeled as lateral structures not allowed to overtop in the PDF models (RT and LT refer to the right and left descending banks, respectively).

Table 7. Deleted storage area connections in the PDF models (RAS labels).

Table 8. Lateral structures allowed to overtop in the PDF models (MRL stands for Mississippi River levee).

Table 9. Venice rating curve.

Table 10. Maximum flow comparisons of the historic PDF simulations (cubic feet per second) (blank values indicate the historic study's values were not available at those locations)

Table 11. Maximum stage comparisons of the Historic PDF runs (ft, NAVD88) (*from the Refined 1973 Flowline Study [USACE 1978], this column is without loop effect, sedimentation, or freeboard effects).

Table 12. Boundary condition explanations for the New Hypo PDF runs ("Total": a location where the total routed flow from the NWS hydrologic model was included; "Local”: a location where only the local flow from the NWS hydrologic model was included).

Table 13. Maximum flow comparisons of the New Hypo 58A PDF simulations (cubic feet per second). 
Table 14. Maximum stage comparisons of the New Hypo 58A PDF simulations (feet, NAVD88)

Table 15. Maximum flow comparisons of the other New Hypo PDF simulations (cubic feet per second).

Table 16. Maximum stage comparisons of the other New Hypo PDF simulations (feet, NAVD88) (*From the Refined 1973 Flowline Study, this column is without loop effect, sedimentation, or freeboard effects)..

Table 17. St. Francis Backwater Area optimization. ...................................................................... 87

Table 18. White River Backwater Area optimization. ...................................................................... 91

Table 19. Yazoo Backwater Levee optimization. …………….............................................................93

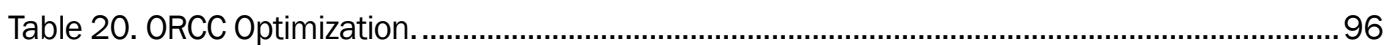

Table 21. Maximum flow comparisons of the Concept Plan simulation

(cubic feet per second).

Table 22. Maximum stage comparisons of the Concept Plan simulation (feet, NAVD88) (*from the Refined 1973 Flowline Study [USACE 1978], this column is without loop effect, sedimentation, or freeboard effects).

Table 23. Maximum flow comparisons of the future sea level rise simulations (cubic feet per second).

Table 24. Maximum stage comparisons of the future sea level rise simulations (feet) (*From the Refined 1973 Flowline Study [USACE 1978], this column is without loop effect, sedimentation, or freeboard effects).

Table 25. Terrain data sources.

Table 26. Manning's $n$ values by landcover.

Table 27. Summary of stage and flow gages used in calibration/validation. 121

Table 28. Summary of modeled vs. observed peak stages for 2011 calibration event. 131

Table 29. Summary of modeled vs. observed peak discharge for 2011 calibration event. 131

Table 30. Summary of modeled vs. observed peak stages for 2008 validation event...................132

Table 31. Summary of modeled vs. observed peak discharge for 2008 validation event. ............132

Table 32. Summary of modeled vs. observed peak stages for 2002 validation event....................133

Table 33. Summary of modeled vs. observed peak discharge for 2002 validation event.............133

Table 34. Summary of hypothetical event maximum water surface elevations for existing conditions. 142

Table 35. Future condition bed change adjustments.

Table 36. Summary of hypothetical maximum water surface elevations for future conditions.

Table 37. Comparison of 2010 and 2016 Atchafalaya flowline analyses.....................................152

Table 38. Flow data used for the MVM model setup.......................................................................162

Table 39. Data used for the MVM model calibration....................................................................164

Table 40. List of breaches and their parameters in the MVM model ........................................... 171

Table 41. MVM calibration results for 2002, 2008, and 2011.................................................. 178

Table 42. MVM calibration results for the 2002-2011 hourly simulation......................................180

Table 43. Flow data used for the MVK model setup ...............................................................188

Table 44. Gages used to calibrate the MVK model. .....................................................................189 


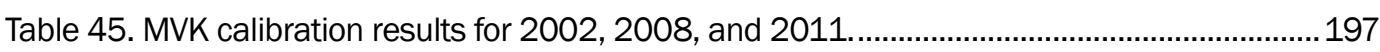

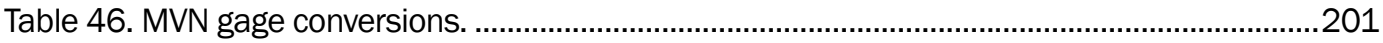

Table 47. Flow and stage data used for MVN model setup......................................................203

Table 48. MVN calibration results for 2002, 2008, and 2011 (n/a values indicate that

data were not available at the gage for that time period). 


\section{Preface}

This assessment was conducted for the Mississippi Valley Division under Project 449963, "Mississippi River and Tributaries Flowline Assessment." The report is published through the Mississippi River Geomorphology and Potamology (MRG\&P) Program. The MRG\&P Program is part of the Mississippi River and Tributaries (MR\&T) Program and is managed by the U.S. Army Corps of Engineers (USACE), Mississippi Valley Division (MVD), and Districts. The MVD Commander was MG Richard G. Kaiser. The MVD Director of Programs was Mr. Jim Bodron. The Vicksburg District (MVK) Commander was COL Michael C. Derosier. The Memphis District (MVM) Commander was COL Michael A. Ellicott. The New Orleans District (MVN) Commander was COL Michael N. Clancy.

The work was performed by the U.S. Army Engineer District, Memphis Hydraulics Branch; U.S. Army Engineer District, Vicksburg - Hydraulics Branch; U.S. Army Engineer District, New Orleans - Hydraulics Branch; and the U.S. Army Engineer Research and Development Center (ERDC), Coastal and Hydraulics Laboratory (CHL), River Engineering Branch. The project managers were Mr. Charles A. McKinnie and Mr. Joseph M.

Windham. Mr. Wesley Crosby was the Technical Lead.

COL Ivan P. Beckman was the Commander of ERDC, and the Director was Dr. David W. Pittman. 


\section{Unit Conversion Factors}

\begin{tabular}{|l|c|l|}
\hline Multiply & By & To Obtain \\
\hline cubic feet & 0.02831685 & cubic meters \\
\hline feet & 0.3048 & meters \\
\hline foot-pounds force & 1.355818 & joules \\
\hline miles (U.S. statute) & $1,609.347$ & meters \\
\hline square feet & 0.09290304 & square meters \\
\hline
\end{tabular}




\section{Introduction}

\subsection{Objective}

This report summarizes the development of an unsteady flow Hydrologic Engineering Center - River Analysis System (HEC-RAS) model for the Mississippi River from Chester, IL, to Venice, LA. Individual segments from the Memphis (MVM), Vicksburg (MVK), and New Orleans (MVN) Districts were combined in a process where each district was given the autonomy and latitude to develop the best hydraulic model possible for its reach. The individual district models were calibrated to the 2011 flood, checked with the 2002 and 2008 high-flow events, and then combined into a single unsteady HEC-RAS model. The combined model was validated using the 2002, 2008, and 2011 high-flow events and then used for the Project Design Flood (PDF) (described in Sections 3 and 4) runs.

This effort is a part of the overall Mississippi River and Tributaries (MR\&T) Flowline Assessment to assess the maximum water surface elevations throughout the MR\&T domain. Table 1 lists the series of reports associated with the overall project, with this report listed in bold font.

Table 1. List of reports included in the overall project.

\begin{tabular}{|l|l|}
\hline Report Name & Description \\
\hline Executive Summary & $\begin{array}{l}\text { The Executive Summary briefly summarizes the important information from the } \\
\text { entire project assessment. }\end{array}$ \\
\hline Main Report & $\begin{array}{l}\text { The Main Report summarizes the results in each of the aspects of the entire } \\
\text { project assessment and shows the combined effects of the PDF event scenarios. }\end{array}$ \\
\hline Hydrology Report & $\begin{array}{l}\text { The Hydrology Report assesses the flow of water arriving to the MR\&T System } \\
\text { during the PDF event scenarios. }\end{array}$ \\
\hline Hydraulics Report & $\begin{array}{l}\text { The Hydraulics Report assesses the water surface elevations in the Mississippi } \\
\text { and Atchafalaya rivers during the PDF event scenarios. }\end{array}$ \\
\hline $\begin{array}{l}\text { Mississippi River } \\
\text { Sedimentation Report }\end{array}$ & $\begin{array}{l}\text { The Mississippi River Sedimentation Report assesses how the next 50 years of } \\
\text { sedimentation are expected to change the Mississippi River channel; these } \\
\text { changes would impact the water surface elevations expected during the PDF } \\
\text { event in the future. }\end{array}$ \\
\hline $\begin{array}{l}\text { Atchafalaya River } \\
\text { Sedimentation Report }\end{array}$ & $\begin{array}{l}\text { The Atchafalaya River Sedimentation Report assesses how the next 50 years of } \\
\text { sedimentation are expected to change the Atchafalaya River channel; these } \\
\text { changes would impact the water surface elevations expected during the PDF } \\
\text { event in the future. }\end{array}$ \\
\hline
\end{tabular}


This report documents the development and use of the combined HEC-RAS unsteady hydraulic model to simulate water surface elevations for historic and new hypothetical PDF events. The overall assessment includes other tasks such as the development of the new hypothetical PDF hydrologic scenarios and comparisons with MR\&T levees that are not discussed within this report.

This report is organized as follows:

- Section 1 explains background information about the project.

- Section 2 describes the model development and validation process.

- Section 3 is focused on model simulations using the PDF event flows from the previous 1955 Hydrology Report.

- Section 4 is focused on model simulations using the new hypothetical PDF event flows. The four sets of hypothetical results correspond with storm events labeled "New Hypo 58A" (Section 5.3.1), "New Hypo 52A" (Section 5.3.2), "New Hypo 56" (Section 5.3.2), and "New Hypo 63" (Section 5.3.2).

- Section 5 describes an alternative set of conditions, based on adjustments to backwater areas and Old River Control Complex (ORCC) operations, which were simulated.

- Section 6 is focused on how sea level rise is expected to impact the simulated water surface elevations in the future.

- Section 7 discusses the development of the Atchafalaya River HEC-RAS unsteady hydraulic model.

\subsection{Background}

The 2011 Mississippi River flood catalyzed the need to re-evaluate the project design water surface elevation (flowline) along the mainstem of the Mississippi River from Chester, IL, to Venice, LA. With significant enhancements in numerical modeling tools and additional data availability since the previous flowline study conducted in 1973, and with the 2011 flood providing at or near maximum design water surface elevations at various locations along the Mississippi River, this was an appropriate time to refine the Mississippi River flowline to better prepare the nation for future flood events.

To this end, the U.S. Army Corps of Engineers (USACE) developed unsteady flow hydraulic models of the MR\&T domain (Chester, IL/Smithland, KY, to Venice, LA) to refine the Mississippi River flowline. 
The MVM, MVK, and MVN Districts worked in parallel to create separate HEC-RAS models of each district's area of responsibility. The 2011 PostFlood Assessment (USACE 2012a) utilized the first iteration of these hydraulic models. The accelerated schedules for both of these studies did not allow time for a detailed calibration to a wide range of flows. Also limiting the calibration effort was the approach to limit the study scopes to examining the relative differences for the 2011 event. For the Mississippi River Flowline Assessment, however, a more detailed calibration of the models was necessary to further refine the Mississippi River flowline. Each district collected additional data and updated one-dimensional (1D), and some two-dimensional (2D), hydraulic models for their respective model reaches within the MR\&T domain.

HEC-RAS has the capability to model split flows, to calculate water surface profiles for gradually varied flows, and to model a single stream reach or a full network of interconnecting channels. It has the ability to model sub-critical, super-critical, and mixed-flow profiles. The basic computation routine solves the $1 \mathrm{D}$ energy equation, taking into consideration energy losses due to channel and overbank friction in the longitudinal direction and expansion and contraction losses at bridges, culverts, and natural constrictions. HEC-RAS neglects variables such as density and temperature. Because it is used primarily within this project as a $1 \mathrm{D}$ model, input must be assignable to a longitudinal coordinate. The modeling of large, elaborate river systems in one dimension involves mathematical assumptions, requiring the use of RAS features to compensate for the three-dimensional hydraulics that exist in nature.

\subsection{Approach}

An unsteady HEC-RAS model was developed, calibrated, and validated for this investigation, as described in the following sections. 


\section{Model Development and Validation}

\subsection{Data compilation}

An unsteady HEC-RAS model is based on a series of assumptions and equations used to represent open channel flow in one dimension (longitudinally from upstream to downstream) and can be set up to simulate in two dimensions as well. It is a robust and flexible model reliant on bathymetric and topographic data throughout the model domain and upon hydraulic properties at all boundaries as well as within the model domain. The most important hydraulic properties in this application of HEC-RAS are water surface elevation (stage) and crosssectional discharge (flow). The most accurate data reasonably obtainable were used for the model development. Each district developed its own Geographic Information System (GIS) library for the construction of its models using HEC-GeoRAS 10.2 for ArcGIS 10.2 (USACE 2012b). The projection and datum for all of the data related to the terrain were USGS Albers Equal Area and North American Vertical Datum of 1988 (NAVD88), respectfully. Due to subsidence in the Southeast Louisiana region, elevations there are referenced to a particular temporal epoch of the NAVD88 datum. For the southern portions of the MVN segment, the gages were surveyed to the NAVD88 2004.65 epoch.

The terrain geometry was developed by supplementing hydrographic surveys of channel bathymetries with available lidar or Digital Elevation Model (DEM) data sets of the overland areas. More detailed descriptions of data sets used within each district's model are included in Appendix A, $\mathrm{B}$, and $\mathrm{C}$, which explain the MVM, the MVK, and the MVM models, respectively. The extents of each district's individual model are listed in Table 2. The use of geometry data from various years was unavoidable for such a large area. All data used in the terrain geometry were obtained between 2001 and 2010. Although survey data were used from multiple years, the overall volume for the system has not changed significantly. Weighting the calibration of the model to the recent 2011 event addresses some local differences in geometry. 
Table 2. Extents of the individual district models.

\begin{tabular}{|l|l|l|}
\hline District & Upstream Extent & Downstream Extent \\
\hline Memphis & $\begin{array}{l}\text { Chester, IL (Mississippi River) } \\
\text { Smithland, KY (Ohio River) }\end{array}$ & Vicksburg, MS \\
\hline Vicksburg & Rosedale, MS & St. Francisville, LA \\
\hline New Orleans & Tarbert Landing, LA & Venice, LA \\
\hline
\end{tabular}

Observed flow and stage data were obtained from the United States Geological Survey (USGS), the USACE, and the National Weather Service (NWS). The typical error of the published flow data for calibration is considered to range from plus or minus $2 \%$ to $8 \%$ or more. The USGS publishes the results of flow measurements taken and assigns an estimated accuracy for each measurement. Multiple gage locations that measure stage can also provide flow estimates through the use of rating curves. Rating curves can be developed by fitting a curve that relates stage, the typical value measured in near real-time at a gage, to flow through a number of instantaneous flow measurements. Because 2011 included some of the highest water levels in modern times, the number of flow measurements at these high stages was limited, and therefore the rating curves used to compute flow from observed stage are subject to significant uncertainty.

\subsection{Model setup and calibration}

\subsubsection{Hydrology connections}

The upstream boundary conditions of the river analysis system (RAS) model require flow data arriving from the multiple drainage areas within the Mississippi River Basin. For the calibration and validation runs, these upstream boundary condition flows came from either a discharge gage at that specific location or the NWS hydrologic model. Figure 1 and Figure 2 show the watershed sub-basins and points where boundary condition data were required. Table 3 lists the river, RAS station, and data source for each point. 
Figure 1. Hydrologic connections of the HEC-RAS model.

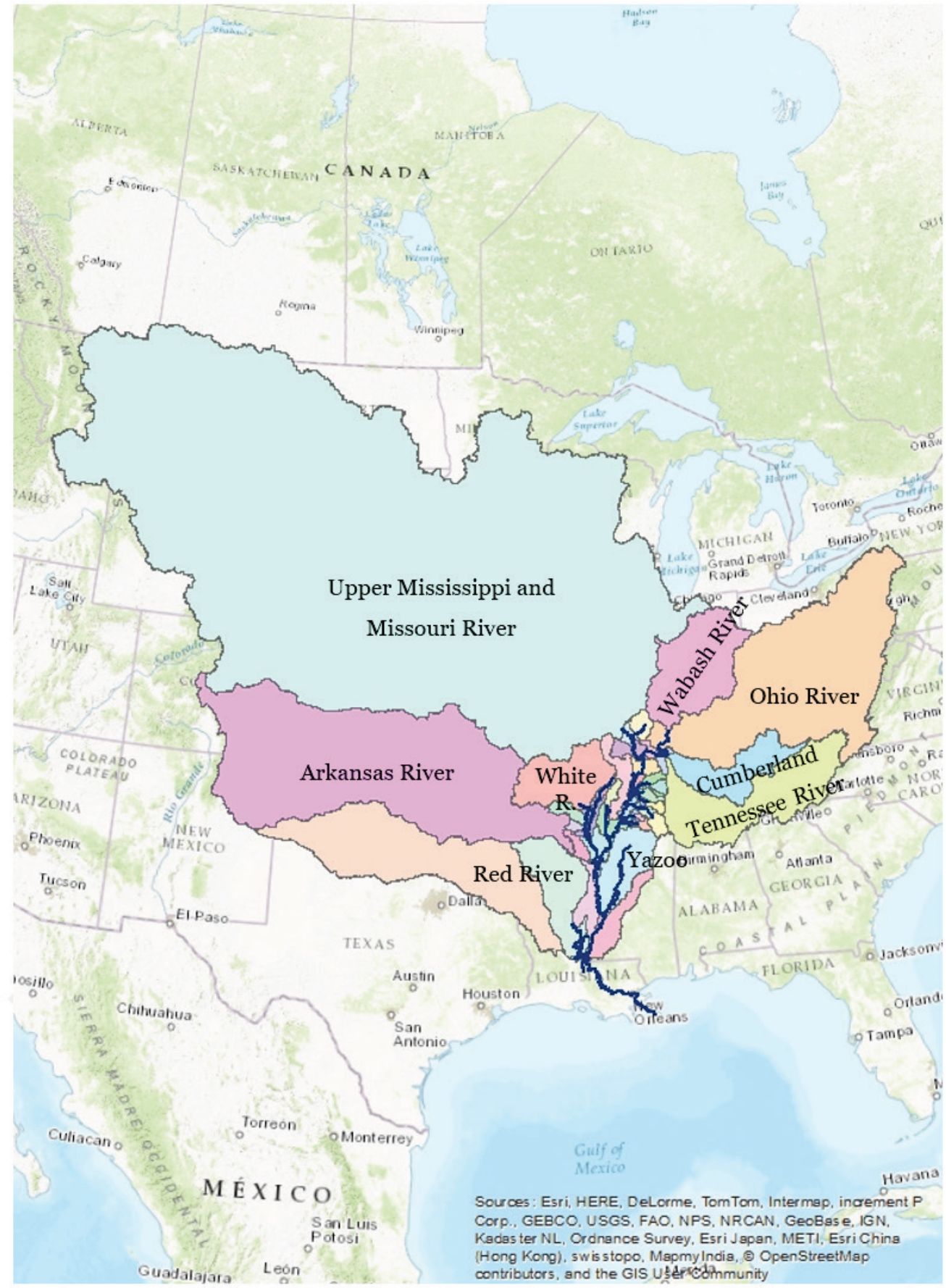


Figure 2. Labeled hydrologic connection points for model calibration simulation.

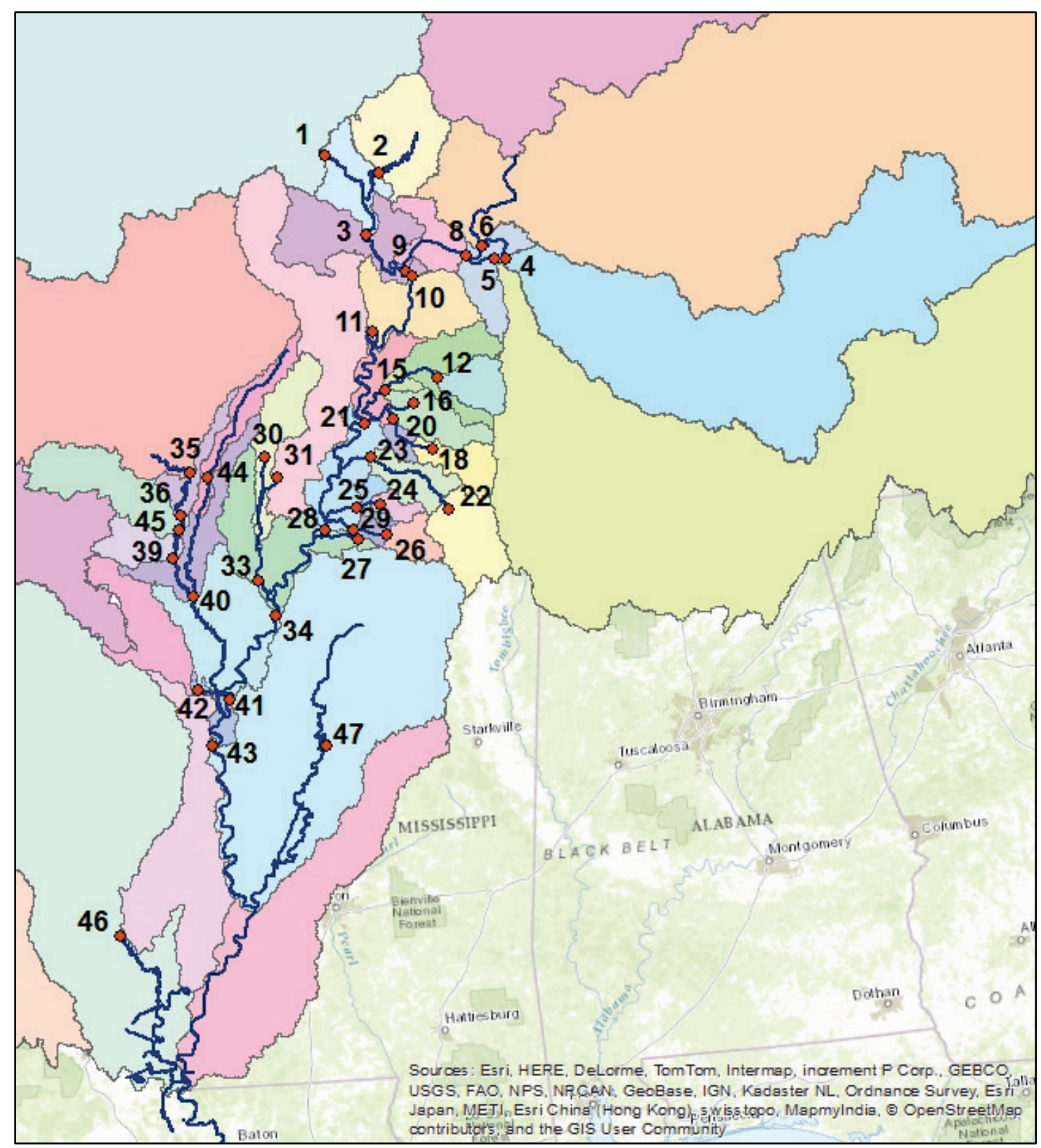

Table 3. Inflow boundary conditions (N/A means that point is not applicable to this set of simulations; those points are used for other simulations [e.g., the historic hydrology simulations]).

\begin{tabular}{|c|l|c|l|}
\hline Point ID & River & RAS Station & Source of Data Used for Boundary Condition \\
\hline 1 & Mississippi & 110.40 & Gaged flows at Chester, IL \\
\hline 2 & Big Muddy & 34.87 & Gaged flows at Murphysboro, IL \\
\hline 3 & Mississippi & 52.15 & NWS Hydrologic Model local routed flow \\
\hline 4 & Cumberland River & 29.36 & Published flow releases \\
\hline 5 & Tennessee River & 18.21 & Published flow releases \\
\hline
\end{tabular}




\begin{tabular}{|c|c|c|c|}
\hline Point ID & River & RAS Station & Source of Data Used for Boundary Condition \\
\hline 6 & Ohio River & -919.00 & USGS flow data and backwater calculations (see Appendix A) \\
\hline 7 & Ohio River & -944.10 & $\mathrm{~N} / \mathrm{A}$ \\
\hline 8 & Ohio River & -934.18 & NWS Hydrologic Model local routed flow \\
\hline 9 & Ohio River & -979.68 & NWS Hydrologic Model local routed flow \\
\hline 10 & Mississippi & 972.56 & NWS Hydrologic Model local routed flow \\
\hline 11 & Mississippi & 908.52 & NWS Hydrologic Model local routed flow \\
\hline 12 & Obion & 72.10 & NWS Hydrologic Model total routed flow for OBNT1 \\
\hline 13 & Obion & 65.29 & $\mathrm{~N} / \mathrm{A}$ \\
\hline 14 & Obion & 52.65 & $\mathrm{~N} / \mathrm{A}$ \\
\hline 15 & Obion & 34.16 & NWS Hydrologic Model local routed flow \\
\hline 16 & North Forked Deer & 20.00 & Gaged flows at Dyersburg, TN \\
\hline 17 & North Forked Deer & 5.20 & $\mathrm{~N} / \mathrm{A}$ \\
\hline 18 & South Forked Deer & 38.68 & Gaged flows at Owl City, TN \\
\hline 19 & South Forked Deer & 28.69 & $\mathrm{~N} / \mathrm{A}$ \\
\hline 20 & South Forked Deer & 8.59 & NWS Hydrologic Model local routed flow \\
\hline 21 & Mississippi & 835.27 & NWS Hydrologic Model local routed flow \\
\hline 22 & Hatchie & 149.62 & Gaged flows at Bolivar, TN \\
\hline 23 & Hatchie & 36.07 & NWS Hydrologic Model local routed flow \\
\hline 24 & Loosahatchie & 35.24 & Gaged flows at Arlington, TN \\
\hline 25 & Loosahatchie & 22.55 & NWS Hydrologic Model local routed flow \\
\hline 26 & Wolf & 46.40 & Gaged flows at Rossville, TN \\
\hline 27 & Wolf & 19.46 & NWS Hydrologic Model local routed flow \\
\hline 28 & Mississippi & 749.01 & NWS Hydrologic Model local routed flow \\
\hline 29 & Nonconnah & 25.64 & Gaged flows at Germantown, TN \\
\hline 30 & Straight Slough & 30.82 & NWS Hydrologic Model local routed flow \\
\hline 31 & St Francis & 82.47 & Gaged flows at Riverfront, AR \\
\hline 32 & St Francis & 17.73 & N/A \\
\hline 33 & St Francis & 37.70 & NWS Hydrologic Model local routed flow \\
\hline 34 & Mississippi & 676.42 & NWS Hydrologic Model local routed flow \\
\hline 35 & White River & 258.94 & Gaged flows at Newport, AR \\
\hline 36 & White River & 204.34 & NWS Hydrologic Model local routed flow \\
\hline 37 & Cache River & 80.53 & $\mathrm{~N} / \mathrm{A}$ \\
\hline 38 & White River & 169.52 & NWS Hydrologic Model local routed flow \\
\hline
\end{tabular}




\begin{tabular}{|c|l|c|l|}
\hline Point ID & River & RAS Station & Source of Data Used for Boundary Condition \\
\hline 39 & White River & 145.72 & NWS Hydrologic Model local routed flow \\
\hline 40 & White River & 100.05 & NWS Hydrologic Model local routed flow \\
\hline 41 & Mississippi & 602.06 & NWS Hydrologic Model local routed flow \\
\hline 42 & Arkansas River & 28.07 & Gaged flow releases from Dam 02 \\
\hline 43 & Mississippi & 564.00 & NWS Hydrologic Model local routed flow \\
\hline 44 & Cache River & 116.44 & Gaged flows at Egypt, AR \\
\hline 45 & White River & 177.90 & Gaged flows at Dewey, AR for Little Red \\
\hline 46 & Ouachita River & 65.54 & Gaged flows at Columbia Lock \\
\hline 47 & Yazoo River & 158.76 & Gaged flows at Greenwood \\
\hline
\end{tabular}

\subsubsection{Model setup}

Figure 3 shows the overall geographic extents of the combined model domain. The individual district HEC-RAS models were developed and calibrated to the 2011 Mississippi River flood, beginning January 1 and continuing through December 31. Adjustments were made to the roughness values (Manning's $n$-values), the ineffective flow areas, and the lateral flow coefficients. The calibration effort aligned the model simulation to both stage and flow during the 2011 event, with particular attention to matching the timing and magnitude of the peak. The HEC-RAS models were also run for the 2002 and 2008 years to check the performance of the model since they were recent years that reached relatively high stages. The observed stage hydrographs for 2002, 2008, and 2011 for the mainstem of the Mississippi River at two locations, Helena, AR, and Natchez, MS, are shown in Figure 4 through Figure 9 (RiverGages.com ${ }^{1}$ ). These hydrographs show the approximate magnitude of the selected events relative to the flood stages at those locations. More detail about the individual district model calibrations can be found in the appendices.

The river path alignment was recalculated during the development of this model, and the RAS station labels used throughout this report differ from the previous river alignment labels. The 1962 river mile labels are typically used, so there are references throughout this report that allow for connections between the 1962 river miles and the new RAS stationing labels.

\footnotetext{
1 http://rivergages.mvr.usace.army.mil/WaterControl/new/layout.cfm
} 
Figure 3. MR\&T Flowline HEC-RAS model domain.

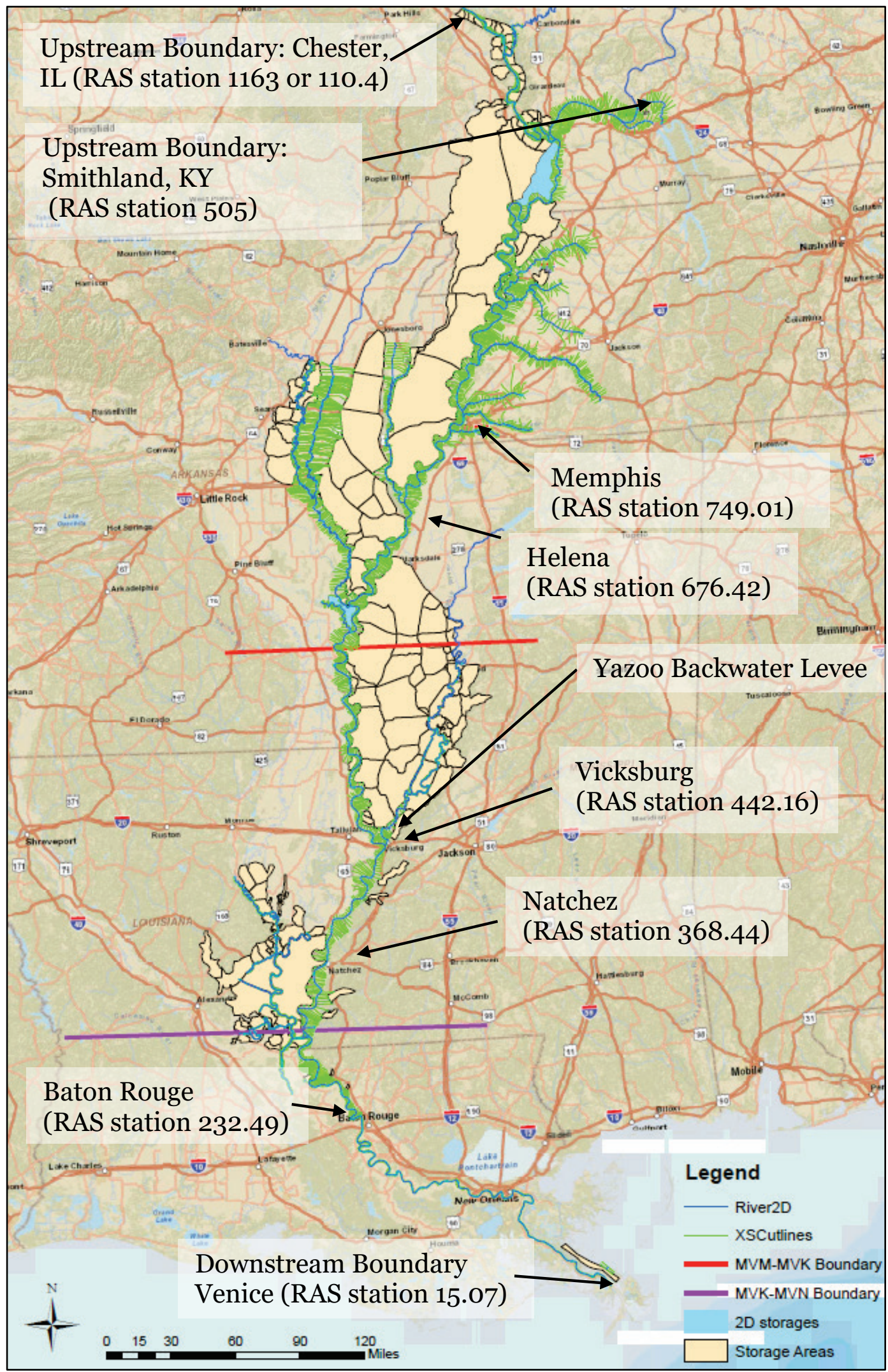


Figure 4. Stage hydrograph at Helena, AR (RAS station 676.42, 1962 River Mile [RM] 663.1), for 2002.

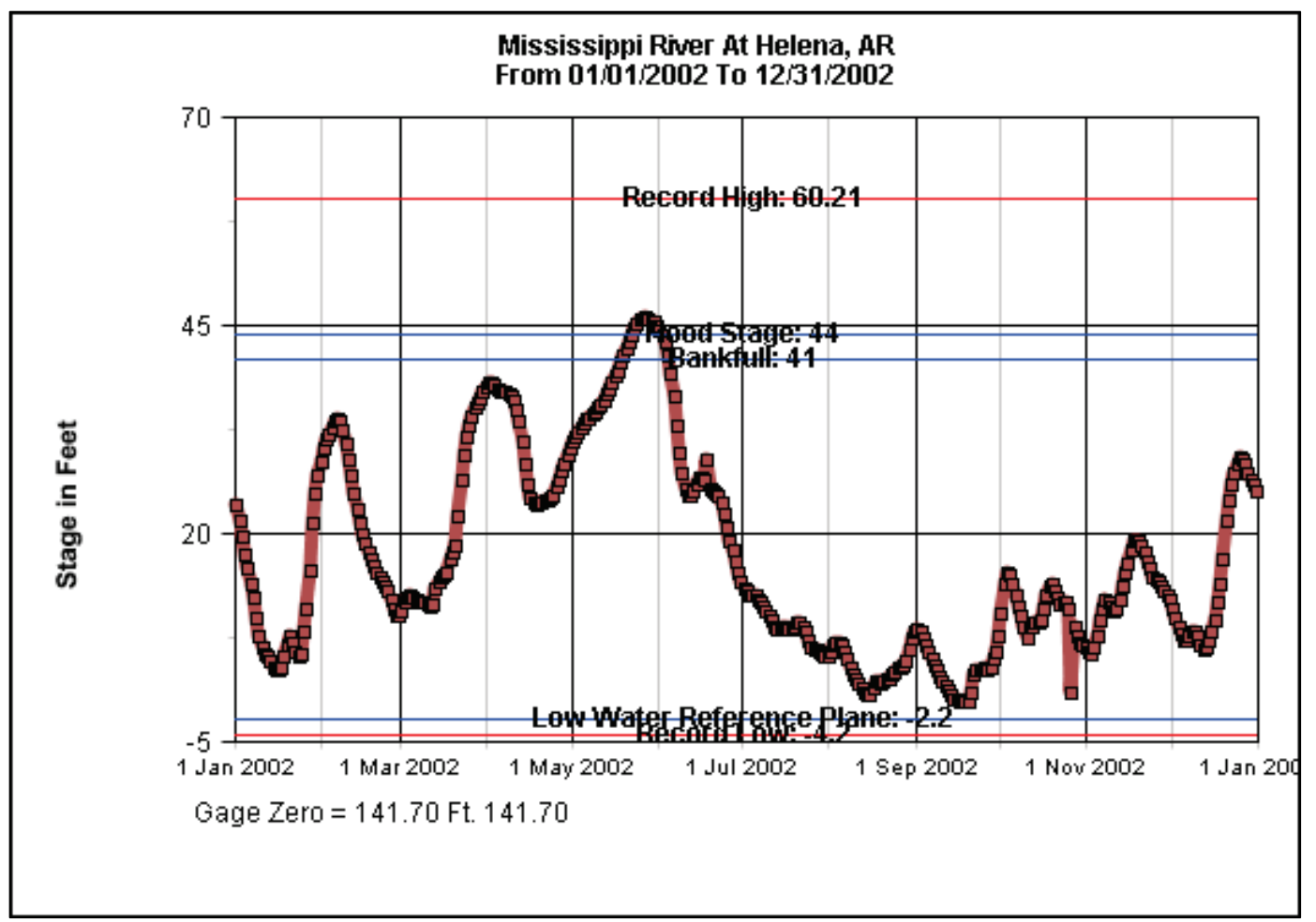

Figure 5. Stage hydrograph at Helena, AR (RAS station 676.42, 1962 RM 663.1), for 2008.

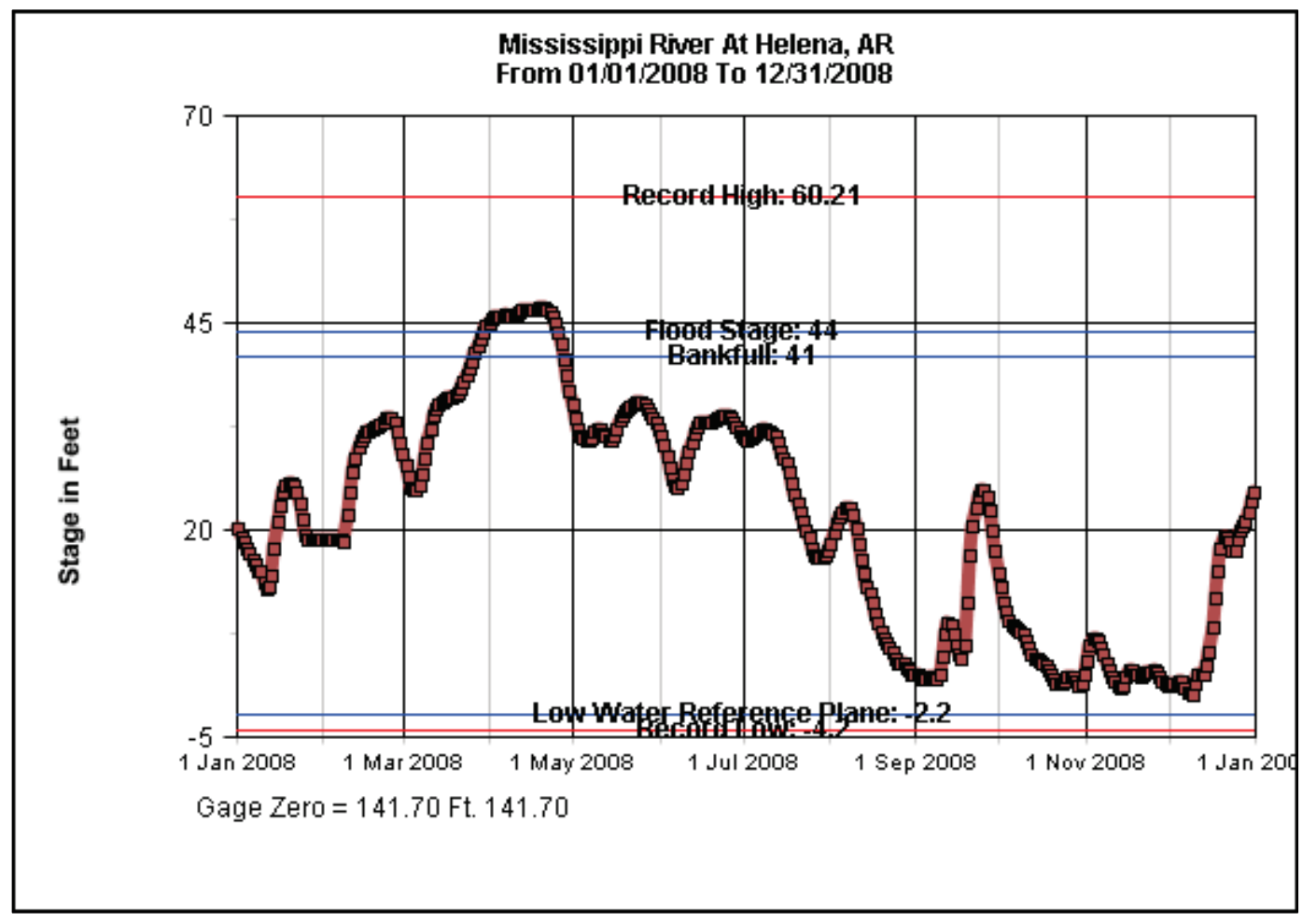


Figure 6. Stage hydrograph at Helena, AR (RAS station 676.42, 1962 RM 663.1), for 2011.

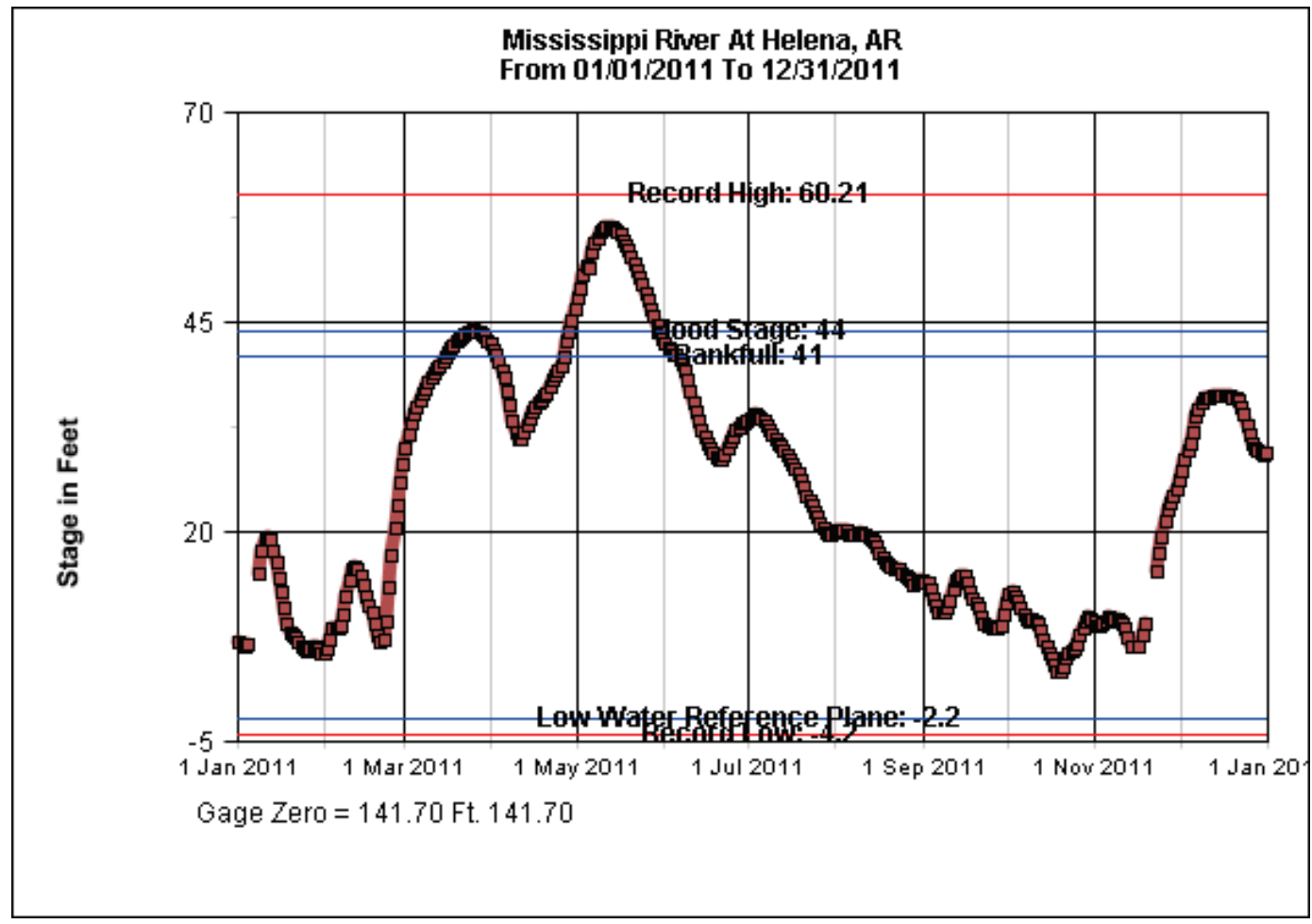

Figure 7. Stage hydrograph at Natchez, MS (RAS station 368.44, 1962 RM 363.3). for 2002.

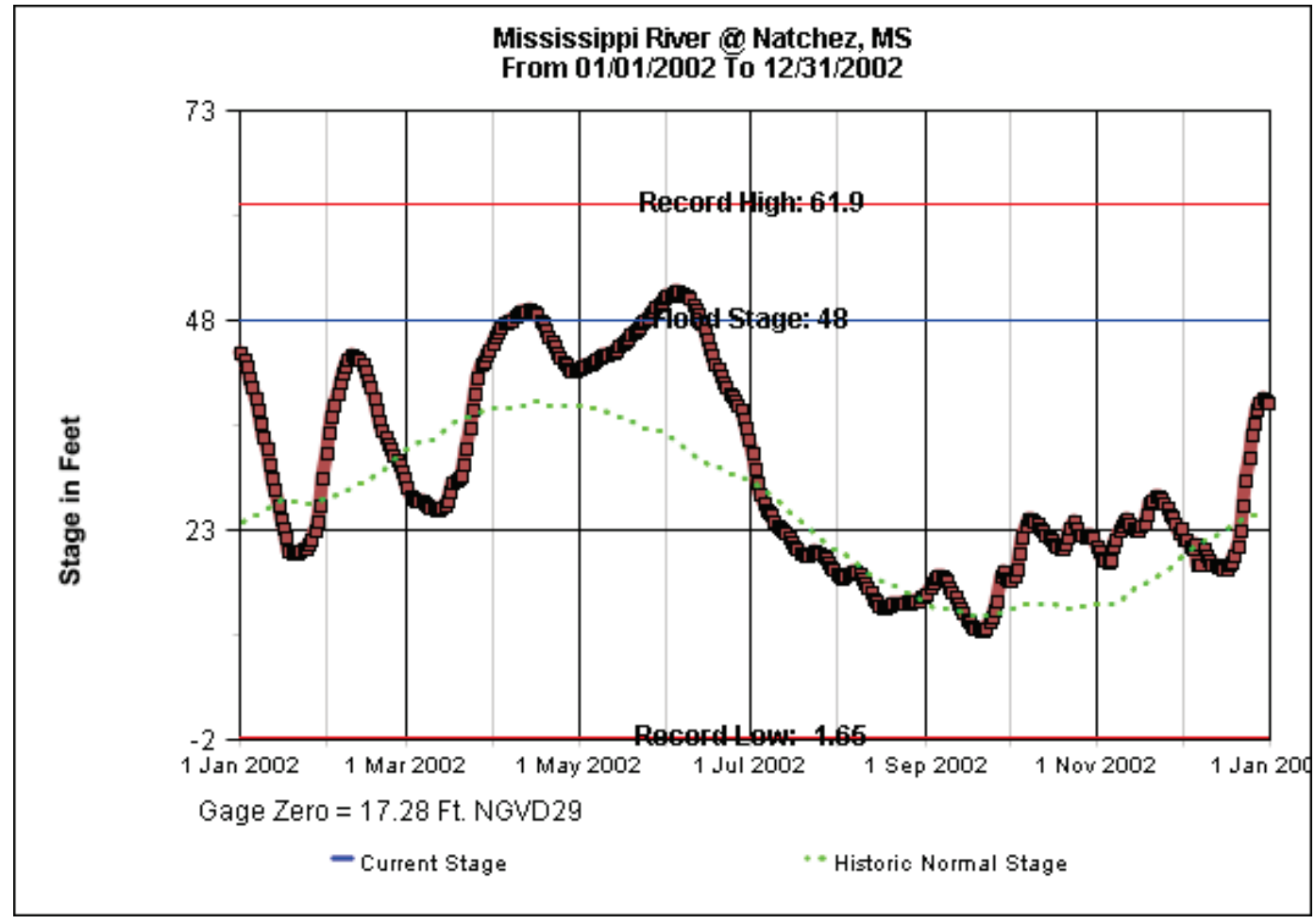


Figure 8. Stage hydrograph at Natchez, MS (RAS station 368.44, 1962 RM 363.3), for 2008.

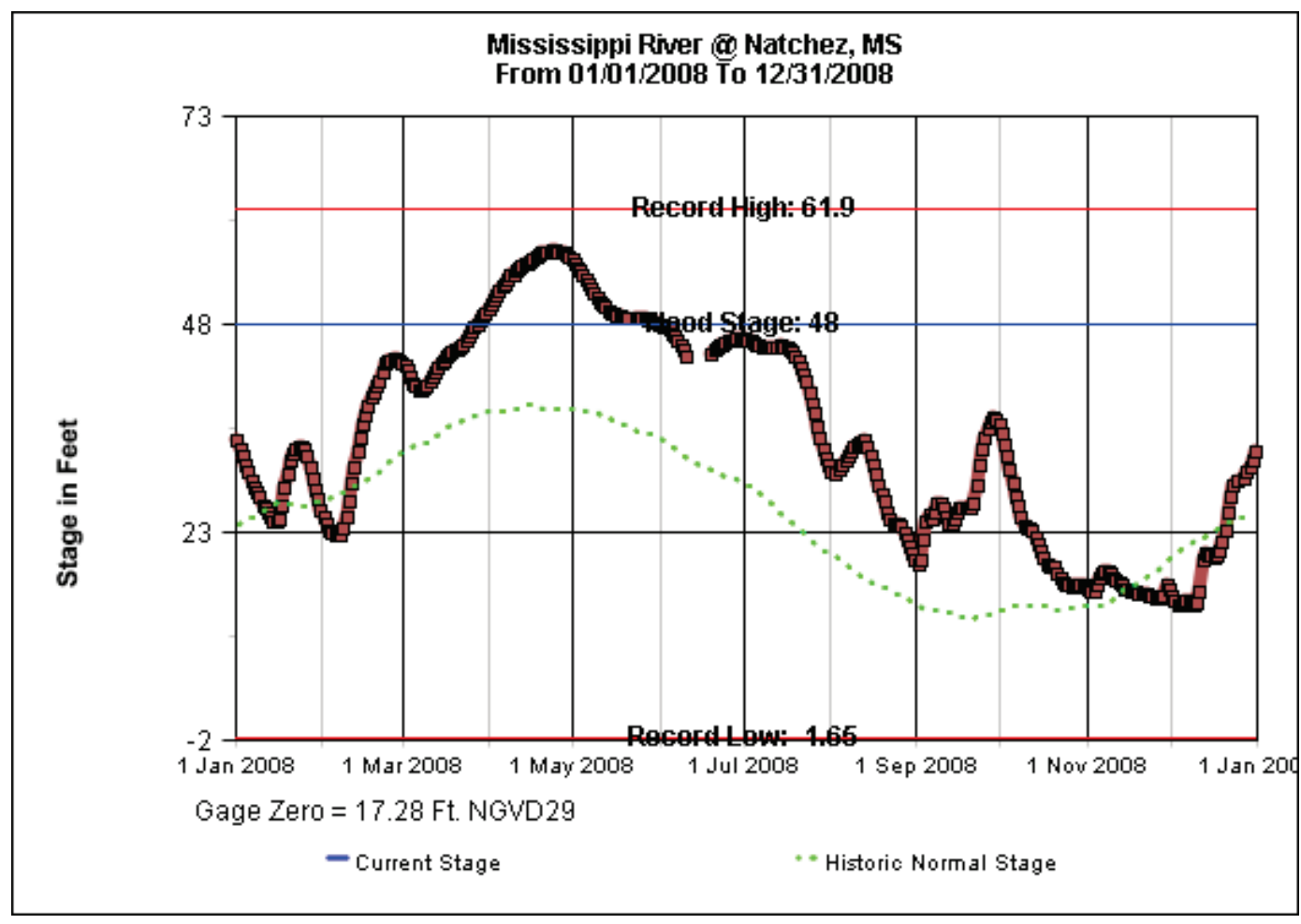

Figure 9. Stage hydrograph at Natchez, MS (RAS station 368.44, 1962 RM 363.3). for 2011.

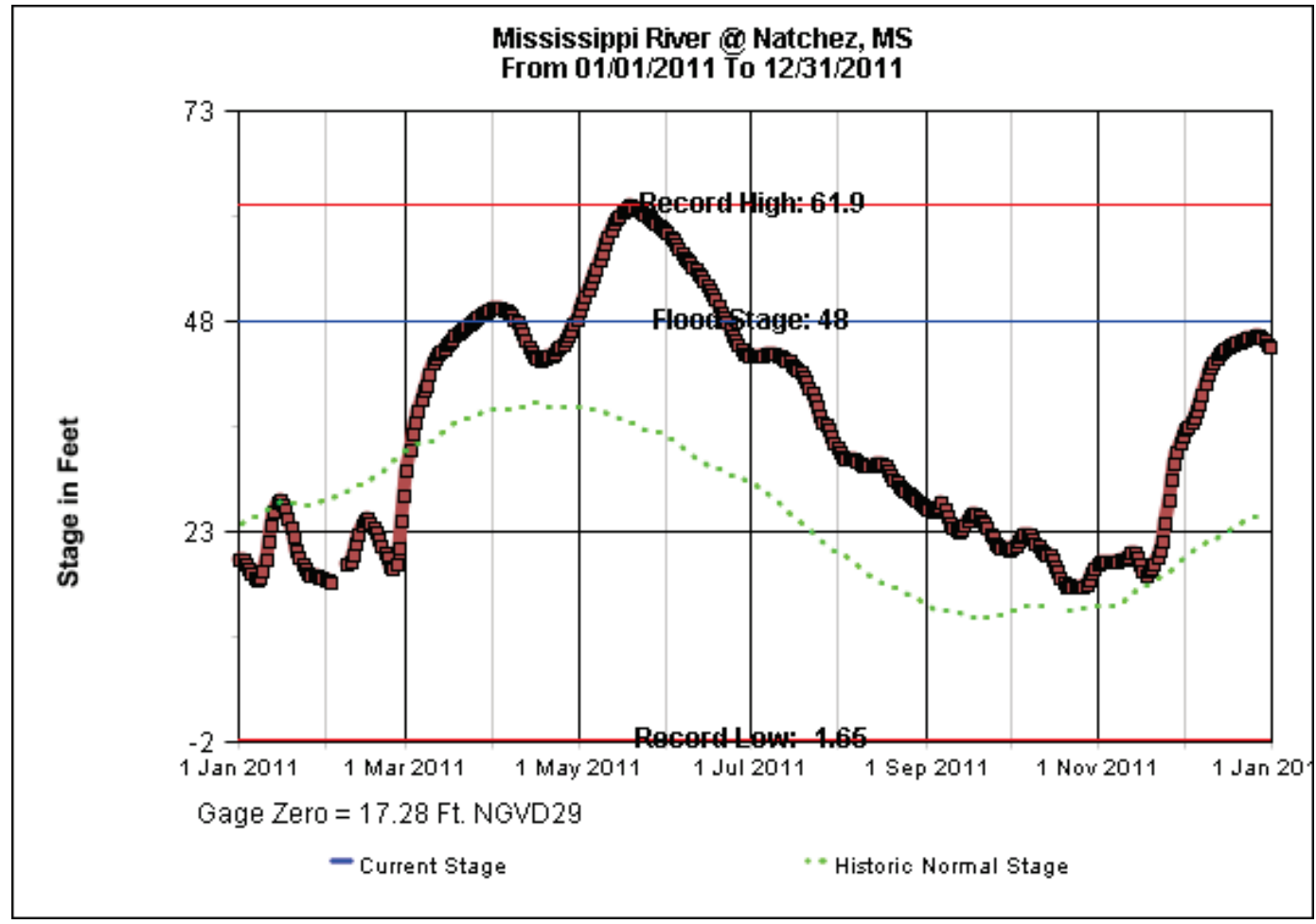


As the initial calibration was underway, 2D modeling capabilities in HEC-RAS were under development (HEC-RAS 5.o Beta). Therefore, complex sites such as Bird's Point-New Madrid Floodway (BPNMF) and the confluence of the Arkansas, White, and Mississippi Rivers were developed in HEC-RAS 5.o Beta to take advantage of new features. The HEC-RAS model was upgraded to newer release versions of the HECRAS software. The final model used the officially released HEC-RAS version 5.0.1. HEC-RAS 5.0 contains a 2D finite-volume algorithm that solves either the full 2D Saint Venant equations or the 2D diffusive wave equations. The software has the ability to perform computations with 1D river reaches and storage areas combined with $2 \mathrm{D}$ flow areas. The combined $1 \mathrm{D} / 2 \mathrm{D}$ computations are performed together for each timestep, making the connections from $1 \mathrm{D}$ areas to $2 \mathrm{D}$ flow areas more accurate than modeling them separately. The grids for the 2D areas are discretized, and an elevation-volume relationship is computed for each cell based on the underlying terrain and bathymetry.

The effort to refine and calibrate the $2 \mathrm{D}$ areas was limited, partly because the software was only in a beta version during the time of the initial calibration. The areas modeled in $2 \mathrm{D}$ were delineated in such a way to represent overbank flow. The cell size used for the BPNMF was $500 \times$ 500 feet ( $\mathrm{ft}$ ) while the cell size used for the Arkansas, White, and Mississippi Rivers confluence was $1000 \times 1000 \mathrm{ft}$. Manning's $n$ values were spatially assigned to the cells using land use datasets for the BPNMF area, and a Manning's $n$ value of 0.15 was used for the Arkansas, White, and Mississippi Rivers confluence area, since it is a densely wooded area.

Considerable effort was given to accurately account for the energy losses through bridges along the main stem and the tributaries. The MVK and MVN segments have bridges over the Mississippi River, but neither have embankments that extend into the floodplain. As far as the bridge piers, auxiliary simulations were initially run to determine typical pier impacts. The piers showed no effect on the flowlines (indicating that energy losses from the piers are minor). Therefore, the decision was made by the team lead at the beginning of the project to not incorporate the Mississippi River bridges into the combined HEC-RAS model. The 2011 calibration confirmed that leaving the Mississippi River bridges out did not impact model accuracy. The MVM segment accounts for any losses from the embankments near its bridges. The Yazoo River reach of the HEC-RAS model, which does experience appreciable bridge energy losses, does contain bridges. In summary, all relevant bridge losses have been accounted for in the model. 


\subsection{Model combination}

The process of combining the three models was accomplished using a two-phase method that allowed the modelers to look at results of the individual district models and combined model in more detail. First, the MVM and MVK models were combined with only the Mississippi River and attached tributaries. This allowed a faster turnaround in the running time and check on the model results. The Mississippi River flow and stage values were evaluated. The first changes on the MVK model prior to combining with the MVM model were to reanalyze the channel $n$-values, extend cross sections as needed, and make changes in the seasonal roughness values.

Once this was accomplished, the MVM and MVK models were combined. Minor modifications were then made in the reach near the intersection of the two models; then the combined model was rerun to ensure that the combining process did not impact modeling performance or accuracy. The runs demonstrated that the flows and resulting stages of the combined model were comparable to the individual model output prior to combining. Figure 10 through Figure 13 depict stage and flow hydrographs for cross sections near the intersection point, RAS stations 588.4 and 562.18 (the Arkansas City gage), for simulations before and after combining the models. These figures demonstrate that the combining process of the MVM and MVK models did not significantly alter the model results for 2011. After combining the main segments, the Red River backwater area was then added to the combined model to complete the MVM and MVK combination process. 
Figure 10. 2011 stage hydrograph at RAS station 588.4.

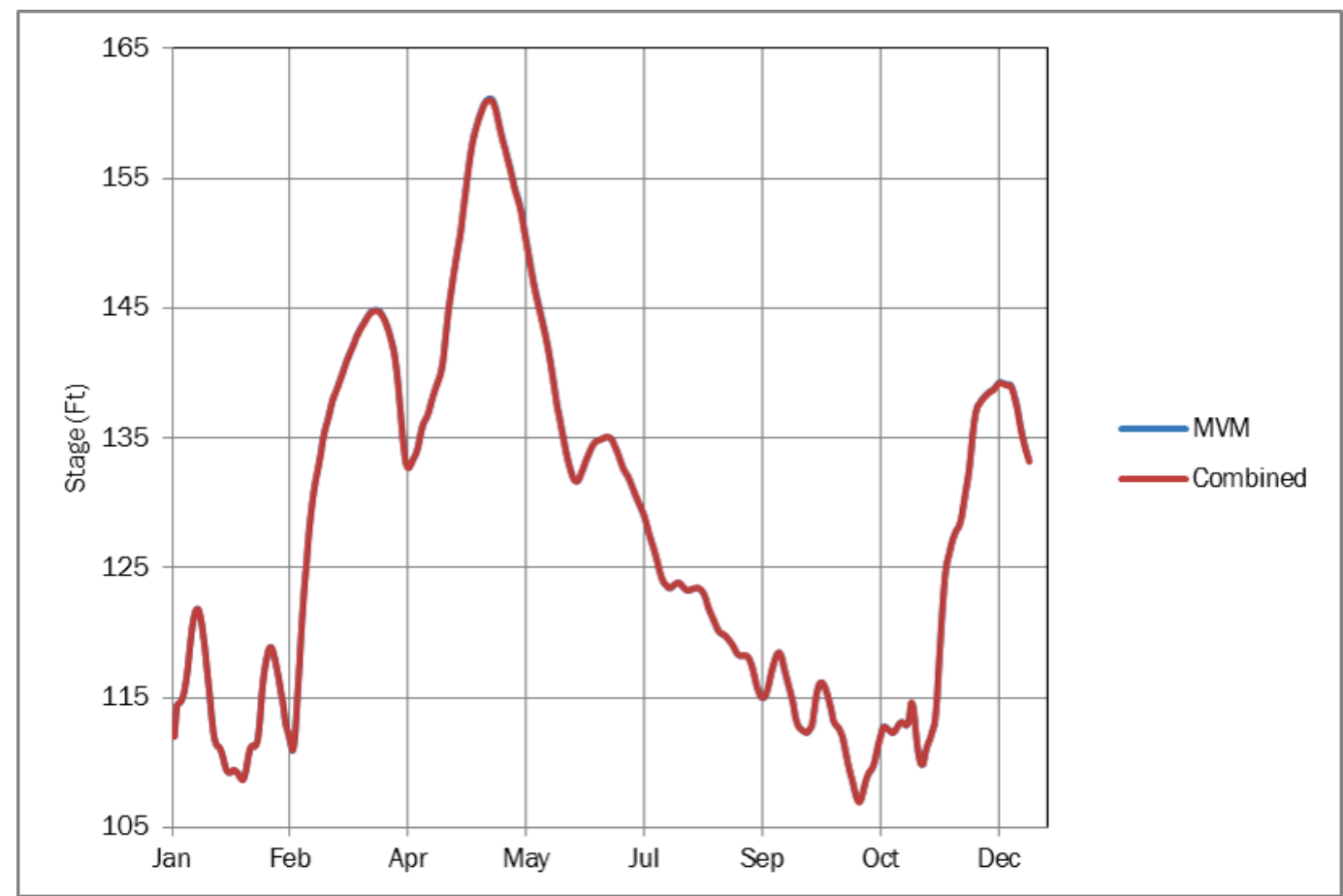

Figure 11. 2011 flow hydrograph at RAS station 588.4.

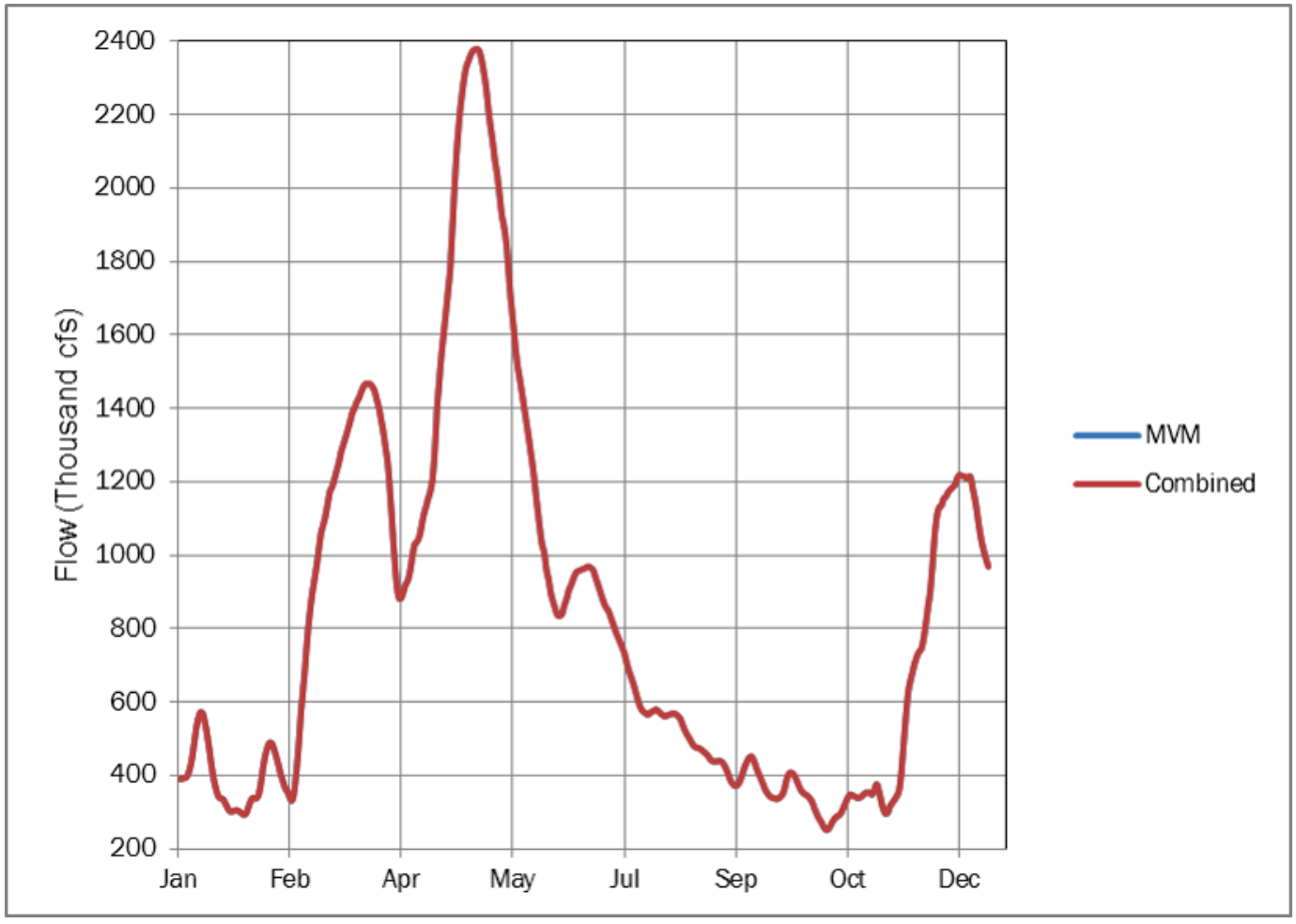


Figure 12. 2011 stage hydrograph at RAS station 562.18.

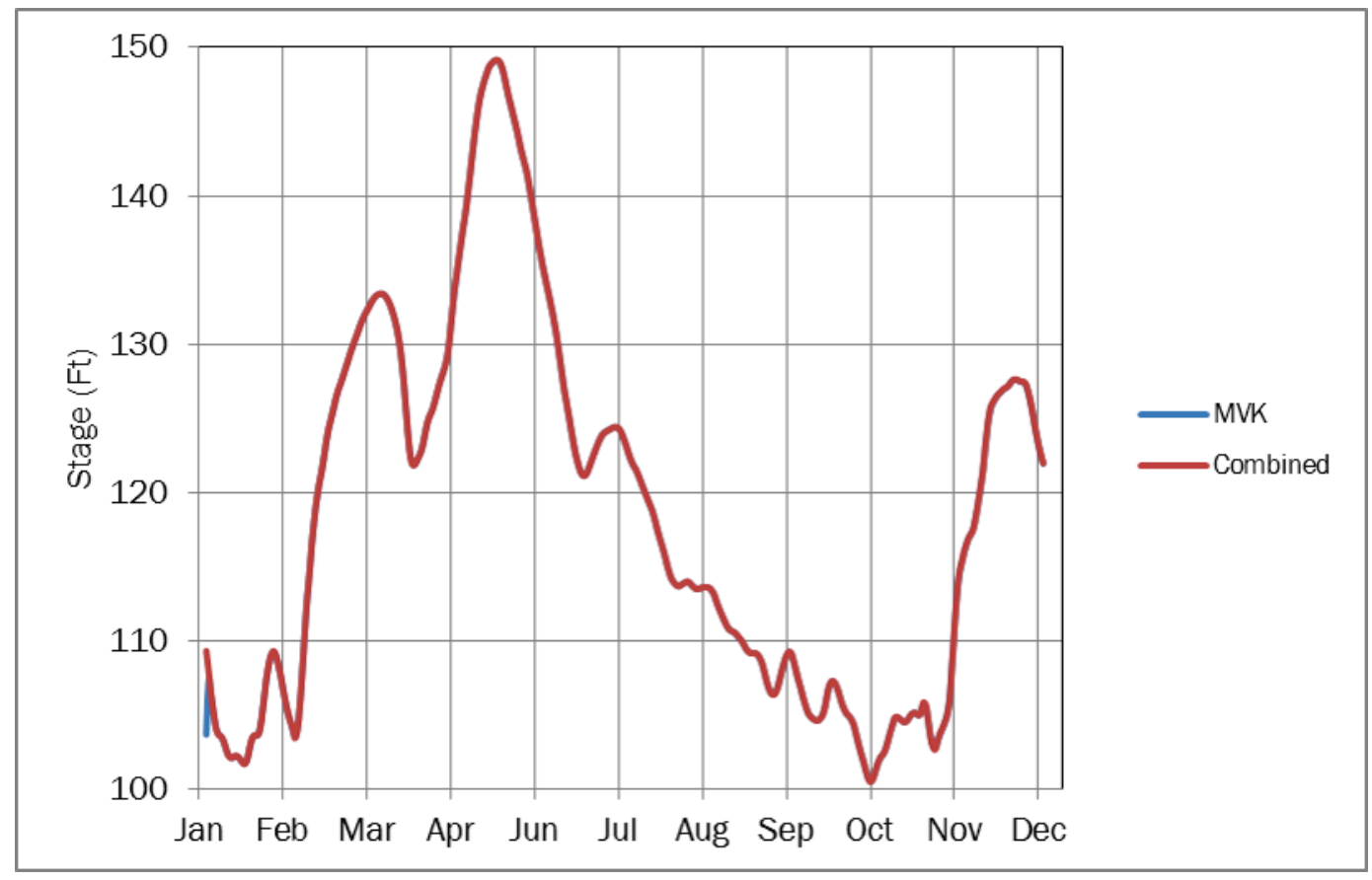

Figure 13. 2011 flow hydrograph at RAS station 562.18.

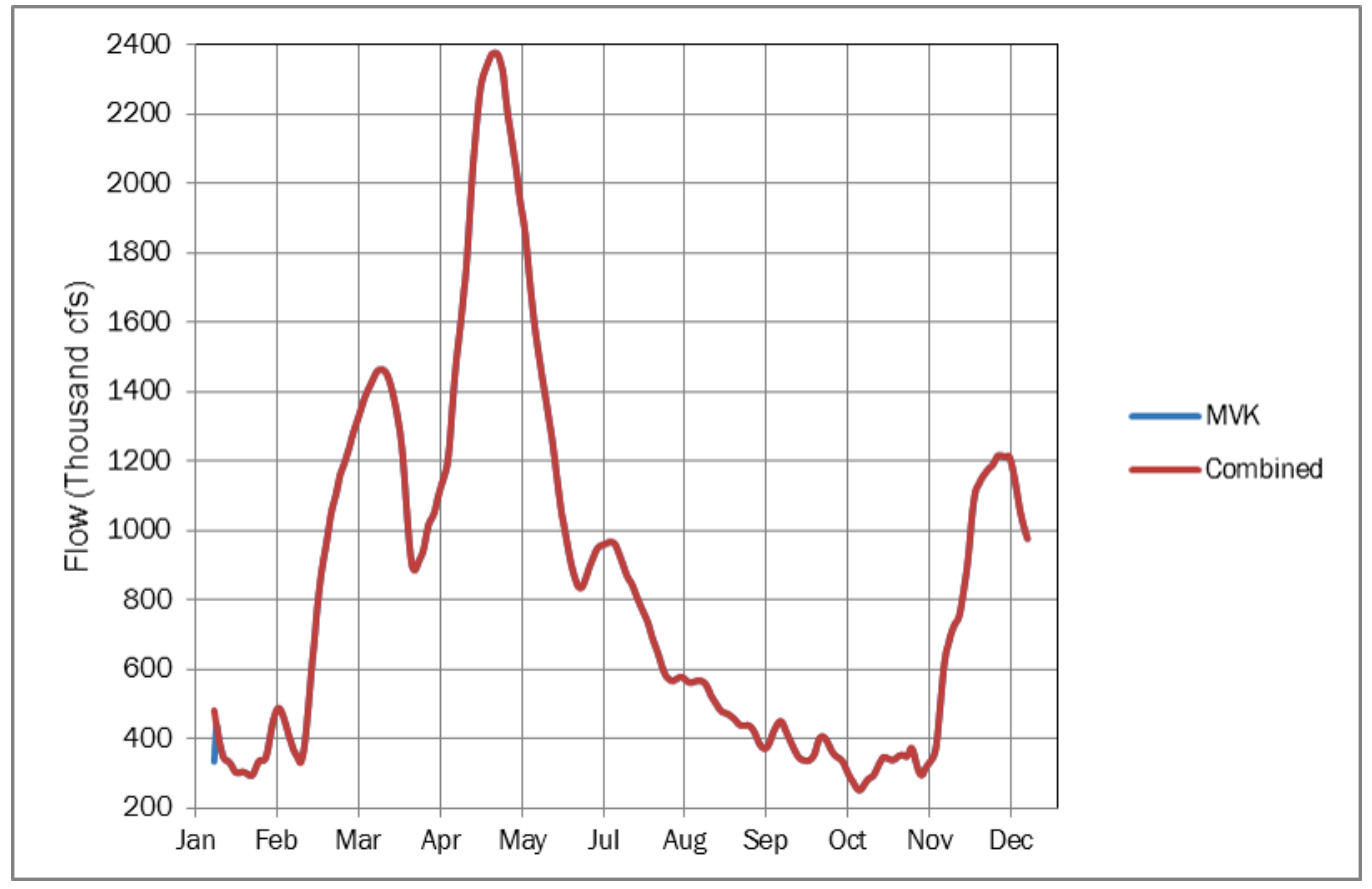


The MVK model was then joined with the MVN model in a similar manner. This required some changes in the lower reach of the MVK model and the upper reach of the MVN model, as well as near the Morganza Floodway and the Bonnet Carré Spillway. Changes at the Morganza Floodway and Bonnet Carré Spillway (see Appendix C for more information about these control structures) were coordinated between MVK and MVN to ensure correct operation. Figure 14 through Figure 17 depict stage and flow hydrographs near the intersection point of the two models (RAS stations 325.46 and 265.00), for simulations before and after combining the models. A slight difference in the stage at RAS station 325.46 is noticed between the MVK model and the combined MVK and MVN model, but the combining process did not significantly alter the model results.

Figure 14. 2011 stage hydrograph at RAS station 325.46.

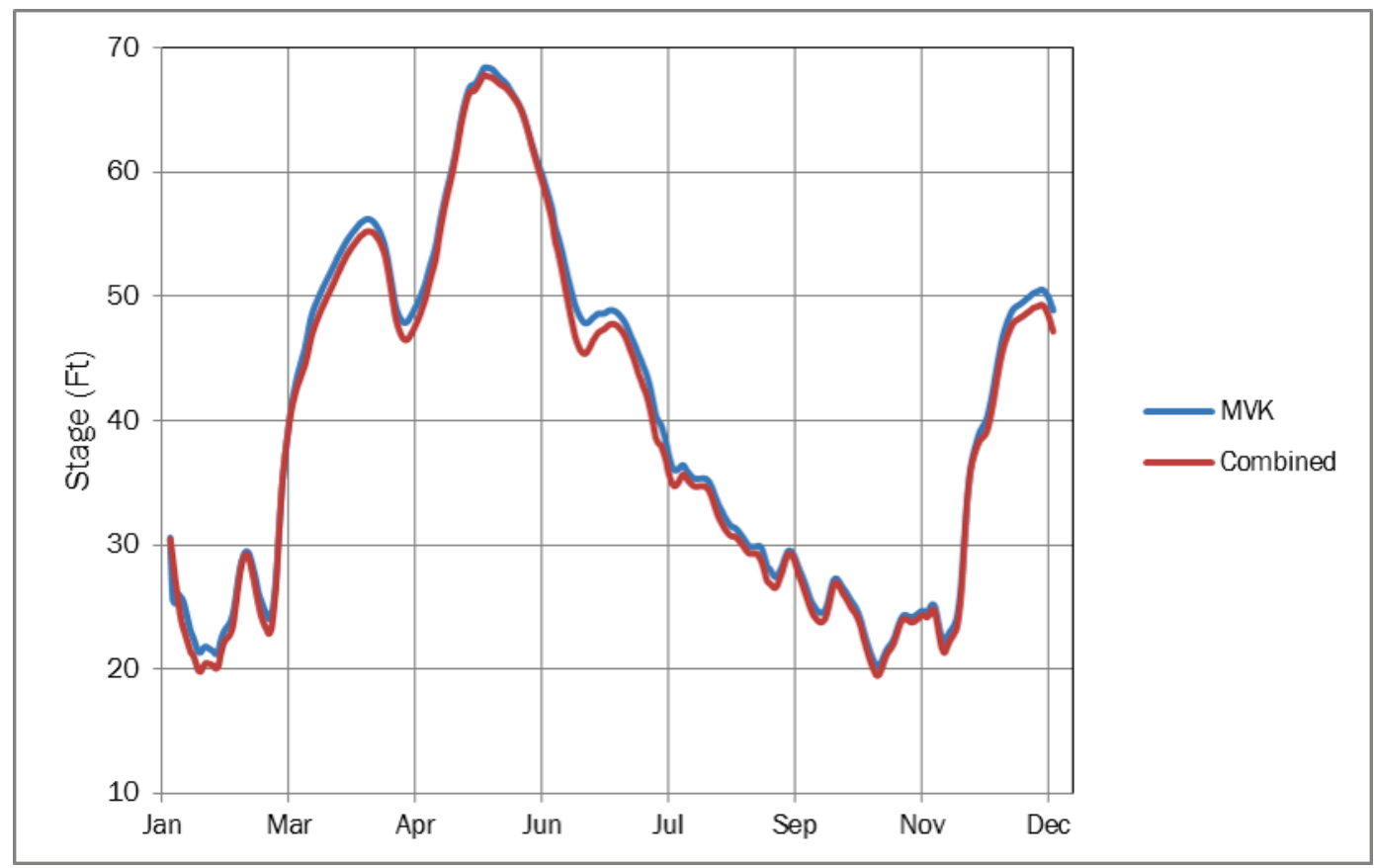


Figure 15. 2011 flow hydrograph at RAS station 325.46.

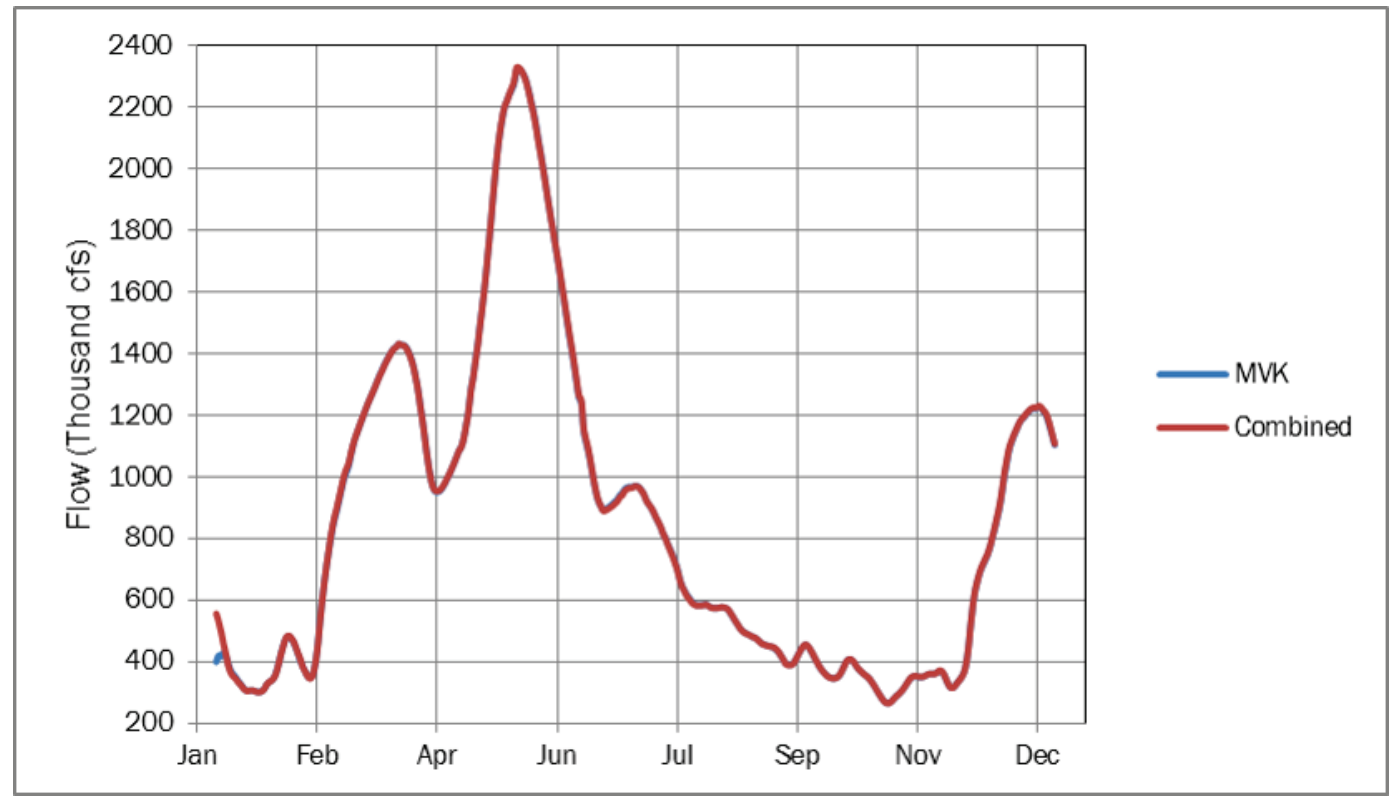

Figure 16. 2011 stage hydrograph at RAS station 265.00.

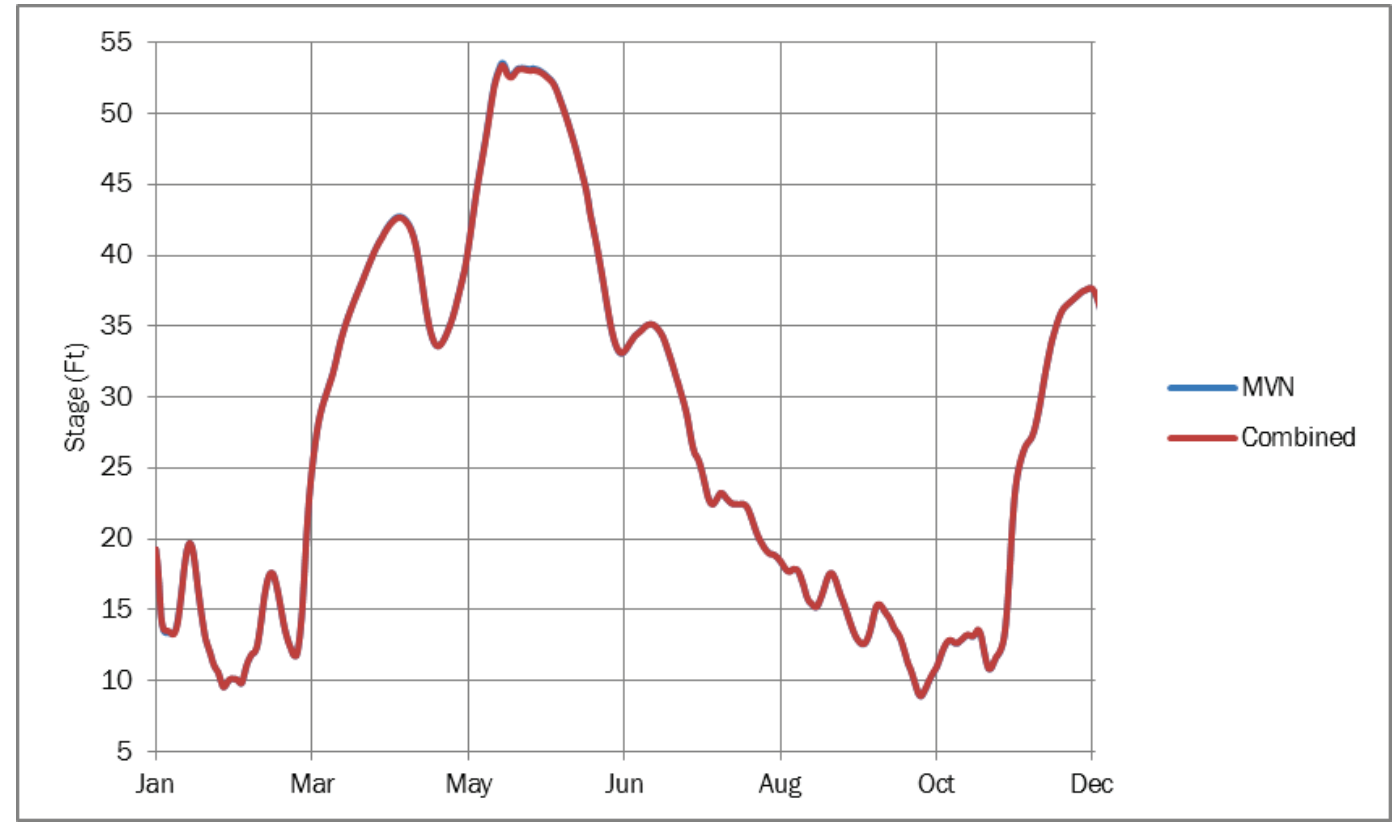


Figure 17. 2011 flow hydrograph at RAS station 265.00.

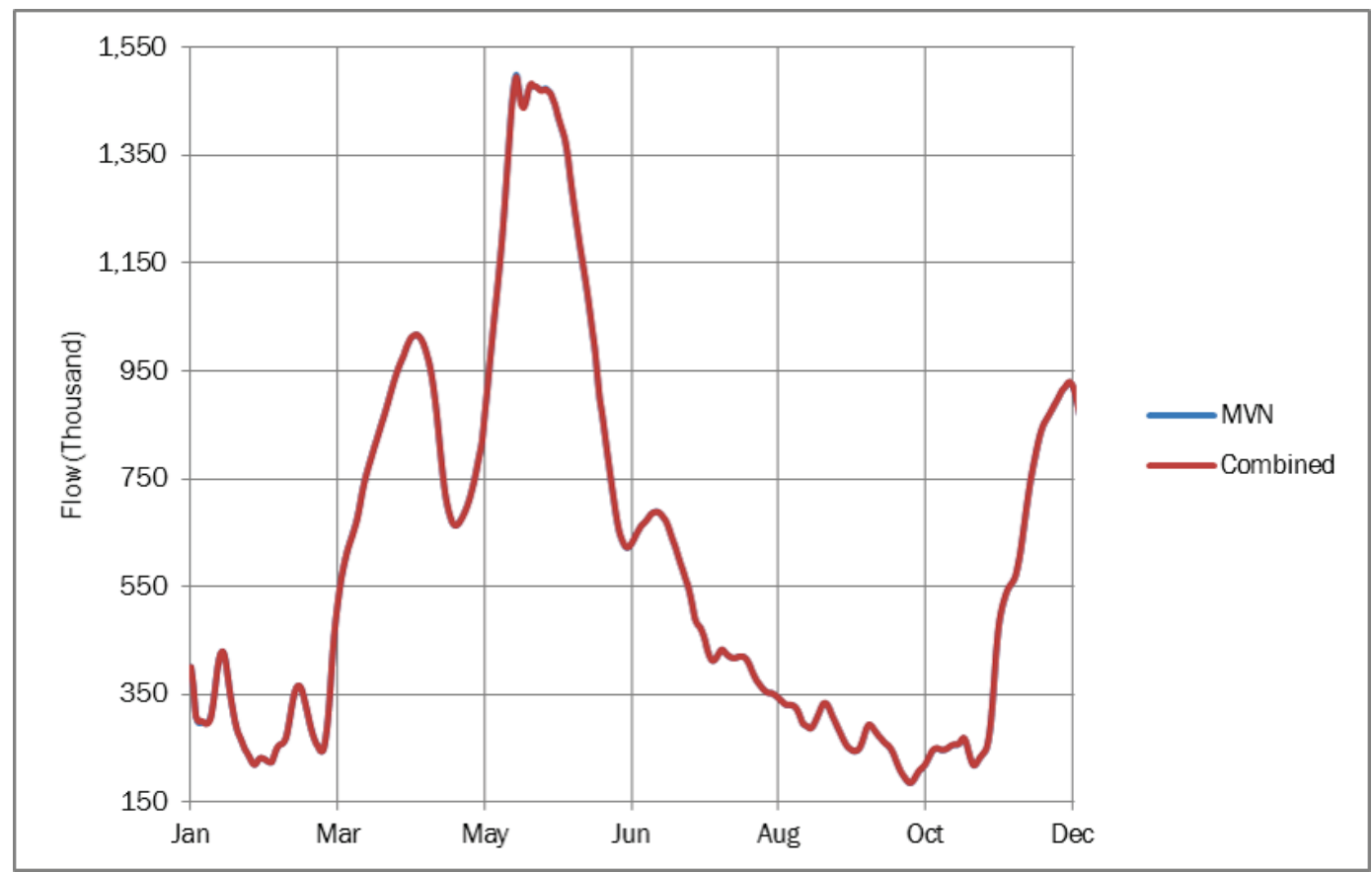

The three separate models were then joined and run as a complete unit. Computed stage and flow hydrographs of the combined MVM, MVK, and MVN models were then checked with the individual and paired models to ensure similarity in the results when comparing the individual vs. combined models. The combined model has a combination of $1 \mathrm{D}$ cross sections and $1 \mathrm{D}$ and $2 \mathrm{D}$ flow areas and was completed using HEC-RAS 5.0.1. The simulation time to run the 2011 full year model is approximately 4 hours on a standard desktop computer.

\subsection{List of model simulations}

Table 4 lists the HEC-RAS plan names that were performed within this project.

Table 4. List of simulations of the HEC-RAS model described in this report.

\begin{tabular}{|l|l|l|}
\hline HEC-RAS Plan Name & Description & $\begin{array}{l}\text { Section of This } \\
\text { Report }\end{array}$ \\
\hline 2011_MVM_MVK_MVN & $\begin{array}{l}\text { 2011 conditions were simulated for calibrating } \\
\text { the combined HEC-RAS model. }\end{array}$ & Section 3.5 \\
\hline 2008_MVM_MVK_MVN & $\begin{array}{l}2008 \text { conditions were simulated to validate the } \\
\text { combined HEC-RAS model. }\end{array}$ & Section 3.5 \\
\hline 2002_MVM_MVK_MVN & $\begin{array}{l}\text { 2002 conditions were simulated to validate the } \\
\text { combined HEC-RAS model. }\end{array}$ & Section 3.5 \\
\hline
\end{tabular}




\begin{tabular}{|c|c|c|}
\hline HEC-RAS Plan Name & Description & $\begin{array}{l}\text { Section of This } \\
\text { Report }\end{array}$ \\
\hline $\begin{array}{l}1955 \text { Historic } 58 \text { AEN Existing } \\
\text { Yazoo_9-28 }\end{array}$ & $\begin{array}{l}\text { Flows for the 58A-EN event from the } 1955 \\
\text { Hydrology Report were run with the Yazoo } \\
\text { Backwater Levee at the existing height. }\end{array}$ & Section 4.3 \\
\hline $\begin{array}{l}1955 \text { Historic 58AEN Authorized } \\
\text { Yazoo }\end{array}$ & $\begin{array}{l}\text { Flows for the 58A-EN event from the } 1955 \\
\text { Hydrology Report were run with the Yazoo } \\
\text { Backwater Levee at the authorized height. }\end{array}$ & Section 4.3 \\
\hline 2016_58A-R_Existing_Yazoo & $\begin{array}{l}\text { Flows for the 58A-R (regulated) event from the } \\
\text { new hydrology were run with the existing Yazoo } \\
\text { Backwater Levee height. }\end{array}$ & Section 5.3.1 \\
\hline 2016_58A-U_Existing_Yazoo & $\begin{array}{l}\text { Flows for the 58A-U (unregulated) event from the } \\
\text { new hydrology were run with the existing Yazoo } \\
\text { Backwater Levee height. }\end{array}$ & Section 5.3.1 \\
\hline 2016_58A-R_Authorized_Yazoo & $\begin{array}{l}\text { Flows for the 58A-R event from the new hydrology } \\
\text { were run with the authorized Yazoo Backwater } \\
\text { Levee height. }\end{array}$ & Section 5.3.1 \\
\hline 2016_58A-U_Authorized_Yazoo & $\begin{array}{l}\text { Flows for the } 58 \mathrm{~A}-\mathrm{U} \text { event from the new hydrology } \\
\text { were run with the authorized Yazoo Backwater } \\
\text { Levee height. }\end{array}$ & Section 5.3.1 \\
\hline $\begin{array}{l}\text { Combined_Optimized_Concept } \\
\text { Run }\end{array}$ & $\begin{array}{l}\text { Flows for the 58A-R event from the new hydrology } \\
\text { were run with the "Concept Run" set of } \\
\text { alternatives for other backwaters and ORCC. }\end{array}$ & Section 6.5 \\
\hline $\begin{array}{l}\text { 2016_58A-R_Existing_YZ_SLR } \\
\text { Adjustment }\end{array}$ & $\begin{array}{l}\text { Flows for the 58A-R event from the new hydrology } \\
\text { were run with the existing Yazoo Backwater Levee } \\
\text { height and the future downstream boundary } \\
\text { condition for sea level rise. }\end{array}$ & Section 7 \\
\hline $\begin{array}{l}\text { Combined Concept Run-SLR } \\
\text { Adjustment }\end{array}$ & $\begin{array}{l}\text { Flows for the } 58 \mathrm{~A}-\mathrm{R} \text { event from the new hydrology } \\
\text { were run the "Concept Run" set of alternatives, } \\
\text { and the future downstream boundary condition } \\
\text { for sea level rise. }\end{array}$ & Section 7 \\
\hline $\begin{array}{l}\text { 2016_58A-R_Authorized_YZ_SLR } \\
\text { Adjustment }\end{array}$ & $\begin{array}{l}\text { Flows for the 58A-R event from the new hydrology } \\
\text { were run with the authorized Yazoo Backwater } \\
\text { Levee height and the future downstream } \\
\text { boundary condition for sea level rise. }\end{array}$ & Section 7 \\
\hline 2016 52A-R Existing Yazoo & $\begin{array}{l}\text { Flows for the } 52 \mathrm{~A}-\mathrm{R} \text { event from the new hydrology } \\
\text { were run with the existing Yazoo Backwater Levee } \\
\text { height. }\end{array}$ & Section 5.3.2 \\
\hline 2016 52A-U Existing Yazoo & $\begin{array}{l}\text { Flows for the } 52 \mathrm{~A}-U \text { event from the new hydrology } \\
\text { were run with the existing Yazoo Backwater Levee } \\
\text { height. }\end{array}$ & Section 5.3 .2 \\
\hline 2016 52A-R Authorized Yazoo & $\begin{array}{l}\text { Flows for the } 52 \mathrm{~A}-\mathrm{R} \text { event from the new hydrology } \\
\text { were run with the authorized Yazoo Backwater } \\
\text { Levee height. }\end{array}$ & Section 5.3 .2 \\
\hline 2016 52A-U Authorized Yazoo & $\begin{array}{l}\text { Flows for the } 52 \mathrm{~A}-\mathrm{U} \text { event from the new hydrology } \\
\text { were run with the authorized Yazoo Backwater } \\
\text { Levee height. }\end{array}$ & Section 5.3 .2 \\
\hline
\end{tabular}




\begin{tabular}{|l|l|l|}
\hline HEC-RAS Plan Name & Description & $\begin{array}{l}\text { Section of This } \\
\text { Report }\end{array}$ \\
\hline 2016 56-R Existing Yazoo & $\begin{array}{l}\text { Flows for the 56-R event from the new hydrology } \\
\text { were run with the existing Yazoo Backwater Levee } \\
\text { height. }\end{array}$ & Section 5.3.2 \\
\hline 2016 56-U Existing Yazoo & $\begin{array}{l}\text { Flows for the 56-U event from the new hydrology } \\
\text { were run with the existing Yazoo Backwater Levee } \\
\text { height. }\end{array}$ & Section 5.3.2 \\
\hline 2016 56-R Authorized Yazoo & $\begin{array}{l}\text { Flows for the 56-R event from the new hydrology } \\
\text { were run with the authorized Yazoo Backwater } \\
\text { Levee height. }\end{array}$ & Section 5.3.2 \\
\hline 2016 56-U Authorized Yazoo & $\begin{array}{l}\text { Flows for the 56-U event from the new hydrology } \\
\text { were run with the authorized Yazoo Backwater } \\
\text { Levee height. }\end{array}$ & Section 5.3.2 \\
\hline 2016 63-R Existing Yazoo & $\begin{array}{l}\text { Flows for the 63-R event from the new hydrology } \\
\text { were run with the existing Yazoo Backwater Levee } \\
\text { height. }\end{array}$ & Section 5.3.2 \\
\hline 2016 63-U Authorized Yazoo & $\begin{array}{l}\text { Flows for the 63-U event from the new hydrology } \\
\text { were run with the existing Yazoo Backwater Levee } \\
\text { height. }\end{array}$ & Section 5.3.2 \\
\hline 2016 63-R Authorized Yazoo & $\begin{array}{l}\text { Flows for the 63-R event from the new hydrology } \\
\text { were run with the authorized Yazoo Backwater } \\
\text { Levee height. }\end{array}$ & Section 5.3.2 \\
\hline Levee height. \\
\hline Fere run with the authorized Yazoo Backwater \\
\hline
\end{tabular}

\subsection{Results}

The results of the calibration event of 2011 as well as the 2002 and 2008 validation events for the combined model are compared with the observational data. (Appendices A, B, and C contain more detailed results from the individual district models.) Of the many possible comparisons that can be made, a few important locations along the mainstem of the Mississippi River have been chosen to present visual comparisons for this report. The appendices contain more detailed results from the individual district models.

Stage comparisons for Helena, AR; Natchez, MS; and Baton Rouge, LA, as well as flow for Baton Rouge, are shown for the 2011 calibration event in Figure 18 through Figure 21. 
Figure 18. 2011 simulated and observed stages for Helena, AR (RAS station 676.42).

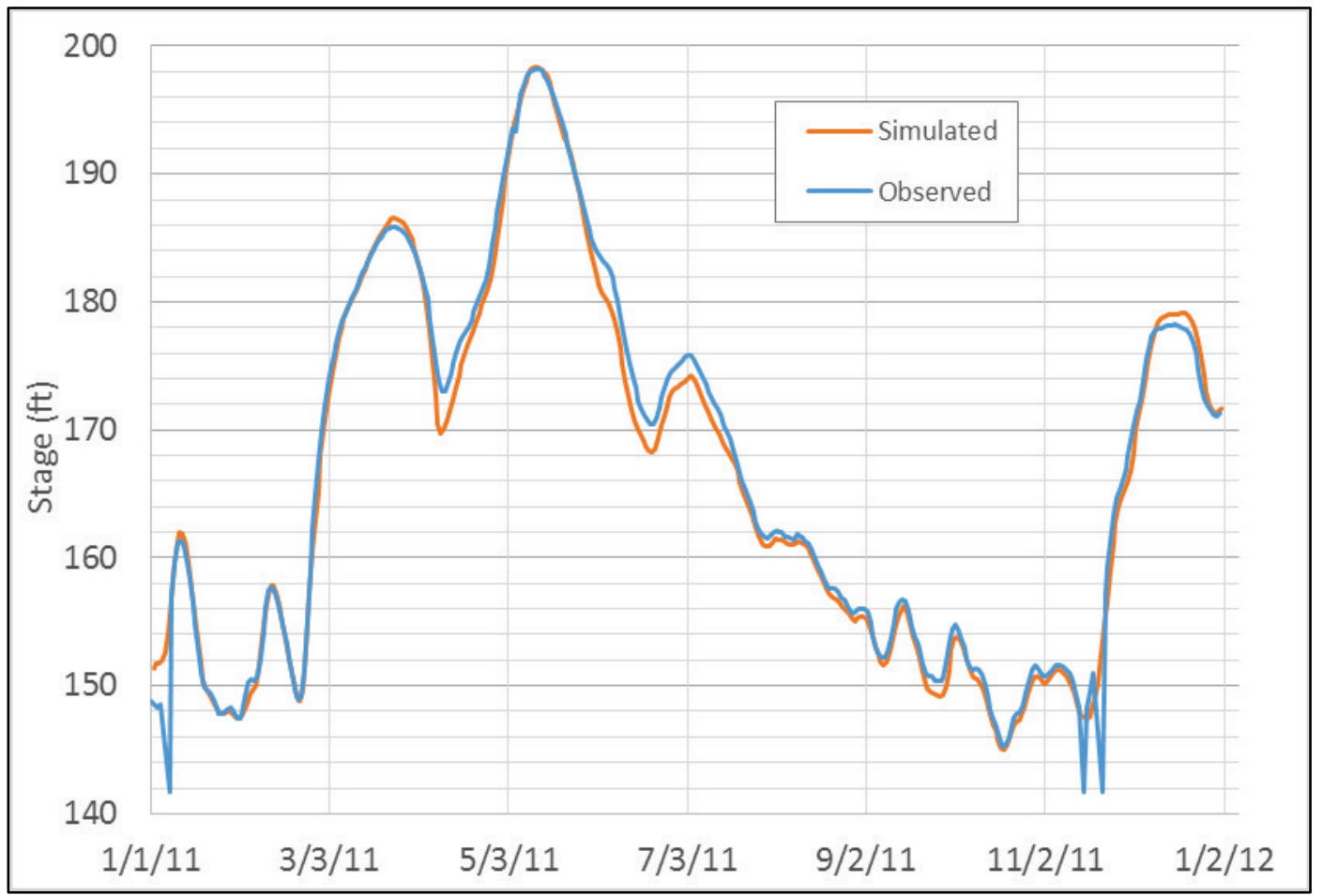

Figure 19. 2011 simulated and observed stages for Natchez, MS (RAS station 368.44).

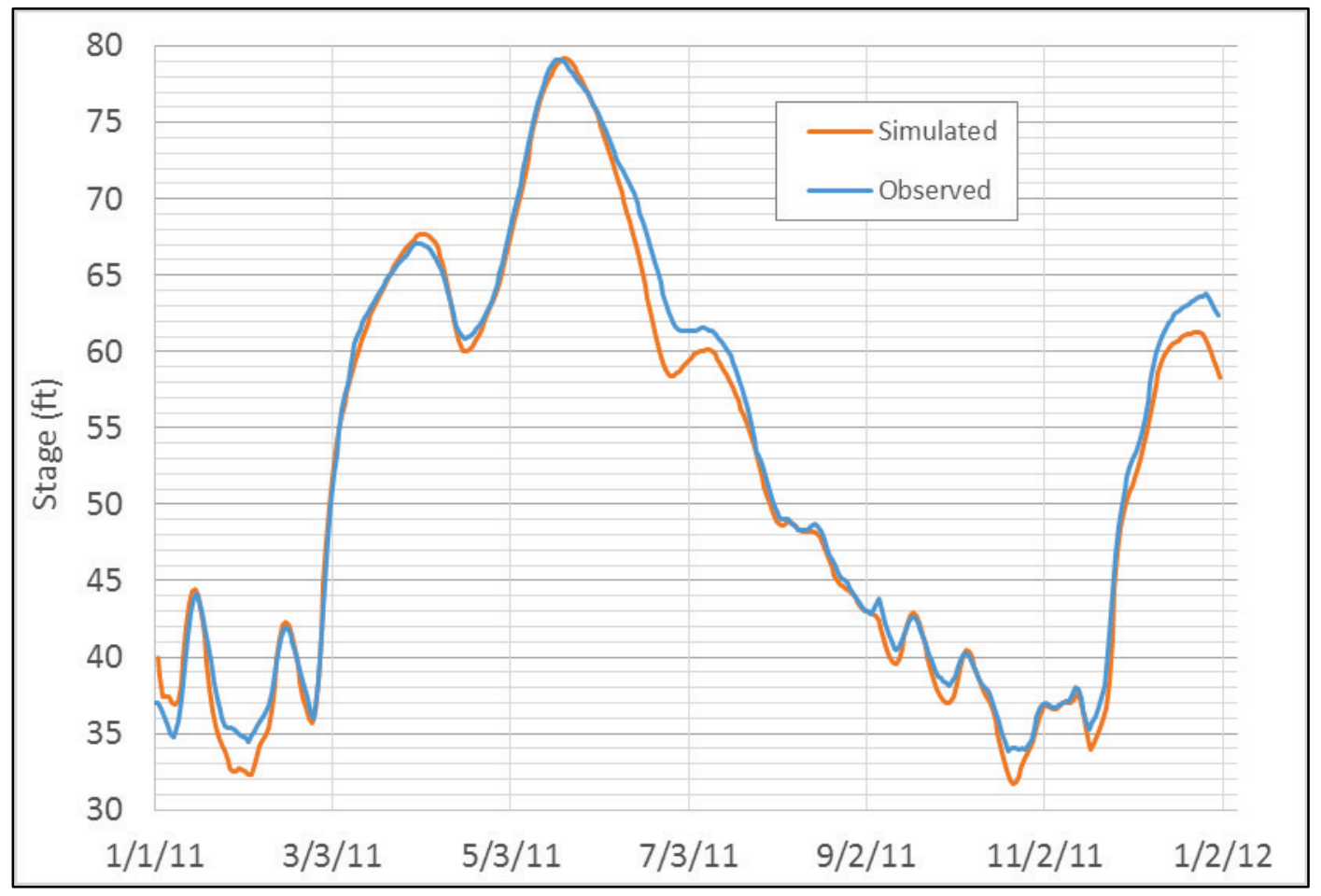


Figure 20. 2011 simulated and observed stages for Baton Rouge, LA (RAS station 232.49).

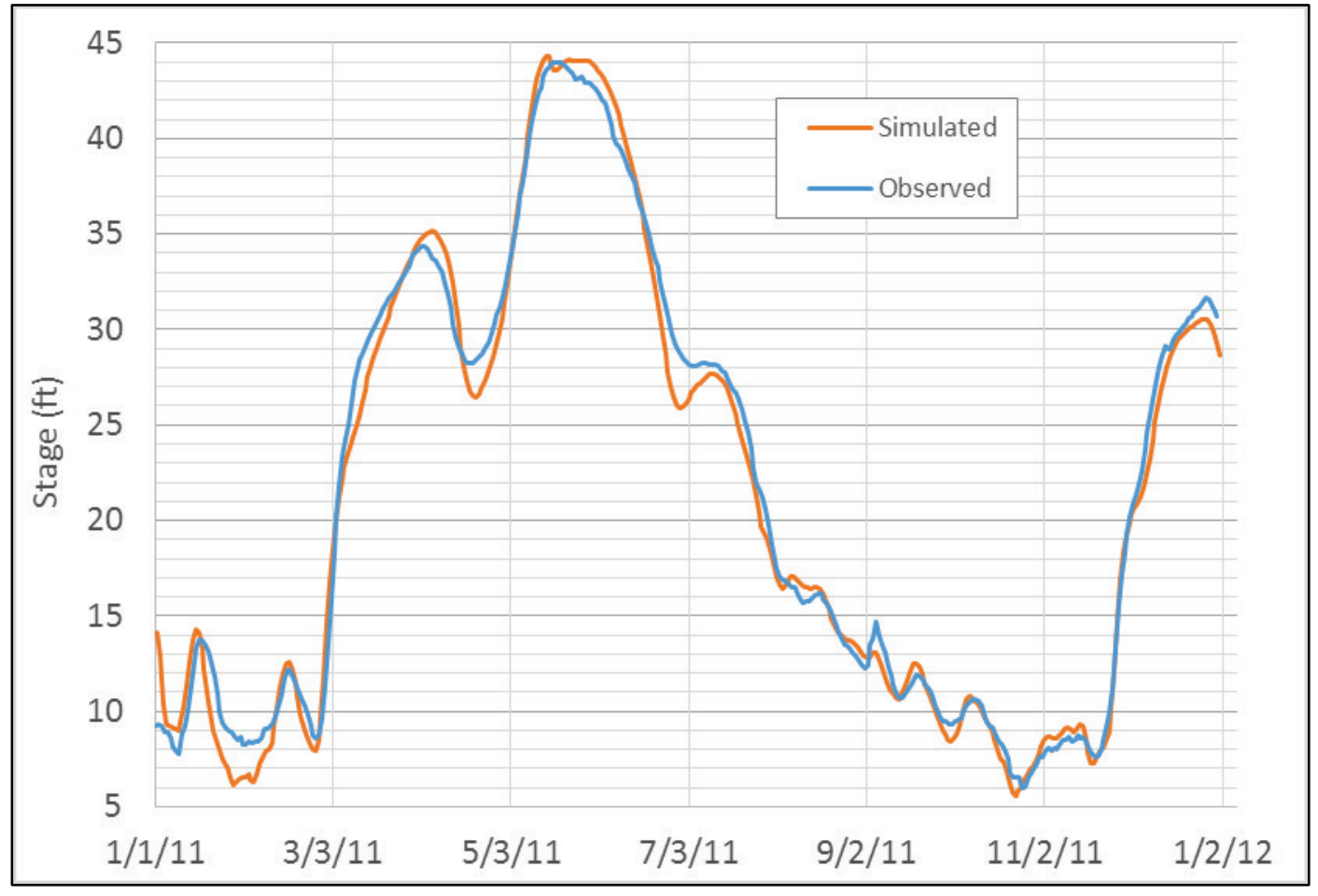

Figure 21. 2011 simulated and observed flows for Baton Rouge, LA (RAS station 232.49).

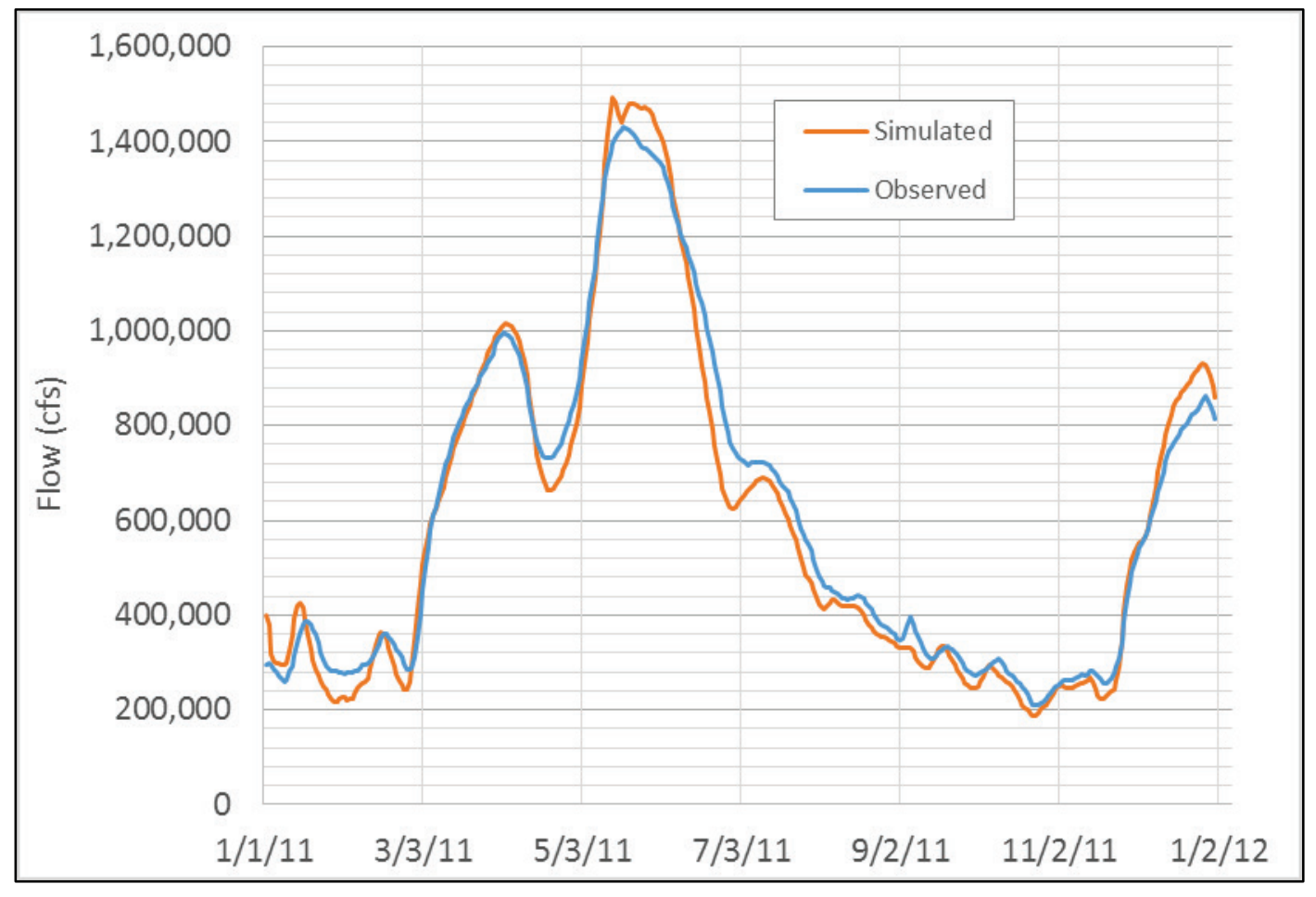


The same comparisons are made for the 2002 and 2008 events to check the performance of the combined model. The 2002 comparisons are shown in Figure 22 through Figure 25, and the 2008 comparisons are shown in Figure 26 through Figure 29. Further details about the individual district models can be found in the appendices.

Figure 22. 2002 simulated and observed stages for Helena, AR.

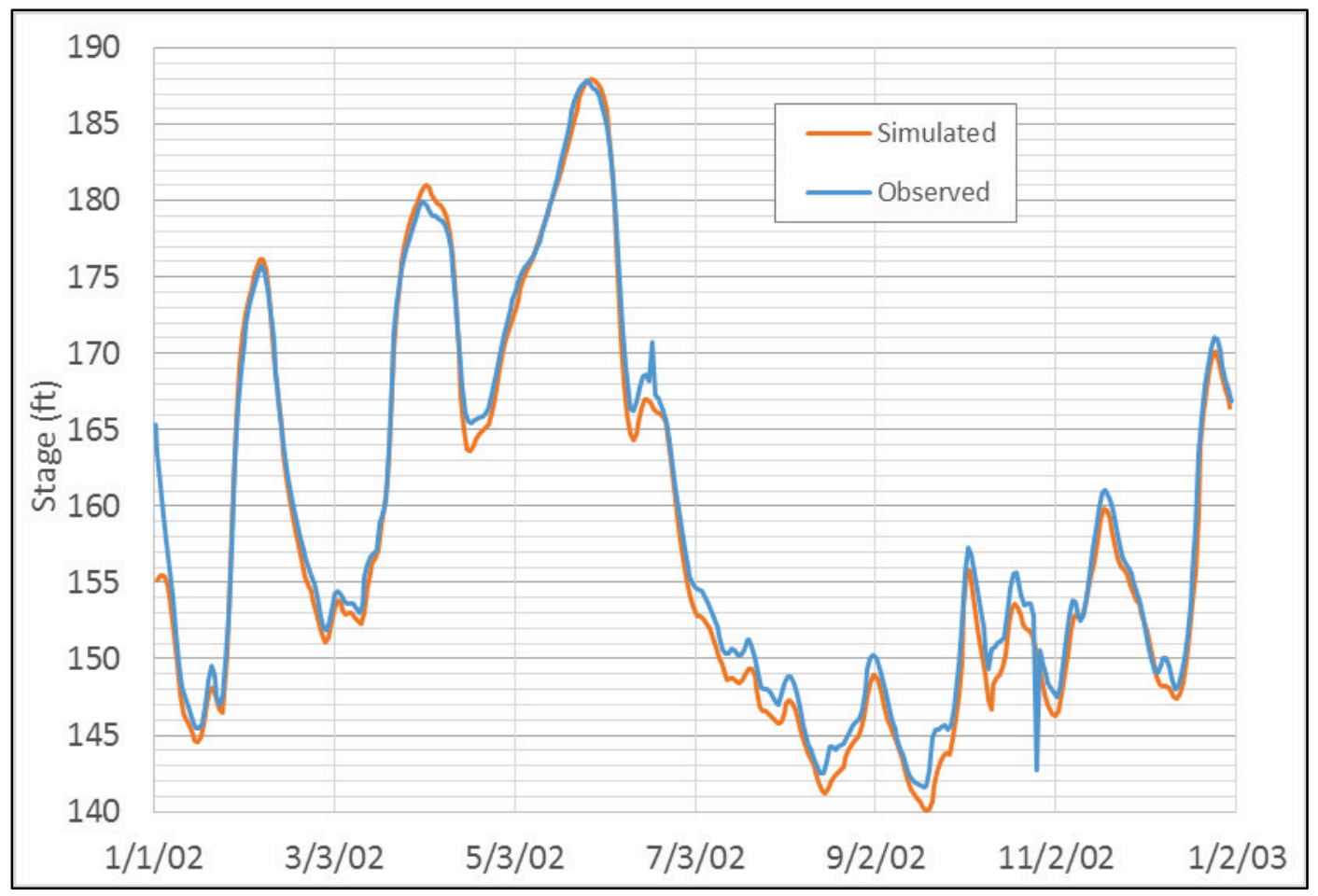


Figure 23. 2002 simulated and observed stages for Natchez, MS.

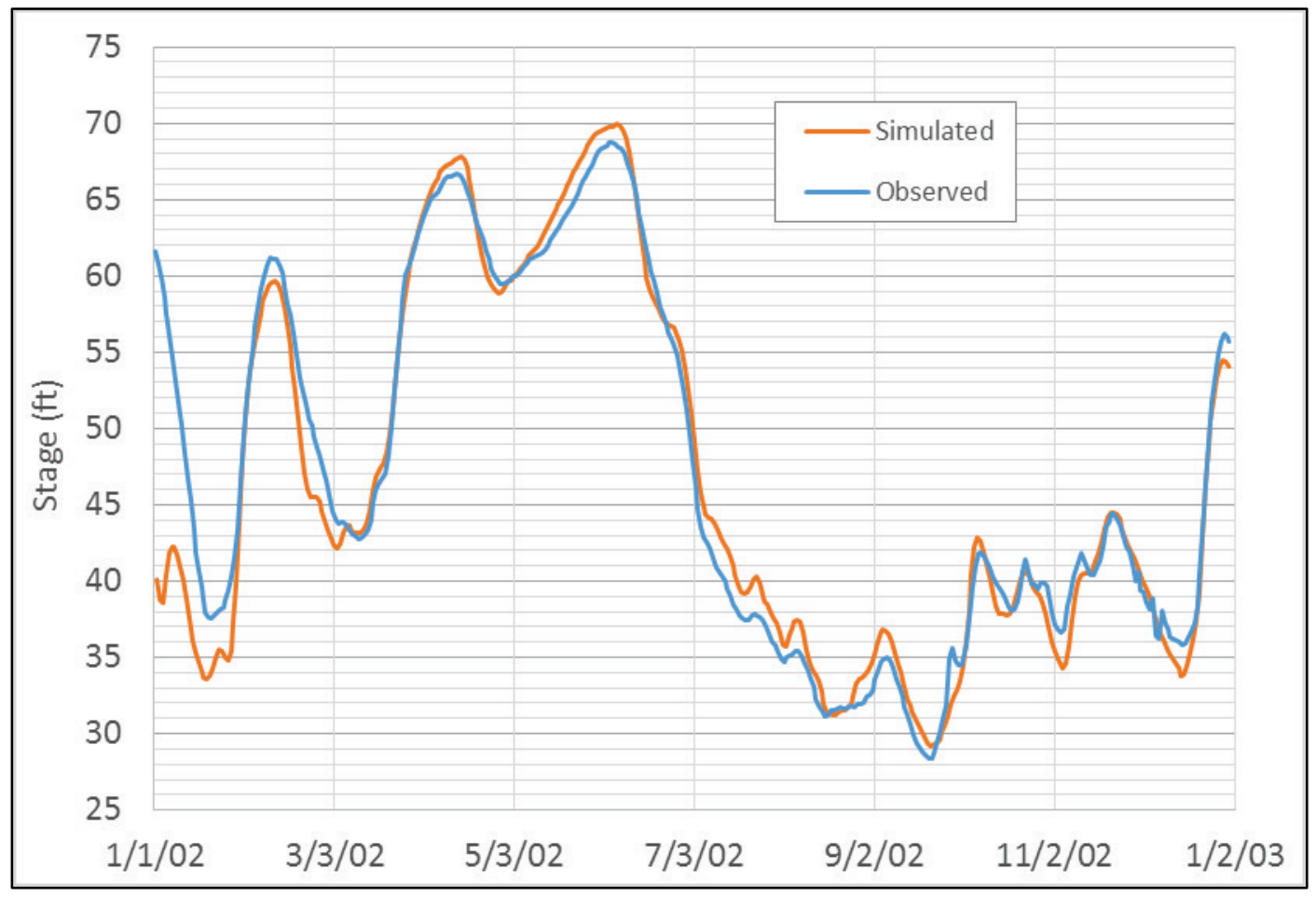

Figure 24. 2002 simulated and observed stages for Baton Rouge, LA.

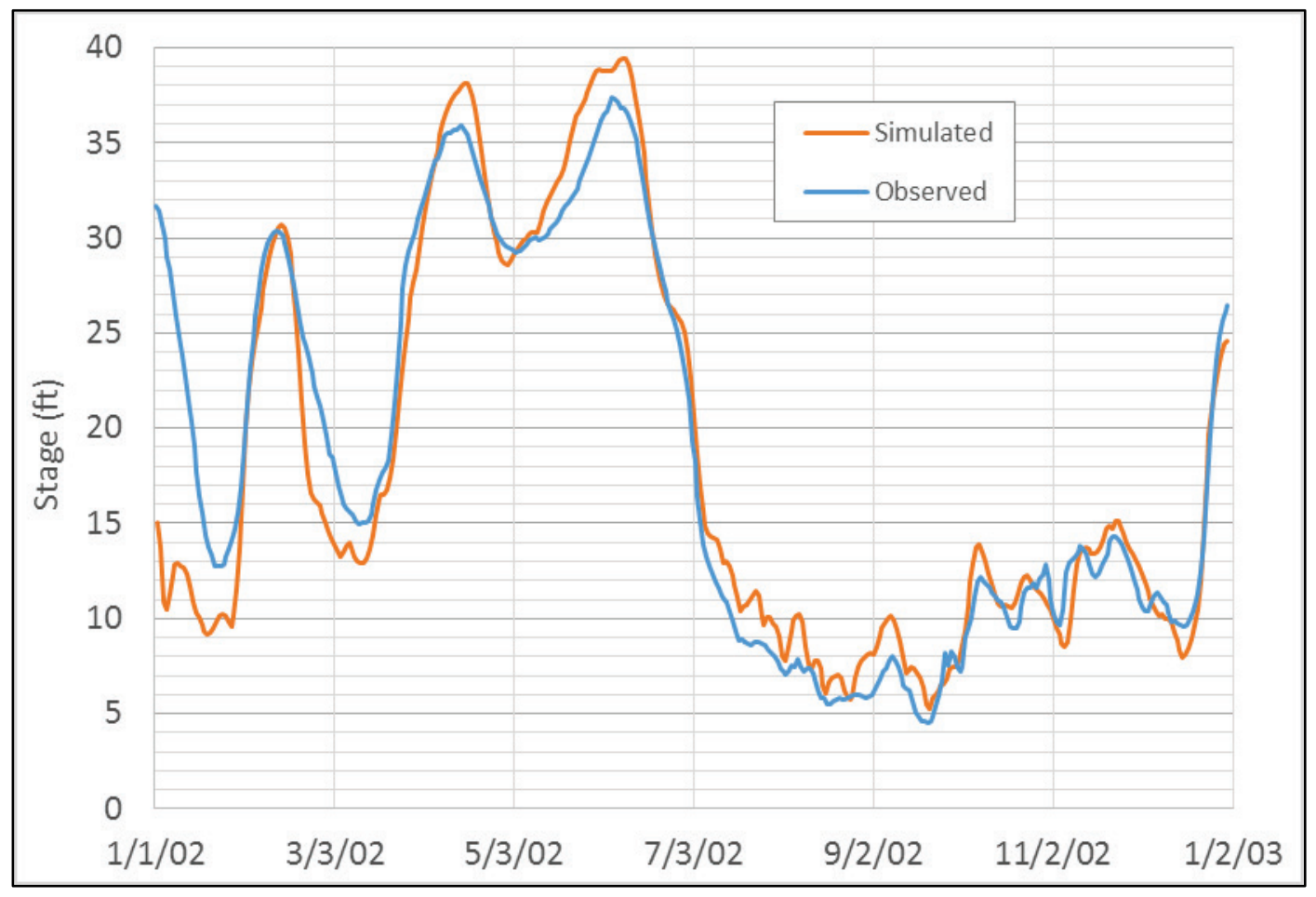


Figure 25. 2002 simulated and observed flows for Baton Rouge, LA (gaps indicate data were not received for that time period).

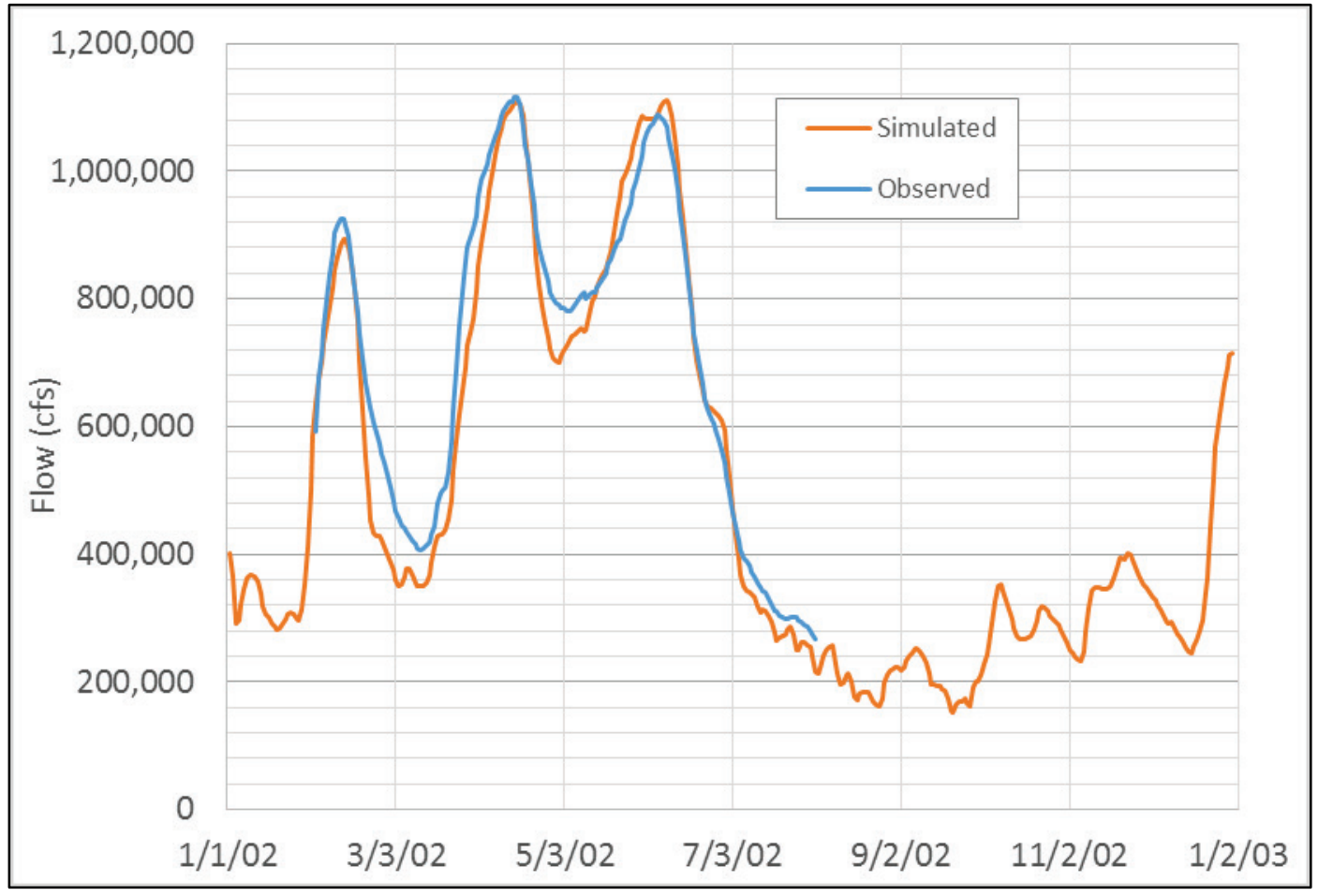

Figure 26. 2008 simulated and observed stages for Helena, AR.

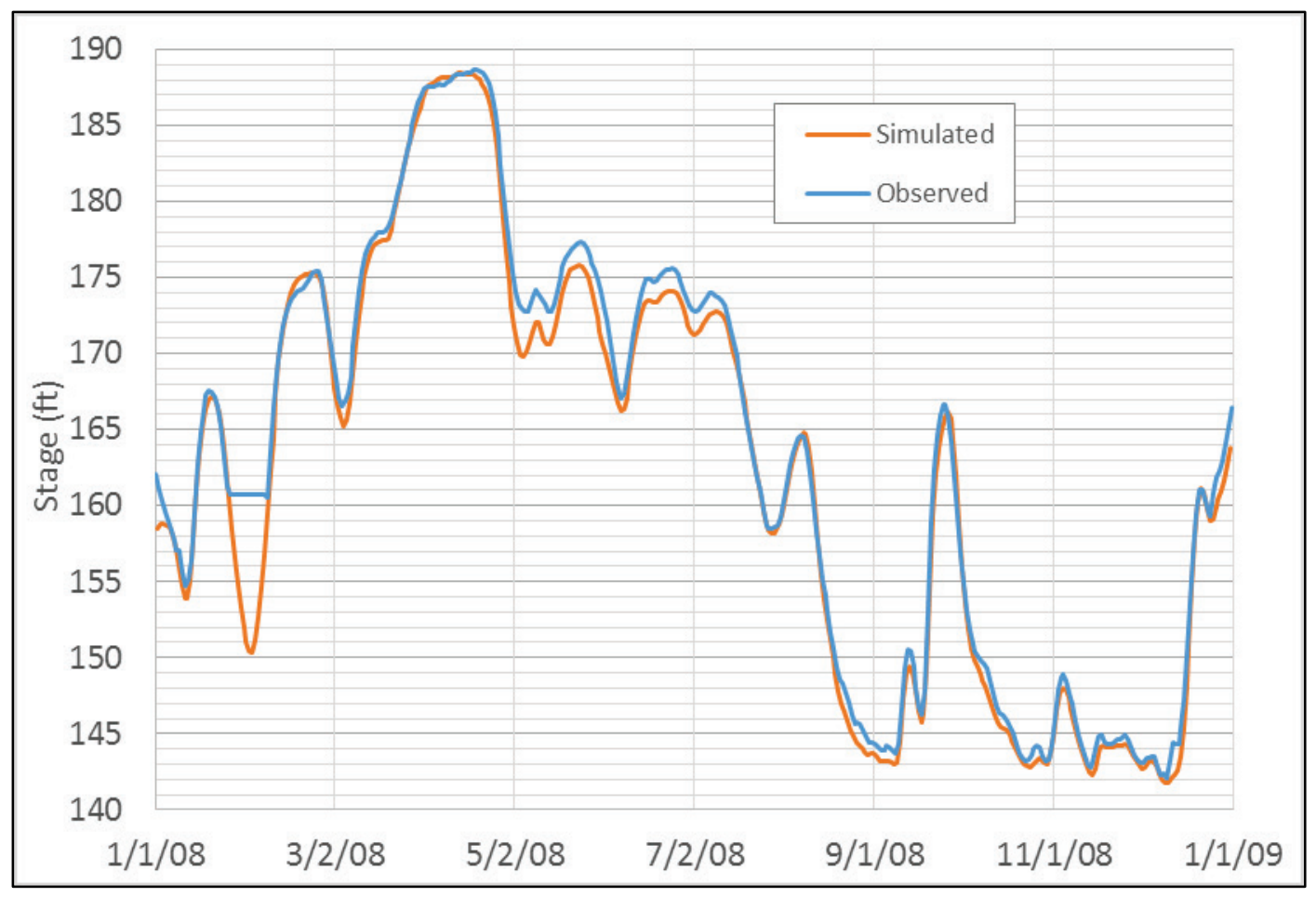


Figure 27. 2008 simulated and observed stages for Natchez, MS.

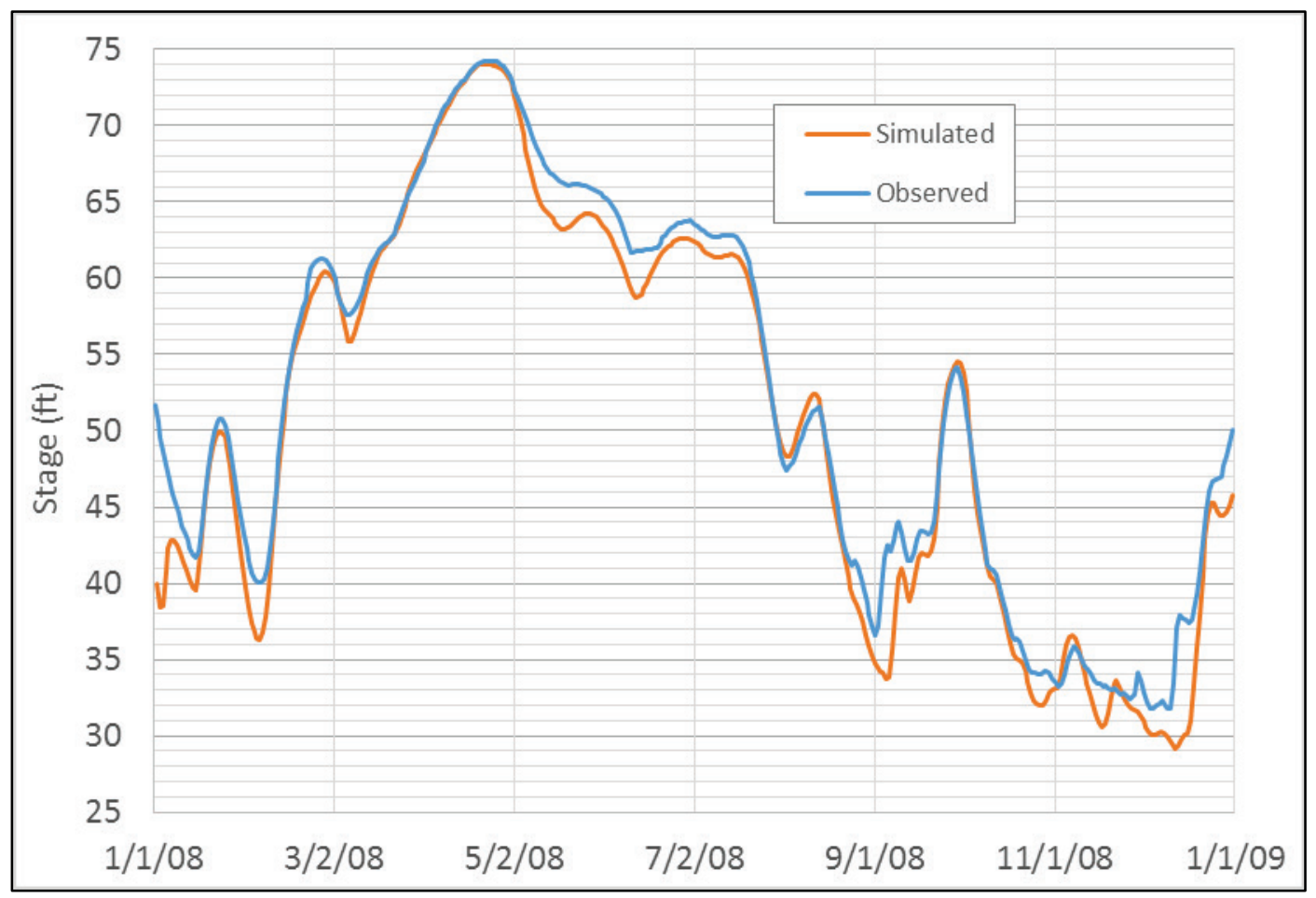

Figure 28. 2008 simulated and observed stages for Baton Rouge, LA.

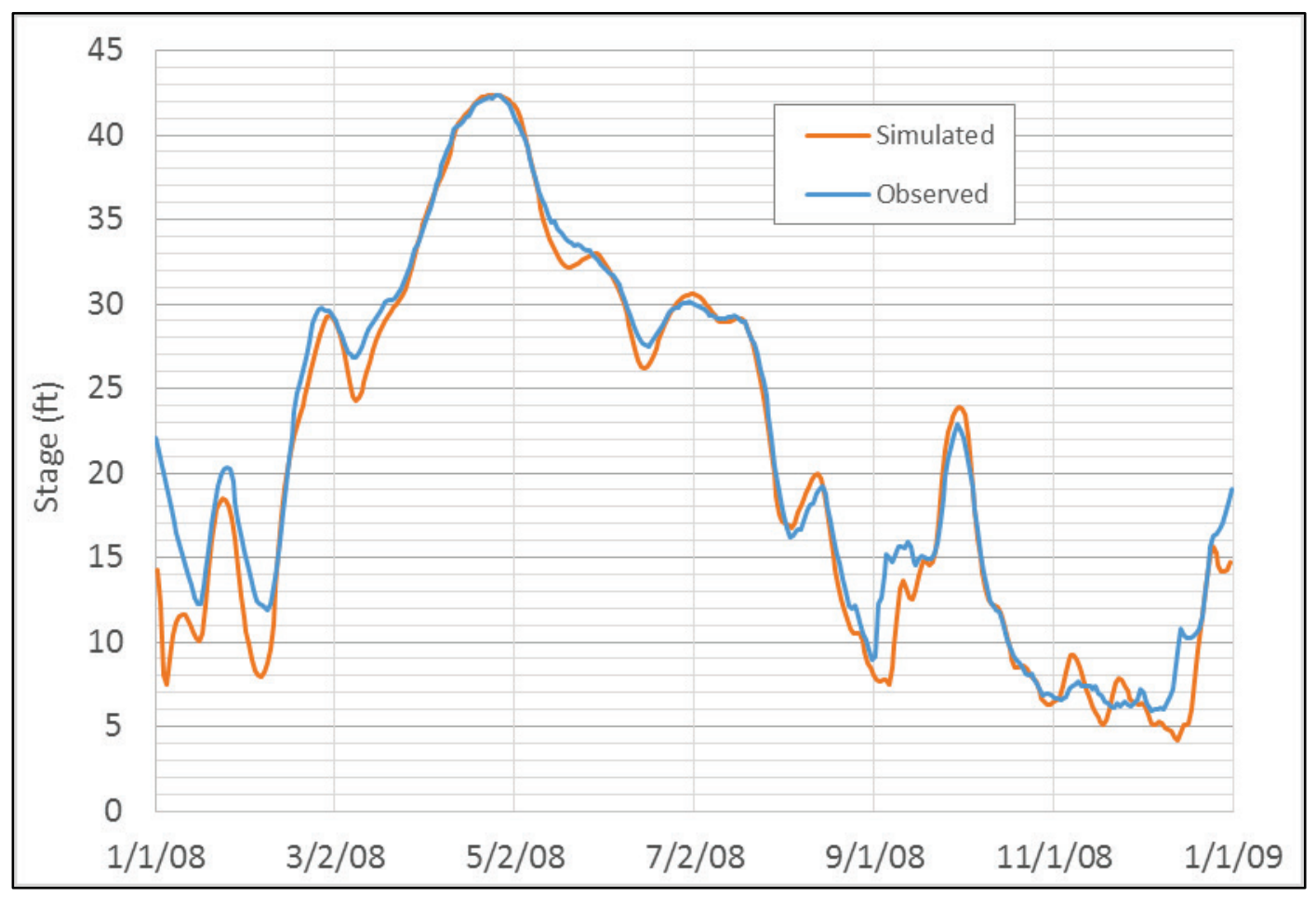


Figure 29. 2008 simulated and observed flows for Baton Rouge, LA.

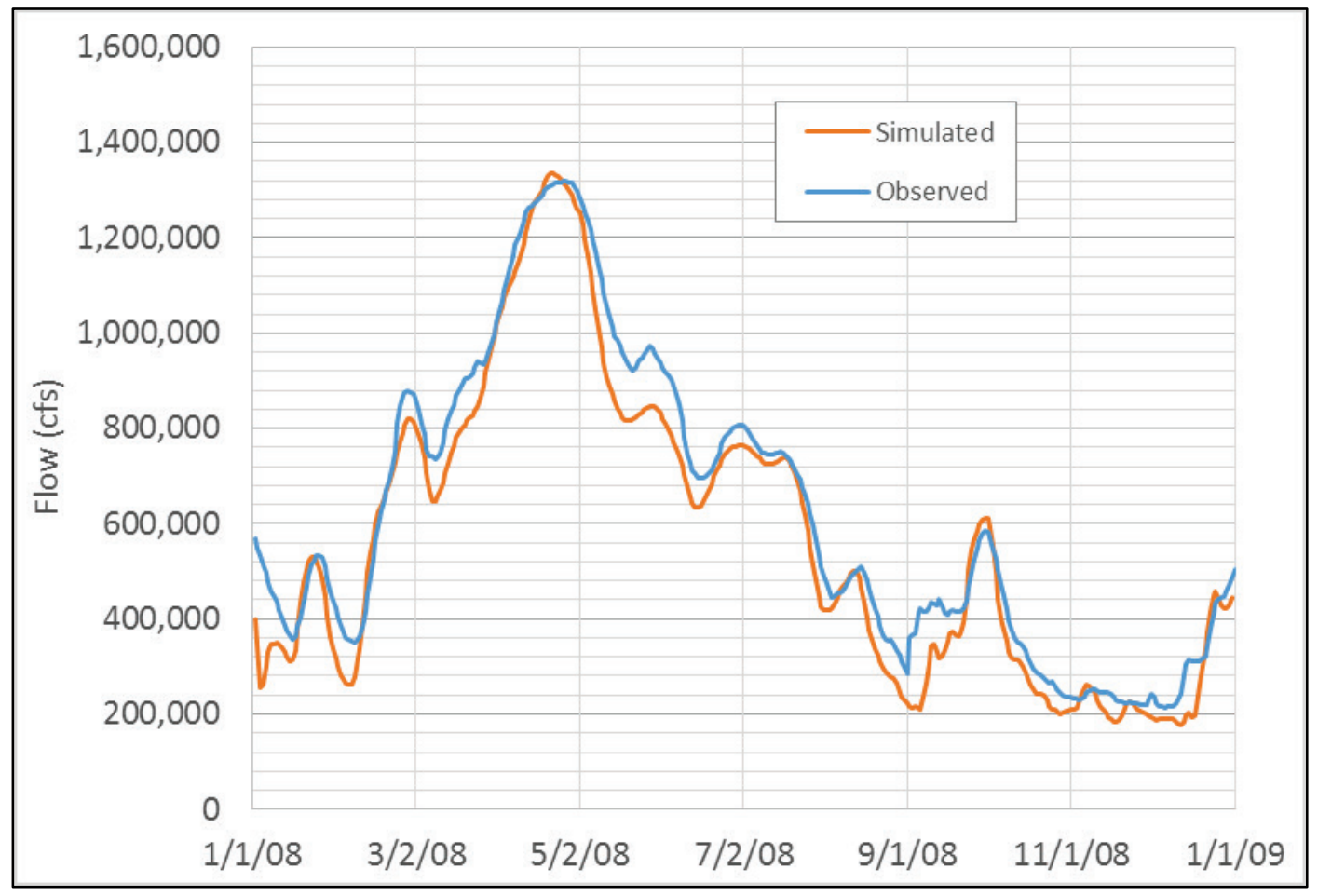




\section{Simulations Using the 1955 Historical Project Design Flood (PDF) Flows}

PDF events were used in designing the MR\&T system to effectively convey a specific flood event from the vicinity of Cairo, IL, downstream through Venice, LA, and into the Gulf of Mexico. The event that was approved to be used in the original study to design the system was called the 58A-EN PDF. This flood factored in the influence of reservoirs that were either built, under construction, or scheduled to be constructed shortly after 1955 (USACE 1955). The 58A-EN flows are resultant of a January 1937 winter storm, with rainfall excess increased 10\%, occurring over the entire basin; followed by a January 1950 storm occurring over select areas; followed by a February 1938 storm occurring over select areas. The original MR\&T-Main Levee system Project PDF events were developed in the 1955-1957 time period (USACE 1957).

At one point during the 1973 flood, it was determined that more rainfall could raise the flows and stages to the point that various levee systems might overtop. Consequently, some of the levees were quickly raised using emergency methods. Following the flood, the MR\&T-Main Levee system was reanalyzed, due to the flood's impact on the basin. It was known at that time that the Mississippi River Basin had geomorphically changed appreciably over the 20 years since the 1955-1956 MR\&T levee system had been approved. These changes included the deterioration of the floodcarrying capacity of many parts of the system. Consequently, a Refined 1973 MR\&T Project Flood Flowline Report (USACE 1978) was developed in which the historical 1955 PDF flows were routed through an updated river system. The updates included cross sections, constructed and proposed levees, floodwalls, flood storage areas, and diversion structures.

\subsection{Methodology}

To assess the changes that have occurred since the approval of the 1955 MR\&T system, this project's model team ran two model simulations of the 1955 historical 58A-EN PDF, namely the "Historic PDF - Existing Yazoo" and "Historic PDF - Authorized Yazoo" simulations. These two runs used the validated HEC-RAS model with adjustments as detailed in Section 3.2. Figure 30 is a schematic of the historical PDF flows at various locations of the MR\&T system. Differences between the historically determined PDF water surface elevations and the current 
HEC-RAS results (based on routing the historical flows) demonstrated the impact of differences in the numerical modeling framework, changes in geometry, and changes in roughness between the current study and the Refined 1973 Flowline Study (USACE 1978). The Refined 1973 Flowline is the current Mississippi River and Tributaries (MR\&T) flowline on which the project design levee elevations are based. The study was basically an analytical evaluation, using the HEC-2 watersurface profile computer program to determine flowline elevations that would be attained for the flows resulting from the 58A-EN Project Design Flood. Channel and overbank cross sections were surveyed for use in analyzing the flood-carrying capacity of the Mississippi River floodway under 1973 conditions.

Figure 30. Historic PDF flows within the MR\&T system (flow in $1000 \mathrm{cfs}$ ).

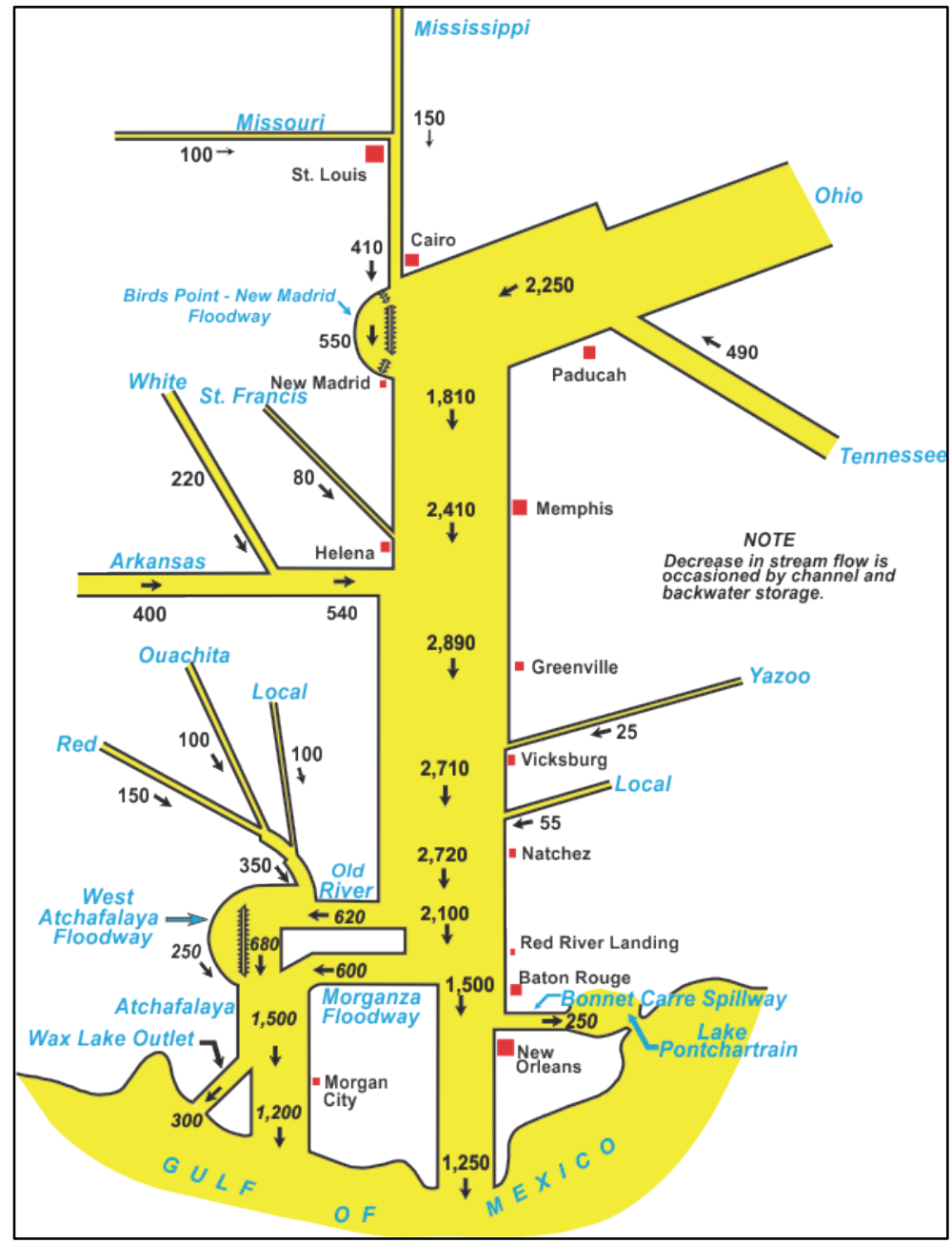


The diversion of the Mississippi River water through the ORCC was accomplished by following the congressionally approved Water Control Plan for the operation of the ORCC structures. This operational plan was also used in the analysis conducted in the 1955 and 1973 studies. The plan is detailed according to House Document 478 (U.S. Congress 1954). The ORCC operational plan directs the USACE to evaluate the forecasted Mississippi River and Red River discharges. Based on the forecast, the USACE is directed to adjust the ORCC operation so that, on an annual basis, 70\% of the Mississippi-Atchafalaya River combined discharge downstream of ORCC passes Red River Landing (RRL) while 30\% of the discharge passes Simmesport. Specifically, the objective is to operate the ORCC so that the 70/30 distribution of flow is met on a daily basis to not deviate too far from the mandated annual percentages. This daily distribution of flow is how the hydraulic model was run to operate the ORCC for this assessment. Additionally, the models were limited to stay below this flow at ORCC. The current PDF peak flow through the ORCC is 620,000 cubic feet per second (cfs). This is based on an upstream Project Design Flood peak flow of 2.72 million cfs.

The remaining flood flow was routed downstream of ORCC. The resulting peak flow in the updated model at RRL was computed as $2,105,900 \mathrm{cfs}$, as compared to the $2,100,000 \mathrm{cfs}$ that was routed in the 1955 study. Below RRL, the Morganza Floodway exists to maintain a Mississippi River downstream flow of 1.5 million cfs. In the Refined 1973 Flowline Study (USACE 1978) model, any measured flow above 1.5 million cfs was diverted through the Morganza Floodway and into the Atchafalaya Basin as according to the approved Water Control Plan for the Floodway (USACE 2000; USACE 2014).

The Bonnet Carré Spillway, located approximately 30 miles upstream of New Orleans on the Mississippi River, was modeled to limit the flows in the Mississippi River to 1.25 million cfs downstream of the structure. The design flows through Morganza Floodway and Bonnet Carré Spillway are $600,000 \mathrm{cfs}$ and $250,000 \mathrm{cfs}$, respectively.

The Red River Backwater area was more difficult to model due to the large amount of flood water storage available. The model was revised to include the backwater area by including levees (lateral structures) and raising other lateral structures to divert the maximum authorized flow of $350,000 \mathrm{cfs}$. The model diverted $364,200 \mathrm{cfs}$, which was more than the 
authorized flow, and was routed to combine with the authorized flow of $620,000 \mathrm{cfs}$ through the ORCC. In addition, proper timing of these two peaks required an additional amount of floodwater be added from the backwater area near the Simmesport gage, on the Atchafalaya River, to get the appropriate flow at that location. The official peak flow at Simmesport on the Atchafalaya River was 930,000 cfs, and the adjusted HEC-RAS model achieved a peak flow of 964,450 cfs.

The first run, "Historic PDF - Existing Yazoo," routed the 1955 58A-EN hydrology through the updated 2011 model to determine the resulting water surface elevations based on current conditions. The simulation was completed by utilizing the historic flows as the upstream boundaries and allowing the model to route the flow throughout the system. The results of this simulation evaluate the effectiveness of multiple MR\&T backwater storage areas (including the Yazoo Backwater area) based on the current system. The "Historic PDF - Existing Yazoo" run was performed with the Yazoo Backwater Levee at the existing elevation (see Section 4.2.6).

The second run, "Historic PDF - Authorized Yazoo," was similar to the first run except that the Yazoo Backwater Levee was raised to its authorized elevation of $112.8 \mathrm{ft}$.

\subsection{Model adjustments}

This section describes the changes that were required to complete the two historic runs "Historic PDF - Existing Yazoo" and "Historic PDF Authorized Yazoo.”

The HEC-RAS model was upgraded to newer release versions of the HEC-RAS software. The combined model was converted from a HECRAS 4.2 beta version to a HEC-RAS 5.0 beta version to the officially released HEC-RAS version 5.0 and then finally to the officially released HEC-RAS version 5.0.1. Each of the calibration and validation simulations were recomputed with the final version 5.0.1. No significant differences were noticed, so no changes were required to upgrade the model to version 5.0.1. 


\subsubsection{Hydrology connections}

The Flowline Study from the 1950s produced flows from a hydrologic perspective that were translated into elevations and stages using hand calculations of the standard step method as well as existing rating curve data. The Flowline studies from the 1970s (USACE 1978) utilized the same flows from the 1950 s but utilized computer software to solve the steady-state equations with more dense cross-sectional data that reflected the geometric conditions at the time. Due to discrepancies in the original hydrology setup and the data requirements of the unsteady model, a perfect comparison that separates out the differences in methodology and geometry cannot be obtained; however, simulating the historic flows in the unsteady model can help provide insight into those differences.

The upstream boundary conditions of the HEC-RAS model were adjusted using the available historic hydrograph data to provide a comparison between the Refined 1973 Flowline Study (USACE 1978) and the current assessment. Figure 31 and Figure 32 show the historic subbasin delineations in red outlines on top of the current subbasin delineations used for the HEC-RAS model. The current subbasins are shown by the colored polygons in the figure. The lettered labels correspond to the red-outlined historic subbasin delineations. The historic hydrology from the 1950 os routed flows through coarse basins by today's standards with the main focus being total flow on the mainstem Mississippi River and large, key tributaries to the system. The current unsteady model represents the system in much finer detail including smaller tributaries and time-varying conveyance and storage computations. To maximize utility of the current unsteady model, the original hydrologic flows had to be manipulated to provide the inputs necessary for an unsteady model simulation. The unsteady model was truncated to locations where tabulated flow hydrograph input was available. For example, the calibrated model included the Tennessee and Cumberland Rivers and had an upstream boundary on the Ohio River at Smithland, KY, but tabulated historic data were not available for any of these locations. Tabulated historic data were available at Metropolis, IL, which is downstream of all the aforementioned locations; thus, the unsteady model boundary was set to begin at Metropolis, IL, to simulate the historic dataset. 
In some cases, the spatially coarser historic hydrograph data needed to be distributed among multiple boundary condition inputs of the finer resolution current HEC-RAS model tributary connections. These flow distributions were primarily done for the historic subbasins labeled X-1, $\mathrm{X}-2$, and $\mathrm{X}-3$ (Figure 32). The flow distribution factors were determined based on the spatial area of the current subbasins divided by the area of the larger, historic subbasin. These factors for specific points (numbered in Figure 32), along with River, RAS Station, and brief explanation, are shown in Table 5. Note that the majority of the flow contributions come from the Mississippi and Ohio Rivers and did not use the drainage area ratio method-they were based on historic published hydrographs; however, the drainage area method allows for the overall volume to be fully captured and maximizes the utility of the current unsteady model.

Figure 31. Subbasins with available historic hydrographs of flow data.

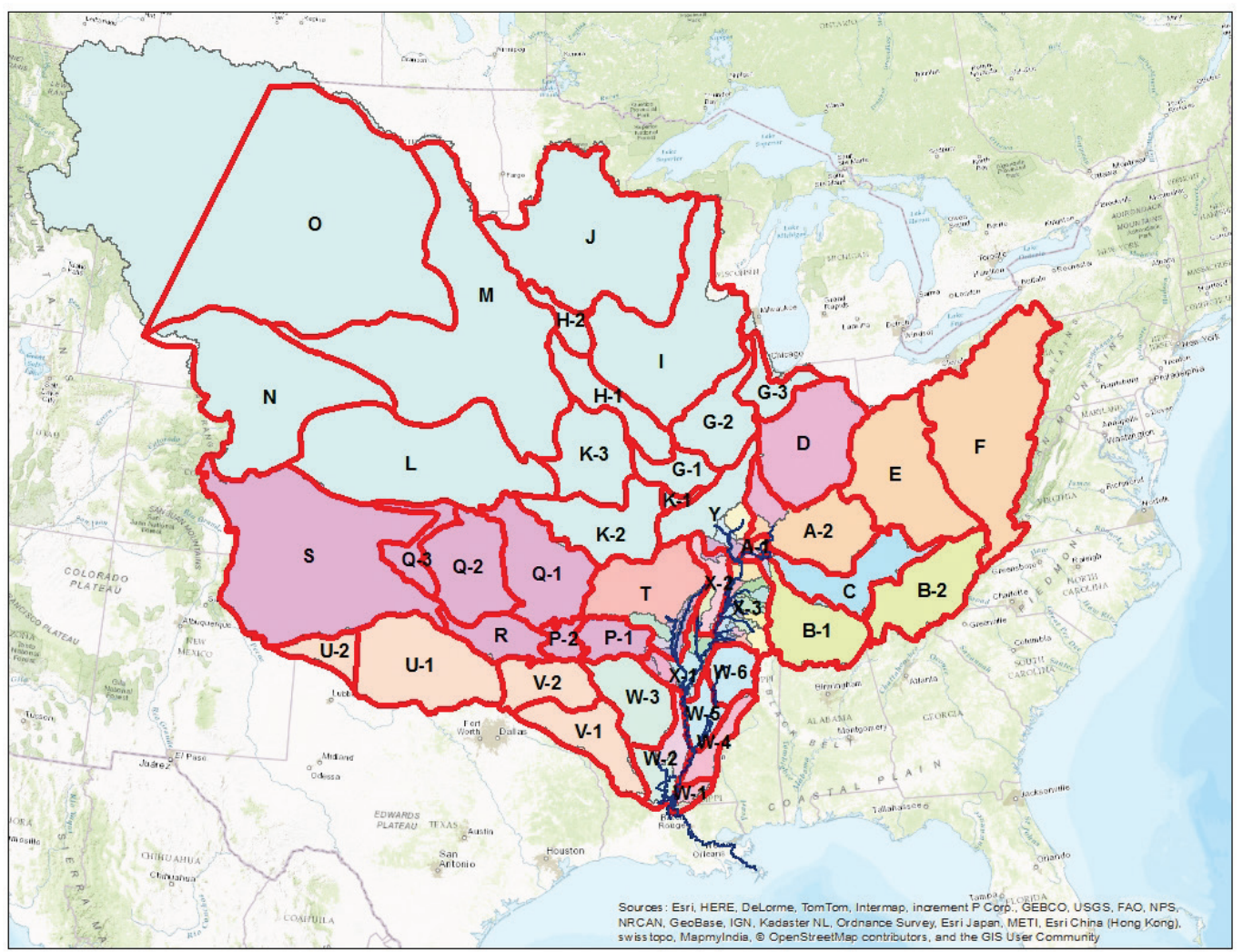


Figure 32. Labeled hydrologic connection points for historic model simulations.

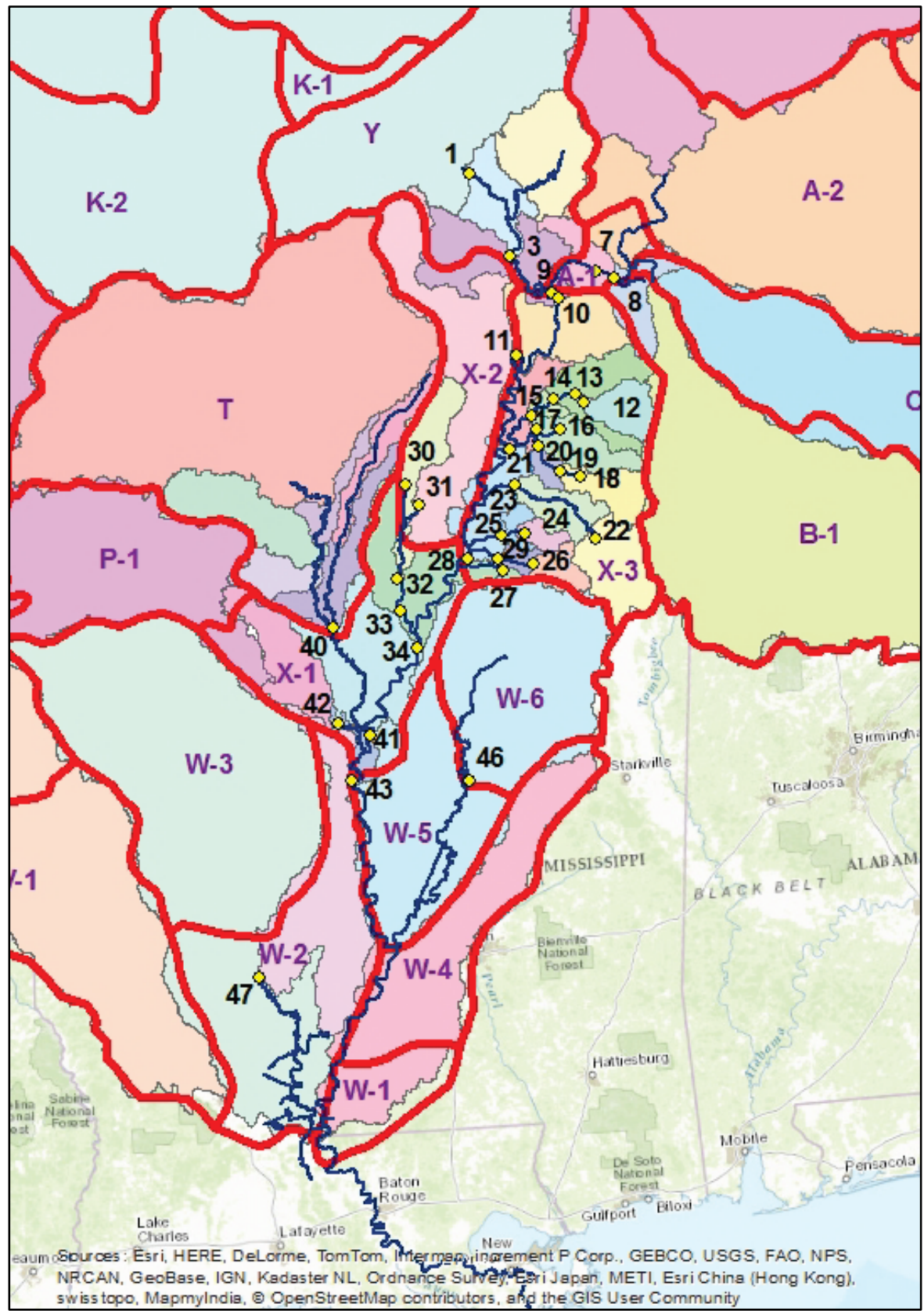

Table 5. Inflow boundary conditions for historic simulations (N/A means that a multiplier was not required for that inflow point).

\begin{tabular}{|c|l|c|l|c|}
\hline Point ID & River & RAS Station & Source of Data Used for Boundary Condition & Multiplier \\
\hline 1 & Mississippi & 110.40 & $\begin{array}{l}\text { Published historic hydrograph at St. Louis routed } \\
\text { to this location by MVS }\end{array}$ & N/A \\
\hline 2 & Big Muddy & 34.87 & Data not available, removed from geometry & N/A \\
\hline 3 & Mississippi & 52.15 & $\begin{array}{l}\text { Basin 7-Y was uniformly distributed among cross } \\
\text { sections to the confluence with the Ohio River }\end{array}$ & N/A \\
\hline
\end{tabular}




\begin{tabular}{|c|c|c|c|c|}
\hline Point ID & River & RAS Station & Source of Data Used for Boundary Condition & Multiplier \\
\hline 4 & Cumberland River & 29.36 & Data not available, removed from geometry & N/A \\
\hline 5 & Tennessee River & 18.21 & Data not available, removed from geometry & $\mathrm{N} / \mathrm{A}$ \\
\hline 6 & Ohio River & -919.00 & Data not available, removed from geometry & N/A \\
\hline 7 & Ohio River & -944.10 & $\begin{array}{l}\text { Published historic hydrograph at Metropolis was } \\
\text { used at this location }\end{array}$ & $\mathrm{N} / \mathrm{A}$ \\
\hline 8 & Ohio River & -934.18 & $\begin{array}{l}\text { A } 1950 \text { s basin outlet does not exist or was not } \\
\text { needed for this location }\end{array}$ & N/A \\
\hline 9 & Ohio River & -979.68 & $\begin{array}{l}\text { A } 1950 \text { s basin outlet does not exist or was not } \\
\text { needed for this location }\end{array}$ & $\mathrm{N} / \mathrm{A}$ \\
\hline 10 & Mississippi & 972.56 & $\begin{array}{l}\text { A } 1950 \text { s basin outlet does not exist or was not } \\
\text { needed for this location }\end{array}$ & N/A \\
\hline 11 & Mississippi & 908.52 & $\begin{array}{l}\text { Redistributed 1950s basin flow using the NWS } \\
\text { basins with a hydrograph multiplier based on a } \\
\text { drainage area ratio }\end{array}$ & 0.157 \\
\hline 12 & Obion & 72.10 & $\begin{array}{l}\text { Redistributed } 1950 \text { s basin flow using the NWS } \\
\text { basins with a hydrograph multiplier based on a } \\
\text { drainage area ratio }\end{array}$ & 0.050 \\
\hline 13 & Obion & 65.29 & $\begin{array}{l}\text { Redistributed } 1950 \text { s basin flow using the NWS } \\
\text { basins with a hydrograph multiplier based on a } \\
\text { drainage area ratio }\end{array}$ & 0.023 \\
\hline 14 & Obion & 52.65 & $\begin{array}{l}\text { Redistributed 1950s basin flow using the NWS } \\
\text { basins with a hydrograph multiplier based on a } \\
\text { drainage area ratio }\end{array}$ & 0.091 \\
\hline 15 & Obion & 34.16 & $\begin{array}{l}\text { Redistributed 1950s basin flow using the NWS } \\
\text { basins with a hydrograph multiplier based on a } \\
\text { drainage area ratio }\end{array}$ & 0.015 \\
\hline 16 & North Forked Deer & 20.00 & $\begin{array}{l}\text { Redistributed 1950s basin flow using the NWS } \\
\text { basins with a hydrograph multiplier based on a } \\
\text { drainage area ratio }\end{array}$ & 0.082 \\
\hline 17 & North Forked Deer & 5.20 & $\begin{array}{l}\text { A } 1950 \text { s basin outlet does not exist or was not } \\
\text { needed for this location }\end{array}$ & $\mathrm{N} / \mathrm{A}$ \\
\hline 18 & $\begin{array}{l}\text { South Forked } \\
\text { Deer }\end{array}$ & 38.68 & $\begin{array}{l}\text { Redistributed 1950s basin flow using the NWS } \\
\text { basins with a hydrograph multiplier based on a } \\
\text { drainage area ratio }\end{array}$ & 0.046 \\
\hline 19 & $\begin{array}{l}\text { South Forked } \\
\text { Deer }\end{array}$ & 28.69 & $\begin{array}{l}\text { Redistributed } 1950 \text { s basin flow using the NWS } \\
\text { basins with a hydrograph multiplier based on a } \\
\text { drainage area ratio }\end{array}$ & 0.022 \\
\hline 20 & $\begin{array}{l}\text { South Forked } \\
\text { Deer }\end{array}$ & 9.69 & $\begin{array}{l}\text { Redistributed } 1950 \text { s basin flow using the NWS } \\
\text { basins with a hydrograph multiplier based on a } \\
\text { drainage area ratio }\end{array}$ & 0.022 \\
\hline 21 & Mississippi & 835.27 & $\begin{array}{l}\text { Redistributed 1950s basin flow using the NWS } \\
\text { basins with a hydrograph multiplier based on a } \\
\text { drainage area ratio }\end{array}$ & 0.077 \\
\hline
\end{tabular}




\begin{tabular}{|c|c|c|c|c|}
\hline Point ID & River & RAS Station & Source of Data Used for Boundary Condition & Multiplier \\
\hline 22 & Hatchie & 149.62 & $\begin{array}{l}\text { Redistributed } 1950 \text { s basin flow using the NWS } \\
\text { basins with a hydrograph multiplier based on a } \\
\text { drainage area ratio }\end{array}$ & 0.129 \\
\hline 23 & Hatchie & 36.07 & $\begin{array}{l}\text { Redistributed } 1950 \text { s basin flow using the NWS } \\
\text { basins with a hydrograph multiplier based on a } \\
\text { drainage area ratio }\end{array}$ & 0.073 \\
\hline 24 & Loosahatchie & 35.24 & $\begin{array}{l}\text { Redistributed 1950s basin flow using the NWS } \\
\text { basins with a hydrograph multiplier based on a } \\
\text { drainage area ratio }\end{array}$ & 0.023 \\
\hline 25 & Loosahatchie & 22.55 & $\begin{array}{l}\text { Redistributed 1950s basin flow using the NWS } \\
\text { basins with a hydrograph multiplier based on a } \\
\text { drainage area ratio }\end{array}$ & 0.021 \\
\hline 26 & Wolf & 46.40 & $\begin{array}{l}\text { Redistributed } 1950 \text { s basin flow using the NWS } \\
\text { basins with a hydrograph multiplier based on a } \\
\text { drainage area ratio }\end{array}$ & 0.043 \\
\hline 27 & Wolf & 19.46 & $\begin{array}{l}\text { Redistributed 1950s basin flow using the NWS } \\
\text { basins with a hydrograph multiplier based on a } \\
\text { drainage area ratio }\end{array}$ & 0.018 \\
\hline 28 & Mississippi & 749.01 & $\begin{array}{l}\text { Redistributed } 1950 \text { s basin flow using the NWS } \\
\text { basins with a hydrograph multiplier based on a } \\
\text { drainage area ratio }\end{array}$ & 0.124 \\
\hline 29 & Nonconnah & 25.64 & $\begin{array}{l}\text { Redistributed } 1950 \text { s basin flow using the NWS } \\
\text { basins with a hydrograph multiplier based on a } \\
\text { drainage area ratio }\end{array}$ & 0.013 \\
\hline 30 & Straight Slough & 30.82 & $\begin{array}{l}\text { Redistributed } 1950 \text { s basin flow with a hydrograph } \\
\text { multiplier based on a drainage area ratio } \\
\text { estimated from topography }\end{array}$ & 0.065 \\
\hline 31 & St Francis & 82.47 & $\begin{array}{l}\text { Redistributed } 1950 \text { s basin flow with a hydrograph } \\
\text { multiplier based on a drainage area ratio } \\
\text { estimated from topography }\end{array}$ & 0.935 \\
\hline 32 & St Francis & 17.73 & $\begin{array}{l}\text { A } 1950 \text { s basin outlet does not exist or was not } \\
\text { needed for this location }\end{array}$ & N/A \\
\hline 33 & St Francis & 37.70 & $\begin{array}{l}\text { A } 1950 \text { s basin outlet does not exist or was not } \\
\text { needed for this location }\end{array}$ & N/A \\
\hline 34 & Mississippi & 676.42 & $\begin{array}{l}\text { Direct input of } 1950 \text { s basin flow because outlet is } \\
\text { at this location without encompassing significant } \\
\text { portions of additional reaches }\end{array}$ & N/A \\
\hline 35 & White River & 258.94 & Data not available, removed from geometry & N/A \\
\hline 36 & White River & 204.34 & Data not available, removed from geometry & N/A \\
\hline 37 & Cache River & 80.53 & Data not available, removed from geometry & N/A \\
\hline 38 & White River & 169.52 & Data not available, removed from geometry & N/A \\
\hline 39 & White River & 145.72 & Data not available, removed from geometry & $\mathrm{N} / \mathrm{A}$ \\
\hline
\end{tabular}




\begin{tabular}{|c|l|c|l|c|}
\hline Point ID & River & RAS Station & Source of Data Used for Boundary Condition & Multiplier \\
\hline 40 & White River & 100.05 & $\begin{array}{l}\text { Published historic hydrograph at Clarendon was } \\
\text { used at this location }\end{array}$ & N/A \\
\hline 41 & Mississippi & 602.06 & $\begin{array}{l}\text { A 1950s basin outlet does not exist or was not } \\
\text { needed for this location }\end{array}$ & N/A \\
\hline 42 & Arkansas River & 28.07 & $\begin{array}{l}\text { Published historic hydrograph at Little Rock routed } \\
\text { to this location by SWL }\end{array}$ & N/A \\
\hline 43 & Mississippi & 564.00 & $\begin{array}{l}\text { Direct input of 1950s basin flow because outlet is } \\
\text { portions of additional reaches }\end{array}$ & N/A \\
\hline 44 & Cache River & 116.44 & Data not available, removed from geometry & N/A \\
\hline 45 & White River & 177.90 & N/A & N/A \\
\hline 46 & Ouachita River & 65.54 & $\begin{array}{l}\text { Published historic hydrograph at St. Louis routed } \\
\text { to this location by MVS }\end{array}$ & N/A \\
\hline 47 & Yazoo River & 158.76 & Data not available, removed from geometry & N/A \\
\hline
\end{tabular}

\subsubsection{Merriwether-Cherokee Levee and Sheep's Ridge road elevations adjustments}

The 2011 Mississippi River flood caused a major breach in the revetment and spur levee in the location of the Merriwether-Cherokee bend of the river (in the MVM near RAS station 885). The area was repaired to prevent a cutoff from forming, but it was not repaired to the original level of protection. Figure 33 shows the Merriwether-Cherokee levee profile used in the validated model as well as the current conditions profile. The weir coefficient was also lowered from a 2.0 in the Pre-2011 geometry to a 1.0 for the Existing Conditions Profile. While this may still seem like a high value for lower elevations, the levee still retains much of its higher ground and is located in line with a bend in the river. For a 1D model, this higher weir coefficient simulates the higher momentum that would be present based on the angle of overtopping. 
Figure 33. Differences in the Merriwether-Cherokee levee profile, pre/post-2011.

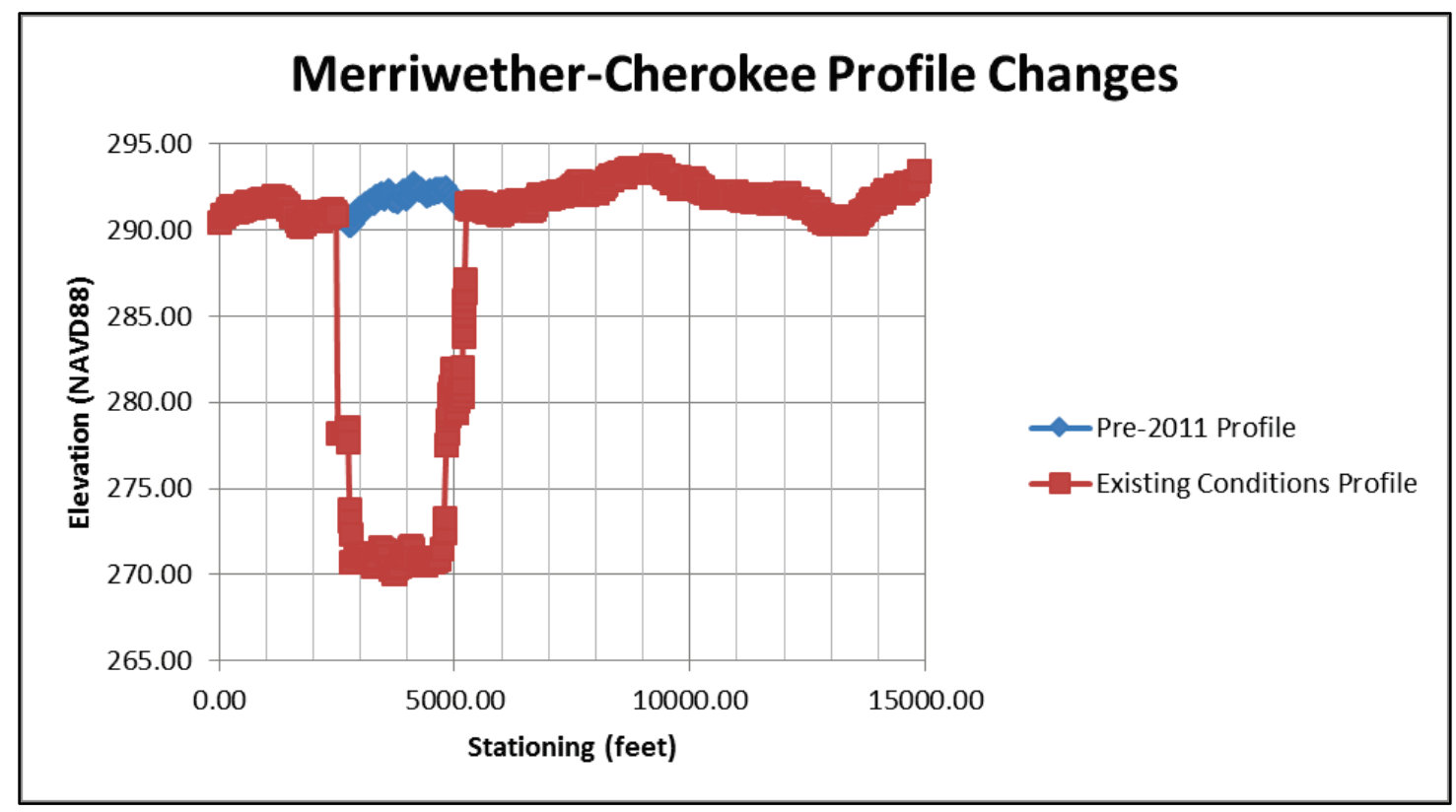

\subsubsection{Mainline levees}

During calibration, the lateral structures representing mainline levees did not overtop; thus, the usage of specific lateral structure coefficients was inconsequential. However, for the PDF events, the higher stages resulted in the potential for many of these lateral structures to be overtopped. Consequentially, the validated HEC-RAS model was modified to not allow overtopping for the PDF events, for these applicable structures, by setting the weir coefficients to zero. Table 6 lists the structures that were adjusted from the validated model to not allow overtopping when computing the PDF water surface elevations. Main line levees that were modeled as storage area connections, and not intended to overtop, were deleted from the geometry. Table 7 lists the storage area connections that were deleted from the model. Some main line levees, however, were allowed to overtop because they are designed to pass flow going into storage during a PDF event. Table 8 lists the main line levee lateral structures that were allowed to overtop. The MVN portion of the model does not use lateral structures to model mainline levees for the calibration or PDF events, so there were no changes needed within the MVN portion to run the PDF events. 
Table 6. Mainline levees modeled as lateral structures not allowed to overtop in the PDF models (RT and LT refer to the right and left descending banks, respectively).

\begin{tabular}{|c|c|c|c|}
\hline River & Reach & LS station(s) & Description \\
\hline Mississippi & Below Big Muddy & $32.839,30.410,26.650,8.240,7.514$ & Commerce to Bird's Point \\
\hline Mississippi & Below Big Muddy & $12.660,6.870$ & Cairo \\
\hline Mississippi & Below Big Muddy & 2.010 & $\mathrm{BP}$ \\
\hline Ohio River & $\mathrm{OHS}$ & $-970.010,-974.990$ & Cairo \\
\hline Ohio River & $\mathrm{OHS}$ & -977.990 & Cairo Floodwall \\
\hline Mississippi & Below Cairo & $959.360,953.240,947.300$ & BPNM Frontline \\
\hline Mississippi & Below Cairo & 942.460 & Hickman Floodwall \\
\hline Mississippi & Below Cairo & $942.440,934.100$ & BPNM Frontline \\
\hline Mississippi & Below Cairo & 941.200 & Upstream Tiptonville Obion \\
\hline Mississippi & Below Cairo & 922.130 & existing high ground \\
\hline Mississippi & Below Cairo & $\begin{array}{c}921.010,920.150,918.780,917.650 \\
916.750\end{array}$ & New Madrid Bend \\
\hline Mississippi & Below Cairo & $908.510,907.340$ & New Madrid \\
\hline Mississippi & Below Cairo & 897.750 & Upstream Caruthersville \\
\hline Mississippi & Below Cairo & 896.750 & Ridge at New Madrid Bend \\
\hline Mississippi & Below Cairo & 892.590 & Near Tiptonville \\
\hline Mississippi & Below Cairo & 891.550 & Tiptonville Obion \\
\hline Mississippi & Below Cairo & 868.160 & $\begin{array}{l}\text { Main Line Upstream } \\
\text { Caruthersville }\end{array}$ \\
\hline Mississippi & Below Cairo & 864.350 & Caruthersville Floodwall \\
\hline Mississippi & Below Cairo & 863.510 & $\begin{array}{l}\text { Main Line Downstream } \\
\text { Caruthersville }\end{array}$ \\
\hline Mississippi & Below Cairo & $862.630,862.000$ & $\begin{array}{l}\text { Main Line LT Downstream } \\
\text { Caruthersville }\end{array}$ \\
\hline Mississippi & Below Cairo & 859.430 & Obion \\
\hline Mississippi & Below Cairo & 844.480 & RT Main Line \\
\hline Obion River & Reach_1 & $24.900,23.740,16.770,12.680,8.230$ & Obion \\
\hline Mississippi & Below Obion & $\begin{array}{c}835.910,826.240,812.830,804.790 \\
797.350\end{array}$ & RT Main Line \\
\hline Mississippi & Below Hatchie & $\begin{array}{c}787.800,777.010,768.660,764.940 \\
758.360\end{array}$ & RT Main Line \\
\hline Mississippi & Below Loosahatch & 754.680 & RT Main Line \\
\hline Mississippi & Below Wolf & $752.940,750.930$ & RT Main Line \\
\hline Mississippi & Below Nonconnah & $\begin{array}{c}\text { 739.450, 733.990, 730.310, 721.850 } \\
711.840,707.820,696.430\end{array}$ & RT Main Line \\
\hline Mississippi & Below Nonconnah & $739.440,735.340,720.770,710.900$ & LT Main Line \\
\hline
\end{tabular}




\begin{tabular}{|c|c|c|c|}
\hline River & Reach & LS station(s) & Description \\
\hline Mississippi & Below St. Fran & $\begin{array}{c}685.730,674.170,666.860,650.580 \\
632.750,614.290\end{array}$ & LT Main Line \\
\hline Mississippi & Below St. Fran & $674.180,658.280,640.350$ & RT Main Line \\
\hline Mississippi & Below St. Fran & 622.010 & Laconia Circle \\
\hline Mississippi & Below White & $608.400,596.800$ & LT Main Line \\
\hline Mississippi & Below Arkansas & $588.390,580.000$ & LT Main Line \\
\hline Mississippi & Below Arkansas & $\begin{array}{c}588.380,582.920,579.900,570.100 \\
562.000\end{array}$ & RT Main Line \\
\hline Nonconnah $\mathrm{Cr}$ & Nonconna $\mathrm{Cr}$ & 4.880 & \\
\hline Arkansas River & Arkansas River & 26.500 & \\
\hline Mississippi & Below Arkansas & $\begin{array}{l}558.800,546.749,539.000,533.469 \\
517.000,504.279,495.8 .00,483.579 \\
479.000,469.649,467.989,464.929\end{array}$ & LT Main Line \\
\hline Mississippi & Below Arkansas & $\begin{array}{c}546.000,496.100,494.200,475.500 \\
454.000\end{array}$ & RT Main Line \\
\hline Mississippi & Below Vicksburg & $\begin{array}{c}442.500,435.000,412.000,394.000 \\
375.800,358.000,342.800\end{array}$ & RT Main Line \\
\hline Mississippi & Below Vicksburg & 321.3 & Old River Hydropower \\
\hline Mississippi & Below Vicksburg & 320.1 & Old River Overbank Weir \\
\hline Mississippi & Below Vicksburg & 319.6 & Old River Low Sill \\
\hline Mississippi & Below Vicksburg & 318.3 & Old River Auxiliary Structure \\
\hline Black River & R2 & $40.36,25.09$ & Tensas - Cocodrie Area \\
\hline Black River & $\mathrm{R} 2$ & $39.190,25.100,23.300$ & $\begin{array}{l}\text { Larto Lake to Jonesville } \\
\text { Levee Area }\end{array}$ \\
\hline Black River & R3 & 8.72 & Tensas - Cocodrie Area \\
\hline Catoua_R & R1 & 16.19 & $\begin{array}{l}\text { Larto Lake to Jonesville } \\
\text { Levee Area }\end{array}$ \\
\hline Little_River & R1 & $19.62,8.5$ & $\begin{array}{l}\text { Larto Lake to Jonesville } \\
\text { Levee Area }\end{array}$ \\
\hline Ouachita River & R1 & 89.55 & Ouachita River LT levee \\
\hline Red River & Below Black & 15.34 & Tensas - Cocodrie Area \\
\hline Tensas_River & R1 & $28.920,19.010,9.230$ & Tensas - Cocodrie Area \\
\hline Tensas_River & R1 & $23.740,18.650,13.210$ & Sicily Island Levee Area \\
\hline Yazoo River & Reach1 & $\begin{array}{c}155.340,155.330,151.100,151.090 \\
148.210,141.870,140.600,139.5265 \\
\text { 129.100, 124.540, 124.530, 122.550, } \\
119.570,116.920,116.910\end{array}$ & Yazoo River Levee \\
\hline Yazoo River & Reach1.5 & $83.360,76.350,76.259$ & Yazoo City Protection Levee \\
\hline
\end{tabular}


Table 7. Deleted storage area connections in the PDF models

(RAS labels).

\begin{tabular}{|c|}
\hline Storage Area Connections \\
\hline 3456 \\
\hline 3457 \\
\hline 3458 \\
\hline 3459 \\
\hline 11023 \\
\hline 3452 \\
\hline 3470 \\
\hline 1447 \\
\hline 1446 \\
\hline 14592 \\
\hline 135 \\
\hline 146 \\
\hline 1466 \\
\hline 2211 \\
\hline Cat_longbranch \\
\hline
\end{tabular}

Table 8. Lateral structures allowed to overtop in the PDF models (MRL stands for Mississippi River levee).

\begin{tabular}{|l|l|c|l|}
\hline River & River & River & River \\
\hline Mississippi & Below Cairo & 973.84 & BPNM Upper Fuse Plug/Inflow Crevasse \\
\hline Mississippi & Below Cairo & 968.240 & BPNM Upper Fuse Plug \\
\hline Mississippi & Below Cairo & 963.280 & BPNM Upper Fuse Plug \\
\hline Mississippi & Below Cairo & 937.020 & Inflow-Outflow \#1 \\
\hline Mississippi & Below Cairo & 915.700 & New Madrid Bend Spur \\
\hline Mississippi & Below Cairo & 914.780 & New Madrid Bend Spur \\
\hline Mississippi & Below Cairo & 913.770 & New Madrid Bend Spur \\
\hline Mississippi & Below Cairo & 913.060 & New Madrid Bend Spur \\
\hline Mississippi & Below Cairo & 913.070 & BPNM Lower Fuse Plug/Inflow-Outflow \#2 \\
\hline Mississippi & Below Cairo & 912.610 & New Madrid Bend Spur \\
\hline Mississippi & Below Cairo & 911.670 & New Madrid Bend Spur \\
\hline Mississippi & Below Nonconnah & 691.600 & St. Francis Sleeve Levee \\
\hline St. Francis & Below SS & 23.99 & St. Francis Backwater \\
\hline
\end{tabular}




\begin{tabular}{|c|c|c|c|}
\hline River & River & River & River \\
\hline White River & Below Cache & 53.37 & White River Backwater 2 \\
\hline White River & Below Cache & 40.53 & White River Backwater 1 \\
\hline Mississippi & Below Arkansas & 553 & Frontline Levee for Greenville Port \\
\hline Mississippi & Below Arkansas & 510 & Wilson Point Levee (non-MRL) \\
\hline Mississippi & Below Arkansas & 500 & Wilson Point Levee (non-MRL) \\
\hline Mississippi & Below Arkansas & 498 & Wilson Point Levee (non-MRL) \\
\hline Mississippi & Below Arkansas & 453.4 & Backwater to Yazoo Diversion Canal \\
\hline Mississippi & Below Arkansas & 450 & Backwater to Yazoo Diversion Canal \\
\hline Mississippi & Below Arkansas & 446.95 & Backwater to Yazoo Diversion Canal \\
\hline Yazoo River & Reach2 & 44.719 & Allowed to overtop during PDF \\
\hline Yazoo River & Reach2 & 44.7 & Yazoo Backwater Levee (designed to overtop) \\
\hline Yazoo River & Reach2 & 33.919 & Allowed to overtop during PDF \\
\hline Yazoo River & Reach2 & 28.10 & Allowed to overtop during PDF \\
\hline Yazoo River & Reach2 & 17.34 & Allowed to overtop during PDF \\
\hline Yazoo River & Reach2 & 17.3 & Yazoo Backwater Levee (designed to overtop) \\
\hline Mississippi & Below Vicksburg & 427 & Big Black River Backwater \\
\hline Mississippi & Below Vicksburg & 411 & Bayou Pierre Backwater \\
\hline Mississippi & Below Vicksburg & 348 & Homochitto River Backwater \\
\hline Mississippi & Below Vicksburg & 343 & Buffalo River Backwater \\
\hline
\end{tabular}

\subsubsection{Bird's Point - New Madrid (BPNMF)}

The BPNMF Inflow Crevasse for PDF scenarios was assumed to be activated at a Cairo gage stage level of $61 \mathrm{ft}$ NAVD88. The length of the breach in the model was 11,099 $\mathrm{ft}$, as designed. The two other breaches (Inflow/Outflow Crevasse \#1 and Inflow/Outflow Crevasse \#2) for the floodway were each 5,500 ft in length, as designed. Inflow/Outflow Crevasse \# 2 was operated 24 hours after the Inflow Crevasse while Inflow/Outflow Crevasse \#1 was operated 48 hours after the Inflow Crevasse.

The current operation plan requires a specific sequence to move the necessary supplies and personnel up the river and have access to the 
activation infrastructure for the operation of BPNMF. The sequence assumes a $2 \mathrm{ft}$ rise per day on the Cairo gage. This $2 \mathrm{ft} /$ day assumption was based on the original PDF hydrograph and is a conservative estimate to allow for potential days in which the rise could be greater than 2 $\mathrm{ft} /$ day. The new stage PDF hydrograph at Cairo was analyzed, and while there are a couple of days with greater than $2 \mathrm{ft}$ of rise, the average daily rate of rise from a $52 \mathrm{ft}$ stage on the Cairo gage to activation at a $61 \mathrm{ft}$ stage is approximately $1.6 \mathrm{ft} /$ day; as such, the $2 \mathrm{ft} /$ day assumption for the operation plan would still be sufficient.

\subsubsection{Seasonal roughness}

Changes in season can cause similar flow rates to pass a given reach of river at differing stages, and one of the factors causing the seasonal changes is a variation in roughness values. Typically, the warm season has larger roughness values and results in higher stages for a given flow rate. While the model was calibrated using seasonal variations in the roughness (Manning's $n$ ) values, all PDF scenarios used constant roughness values corresponding to the warm season.

\subsubsection{Flow roughness}

Since the PDF flows in some cases were higher than the flows that the model was calibrated to, it was necessary to extrapolate the relationship between Manning's $n$ and flow rate. The model will extrapolate the last change in Manning's $n$ from the calibrated model and apply that change at the higher flow rates of the PDF flows. As the water begins entering the overbank, there's typically a rougher $n$ value necessary especially in a 1D model, but as the water begins to have some depth in the overbank, a smoother $n$ value is likely to occur. For the calibration effort, some areas had their peak flow under a smoother condition meaning a larger hydraulic radius and more depth in the overbank. Some areas, however, of longer overbanks passed the peak flow under a rougher condition and never got enough depth in the overbanks to become more efficient in the model. Since there is not a good method of quantifying the change that would likely occur in the areas of longer overbanks as well as some of the shorter overbanks as they gained more depth, they were left to extrapolate that rougher condition. This is a more conservative approach, and differences would be within the uncertainty of the model. 


\subsubsection{Yazoo Backwater Levee}

The Yazoo Backwater Levee was only partially complete during the studies of the 1970 s and was bypassed during the 1973 flood. One of the main changes in the backwater areas following the 1973 flood was the completion of the Yazoo River backwater area; however, the grade of the levee was built to the 1956 approved elevation. This was done to ensure the mainstem levees could be raised prior to raising the backwater levee. The Mississippi River mainstem levees have now been raised to the 1973 approved grade.

The "Historic PDF - Existing Yazoo" simulation used the existing Yazoo Backwater Levee profile as shown in Figure 34 with some levee elevations as low as approximately $107 \mathrm{ft}$. However, for the "Historic PDF - Authorized Yazoo" simulation, the Yazoo Backwater Levee profile was raised to $112.8 \mathrm{ft}$, as shown in Figure 35. Note that the backwater levee cannot be raised to the $112.8 \mathrm{ft}$ until all mainstem levees from Greenville, MS, south to the ORCC have been raised to their authorized grade. This ensures the backwater levee raise will not endanger the mainstem levees.

Figure 34. Plot of the existing Yazoo Backwater Levee profile.

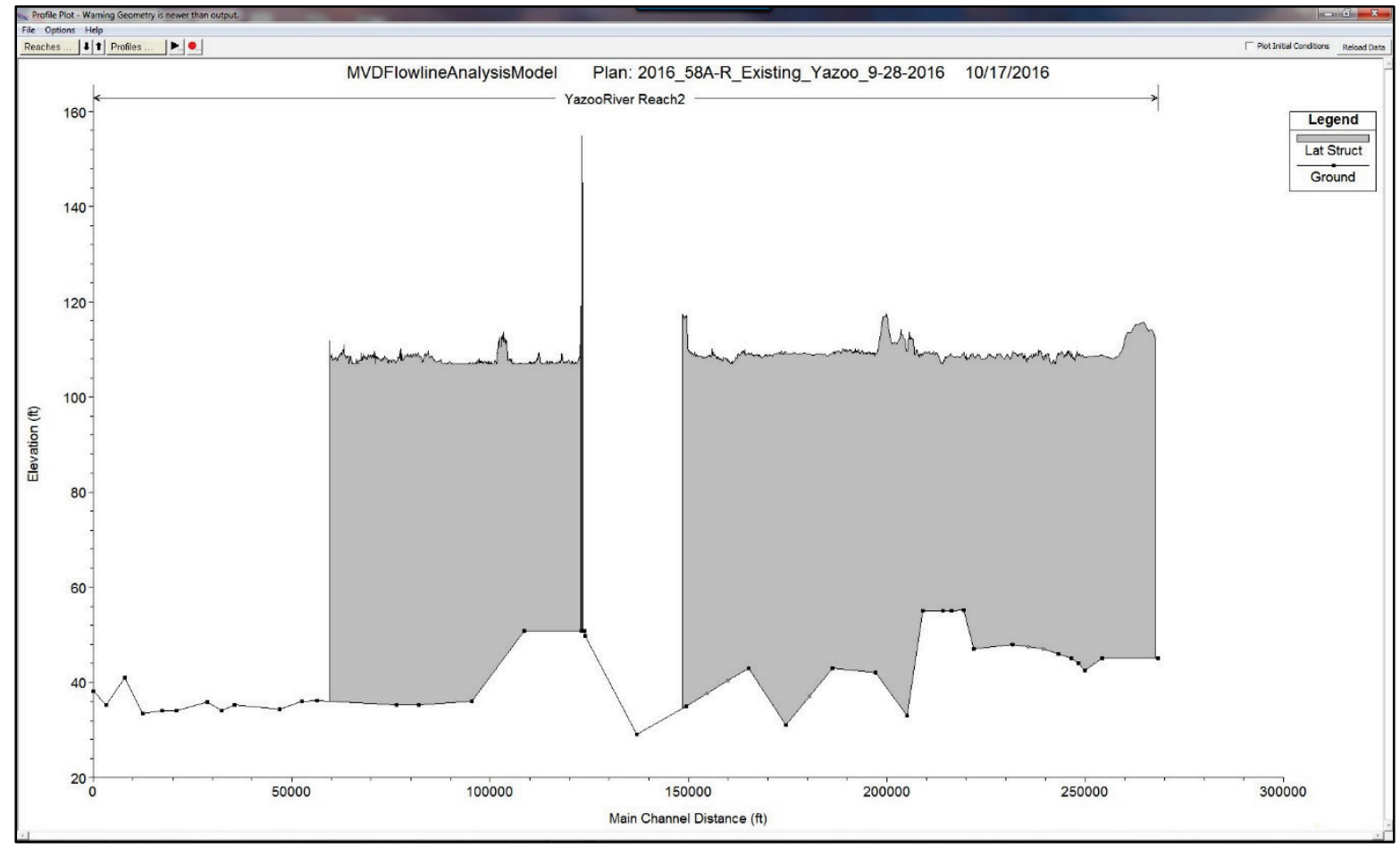


Figure 35. Plot of the authorized (112.8 ft) Yazoo Backwater Levee profile.

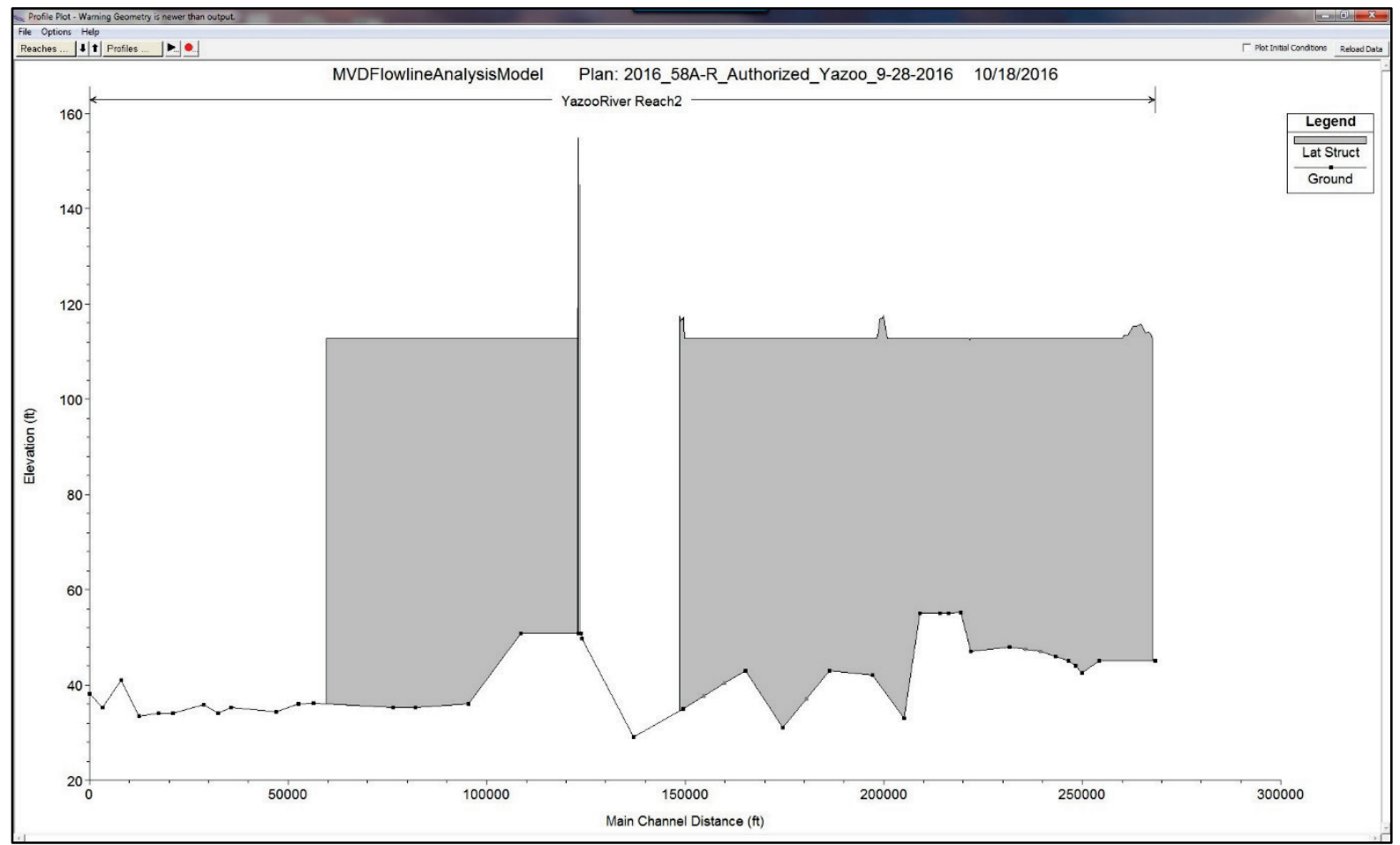

\subsubsection{Morganza Floodway}

The operation of the Morganza Floodway, or Morganza Control Structure (MCS), was modeled to follow the Interim Standing Instructions to the Project Manager for Water Control for the MCS, which was recently revised in August 2014 (USACE 2000; USACE 2014). Based on lessons learned from the 2011 Flood, it was proposed to more clearly define the standing instructions to operate the structure safely while preventing unnecessary stress on the MR\&T System. In the new Standing Instructions, the structure would be operated when a 10-day forecast shows the river reaching 1.5 million cfs at RRL. The operation of the structure would begin before a stage of $57 \mathrm{ft}$ was reached. The MCS will continue to open to increase the flow diversion through the structure and to maintain no more than 1.5 million cfs in the Mississippi River below Morganza, until the floodway capacity of 600,000 cfs is reached.

\subsubsection{Bonnet Carré Spillway}

Under the MR\&T project, the Bonnet Carré Spillway is operated when flow in the river below Morganza exceeds 1,250,000 cfs. The floodway operation is also authorized to lower stages along the river below the spillway to protect the levee system. The Bonnet Carré Spillway had 
320 out of 350 bays opened for the 2011 Flood, resulting in a total flow through the structure of $315,930 \mathrm{cfs}$. The PDF for the Spillway is $250,000 \mathrm{cfs}$, but this is not the flow capacity of the Spillway according to the Water Control Manual, dated 1999 (USACE 1999). The true capacity of the Spillway is limited by the guide levees that run from the Structure to Lake Pontchartrain. It is not unprecedented for the flows through Bonnet Carré to be higher than 250,000 cfs, which was the case in 1945 and 1983.

The Bonnet Carré Spillway was modeled in accordance with the 2011 operation. This means that if necessary, the modeled spillway would divert more than 250,000 cfs from the Mississippi River.

Another change incorporated for the PDF events was the addition of a lateral structure with a rating curve to simulate the spillway. This was a revision from the calibration simulation since the recorded spillway flows were input through the unsteady flow file as a negative flow hydrograph during calibration. The change was incorporated so the actual flow could be modeled during calibration while allowing the spillway flow to be based on the river flow during the PDF events. Figure 36 shows a comparison between the simulated flow through Bonnet Carré using the rating curve for the 2011 event and the observed 2011 flow values. The results from using the rating curve sufficiently match the recorded flows through Bonnet Carré during 2011. 
Figure 36. Comparison using the Bonnet Carré rating curve instead of observations for 2011.

250,000

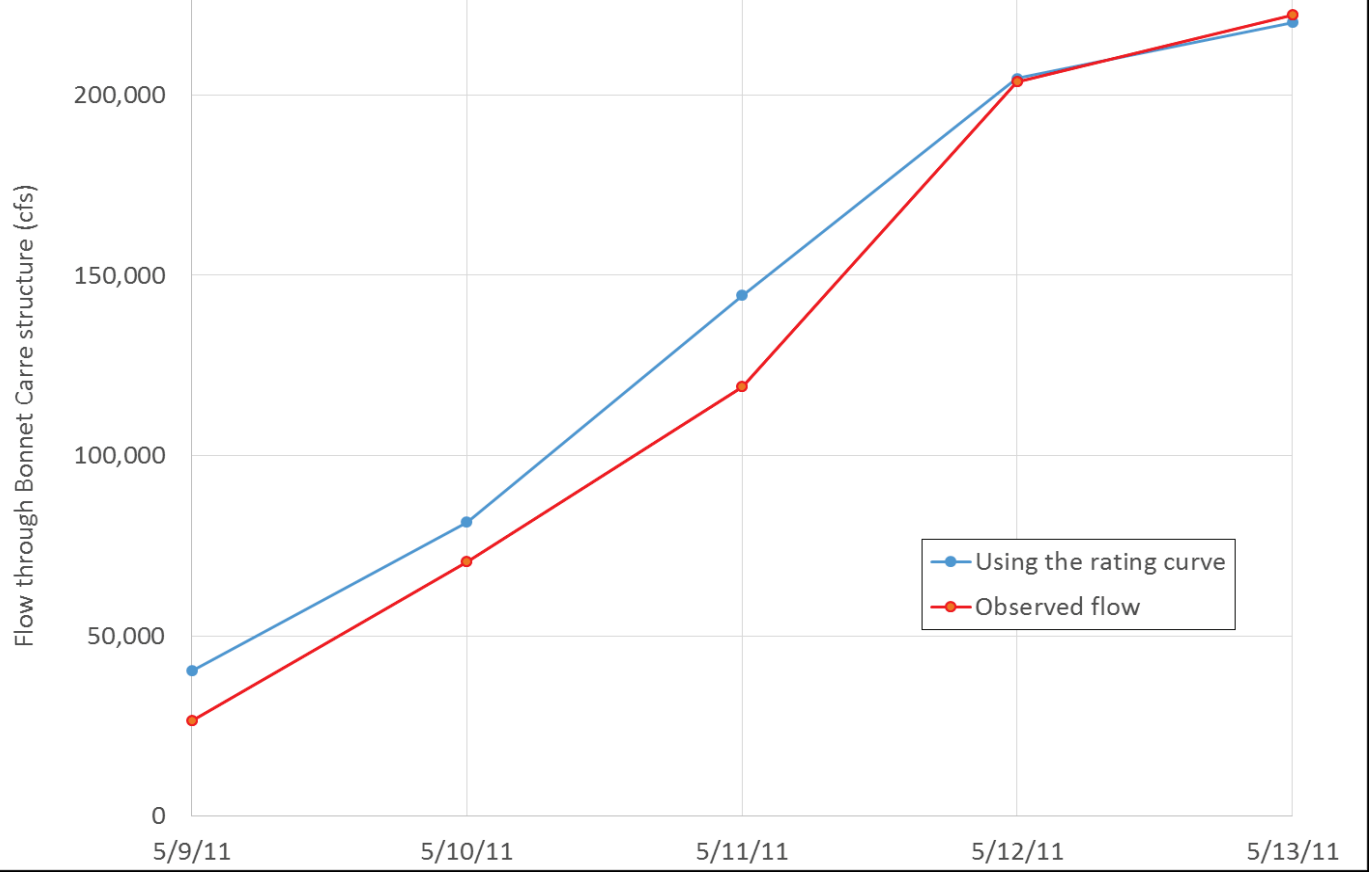

\subsubsection{Downstream boundary at Venice}

The downstream boundary of the model is at Venice, LA (Figure 37, RAS station 15.07), approximately 20 river miles upstream of the Gulf of Mexico (depending on which pass [e.g., Southwest Pass or Pass a Loutre] in the delta is considered). For the downstream boundary, observed stages were used to simulate the boundary for the calibration and validation events. However, to simulate the historical PDF events, a downstream boundary was needed that would produce a stage, for each time-step, that accounts for the dependence of the flow at Venice on the stage. Therefore, a rating curve, based on a non-linear regression analysis of observed historical data, was developed. The total available period of record (2003-2016 for the flow data) was used in formulating the rating curve. Although stage readings at Venice are recorded on a daily basis, flow readings are taken periodically, on average approximately 11 per year. A total of 133 flow readings recorded in the field from December 2003-August 2016 were available to formulate the rating curve. Once the field flow measurements were matched with the corresponding stage data, the points were fit to second-order log regression equation. Since the maximum flow of the measurements are surpassed by the PDF flows, the curve was extrapolated as needed. The appendix contains more information on the development of the curve. 
The water surface elevations at Venice are influenced by the tidal effects of the Gulf of Mexico and the flow in the Mississippi River, so a rating curve relationship between discharge and water surface elevation at Venice is an appropriate downstream boundary condition. Other modeling efforts, such as the Atchafalaya River model, use the Gulf of Mexico for the downstream boundary, so a rating curve is not required at the downstream end.

Figure 37. The model downstream boundary is located at Venice, LA, pinpointed in figure.

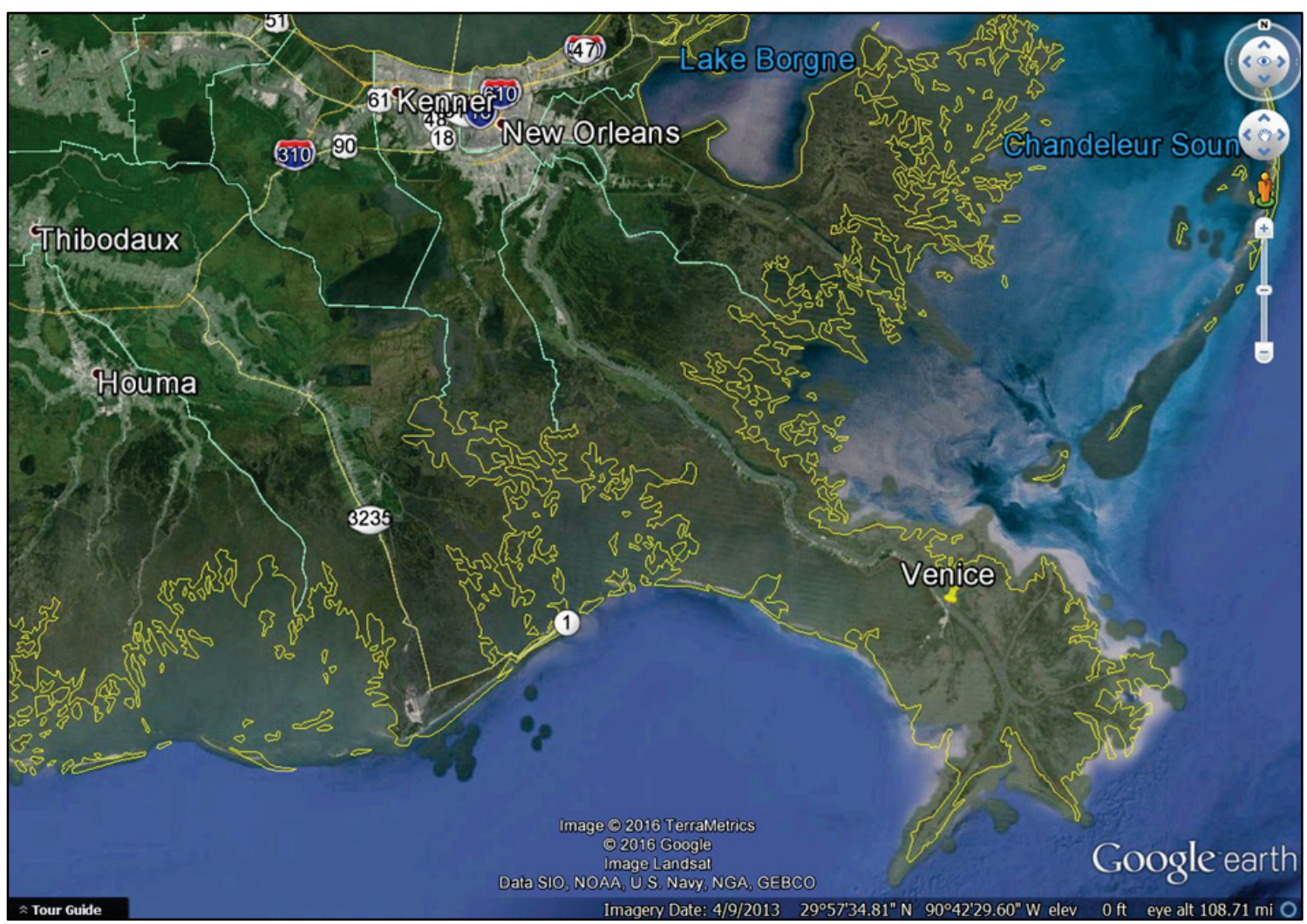

Table 9. Venice rating curve.

\begin{tabular}{|c|c|}
\hline Venice Stage (ft, 2004.65) & Mississippi River Flow \\
\hline 1.26 & 100,000 \\
\hline 1.57 & 150,000 \\
\hline 1.83 & 200,000 \\
\hline 2.06 & 250,000 \\
\hline 2.26 & 300,000 \\
\hline 2.45 & 350,000 \\
\hline
\end{tabular}




\begin{tabular}{|c|c|}
\hline Venice Stage (ft, 2004.65) & Mississippi River Flow \\
\hline 2.61 & 400,000 \\
\hline 2.77 & 450,000 \\
\hline 2.91 & 500,000 \\
\hline 3.04 & 550,000 \\
\hline 3.17 & 600,000 \\
\hline 3.29 & 650,000 \\
\hline 3.4 & 700,000 \\
\hline 3.5 & 750,000 \\
\hline 3.6 & 800,000 \\
\hline 3.7 & 850,000 \\
\hline 3.79 & 900,000 \\
\hline 3.88 & 950,000 \\
\hline 3.97 & $1,000,000$ \\
\hline 4.05 & $1,050,000$ \\
\hline 4.13 & $1,100,000$ \\
\hline 4.21 & $1,150,000$ \\
\hline 4.28 & $1,200,000$ \\
\hline 4.35 & $1,250,000$ \\
\hline 4.68 & $1,500,000$ \\
\hline 4.97 & $1,750,000$ \\
\hline 5.23 & $2,000,000$ \\
\hline
\end{tabular}

\subsection{Results}

Differences between the historically recorded PDF water surface elevations and the current HEC-RAS results, driven by the historical flows, demonstrated the impact of differences in the numerical modeling framework, changes in geometry, and changes in roughness between the Refined 1973 Flowline (1978) study and the current assessment. Table 10 lists the previously published flows from the 1955 hydrology in comparison with the flows resulting from the new HEC-RAS model 
developed for this assessment. In general, the flows that have been routed through the HEC-RAS model compare very closely with the flows reported in the Refined 1973 Flowline Study (USACE 1978). Table 11 lists the water surface comparisons between the results of this assessment and the previous elevations from the Refined 1973 Study (USACE 1978) without adjustments for loop effect and channel degradation (converted to NAVD88). The loop effect and channel degradation were performed and are documented in separate reports (USACE 2018a; USACE 2018c; USACE 2018d).

Table 10. Maximum flow comparisons of the historic PDF simulations (cubic feet per second) (blank values indicate the historic study's values were not available at those locations).

\begin{tabular}{|l|c|c|c|c|}
\hline Description & $\begin{array}{c}\text { RAS } \\
\text { Station }\end{array}$ & $\begin{array}{c}\text { Published 1955 } \\
\text { Hydrology }\end{array}$ & $\begin{array}{c}\text { Historic - PDF } \\
\text { Existing Yazoo }\end{array}$ & $\begin{array}{c}\text { Historic - PDF } \\
\text { Authorized } \\
\text { Yazoo }\end{array}$ \\
\hline Mississippi at Chester & 110.4 & 240,000 & 301,000 & 301,000 \\
\hline Ohio River at Cairo & -979.68 & $2,250,000$ & $2,255,000$ & $2,255,000$ \\
\hline Mississippi at Ohio River & 973.85 & $2,360,000$ & $2,393,000$ & $2,393,000$ \\
\hline Mississippi at Hickman & 942.45 & $1,810,000$ & $1,881,000$ & $1,881,000$ \\
\hline Mississippi at Memphis & 749.01 & $2,410,000$ & $2,415,000$ & $2,415,000$ \\
\hline Mississippi at Helena & 676.42 & $2,460,000$ & $2,445,000$ & $2,445,000$ \\
\hline Mississippi at Arkansas City & 562.18 & $2,890,000$ & $2,874,000$ & $2,874,000$ \\
\hline Arkansas River at Dam 02 & 28.07 & 400,000 & 403,000 & 403,000 \\
\hline St. Francis at 82.47 & 82.47 & 80,000 & 74,000 & 74,000 \\
\hline White River at Clarendon & 100.05 & 220,000 & 223,000 & 223,000 \\
\hline Mississippi at Greenville & 539.13 & & $2,869,000$ & $2,867,000$ \\
\hline Mississippi at Lake Providence & 494.47 & & $2,866,000$ & $2,863,000$ \\
\hline Mississippi at Vicksburg & 442.16 & $2,710,000$ & $2,678,000$ & $2,849,000$ \\
\hline Mississippi at Natchez & 368.44 & $2,720,000$ & $2,694,000$ & $2,852,000$ \\
\hline Mississippi at RRL & 306.43 & $2,100,000$ & $2,077,000$ & $2,226,000$ \\
\hline Mississippi at Baton Rouge Gage & 233.1 & $1,500,000$ & $1,501,000$ & $1,616,000$ \\
\hline Mississippi at Donaldsonville gage & 179.04 & $1,500,000$ & $1,501,000$ & $1,615,000$ \\
\hline Mississippi at Carrollton Gage & 107.2 & $1,250,000$ & $1,250,000$ & $1,360,000$ \\
\hline Mississippi at Empire Gage & 33.79 & $1,250,000$ & $1,216,000$ & $1,303,000$ \\
\hline Mississippi at Venice gage & 15.07 & $1,250,000$ & 892,000 & 951,000 \\
\hline
\end{tabular}

The flow comparisons from the simulations show that the flows match very well to the published flows. The 240,000 cfs flow rate from the Mississippi River above the confluence with the Ohio River is the flow 
rate at St. Louis and can be misinterpreted as the contributing flow from the Mississippi River above the Ohio River confluence. In the original study, engineers combined the flow from St. Louis, the local basin flow from 7-Y, and the total flow at Metropolis, IL, on the Ohio River to determine the combined flow of 2,360,000 cfs below the confluence. An intermediate computation point was not used in the original study between St. Louis and the confluence with the Ohio River. Although not published, the combined flow from the hydrograph at St. Louis and the local basin flow 7-Y would have been computed as 410,000 cfs. Details about how flows were input into the unsteady model for the Mississippi River above the confluence are in Figure 32 and Table 5.

Changes between the previously published stages in the Refined 1973 Flowline Study (USACE 1978) and the results of these historic simulations of this assessment highlight differences between the modeling framework, changes in the geometry, and changes in roughness. Geomorphic assessments of the Mississippi River (Biedenharn et al. 2017) provide comparison information for the trends in changes to water levels for varying flow rates over long periods of time. The broad-scale geomorphic results from Biedenharn et al. (2017) show dynamic equilibrium or slightly decreasing stages for reaches of the river between Hickman and Arkansas City for high flows. The simulated water surfaces in Table 11 agree with the geomorphic assessment since they show lower water surfaces than the Refined 1973 Flowline Study between Hickman and Arkansas City. The reaches of the river from Arkansas City to RRL have experienced increasing stages for high flows, according to geomorphic analysis (Biedenharn et al. 2017). From Table 11, peak water surfaces from around Vicksburg and going downstream to around Baton Rouge agree with the geomorphic observation of increasing stage trends as the simulated water surfaces are higher for the current assessment than the Refined 1973 Flowline Study (USACE 1978) for that reach of the river.

Simulated stages at Arkansas City, Greenville, and Lake Providence are in slight disagreement with the observed trends in the geomorphic assessment since the current assessment simulated a lower water surface than the Refined 1973 Flowline Study (USACE 1978). This is likely caused by a difference in how the unsteady hydraulics were computed between the two time periods. The current HEC-RAS model is a robust model that computes a fully unsteady simulation including dynamic interactions with storage areas and backwater areas. Differences can also be explained by the fact that the simulated flow during the Historic PDF 
event is much higher than the geomorphic assessments are able to consider, since there are no observations of river stages for that high of a flow. Figures in Section 4.3 also show some historic simulated results.

Table 11. Maximum stage comparisons of the Historic PDF runs ( $\mathrm{ft}, \mathrm{NAVD88}$ ( ${ }^{*}$ from the Refined 1973 Flowline Study [USACE 1978], this column is without loop effect, sedimentation, or freeboard effects).

\begin{tabular}{|l|c|c|c|c|}
\hline Description & $\begin{array}{c}\text { RAS } \\
\text { Station }\end{array}$ & $\begin{array}{c}\text { Refined 1973 } \\
\text { Flowline (58A- } \\
\text { EN)* }\end{array}$ & $\begin{array}{c}\text { Historic - } \\
\text { PDF Existing } \\
\text { Yazoo }\end{array}$ & $\begin{array}{c}\text { Historic - PDF } \\
\text { Authorized } \\
\text { Yazoo }\end{array}$ \\
\hline Mississippi at Chester & 110.4 & & 360.9 & 360.9 \\
\hline Ohio River at Cairo & -979.68 & & 332.5 & 332.5 \\
\hline Mississippi at Ohio River & 973.85 & 331.7 & 332.0 & 332.0 \\
\hline Mississippi at Hickman & 942.45 & 320.7 & 318.6 & 318.6 \\
\hline Mississippi at Memphis & 749.01 & 237.2 & 235.8 & 235.8 \\
\hline Mississippi at Helena & 676.42 & 202.9 & 201.9 & 201.9 \\
\hline Mississippi at Arkansas City & 562.18 & 155.5 & 154.8 & 154.8 \\
\hline Arkansas River at Dam 02 & 28.07 & & 172.2 & 172.2 \\
\hline St. Francis at 82.47 & 82.47 & & 216.7 & 216.7 \\
\hline White River at Clarendon & 100.05 & & 179.1 & 179.1 \\
\hline Mississippi at Greenville & 539.13 & 145.2 & 144.0 & 144.2 \\
\hline Mississippi at Lake Providence & 494.47 & 129.4 & 127.5 & 128.1 \\
\hline Mississippi at Vicksburg & 442.16 & 106.9 & 107.0 & 108.8 \\
\hline Mississippi at Natchez & 368.44 & 82.7 & 83.6 & 85.2 \\
\hline Mississippi at RRL & 306.43 & 63.5 & 63.5 & 65.5 \\
\hline Mississippi at Baton Rouge Gage & 233.1 & 45.7 & 44.4 & 47.1 \\
\hline Mississippi at Donaldsonville gage & 179.04 & 33.8 & 31.7 & 34.3 \\
\hline Mississippi at Carrollton Gage & 107.2 & 19.6 & 16.8 & 18.6 \\
\hline Mississippi at Empire Gage & 33.79 & 9.8 & 5.8 & 6.2 \\
\hline Mississippi at Venice gage & 15.07 & 8.1 & 3.8 & 3.9 \\
\hline
\end{tabular}




\section{Simulations Using the New Hypothetical Flows}

\subsection{Methodology}

This section documents the methodology used to simulate the MR\&T system hydraulic response to newly generated hypothetical ("New Hypo") PDF events. For more detailed information on the development of the New Hypo PDF events, refer to the Hydrology Report associated with this assessment (USACE 2018b).

The New Hypo PDF simulations are based on replicating the same design storms labeled 58A, 52A, 56, and 63 in the 1955 Report (USACE 1955). The Hydrology Report associated with this assessment (USACE 2018b) discusses how the design storm events were regenerated using a current NWS hydrology model to determine new flows. The explanations in the next four paragraphs come from that report.

The 52A event is from a late spring season storm combination of one transposed storm and two storms as they actually occurred. The rainfall for the 7-11 May 1943 storm was reduced by 20\%, rotated $14.5^{\circ}$ clockwise about Warner, OK, and transposed 430 miles north over the Missouri and Upper Mississippi River Basins. This storm was followed by the 15-20 May 1943 storm 3 days later with the greatest rainfall hitting the Arkansas Basin. Two days after that storm, the 2830 June 1928 storm follows, which primarily hit the Ohio Basin.

The 56 event is an early spring season storm combination of two storms as they actually occurred. The 2-30 March 1945 storm was sequenced prior to the main event period to establish the intended antecedent conditions. The main event consisted of the 23-26 March 1913 storm over the Ohio, Upper Mississippi, Arkansas, and White Basins and over the drainage area of the Mississippi River from St. Louis, MO, to Cairo, IL, which was followed 3 days later by the 12-16 April 1927 storm over all areas. This flood gave the largest flows from the White and Red River Basins and the second largest flows for the Mississippi River at Arkansas City and Latitude of RRL.

The 58A event consists of a winter storm combination of one storm as it actually occurred with a rainfall depth increase of $10 \%$, another storm as it 
actually occurred, and one transposed storm. The actual 6-24 January 1937 storm over all areas with rainfall depth increased by $10 \%$ was followed 4 days later by the 3-16 January 1950 storm over all areas above Cairo, IL, and 3 days later by the 14-18 February 1938 storm rotated $20^{\circ}$ clockwise about Calvin, OK, and transposed 90 miles northwest over all areas downstream from Cairo, IL. This flood gave the largest flows from the Ohio River Basin and for the Mississippi River at Arkansas City and Latitude of RRL. It yielded the second largest flows from the Arkansas and Red River Basins and for the Mississippi River at Cairo.

The 63 event is an early spring season storm combination of two storms as they actually occurred and one transposed storm. The actual 12-16 April 1927 storm over all areas was followed 2 days later by the actual 15-20 May 1943 storm over all areas and 3 days later by the 7-12 May 1943 storm rotated $21^{\circ}$ about Calvin, OK, and transposed 105 miles north over all areas downstream from Cairo, IL. This flood gave the largest flows from the Arkansas River Basin, the second largest flows from the White River Basin, and the third largest flows from the Missouri and Upper Mississippi River Basins, and for the Mississippi River at St. Louis, Arkansas City, and Latitude of RRL.

The storm event labels used in this report are listed below.

- New Hypo 58A-U: The simulation labeled "New Hypo 58A-U" represents the use of the NWS model to simulate the 58A design storm without reservoir regulation impacts ("U" for unregulated). For more discussion about the reservoirs, see the Hydrology Report (USACE Hydrology 2018b).

- New Hypo 58A-R: The simulation labeled "New Hypo 58A-R" represents the use of the NWS model to simulate the 58A design storm with the expected reservoir regulation based on current operational procedures (" $\mathrm{R}$ " for regulated). This is similar to the 1955 Report label of 58A-EN, which included reservoir regulation at that time, but $58 \mathrm{~A}-\mathrm{R}$ represents current regulation procedures.

- New Hypo 52A-R: The simulation labeled "New Hypo 52A-R" represents the use of the NWS model to simulate the 52A design storm with the expected reservoir regulation based on current operational procedures (" $R$ " for regulated).

- New Hypo 56-R: The simulation labeled "New Hypo 56-R" represents the use of the NWS model to simulate the 56 design storm with the 
expected reservoir regulation based on current operational procedures (" $R$ " for regulated).

- New Hypo 63-R: The simulation labeled "New Hypo 63-R" represents the use of the NWS model to simulate the 63 design storm with the expected reservoir regulation based on current operational procedures (" $R$ ” for regulated).

Ten New Hypo PDF simulations were performed with the HEC-RAS model: "New Hypo 58A-U PDF - Existing Yazoo," "New Hypo 58A-U PDF - Authorized Yazoo," "New Hypo 58A-R PDF - Existing Yazoo," "New Hypo 58A-R PDF - Authorized Yazoo," "New Hypo 52A-R PDF Existing Yazoo," "New Hypo 52A-R PDF - Authorized Yazoo," "New Hypo 56-R PDF - Existing Yazoo," "New Hypo 56-R PDF - Authorized Yazoo," "New Hypo 63-R PDF - Existing Yazoo," and "New Hypo 63-R PDF - Authorized Yazoo." Unregulated simulations of the 52A, 56, and 63 events were not simulated within the HEC-RAS model, though some information about them can be found in the Hydrology Report (USACE 2018b).

\subsection{Model adjustments}

Most of the assumptions and boundary conditions for the New Hypo PDF simulations matched those of the Historic PDF simulations. The assumptions described in Section 3.2 for Merriwether-Cherokee, main line levees, storage areas, BPNMF, seasonal roughness values, flow roughness values, Morganza Floodway, Bonnet Carré Spillway, Venice, and Gulf of Mexico were also applied to the New Hypo PDF runs.

\subsubsection{Flow adjustments from National Weather Service (NWS) model}

For the new hypothetical HEC-RAS simulations, all of the upstream boundary conditions of inflow required data from the NWS hydrologic model. Up to this point of the assessment, many of the boundary conditions of the HEC-RAS model were supplied with either available gage data or available historic hydrograph data. For the new hypothetical simulations, neither of these alternative options were available. The inflow connections for the new hypothetical simulations were in the same locations as used in the calibration and validation simulations (Figure 2). The MVK noticed that some localized basins used in the NWS modeling did not factor in manmade structures such as levees, so flows had to be relocated, reduced, or removed from the RAS model. Table 12 lists the 
locations used in the flow file, along with NWS basins and percent flows used for each location to account for manmade structures and to correct some distributions. The flow multipliers were calculated based on the appropriate area of the watershed that drains to the MR\&T system.

The MVM and NVN portions of the NWS model did not require any adjustments to the flows from the hydrology model.

Table 12. Boundary condition explanations for the New Hypo PDF runs ("Total": a location where the total routed flow from the NWS hydrologic model was included; “Local": a location where only the local flow from the NWS hydrologic model was included).

\begin{tabular}{|c|c|c|c|c|c|}
\hline $\begin{array}{l}\text { Boundary Condition } \\
\text { Location }\end{array}$ & Type & $\begin{array}{l}\text { NWS } \\
\text { Basin }\end{array}$ & $\begin{array}{l}\text { Local/ } \\
\text { Total }\end{array}$ & $\begin{array}{l}\text { Flow } \\
\text { Multiplier }\end{array}$ & Comment \\
\hline $\begin{array}{l}\text { Atchafalaya } \\
\text { BelowOldRiver: } 0.00\end{array}$ & Rating Curve & N/A & N/A & $\mathrm{N} / \mathrm{A}$ & \\
\hline Black River R2: 25.16 & $\begin{array}{l}\text { T.S. Gate } \\
\text { Openings }\end{array}$ & N/A & N/A & N/A & \\
\hline $\begin{array}{l}\text { Black River R2: } 24.68005 \\
\text { to } 10.17325\end{array}$ & $\begin{array}{l}\text { Uniform } \\
\text { Lateral Inflow }\end{array}$ & $\begin{array}{l}\mathrm{ACML} \\
1 \mathrm{LCL}\end{array}$ & Local & $18 \%$ & $\begin{array}{l}\text { NWS drainage area covered two or } \\
\text { more separate drainage areas }\end{array}$ \\
\hline Boeuf_River R1: 10.95 & $\begin{array}{l}\text { Flow } \\
\text { Hydrograph }\end{array}$ & $\begin{array}{l}\text { JNEL1 } \\
\text { LCL }\end{array}$ & Local & $10 \%$ & $\begin{array}{l}\text { NWS drainage area covered two or } \\
\text { more separate drainage areas }\end{array}$ \\
\hline Boeuf_River R1: 1.32 & $\begin{array}{l}\text { Lateral Inflow } \\
\text { Hydrograph }\end{array}$ & $\begin{array}{l}\text { JNEL1 } \\
\text { LCL }\end{array}$ & Local & $6 \%$ & $\begin{array}{l}\text { NWS drainage area covered two or } \\
\text { more separate drainage areas }\end{array}$ \\
\hline Catoua_R R1: 16.12 & $\begin{array}{l}\text { T.S. Gate } \\
\text { Openings }\end{array}$ & N/A & N/A & N/A & \\
\hline CouleeDesGrues 1: 5.47 & $\begin{array}{l}\text { Flow } \\
\text { Hydrograph }\end{array}$ & N/A & N/A & N/A & baseflow \\
\hline DUMMY 1: 0.04 & $\begin{array}{l}\text { Flow } \\
\text { Hydrograph }\end{array}$ & N/A & N/A & N/A & baseflow \\
\hline $\begin{array}{l}\text { Little_River R1: } 20.96 \text { to } \\
0.99\end{array}$ & $\begin{array}{l}\text { Uniform } \\
\text { Lateral Inflow }\end{array}$ & $\begin{array}{l}\text { JNEL1 } \\
\text { LCL }\end{array}$ & Local & $3 \%$ & $\begin{array}{l}\text { NWS drainage area covered two or } \\
\text { more separate drainage areas }\end{array}$ \\
\hline Little_River R1: 8.53 & $\begin{array}{l}\text { T.S. Gate } \\
\text { Openings }\end{array}$ & N/A & N/A & N/A & \\
\hline $\begin{array}{l}\text { Mississippi Below } \\
\text { Arkansas: } 563.01\end{array}$ & $\begin{array}{l}\text { Lateral Inflow } \\
\text { Hydrograph }\end{array}$ & $\begin{array}{l}\text { ARSA4 } \\
\text { LCL }\end{array}$ & Local & $100 \%$ & \\
\hline $\begin{array}{l}\text { Mississippi Below } \\
\text { Arkansas: } 494.47\end{array}$ & $\begin{array}{l}\text { Lateral Inflow } \\
\text { Hydrograph }\end{array}$ & $\begin{array}{l}\text { VCKM } \\
6 \mathrm{LCL}\end{array}$ & Local & $20 \%$ & $\begin{array}{l}\text { NWS drainage area covered two or } \\
\text { more separate drainage areas }\end{array}$ \\
\hline $\begin{array}{l}\text { Mississippi Below } \\
\text { Vicksburg: } 441.51 \text { to } \\
369.20\end{array}$ & $\begin{array}{l}\text { Uniform } \\
\text { Lateral Inflow }\end{array}$ & $\begin{array}{l}\text { NTZM } \\
6 \mathrm{LCL}\end{array}$ & Local & $87 \%$ & $\begin{array}{l}\text { NWS drainage area covered two or } \\
\text { more separate drainage areas }\end{array}$ \\
\hline $\begin{array}{l}\text { Mississippi Below } \\
\text { Vicksburg: } 368.44 \text { to } \\
322.00\end{array}$ & $\begin{array}{l}\text { Uniform } \\
\text { Lateral Inflow }\end{array}$ & $\begin{array}{l}\text { RRLL1 } \\
\text { LCL }\end{array}$ & Local & $94 \%$ & $\begin{array}{l}\text { NWS drainage area covered two or } \\
\text { more separate drainage areas }\end{array}$ \\
\hline $\begin{array}{l}\text { Mississippi Below } \\
\text { Vicksburg: } 321.03\end{array}$ & $\begin{array}{l}\text { Lateral Inflow } \\
\text { Hydrograph }\end{array}$ & N/A & N/A & $\mathrm{N} / \mathrm{A}$ & Hydropower removal \\
\hline
\end{tabular}




\begin{tabular}{|c|c|c|c|c|c|}
\hline $\begin{array}{l}\text { Boundary Condition } \\
\text { Location }\end{array}$ & Type & $\begin{array}{l}\text { NWS } \\
\text { Basin }\end{array}$ & $\begin{array}{l}\text { Local/ } \\
\text { Total }\end{array}$ & $\begin{array}{l}\text { Flow } \\
\text { Multiplier }\end{array}$ & Comment \\
\hline $\begin{array}{l}\text { Mississippi Below } \\
\text { Vicksburg: } 319.16\end{array}$ & $\begin{array}{l}\text { Lateral Inflow } \\
\text { Hydrograph }\end{array}$ & N/A & N/A & N/A & Low Sill removal \\
\hline $\begin{array}{l}\text { Mississippi Below } \\
\text { Vicksburg: } 318\end{array}$ & $\begin{array}{l}\text { Lateral Inflow } \\
\text { Hydrograph }\end{array}$ & N/A & N/A & N/A & Auxiliary Structure removal \\
\hline $\begin{array}{l}\text { Mississippi Below } \\
\text { Vicksburg: } 15.07\end{array}$ & $\begin{array}{l}\text { Stage } \\
\text { Hydrograph }\end{array}$ & N/A & N/A & N/A & Downstream boundary \\
\hline $\begin{array}{l}\text { Morganza Outlet To } \\
\text { Atchafalaya: } 1.05\end{array}$ & Rules & N/A & N/A & N/A & Morganza Rating Curve Operation \\
\hline $\begin{array}{l}\text { Morganza Outlet To } \\
\text { Atchafalaya: } .5\end{array}$ & $\begin{array}{l}\text { Stage } \\
\text { Hydrograph }\end{array}$ & N/A & N/A & N/A & $\begin{array}{l}\text { Downstream boundary for dummy } \\
\text { Morganza Channel }\end{array}$ \\
\hline Old River1 1: 0.44 & $\begin{array}{l}\text { Flow } \\
\text { Hydrograph }\end{array}$ & N/A & N/A & N/A & Baseflow \\
\hline Old River6 1: 0.12 & $\begin{array}{l}\text { Flow } \\
\text { Hydrograph }\end{array}$ & N/A & N/A & $\mathrm{N} / \mathrm{A}$ & Baseflow \\
\hline $\begin{array}{l}\text { Old River Outflow Auxiliary: } \\
10.10\end{array}$ & $\begin{array}{l}\text { Flow } \\
\text { Hydrograph }\end{array}$ & N/A & N/A & N/A & $\begin{array}{l}\text { Old River Auxiliary inflows from MS } \\
\text { River }\end{array}$ \\
\hline $\begin{array}{l}\text { Old River Outflow LowSill: } \\
0.45\end{array}$ & $\begin{array}{l}\text { Flow } \\
\text { Hydrograph }\end{array}$ & N/A & N/A & N/A & $\begin{array}{l}\text { Old River Low Sill inflows from MS } \\
\text { River }\end{array}$ \\
\hline $\begin{array}{l}\text { Old River Outflow Sidney } \\
\text { Murray: } 19.39\end{array}$ & $\begin{array}{l}\text { Flow } \\
\text { Hydrograph }\end{array}$ & N/A & N/A & N/A & $\begin{array}{l}\text { Old River Hydropower inflows from } \\
\text { MS River }\end{array}$ \\
\hline $\begin{array}{l}\text { Ouachita River R1: } \\
116.9832\end{array}$ & $\begin{array}{l}\text { Flow } \\
\text { Hydrograph }\end{array}$ & COLL1 & Total & $89 \%$ & $\begin{array}{l}\text { NWS drainage area covered two or } \\
\text { more separate drainage areas }\end{array}$ \\
\hline $\begin{array}{l}\text { Ouachita River R1: } \\
116.6533 \text { to } 73.65819\end{array}$ & $\begin{array}{l}\text { Uniform } \\
\text { Lateral Inflow }\end{array}$ & $\begin{array}{l}\text { JNEL1 } \\
\text { LCL }\end{array}$ & Local & $8 \%$ & $\begin{array}{l}\text { NWS drainage area covered two or } \\
\text { more separate drainage areas }\end{array}$ \\
\hline $\begin{array}{l}\text { Ouachita River R1: } \\
116.3172 \text { to } 93.5867\end{array}$ & $\begin{array}{l}\text { Uniform } \\
\text { Lateral Inflow }\end{array}$ & $\begin{array}{l}\text { JNEL1 } \\
\text { LCL }\end{array}$ & Local & $2 \%$ & $\begin{array}{l}\text { NWS drainage area covered two or } \\
\text { more separate drainage areas }\end{array}$ \\
\hline $\begin{array}{l}\text { Ouachita River R2: } \\
65.53948 \text { to } 41.89866\end{array}$ & $\begin{array}{l}\text { Uniform } \\
\text { Lateral Inflow }\end{array}$ & $\begin{array}{l}\text { JNEL1 } \\
\text { LCL }\end{array}$ & Local & $18 \%$ & $\begin{array}{l}\text { NWS drainage area covered two or } \\
\text { more separate drainage areas }\end{array}$ \\
\hline outlet 1: 0 & $\begin{array}{l}\text { Stage } \\
\text { Hydrograph }\end{array}$ & N/A & N/A & $\mathrm{N} / \mathrm{A}$ & $\begin{array}{l}\text { Dummy outlet on downstream end } \\
\text { of Mississippi River }\end{array}$ \\
\hline $\begin{array}{l}\text { Red River above Black } \\
\text { River: } 38.41\end{array}$ & $\begin{array}{l}\text { Flow } \\
\text { Hydrograph }\end{array}$ & $\begin{array}{l}\text { RRBL } \\
1\end{array}$ & Total & $100 \%$ & \\
\hline $\begin{array}{l}\text { Red River above Black } \\
\text { River: } 9.07\end{array}$ & $\begin{array}{l}\text { T.S. Gate } \\
\text { Openings }\end{array}$ & N/A & N/A & N/A & L\&D 1 \\
\hline $\begin{array}{l}\text { Red River above Black } \\
\text { River: } 8.85 \text { to }-0.11\end{array}$ & $\begin{array}{l}\text { Uniform } \\
\text { Lateral Inflow }\end{array}$ & $\begin{array}{l}\text { BBLL1 } \\
\text { LCL }\end{array}$ & Local & $4 \%$ & $\begin{array}{l}\text { NWS drainage area covered two or } \\
\text { more separate drainage areas }\end{array}$ \\
\hline $\begin{array}{l}\text { Tensas_River R1: } \\
31.09949\end{array}$ & $\begin{array}{l}\text { Flow } \\
\text { Hydrograph }\end{array}$ & $\begin{array}{l}\text { VCKM } \\
6 \mathrm{LCL}\end{array}$ & Local & $4 \%$ & $\begin{array}{l}\text { NWS drainage area covered two or } \\
\text { more separate drainage areas }\end{array}$ \\
\hline $\begin{array}{l}\text { Tensas_River R1: } \\
31.09949\end{array}$ & $\begin{array}{l}\text { Flow } \\
\text { Hydrograph }\end{array}$ & CYNL1 & Total & $93 \%$ & $\begin{array}{l}\text { NWS drainage area covered two or } \\
\text { more separate drainage areas }\end{array}$ \\
\hline $\begin{array}{l}\text { Tensas_River R1: } \\
31.09949\end{array}$ & $\begin{array}{l}\text { Flow } \\
\text { Hydrograph }\end{array}$ & $\begin{array}{l}\text { NTZM } \\
6 \mathrm{LCL}\end{array}$ & Local & $11 \%$ & $\begin{array}{l}\text { NWS drainage area covered two or } \\
\text { more separate drainage areas }\end{array}$ \\
\hline
\end{tabular}




\begin{tabular}{|c|c|c|c|c|c|}
\hline $\begin{array}{l}\text { Boundary Condition } \\
\text { Location }\end{array}$ & Type & $\begin{array}{l}\text { NWS } \\
\text { Basin }\end{array}$ & \begin{tabular}{|l|} 
Local/ \\
Total
\end{tabular} & \begin{tabular}{|l|} 
Flow \\
Multiplier
\end{tabular} & Comment \\
\hline W-Wit 1: 30.31 & $\begin{array}{l}\text { Lateral Inflow } \\
\text { Hydrograph }\end{array}$ & $\mathrm{N} / \mathrm{A}$ & N/A & $\mathrm{N} / \mathrm{A}$ & Baseflow \\
\hline $\begin{array}{l}\text { Yazoo River Reach1: } \\
158.76\end{array}$ & $\begin{array}{l}\text { Flow } \\
\text { Hydrograph }\end{array}$ & $\begin{array}{l}\text { GREM } \\
6\end{array}$ & Total & $100 \%$ & \\
\hline $\begin{array}{l}\text { Yazoo River Reach1: } \\
157.17 \text { to } 116.88\end{array}$ & $\begin{array}{l}\text { Uniform } \\
\text { Lateral Inflow }\end{array}$ & $\begin{array}{l}\text { BELM } \\
6 \mathrm{LCL}\end{array}$ & Local & $100 \%$ & \\
\hline $\begin{array}{l}\text { Yazoo River Reach1.5: } \\
107.39 \text { to } 76.51\end{array}$ & $\begin{array}{l}\text { Uniform } \\
\text { Lateral Inflow }\end{array}$ & $\begin{array}{l}\text { YZOM } \\
6 \mathrm{LCL}\end{array}$ & Local & $100 \%$ & \\
\hline $\begin{array}{l}\text { Yazoo River Reach2: } 31.81 \\
\text { to } 17.93\end{array}$ & $\begin{array}{l}\text { Uniform } \\
\text { Lateral Inflow }\end{array}$ & $\begin{array}{l}\text { VCKM } \\
6 \mathrm{LCL}\end{array}$ & Local & $20 \%$ & $\begin{array}{l}\text { NWS drainage area covered two or } \\
\text { more separate drainage areas }\end{array}$ \\
\hline Storage Area: 1022 & $\begin{array}{l}\text { Lateral Inflow } \\
\text { Hydrograph }\end{array}$ & $\begin{array}{l}\text { ANGM } \\
6\end{array}$ & Total & $100 \%$ & \\
\hline Storage Area: 1022 & $\begin{array}{l}\text { Lateral Inflow } \\
\text { Hydrograph }\end{array}$ & $\begin{array}{l}\text { VCKM } \\
6 L C L\end{array}$ & Local & $56 \%$ & $\begin{array}{l}\text { NWS drainage area covered two or } \\
\text { more separate drainage areas }\end{array}$ \\
\hline Storage Area: 12 & $\begin{array}{l}\text { Lateral Inflow } \\
\text { Hydrograph }\end{array}$ & $\begin{array}{l}\text { RRAL1 } \\
\text { LCL }\end{array}$ & Local & $22 \%$ & $\begin{array}{l}\text { NWS drainage area covered two or } \\
\text { more separate drainage areas }\end{array}$ \\
\hline Storage Area: 12 & $\begin{array}{l}\text { Lateral Inflow } \\
\text { Hydrograph }\end{array}$ & $\begin{array}{l}\text { CTLL1 } \\
\text { LCL }\end{array}$ & Local & $2 \%$ & $\begin{array}{l}\text { NWS drainage area covered two or } \\
\text { more separate drainage areas }\end{array}$ \\
\hline Storage Area: 12 & $\begin{array}{l}\text { Lateral Inflow } \\
\text { Hydrograph }\end{array}$ & $\begin{array}{l}\text { ACML } \\
1 \mathrm{LCL}\end{array}$ & Local & $18 \%$ & $\begin{array}{l}\text { NWS drainage area covered two or } \\
\text { more separate drainage areas }\end{array}$ \\
\hline Storage Area: 12 & $\begin{array}{l}\text { Lateral Inflow } \\
\text { Hydrograph }\end{array}$ & $\begin{array}{l}\text { JNEL1 } \\
\text { LCL }\end{array}$ & Local & $3 \%$ & $\begin{array}{l}\text { NWS drainage area covered two or } \\
\text { more separate drainage areas }\end{array}$ \\
\hline Storage Area: 13 & $\begin{array}{l}\text { Lateral Inflow } \\
\text { Hydrograph }\end{array}$ & $\begin{array}{l}\text { RRAL1 } \\
\text { LCL }\end{array}$ & Local & $69 \%$ & $\begin{array}{l}\text { NWS drainage area covered two or } \\
\text { more separate drainage areas }\end{array}$ \\
\hline Storage Area: 13 & $\begin{array}{l}\text { Lateral Inflow } \\
\text { Hydrograph }\end{array}$ & $\begin{array}{l}\text { CTLL1 } \\
\text { LCL }\end{array}$ & Local & $2 \%$ & $\begin{array}{l}\text { NWS drainage area covered two or } \\
\text { more separate drainage areas }\end{array}$ \\
\hline Storage Area: 13 & $\begin{array}{l}\text { Lateral Inflow } \\
\text { Hydrograph }\end{array}$ & $\begin{array}{l}\mathrm{ACML} \\
1 \mathrm{LCL}\end{array}$ & Local & $17 \%$ & $\begin{array}{l}\text { NWS drainage area covered two or } \\
\text { more separate drainage areas }\end{array}$ \\
\hline Storage Area: 149 & $\begin{array}{l}\text { Lateral Inflow } \\
\text { Hydrograph }\end{array}$ & $\begin{array}{l}\text { RRLL1 } \\
\text { LCL }\end{array}$ & Local & $6 \%$ & $\begin{array}{l}\text { NWS drainage area covered two or } \\
\text { more separate drainage areas }\end{array}$ \\
\hline Storage Area: 149 & $\begin{array}{l}\text { Lateral Inflow } \\
\text { Hydrograph }\end{array}$ & $\begin{array}{l}\text { BBLL1 } \\
\text { LCL }\end{array}$ & Local & $67 \%$ & $\begin{array}{l}\text { NWS drainage area covered two or } \\
\text { more separate drainage areas }\end{array}$ \\
\hline Storage Area: 149 & $\begin{array}{l}\text { Lateral Inflow } \\
\text { Hydrograph }\end{array}$ & $\begin{array}{l}\text { ACML } \\
1 \mathrm{LCL}\end{array}$ & Local & $47 \%$ & $\begin{array}{l}\text { NWS drainage area covered two or } \\
\text { more separate drainage areas }\end{array}$ \\
\hline Storage Area: 149 & $\begin{array}{l}\text { Lateral Inflow } \\
\text { Hydrograph }\end{array}$ & CYNL1 & Total & $1 \%$ & $\begin{array}{l}\text { NWS drainage area covered two or } \\
\text { more separate drainage areas }\end{array}$ \\
\hline Storage Area: 149 & $\begin{array}{l}\text { Lateral Inflow } \\
\text { Hydrograph }\end{array}$ & $\begin{array}{l}\text { JNEL1 } \\
\text { LCL }\end{array}$ & Local & $13 \%$ & $\begin{array}{l}\text { NWS drainage area covered two or } \\
\text { more separate drainage areas }\end{array}$ \\
\hline Storage Area: 149 & $\begin{array}{l}\text { Lateral Inflow } \\
\text { Hydrograph }\end{array}$ & $\begin{array}{l}\text { NTZM } \\
6 \mathrm{LCL}\end{array}$ & Local & $2 \%$ & $\begin{array}{l}\text { NWS drainage area covered two or } \\
\text { more separate drainage areas }\end{array}$ \\
\hline Storage Area: 19426 & $\begin{array}{l}\text { Lateral Inflow } \\
\text { Hydrograph }\end{array}$ & COLL1 & Total & $11 \%$ & $\begin{array}{l}\text { NWS drainage area covered two or } \\
\text { more separate drainage areas }\end{array}$ \\
\hline
\end{tabular}




\begin{tabular}{|c|c|c|c|c|c|}
\hline $\begin{array}{l}\text { Boundary Condition } \\
\text { Location }\end{array}$ & Type & $\begin{array}{l}\text { NWS } \\
\text { Basin }\end{array}$ & $\begin{array}{l}\text { Local/ } \\
\text { Total }\end{array}$ & \begin{tabular}{|l|} 
Flow \\
Multiplier
\end{tabular} & Comment \\
\hline Storage Area: 222 & $\begin{array}{l}\text { Lateral Inflow } \\
\text { Hydrograph }\end{array}$ & $\begin{array}{l}\text { RRLL1 } \\
\text { LCL }\end{array}$ & Local & $1 \%$ & $\begin{array}{l}\text { NWS drainage area covered two or } \\
\text { more separate drainage areas }\end{array}$ \\
\hline Storage Area: 29 & $\begin{array}{l}\text { Lateral Inflow } \\
\text { Hydrograph }\end{array}$ & CYNL1 & Total & $7 \%$ & $\begin{array}{l}\text { NWS drainage area covered two or } \\
\text { more separate drainage areas }\end{array}$ \\
\hline Storage Area: 29 & $\begin{array}{l}\text { Lateral Inflow } \\
\text { Hydrograph }\end{array}$ & $\begin{array}{l}\text { JNEL1 } \\
\text { LCL }\end{array}$ & Local & $16 \%$ & $\begin{array}{l}\text { NWS drainage area covered two or } \\
\text { more separate drainage areas }\end{array}$ \\
\hline Storage Area: 810 & $\begin{array}{l}\text { Lateral Inflow } \\
\text { Hydrograph }\end{array}$ & $\begin{array}{l}\text { BBLL1 } \\
\text { LCL }\end{array}$ & Local & $11 \%$ & $\begin{array}{l}\text { NWS drainage area covered two or } \\
\text { more separate drainage areas }\end{array}$ \\
\hline Storage Area: 812 & $\begin{array}{l}\text { Lateral Inflow } \\
\text { Hydrograph }\end{array}$ & $\begin{array}{l}\text { CTLL1 } \\
\text { LCL }\end{array}$ & Local & $97 \%$ & $\begin{array}{l}\text { NWS drainage area covered two or } \\
\text { more separate drainage areas }\end{array}$ \\
\hline Storage Area: 812 & $\begin{array}{l}\text { Lateral Inflow } \\
\text { Hydrograph }\end{array}$ & RHLL1 & Total & $100 \%$ & \\
\hline Storage Area: Bayou Pierre & $\begin{array}{l}\text { Lateral Inflow } \\
\text { Hydrograph }\end{array}$ & $\begin{array}{l}\text { WBPM } \\
6 \mathrm{LCL}\end{array}$ & Total & $100 \%$ & \\
\hline Storage Area:Big Black & $\begin{array}{l}\text { Lateral Inflow } \\
\text { Hydrograph }\end{array}$ & $\begin{array}{l}\text { BOVM } \\
6\end{array}$ & Total & $100 \%$ & \\
\hline Storage Area:Buffalo & $\begin{array}{l}\text { Lateral Inflow } \\
\text { Hydrograph }\end{array}$ & $\begin{array}{l}\text { WOOM } \\
6 \mathrm{LCL}\end{array}$ & Total & $100 \%$ & \\
\hline Storage Area:Homochito & $\begin{array}{l}\text { Lateral Inflow } \\
\text { Hydrograph }\end{array}$ & $\begin{array}{l}\text { RSAM } \\
6\end{array}$ & Total & $100 \%$ & \\
\hline $\begin{array}{l}\text { Storage Area:Lower Sunk } \\
\text { Lake }\end{array}$ & $\begin{array}{l}\text { Lateral Inflow } \\
\text { Hydrograph }\end{array}$ & $\begin{array}{l}\text { BBLL1 } \\
\text { LCL }\end{array}$ & Local & $17 \%$ & $\begin{array}{l}\text { NWS drainage area covered two or } \\
\text { more separate drainage areas }\end{array}$ \\
\hline $\begin{array}{l}\text { Storage Area:Muscle Lake } \\
\text { Area }\end{array}$ & $\begin{array}{l}\text { Lateral Inflow } \\
\text { Hydrograph }\end{array}$ & $\begin{array}{l}\text { SMML } \\
1 \mathrm{LCL}\end{array}$ & Local & $74 \%$ & $\begin{array}{l}\text { NWS drainage area covered two or } \\
\text { more separate drainage areas }\end{array}$ \\
\hline
\end{tabular}

\subsubsection{Old River Control Complex (ORCC)}

The flow diversion for the ORCC typically operates at a distribution of 70\% Mississippi River and 30\% Atchafalaya River (70/30) for the total latitude of flow from the Mississippi River and Red River combined. During the New Hypo PDF event simulations, the flow was assumed to remain at the $70 / 30$ distribution until the flow through the ORCC reached its authorized capacity of $620,000 \mathrm{cfs}$. The calculation of the flow diversion is based on a 1-day forecast of the Mississippi and Red Rivers. Since HEC-RAS does not have the functionality to automatically handle this type of flow distribution in the ORCC operations, a separate spreadsheet was used to manually check and iterate the HEC-RAS simulations until the ORCC was properly operated within the HEC-RAS model. The iterative steps follow: 
1. Run with an initial estimate of diversion flow through ORCC.

2. Extract the hourly simulated flows in the RRL location of the Mississippi River and the Simmesport location of the Atchafalaya River.

3. Compute the percentages and compare with the $70 / 30$.

4. Adjust the hourly ORCC diversion to get closer to the 70/30 proportion. Specifically, calculate the percentage away from the $30 \%$ on the Atchafalaya River and adjust the ORCC diversion by a factor (between 1 and 3) of that percentage. The factor is determined based on the level of flood water in the Red River; a value of 1 was used if the stages were near top of bank, and a value of 3 was used if the stages were near the larger flood level. For example, if the Atchafalaya River flow is $33 \%$, or $3 \%$ too high, then the ORCC diversion will be reduced by $3 \%$ (using a factor of 1 ) to $9 \%$ (using a factor of 3 ) of what it was.

5. Run with the new ORCC diversion estimate.

6. Repeat steps $2-5$ until the $70 / 30$ is reached (rounded to the nearest percentage).

\subsection{Results}

The flows and stages of the New Hypo PDF simulations indicate the expected hydraulic behavior using the newly generated hypothetical design storm hydrology. The unsteady HEC-RAS model calculates how the New Hypo PDF storm flows (from USACE 2018b) would be routed through the system. Flow hydrographs are used to see how the flows vary as the events propagate. The peak flows and peak water surface elevations can also be extracted at key locations.

\subsubsection{New Hypo 58A PDF}

Figure 38 through Figure 42 show the flow hydrographs of the New Hypo PDF 58A-R simulations at key locations. The Refined 1973 Flowline Study (USACE 1978), Historic PDF Authorized Yazoo and Historic PDF Existing Yazoo used the previously developed inflow hydrographs from the 1955 Hydrology, hence the "1955" label in the figures. In comparison with those three lines, only the 58A-R Authorized Yazoo results are shown in the figures for visual clarity. Other simulation results are presented in Table 13 and Table 14. Table 13 compares the previously published flows from the 1955 hydrology with the New Hypo PDF flows within the new HEC-RAS model developed for this assessment. Table 14 shows the water surface comparisons between the previous elevations from the Refined 1973 Flowline Study (converted to 
NAVD88) and the New Hypo PDF results of this assessment. The water surface profiles of the Refined 1973 Flowline Study (USACE 1978), Historic PDF Authorized Yazoo, and 58A-R Authorized Yazoo results are shown in 100-mile increments in Figure 43 through Figure 52.

Results show that the flows are higher in the current assessment than the Refined 1973 Flowline Study (USACE 1978). This is to be expected since the new Hydrology Report associated with the current assessment provided higher flows which were used as input boundary conditions to this HEC-RAS model. For more discussion about the increase in flow, see the Hydrology Report (USACE Hydrology 2018a). Figure 38 through Figure 42 show that the peak flows of the 58A-R Authorized Yazoo simulation were higher and arrived sooner than the previous results.

Table 14 and Figure 43 through Figure 52 show that the computed water surfaces are generally higher for the current assessment than the results using the 1955 hydrology. Many water surface elevations are approximately $4 \mathrm{ft}$ higher in the 58A-R Authorized Yazoo simulation than the Refined 1973 Flowline Study water surfaces, converted to NAVD88. None of the data sets shown here include the loop effect or channel degradation impacts.

The water surface results for the downstream end of the river are lower in the current assessment than the Refined 1973 Flowline Study (USACE 1978) due to differences in downstream boundary condition assumptions. The rating curve boundary condition is a significant difference from the Refined 1973 Flowline Study. The amount of water that is flowing out of the river through natural and man-made diversions is also much higher now in the lower part of the Mississippi River than it was in the 1970s. There are other dynamics that could occur at the downstream end of the river due to coastal events that were not included within the scope of this assessment, and these would have significant impacts in terms of the expected maximum range of water surfaces for that reach.

A couple of the biggest differences in stage occur just upstream of Memphis (Figure 45) and near Baton Rouge (Figure 50). The Refined 1973 Flowline Study (USACE 1978) profile upstream of Memphis is not as smooth as the current HEC-RAS model. This was noticed during the calibration to the 2011 event. In other words, the current HEC-RAS model has been calibrated to the 2011 conditions such that a high flow 
event exhibits a smoother profile than shown in the Refined 1973 Flowline Study (USACE 1978) results. As seen in Figure 45 approximately $3 \mathrm{ft}$ of the $8 \mathrm{ft}$ of difference in stage can be attributed to the smoother model simulation here at this specific location. The 58A-R Authorized Yazoo stage at Baton Rouge is $7.1 \mathrm{ft}$ higher than the Refined 1973 Flowline Study (USACE 1978), as seen in Table 14. Due to the higher flows and earlier arrival time, the unsteady hydraulic results show a generally increasing difference in water surface from Vicksburg moving downstream until near Baton Rouge where it peaks. The Baton Rouge location is also near where the geomorphic trends (Biedenharn et al. 2017) switch from being aggradational upstream of this location to a state of dynamic equilibrium downstream.

Table 13. Maximum flow comparisons of the New Hypo 58A PDF simulations (cubic feet per second).

\begin{tabular}{|c|c|c|c|c|c|c|}
\hline Location & $\begin{array}{l}\text { RAS } \\
\text { Station }\end{array}$ & $\begin{array}{l}\text { Published } \\
1955 \\
\text { Hydrology }\end{array}$ & $\begin{array}{l}\text { New Hypo } \\
\text { PDF 58A-R } \\
\text { Existing } \\
\text { Yazoo }\end{array}$ & $\begin{array}{l}\text { New Hypo } \\
\text { PDF 58A-U } \\
\text { Existing } \\
\text { Yazoo }\end{array}$ & $\begin{array}{l}\text { New Hypo } \\
\text { PDF 58A-R } \\
\text { Authorized } \\
\text { Yazoo }\end{array}$ & $\begin{array}{l}\text { New Hypo PDF } \\
58 A-U \\
\text { Authorized } \\
\text { Yazoo }\end{array}$ \\
\hline $\begin{array}{l}\text { Mississippi at } \\
\text { Chester }\end{array}$ & 110.4 & 240,000 & 508,000 & 546,000 & 508,000 & 546,000 \\
\hline Ohio River at Cairo & -979.68 & $2,250,000$ & $2,326,000$ & $2,458,000$ & $2,326,000$ & $2,458,000$ \\
\hline $\begin{array}{l}\text { Mississippi at Ohio } \\
\text { River }\end{array}$ & 973.85 & $2,360,000$ & $2,791,000$ & $2,937,000$ & $2,791,000$ & $2,937,000$ \\
\hline $\begin{array}{l}\text { Mississippi at } \\
\text { Hickman }\end{array}$ & 942.45 & $1,810,000$ & $1,973,000$ & $1,988,000$ & $1,973,000$ & $1,988,000$ \\
\hline $\begin{array}{l}\text { Mississippi at } \\
\text { Memphis }\end{array}$ & 749.01 & $2,410,000$ & $2,862,000$ & $2,956,000$ & $2,862,000$ & $2,956,000$ \\
\hline $\begin{array}{l}\text { Mississippi at } \\
\text { Helena }\end{array}$ & 676.42 & $2,460,000$ & $2,787,000$ & $2,861,000$ & $2,787,000$ & $2,861,000$ \\
\hline $\begin{array}{l}\text { Mississippi at } \\
\text { Arkansas City }\end{array}$ & 562.18 & $2,890,000$ & $3,263,000$ & $3,367,000$ & $3,263,000$ & $3,367,000$ \\
\hline $\begin{array}{l}\text { Arkansas River at } \\
\text { Dam } 02\end{array}$ & 28.07 & 400,000 & 487,000 & 521,000 & 487,000 & 521,000 \\
\hline St. Francis at 82.47 & 82.47 & 80,000 & 85,000 & 85,000 & 85,000 & 85,000 \\
\hline $\begin{array}{l}\text { White River at } \\
\text { Clarendon }\end{array}$ & 100.05 & 220,000 & 233,000 & 271,000 & 233,000 & 271,000 \\
\hline $\begin{array}{l}\text { Mississippi at } \\
\text { Greenville }\end{array}$ & 539.13 & & $3,259,000$ & $3,362,000$ & $3,260,000$ & $3,364,000$ \\
\hline $\begin{array}{l}\text { Mississippi at Lake } \\
\text { Providence }\end{array}$ & 494.47 & & $3,253,000$ & $3,357,000$ & $3,257,000$ & $3,361,000$ \\
\hline $\begin{array}{l}\text { Mississippi at } \\
\text { Vicksburg }\end{array}$ & 442.16 & $2,710,000$ & $3,076,000$ & $3,245,000$ & $3,087,000$ & $3,122,000$ \\
\hline
\end{tabular}




\begin{tabular}{|l|c|c|l|l|l|l|}
\hline & $\begin{array}{l}\text { RAS } \\
\text { Station }\end{array}$ & $\begin{array}{l}\text { Published } \\
1955 \\
\text { Hydrology }\end{array}$ & $\begin{array}{l}\text { New Hypo } \\
\text { PDF 58A-R } \\
\text { Existing } \\
\text { Yazoo }\end{array}$ & $\begin{array}{l}\text { New Hypo } \\
\text { PDF 58A-U } \\
\text { Existing } \\
\text { Yazoo }\end{array}$ & $\begin{array}{l}\text { New Hypo } \\
\text { PDF 58A-R } \\
\text { Authorized } \\
\text { Yazoo }\end{array}$ & $\begin{array}{l}\text { New Hypo PDF } \\
\text { 58A-U } \\
\text { Authorized } \\
\text { Yazoo }\end{array}$ \\
\hline $\begin{array}{l}\text { Mississippi at } \\
\text { Natchez }\end{array}$ & 368.44 & $2,720,000$ & $3,072,000$ & $3,242,000$ & $3,099,000$ & $3,135,000$ \\
\hline Mississippi at RRL & 306.43 & $2,100,000$ & $2,449,000$ & $2,618,000$ & $2,475,000$ & $2,514,000$ \\
\hline $\begin{array}{l}\text { Mississippi at Baton } \\
\text { Rouge Gage }\end{array}$ & 233.1 & $1,500,00$ & $1,838,000$ & $2,007,000$ & $1,869,000$ & $1,910,000$ \\
\hline $\begin{array}{l}\text { Mississippi at } \\
\text { Donaldsonville gage }\end{array}$ & 179.04 & $1,500,00$ & $1,837,000$ & $2,007,000$ & $1,868,000$ & $1,910,000$ \\
\hline $\begin{array}{l}\text { Mississippi at } \\
\text { Carrollton Gage }\end{array}$ & 107.2 & $1,250,000$ & $1,581,000$ & $1,751,000$ & $1,613,000$ & $1,654,000$ \\
\hline $\begin{array}{l}\text { Mississippi at } \\
\text { Empire Gage }\end{array}$ & 33.79 & $1,250,000$ & $1,513,000$ & $1,675,000$ & $1,543,000$ & $1,583,000$ \\
\hline $\begin{array}{l}\text { Mississippi at } \\
\text { Venice gage (15.07) }\end{array}$ & 15.07 & $1,250,000$ & $1,094,000$ & $1,204,000$ & $1,115,000$ & $1,142,000$ \\
\hline
\end{tabular}

Table 14. Maximum stage comparisons of the New Hypo 58A PDF simulations (feet, NAVD88) (*from the Refined 1973 Flowline Study [USACE 1978], this column is without loop effect, sedimentation, or freeboard effects).

\begin{tabular}{|c|c|c|c|c|c|c|}
\hline Location & $\begin{array}{l}\text { RAS } \\
\text { Station }\end{array}$ & $\begin{array}{l}\text { Refined } \\
1973 \\
\text { Flowline } \\
\text { (58A-EN)* }\end{array}$ & $\begin{array}{l}\text { New Hypo } \\
\text { PDF 58A-R } \\
\text { Existing } \\
\text { Yazoo }\end{array}$ & $\begin{array}{l}\text { New Hypo } \\
\text { PDF 58A-U } \\
\text { Existing } \\
\text { Yazoo }\end{array}$ & $\begin{array}{l}\text { New Hypo } \\
\text { PDF 58A-R } \\
\text { Authorized } \\
\text { Yazoo }\end{array}$ & $\begin{array}{l}\text { New Hypo } \\
\text { PDF 58A-U } \\
\text { Authorized } \\
\text { Yazoo }\end{array}$ \\
\hline Mississippi at Chester & 110.4 & & 372.5 & 374.3 & 372.5 & 374.3 \\
\hline Ohio River at Cairo & -979.68 & & 334.8 & 335.5 & 334.8 & 335.5 \\
\hline $\begin{array}{l}\text { Mississippi at Ohio } \\
\text { River }\end{array}$ & 973.85 & 331.7 & 334.3 & 335.0 & 334.3 & 335.0 \\
\hline $\begin{array}{l}\text { Mississippi at } \\
\text { Hickman }\end{array}$ & 942.45 & 320.7 & 321.4 & 322.2 & 321.4 & 322.2 \\
\hline $\begin{array}{l}\text { Mississippi at } \\
\text { Memphis }\end{array}$ & 749.01 & 237.2 & 241.4 & 242.7 & 241.4 & 242.7 \\
\hline Mississippi at Helena & 676.42 & 202.9 & 206.0 & 207.1 & 206.0 & 207.1 \\
\hline $\begin{array}{l}\text { Mississippi at } \\
\text { Arkansas City }\end{array}$ & 562.18 & 155.5 & 158.9 & 160.1 & 159.0 & 160.1 \\
\hline $\begin{array}{l}\text { Arkansas River at } \\
\text { Dam 02 }\end{array}$ & 28.07 & & 177.1 & 178.3 & 177.2 & 178.3 \\
\hline St. Francis & 82.47 & & 217.1 & 217.1 & 217.1 & 217.1 \\
\hline $\begin{array}{l}\text { White River at } \\
\text { Clarendon }\end{array}$ & 100.05 & & 181.9 & 183.9 & 181.9 & 183.9 \\
\hline $\begin{array}{l}\text { Mississippi at } \\
\text { Greenville }\end{array}$ & 539.13 & 145.2 & 148.0 & 149.2 & 148.2 & 149.1 \\
\hline $\begin{array}{l}\text { Mississippi at Lake } \\
\text { Providence }\end{array}$ & 494.47 & 129.4 & 131.7 & 133.1 & 132.0 & 132.9 \\
\hline
\end{tabular}




\begin{tabular}{|l|c|c|l|l|l|c|}
\hline & RAS & $\begin{array}{l}\text { Refined } \\
1973 \\
\text { Flowline } \\
\text { (58A-EN)* }\end{array}$ & $\begin{array}{l}\text { New Hypo } \\
\text { PDF 58A-R } \\
\text { Existing } \\
\text { Yazoo }\end{array}$ & $\begin{array}{l}\text { New Hypo } \\
\text { PDF 58A-U } \\
\text { Existing } \\
\text { Yazoo }\end{array}$ & $\begin{array}{l}\text { New Hypo } \\
\text { PDF 58A-R } \\
\text { Authorized } \\
\text { Yazoo }\end{array}$ & $\begin{array}{l}\text { New Hypo } \\
\text { PDF 58A-U } \\
\text { Authorized } \\
\text { Yazoo }\end{array}$ \\
\hline $\begin{array}{l}\text { Mississippi at } \\
\text { Vicksburg }\end{array}$ & 442.16 & 106.9 & 111.3 & 113.3 & 111.7 & 112.1 \\
\hline Mississippi at Natchez & 368.44 & 82.7 & 88 & 90.1 & 88.4 & 88.9 \\
\hline Mississippi at RRL & 306.43 & 63.5 & 69.3 & 72.2 & 69.8 & 70.5 \\
\hline $\begin{array}{l}\text { Mississippi at Baton } \\
\text { Rouge Gage }\end{array}$ & 233.1 & 45.7 & 52.1 & 55.8 & 52.8 & 53.7 \\
\hline $\begin{array}{l}\text { Mississippi at } \\
\text { Donaldsonville gage }\end{array}$ & 179.04 & 33.8 & 39.4 & 43.1 & 40.1 & 41.0 \\
\hline $\begin{array}{l}\text { Mississippi at } \\
\text { Carrollton Gage }\end{array}$ & 107.2 & 19.6 & 22.3 & 25.1 & 22.8 & 23.5 \\
\hline $\begin{array}{l}\text { Mississippi at Empire } \\
\text { Gage }\end{array}$ & 33.79 & 9.8 & 7.0 & 7.8 & 7.2 & 7.3 \\
\hline $\begin{array}{l}\text { Mississippi at Venice } \\
\text { gage }\end{array}$ & 15.07 & 8.1 & 4.1 & 4.3 & 4.2 & 4.2 \\
\hline
\end{tabular}

Figure 38. New Hypo PDF 58A-R flow hydrograph at the Below Cairo location (the flows are the same at this location for the "Existing Yazoo" and "Authorized Yazoo" runs since it is relatively far upstream).

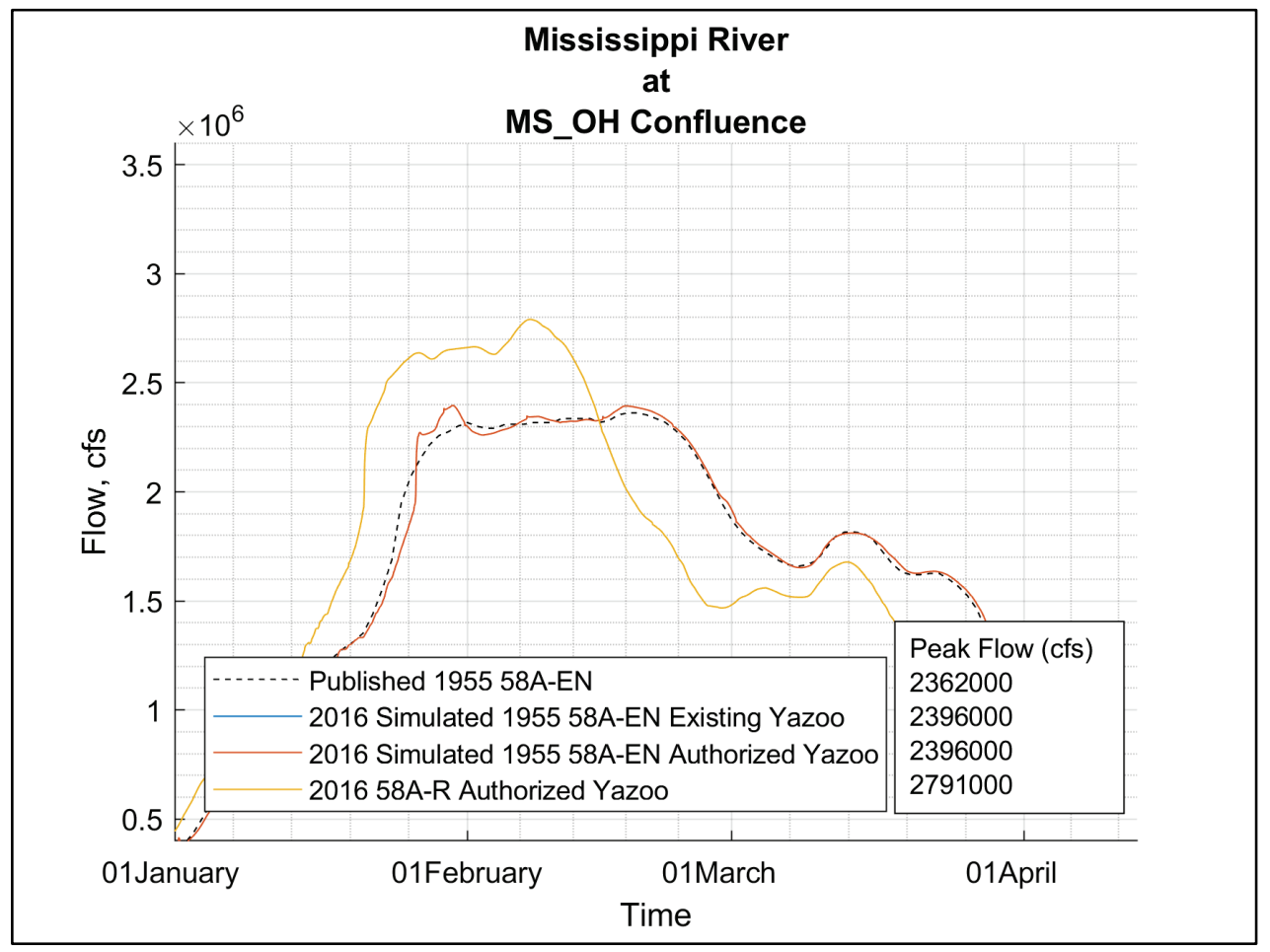


Figure 39. New Hypo PDF 58A-R flow hydrograph at the Memphis location (the flows are the same at this location for the "Existing Yazoo" and "Authorized Yazoo" runs since it is relatively far upstream).

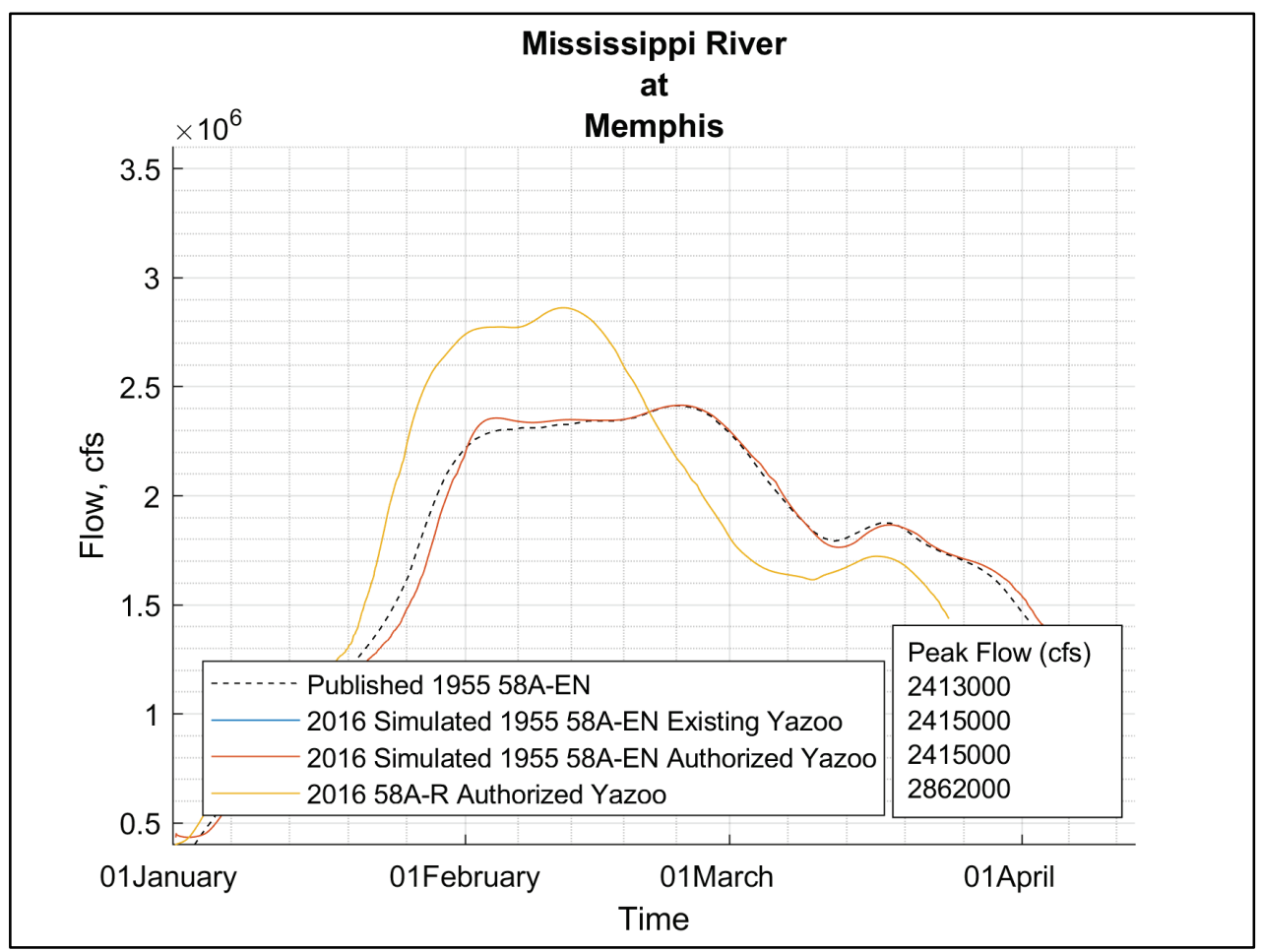

Figure 40. New Hypo PDF 58A-R flow hydrograph at the Helena location (the flows are the same at this location for the "Existing Yazoo" and "Authorized Yazoo" runs since it is relatively far upstream).

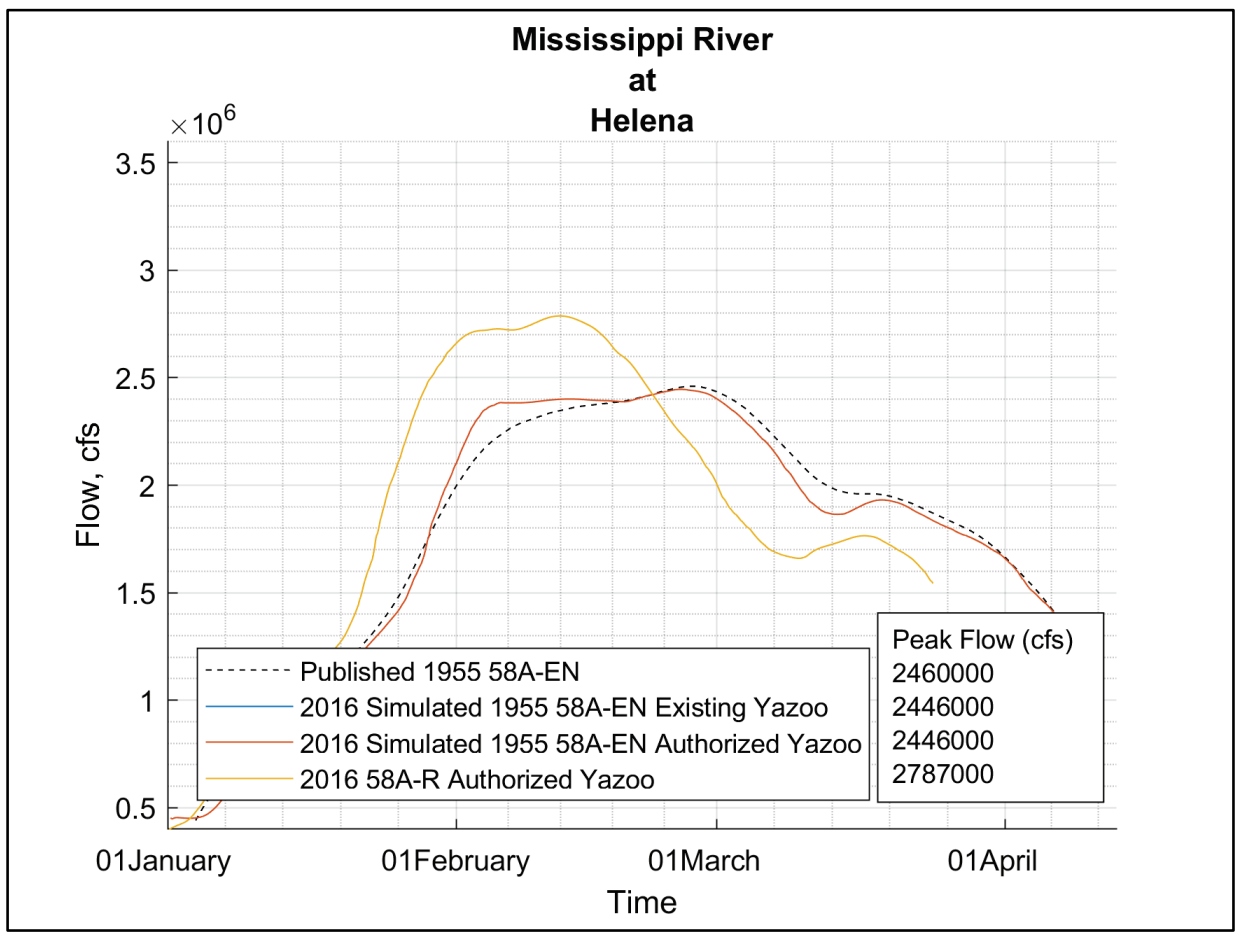


Figure 41. New Hypo PDF 58A-R flow hydrograph at the Arkansas City location (the flows are the same at this location for the "Existing Yazoo" and "Authorized Yazoo"

runs since it is relatively far upstream).

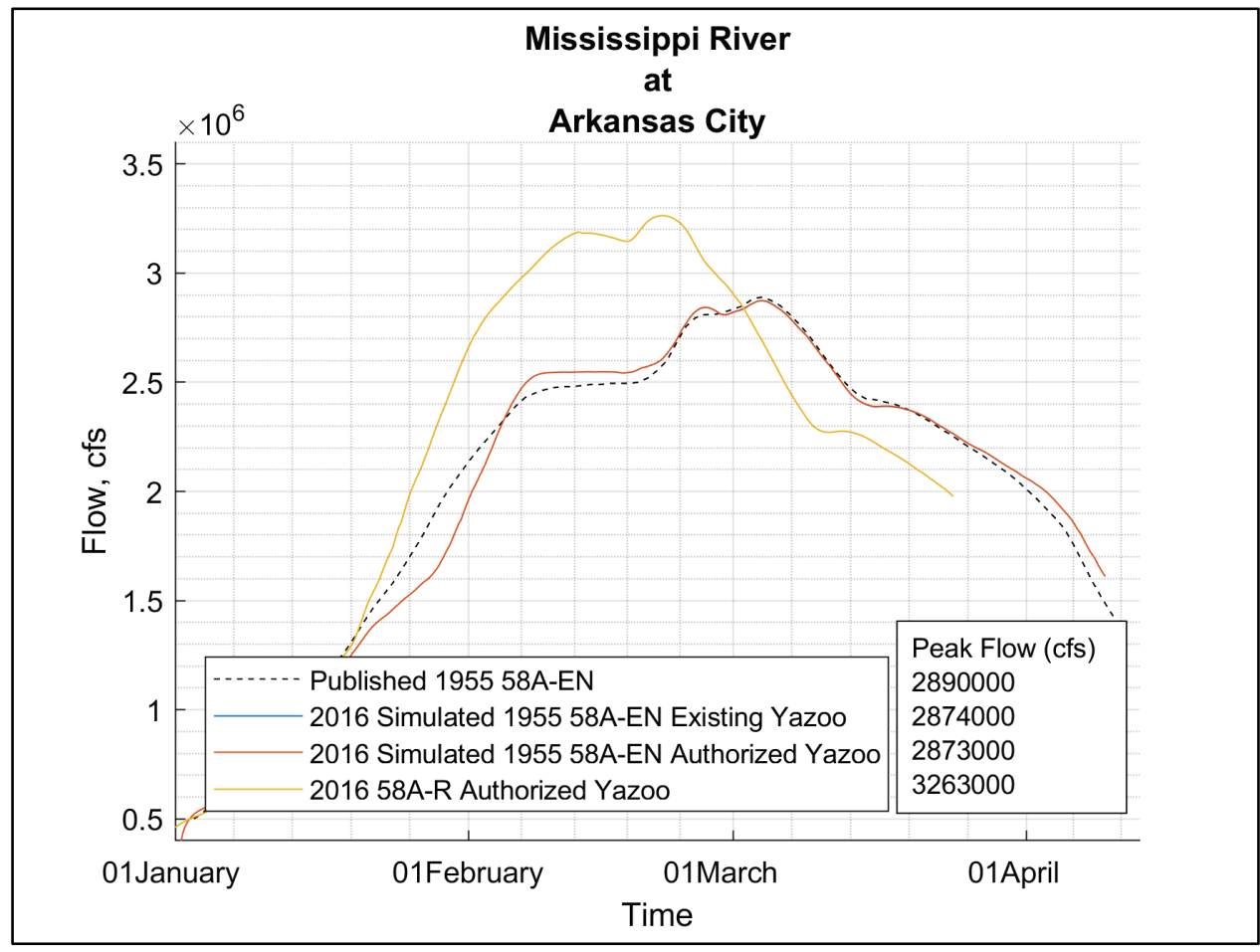

Figure 42. New Hypo PDF 58A-R flow hydrograph at the RRL location.

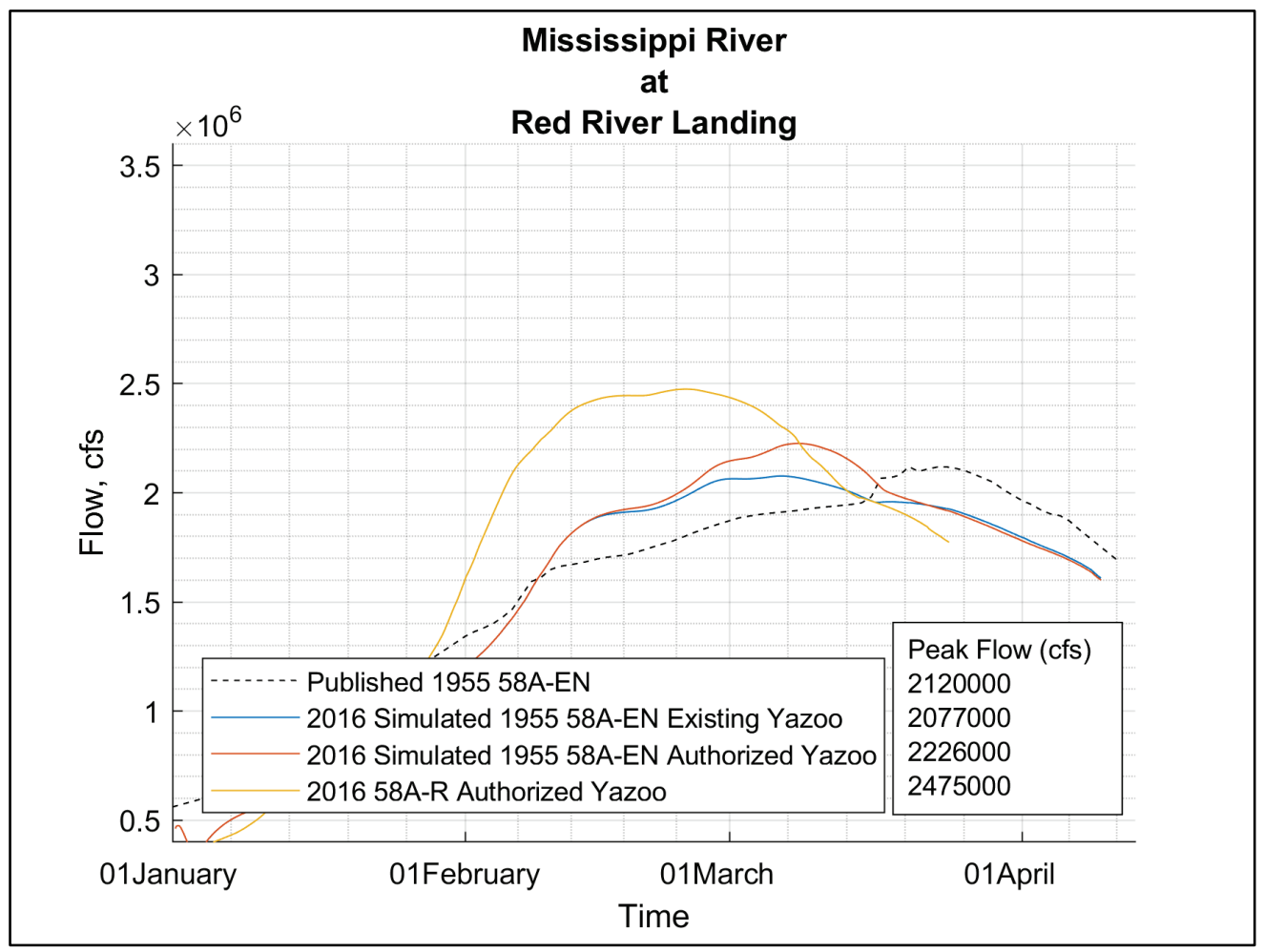


Figure 43. New Hypo 58A-R water surface profile for RMs 910 - 953 (Refined 1973 Computed Flowline is without loop, sediment, and freeboard effects).

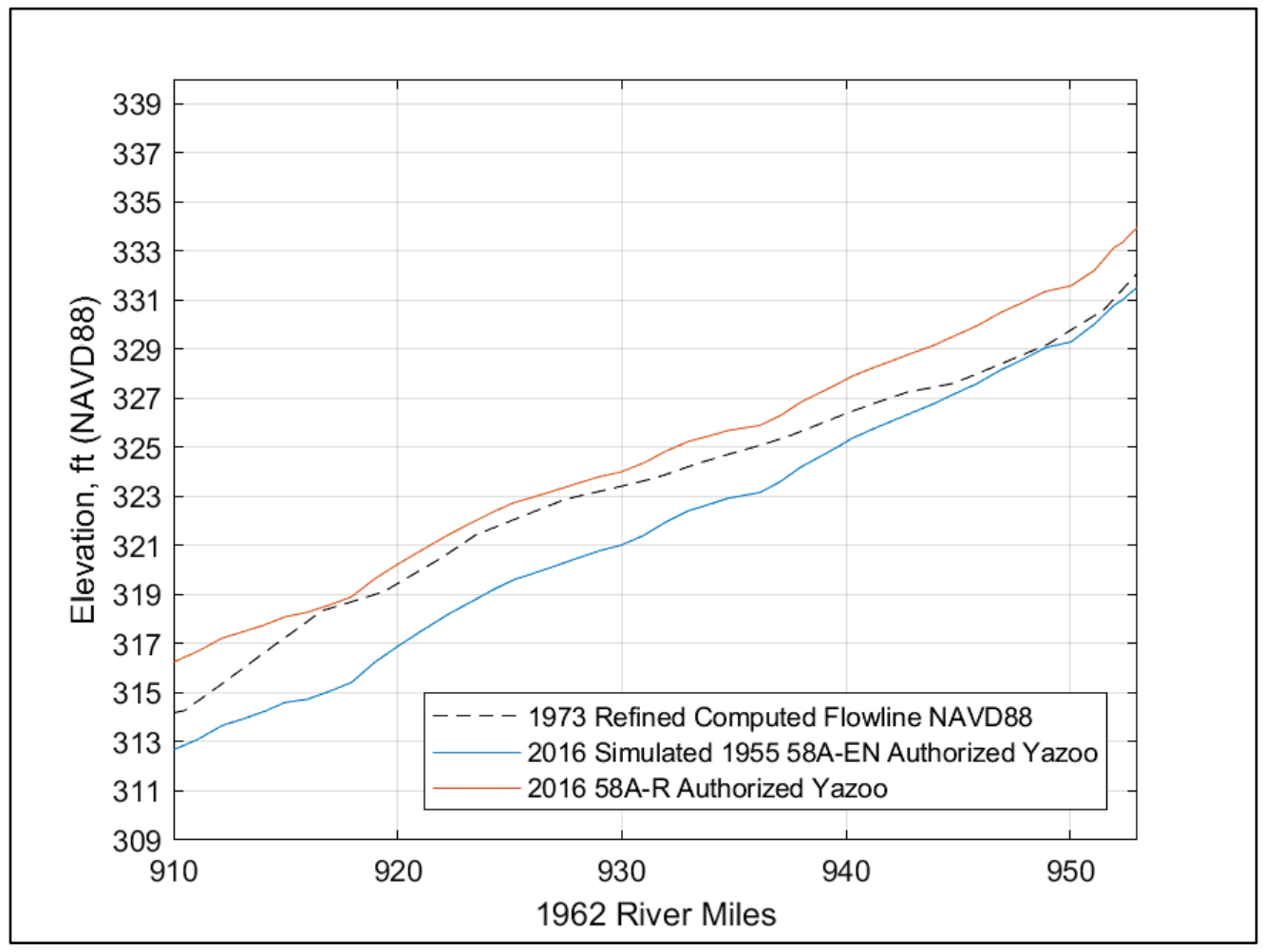

Figure 44. New Hypo 58A-R water surface profile for RMs 810 - 910 (Refined 1973 Computed Flowline is without loop, sediment, and freeboard effects).

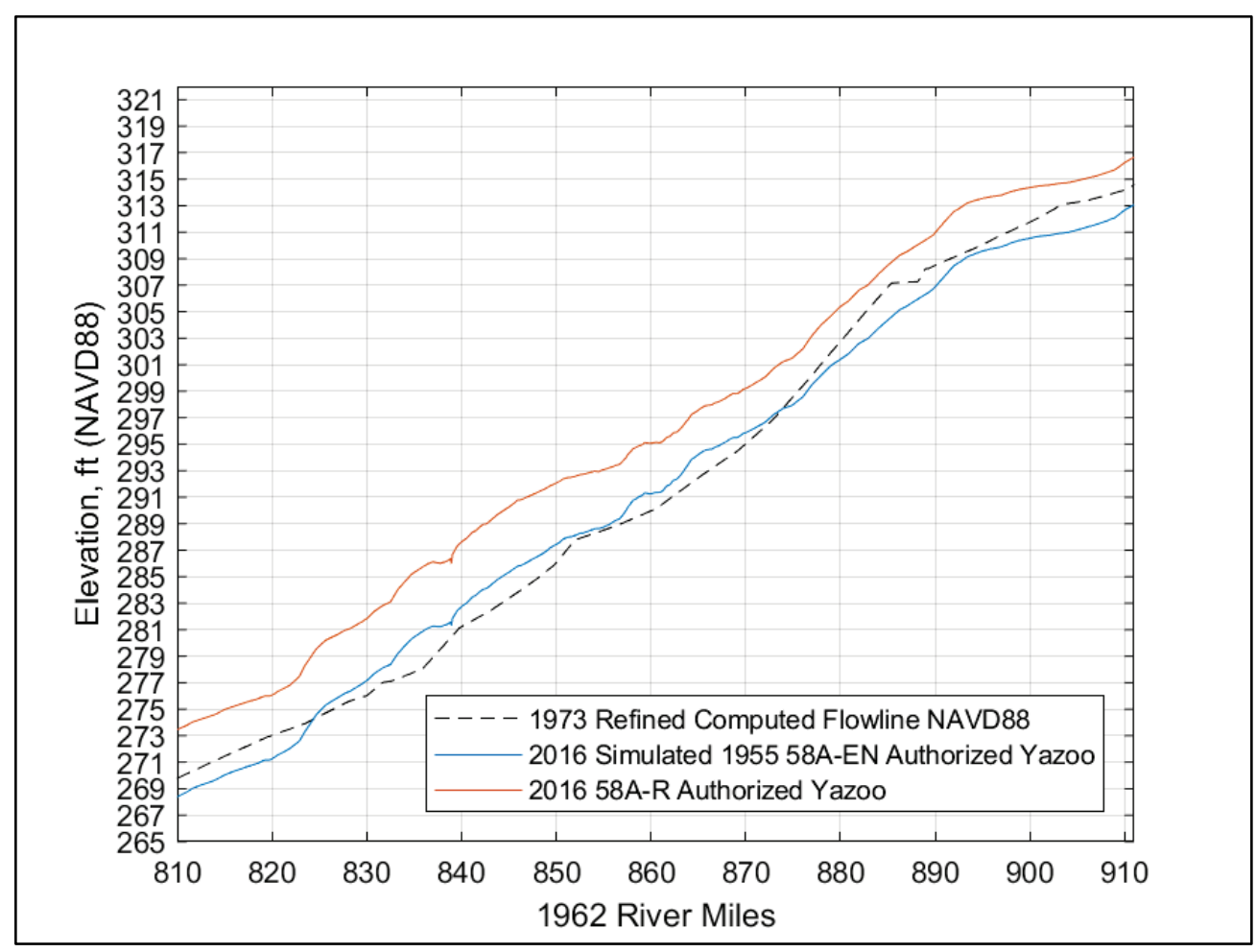


Figure 45. New Hypo 58A-R water surface profile for RMs 710 - 810 (Refined 1973 Computed Flowline is without loop, sediment, and freeboard effects).

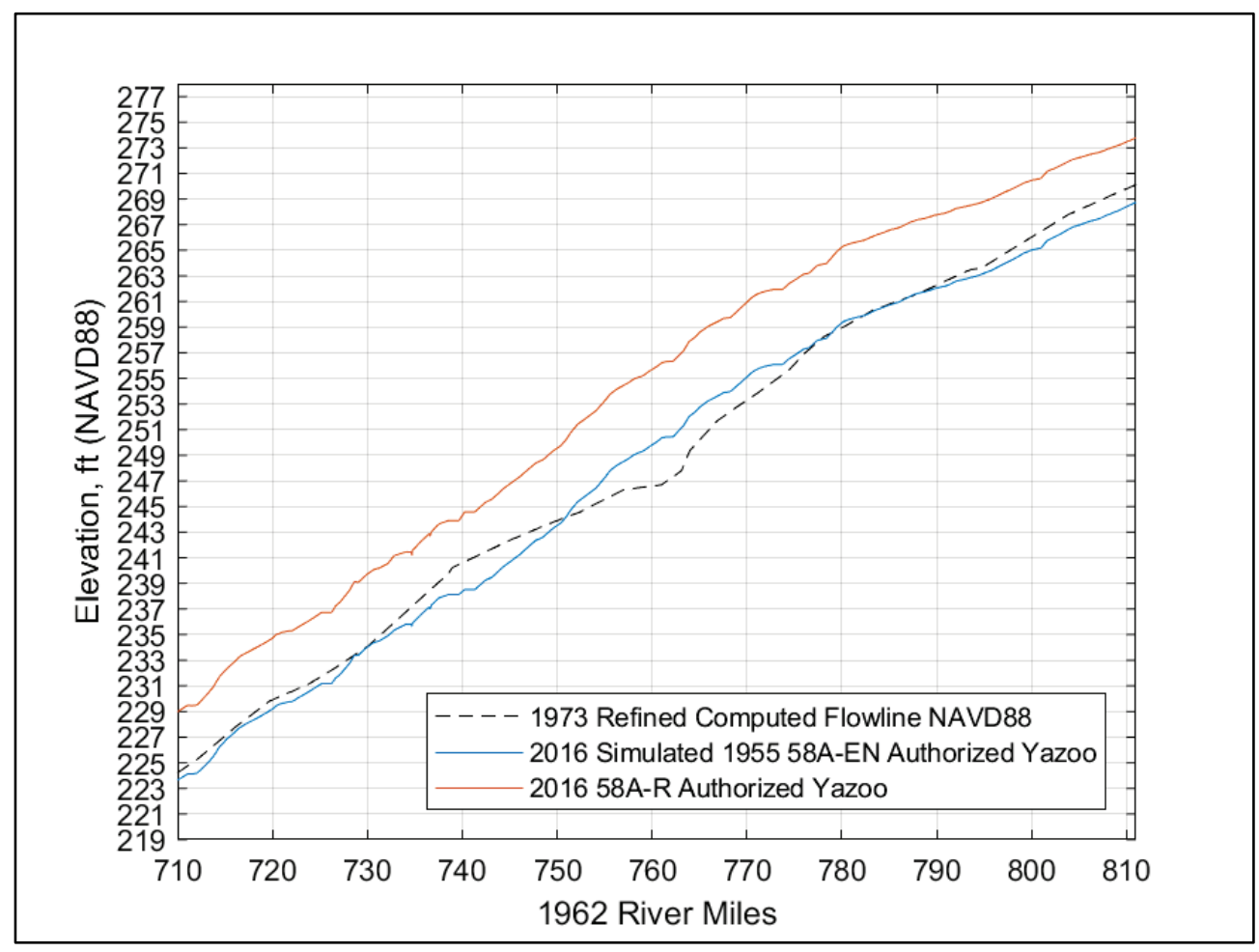

Figure 46. New Hypo 58A-R water surface profile for RMs 610 - 710 (Refined 1973 Computed Flowline is without loop, sediment, and freeboard effects).

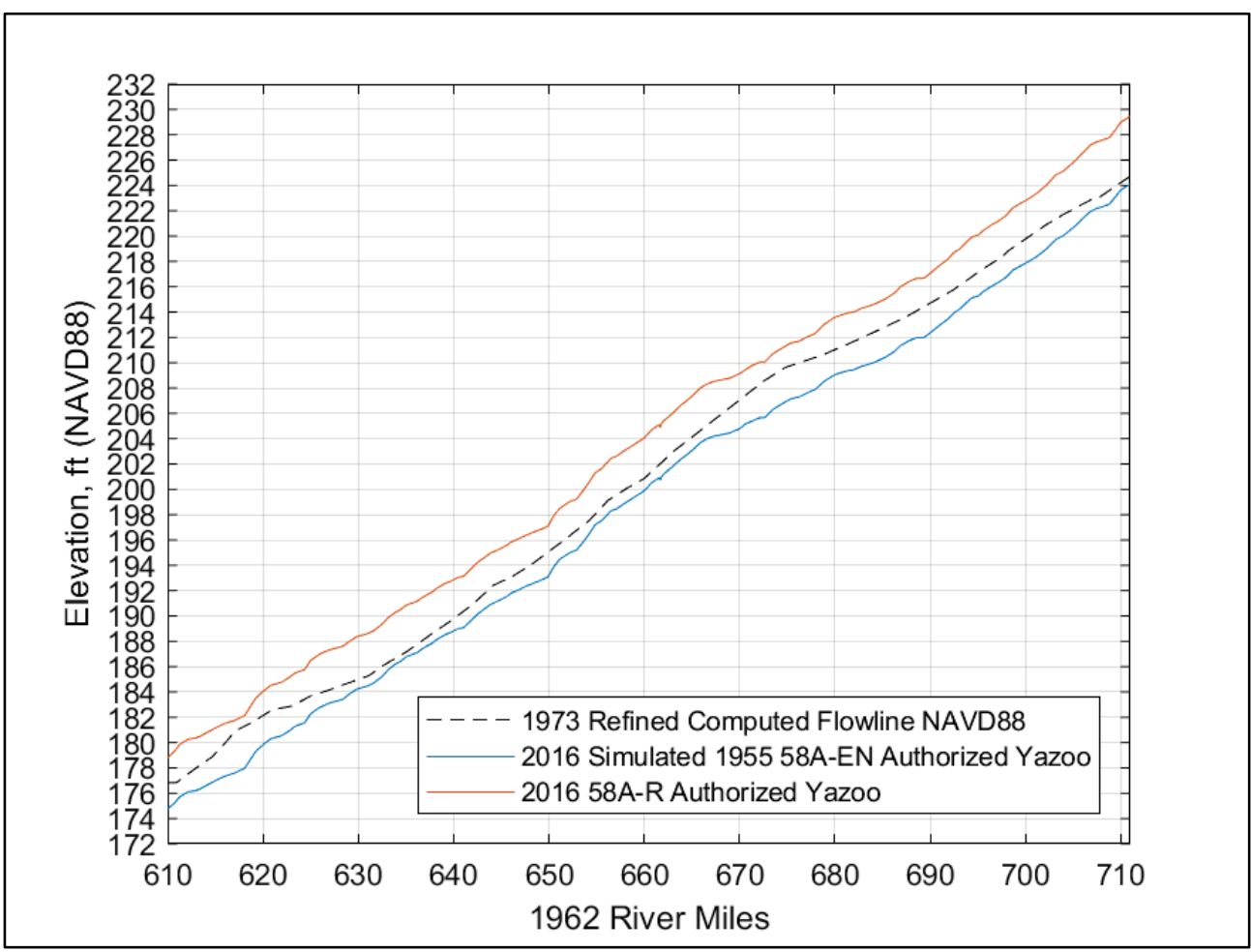


Figure 47. New Hypo 58A-R water surface profile for RMs 511 - 611 (Refined 1973 Computed Flowline is without loop, sediment, and freeboard effects).

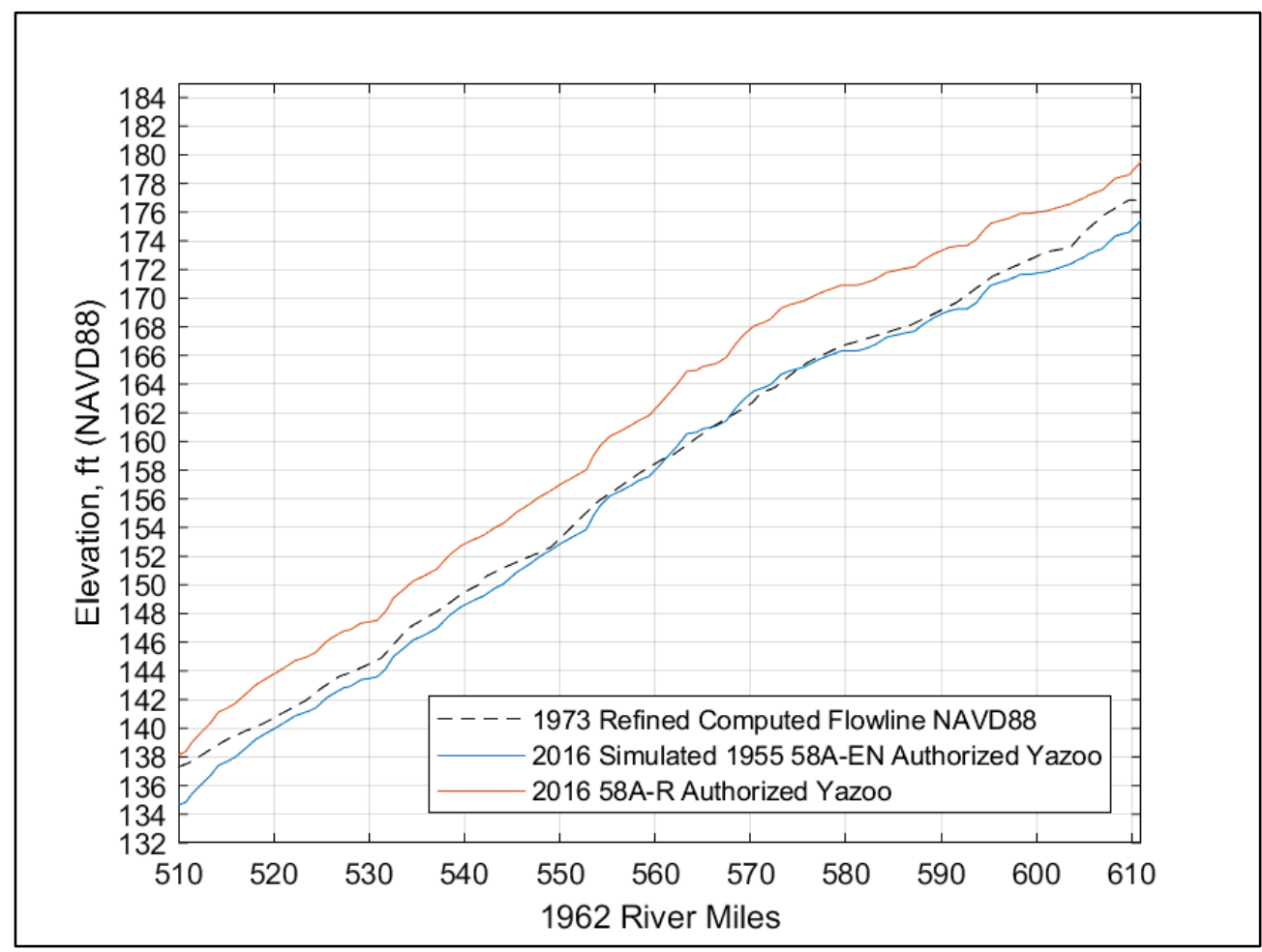

Figure 48. New Hypo 58A-R water surface profile for RMs 410 - 510 (Refined 1973 Computed Flowline is without loop, sediment, and freeboard effects).

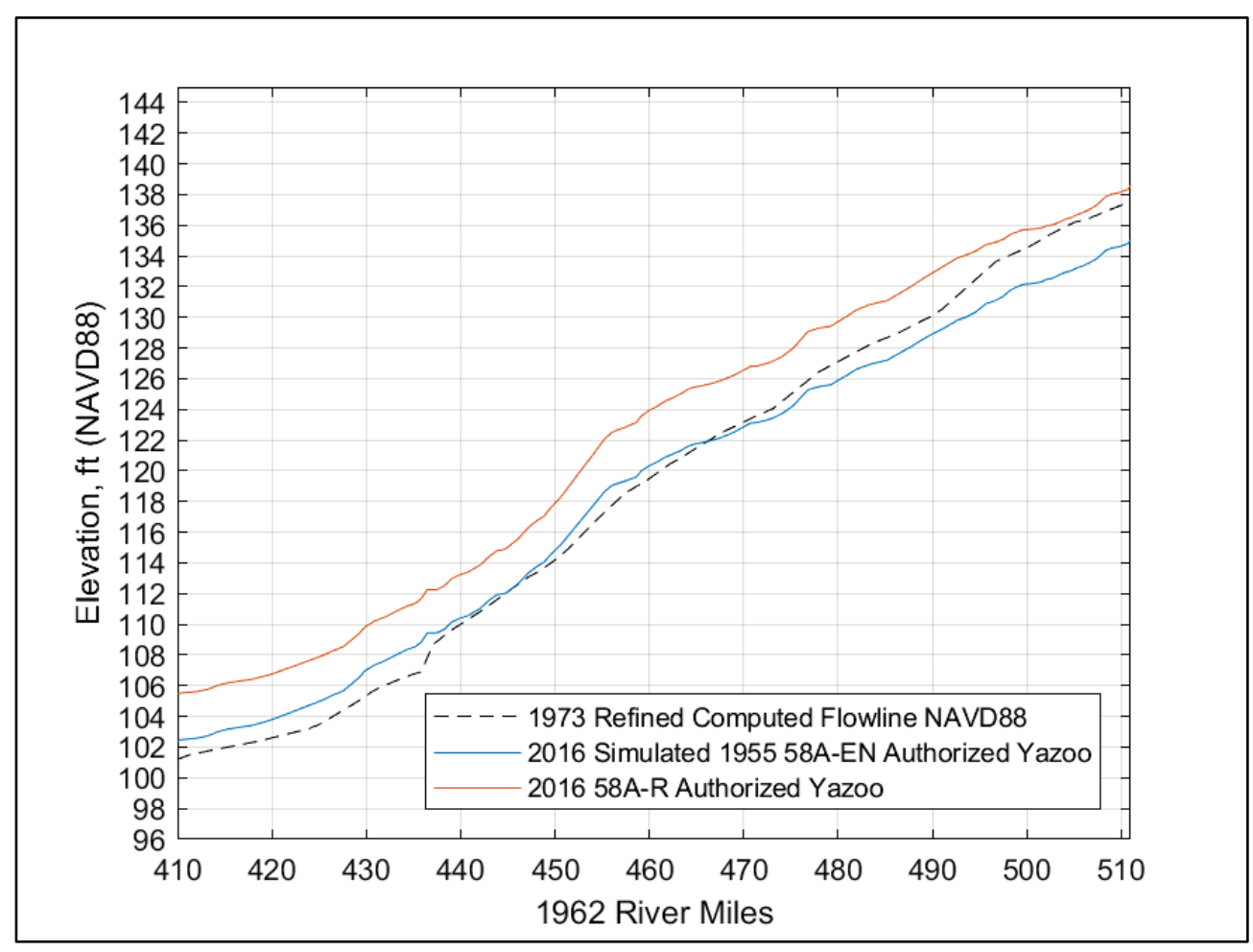


Figure 49. New Hypo 58A-R water surface profile for RMs 310 - 410 (Refined 1973 Computed Flowline is without loop, sediment, and freeboard effects).

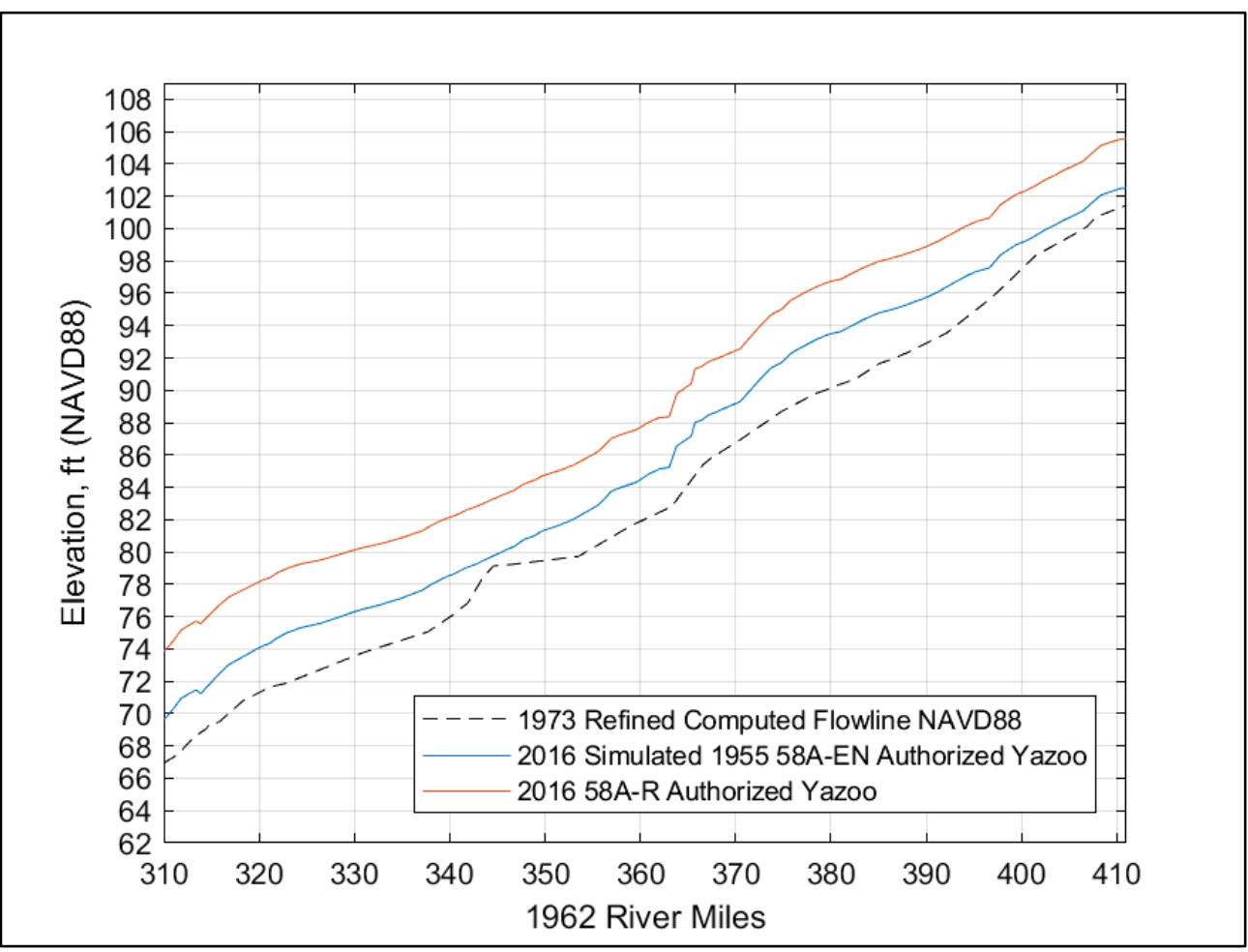

Figure 50. New Hypo 58A-R water surface profile for RMs 210 - 310 (Refined 1973 Computed Flowline is without loop, sediment, and freeboard effects.)

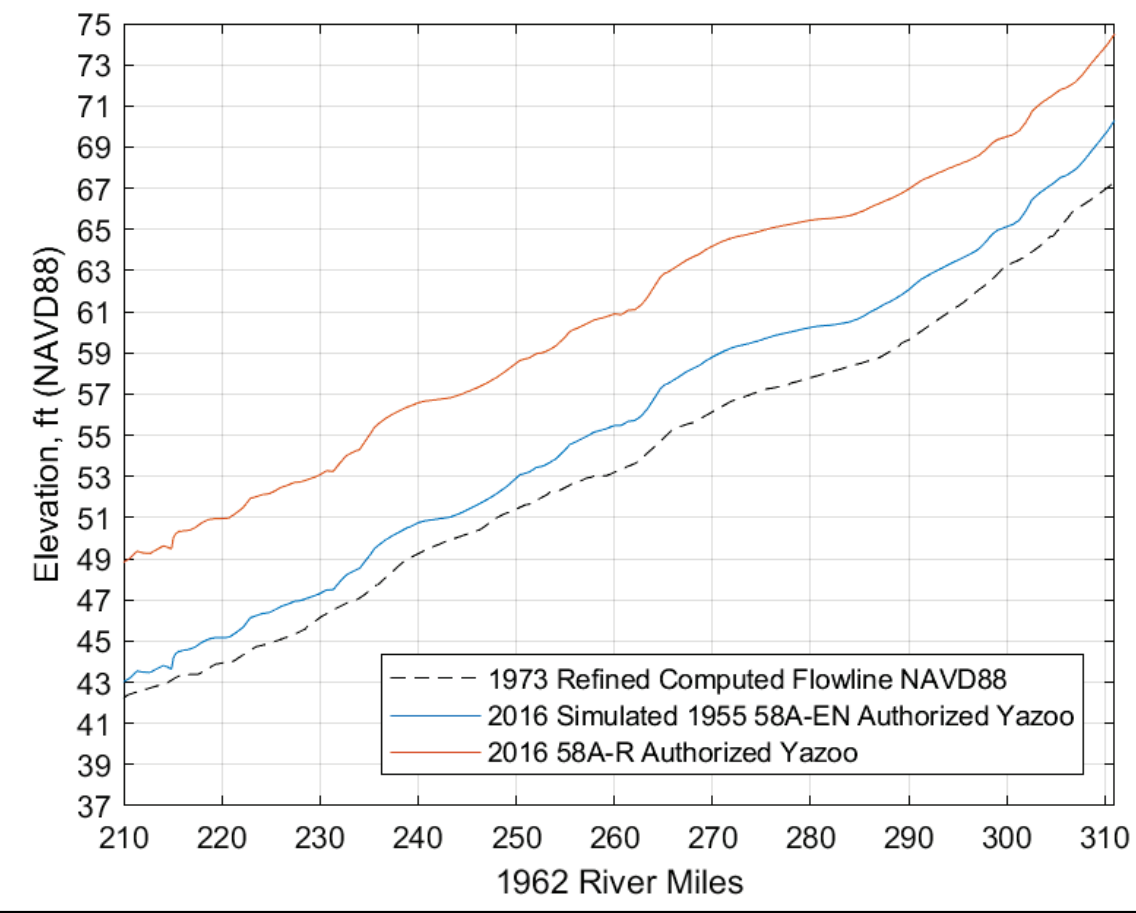


Figure 51. New Hypo 58A-R water surface profile for RMs 110 - 210 (Refined 1973 Computed Flowline is without loop, sediment, and freeboard effects).

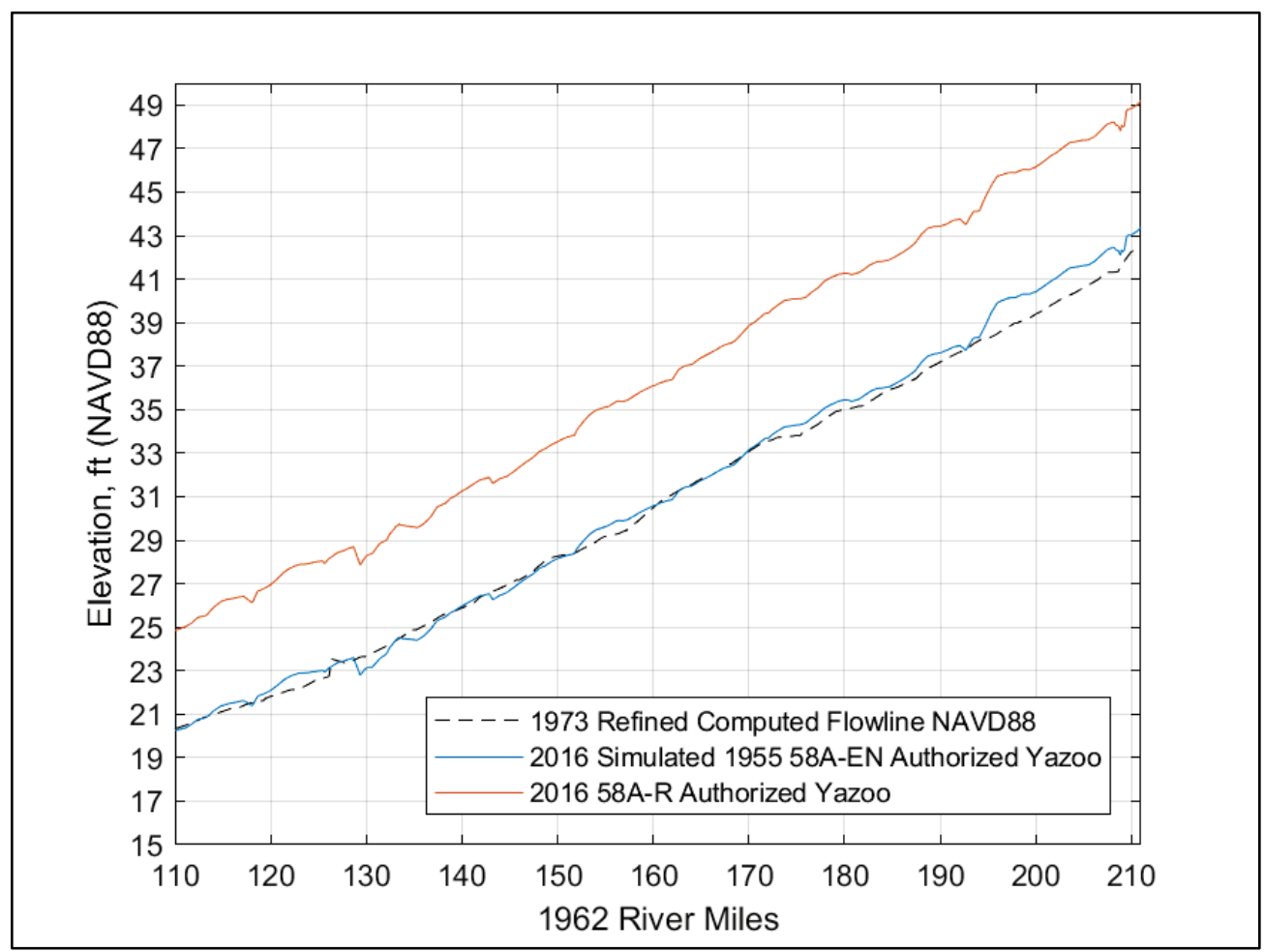

Figure 52. New Hypo 58A-R water surface profile for RMs 11 - 110 (Refined 1973 Computed Flowline is without loop, sediment, and freeboard effects).

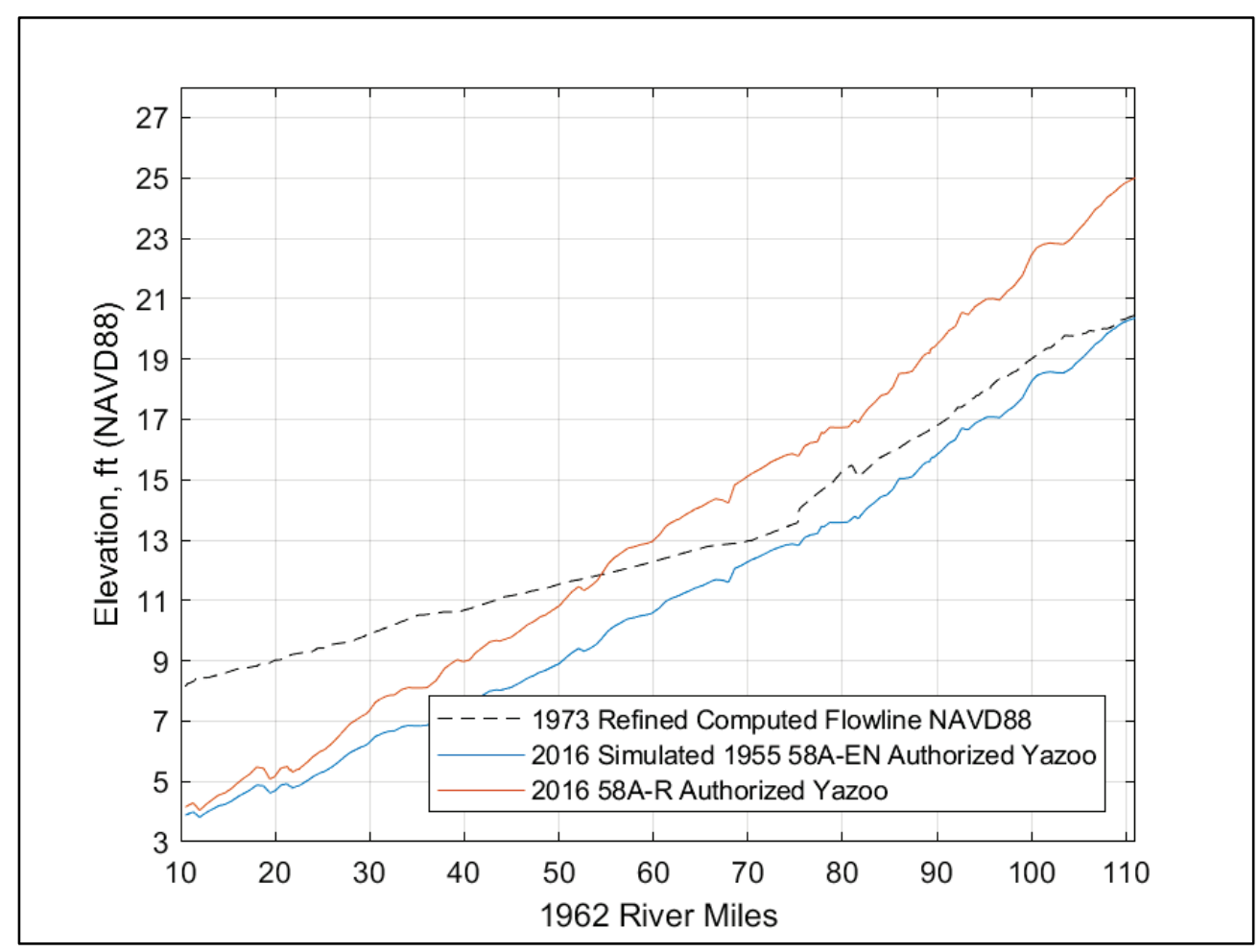




\subsubsection{Other new hypo PDF simulations}

The complete set of other New Hypo PDF events were also simulated with the HEC-RAS model, namely "New Hypo 52A-R PDF - Existing Yazoo," "New Hypo 52A-R PDF - Authorized Yazoo," "New Hypo 56-R PDF - Existing Yazoo," "New Hypo 56-R PDF - Authorized Yazoo," "New Hypo 63-R PDF - Existing Yazoo," and "New Hypo 63-R PDF Authorized Yazoo." The tabulated maximum flow results at key locations are listed in Table 15, and maximum stage results are listed in Table 16. More information about the flow hydrographs of each other New Hypo PDF event can be found in the Hydrology Report (USACE 2018b). Water surface elevation profiles are shown in Figure 53 through Figure 62. 
Table 15. Maximum flow comparisons of the other New Hypo PDF simulations (cubic feet per second).

\begin{tabular}{|c|c|c|c|c|c|c|c|c|c|c|}
\hline Location & $\begin{array}{l}\text { HEC- } \\
\text { RAS } \\
\text { Station }\end{array}$ & $\begin{array}{l}1955 \\
\text { Published } \\
\text { 58A-EN }\end{array}$ & $\begin{array}{l}2016 \text { PDF } \\
58 A-R \\
\text { Existing } \\
\text { Yazoo }\end{array}$ & $\begin{array}{l}2016 \text { PDF } \\
\text { 58A-R } \\
\text { Authorized } \\
\text { Yazoo }\end{array}$ & $\begin{array}{l}2016 \text { PDF } \\
52 A-R \\
\text { Existing } \\
\text { Yazoo }\end{array}$ & $\begin{array}{l}2016 \text { PDF } \\
52 A-R \\
\text { Authorized } \\
\text { Yazoo }\end{array}$ & $\begin{array}{l}2016 \text { PDF } \\
56-R \\
\text { Existing } \\
\text { Yazoo }\end{array}$ & $\begin{array}{l}2016 \text { PDF } \\
56-R \\
\text { Authorized } \\
\text { Yazoo }\end{array}$ & \begin{tabular}{|l}
2016 PDF \\
$63-R$ \\
Existing \\
Yazoo
\end{tabular} & $\begin{array}{l}2016 \text { PDF } \\
63-R \\
\text { Authorized } \\
\text { Yazoo }\end{array}$ \\
\hline $\begin{array}{l}\text { Mississippi at } \\
\text { Chester }\end{array}$ & 110.4 & 240,000 & 508,000 & 508,000 & $1,133,000$ & $1,133,000$ & 995,000 & 995,000 & $1,245,000$ & $1,245,000$ \\
\hline Ohio River at Cairo & -979.68 & $2,250,000$ & $2,326,000$ & $2,326,000$ & 498,000 & 498,000 & $1,468,000$ & $1,468,000$ & $1,078,000$ & $1,078,000$ \\
\hline $\begin{array}{l}\text { Mississippi at Ohio } \\
\text { River }\end{array}$ & 973.85 & $2,360,000$ & $2,791,000$ & $2,791,000$ & $1,354,000$ & $1,354,000$ & $2,365,000$ & $2,365,000$ & $2,207,000$ & $2,207,000$ \\
\hline $\begin{array}{l}\text { Mississippi at } \\
\text { Hickman }\end{array}$ & 942.45 & $1,810,000$ & $1,973,000$ & $1,973,000$ & $1,339,000$ & $1,339,000$ & $1,881,000$ & $1,881,000$ & $1,884,000$ & $1,884,000$ \\
\hline $\begin{array}{l}\text { Mississippi at } \\
\text { Memphis }\end{array}$ & 749.01 & $2,410,000$ & $2,862,000$ & $2,862,000$ & $1,306,000$ & $1,306,000$ & $2,387,000$ & $2,387,000$ & $2,152,000$ & $2,152,000$ \\
\hline $\begin{array}{l}\text { Mississippi at } \\
\text { Helena }\end{array}$ & 676.42 & $2,460,000$ & $2,787,000$ & $2,787,000$ & $1,293,000$ & $1,293,000$ & $2,377,000$ & $2,376,000$ & $2,151,000$ & $2,151,000$ \\
\hline $\begin{array}{l}\text { Mississippi at } \\
\text { Arkansas City }\end{array}$ & 562.18 & $2,890,000$ & $3,263,000$ & $3,263,000$ & $1,498,000$ & $1,498,000$ & $2,872,000$ & $2,871,000$ & $2,778,000$ & $2,778,000$ \\
\hline $\begin{array}{l}\text { Arkansas River at } \\
\text { Dam 02 }\end{array}$ & 28.07 & 400,000 & 487,000 & 487,000 & 442,000 & 442,000 & 536,000 & 536,000 & 629,000 & 629,000 \\
\hline St. Francis at 82.47 & 82.47 & 80,000 & 85,000 & 85,000 & 11,000 & 11,000 & 53,000 & 53,000 & 51,000 & 51,000 \\
\hline $\begin{array}{l}\text { White River at } \\
\text { Clarendon }\end{array}$ & 100.05 & 220,000 & 233,000 & 233,000 & 65,000 & 65,000 & 205,000 & 205,000 & 143,000 & 143,000 \\
\hline $\begin{array}{l}\text { Mississippi at } \\
\text { Greenville }\end{array}$ & 539.13 & & $3,259,000$ & $3,260,000$ & $1,489,000$ & $1,489,000$ & $2,867,000$ & $2,865,000$ & $2,772,000$ & $2,771,000$ \\
\hline $\begin{array}{l}\text { Mississippi at Lake } \\
\text { Providence }\end{array}$ & 494.47 & & $3,253,000$ & $3,257,000$ & $1,475,000$ & $1,475,000$ & $2,864,000$ & $2,861,000$ & $2,768,000$ & $2,765,000$ \\
\hline $\begin{array}{l}\text { Mississippi at } \\
\text { Vicksburg }\end{array}$ & 442.16 & $2,710,000$ & $3,076,000$ & $3,087,000$ & $1,452,000$ & $1,452,000$ & $2,683,000$ & $2,805,000$ & $2,642,000$ & $2,702,000$ \\
\hline $\begin{array}{l}\text { Mississippi at } \\
\text { Natchez }\end{array}$ & 368.44 & $2,720,000$ & $3,072,000$ & $3,099,000$ & $1,443,000$ & $1,443,000$ & $2,692,000$ & $2,808,000$ & $2,628,000$ & $2,685,000$ \\
\hline Mississippi at RRL & 306.43 & $2,100,000$ & $2,449,000$ & $2,475,000$ & $1,008,000$ & $1,008,000$ & $2,070,000$ & $2,179,000$ & 2005,000 & $2,060,000$ \\
\hline
\end{tabular}




\begin{tabular}{|c|c|c|c|c|c|c|c|c|c|c|}
\hline Location & $\begin{array}{l}\text { HEC- } \\
\text { RAS } \\
\text { Station }\end{array}$ & $\begin{array}{l}1955 \\
\text { Published } \\
\text { 58A-EN }\end{array}$ & $\begin{array}{l}2016 \text { PDF } \\
58 A-R \\
\text { Existing } \\
\text { Yazoo }\end{array}$ & $\begin{array}{l}2016 \text { PDF } \\
58 A-R \\
\text { Authorized } \\
\text { Yazoo }\end{array}$ & $\begin{array}{l}2016 \text { PDF } \\
52 A-R \\
\text { Existing } \\
\text { Yazoo }\end{array}$ & $\begin{array}{l}2016 \text { PDF } \\
\text { 52A-R } \\
\text { Authorized } \\
\text { Yazoo }\end{array}$ & $\begin{array}{l}2016 \text { PDF } \\
56-R \\
\text { Existing } \\
\text { Yazoo }\end{array}$ & $\begin{array}{l}2016 \text { PDF } \\
56-R \\
\text { Authorized } \\
\text { Yazoo }\end{array}$ & $\begin{array}{l}2016 \text { PDF } \\
63-R \\
\text { Existing } \\
\text { Yazoo }\end{array}$ & $\begin{array}{l}2016 \text { PDF } \\
63-R \\
\text { Authorized } \\
\text { Yazoo }\end{array}$ \\
\hline $\begin{array}{l}\text { Mississippi at Baton } \\
\text { Rouge Gage }\end{array}$ & 233.1 & $1,500,00$ & $1,838,000$ & $1,869,000$ & 998,000 & 998,000 & $1,502,000$ & $1,568,000$ & $1,503,000$ & $1,503,000$ \\
\hline $\begin{array}{l}\text { Mississippi at } \\
\text { Donaldsonville gage }\end{array}$ & 179.04 & $1,500,00$ & $1,837,000$ & $1,868,000$ & 997,000 & 997,000 & $1,502,000$ & $1,567,000$ & $1,503,000$ & $1,503,000$ \\
\hline $\begin{array}{l}\text { Mississippi at } \\
\text { Carrollton Gage }\end{array}$ & 107.2 & $1,250,000$ & $1,581,000$ & $1,613,000$ & 993,000 & 993,000 & $1,252,000$ & $1,312,000$ & $1,252,000$ & $1,252,000$ \\
\hline $\begin{array}{l}\text { Mississippi at } \\
\text { Empire Gage }\end{array}$ & 33.79 & $1,250,000$ & $1,513,000$ & $1,543,000$ & 978,000 & 978,000 & $1,215,000$ & $1,258,000$ & $1,214,000$ & $1,215,000$ \\
\hline $\begin{array}{l}\text { Mississippi at } \\
\text { Venice gage }\end{array}$ & 15.07 & $1,250,000$ & $1,094,000$ & $1,115,000$ & 727,000 & 727,000 & 892,000 & 920,000 & 891,000 & 891,000 \\
\hline
\end{tabular}

Table 16. Maximum stage comparisons of the other New Hypo PDF simulations (feet, NAVD88) (*From the Refined 1973 Flowline Study, this column is without loop effect, sedimentation, or freeboard effects).

\begin{tabular}{|c|c|c|c|c|c|c|c|c|c|}
\hline Location & $\begin{array}{l}\text { HEC-RAS } \\
\text { Station }\end{array}$ & $\begin{array}{c}\text { Refined } \\
1973 \\
\text { Flowline } \\
\text { (58A-EN)* }\end{array}$ & $\begin{array}{c}2016 \text { PDF } \\
58 A-R \\
\text { Authorized } \\
\text { Yazoo }\end{array}$ & $\begin{array}{l}2016 \text { PDF } \\
52 A-R \\
\text { Existing } \\
\text { Yazoo }\end{array}$ & $\begin{array}{l}2016 \text { PDF } \\
52 A-R \\
\text { Authorized } \\
\text { Yazoo }\end{array}$ & $\begin{array}{l}2016 \text { PDF } \\
56-R \\
\text { Existing } \\
\text { Yazoo }\end{array}$ & $\begin{array}{c}2016 \text { PDF } \\
56-R \\
\text { Authorized } \\
\text { Yazoo }\end{array}$ & $\begin{array}{l}2016 \text { PDF } \\
63-R \\
\text { Existing } \\
\text { Yazoo }\end{array}$ & $\begin{array}{c}2016 \text { PDF } \\
\text { 63-R } \\
\text { Authorized } \\
\text { Yazoo }\end{array}$ \\
\hline $\begin{array}{l}\text { Mississippi at } \\
\text { Chester }\end{array}$ & 110.4 & & 372.5 & 391.8 & 391.8 & 388.8 & 388.8 & 393.1 & 393.1 \\
\hline Ohio River at Cairo & -979.68 & & 334.8 & 322.2 & 322.2 & 332.1 & 332.1 & 332.1 & 332.1 \\
\hline $\begin{array}{l}\text { Mississippi at Ohio } \\
\text { River }\end{array}$ & 973.85 & 331.7 & 334.3 & 322.2 & 322.2 & 332.0 & 332.0 & 332.0 & 332.0 \\
\hline $\begin{array}{l}\text { Mississippi at } \\
\text { Hickman }\end{array}$ & 942.45 & 320.7 & 321.4 & 309.1 & 309.1 & 318.0 & 318.0 & 317.7 & 317.7 \\
\hline $\begin{array}{l}\text { Mississippi at } \\
\text { Memphis }\end{array}$ & 749.01 & 237.2 & 241.4 & 218.4 & 218.4 & 235.1 & 235.1 & 231.8 & 231.8 \\
\hline $\begin{array}{l}\text { Mississippi at } \\
\text { Helena }\end{array}$ & 676.42 & 202.9 & 206 & 183.7 & 183.7 & 200.8 & 200.8 & 197.8 & 197.8 \\
\hline
\end{tabular}




\begin{tabular}{|c|c|c|c|c|c|c|c|c|c|}
\hline Location & $\begin{array}{l}\text { HEC-RAS } \\
\text { Station }\end{array}$ & $\begin{array}{c}\text { Refined } \\
1973 \\
\text { Flowline } \\
\text { (58A-EN)* }\end{array}$ & $\begin{array}{l}2016 \text { PDF } \\
58 A-R \\
\text { Authorized } \\
\text { Yazoo }\end{array}$ & $\begin{array}{l}2016 \text { PDF } \\
52 A-R \\
\text { Existing } \\
\text { Yazoo }\end{array}$ & $\begin{array}{l}2016 \text { PDF } \\
52 A-R \\
\text { Authorized } \\
\text { Yazoo }\end{array}$ & $\begin{array}{l}2016 \text { PDF } \\
56-R \\
\text { Existing } \\
\text { Yazoo }\end{array}$ & $\begin{array}{c}2016 \text { PDF } \\
56-R \\
\text { Authorized } \\
\text { Yazoo }\end{array}$ & $\begin{array}{c}2016 \text { PDF } \\
63-R \\
\text { Existing } \\
\text { Yazoo }\end{array}$ & $\begin{array}{c}2016 \text { PDF } \\
\text { 63-R } \\
\text { Authorized } \\
\text { Yazoo }\end{array}$ \\
\hline $\begin{array}{l}\text { Mississippi at } \\
\text { Arkansas City }\end{array}$ & 562.18 & 155.5 & 159 & 135.3 & 135.3 & 154.7 & 154.8 & 153.7 & 153.7 \\
\hline $\begin{array}{l}\text { Arkansas River at } \\
\text { Dam } 02\end{array}$ & 28.07 & & 177.2 & 165.1 & 165.1 & 172.8 & 172.8 & 174.8 & 174.8 \\
\hline St. Francis at 82.47 & 82.47 & & 217.1 & 209.1 & 209.1 & 215.0 & 215.0 & 214.8 & 214.8 \\
\hline $\begin{array}{l}\text { White River at } \\
\text { Clarendon }\end{array}$ & 100.05 & & 181.9 & 167.5 & 167.5 & 178.8 & 178.8 & 175.5 & 175.5 \\
\hline $\begin{array}{l}\text { Mississippi at } \\
\text { Greenville }\end{array}$ & 539.13 & 145.2 & 148.2 & 126.1 & 126.1 & 144.0 & 144.1 & 143.0 & 143.0 \\
\hline $\begin{array}{l}\text { Mississippi at Lake } \\
\text { Providence }\end{array}$ & 494.47 & 129.4 & 132 & 109.5 & 109.5 & 127.5 & 127.8 & 126.6 & 126.7 \\
\hline $\begin{array}{l}\text { Mississippi at } \\
\text { Vicksburg }\end{array}$ & 442.16 & 106.9 & 111.7 & 91.4 & 91.4 & 107.0 & 108.3 & 106.4 & 107.0 \\
\hline $\begin{array}{l}\text { Mississippi at } \\
\text { Natchez }\end{array}$ & 368.44 & 82.7 & 88.4 & 69.5 & 69.5 & 83.5 & 84.7 & 82.9 & 83.4 \\
\hline Mississippi at RRL & 306.43 & 63.5 & 69.8 & 53.0 & 53.0 & 63.5 & 64.7 & 63.3 & 63.5 \\
\hline $\begin{array}{l}\text { Mississippi at Baton } \\
\text { Rouge Gage }\end{array}$ & 233.1 & 45.7 & 52.8 & 36.9 & 36.9 & 44.4 & 45.9 & 44.4 & 44.4 \\
\hline $\begin{array}{l}\text { Mississippi at } \\
\text { Donaldsonville gage }\end{array}$ & 179.04 & 33.8 & 40.1 & 25.8 & 25.8 & 31.7 & 33.2 & 31.7 & 31.7 \\
\hline $\begin{array}{l}\text { Mississippi at } \\
\text { Carrollton Gage }\end{array}$ & 107.2 & 19.6 & 22.8 & 13.5 & 13.5 & 16.8 & 17.7 & 16.8 & 16.8 \\
\hline $\begin{array}{l}\text { Mississippi at } \\
\text { Empire Gage }\end{array}$ & 33.79 & 9.8 & 7.2 & 5.0 & 5.0 & 5.9 & 6.0 & 5.8 & 5.8 \\
\hline $\begin{array}{l}\text { Mississippi at } \\
\text { Venice gage }\end{array}$ & 15.07 & 8.1 & 4.2 & 3.5 & 3.5 & 3.8 & 3.8 & 3.8 & 3.8 \\
\hline
\end{tabular}


Figure 53. Other New Hypo PDFwater surface profiles for RMs 910 - 953 (Refined 1973 Computed Flowline is without loop, sediment, and freeboard effects).

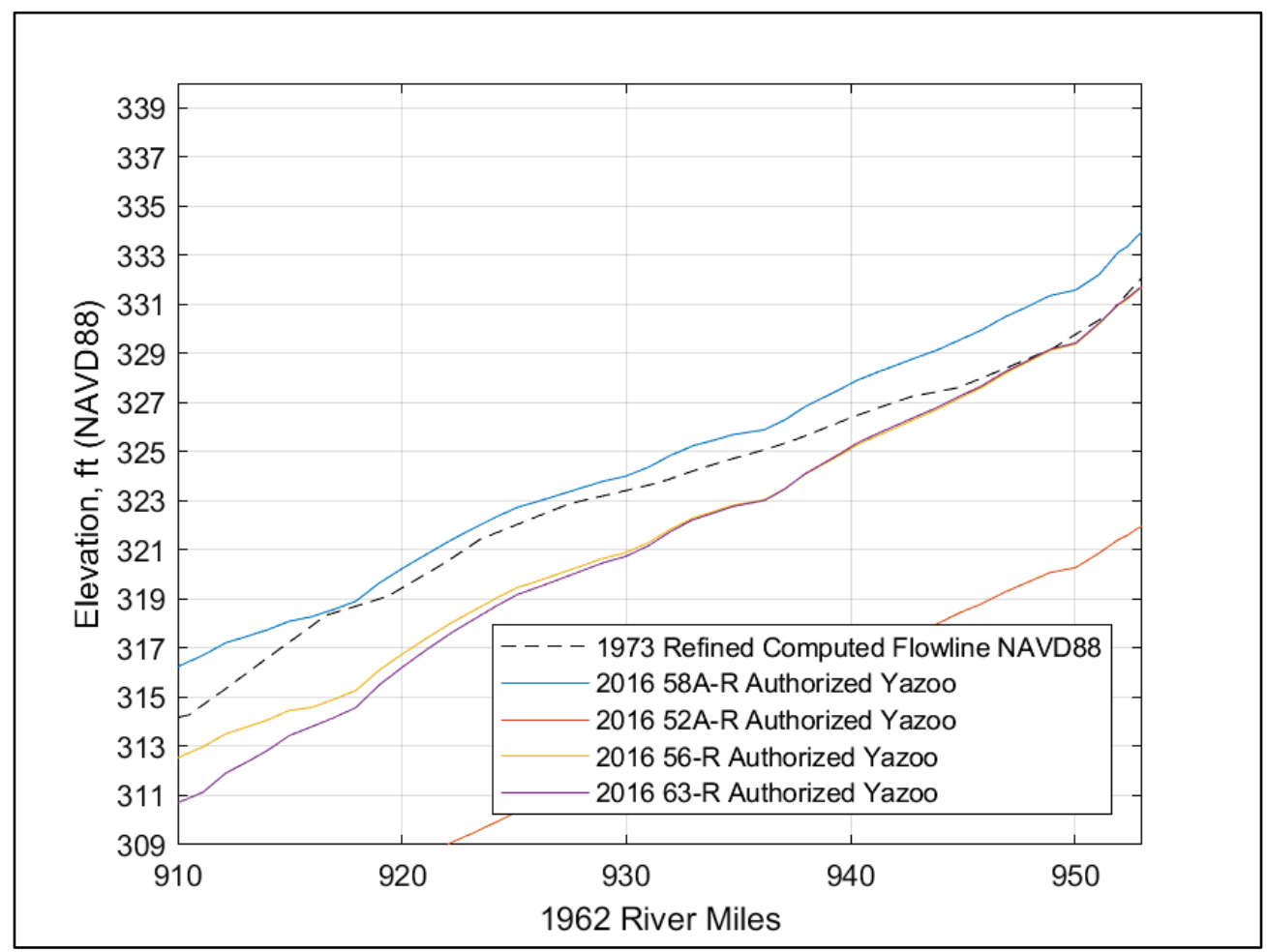

Figure 54. Other New Hypo PDF water surface profiles for RMs 810 - 910 (Refined 1973 Computed Flowline is without loop, sediment, and freeboard effects).

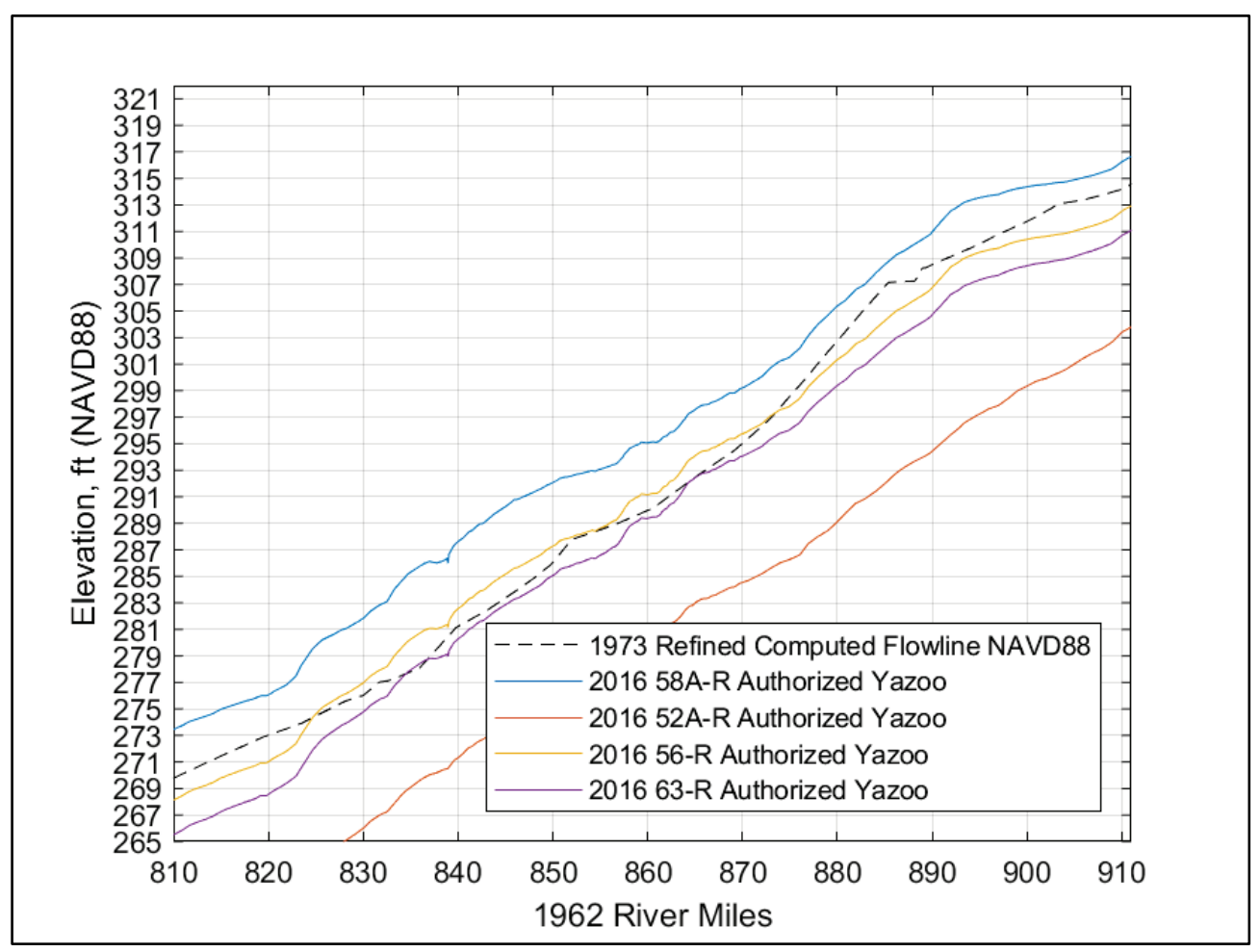


Figure 55. Other New Hypo PDF water surface profiles for RMs 710 - 810 (Refined 1973 Computed Flowline is without loop, sediment, and freeboard effects).

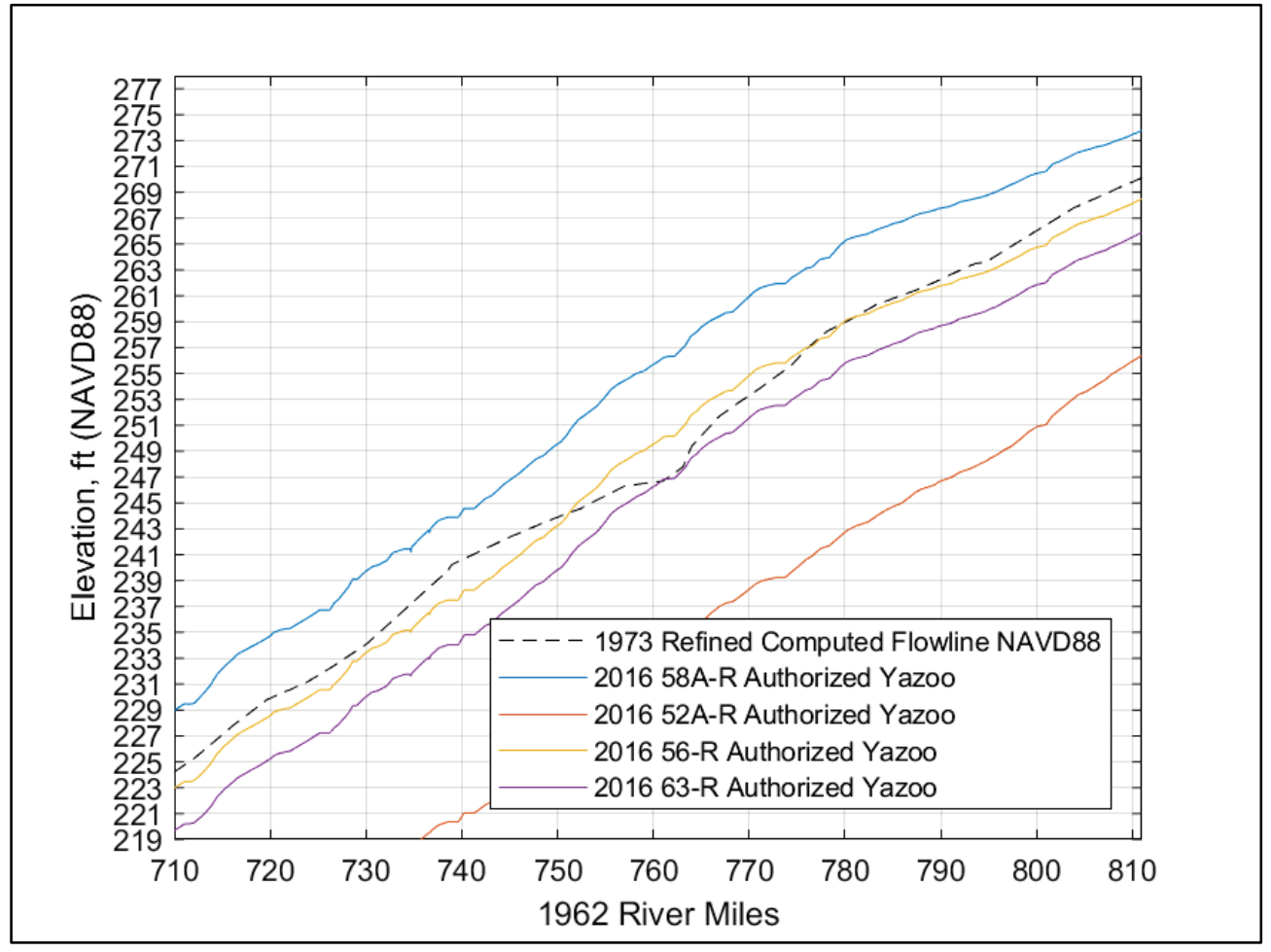

Figure 56. Other New Hypo PDF water surface profiles for RMs 610 - 710 (Refined 1973 Computed Flowline is without loop, sediment, and freeboard effects).

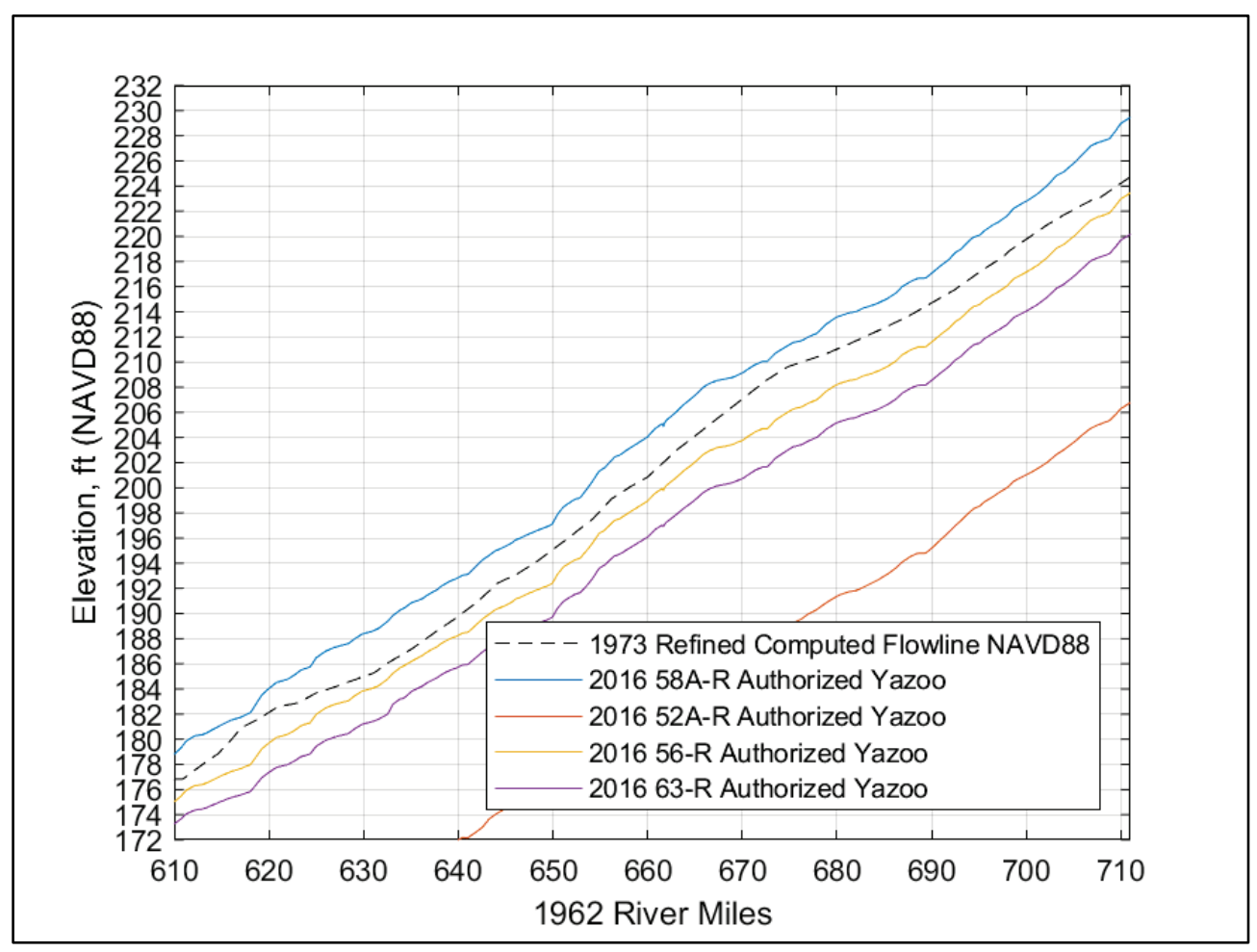


Figure 57. Other New Hypo PDF water surface profiles for RMs 510 - 610 (Refined 1973 Computed Flowline is without loop, sediment, and freeboard effects).

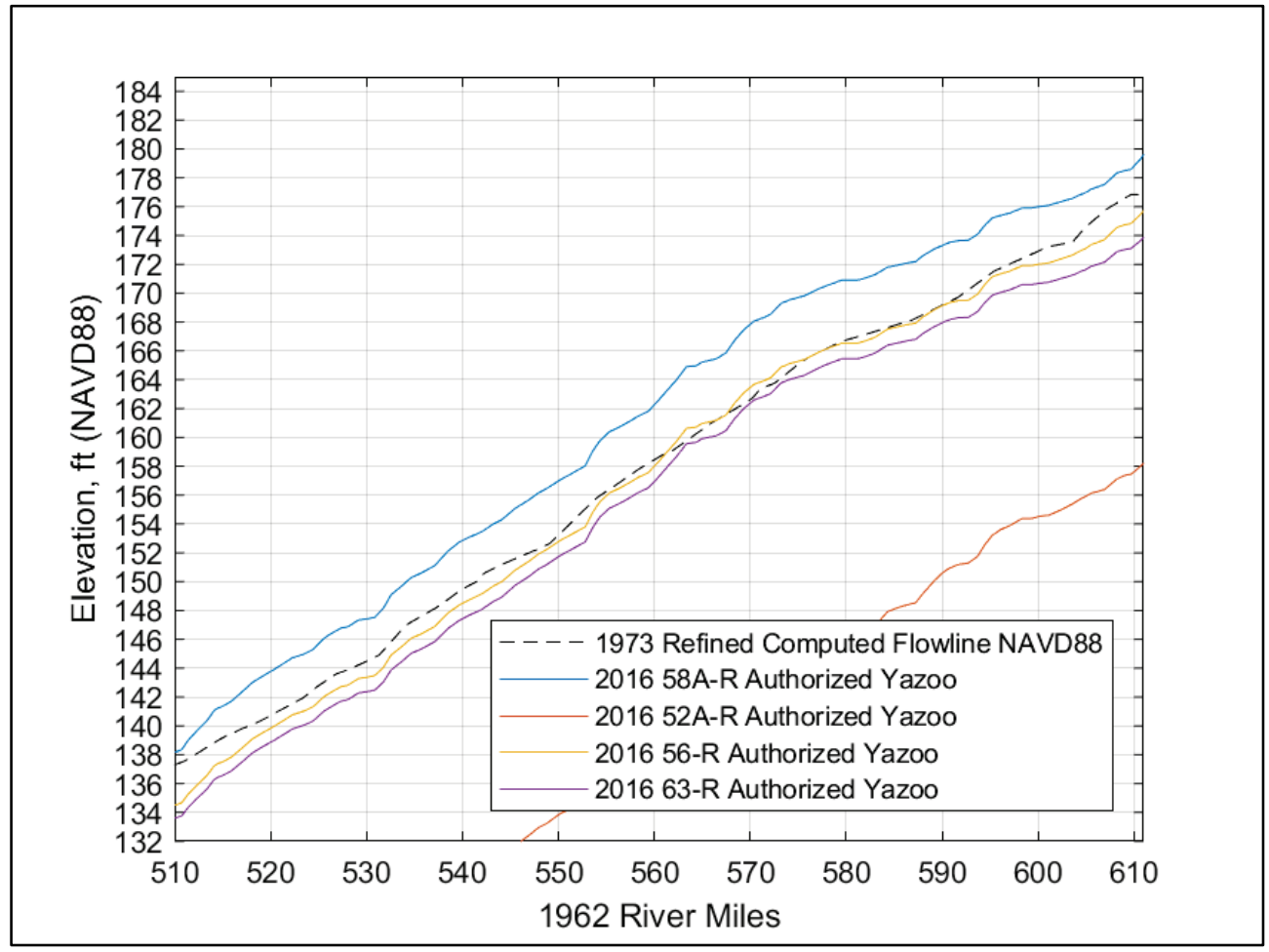

Figure 58. Other New Hypo PDF water surface profiles for RMs 410 - 510 (Refined 1973 Computed Flowline is without loop, sediment, and freeboard effects).

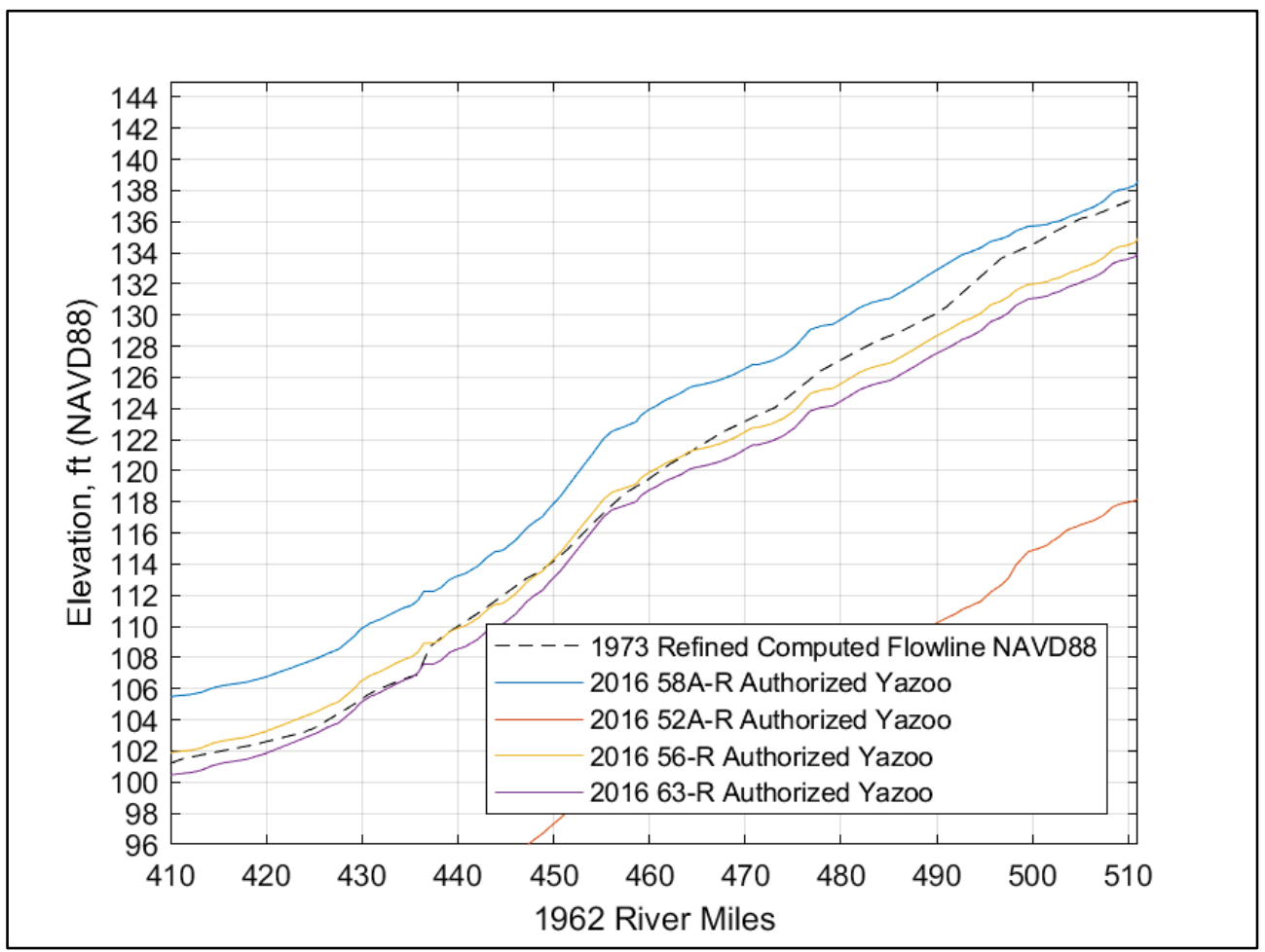


Figure 59. Other New Hypo PDF water surface profiles for RMs 310 - 410 (Refined 1973 Computed Flowline is without loop, sediment, and freeboard effects).

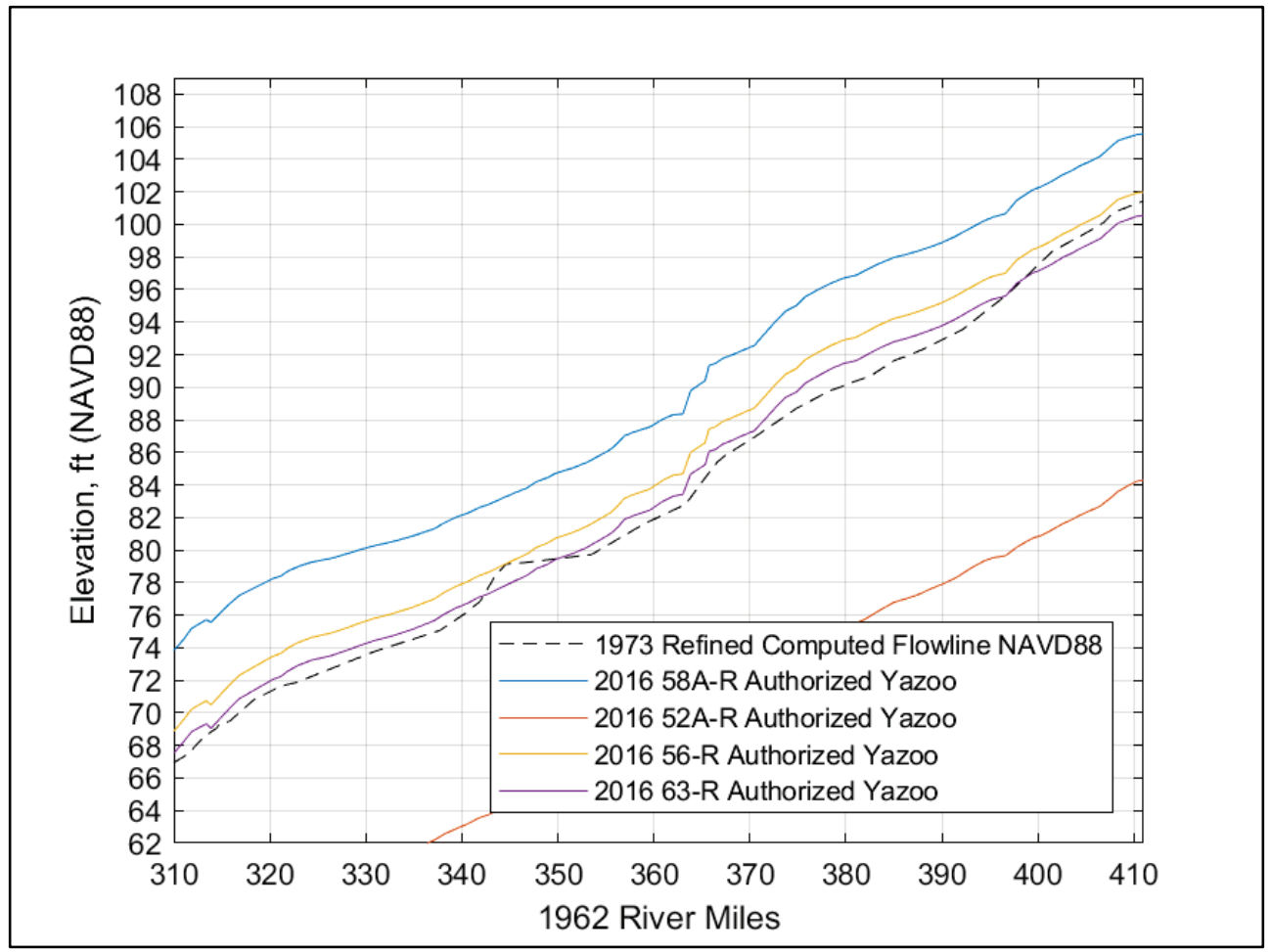

Figure 60. Other New Hypo PDF water surface profiles for RMs 210 - 310 (Refined 1973 Computed Flowline is without loop, sediment, and freeboard effects).

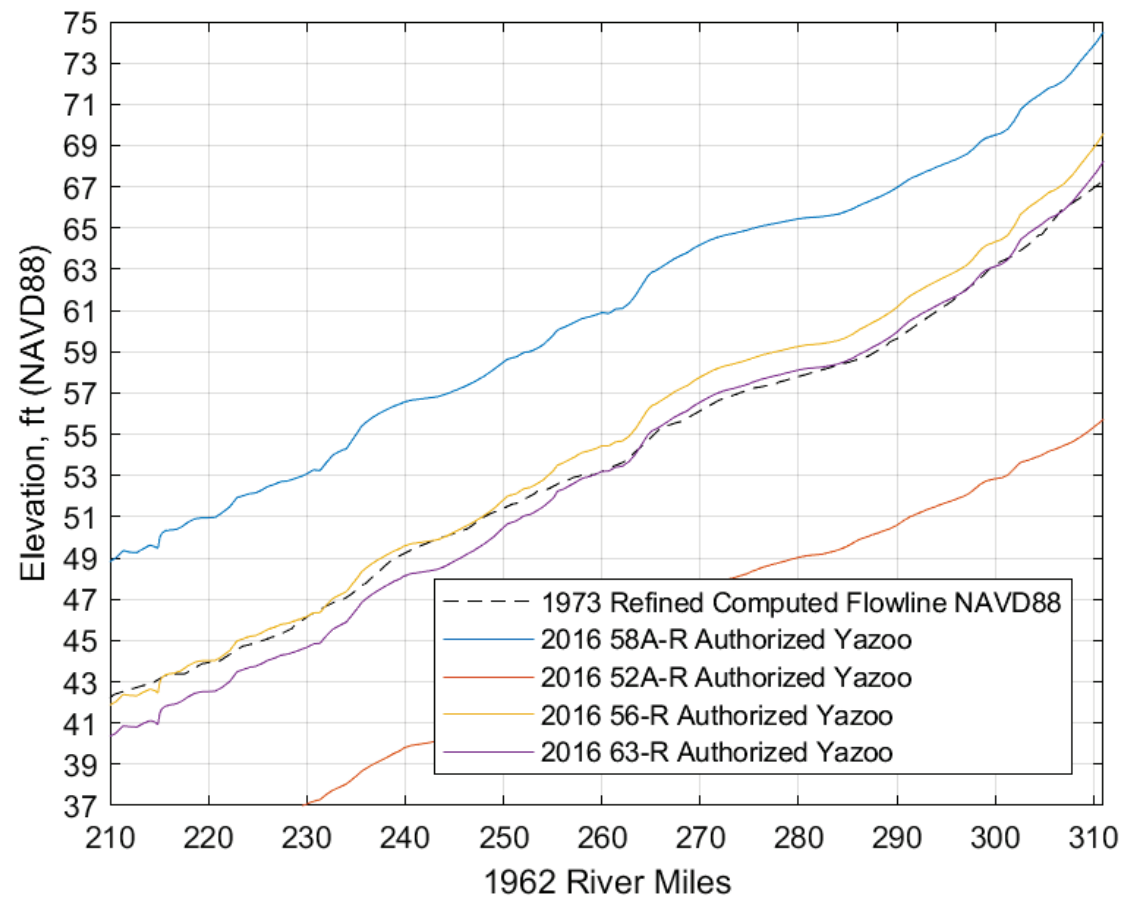


Figure 61. Other New Hypo PDF water surface profiles for RMs 110 - 210 (Refined 1973 Computed Flowline is without loop, sediment, and freeboard effects).

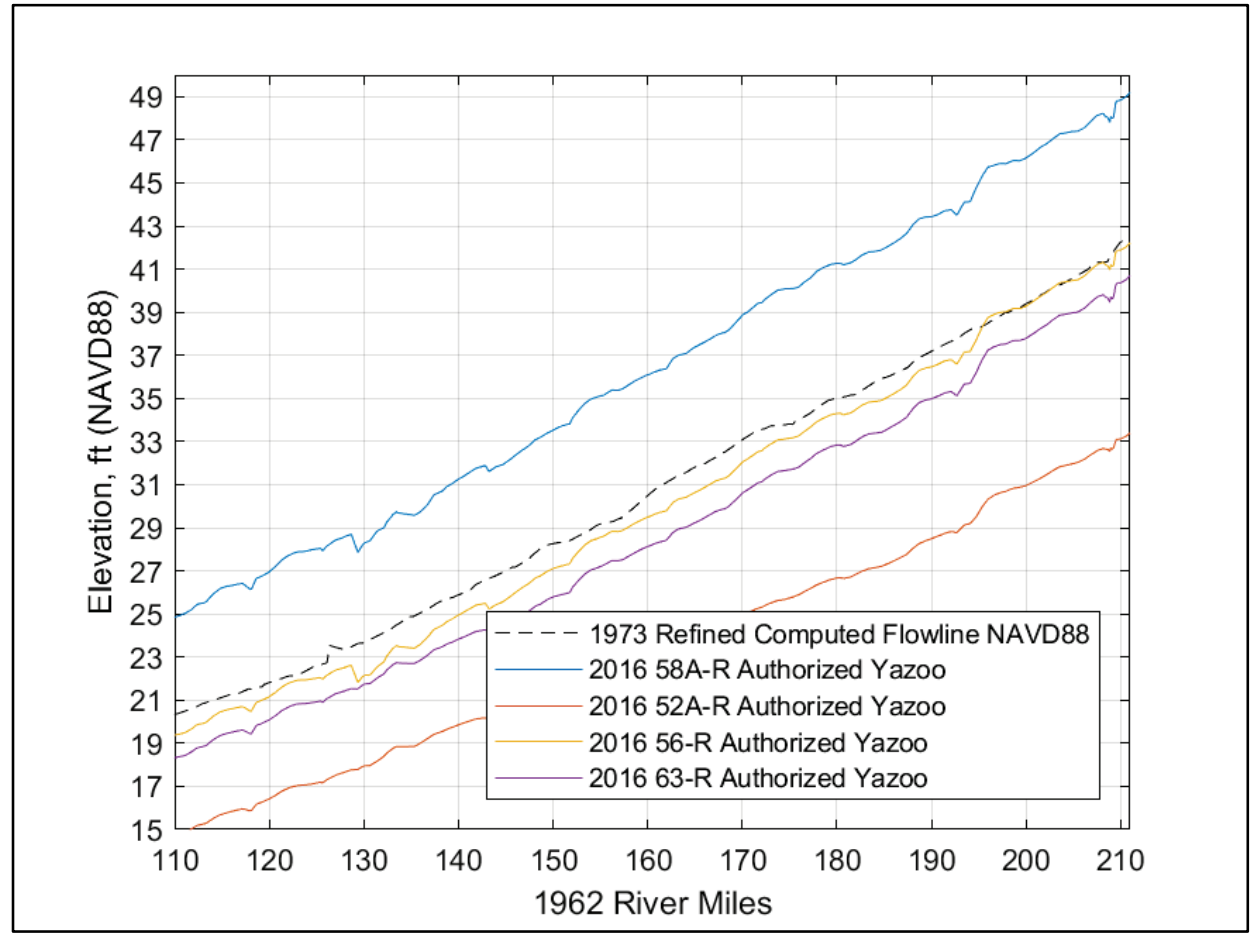

Figure 62. Other New Hypo PDF water surface profiles for RMs 11 - 110 (Refined 1973 Computed Flowline is without loop, sediment, and freeboard effects).

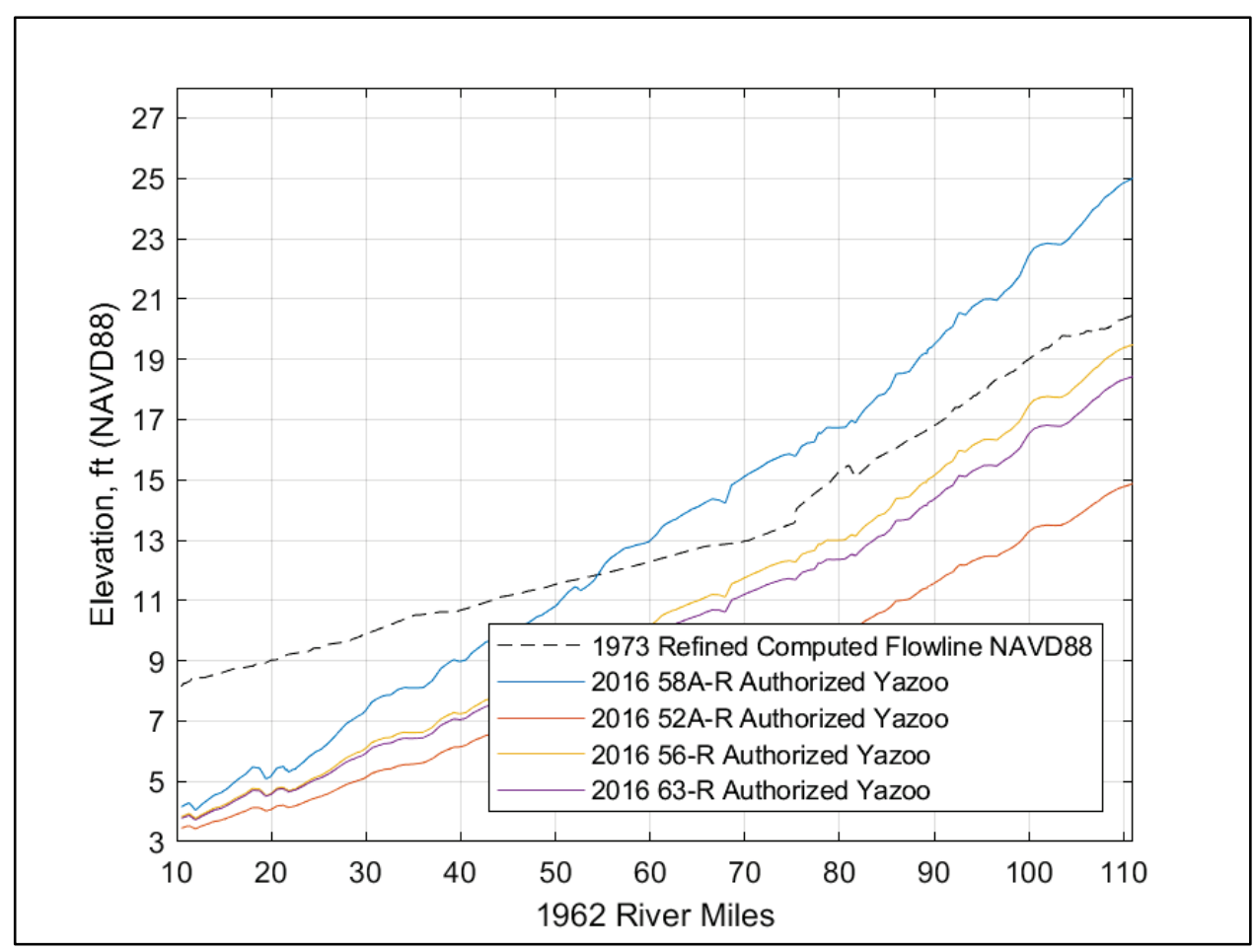


The New Hypo 58A-R PDF simulation produced the highest peak water surfaces among the New Hypo PDF events for all Mississippi River locations between Cairo, IL, and Venice, LA, which was anticipated based on the magnitude of peak flows and is in agreement with the 1955 relative comparisons of the events. The New Hypo 52A-R PDF event produced significantly lower peak water surfaces than the other New Hypo PDF events. The 56-R and 63-R simulations produced similar results to each other for most locations, but the results were still lower than the 58A-R results. Due to the higher peak water surfaces, the 58A-R PDF is the simulation with the greatest focus in this assessment. 


\section{58A-R Concept Plan}

The Mississippi River Commission (MRC) was briefed on the Mississippi River Project Design Flood review on 17 August 2016. This briefing detailed the results of the hydraulic modeling effort that had been accomplished concerning the routing of the newly computed flows through the MR\&T. It was noted in the briefing that the flows were increased throughout the Project Reach from Cairo, IL, down the Mississippi River to Venice, LA.

During the discussion of the ramifications of the increased flood water down through the Mississippi River Valley, the following question was asked by the MRC staff: "Could the four authorized backwater storage areas (St Francis River, White River, Yazoo River, and Red River) and the water control structures (Old River Control Complex [ORCC], Morganza Spillway, and Bonnet Carré Spillway) be utilized in some way to remove the extra floodwater from the system so that the peak flows would be reduced to the levels of the 1955 PDF wherever possible in the system?” The request stated that for this alternative, there would be no constraint, concerning overtopping of the backwater levees or how the floodwater would reach the backwater levees. Also, there was no guidance on how the distribution of flow at the ORCC should be followed to achieve the goal.

This modeling plan to answer these questions was entitled the "Concept Plan" and consisted of adjusting the HEC-RAS model as described in Sections 5.1, 5.2, 5.3, and 5.4. A summary of the plan is as follows:

1. Run the model with all four backwater areas adjusted to provide the optimum use of the areas. This phase used the reduced peak flows below each of the St. Francis, White, and Yazoo Backwater Levee reaches after they were optimized.

2. Use the reduced flood flow through the system down to the ORCC. During this phase, it was necessary to make four modeling runs at the ORCC to prevent the peak flow from exceeding 2,100,000 cfs at RRL and 930,000 cfs at Simmesport, both flows which were authorized in the 1955 PDF study and used in the 1973 study.

The results of this study are shown in the following figures and tables. Note that there were no structures constructed or modified to accomplish the task that was reflected. There was a change in the elevation of the overtopping backwater levees, the inflow channels near the overtopping 
areas, and a change in the regulation of the ORCC during the peak flood flow occurrence.

\subsection{St. Francis Backwater Area optimization}

The St. Francis Backwater Area is located along the lower reach of the St. Francis River and upstream of Helena, AR. There is a fuse plug section adjacent to the Huxtable Pumping Station that is lower than the main line levee grade, which permits flow to enter the storage area during passage of the Project Flood (see Figure 63). The authorized St. Francis Fuseplug elevation has a variable slope over its length but averages elevation 207.2 $\mathrm{ft}$. It was necessary to make several runs to estimate the optimum rate and quantity of floodwater that could be stored during the peak of the project flood. Figure 64 shows the variation of peak flow downstream at Helena versus the backwater levee elevation. Results of the St. Francis Backwater Area flow optimization runs are listed in Table 17. The greatest reduction in Mississippi River peak flow at the Helena gage is achieved with a St. Francis Backwater Levee elevation of $205.1 \mathrm{ft}$. 
Figure 63. Map of St. Francis Backwater Area.

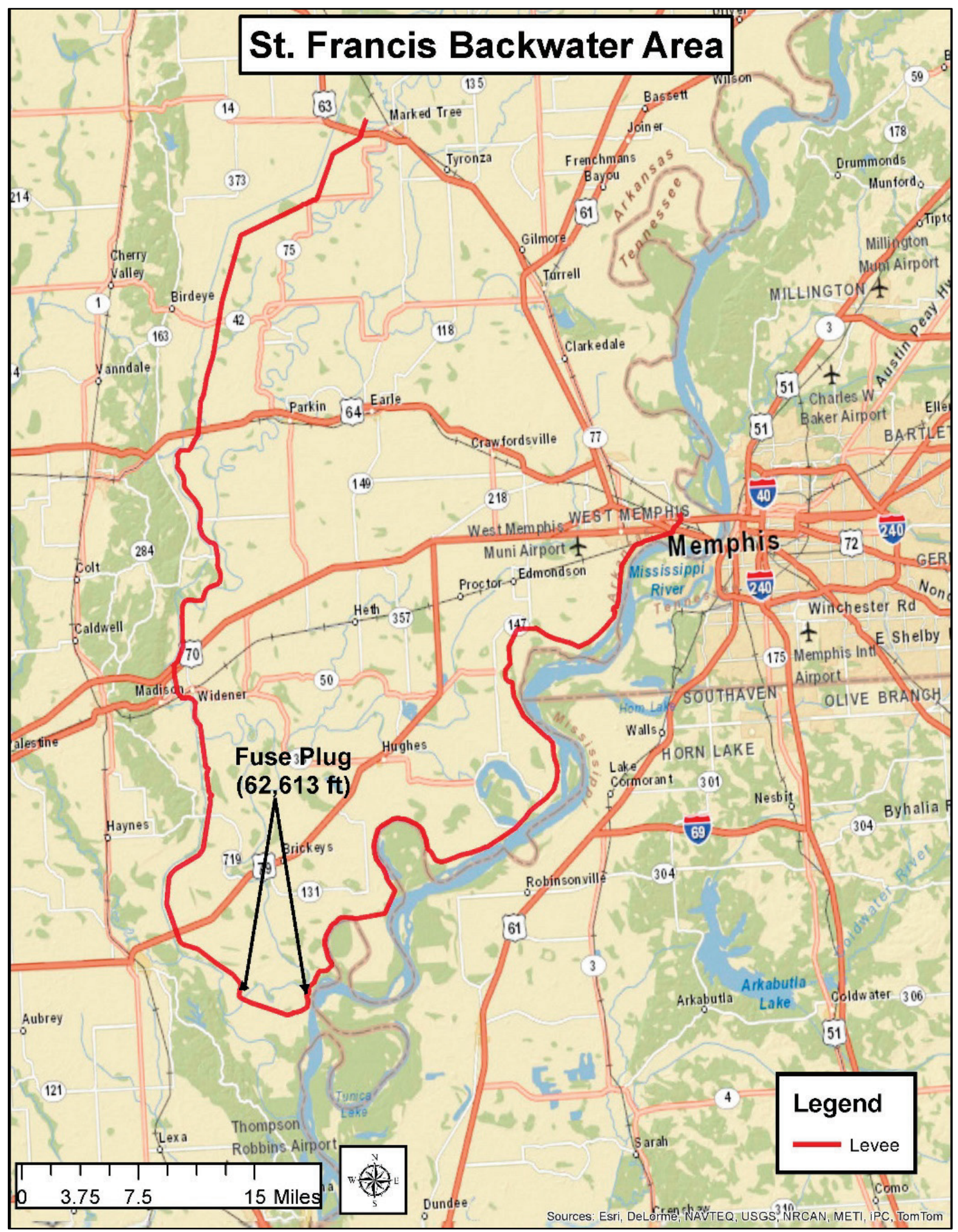


Figure 64. St. Francis Backwater Levee optimization.

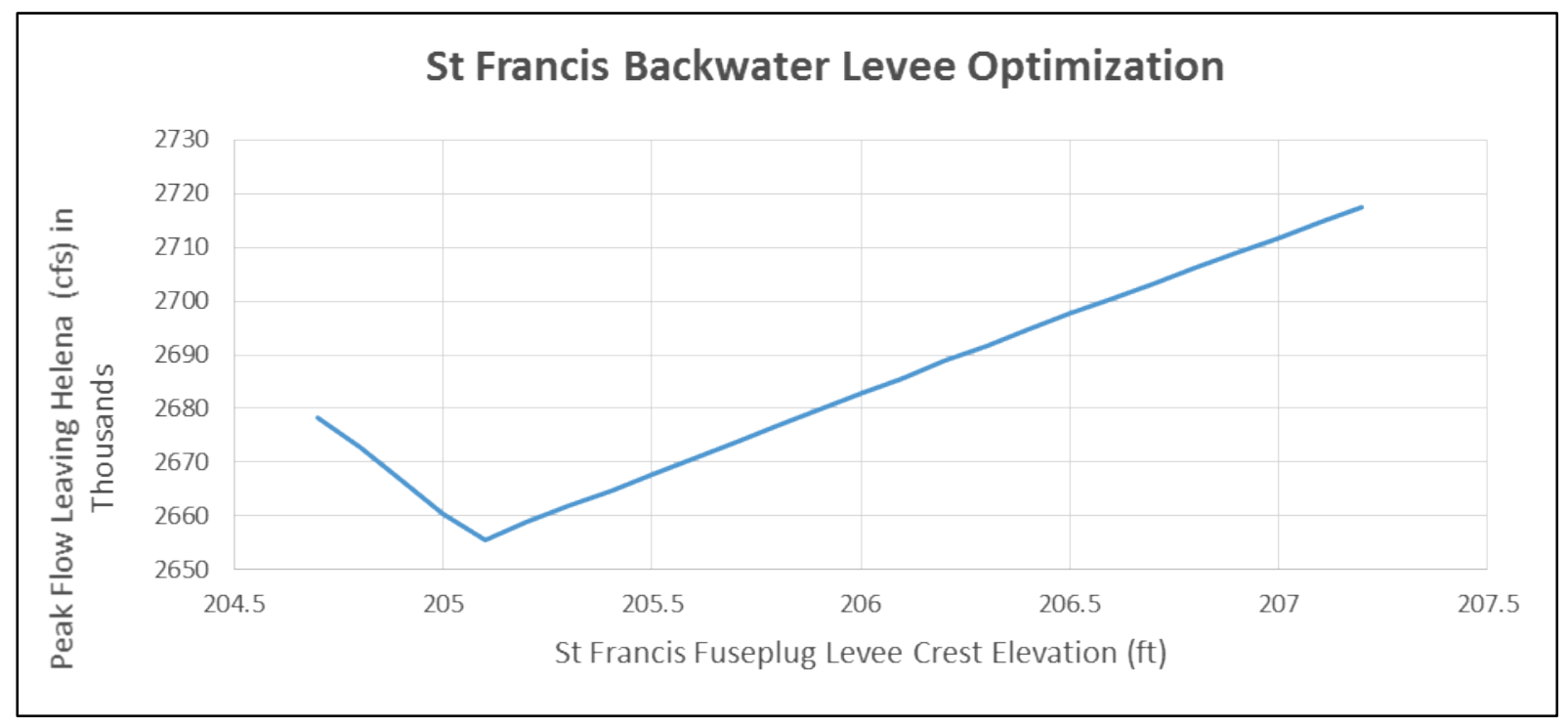

Table 17. St. Francis Backwater Area optimization.

\begin{tabular}{|l|c|c|l|l|}
\hline \multirow{2}{*}{ Plans } & \multicolumn{2}{|l|}{$\begin{array}{l}\text { Mississippi River Peak Flow } \\
\text { Leaving Helena Gage (cfs) }\end{array}$} & $\begin{array}{l}\text { Elevation of St. } \\
\text { Francis } \\
\text { Fuseplug Levee }\end{array}$ & $\begin{array}{l}\text { Peak Flow } \\
\text { Overtopping the } \\
\text { St. Francis } \\
\text { Fuseplug Levee }\end{array}$ \\
\hline & 1973 PDF & 2016 PDF & & \\
\hline Existing St. Francis & \multirow{2}{*}{$2,460,000$} & $2,779,000$ & $210.5^{*}$ & 11,000 \\
\cline { 1 - 4 } Optimized St. Francis & & $2,658,000$ & 205.1 & 190,000 \\
\hline
\end{tabular}

* The Authorized St. Francis Fuseplug elevation is $207.2 \mathrm{ft}$. Lowering the fuseplug to $207.2 \mathrm{ft}$ produces a peak overtopping flow of 103,400 cfs and a 2016 58A-R PDF flow at Helena of 2,718,000. Note: The St. Francis backwater area fuseplugs would not have overtopped in the 2011 event for the Authorized or Concept grades.

\subsection{White River Backwater Area optimization}

The White River Backwater Area, shown in Figure 65, is located along the lower reaches of the White River and upstream of where the White River flows into the Mississippi River. The peak flow change resulting from use of the White River Backwater Area was assessed approximately 55 river miles downstream at the next gaging station at Arkansas City, AR, on the Mississippi River. There are two fuseplug sections designated as "Upper" and "Lower" that are lower than the mainline levee grade that permits flow to enter the storage area during passage of the Project Flood. The authorized White River Backwater Fuseplug elevations have a variable slope over their respective lengths, but average elevations are $175.4 \mathrm{ft}$ and $173.9 \mathrm{ft}$ for the Upper and Lower fuseplugs, respectively. It was necessary 
to make several runs to estimate the optimum rate and quantity of floodwater that could be stored during the peak of the project flood. The White River fuseplugs function together, so they were optimized simultaneously. Their elevations were lowered by the same amount from the authorized level until optimal conditions were reached at Arkansas City. Figure 66 and Figure 67 show the variation of peak flow downstream at Arkansas City, AR, versus the backwater levee elevation for Upper and Lower fuseplugs. Results of the White River Backwater Area flow optimization runs are shown in Table 18. The greatest reduction in Mississippi River peak flow at the Arkansas City gage is achieved with an Upper White Backwater Levee elevation of $172.2 \mathrm{ft}$ and a Lower White Backwater Levee elevation of $170.7 \mathrm{ft}$. 
Figure 65. Map of White River Backwater Area.

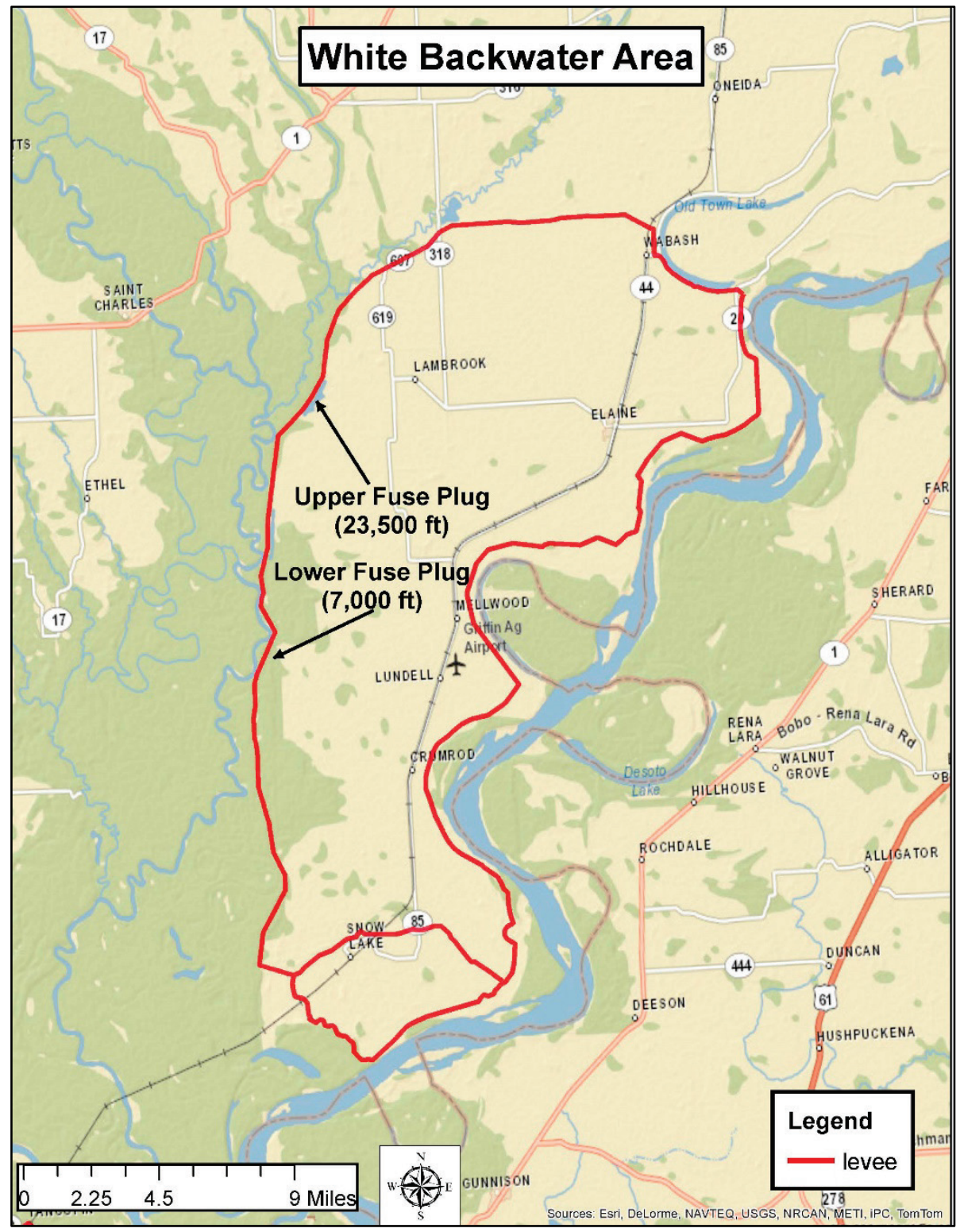


Figure 66. Upper White Backwater Levee optimization.

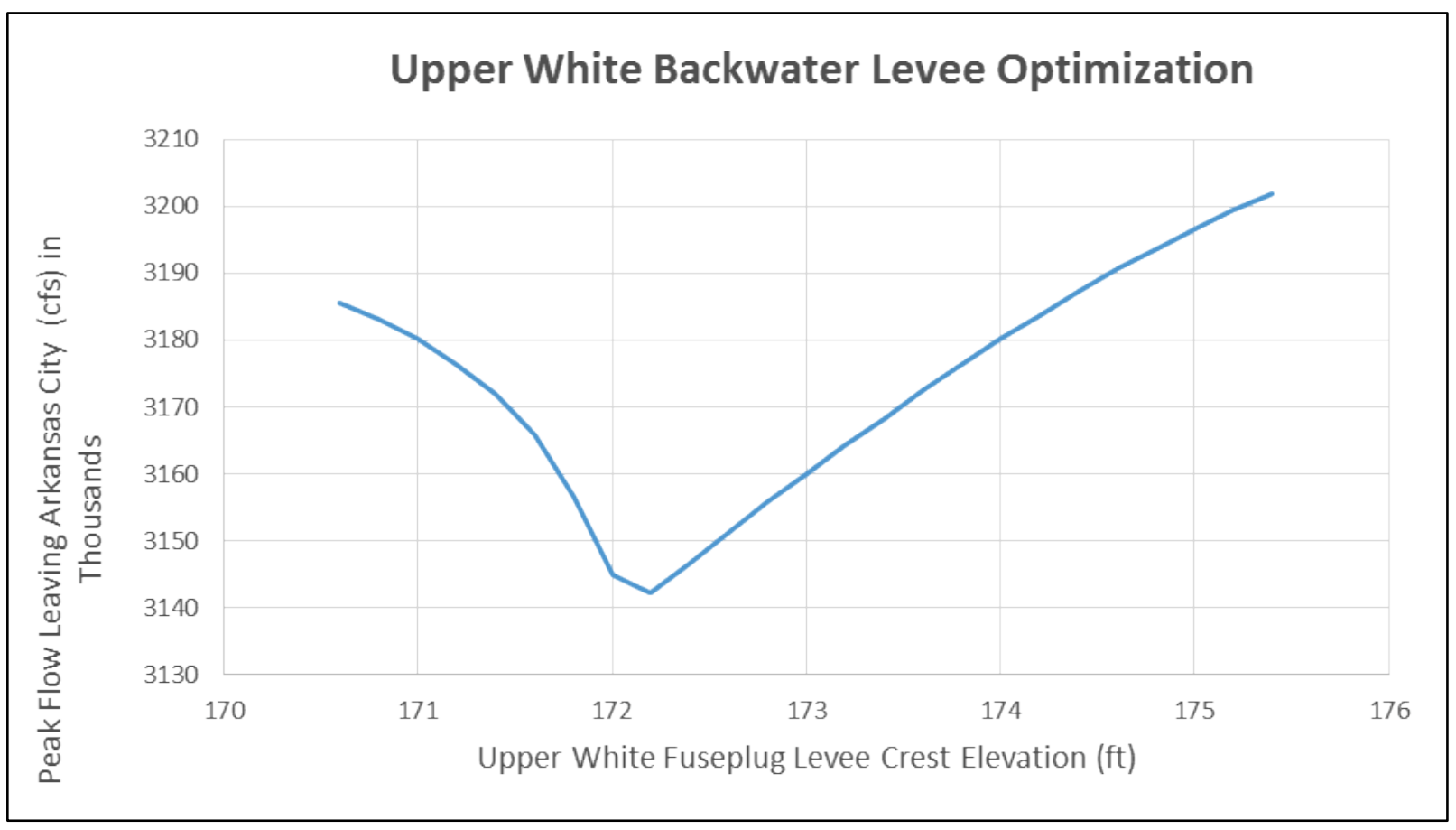

Figure 67. Lower White Backwater Levee optimization.

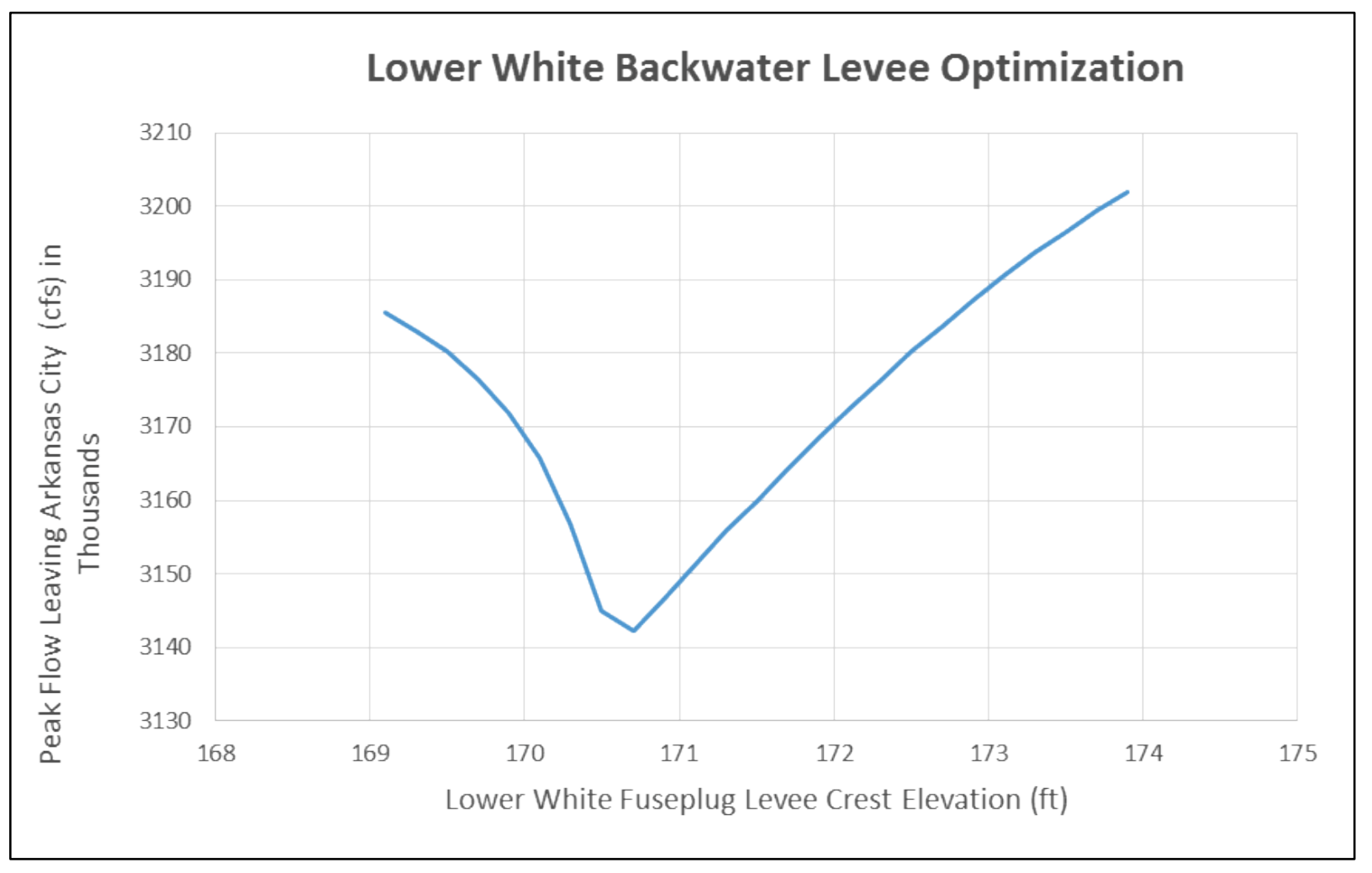


Table 18. White River Backwater Area optimization.

\begin{tabular}{|l|c|c|l|l|c|}
\hline \multirow{2}{*}{ Plans } & \multicolumn{2}{|l|}{$\begin{array}{l}\text { Mississippi River Peak Flow } \\
\text { Leaving Arkansas City gage (cfs) }\end{array}$} & $\begin{array}{l}\text { Elevation of } \\
\text { Upper White } \\
\text { Fuseplug levee }\end{array}$ & $\begin{array}{l}\text { Elevation of } \\
\text { Lower White } \\
\text { Fuseplug levee }\end{array}$ & $\begin{array}{l}\text { Peak Flow } \\
\text { Overtopping } \\
\text { the White } \\
\text { Fuseplug } \\
\text { Levees }\end{array}$ \\
\hline & 1973 PDF & 2016 PDF & & & \\
\hline Existing White & \multirow{2}{*}{$2,890,000$} & $3,242,000$ & $176.0 *$ & $174.2 *$ & 34,600 \\
\cline { 1 - 5 } Optimized White & & $3,154,400$ & 172.2 & 170.7 & 114,000 \\
\hline
\end{tabular}

* The authorized White River Fuseplug elevations are 175.4 (Upper) and 173.9 (Lower). Lowering the fuseplugs to these authorized grades produces a peak overtopping flow of 36,000 and a 2016 58A-R PDF flow at Arkansas City of 3,202,000. Note: The White Backwater Area fuseplugs would not have overtopped in the 2011 event for the Authorized or Concept grades

\subsection{Yazoo Backwater Levee optimization}

The Yazoo Backwater Levee elevation controls the amount of floodwater that can enter the storage area during the passage of the Project Flood (see Figure 68). It was necessary to make several runs, varying the backwater levee elevation to determine the optimum amount of floodwater that can be stored during the peak of the project flood. Figure 69 shows the variation of peak flow downstream of Vicksburg versus the Yazoo Backwater Levee elevation. Results of the Yazoo Backwater optimization runs are listed in Table 19. The greatest reduction in Mississippi River peak flow at the Vicksburg gage is achieved with a Yazoo Backwater Levee elevation of $109.8 \mathrm{ft}$. 
Figure 68. Map of Yazoo Backwater Area.

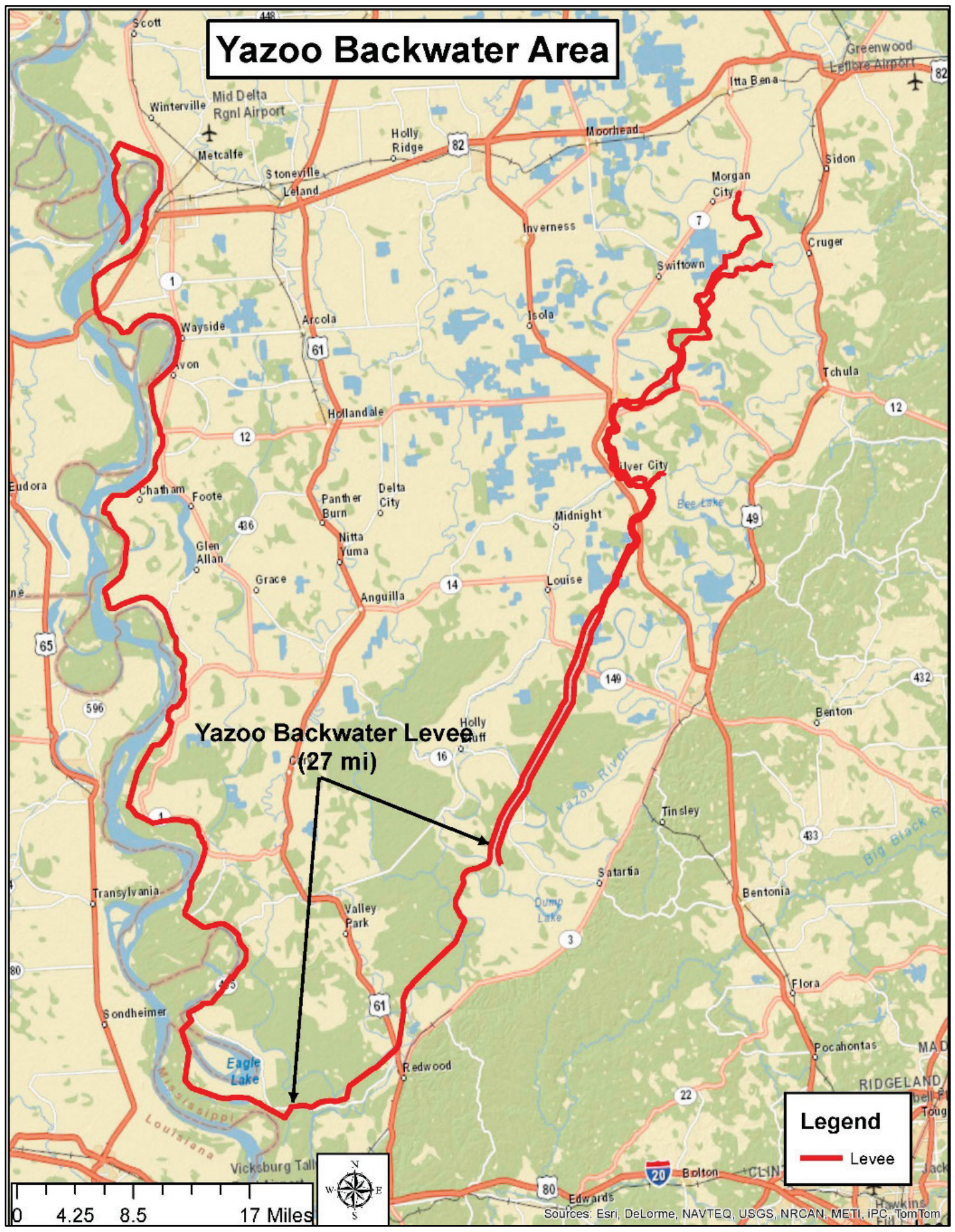


Figure 69. Yazoo Backwater optimization.

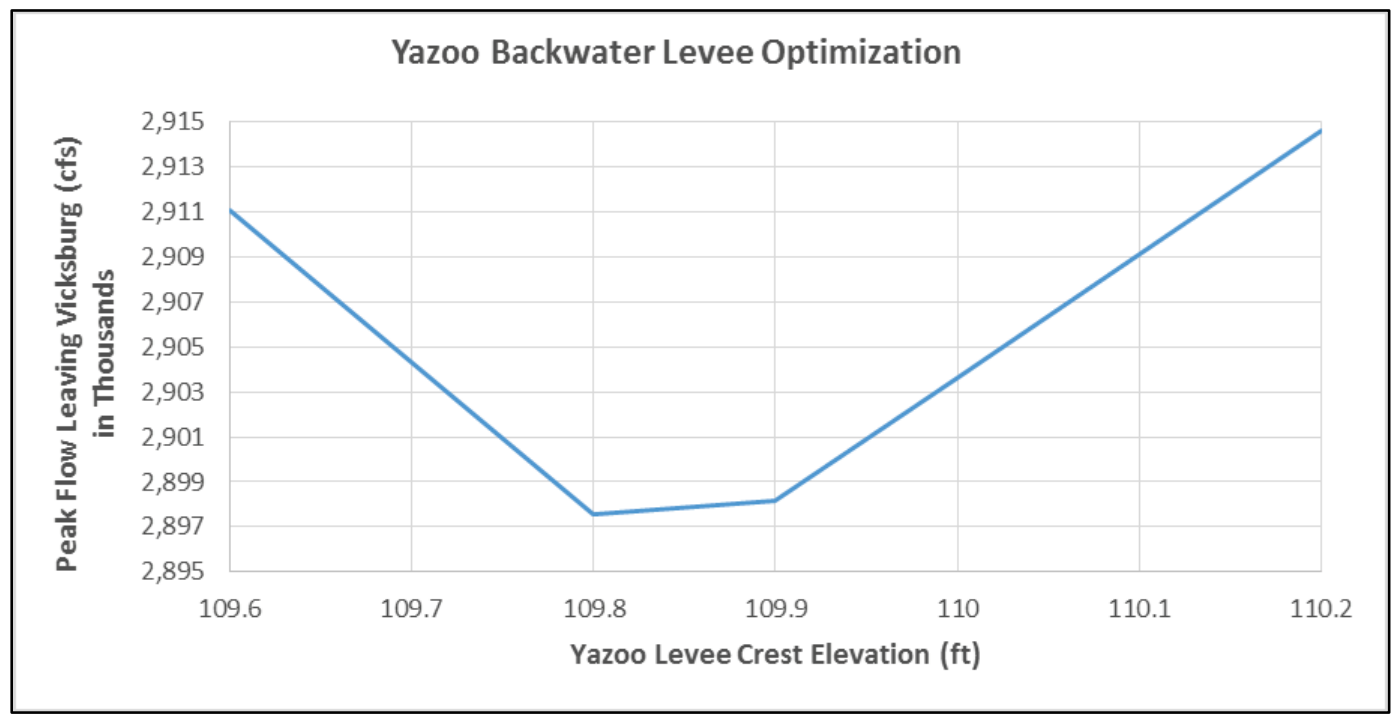

Table 19. Yazoo Backwater Levee optimization.

\begin{tabular}{|c|c|c|c|c|c|c|}
\hline \multirow[t]{2}{*}{ Plans } & \multicolumn{2}{|c|}{$\begin{array}{l}\text { Mississippi River Peak Flow } \\
\text { at Arkansas City Gage (cfs) }\end{array}$} & \multirow[t]{2}{*}{$\begin{array}{l}\text { Elevation of } \\
\text { Yazoo } \\
\text { Backwater } \\
\text { Levee (ft) }\end{array}$} & \multirow[t]{2}{*}{$\begin{array}{l}\text { Peak Flow } \\
\text { Overtopping } \\
\text { the Yazoo } \\
\text { Backwater } \\
\text { Levee (cfs) }\end{array}$} & \multicolumn{2}{|c|}{$\begin{array}{l}\text { Mississippi River Peak Flow } \\
\text { Leaving Vicksburg Gage (cfs) }\end{array}$} \\
\hline & 1973 PDF & $\begin{array}{l}\text { Concept } \\
\text { Optimized }\end{array}$ & & & 1973 PDF & $\begin{array}{l}\text { Concept } \\
\text { Optimized }\end{array}$ \\
\hline $\begin{array}{l}\text { Existing Yazoo } \\
\text { Levee }\end{array}$ & \multirow{3}{*}{$2,890,000$} & $3,179,000$ & 107.0 & 342,000 & \multirow{3}{*}{$2,710,000$} & $2,921,000$ \\
\hline $\begin{array}{l}\text { Authorized } \\
\text { Yazoo Levee }\end{array}$ & & $3,179,000$ & 112.8 & 156,000 & & $3,032,000$ \\
\hline $\begin{array}{l}\text { Optimized } \\
\text { Yazoo Levee }\end{array}$ & & $3,179,000$ & 109.8 & 327,000 & & $2,845,000$ \\
\hline
\end{tabular}

\subsection{ORCC}

After the Yazoo Backwater Levee was optimized, the 70/30 ORCC operational guidance, with an ORCC limit of 620,000 cfs, was used to make the initial optimization run for ORCC, as listed in the first row of Table 20. The peak flow at RRL was 2,295,000 cfs using this guidance. The Refined 1973 PDF flood flow at RRL is 2,100,000 cfs, which is 195,000 cfs less than the $70 / 30$ run with a 620,000 cfs ORCC limit. Since the ORCC structures have more capacity than the 620,000 cfs (presently authorized), it was decided that the extra flow would be diverted through the structures to limit the peak flow past RRL to 2,100,000 cfs. The Auxiliary Structure of ORCC was not in place during the previous study, 
and this structure has increased the capacity of the ORCC. The second run diverted an ORCC peak flow of 819,000 cfs to equal the Refined 1973 PDF at RRL. This resulted in a peak flow of 1,013,000 cfs at the Simmesport gage because of the extra flow diverted through ORCC, which is 83,000 cfs higher than the Refined 1973 PDF flow of 930,000 cfs. The activation of the Tensas Cocodrie backwater levee, shown in Figure 70, was necessary so that the flow at the Simmesport gage was reduced to 957,000 cfs. The activation of Tensas Cocodrie was done in two separate ways:

1. Lowering the levee from elevation 60 to elevation 55.1 in a 2-mile reach between HEC-RAS RMs 3.2 and 5.2 on the Red River.

2. Lowering the levee $3 \mathrm{ft}$ in an approximately 12 mile reach.

Results from each of these two separate runs are listed in the bottom two rows of Table 20. 
Figure 70. Map of Tensas Cocodrie Backwater Area.

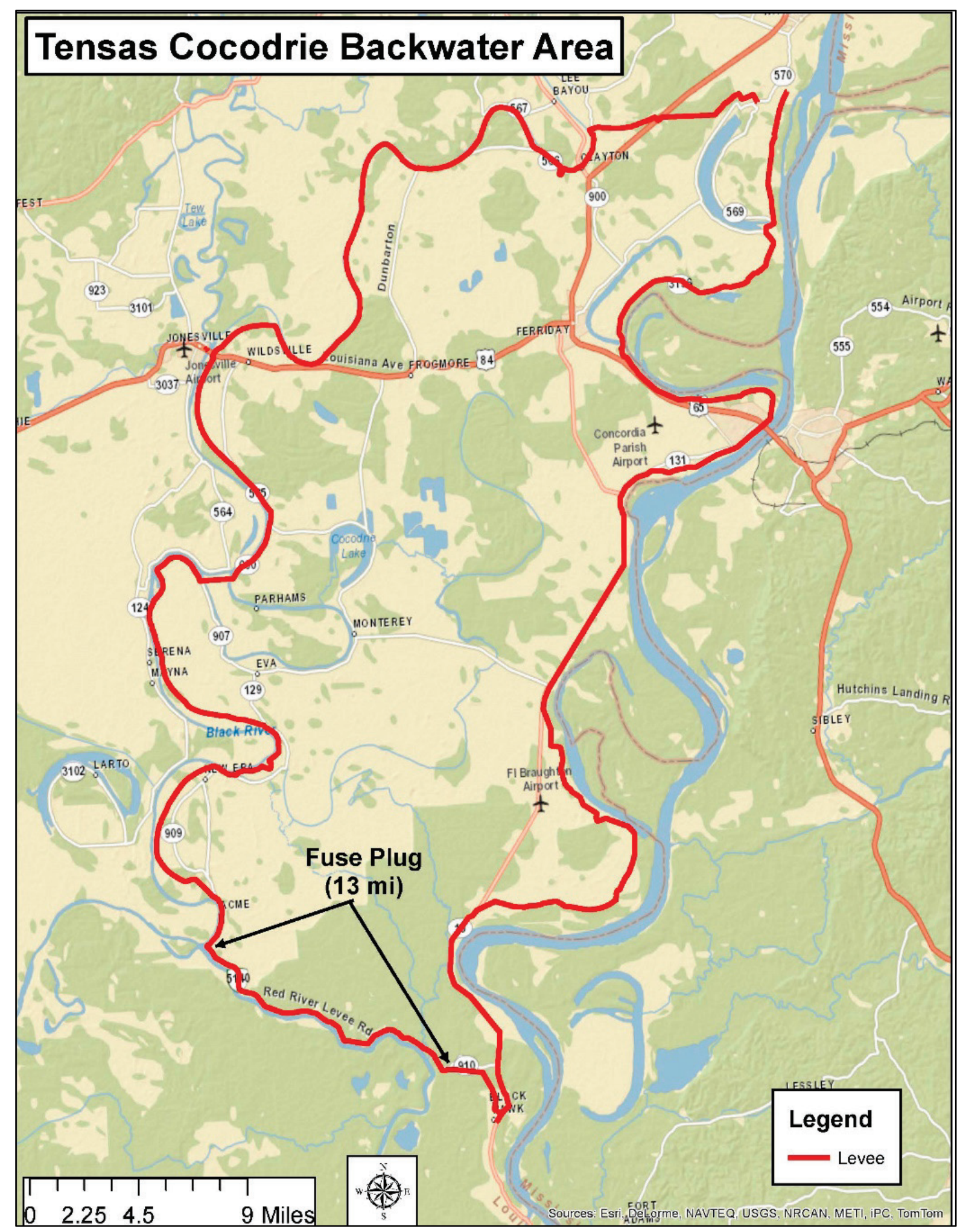


Table 20. ORCC Optimization.

\begin{tabular}{|c|c|c|c|c|c|c|c|c|c|}
\hline \multicolumn{10}{|c|}{ ORCC Plans to Divert Mississippi River Flood Flow to Limit RRL Peak Flow to $2,100,000$ cfs } \\
\hline \multirow[b]{2}{*}{ Plans } & \multicolumn{2}{|c|}{$\begin{array}{l}\text { Mississippi River Peak } \\
\text { Flow at Vicksburg Gage } \\
\text { (cfs) }\end{array}$} & \multirow{2}{*}{$\begin{array}{l}\text { ORCC } \\
\text { Diversion } \\
\text { Peak Flow } \\
\text { Diverted } \\
\text { (cfs) }\end{array}$} & \multicolumn{2}{|c|}{$\begin{array}{l}\text { Mississippi River Peak } \\
\text { Flow at RRL Gage (cfs) }\end{array}$} & \multirow{2}{*}{$\begin{array}{l}\text { Peak Flow } \\
\text { Overtopping } \\
\text { the Tensas } \\
\text { Cocodrie } \\
\text { Levee }\end{array}$} & \multicolumn{2}{|c|}{$\begin{array}{l}\text { Atchafalaya River at } \\
\text { Simmesport Gage } \\
\text { (cfs) }\end{array}$} & \multirow{2}{*}{$\begin{array}{c}\text { Description of } \\
\text { Activation of the } \\
\text { Tensas Cocodrie Levee }\end{array}$} \\
\hline & 1973 PDF & $\begin{array}{l}\text { Concept } \\
\text { Optimized }\end{array}$ & & 1973 PDF & $\begin{array}{l}\text { Concept } \\
\text { Optimized }\end{array}$ & & $\begin{array}{l}1973 \\
\text { PDF }\end{array}$ & $\begin{array}{l}\text { Concept } \\
\text { Optimized }\end{array}$ & \\
\hline $\begin{array}{l}\text { Authorized ORCC } \\
\text { Operation } 70 / 30 \\
\text { split with limit on } \\
\text { diversion of } \\
620,000 \text { cfs }\end{array}$ & \multirow{4}{*}{$2,710,000$} & \multirow{4}{*}{$2,898,000$} & 620,000 & \multirow{4}{*}{$2,100,000$} & $\begin{array}{c}2,295,000 \\
\text { at } 72 \%\end{array}$ & 0 & \multirow{4}{*}{930,000} & $\begin{array}{l}881,000 \\
\text { at } \\
28 \%\end{array}$ & none \\
\hline $\begin{array}{l}\text { ORCC set so that } \\
\text { only } 2,100,000 \text { cfs } \\
\text { passes RRL, with } \\
\text { existing Red River } \\
\text { Back Water(RRBW) } \\
\text { levee elevation }\end{array}$ & & & 819,000 & & $\begin{array}{c}2,100,000 \\
\text { at } \\
67 \%\end{array}$ & 0 & & $\begin{array}{c}1,013,000 \\
\text { at } \\
33 \%\end{array}$ & 39,000 \\
\hline $\begin{array}{l}\text { ORCC set so that } \\
\text { only } 2,100,000 \text { cfs } \\
\text { passes RRL, with } \\
\text { current RRBW levee } \\
\text { activated for 2-mile } \\
\text { segment }\end{array}$ & & & 819,000 & & $\begin{array}{c}2,100,000 \\
\text { at } \\
68 \%\end{array}$ & 123,000 & & $\begin{array}{l}968,000 \\
\text { at } \\
32 \%\end{array}$ & $\begin{array}{l}\text { Tensas Cocodrie levee } \\
\text { lowered from } \\
\text { elevation } 60 \text { to } \\
\text { elevation } 55.1 \text { in a } 2- \\
\text { mile reach between } \\
\text { model miles } 3.2 \text { and } \\
5.2 \text { on Red River }\end{array}$ \\
\hline $\begin{array}{l}\text { ORCC set so that } \\
\text { only } 2,100,000 \text { cfs } \\
\text { passes RRL, with } \\
\text { current RRBW levee } \\
\text { activated for } 12- \\
\text { mile segment }\end{array}$ & & & 819,000 & & $\begin{array}{c}2,100,000 \\
\text { at } \\
69 \%\end{array}$ & 125,000 & & $\begin{array}{l}957,000 \\
\text { at } 31 \%\end{array}$ & $\begin{array}{l}\text { Tensas Cocodrie levee } \\
\text { was lowered } 3 \mathrm{ft} \text { in an } \\
\text { approx. } 12 \text {-mile reach } \\
\text { between model miles } \\
3.21 \text { and } 15.35 \text { on } \\
\text { Red River. }\end{array}$ \\
\hline
\end{tabular}

Note: The Morganza Control Structure and Bonnet Carré Spillway were operated as authorized in all runs. 


\subsection{Results}

The complete HEC-RAS simulation incorporating all of the previously discussed backwater area optimizations is labeled the Concept Plan. Peak flow results at key locations are shown in Table 21, and peak stage results are shown in Table 22. Flow hydrographs of the Concept Plan are shown in Figure 71 through Figure 75 . Notice that the effects of the backwater area optimizations are seen at the Helena location and downstream of Helena. Water surface profile plots of peak stages in 100-mile increments are shown in Figure 76 through Figure 85 .

Table 21. Maximum flow comparisons of the Concept Plan simulation (cubic feet per second).

\begin{tabular}{|c|c|c|c|c|}
\hline Location & $\begin{array}{c}\text { RAS } \\
\text { Station }\end{array}$ & $\begin{array}{c}\text { Published } 1955 \\
\text { Hydrology }\end{array}$ & $\begin{array}{c}\text { New Hypo PDF } \\
\text { 58A-R Authorized } \\
\text { Yazoo }\end{array}$ & $\begin{array}{c}\text { New Hypo PDF 58A-R } \\
\text { Concept }\end{array}$ \\
\hline Mississippi at Chester & 110.4 & 240,000 & 508,000 & 508,000 \\
\hline Ohio River at Cairo & -979.68 & $2,250,000$ & $2,326,000$ & $2,326,000$ \\
\hline Mississippi at Ohio River & 973.85 & $2,360,000$ & $2,791,000$ & $2,791,000$ \\
\hline Mississippi at Hickman & 942.45 & $1,810,000$ & $1,973,000$ & $1,973,000$ \\
\hline Mississippi at Memphis & 749.01 & $2,410,000$ & $2,862,000$ & $2,864,000$ \\
\hline Mississippi at Helena & 676.42 & $2,460,000$ & $2,787,000$ & $2,660,000$ \\
\hline Mississippi at Arkansas City & 562.18 & $2,890,000$ & $3,263,000$ & $3,180,000$ \\
\hline Arkansas River at Dam 02 & 28.07 & 400,000 & 487,000 & 487,000 \\
\hline St. Francis at 82.47 & 82.47 & 80,000 & 85,000 & 85,000 \\
\hline White River at Clarendon & 100.05 & 220,000 & 233,000 & 235,000 \\
\hline Mississippi at Greenville & 539.13 & & $3,260,000$ & $3,172,000$ \\
\hline Mississippi at Lake Providence & 494.47 & & $3,257,000$ & $3,168,000$ \\
\hline Mississippi at Vicksburg & 442.16 & $2,710,000$ & $3,087,000$ & $2,898,000$ \\
\hline Mississippi at Natchez & 368.44 & $2,720,000$ & $3,099,000$ & $2,919,000$ \\
\hline Mississippi at RRL & 306.43 & $2,100,000$ & $2,475,000$ & $2,106,000$ \\
\hline Mississippi at Baton Rouge Gage & 233.1 & $1,500,00$ & $1,869,000$ & $1,505,000$ \\
\hline Mississippi at Donaldsonville gage & 179.04 & $1,500,00$ & $1,868,000$ & $1,505,000$ \\
\hline Mississippi at Carrollton Gage & 107.2 & $1,250,000$ & $1,613,000$ & 1,251000 \\
\hline Mississippi at Empire Gage & 33.79 & $1,250,000$ & $1,543,000$ & $1,219,000$ \\
\hline Mississippi at Venice gage (15.07) & 15.07 & $1,250,000$ & $1,115,000$ & 895,000 \\
\hline
\end{tabular}


Table 22. Maximum stage comparisons of the Concept Plan simulation (feet, NAVD88) (*from the Refined 1973 Flowline Study [USACE 1978], this column is without loop effect, sedimentation, or freeboard effects).

\begin{tabular}{|l|c|c|c|c|}
\hline \multicolumn{1}{|c|}{ Location } & RAS Station & $\begin{array}{c}\text { Refined 1973 } \\
\text { Flowline } \\
\text { (58A-EN)* }\end{array}$ & $\begin{array}{c}\text { New Hypo PDF } \\
\text { 58A-R Authorized } \\
\text { Yazoo }\end{array}$ & $\begin{array}{c}\text { New Hypo PDF 58A-R } \\
\text { Concept }\end{array}$ \\
\hline Mississippi at Chester & 110.4 & & 372.5 & 372.5 \\
\hline Ohio River at Cairo & -979.68 & & 334.8 & 334.8 \\
\hline Mississippi at Ohio River & 973.85 & 331.7 & 334.3 & 334.3 \\
\hline Mississippi at Hickman & 942.45 & 320.7 & 321.4 & 321.4 \\
\hline Mississippi at Memphis & 749.01 & 237.2 & 241.4 & 241.2 \\
\hline Mississippi at Helena & 676.42 & 202.9 & 206.0 & 204.4 \\
\hline Mississippi at Arkansas City & 562.18 & 155.5 & 159.0 & 158.0 \\
\hline Arkansas River at Dam 02 & 28.07 & & 177.2 & 176.4 \\
\hline St. Francis at 82.47 & 82.47 & & 217.1 & 217.1 \\
\hline White River at Clarendon & 100.05 & & 181.9 & 181.5 \\
\hline Mississippi at Greenville & 539.13 & 145.2 & 148.2 & 146.5 \\
\hline Mississippi at Lake Providence & 494.47 & 129.4 & 132 & 130.5 \\
\hline Mississippi at Vicksburg & 442.16 & 106.9 & 111.7 & 109.3 \\
\hline Mississippi at Natchez & 368.44 & 82.7 & 88.4 & 85.1 \\
\hline Mississippi at RRL & 306.43 & 63.5 & 69.8 & 63.7 \\
\hline Mississippi at Baton Rouge Gage & 233.1 & 45.7 & 52.8 & 44.5 \\
\hline Mississippi at Donaldsonville gage & 179.04 & 33.8 & 40.1 & 31.8 \\
\hline Mississippi at Carrollton Gage & 107.2 & 19.6 & 22.8 & 16.8 \\
\hline Mississippi at Empire Gage & 33.79 & 9.8 & 7.2 & 5.8 \\
\hline Mississippi at Venice gage (15.07) & 15.07 & 8.1 & 4.2 & 3.8 \\
\hline
\end{tabular}


Figure 71. Concept Plan flow hydrograph at the Below Cairo location (the flows are the same at this location for the "Authorized Yazoo" and "Concept" runs since it is relatively far upstream).

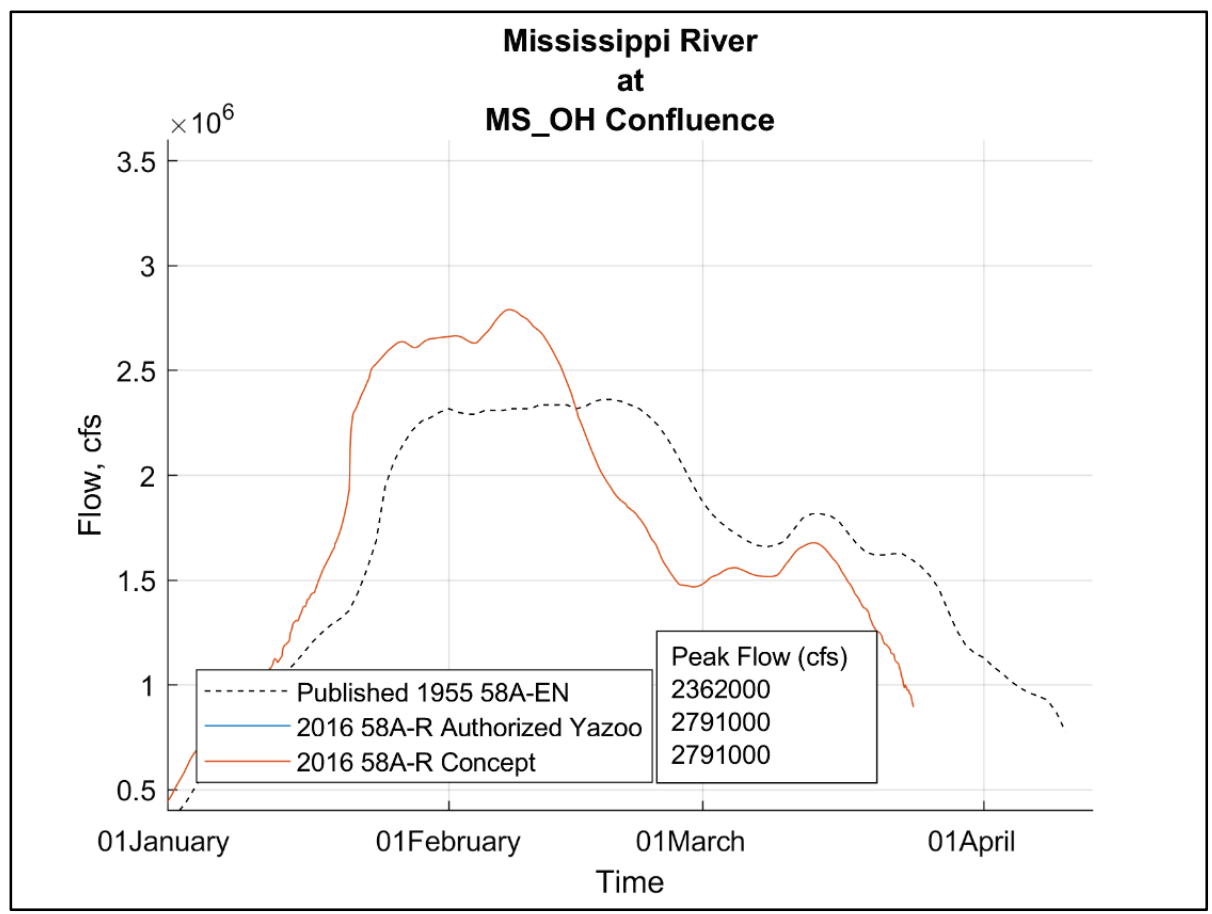

Figure 72. Concept Plan flow hydrograph at the Memphis location (the flows are the same at this location for the "Authorized Yazoo" and "Concept" runs since it is relatively far upstream).

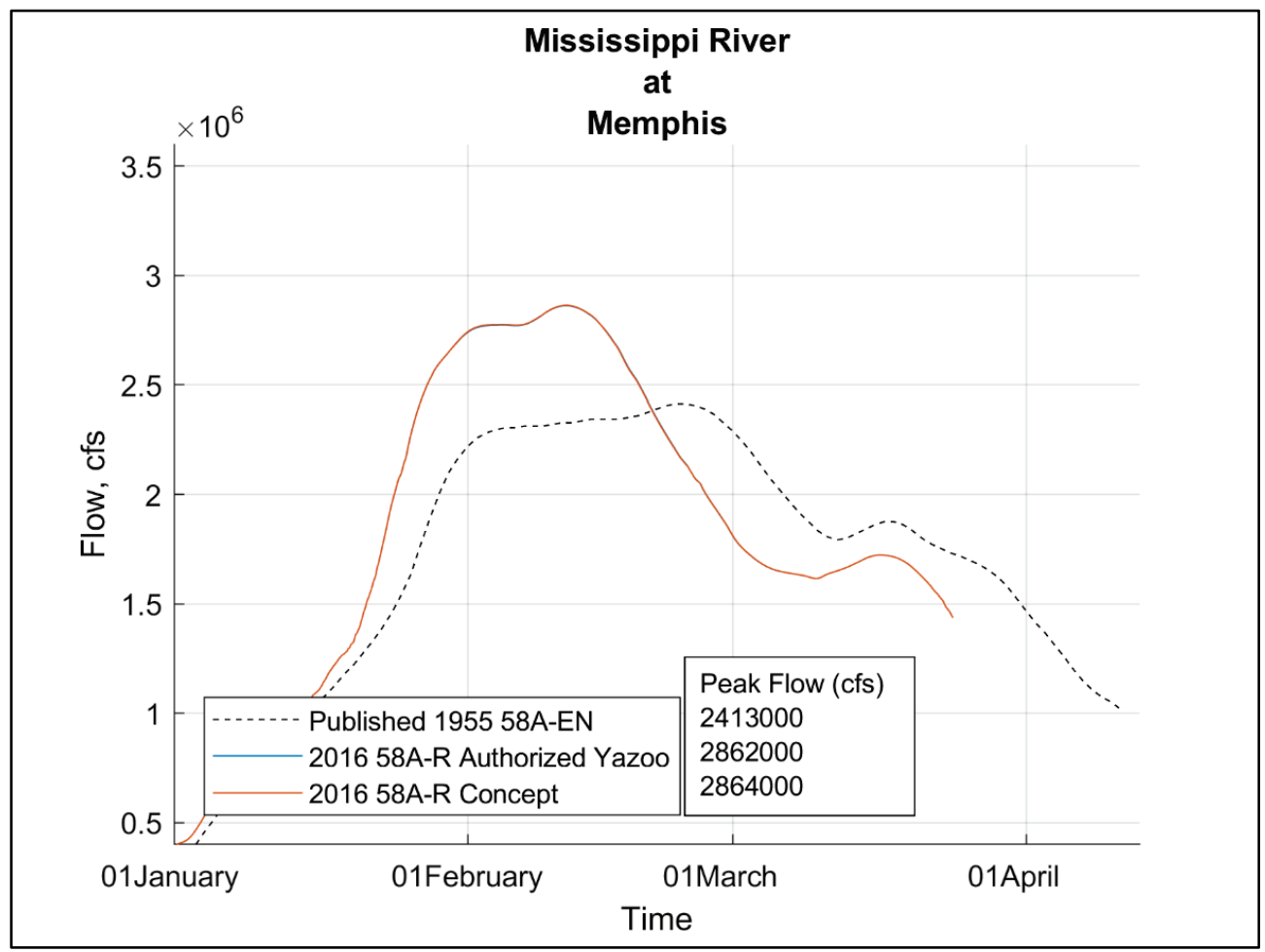


Figure 73. Concept Plan flow hydrograph at the Helena location.

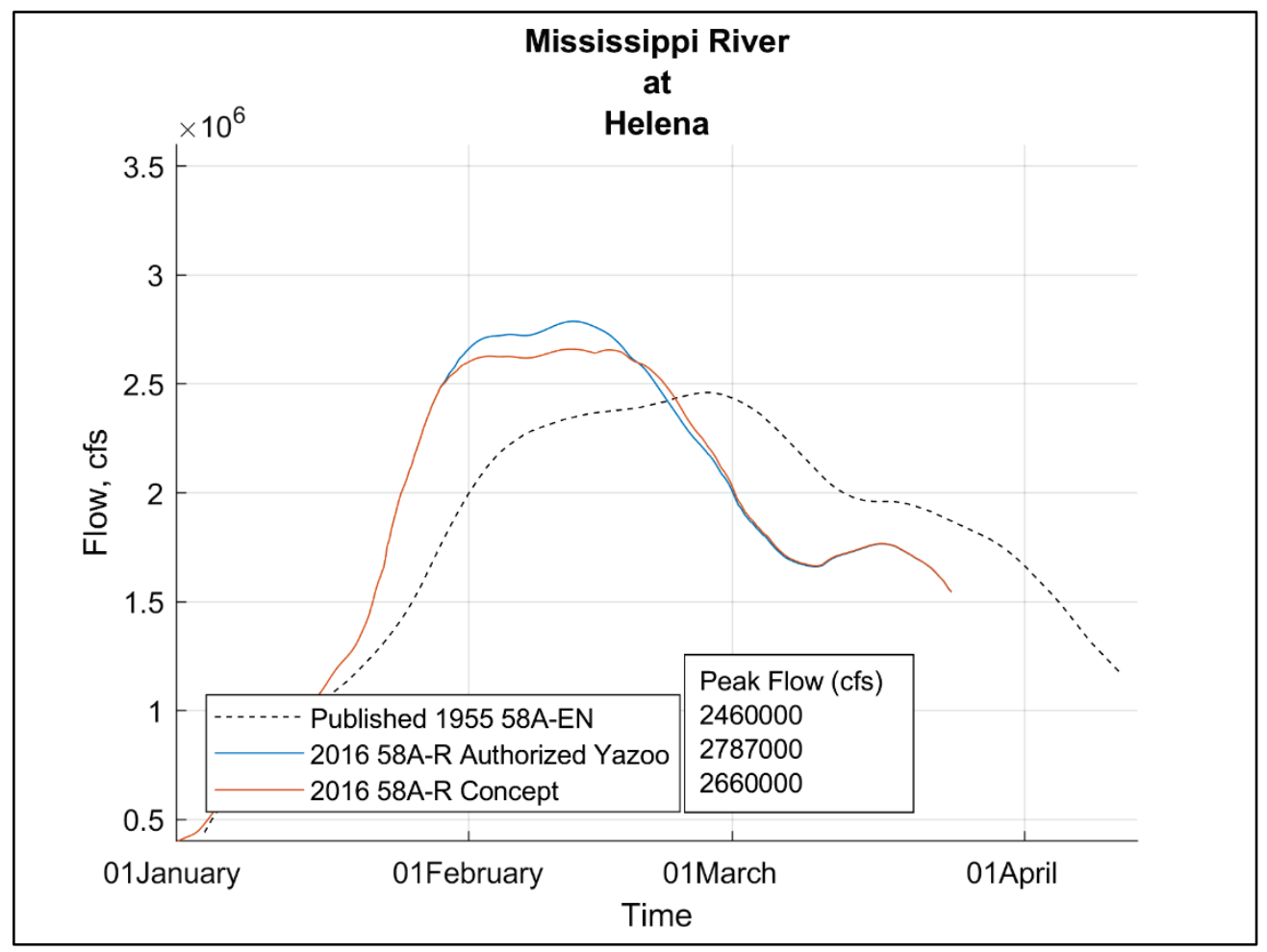

Figure 74. Concept Plan flow hydrograph at the Arkansas City location.

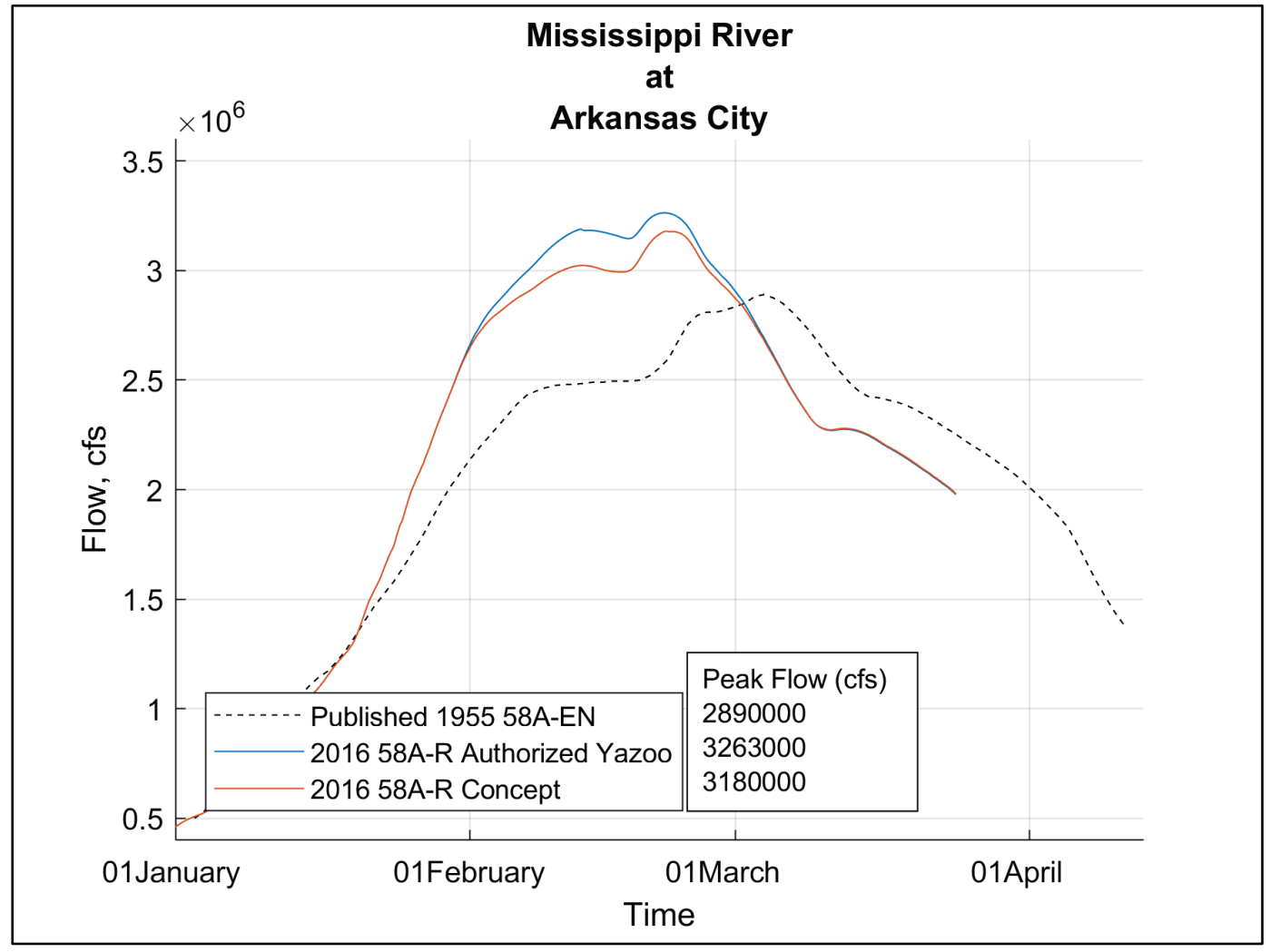


Figure 75. Concept Plan flow hydrograph at the RRL location.

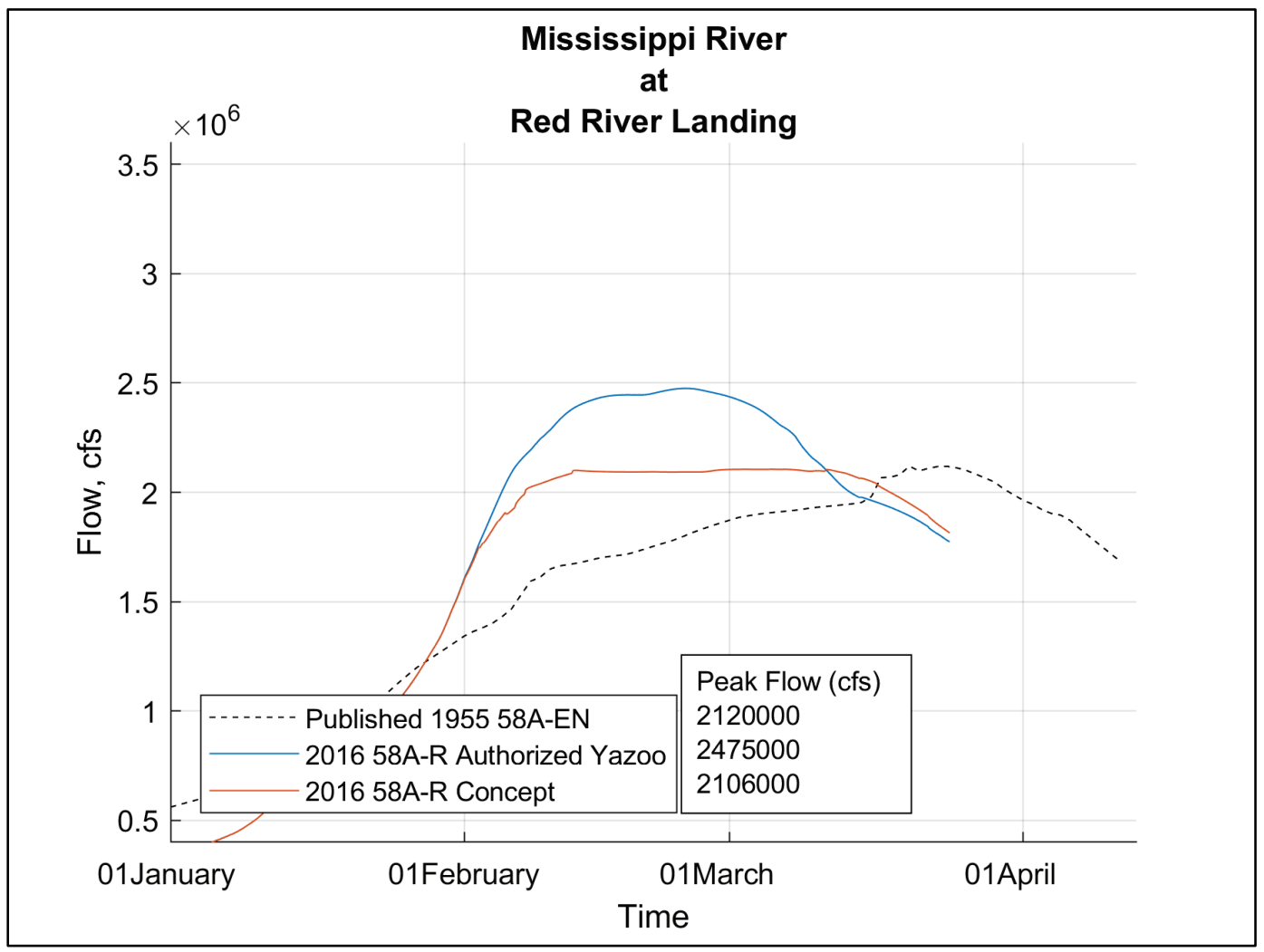

Figure 76. Concept Plan water surface profile for RMs 910 - 953 (Refined 1973 Computed Flowline is without loop, sediment, and freeboard effects. The Concept results are on top of the Authorized Yazoo results in this figure).

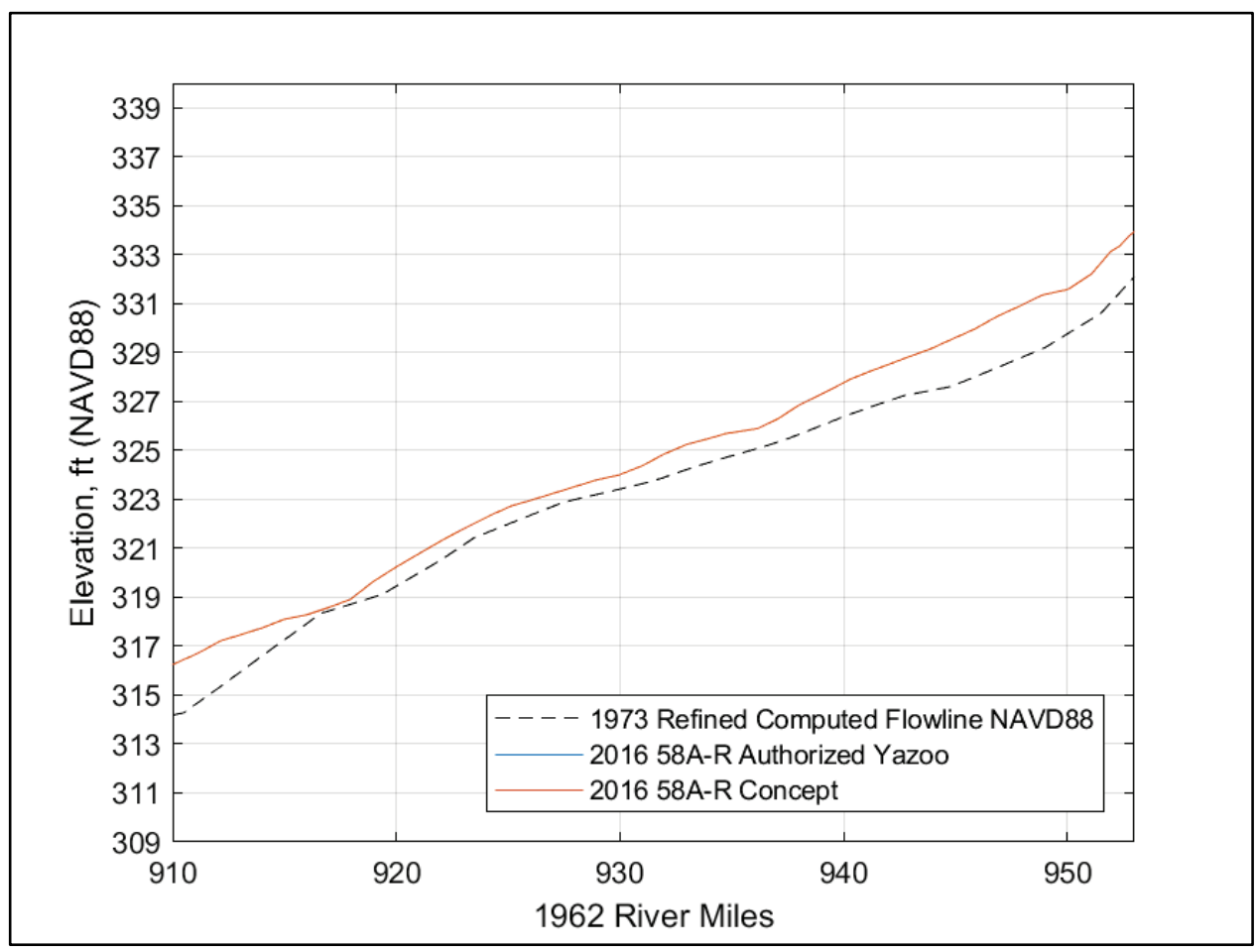


Figure 77. Concept Plan water surface profile for RMs 810 - 910 (Refined 1973 Computed Flowline is without loop, sediment, and freeboard effects. The Concept results are on top of the Authorized Yazoo results in this figure).

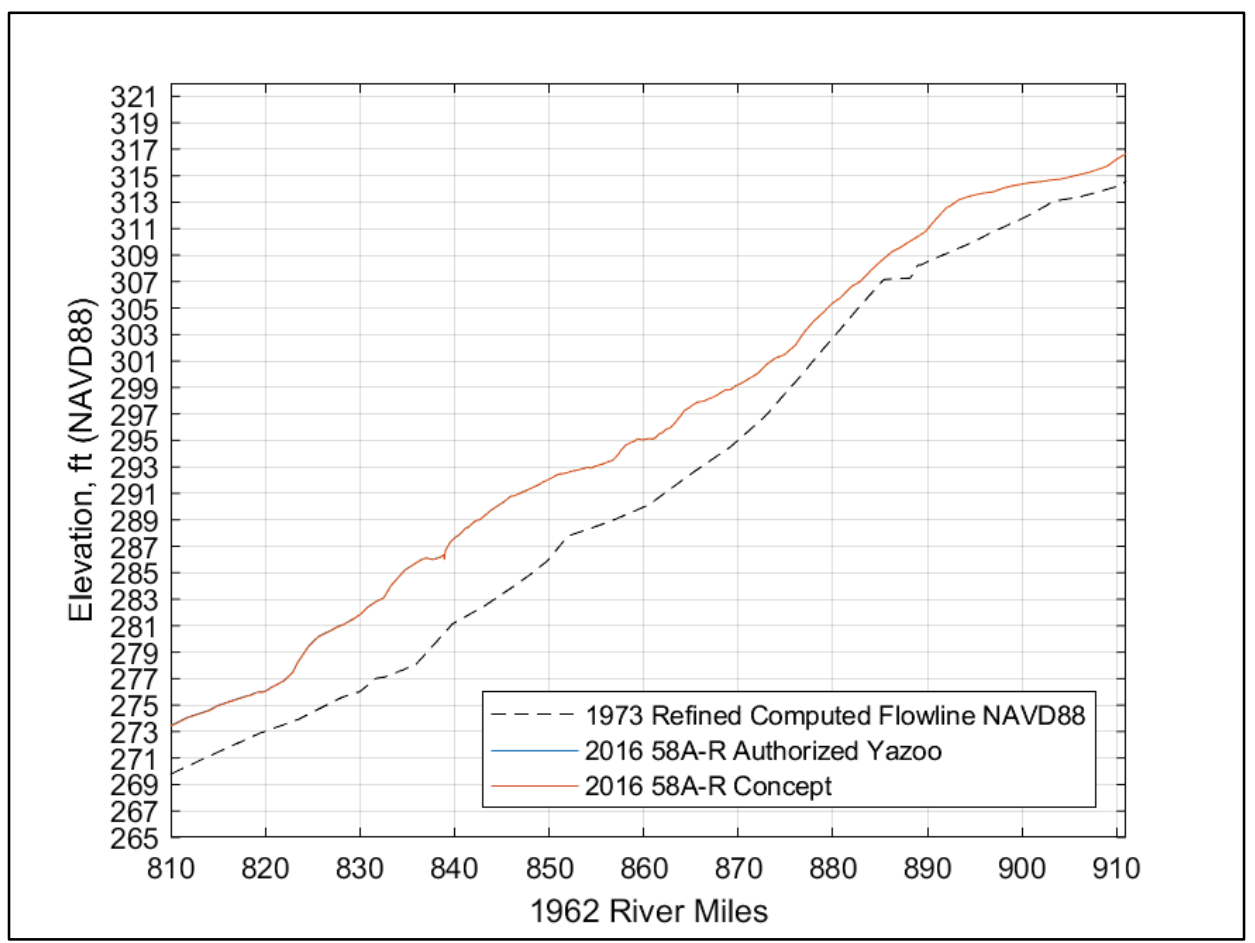

Figure 78. Concept Plan water surface profile for RMs 710 - 810 (Refined 1973 Computed Flowline is without loop, sediment, and freeboard effects).

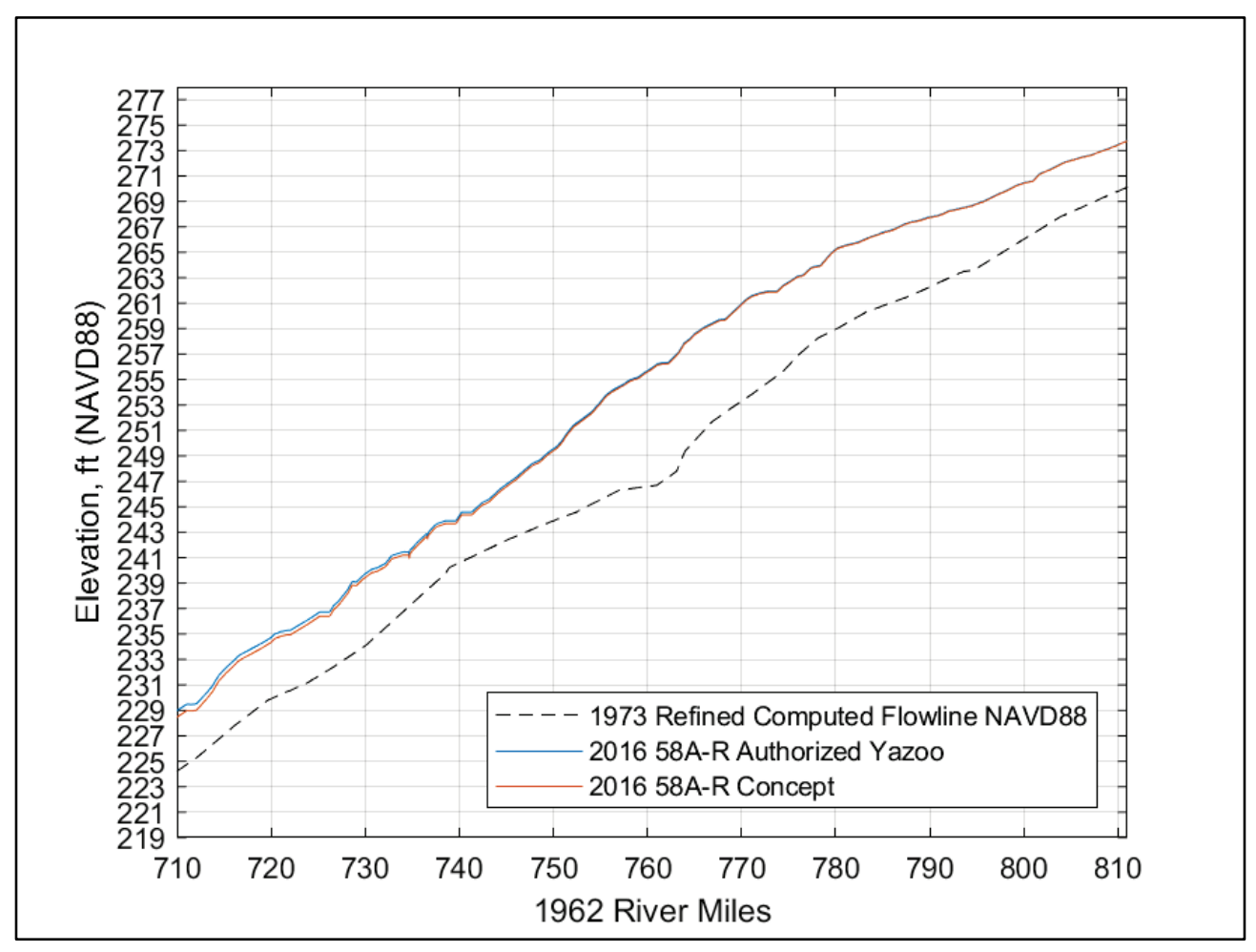


Figure 79. Concept Plan water surface profile for RMs 610 - 710 (Refined 1973 Computed Flowline is without loop, sediment, and freeboard effects).

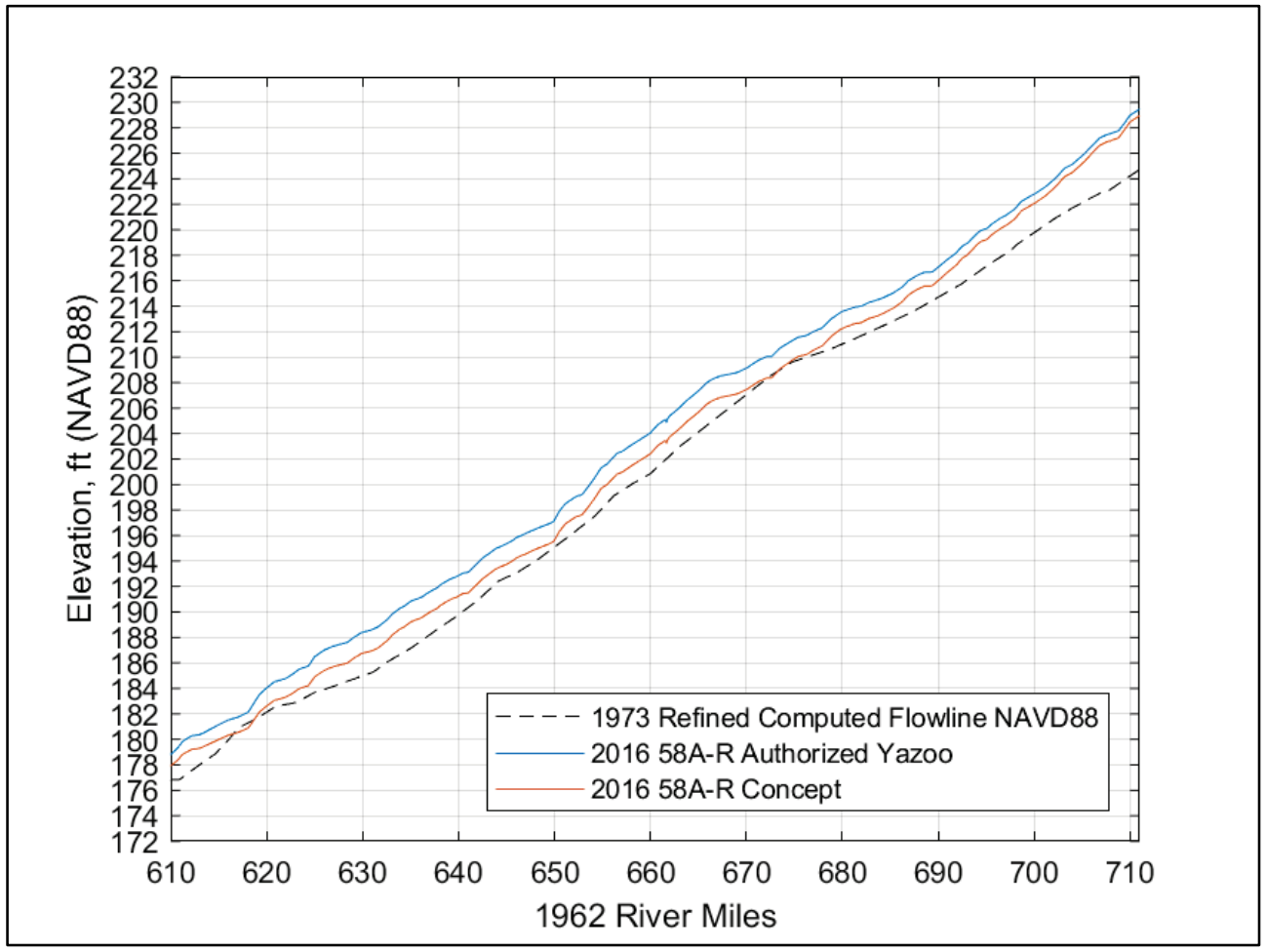

Figure 80. Concept Plan water surface profile for RMs 510 - 610 (Refined 1973 Computed Flowline is without loop, sediment, and freeboard effects).

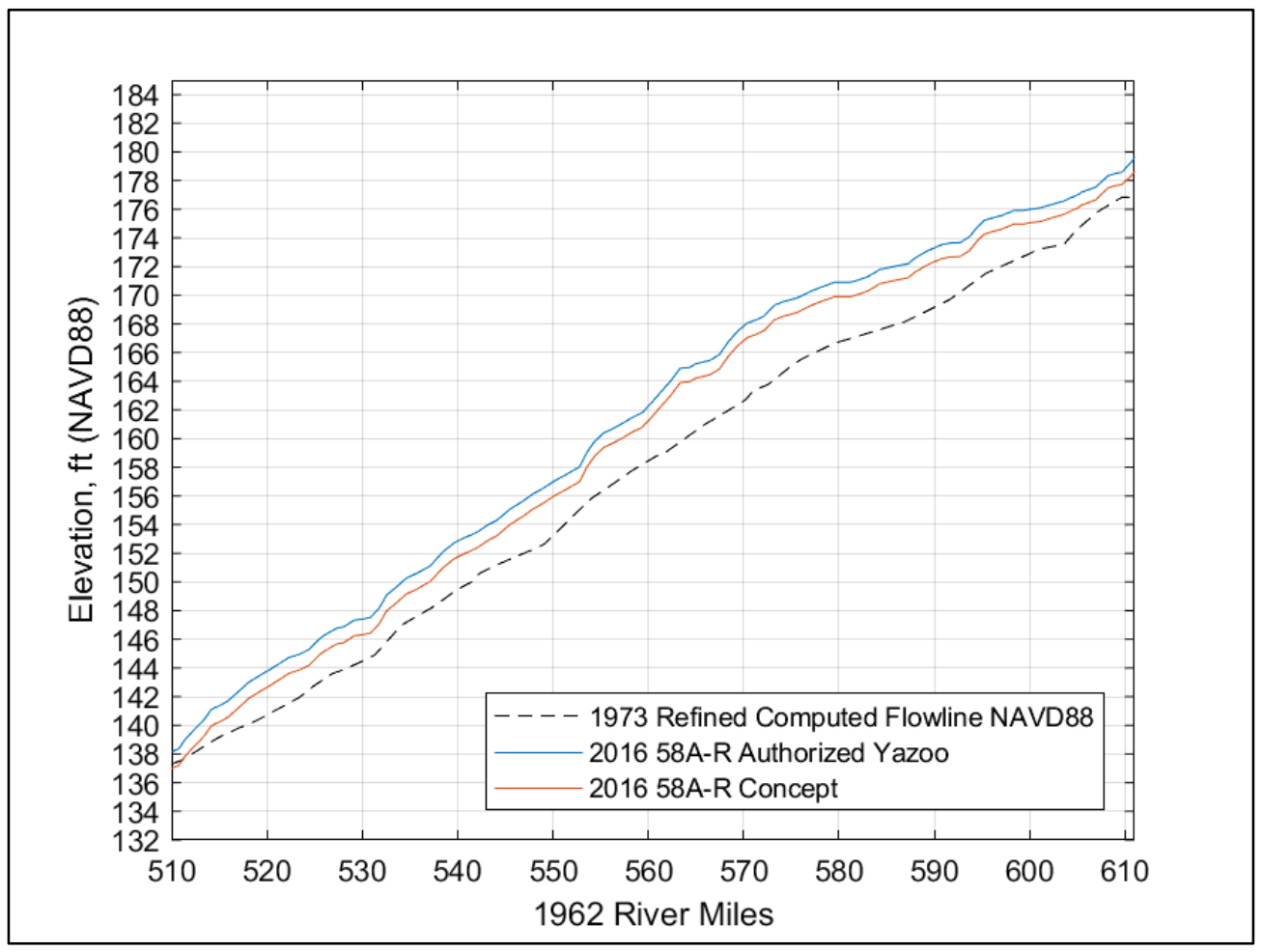


Figure 81. Concept Plan water surface profile for RMs 410 - 510.(Refined 1973 Computed Flowline is without loop, sediment, and freeboard effects).

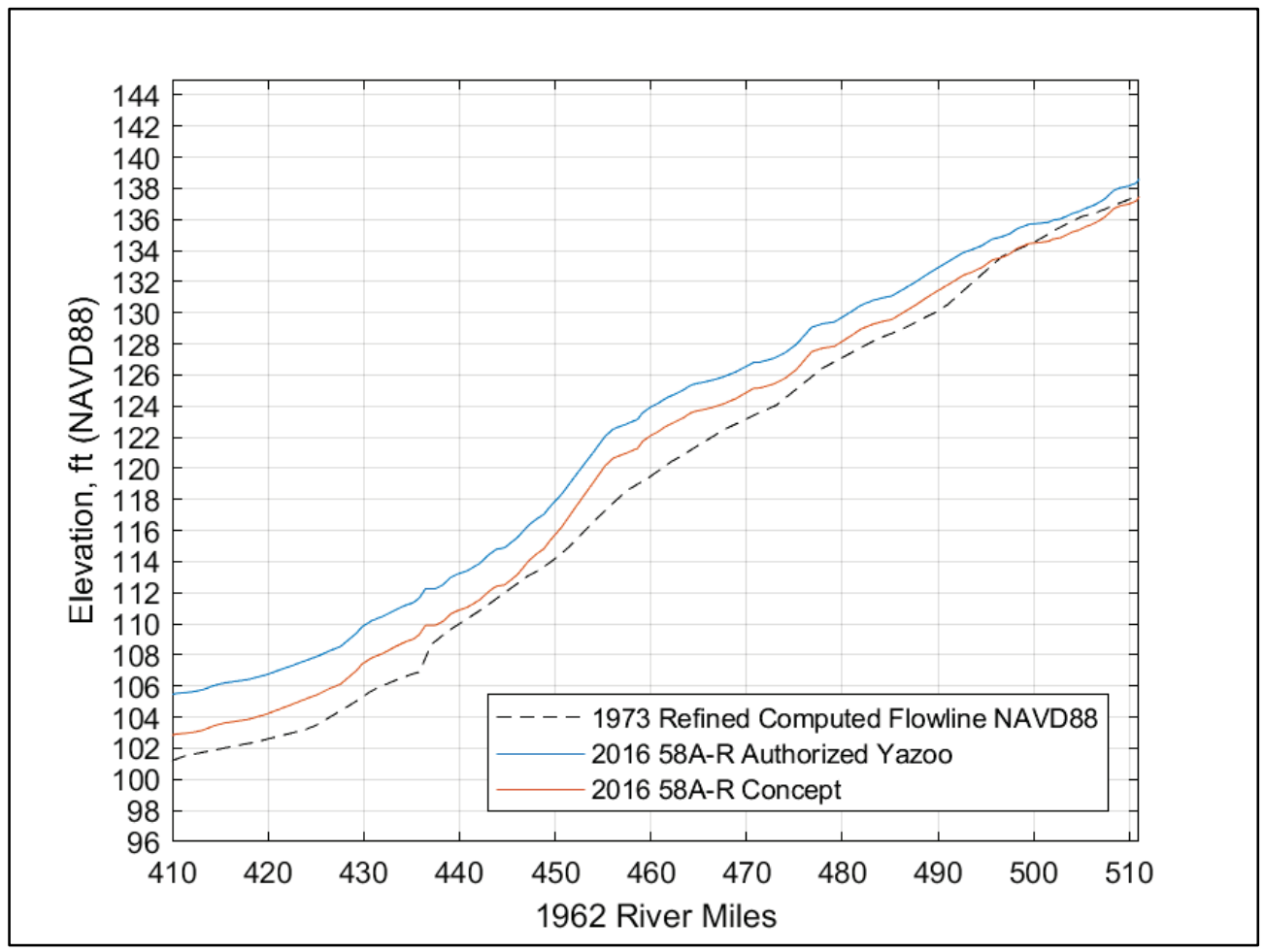

Figure 82. Concept Plan water surface profile for RMs 310 - 410 (Refined 1973 Computed Flowline is without loop, sediment, and freeboard effects).

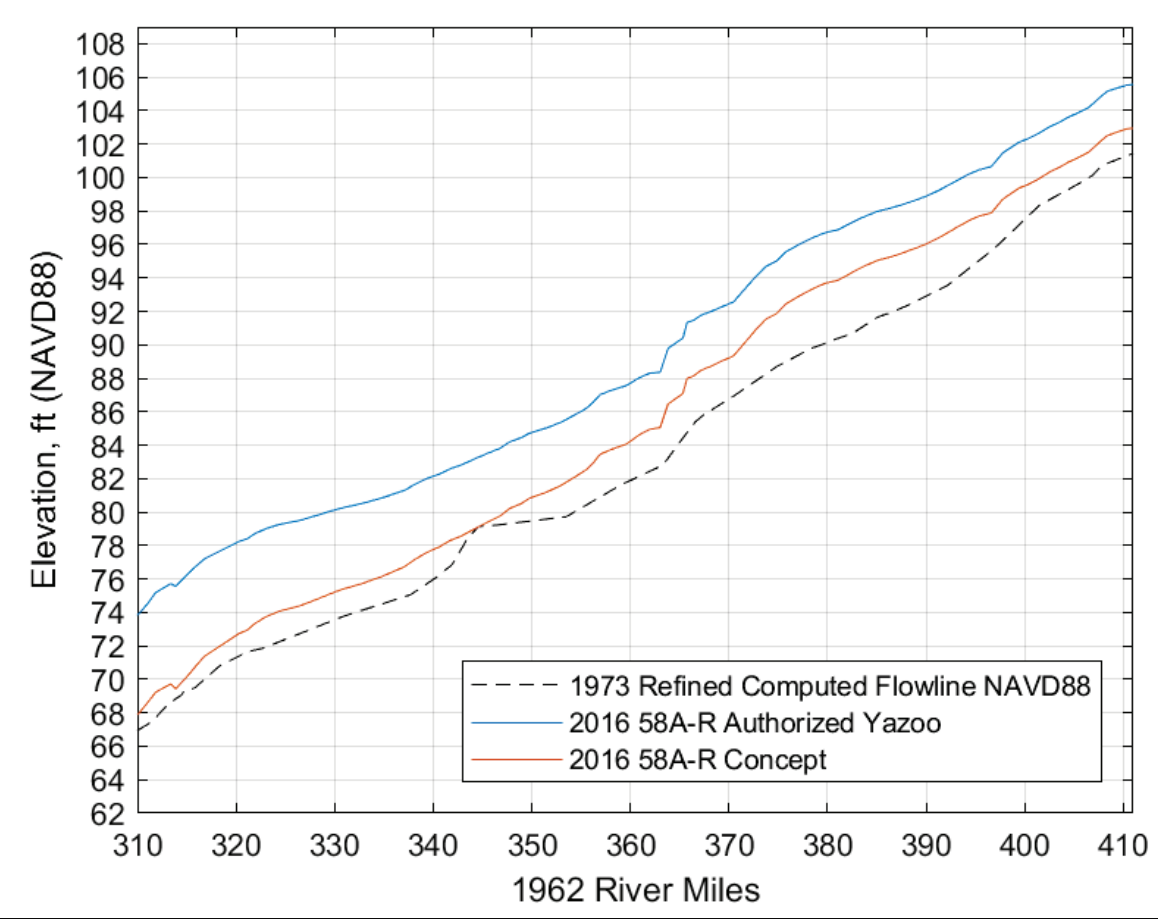


Figure 83. Concept Plan water surface profile for RMs 210 - 310 (Refined 1973 Computed Flowline is without loop, sediment, and freeboard effects).

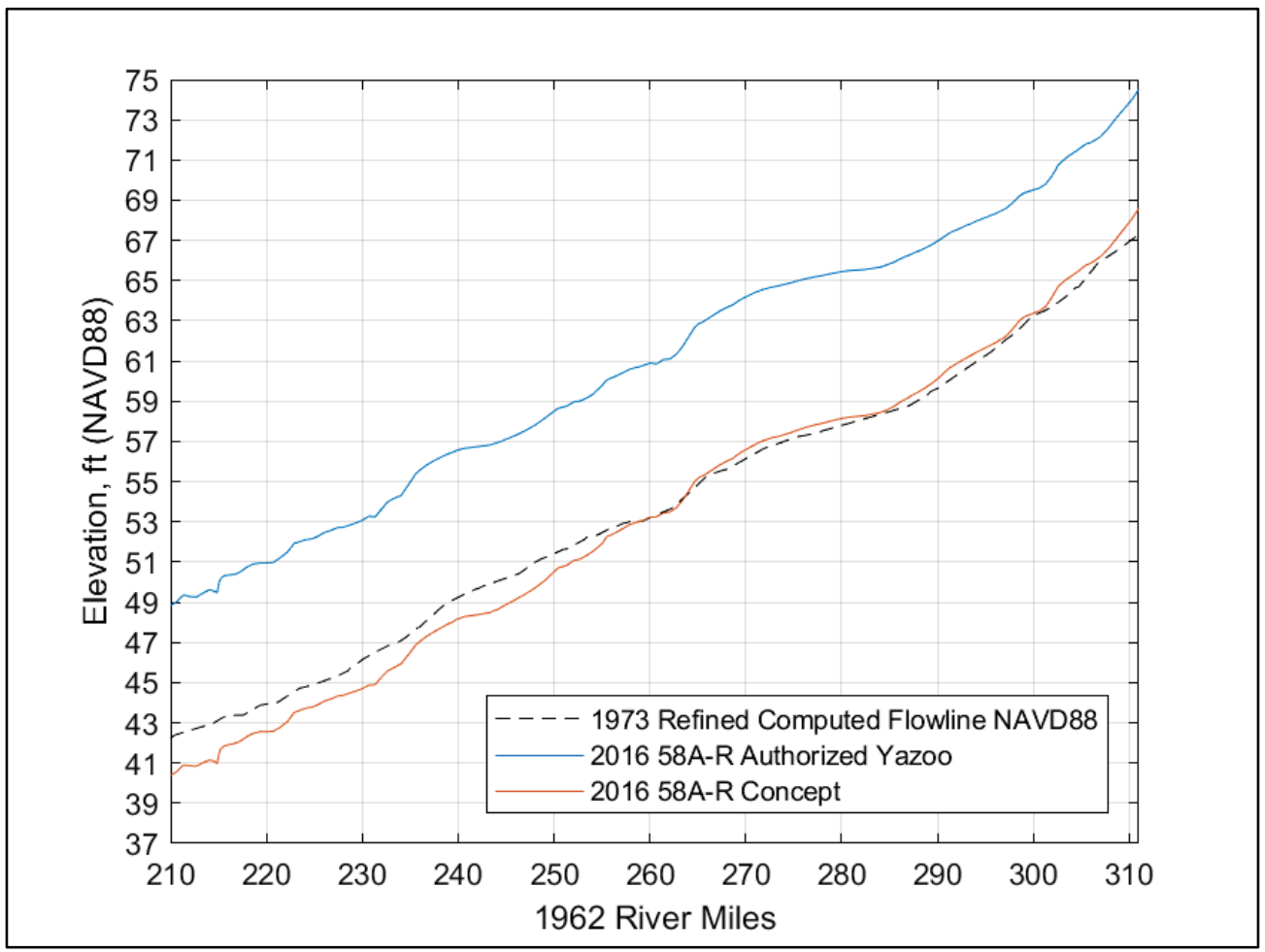

Figure 84. Concept Plan water surface profile for RMs 110 - 210 (Refined 1973 Computed Flowline is without loop, sediment, and freeboard effects).

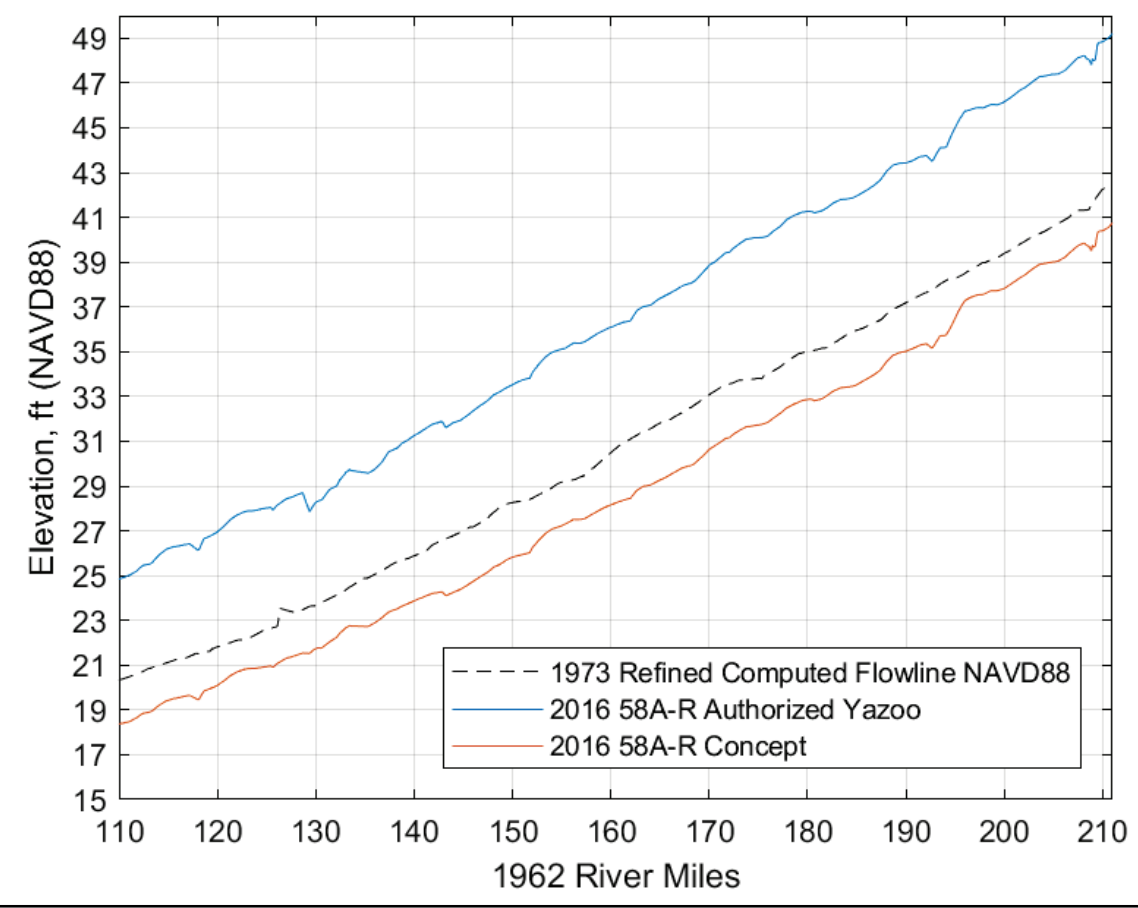


Figure 85. Concept Plan water surface profile for RMs 11 - 110 (Refined 1973 Computed Flowline is without loop, sediment, and freeboard effects).

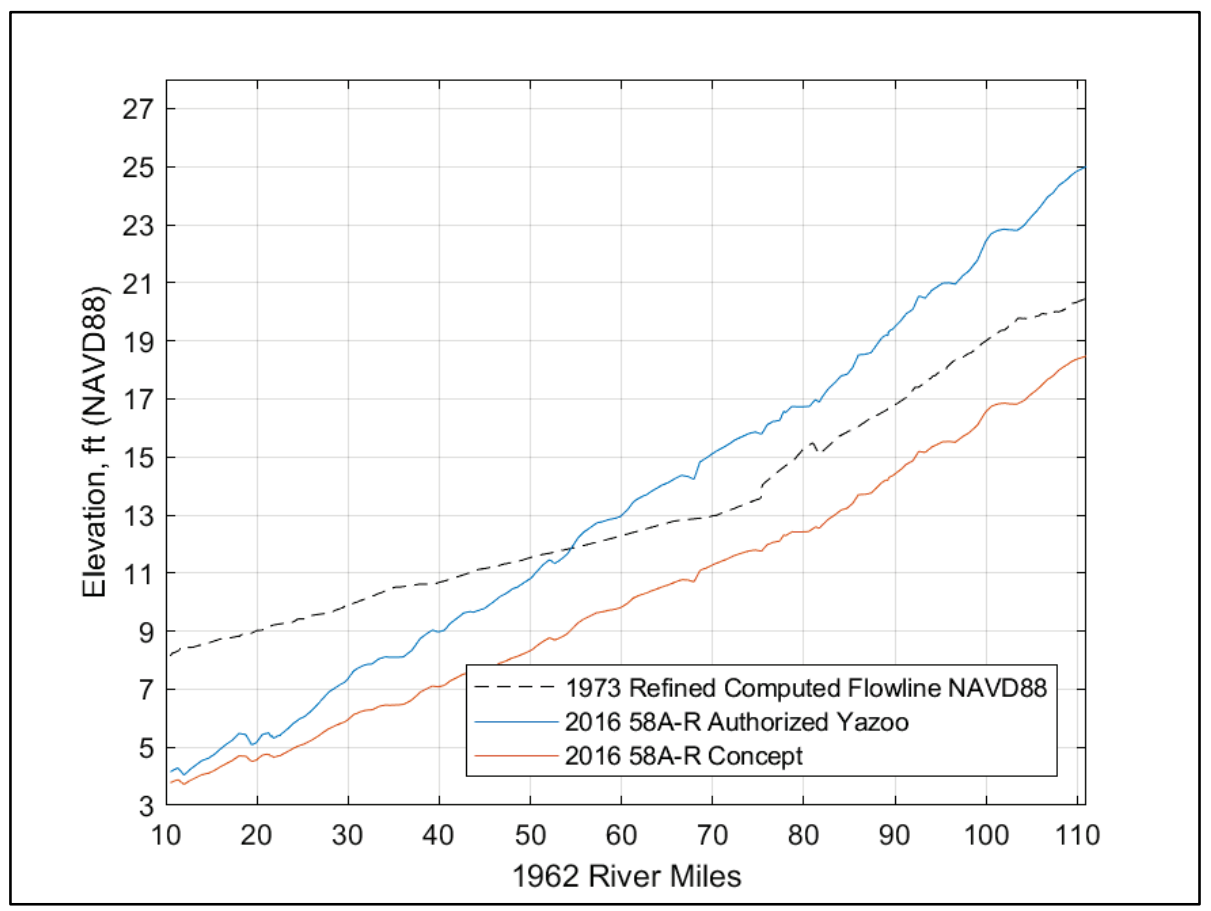

\subsection{Discussion}

The modeling effort shows that by assuming new elevations of the four backwater storage areas (St. Francis, White, Yazoo, and Red) and increasing the flows through the ORCC above the current authorized amount, increased flows from the $201658 \mathrm{~A}-\mathrm{R}$ could be reduced to the 1955 PDF levels but only for the areas below the ORCC. All flows on the Mississippi River above the ORCC still exceed the design amount from the 1955 PDF study. Since it was found that the flows below the ORCC can be reduced to the 1955 PDF flows, operational changes were not considered for the Morganza Control Structure and Bonnet Carré Spillway. As stated before, this scenario was run specifically to answer the question of whether it would be possible to remove the additional flows off of the Mississippi River by optimizing backwater levees/fuseplugs and operations of control structures. This technical investigation does not take into consideration increased inundation, potential consequences, costs, environmental impacts, or what, if any, authorization change would be required. Additional analysis, which will be a risk-informed strategic plan to respond to the additional flow, inadequacies within the system, and inform the operation and completion of the MR\&T system, is being considered as the next step in the MR\&T Flowline assessment. A variety of analyses related to the MR\&T main stem and backwater levees, reservoir management, and water control plans may be considered. 


\section{Future Sea Level Rise}

In the next 50 years (i.e., 2066), eustatic sea level rise is calculated to be $2.4 \mathrm{ft}$. higher, relative to present sea level, when determined using the "High" sea level rise scenario from ER 1100-2-8162 (par. B-4) (USACE 2013). Since ER-1100-2-8162 requires that sea level rise be examined for projects that may be impacted by it, the study team computed several flowlines considering a "Future Conditions" scenario, which considered the impacts of sea level rise. To compute the flowline for future conditions, the HEC-RAS model's downstream boundary was adjusted to simulate the potential sea level rise expected in the next 50 years. In studies where the datum is not adjusted for subsidence or uplift, the sea level changes that are relevant for examination are subsidence and eustatic sea level rise. Subsidence is local relative land movement, and eustatic sea level rise is attributable to increased ocean water volume. Although there is a significant amount of subsidence occurring in the lower reach of the Mississippi River, most notably below Belle Chasse at RM 80.2, the Future Conditions calculations were not adjusted for subsidence.

This assumption is applicable since the flowline was computed relative to the terrestrial datum NAVD88, which does not subside. Note that this assumption will only hold if the flowline is continually corrected for subsidence through readjustment to the latest NAVD88 epochs as they are issued; it is assumed here that it will be. In dealing with subsidence in this manner, the area of emphasis for the study was the future eustatic sea level rise.

Since the downstream boundary of the Mississippi River HEC-RAS model is at Venice, LA (10.5 miles upstream from the Gulf of Mexico), the boundary will not experience the full sea level rise that will be observed in the ocean until sometime well after the period of analysis, especially considering the high river flow conditions relevant to this assessment. The dampening effect of sea level rise with distance upriver is demonstrated in Driessen and Van Ledden (2013). An adjustment to the existing Venice rating curve was needed to incorporate the effect of sea level rise. These adjustments are further discussed in Appendix C. Similarly, new ratings (outlet flow vs. river flow) were also needed at several lateral outlets (e.g., Fort St. Phillip and Bohemia Diversions) into the Gulf of Mexico to represent the behavior of these outlets under future conditions. 
An existing AdH model (Sharp et al. 2013) that was developed by the Coastal and Hydraulics Lab at ERDC to study the West Bay sediment diversion effects was used to model a range of flows in the downstream area of the RAS model domain in two dimensions, allowing the elevated sea level corresponding to future conditions to be applied at the boundaries of the model domain. A range of river flows were simulated to determine rating curves from stages and flows at various outlets of the HEC-RAS model, which were then applied to the future conditions RAS model. Note that this approach does not incorporate any subsidence in the channel inverts of the outlets, in addition to any change to river channel or overbank geometry at all. This approach is consistent with the approach used throughout the flowline effort. In reality, the topography and bathymetry of the outlets are likely to change in the future but in such an unpredictable way that it would be extremely difficult to estimate for a future conditions simulation. Therefore, the existing conditions geometry was preserved. This allowance for future condition sea level does not include the effects of tides, tropical storms, or wave effects. Figure 86 shows the adjustment to the rating curve in the HEC-RAS boundary condition at Venice.

Figure 86 . Sea level rise adjustment to the Venice rating curve.

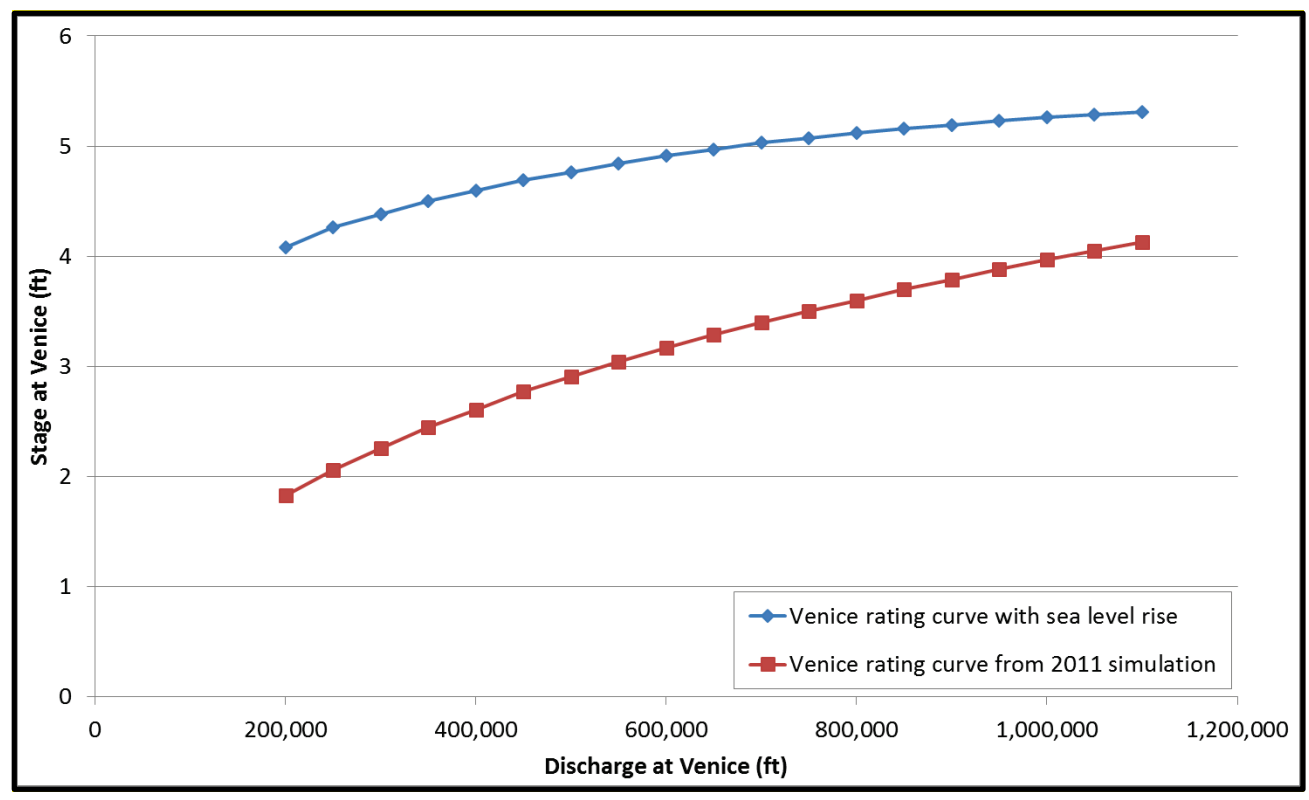

The sea level rise adjustments were implemented in the HEC-RAS model, and the three primary simulations were recomputed: "New Hypo 58A-R PDF - Authorized Yazoo," "New Hypo 58A-R PDF - Existing Yazoo," and the "New Hypo PDF 58A-R Concept." Peak flow comparisons at key 
locations are listed in Table 23, and peak water surface elevations are listed in Table 24. Table 23 demonstrates that, for Future Conditions, the flow at Venice is lower than Current Conditions for the New Hypo $58 \mathrm{~A}-\mathrm{R}$ simulations by 78,000 cfs for the Concept Plan, 62,000 cfs for Existing Yazoo, and 64,000 cfs for Authorized Yazoo. At Empire, the difference is only 3,000 cfs while there is no difference in Current vs. Future flow from Carrollton to any point upstream. The differences in flow for outlets vs. river for Future Conditions are caused by the more efficient conveyance in the outlets vs. the river between the diversion point and the Gulf, when considering Future vs. Current. Whereas the flow differences in Future vs. Current conditions are relatively minimal, the stage differences between the two scenarios are more significant. Table 24 demonstrates that for Future Conditions, the stage at Venice is $1.2 \mathrm{ft}$ higher than for Current Conditions for the New Hypo $58 \mathrm{~A}-\mathrm{R}$ simulations while at Carrollton this difference is $0.4 \mathrm{ft}$. The difference in Future vs. Current is noted as far upstream as Baton Rouge, where there is a $0.1 \mathrm{ft}$ difference. Figure 87 through Figure 90 depict the impact of future sea level rise on the water surface elevations in the lower 410 river miles. 
Table 23. Maximum flow comparisons of the future sea level rise simulations (cubic feet per second).

\begin{tabular}{|c|c|c|c|c|c|c|c|c|}
\hline Location & $\begin{array}{l}\text { RAS } \\
\text { Station }\end{array}$ & $\begin{array}{l}\text { Published } \\
1955 \\
\text { Hydrology }\end{array}$ & $\begin{array}{l}\text { New Hypo PDF } \\
\text { 58A-R Concept }\end{array}$ & $\begin{array}{l}\text { New Hypo } \\
\text { PDF 58A-R } \\
\text { Concept } \\
\text { Future }\end{array}$ & $\begin{array}{c}\text { New Hypo PDF } \\
\text { 58A-R Existing } \\
\text { Yazoo }\end{array}$ & $\begin{array}{c}\text { New Hypo } \\
\text { PDF 58A-R } \\
\text { Existing } \\
\text { Yazoo, Future }\end{array}$ & $\begin{array}{c}\text { New Hypo PDF } \\
58 A-R \\
\text { Authorized } \\
\text { Yazoo }\end{array}$ & $\begin{array}{c}\text { New Hypo PDF } \\
58 A-R \\
\text { Authorized } \\
\text { Yazoo, Future }\end{array}$ \\
\hline Mississippi at Chester & 110.4 & 240,000 & 508,000 & 508,000 & 508,000 & 508,000 & 508,000 & 508,000 \\
\hline Ohio River at Cairo & -979.68 & $2,250,000$ & $2,326,000$ & $2,326,000$ & $2,326,000$ & $2,326,000$ & $2,326,000$ & $2,326,000$ \\
\hline Mississippi at Ohio River & 973.85 & $2,360,000$ & $2,791,000$ & $2,791,000$ & $2,791,000$ & $2,791,000$ & $2,791,000$ & $2,791,000$ \\
\hline Mississippi at Hickman & 942.45 & $1,810,000$ & $1,973,000$ & $1,973,000$ & $1,973,000$ & $1,973,000$ & $1,973,000$ & $1,973,000$ \\
\hline Mississippi at Memphis & 749.01 & $2,410,000$ & $2,864,000$ & $2,864,000$ & $2,862,000$ & $2,862,000$ & $2,862,000$ & $2,863,000$ \\
\hline Mississippi at Helena & 676.42 & $2,460,000$ & $2,660,000$ & $2,660,000$ & $2,787,000$ & $2,787,000$ & $2,787,000$ & $2,788,000$ \\
\hline Mississippi at Arkansas City & 562.18 & $2,890,000$ & $3,180,000$ & $3,180,000$ & $3,263,000$ & $3,263,000$ & $3,263,000$ & $3,263,000$ \\
\hline Arkansas River at Dam 02 & 28.07 & 400,000 & 487,000 & 487,000 & 487,000 & 487,000 & 487,000 & 487,000 \\
\hline St. Francis River at 82.47 & 82.47 & 80,000 & 85,000 & 85,000 & 85,000 & 85,000 & 85,000 & 85,000 \\
\hline White River at Clarendon & 100.05 & 220,000 & 235,000 & 235,000 & 233,000 & 233,000 & 233,000 & 233,000 \\
\hline Mississippi at Greenville & 539.13 & & $3,172,000$ & $3,172,000$ & $3,259,000$ & $3,259,000$ & $3,260,000$ & $3,260,000$ \\
\hline $\begin{array}{l}\text { Mississippi at Lake } \\
\text { Providence }\end{array}$ & 494.47 & & $3,168,000$ & $3,168,000$ & $3,253,000$ & $3,253,000$ & $3,257,000$ & $3,257,000$ \\
\hline Mississippi at Vicksburg & 442.16 & $2,710,000$ & $2,898,000$ & $2,898,000$ & $3,076,000$ & $3,076,000$ & $3,087,000$ & $3,087,000$ \\
\hline Mississippi at Natchez & 368.44 & $2,720,000$ & $2,919,000$ & $2,919,000$ & $3,072,000$ & $3,072,000$ & $3,099,000$ & $3,099,000$ \\
\hline Mississippi at RRL & 306.43 & $2,100,000$ & $2,106,000$ & $2,106,000$ & $2,449,000$ & $2,449,000$ & $2,475,000$ & $2,475,000$ \\
\hline Mississippi at Baton Rouge & 233.1 & $1,500,00$ & $1,505,000$ & $1,505,000$ & $1,838,000$ & $1,838,000$ & $1,869,000$ & $1,869,000$ \\
\hline Mississippi at Donaldsonville & 179.04 & $1,500,00$ & $1,505,000$ & $1,505,000$ & $1,837,000$ & $1,837,000$ & $1,868,000$ & $1,868,000$ \\
\hline Mississippi at Carrollton & 107.2 & $1,250,000$ & $1,251,000$ & $1,252,000$ & $1,581,000$ & $1,582,000$ & $1,613,000$ & $1,613,000$ \\
\hline Mississippi at Empire & 33.79 & $1,250,000$ & $1,219,000$ & $1,203,000$ & $1,513,000$ & $1,510,000$ & $1,543,000$ & $1,539,000$ \\
\hline Mississippi at Venice & 15.07 & $1,250,000$ & 895,000 & 814,000 & $1,094,000$ & $1,031,000$ & $1,115,000$ & $1,051,000$ \\
\hline
\end{tabular}


Table 24. Maximum stage comparisons of the future sea level rise simulations (feet) (*From the Refined 1973 Flowline Study [USACE 1978], this column is without loop effect, sedimentation, or freeboard effects).

\begin{tabular}{|c|c|c|c|c|c|c|c|c|}
\hline Location & $\begin{array}{c}\text { RAS } \\
\text { Station }\end{array}$ & $\begin{array}{l}\text { Refined } 1973 \\
\text { Flowline } \\
\text { (58A-EN)* }\end{array}$ & $\begin{array}{l}\text { New Hypo PDF } \\
58 A-R \text { Concept }\end{array}$ & $\begin{array}{l}\text { New Hypo } \\
\text { PDF 58A-R } \\
\text { Concept } \\
\text { Future }\end{array}$ & $\begin{array}{c}\text { New Hypo PDF } \\
\text { 58A-R Existing } \\
\text { Yazoo }\end{array}$ & $\begin{array}{l}\text { New Hypo } \\
\text { PDF 58A-R } \\
\text { Existing } \\
\text { Yazoo, Future }\end{array}$ & $\begin{array}{c}\text { New Hypo PDF } \\
58 A-R \\
\text { Authorized } \\
\text { Yazoo }\end{array}$ & $\begin{array}{l}\text { New Hypo PDF } \\
\text { 58A-R } \\
\text { Authorized } \\
\text { Yazoo, Future }\end{array}$ \\
\hline Mississippi at Chester & 110.4 & & 372.5 & 372.5 & 372.5 & 372.5 & 372.5 & 372.5 \\
\hline Ohio River at Cairo & -979.68 & & 334.8 & 334.8 & 334.8 & 334.8 & 334.8 & 334.8 \\
\hline Mississippi at Ohio River & 973.85 & 331.7 & 334.3 & 334.3 & 334.3 & 334.3 & 334.3 & 334.3 \\
\hline Mississippi at Hickman & 942.45 & 320.7 & 321.4 & 321.4 & 321.4 & 321.4 & 321.4 & 321.4 \\
\hline Mississippi at Memphis & 749.01 & 237.2 & 241.2 & 241.2 & 241.4 & 241.4 & 241.4 & 241.5 \\
\hline Mississippi at Helena & 676.42 & 202.9 & 204.4 & 204.4 & 206.0 & 206.0 & 206.0 & 206.0 \\
\hline Mississippi at Arkansas City & 562.18 & 155.5 & 158 & 158.0 & 158.9 & 158.9 & 159 & 159.0 \\
\hline Arkansas River at Dam 02 & 28.07 & & 176.4 & 176.4 & 177.1 & 177.1 & 177.2 & 177.2 \\
\hline St. Francis River at 82.47 & 82.47 & & 217.1 & 217.1 & 217.1 & 217.1 & 217.1 & 217.1 \\
\hline White River at Clarendon & 100.05 & & 181.5 & 181.5 & 181.9 & 181.9 & 181.9 & 181.9 \\
\hline Mississippi at Greenville & 539.13 & 145.2 & 146.5 & 147.1 & 148 & 148.0 & 148.2 & 148.2 \\
\hline $\begin{array}{l}\text { Mississippi at Lake } \\
\text { Providence }\end{array}$ & 494.47 & 129.4 & 130.5 & 130.5 & 131.7 & 131.7 & 132 & 132.0 \\
\hline Mississippi at Vicksburg & 442.16 & 106.9 & 109.3 & 109.3 & 111.3 & 111.3 & 111.7 & 111.7 \\
\hline Mississippi at Natchez & 368.44 & 82.7 & 85.1 & 85.1 & 88 & 88.0 & 88.4 & 88.4 \\
\hline Mississippi at RRL & 306.43 & 63.5 & 63.7 & 63.8 & 69.3 & 69.3 & 69.8 & 69.8 \\
\hline Mississippi at Baton Rouge & 233.1 & 45.7 & 44.5 & 44.6 & 52.1 & 52.2 & 52.8 & 52.9 \\
\hline Mississippi at Donaldsonville & 179.04 & 33.8 & 31.8 & 32.1 & 39.4 & 39.6 & 40.1 & 40.3 \\
\hline Mississippi at Carrollton & 107.2 & 19.6 & 16.8 & 17.4 & 22.3 & 22.7 & 22.8 & 23.2 \\
\hline Mississippi at Empire & 33.79 & 9.8 & 5.8 & 6.9 & 7 & 7.8 & 7.2 & 7.9 \\
\hline Mississippi at Venice & 15.07 & 8.1 & 3.8 & 5.1 & 4.1 & 5.3 & 4.2 & 5.3 \\
\hline
\end{tabular}


Figure 87. Future sea level rise water surface profiles for RMs 310 - 410.

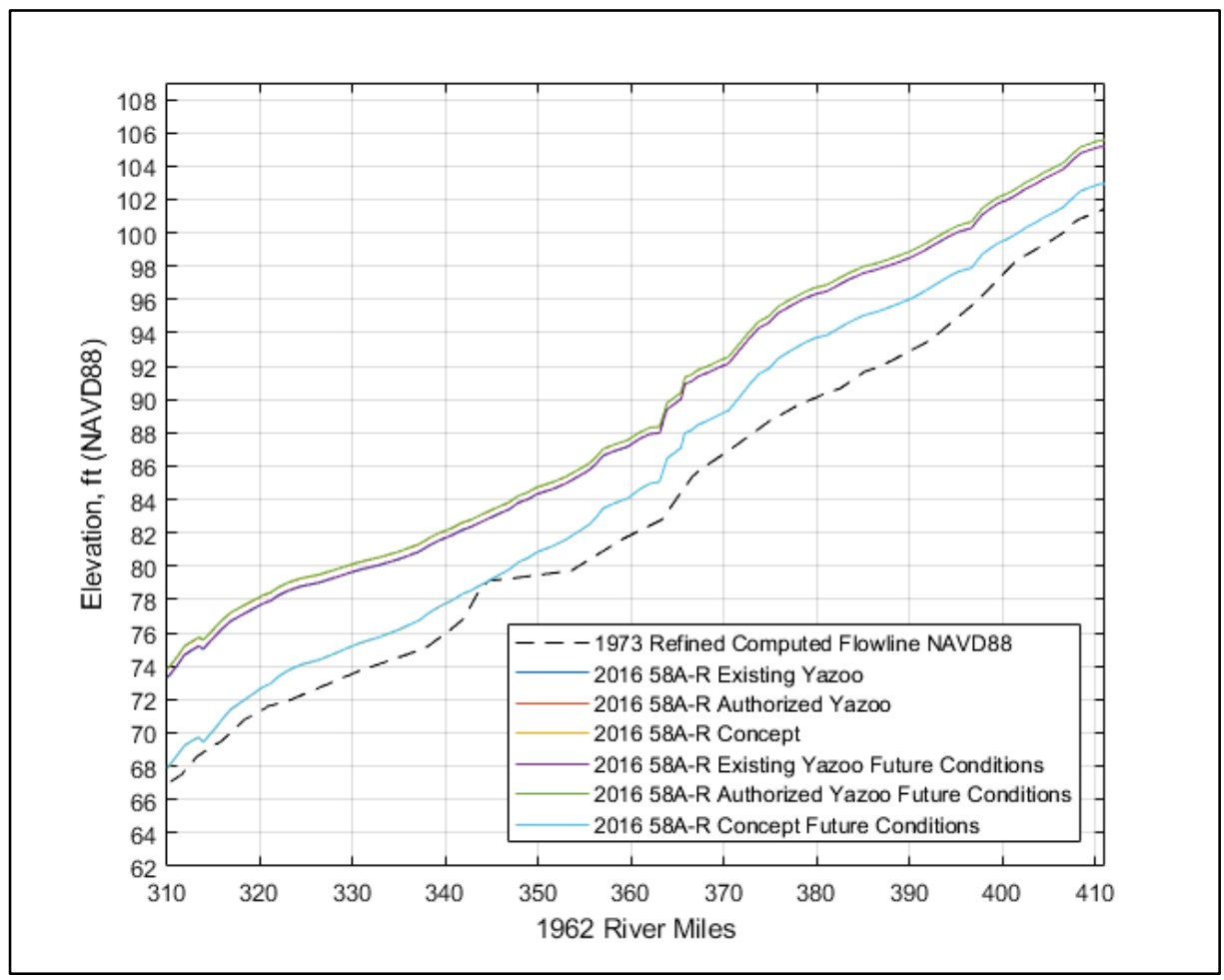

Figure 88. Future sea level rise water surface profiles for RMs 210 - 310.

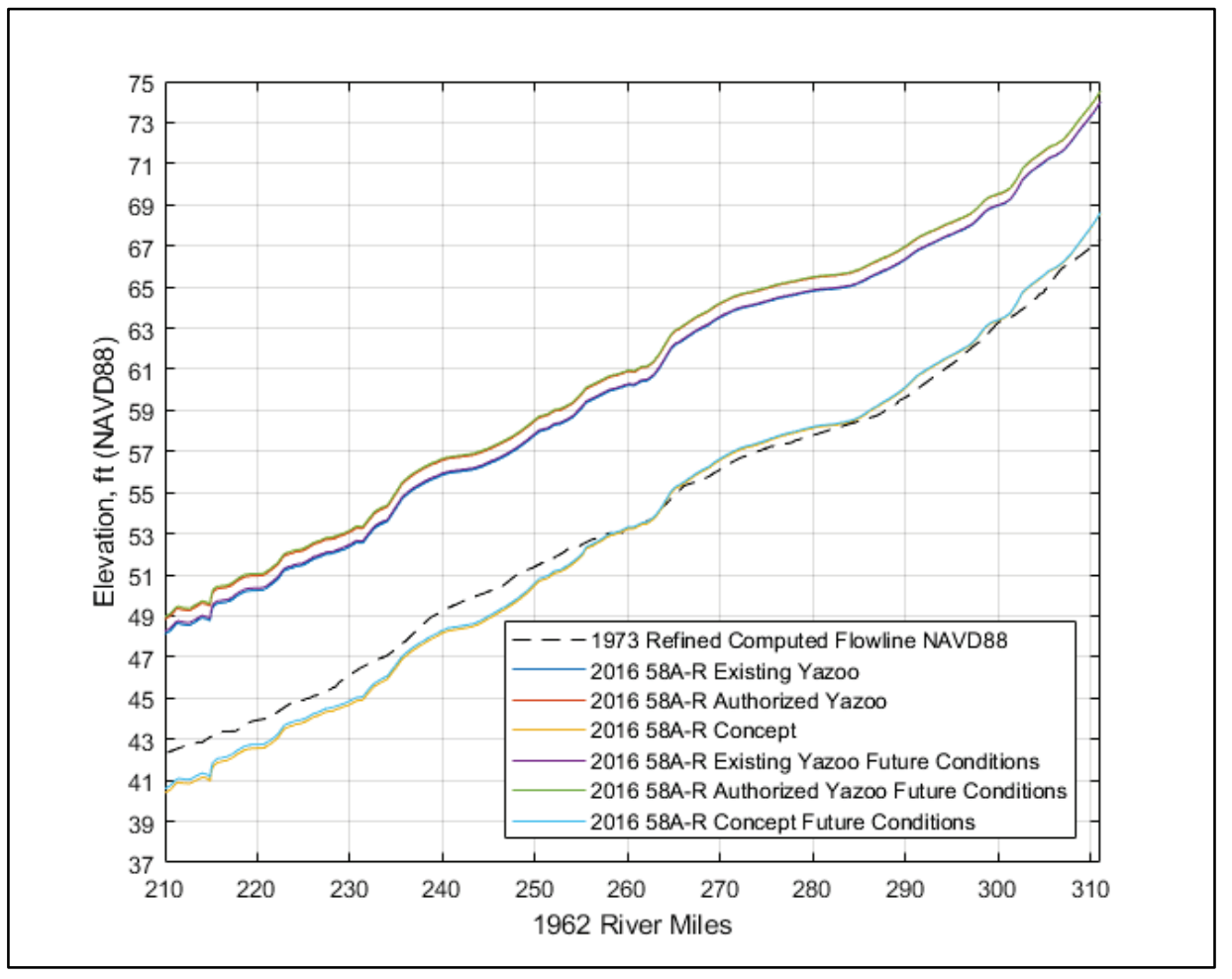


Figure 89. Future sea level rise water surface profiles for RMs 110- 210.

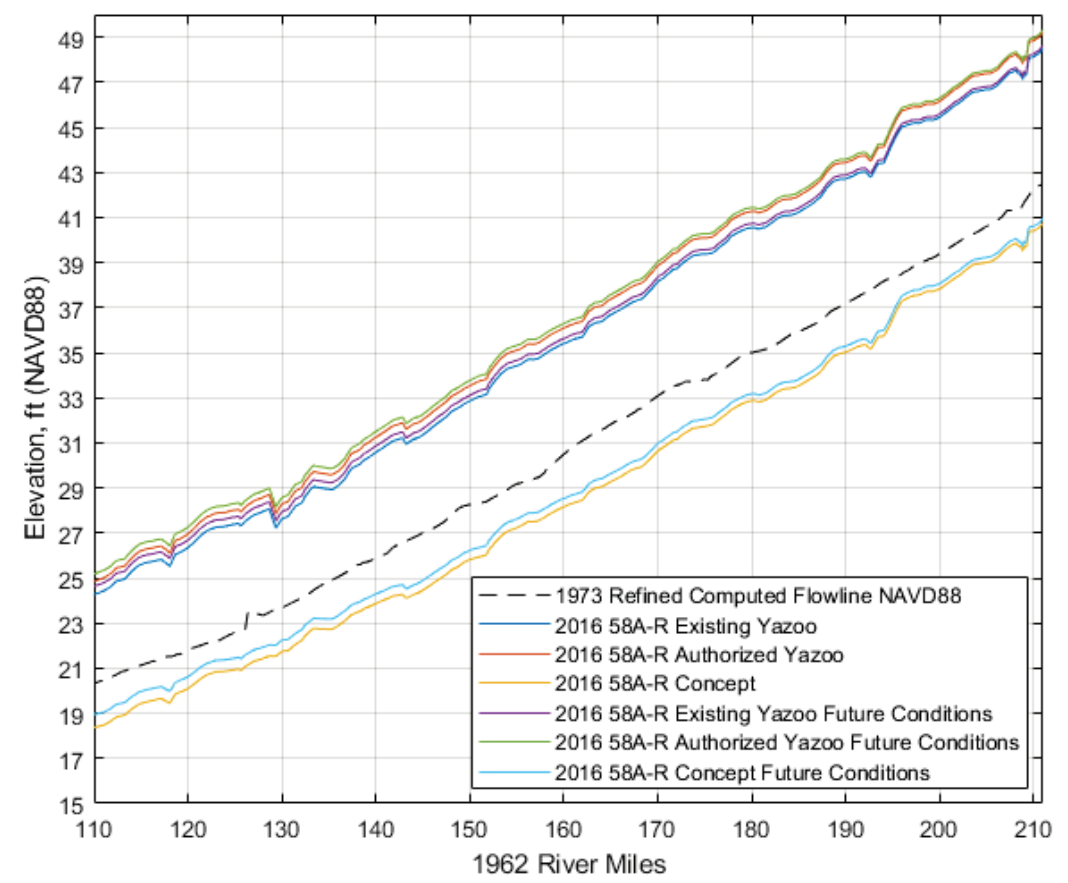

Figure 90. Future sea level rise water surface profiles for RMs 11 - 110.

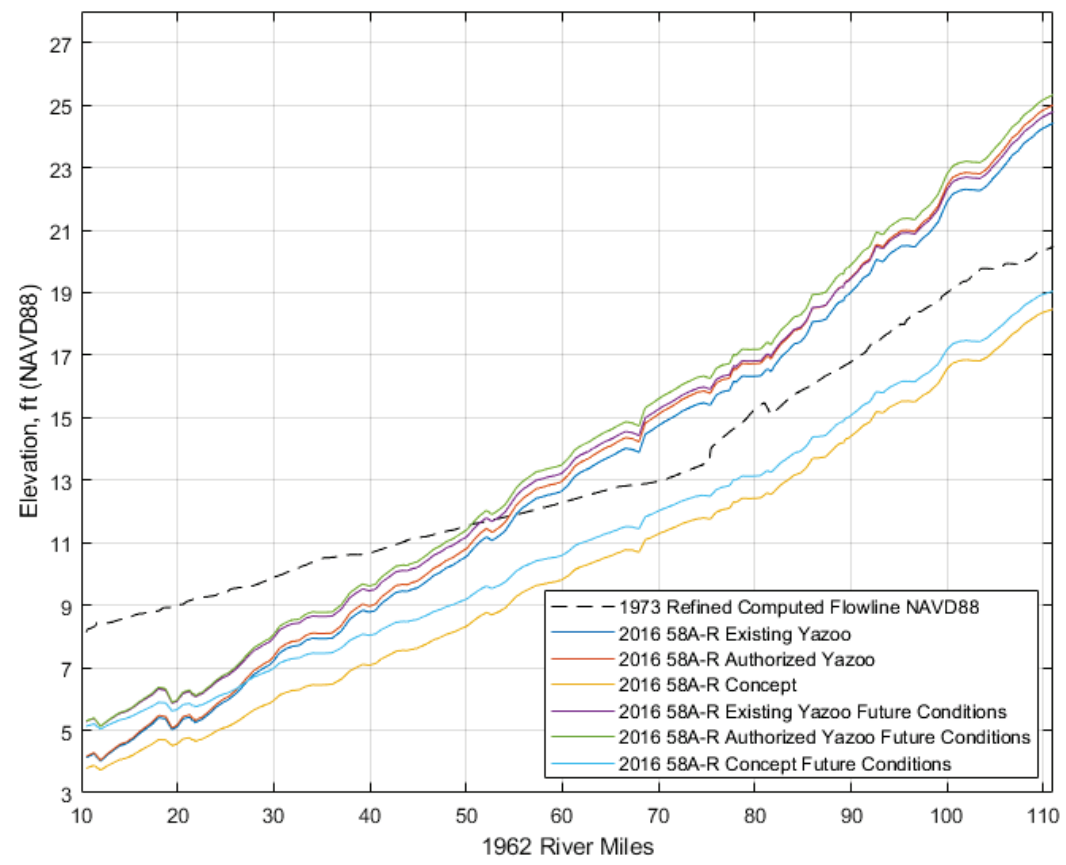




\section{Atchafalaya River}

The MVN employed the HEC-RAS (version 5.0.3; U.S. Army Corps of Engineers, downloaded September 2016) hydraulic modeling software for the Atchafalaya River from Simmesport, LA, to the Gulf of Mexico. Figure 91 displays the Atchafalaya River federal levee system from Simmesport to the Gulf of Mexico.

Figure 91. Map of federal levees of the Atchafalaya basin.

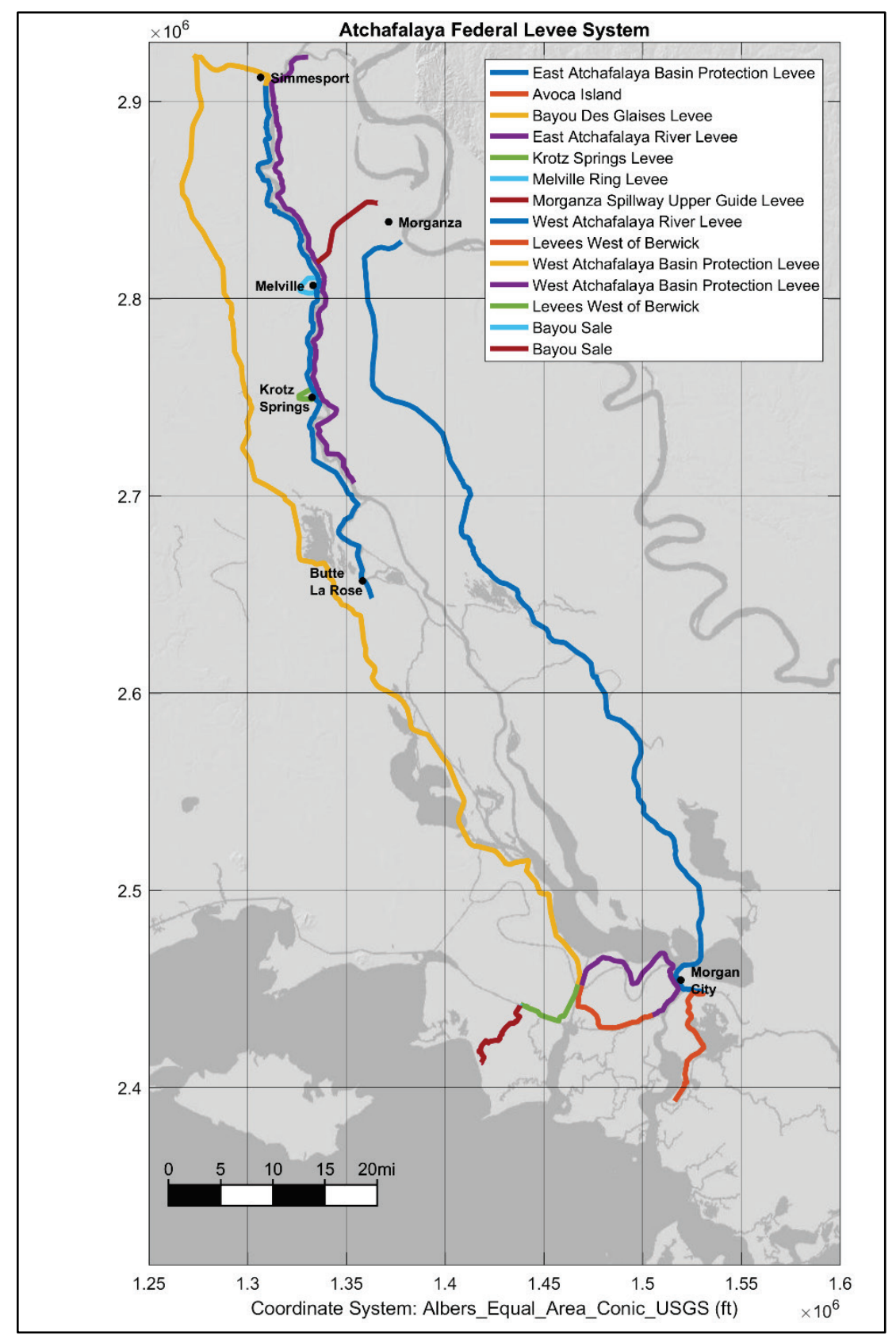




\subsection{HEC-RAS geometry}

The model domain includes the entire Atchafalaya floodway. A schematic of the hydraulic model domain is shown in Figure 92. The 2D mesh contains 41,632 cells. The 1D portion contains 286 cross sections, 512 lateral structures, 7 junctions/splits. The 1D cross sections are drawn bank-to-bank to effectively capture conveyance within the channel. Lateral structures drawn along the natural or artificial levees to link the 1D rivers to the $2 \mathrm{D}$ areas. The overbank areas are modeled as 2D flow areas. The vertical datum being used for the model is the NAVD88. The lateral extent of the model was limited by the basin levees. This does not allow flow out of the system should levees overtop. The system was not overtopped in any of the hindcast simulations. The model is specifically set up to not allow overtopping of the levee system to properly calculate design water surface elevations.

Figure 93 displays the various sources of bathymetric/topographic data used in the Atchafalaya RAS model. The primary source of topographic information for the model comes from the 2013 USGS lidar (NOAA 2013). The primary source of bathymetric data for the Atchafalaya River is the 2010 multibeam sonar dataset. A mix of other terrain sources covers the remaining model domain. In areas where no bathymetric surveys were available, the high-resolutions ADCIRC SL17 mesh was used. Some channel surveys for the wax lake outlet were also applied to the model. Table 25 contains information on the various terrain data sources applied in the model. The terrain was constructed to allow the bathymetric surveys to overwrite the water surface that was captured in the lidar. RasMapper was used to mosaic the various terrain sources into one terrain. Figure 94 displays a zoomed-in view of the model geometry showing the various 1D and 2D features, as well as the resulting RAS terrain.

Two different terrains were created for the project. One terrain was developed mainly to map elevations to the lateral structures. Another terrain was developed purely for the 2D modeling. The terrain developed for 2D modeling includes bathymetry at all major channels. 
Table 25. Terrain data sources.

\begin{tabular}{|l|l|c|}
\hline Terrain Data & Source & $\begin{array}{c}\text { Spatial } \\
\text { Resolution }\end{array}$ \\
\hline $\begin{array}{l}\text { Atchafalaya River Multibeam SONAR } \\
2010\end{array}$ & MVN & $2 \mathrm{ft}$ \\
\hline Atchafalaya River Levee lidar 2007 & MVN & $1 \mathrm{ft}$ \\
\hline ADCIRC SL17 Bathymetry & $\begin{array}{l}\text { University of Notre Dame Computational } \\
\text { Hydraulics Laboratory }\end{array}$ & $20 \mathrm{ft}$ \\
\hline Atchafalaya lidar 2013 & $\begin{array}{l}\text { Northrop Grumman, Advanced GEOINT } \\
\text { Solutions Operating Unit }\end{array}$ & $1 \mathrm{~m}$ \\
\hline Louisiana lidar (FEMA) 1999 & FEMA* and MVN & $5 \mathrm{~m}$ \\
\hline
\end{tabular}

*Federal Emergency Management Administration

\subsection{RAS geometry details}

Manning's $n$ values were obtained from a few sources including previous modeling studies and direct calibration of the 2011 event. The 2D area Manning's $n$ values are mapped from the National Land Cover Database (NLCD) 2011 Land Cover Dataset (Homer et al. 2015) using the values contained in Table 26.

Table 26. Manning's $n$ values by landcover.

\begin{tabular}{|c|l|c|}
\hline Value & Description & $n$-value \\
\hline 11 & Open water & 0.022 \\
\hline 21 & Developed, open space & 0.12 \\
\hline 22 & Developed, low intensity & 0.121 \\
\hline 23 & Developed, medium intensity & 0.05 \\
\hline 24 & Developed, high intensity & 0.05 \\
\hline 31 & Barren land & 0.05 \\
\hline 41 & Deciduous forest & 0.16 \\
\hline 42 & Evergreen forest & 0.18 \\
\hline 43 & Mixed forest & 0.17 \\
\hline 52 & Shrub/Scrub & 0.07 \\
\hline 71 & Grassland/Herbaceous & 0.035 \\
\hline 81 & Pasture/Hay & 0.033 \\
\hline 82 & Cultivated crops & 0.04 \\
\hline 90 & Woody wetlands & 0.14 \\
\hline 95 & Emergent herbaceous wetlands & 0.035 \\
\hline
\end{tabular}


No bridges or inline structures were modeled in the 1D geometry; however, the 2D model accounts for major bridge abutments and other raised features. Levees were modeled as lateral structures connecting the $1 \mathrm{D}$ model to the overbank areas. Breaklines were drawn to properly align the layout of computational grid elements with any significantly raised features that might impede flow in the basin. No culverts under roadways were modeled. The 2D areas were initially created on a $1500 \times 1500 \mathrm{ft}$ cell spacing, although further refinements with breaklines increased resolution in certain areas.

\subsection{Boundary conditions}

Flows entering the Atchafalaya Basin originate from the 70/30 split at the ORCC. During extreme floods, flows also enter the basin at the Morganza Spillway. Local rainfall is also another source of flow, although it was not accounted for in this analysis.

The upstream boundary of the Atchafalaya model is located slightly upstream from the railroad bridge at Simmesport, LA. The downstream boundary is in the Gulf of Mexico, south of the Wax Lake and Atchafalaya Deltas. The downstream boundary is set far enough into the Gulf to not be influenced by river conditions. The hydraulic boundary conditions needed to run the model include a stage hydrograph at the Gulf of Mexico, a flow hydrograph at Simmesport, and a flow hydrograph at the Morganza Spillway. For all simulations, the required boundary condition time series are stored in HEC Data Storage System (DSS) files.

For simulation of actual events, measured flows at Simmesport and Morganza were obtained from the USGS and USACE. The downstream water levels were supplied from USACE. 
Figure 92. ORCC to Morgan City, LA (MVN), hydraulic model schematic.

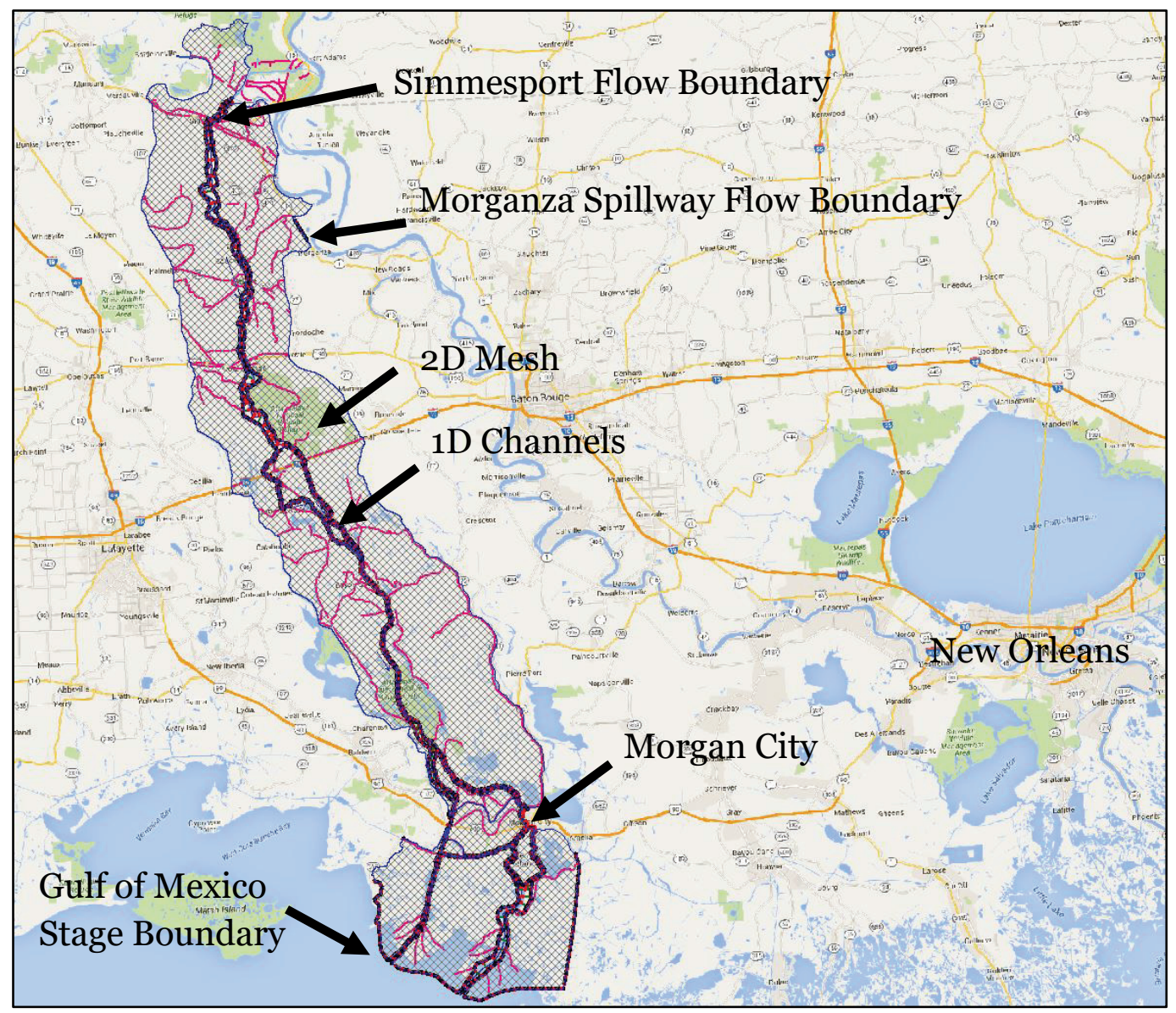


Figure 93. Terrain data sources of the Atchafalaya model.

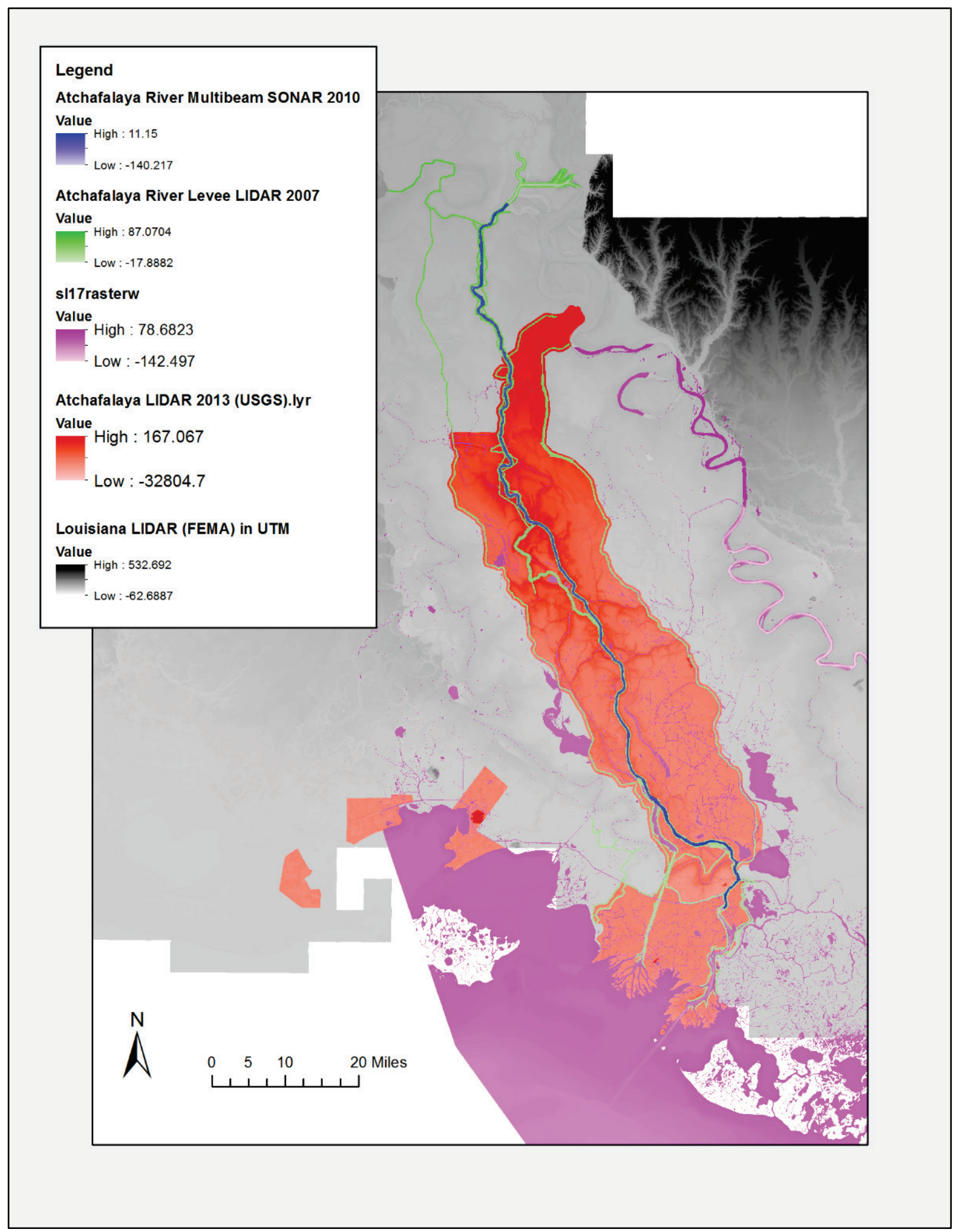


Figure 94. Zoomed view of 1D/2D RAS geometry.

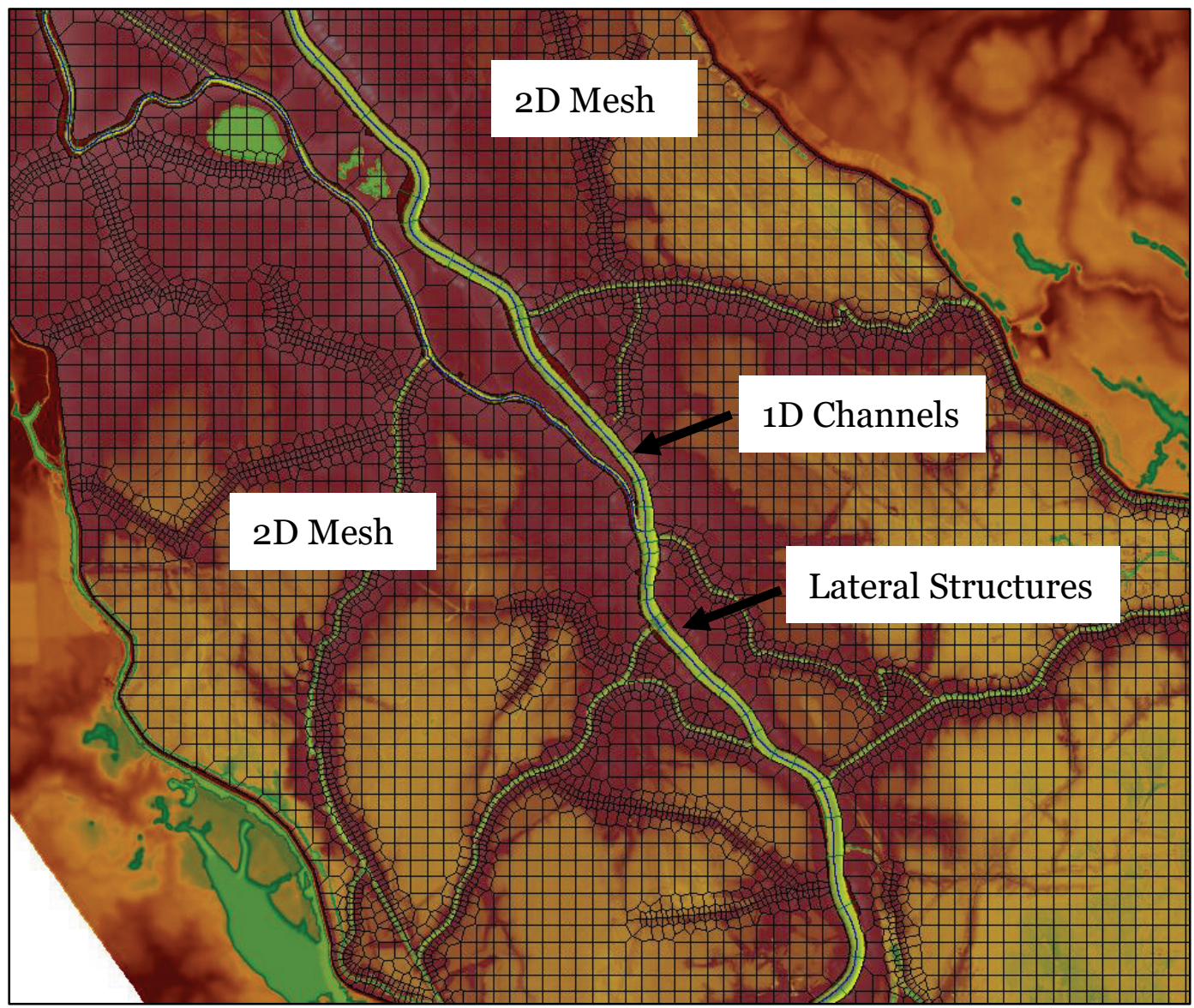

\subsection{Flow stage calibration and validation}

For the external and internal boundaries of the Atchafalaya River unsteady flow HEC-RAS model, flow and stage data were obtained from the USGS and the USACE. The gage measurements were adjusted to the NAVD 88 datum. Table 27 contains the gage name, RAS station, and whether the gage reports stage and/or flow data. Figure 95 displays the locations of the gages. The Simmesport gage was used as an inflow boundary condition at the upper end of the model. Additionally, for the 2011 calibration event, flows estimated at the Morganza Spillway were forced at the model boundary. The Morganza Spillway was not operated for the 2002 and 2008 events. Stage and flow measurement gages located at Calumet, LA, and Morgan City, LA, were used in calibration of the model within the model domain. The remainder of the USACE gages only measure stage, and were used in calibration.

The following section presents modeled vs. observed data for the 2011 calibration run (Figure 96 through Figure 110; Table 28 and Table 29) and 
the 2002 (Table 32 and Table 33) and 2008 (Table 30 and Table 31) validation run. These events are the same events as used for calibration/ validation in the main stem modeling effort. The 2011 event was selected because it was a major event for the basin. The model performs well at the gages in the basin. Modeled peak water levels at all gages are within $+/-1.38 \mathrm{ft}$ of the measurements, although most gages have a smaller difference. The modeled hydrograph shape is also consistent with the observations. Figure 103 displays the modeled vs. observed flows at Morgan City. The model here seems to overpredict flows by approximately $10 \%$ for the 2011 event; however, the quality of the observed flow data is questionable, especially near the peak of the flood. Figure 102 shows the modeled and observed stages at Morgan City. The stages match well. There seems to be an inconsistency with the hydrograph shape of the observed flows and observed stages at Morgan City for the 2011 event. Table 30 through Table 33 contain the observed vs. modeled stages for the 2002 and 2008 validation events. Figure 111, Figure 112, and Figure 113 display the modeled maximum water surface elevation within the basin for the 2002, 2008, and 2011 simulations.

Table 27. Summary of stage and flow gages used in calibration/validation.

\begin{tabular}{|l|l|l|l|l|}
\hline River & Station Name & RAS Station & Parameter & Entity \\
\hline Atchafalaya & Simmesport & Atch 7 732010.6 & Stage/Flow & USACE/USGS \\
\hline Atchafalaya & Morganza Diversion & 2d Boundary Condition & Flow & USACE \\
\hline Atchafalaya & Melville & Atch $7 \quad 608311.8$ & Stage & USACE \\
\hline Atchafalaya & Krotz Springs & Atch 7561101.4 & Stage & USGS \\
\hline Atchafalaya & Whiskey Bay Pilot Channel & Atch Split 125437.1 & Stage & USACE \\
\hline Atchafalaya & Butte La Rose & Atch Split 76965.38 & Stage & USACE \\
\hline Atchafalaya & Chicot Pass near Myette Point & Atch 5 256773 & Stage & USACE \\
\hline Atchafalaya & Six Mile Lake & Wax Lake 2 130064.4 & Stage & USACE \\
\hline Atchafalaya & Morgan City & Atch 4 138318.5 & Stage/Flow & USACE \\
\hline Wax Lake Outlet & Calumet & Wax Lake 2 130064.4 & Stage/Flow & USACE \\
\hline Wax Lake Outlet & Crewboat Channel & Wax Lake 1 38069.36 & Stage & USACE \\
\hline Atchafalaya & Avoca Island Cutoff & Atch 1 68558.72 & Stage & USACE \\
\hline Atchafalaya & Eugene Island & Downstream Stage Boundary & Stage & USGS \\
\hline
\end{tabular}


Figure 95. Location of stage and flow gages.

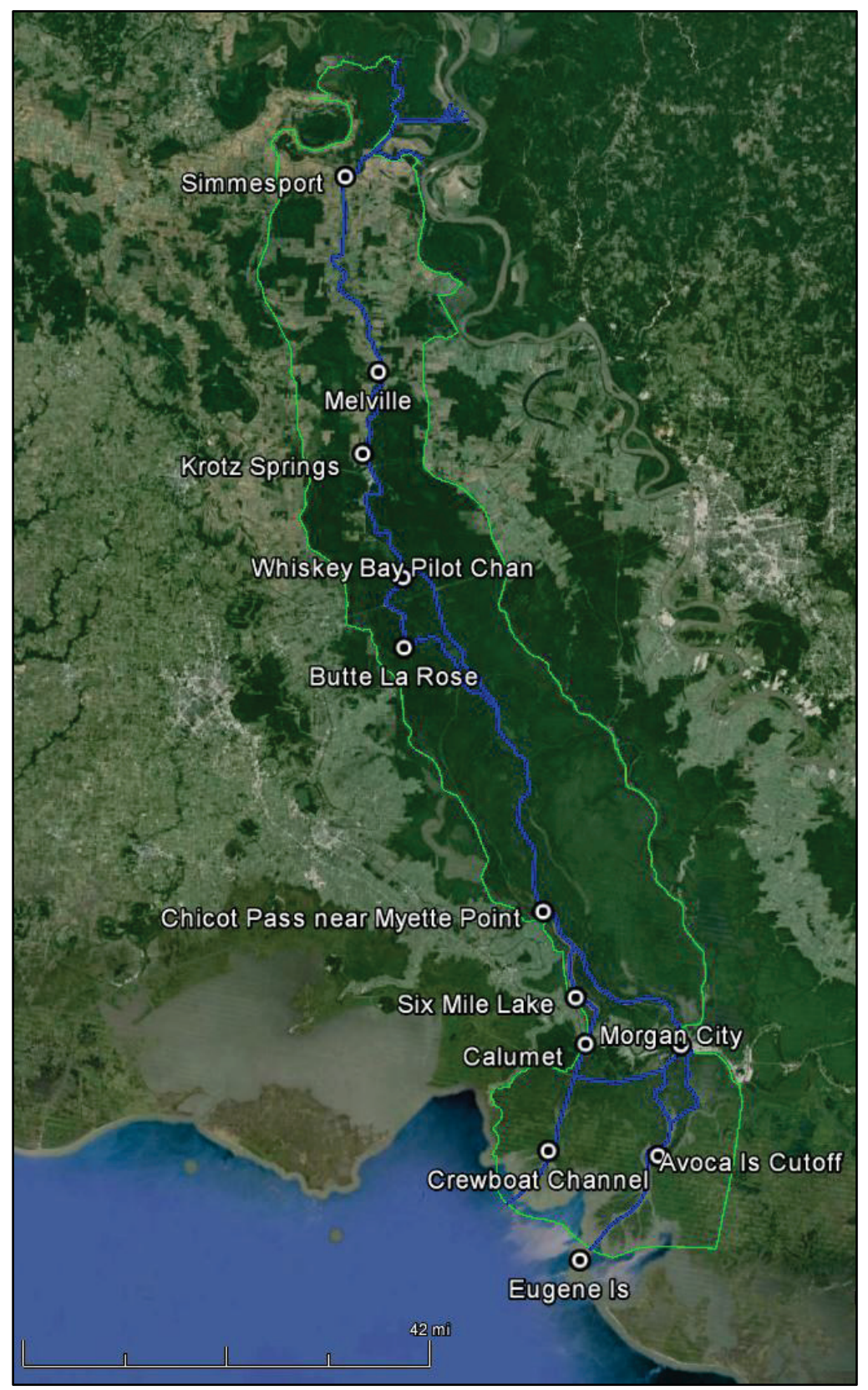


Figure 96. Maximum inundation depth for 2011 calibration event.

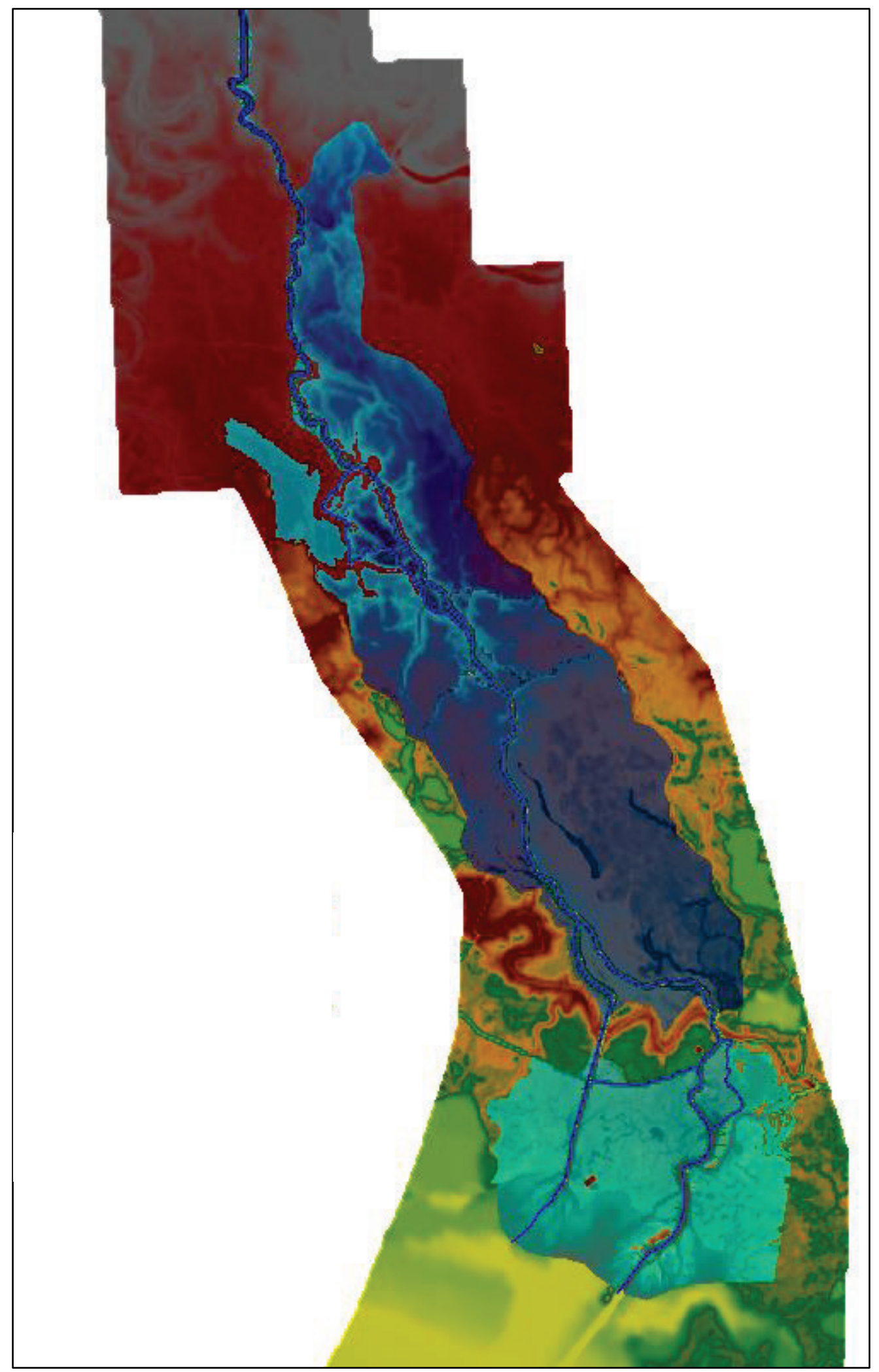


Figure 97. Modeled vs. observed stages at Simmesport, LA.

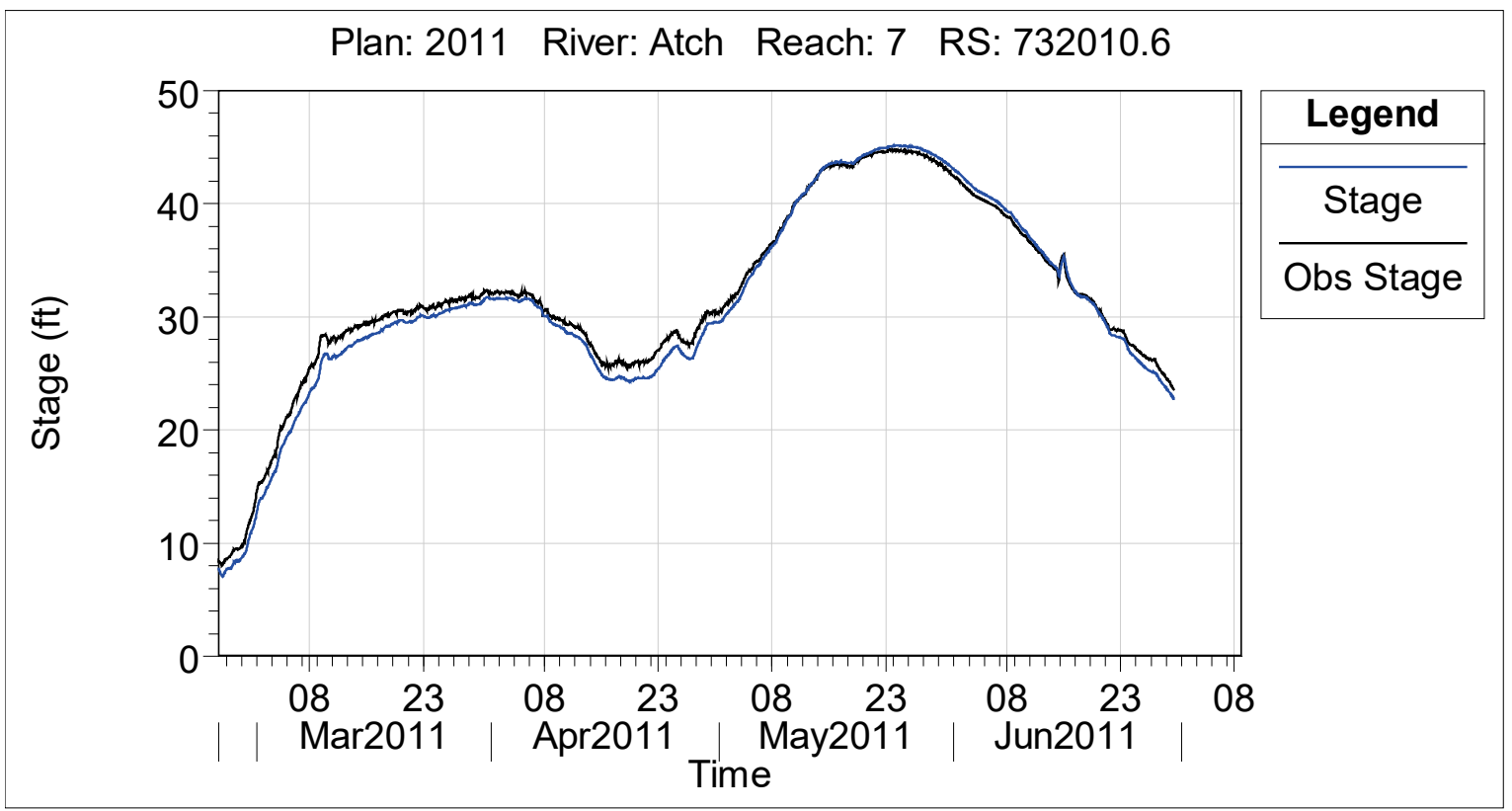

Figure 98. Modeled vs. observed flows at Simmesport, LA.

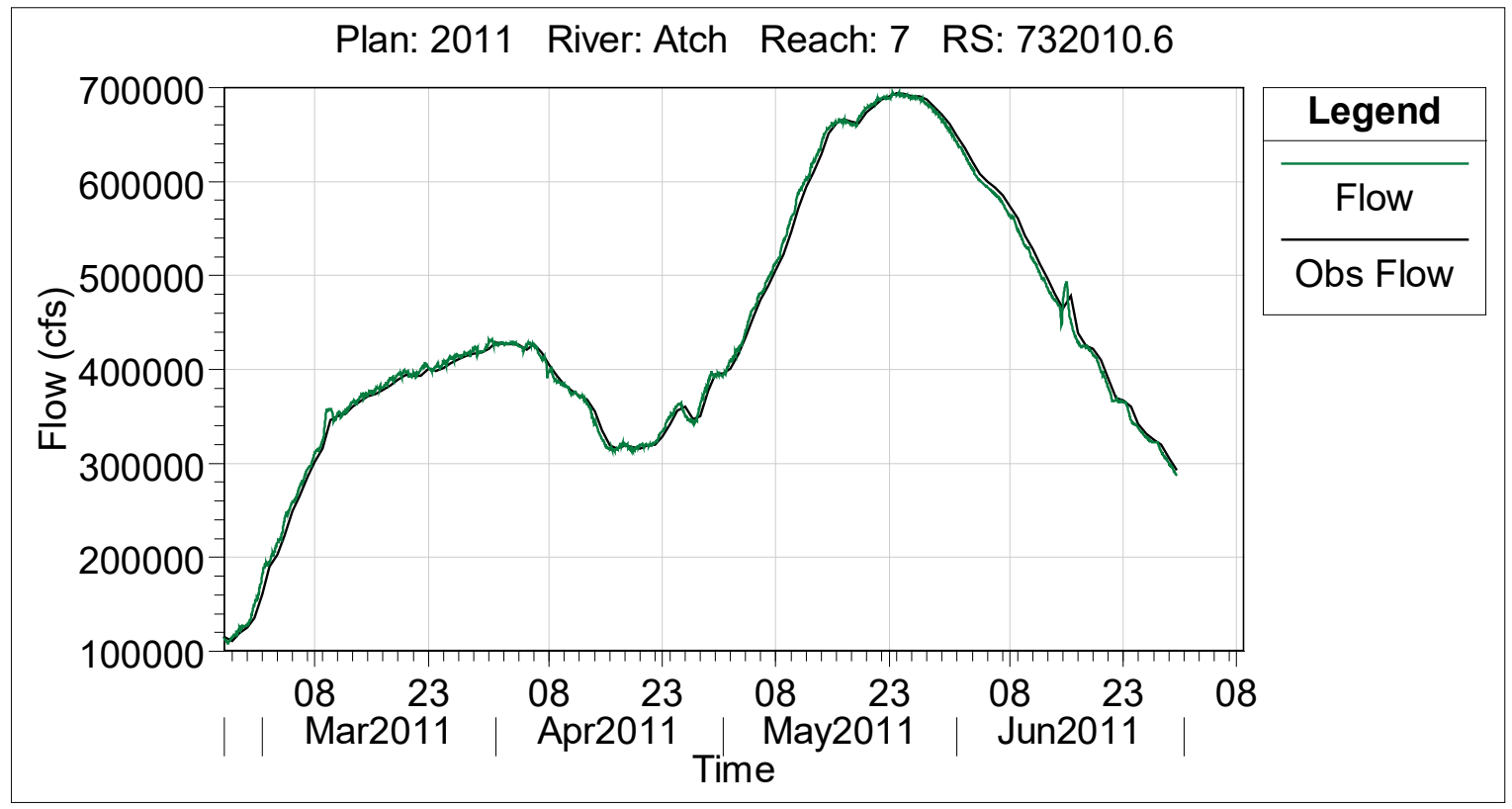


Figure 99. Modeled vs. observed stages at Mellville, LA.

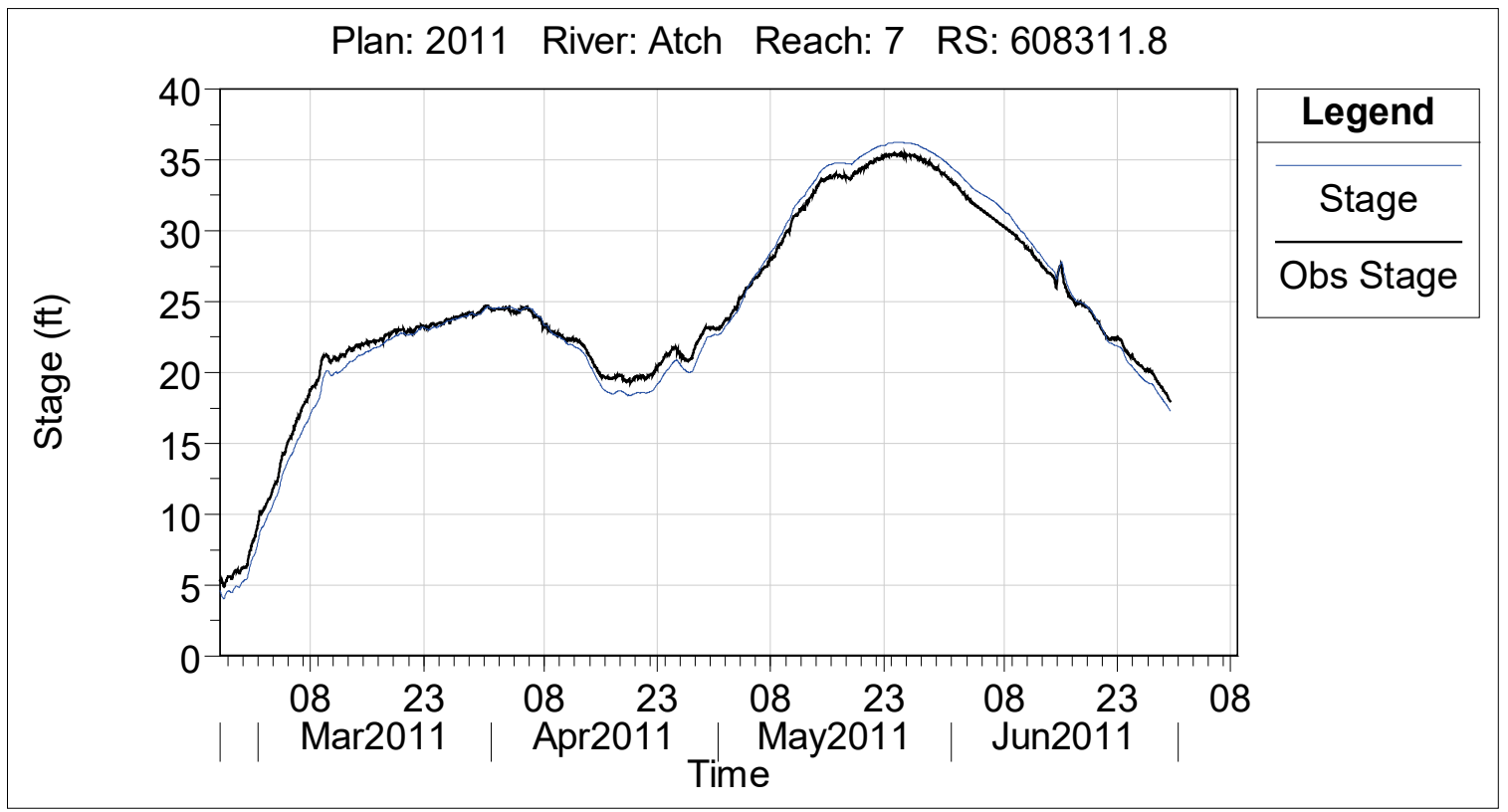

Figure 100. Modeled vs. observed stages at Krotz Springs, LA.

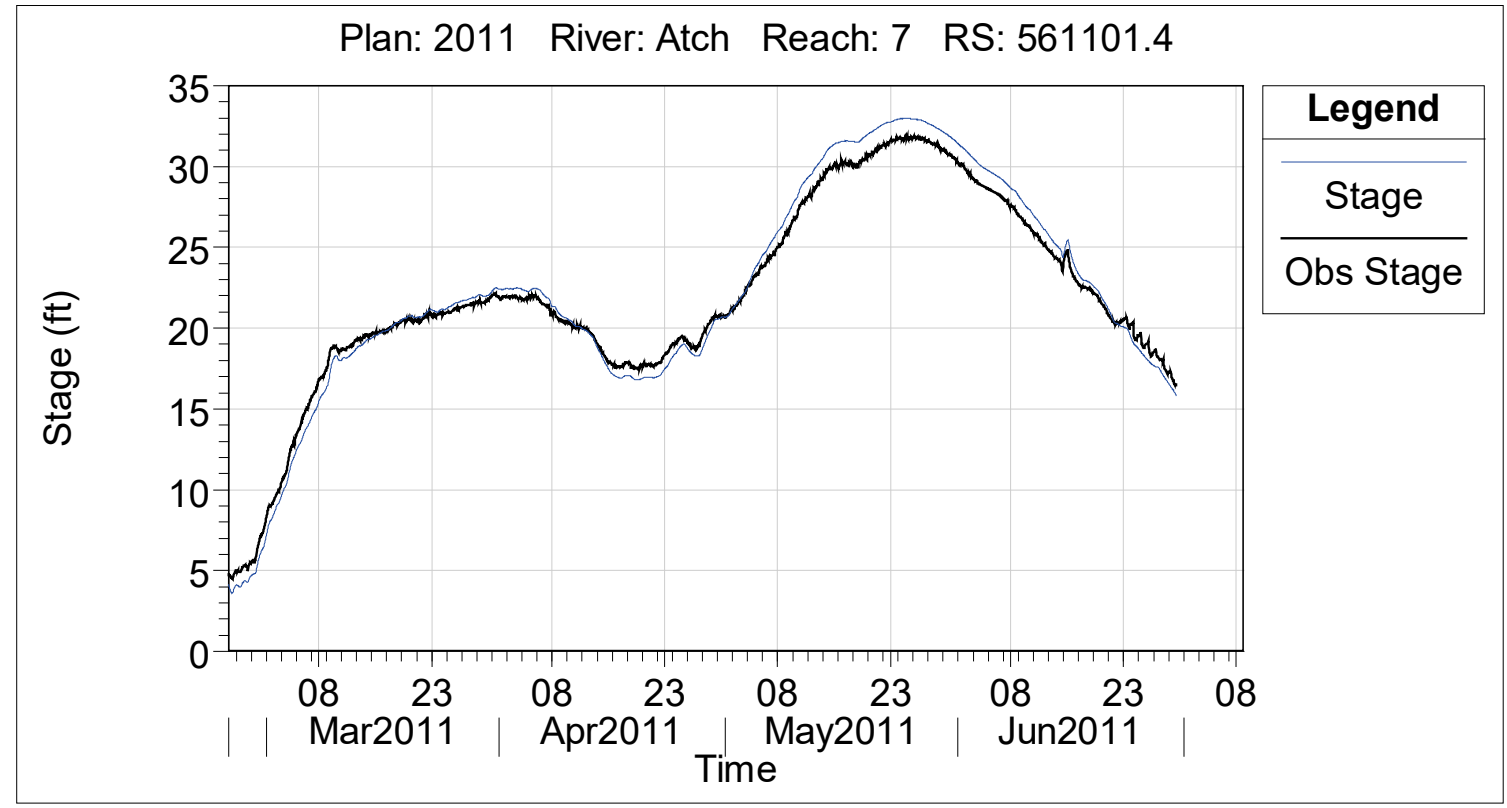


Figure 101. Modeled vs. observed stages at Chicot Pass near Myette Point.

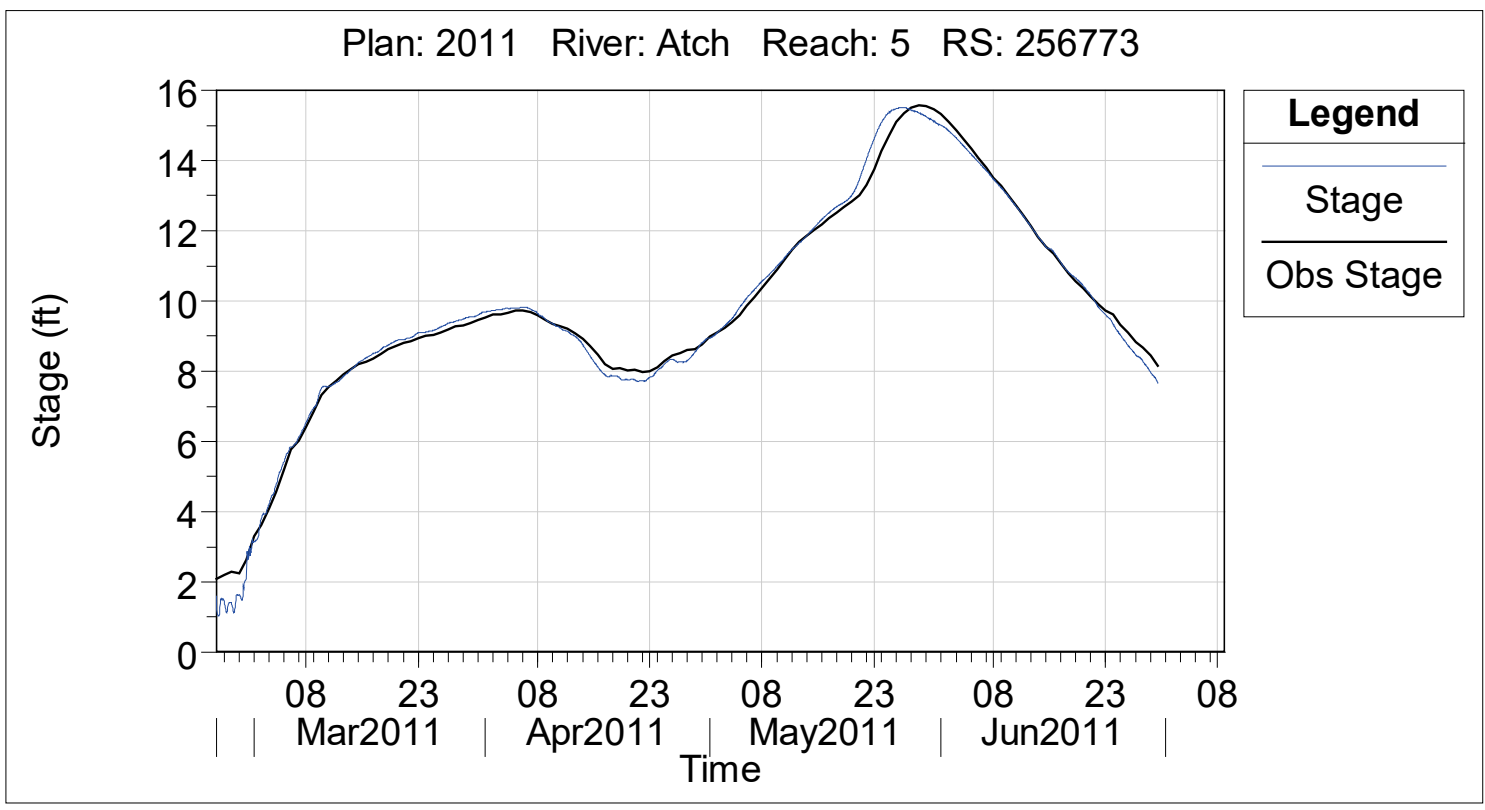

Figure 102. Modeled vs. observed stages at Morgan City, LA.

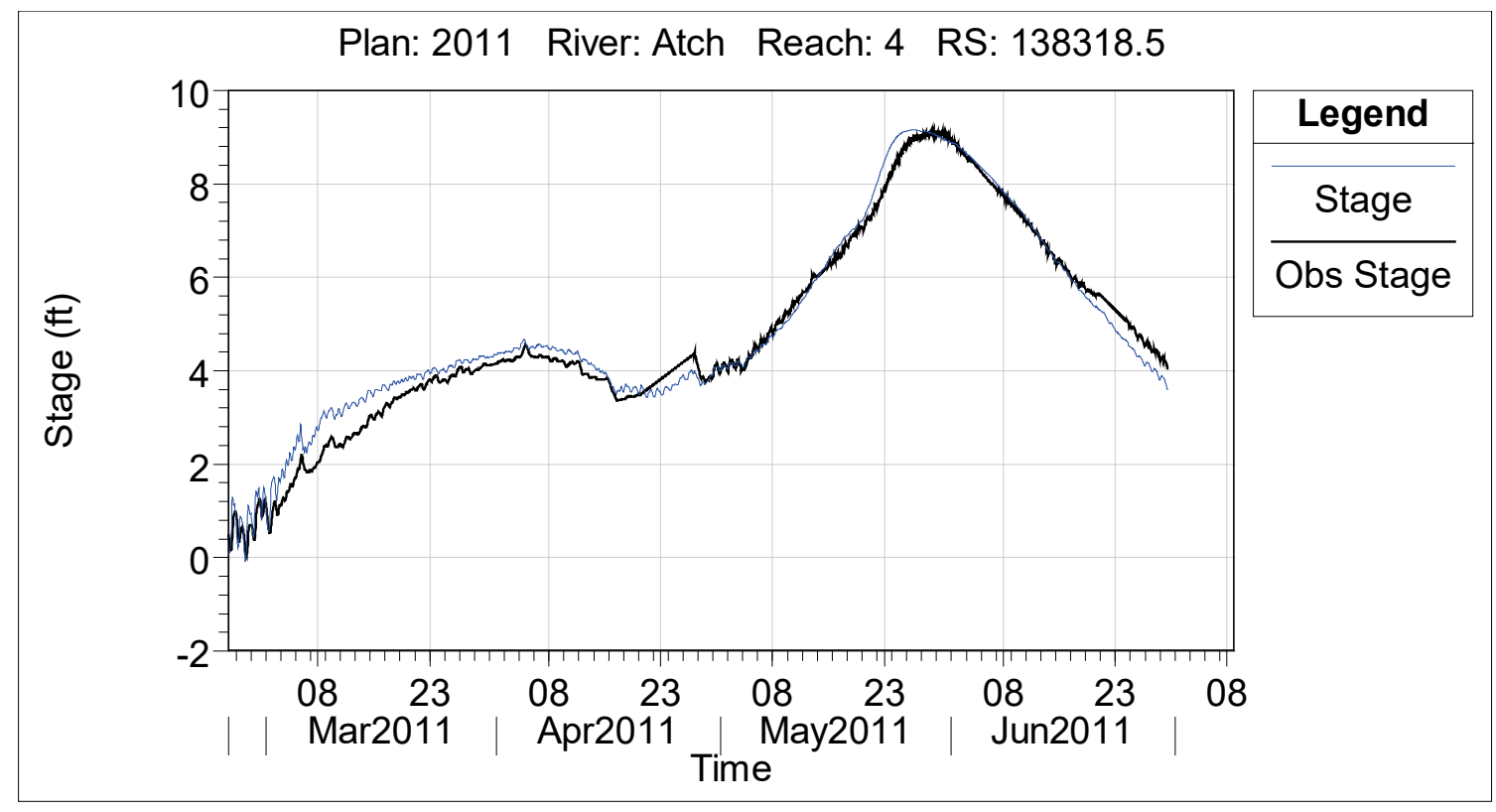


Figure 103. Modeled vs. observed flows at Morgan City, LA.

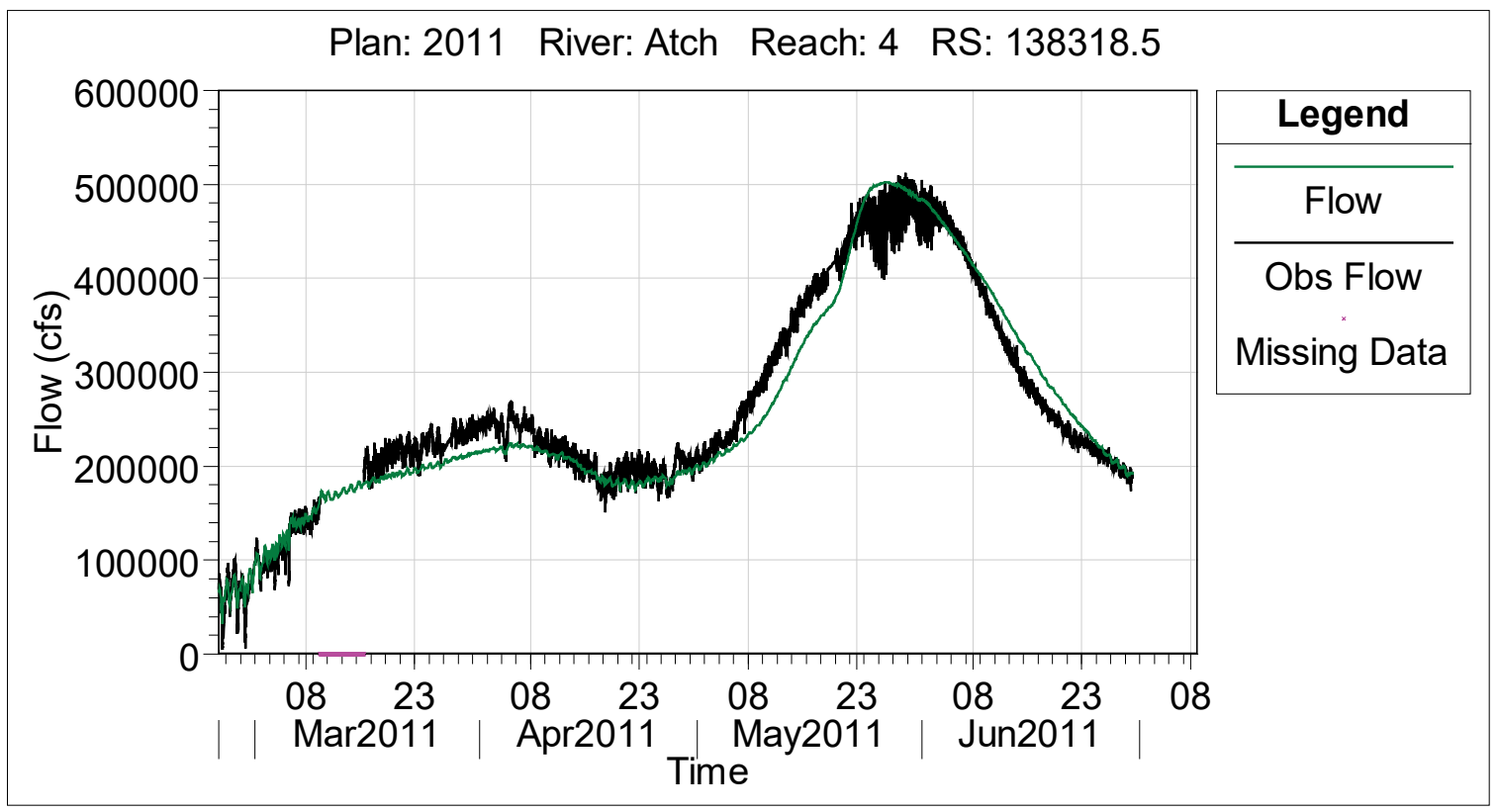

Figure 104. Modeled vs. observed stages at Avoca Island Cutoff.

Plan: 2011 River: Atch Reach: 1 RS: 68558.72

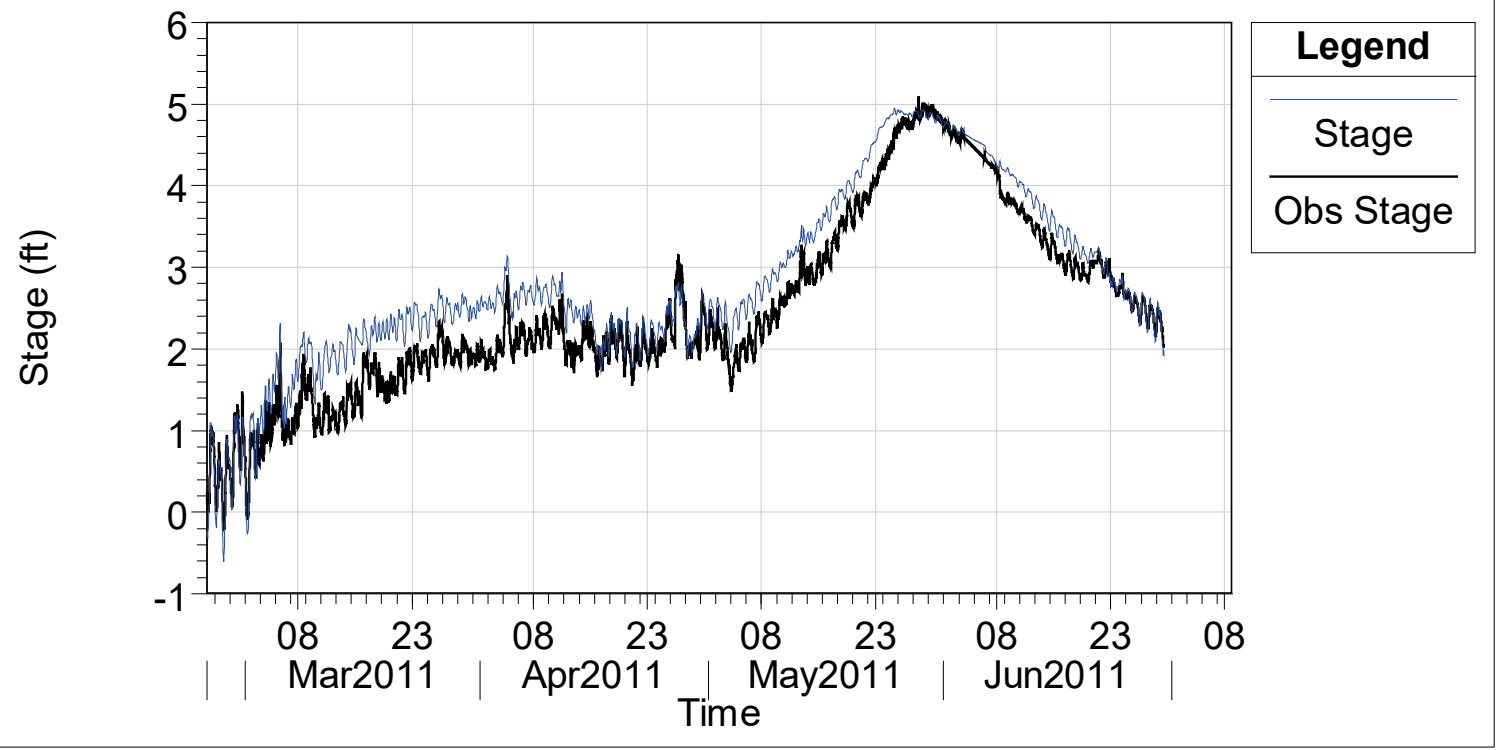


Figure 105. Modeled vs. observed stages at Whiskey Bay Pilot Channel.

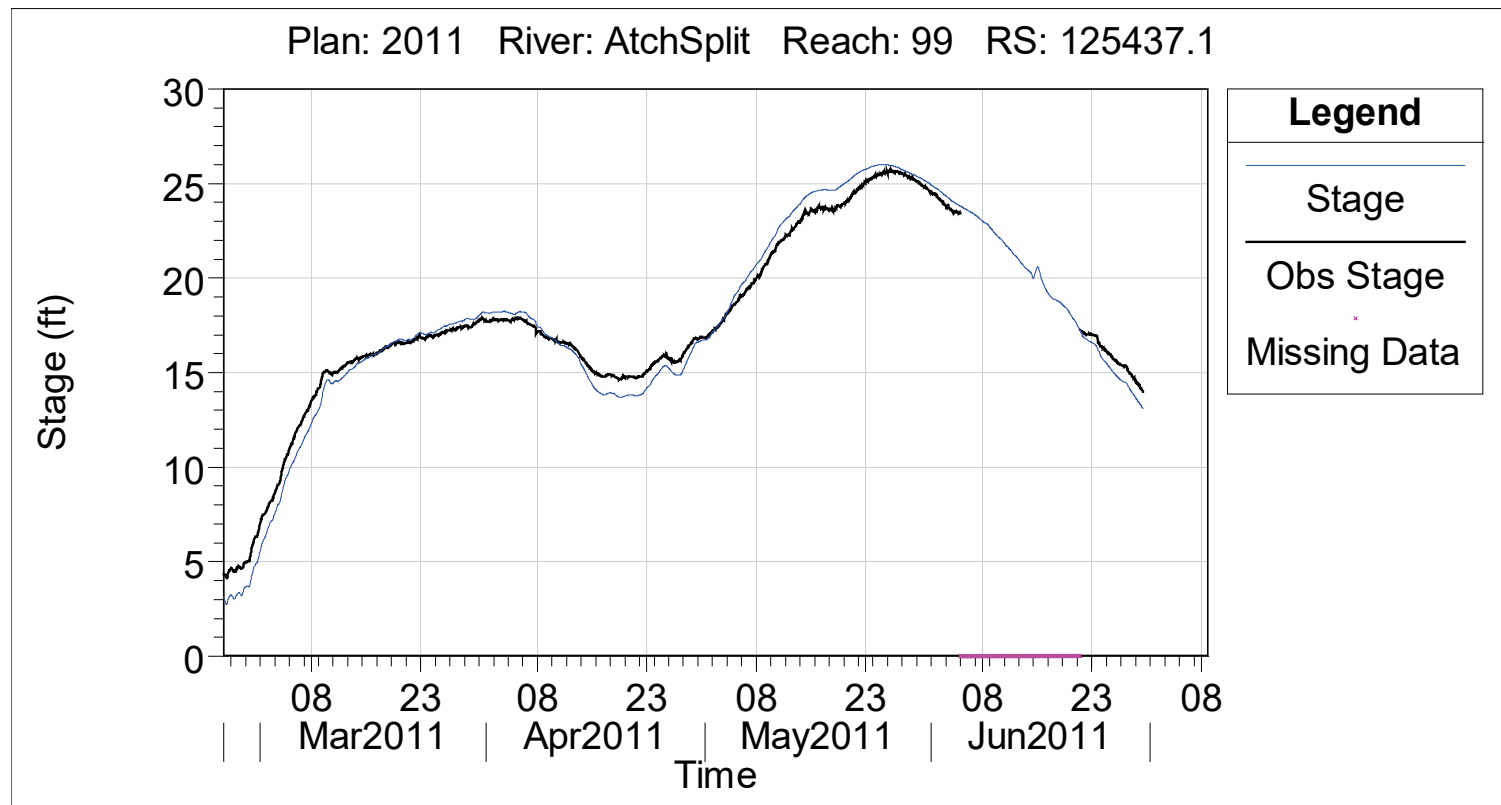

Figure 106. Modeled vs. observed stages at Butte La Rose.

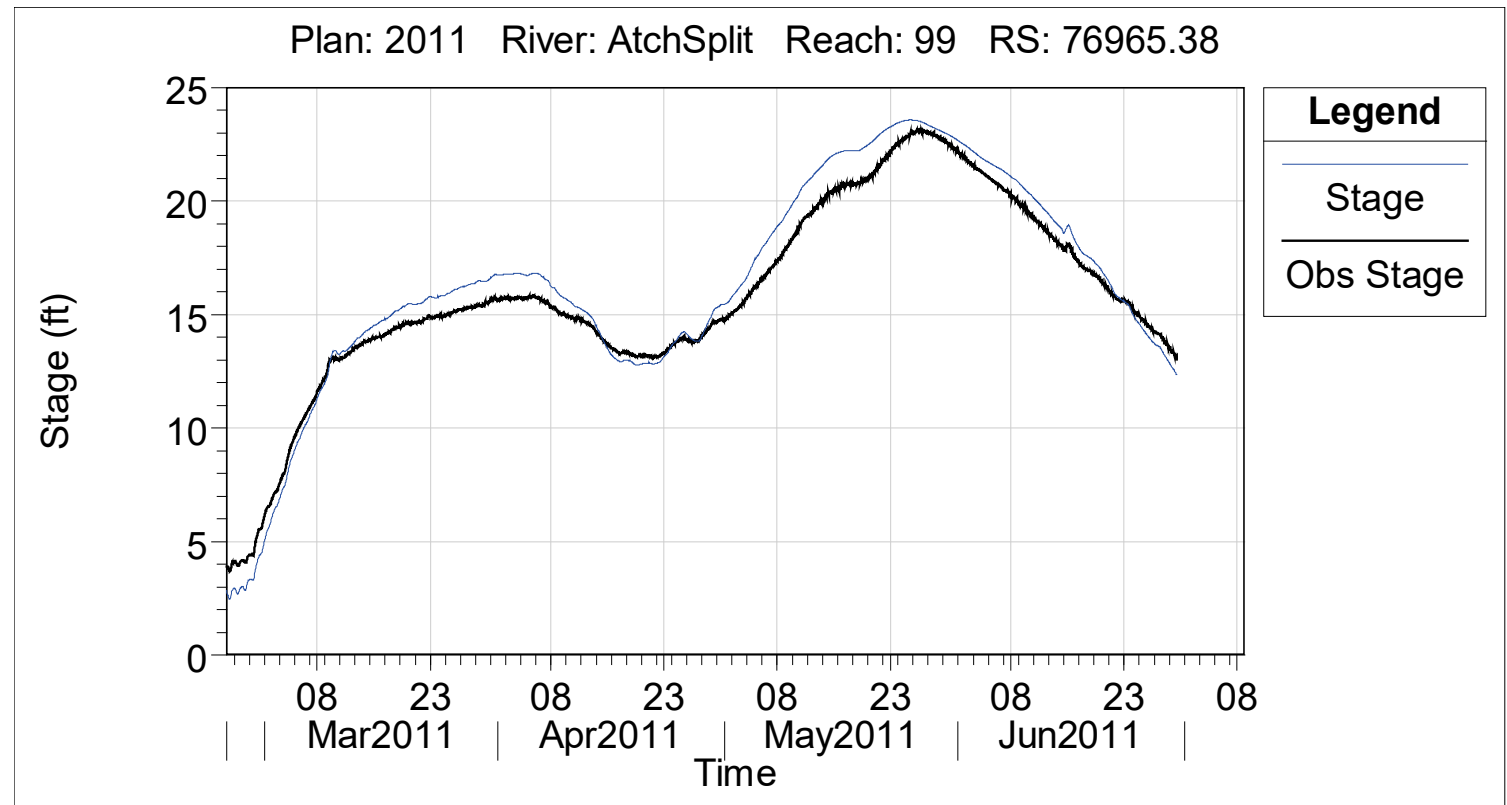


Figure 107. Modeled vs. observed stages at Six Mile Lake.

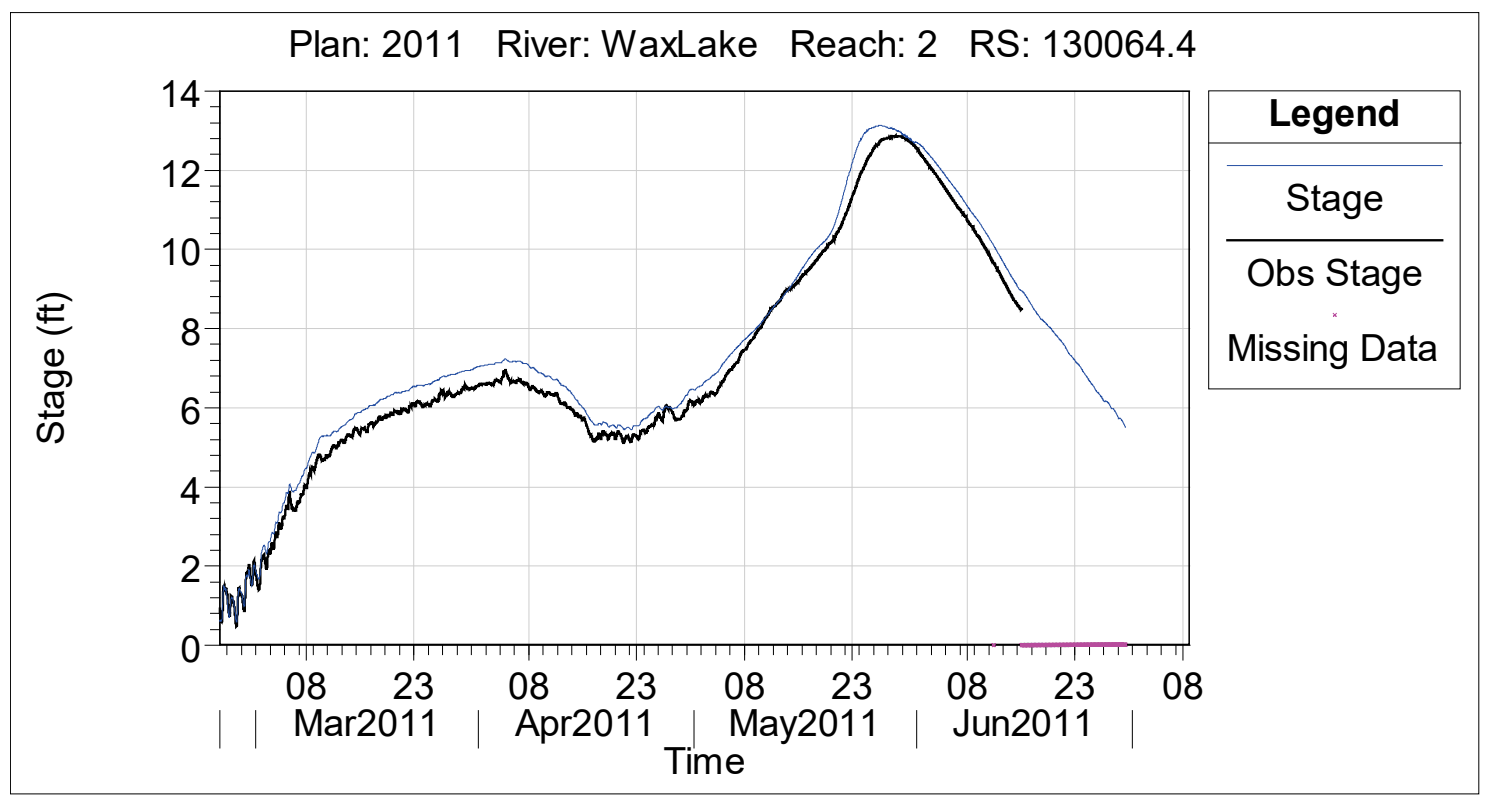

Figure 108. Modeled vs. observed stages at Calumet.

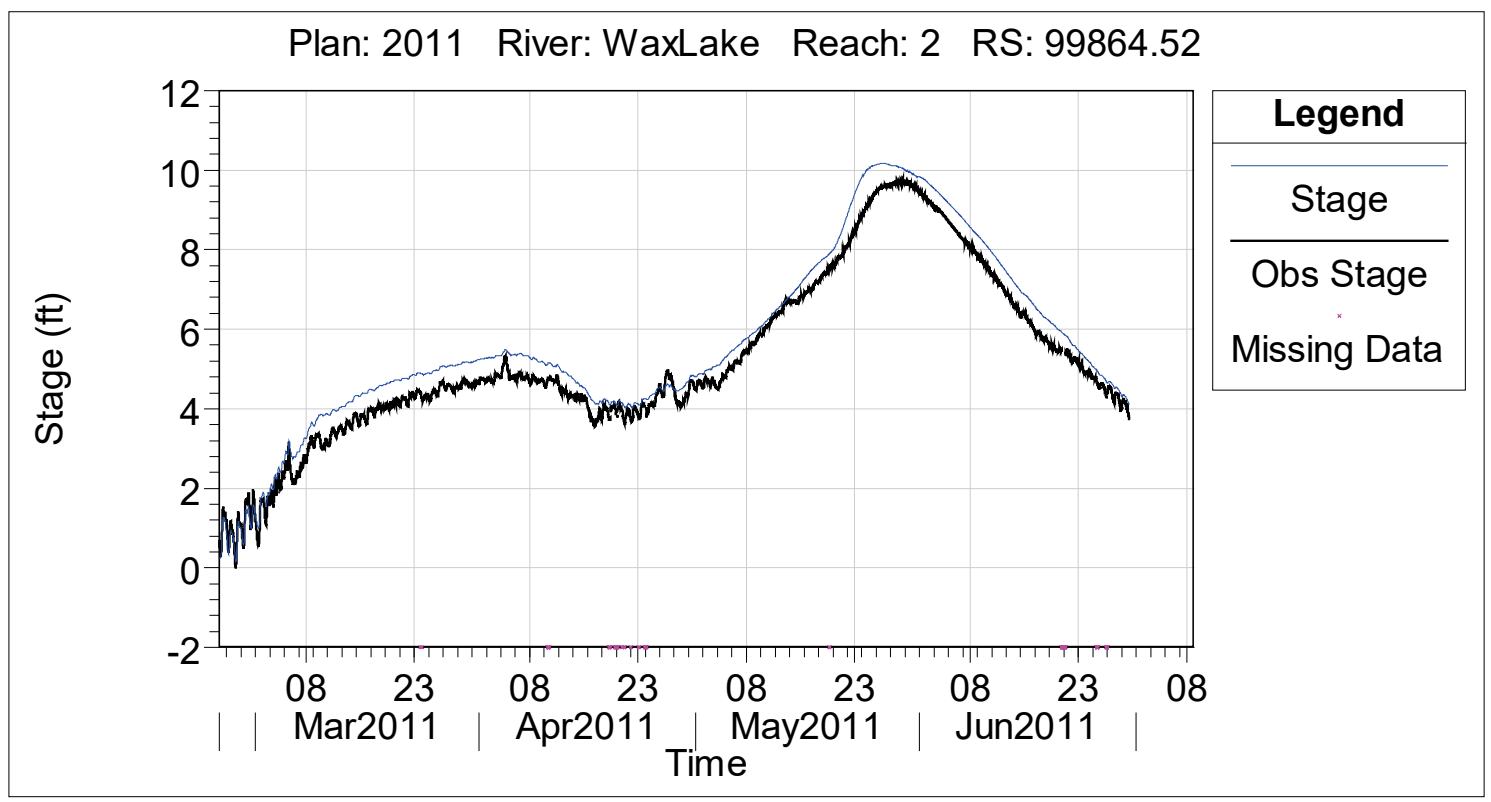


Figure 109. Modeled vs. observed flows at Calumet.

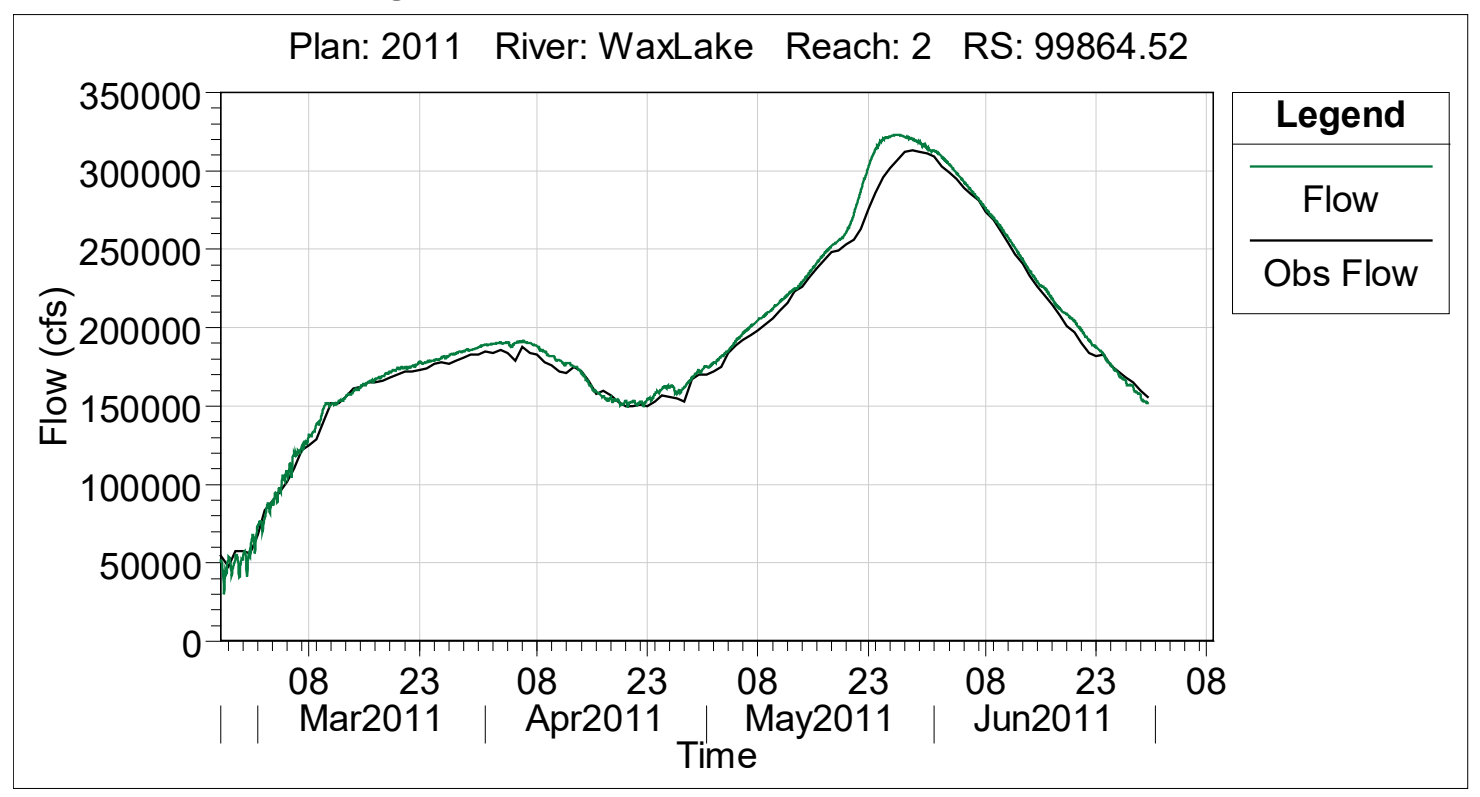

Figure 110. Modeled vs. observed stages at Crewboat Channel.

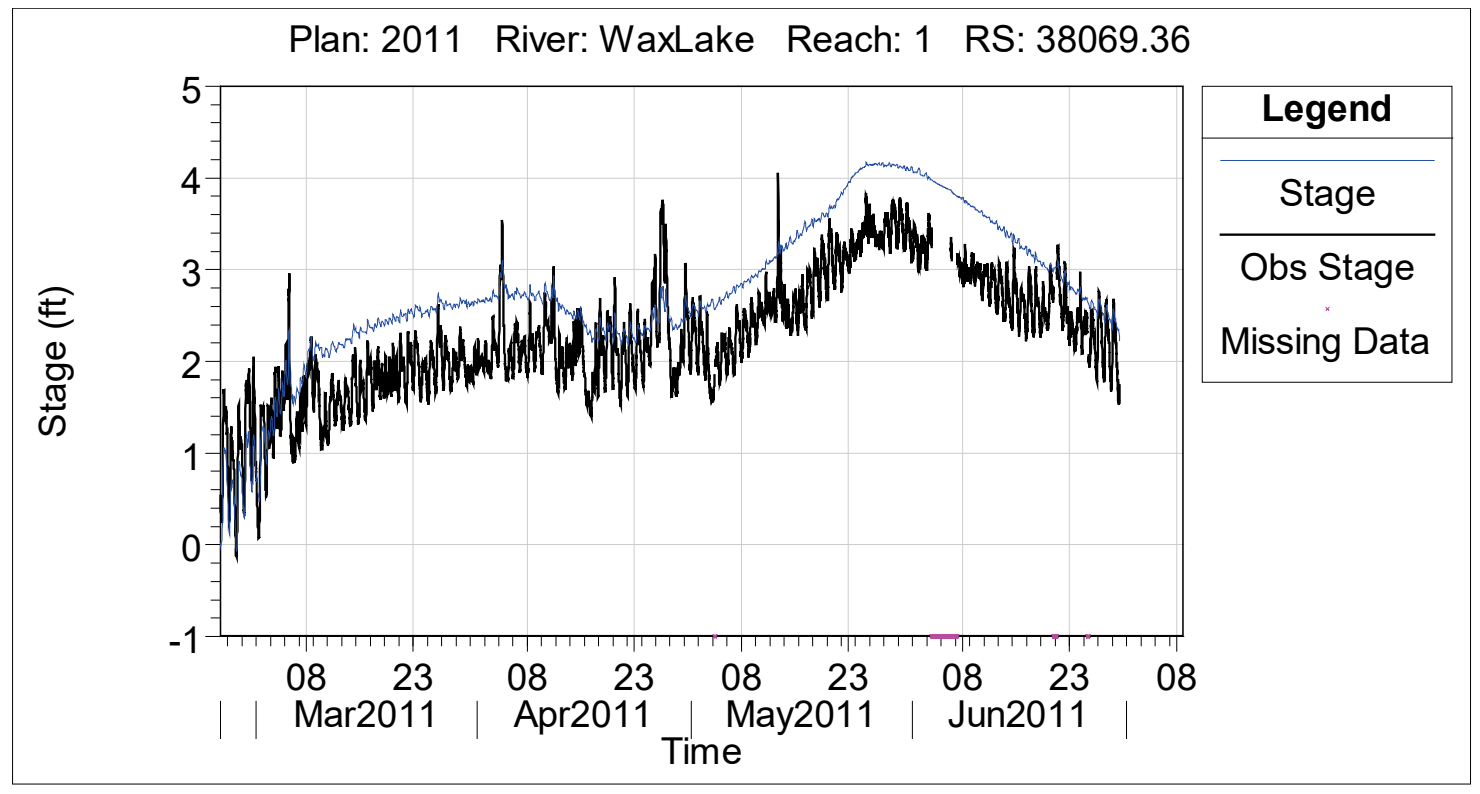


Table 28. Summary of modeled vs. observed peak stages for 2011 calibration event.

\begin{tabular}{|l|l|l|c|c|c|}
\hline River & Station Name & RAS Station & $\begin{array}{c}\text { Peak Modeled } \\
\text { Stage (ft NAVD88) }\end{array}$ & $\begin{array}{c}\text { Peak Observed } \\
\text { Stage (ft NAVD88) }\end{array}$ & Difference (ft) \\
\hline Atchafalaya & Simmesport & $\begin{array}{l}\text { Atch } 7 \\
732010.6\end{array}$ & 45.17 & 44.82 & 0.35 \\
\hline Atchafalaya & Melville & $\begin{array}{l}\text { Atch 7 } \\
608311.8\end{array}$ & 36.23 & 35.47 & 0.76 \\
\hline Atchafalaya & Krotz Springs & $\begin{array}{l}\text { Atch 7 } \\
561101.4\end{array}$ & 32.97 & 31.86 & 1.11 \\
\hline Atchafalaya & $\begin{array}{l}\text { Whiskey Bay Pilot } \\
\text { Channel }\end{array}$ & $\begin{array}{l}\text { Atch Split } \\
125437.1\end{array}$ & 26.01 & 25.73 & 0.28 \\
\hline Atchafalaya & Butte La Rose & $\begin{array}{l}\text { Atch Split } \\
76965.38\end{array}$ & 23.58 & 23.14 & 0.44 \\
\hline Atchafalaya & $\begin{array}{l}\text { Chicot Pass near } \\
\text { Myette Point }\end{array}$ & $\begin{array}{l}\text { Atch 5 } \\
256773\end{array}$ & 15.51 & 15.57 & -0.06 \\
\hline Atchafalaya & Six Mile Lake & $\begin{array}{l}\text { Wax Lake } 2 \\
130064.4\end{array}$ & 13.13 & 12.87 & 0.26 \\
\hline Atchafalaya & Morgan City & $\begin{array}{l}\text { Atch 4 } \\
138318.5\end{array}$ & 9.15 & 9.15 & 0 \\
\hline $\begin{array}{l}\text { Wax Lake } \\
\text { Outlet }\end{array}$ & Calumet & $\begin{array}{l}\text { Wax Lake 2 } \\
99864.52\end{array}$ & 10.17 & 9.77 & 0.4 \\
\hline $\begin{array}{l}\text { Wax Lake } \\
\text { Outlet }\end{array}$ & $\begin{array}{l}\text { Crewboat } \\
\text { Channel }\end{array}$ & $\begin{array}{l}\text { Wax Lake 1 } \\
38069.36\end{array}$ & 4.17 & 4.06 & 0.11 \\
\hline Atchafalaya & $\begin{array}{l}\text { Avoca Island } \\
\text { Cutoff }\end{array}$ & $\begin{array}{l}\text { Atch 1 } \\
68558.72\end{array}$ & 4.95 & 5.1 & -15 \\
\hline
\end{tabular}

Table 29. Summary of modeled vs. observed peak discharge for 2011 calibration event.

\begin{tabular}{|l|l|l|c|c|c|c|}
\hline River & $\begin{array}{l}\text { Station } \\
\text { Name }\end{array}$ & RAS Station & $\begin{array}{c}\text { Peak Modeled } \\
\text { Discharge (cfs) }\end{array}$ & $\begin{array}{c}\text { Peak Observed } \\
\text { Discharge (cfs) }\end{array}$ & $\begin{array}{c}\text { Difference } \\
\text { (cfs) }\end{array}$ & $\begin{array}{c}\% \\
\text { Difference }\end{array}$ \\
\hline Atchafalaya & Simmesport & $\begin{array}{l}\text { Atch } 7 \\
732010.6\end{array}$ & 694,867 & 694,000 & 867 & $0.12 \%$ \\
\hline Atchafalaya & Morgan City & $\begin{array}{l}\text { Atch } 4 \\
138318.5\end{array}$ & 502,118 & 512,000 & $-9,882$ & $-1.93 \%$ \\
\hline $\begin{array}{l}\text { Wax Lake } \\
\text { Outlet }\end{array}$ & Calumet & $\begin{array}{l}\text { Wax Lake } \\
299864.52\end{array}$ & 322,947 & 313,000 & 9,947 & $3.18 \%$ \\
\hline
\end{tabular}


Table 30. Summary of modeled vs. observed peak stages for 2008 validation event.

\begin{tabular}{|c|c|c|c|c|c|}
\hline River & Station Name & RAS Station & $\begin{array}{c}\text { Peak Modeled } \\
\text { Stage (ft NAVD88) }\end{array}$ & $\begin{array}{c}\text { Peak Observed } \\
\text { Stage (ft NAVD88) }\end{array}$ & Difference (ft) \\
\hline Atchafalaya & Simmesport & $\begin{array}{l}\text { Atch } 7 \\
732010.6\end{array}$ & 41.48 & 41.22 & 0.26 \\
\hline Atchafalaya & Melville & $\begin{array}{l}\text { Atch } 7 \\
608311.8\end{array}$ & 32.94 & 32.23 & 0.71 \\
\hline Atchafalaya & Krotz Springs & $\begin{array}{l}\text { Atch } 7 \\
561101.4\end{array}$ & 29.97 & missing & missing \\
\hline Atchafalaya & $\begin{array}{l}\text { Whiskey Bay Pilot } \\
\text { Channel }\end{array}$ & $\begin{array}{l}\text { Atch Split } \\
125437.1\end{array}$ & 40.04 & 22.68 & 17.36 \\
\hline Atchafalaya & Butte La Rose & $\begin{array}{l}\text { Atch Split } \\
76965.38\end{array}$ & 35.80 & 20.02 & 15.78 \\
\hline Atchafalaya & $\begin{array}{l}\text { Chicot Pass near } \\
\text { Mvette Point }\end{array}$ & Atch 5256773 & 12.51 & 12.63 & -0.12 \\
\hline Atchafalaya & Six Mile Lake & $\begin{array}{l}\text { Wax Lake } 2 \\
130064.4\end{array}$ & 13.77 & missing & missing \\
\hline Atchafalaya & Morgan City & $\begin{array}{l}\text { Atch } 4 \\
138318.5\end{array}$ & 6.86 & 6.79 & 0.07 \\
\hline $\begin{array}{l}\text { Wax Lake } \\
\text { Outlet }\end{array}$ & Calumet & $\begin{array}{l}\text { Wax Lake } 2 \\
99864.52\end{array}$ & 12.93 & 7.36 & 5.57 \\
\hline $\begin{array}{l}\text { Wax Lake } \\
\text { Outlet }\end{array}$ & Crewboat Channel & $\begin{array}{l}\text { Wax Lake } 1 \\
38069.36\end{array}$ & 11.31 & missing & missing \\
\hline Atchafalaya & Avoca Island Cutoff & $\begin{array}{l}\text { Atch } 1 \\
68558.72\end{array}$ & 3.94 & missing & missing \\
\hline
\end{tabular}

Table 31. Summary of modeled vs. observed peak discharge for 2008 validation event.

\begin{tabular}{|l|l|l|c|c|c|c|}
\hline River & Station Name & RAS Station & $\begin{array}{c}\text { Peak Modeled } \\
\text { Discharge (cfs) }\end{array}$ & $\begin{array}{c}\text { Peak Observed } \\
\text { Discharge (cfs) }\end{array}$ & $\begin{array}{c}\text { Difference } \\
\text { (cfs) }\end{array}$ & \% Difference \\
\hline Atchafalaya & Simmesport & $\begin{array}{l}\text { Atch 7 } \\
732010.6\end{array}$ & 613,825 & 614,019 & -194 & $-0.03 \%$ \\
\hline Atchafalaya & Morgan City & $\begin{array}{l}\text { Atch 4 } \\
138318.5\end{array}$ & 358,046 & 350,000 & 8,046 & $2.30 \%$ \\
\hline $\begin{array}{l}\text { Wax Lake } \\
\text { Outlet }\end{array}$ & Calumet & $\begin{array}{l}\text { Wax Lake } 2 \\
99864.52\end{array}$ & 250,717 & 248,000 & 2,717 & $1.10 \%$ \\
\hline
\end{tabular}


Table 32. Summary of modeled vs. observed peak stages for 2002 validation event.

\begin{tabular}{|c|c|c|c|c|c|}
\hline River & Station Name & $\begin{array}{c}\text { RAS } \\
\text { Station }\end{array}$ & $\begin{array}{c}\text { Peak Modeled } \\
\text { Stage } \\
\text { (ft NAVD88) }\end{array}$ & $\begin{array}{c}\text { Peak Observed } \\
\text { Stage } \\
\text { (ft NAVD88) }\end{array}$ & Difference $(\mathrm{ft})$ \\
\hline Atchafalaya & Simmesport & $\begin{array}{l}\text { Atch } 7 \\
732010.6\end{array}$ & 35.17 & 35.32 & -0.15 \\
\hline Atchafalaya & Melville & $\begin{array}{l}\text { Atch } 7 \\
608311.8\end{array}$ & 27.68 & 27.41 & 0.27 \\
\hline Atchafalaya & Krotz Springs & $\begin{array}{l}\text { Atch } 7 \\
561101.4\end{array}$ & 25.29 & missing & missing \\
\hline Atchafalaya & $\begin{array}{l}\text { Whiskey Bay Pilot } \\
\text { Channel }\end{array}$ & $\begin{array}{l}\text { Atch Split } \\
125437.1\end{array}$ & 20.37 & missing & missing \\
\hline Atchafalaya & Butte La Rose & $\begin{array}{l}\text { Atch Split } \\
76965.38\end{array}$ & 18.72 & missing & missing \\
\hline Atchafalaya & $\begin{array}{l}\text { Chicot Pass near } \\
\text { Myette Point }\end{array}$ & $\begin{array}{l}\text { Atch } 5 \\
256773\end{array}$ & 10.91 & 10.92 & -0.01 \\
\hline Atchafalaya & Six Mile Lake & $\begin{array}{l}\text { Wax Lake } 2 \\
130064.4\end{array}$ & 8.28 & missing & missing \\
\hline Atchafalaya & Morgan City & $\begin{array}{l}\text { Atch } 4 \\
138318.5\end{array}$ & 5.74 & 5.27 & 0.47 \\
\hline $\begin{array}{l}\text { Wax Lake } \\
\text { Outlet }\end{array}$ & Calumet & $\begin{array}{l}\text { Wax Lake } 2 \\
99864.52\end{array}$ & 6.43 & missing & missing \\
\hline $\begin{array}{l}\text { Wax Lake } \\
\text { Outlet }\end{array}$ & $\begin{array}{l}\text { Crewboat } \\
\text { Channel }\end{array}$ & $\begin{array}{l}\text { Wax Lake } 1 \\
38069.36\end{array}$ & 3.83 & missing & missing \\
\hline Atchafalaya & $\begin{array}{l}\text { Avoca Island } \\
\text { Cutoff }\end{array}$ & $\begin{array}{l}\text { Atch } 1 \\
68558.72\end{array}$ & 3.95 & missing & missing \\
\hline
\end{tabular}

Table 33. Summary of modeled vs. observed peak discharge for 2002 validation event.

\begin{tabular}{|c|c|c|c|c|c|c|}
\hline River & Station Name & $\begin{array}{l}\text { RAS } \\
\text { Station }\end{array}$ & $\begin{array}{c}\text { Peak } \\
\text { Modeled } \\
\text { Discharge } \\
\text { (cfs) }\end{array}$ & $\begin{array}{c}\text { Peak } \\
\text { Observed } \\
\text { Discharge } \\
\text { (cfs) }\end{array}$ & $\begin{array}{l}\text { Difference } \\
\text { (cfs) }\end{array}$ & $\begin{array}{c}\% \\
\text { Difference }\end{array}$ \\
\hline Atchafalaya & Simmesport & $\begin{array}{l}\text { Atch } 7 \\
732010.6\end{array}$ & 489,618 & 489,800 & -182 & $-0.04 \%$ \\
\hline Atchafalaya & Morgan City & $\begin{array}{l}\text { Atch } 4 \\
138318.5\end{array}$ & 272,535 & 298,000 & $-25,465$ & $-8.55 \%$ \\
\hline $\begin{array}{l}\text { Wax Lake } \\
\text { Outlet }\end{array}$ & Calumet & $\begin{array}{l}\text { Wax Lake } 2 \\
99864.52\end{array}$ & 211,710 & 191,000 & 20,710 & $10.84 \%$ \\
\hline
\end{tabular}


Figure 111. Maximum water surface elevation for the 2002 flood.

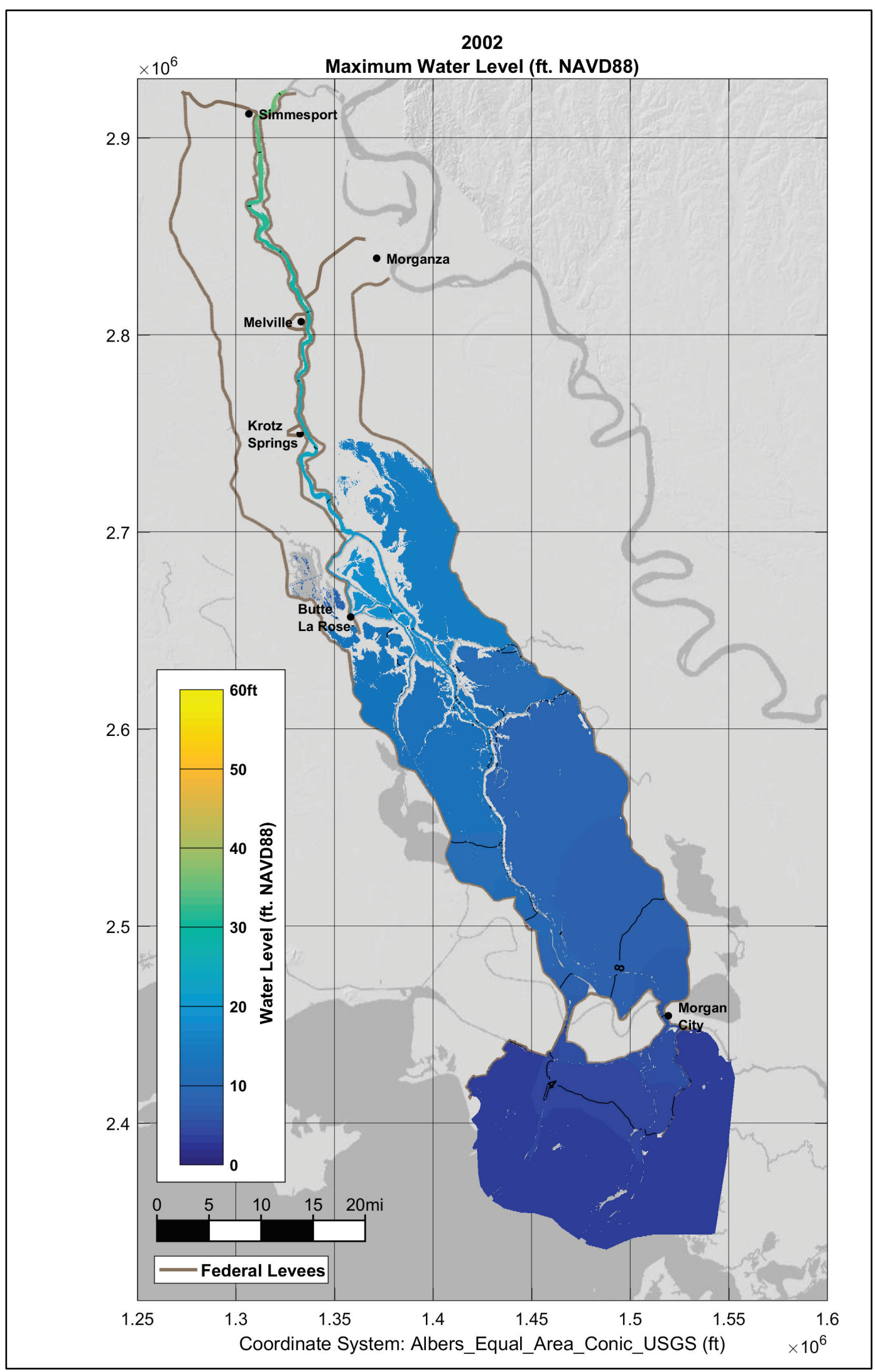


Figure 112. Maximum water surface elevation for the 2008 flood.

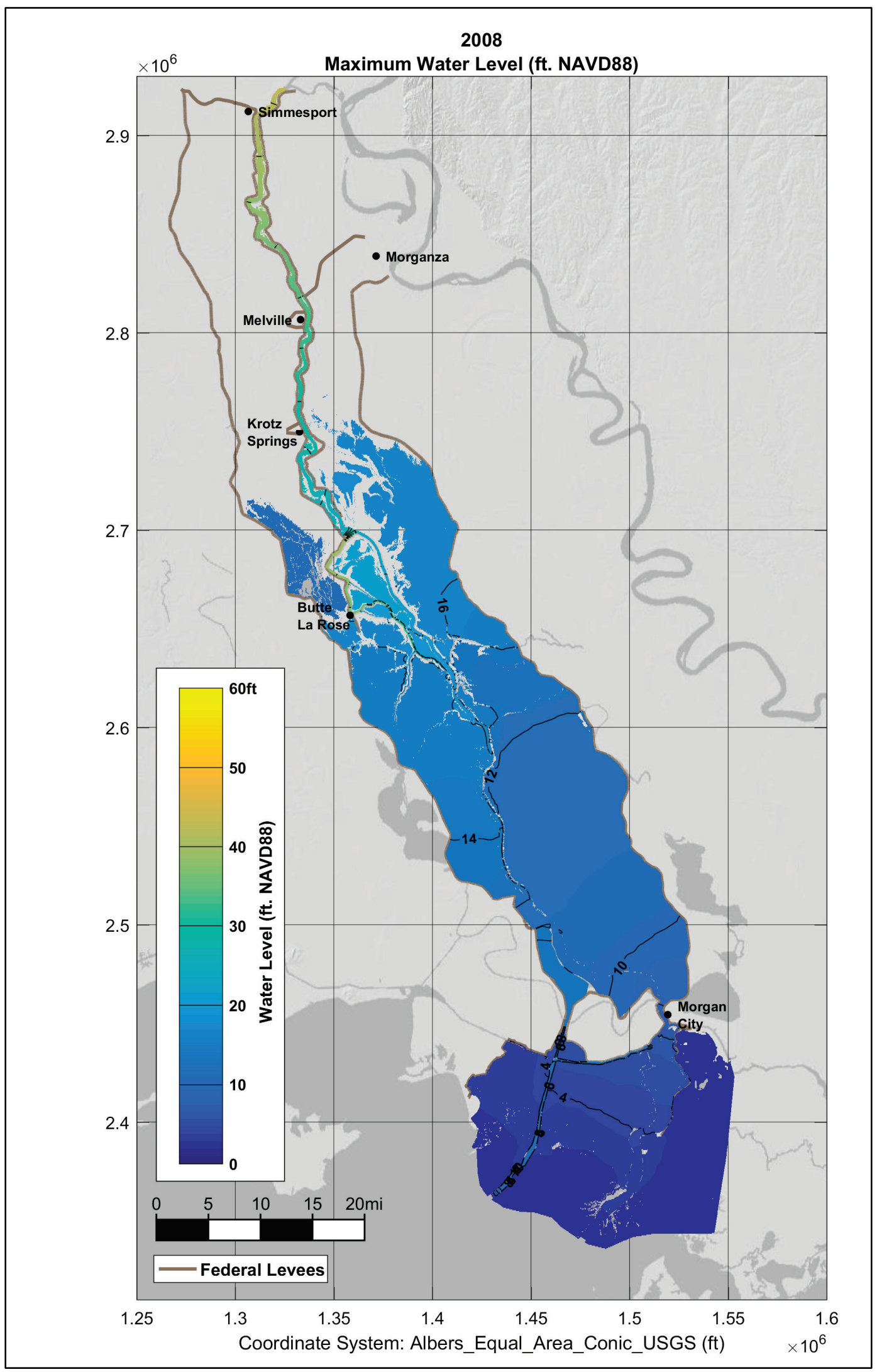


Figure 113. Maximum water surface elevation for the 2011 flood.

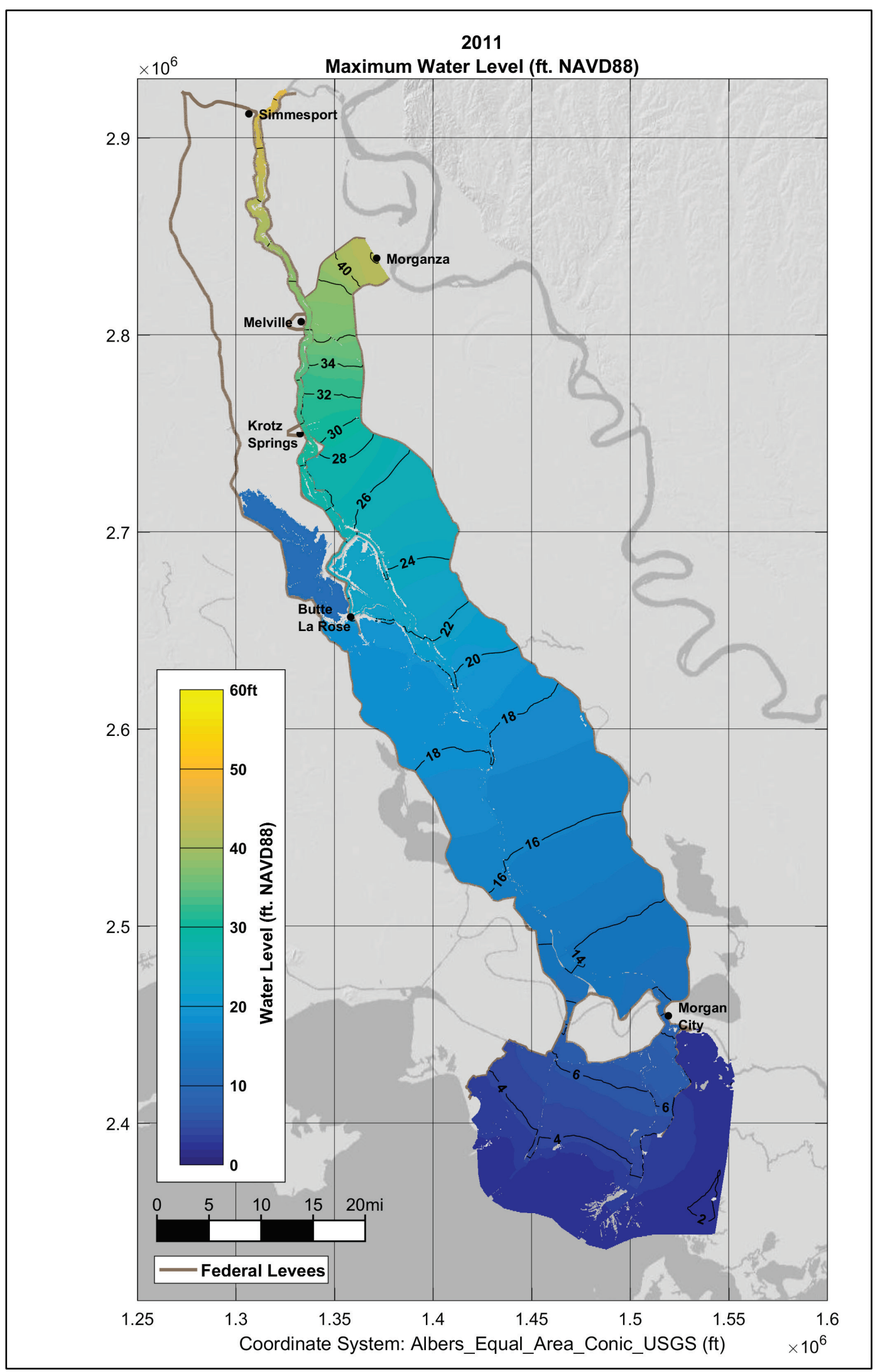




\subsection{Simulation of hypothetical design events}

Twenty-six hypothetical flood events were simulated with the calibrated Atchafalaya River HEC-RAS model. A list of all plans simulated is provided below. For the Atchafalaya, a special focus was assigned to the "2016 58A-R Authorized Yazoo," "2016 58A-R Existing Yazoo," and the "2016 Concept Existing" plans. These plans produce the most extreme water levels for the basin and thus are controlling the final flowline.

For the simulation of the hypothetical events, flows were provided from the Vicksburg portion of the Mississippi River RAS model at the Morganza Spillway and the Simmesport flow boundary. For simulation of existing condition hypothetical events, the stage boundary at the Gulf was set to $0.9 \mathrm{ft}$ NAVD88. For future conditions, the elevation of the Gulf was assumed to be $3.3 \mathrm{ft}$ NAVD88. These values represent a mean Gulf water surface elevation and are consistent with the mainstem Mississippi River model. A sensitivity analysis was conducted on the effects of the downstream boundary.

The PDF events are much larger than the 2011 calibration event. Note that the RAS model has more uncertainty for larger events, especially considering the fact that there are no PDF-scale events in the historic record.

\subsubsection{Existing condition simulations}

- Forced 58AEN

- Existing 58AEN

- Authorized 58AEN

- 2016 Unreg YBW at 112.8

- 2016 Unreg Existing YBW

- 2016 Reg YBW at 112.8

- 2016 Reg Existing YBW

- 1955 Historic 58 AEN Authorized Yahoo

- 1955 Historic 58 AEN Existing Yahoo

- 2016 58A-R Authorized Yazoo

- 2016 58A-R Existing Yazoo

- 2016 58A-U Authorized Yazoo

- 2016 58A-U Existing Yazoo

- 2016_52-R_Authorized_Yazoo

- 2016_52-R_Existing_Yazoo 
- 2016_52-U_Authorized_Yazoo

- 2016_52-U_Existing_Yazoo

- 2016_56-R_Authorized_Yazoo

- 2016_56-R_Existing_Yazoo

- 2016_56-U_Authorized_Yazoo

- 2016_56-U_Existing_Yazoo

- 2016_63-R_Authorized_Yazoo

- 2016_63-R_Existing_Yazoo

- 2016_63-U_Authorized_Yazoo

- 2016_63-U_Existing_Yazoo

- 2016 Concept Existing

Figure 114 displays the resulting maximum water surface for simulation of the 2016 58A-R Authorized Yazoo Plan. Figure 115 displays the maximum water surface of the 2016 58A-R Existing Yazoo Plan. Figure 116 displays the maximum water surface from the 2016 Concept Plan. The simulations appear to provide realistic inundation extent and depth for the hypothetical events. Table 34 contains the results for the three critical-case hypothetical events. The 58A-R plans produce approximately equivalent water surface elevations, and the concept plan produces approximately equivalent water surface elevations. The 2015 Concept Plan is slightly higher by approximately 1 to $1.5 \mathrm{ft}$ in the upper basin and nearly equivalent in the lower reaches. 
Figure 114. Maximum water surface elevation of the 2016 58A-R Authorized Yazoo Plan.

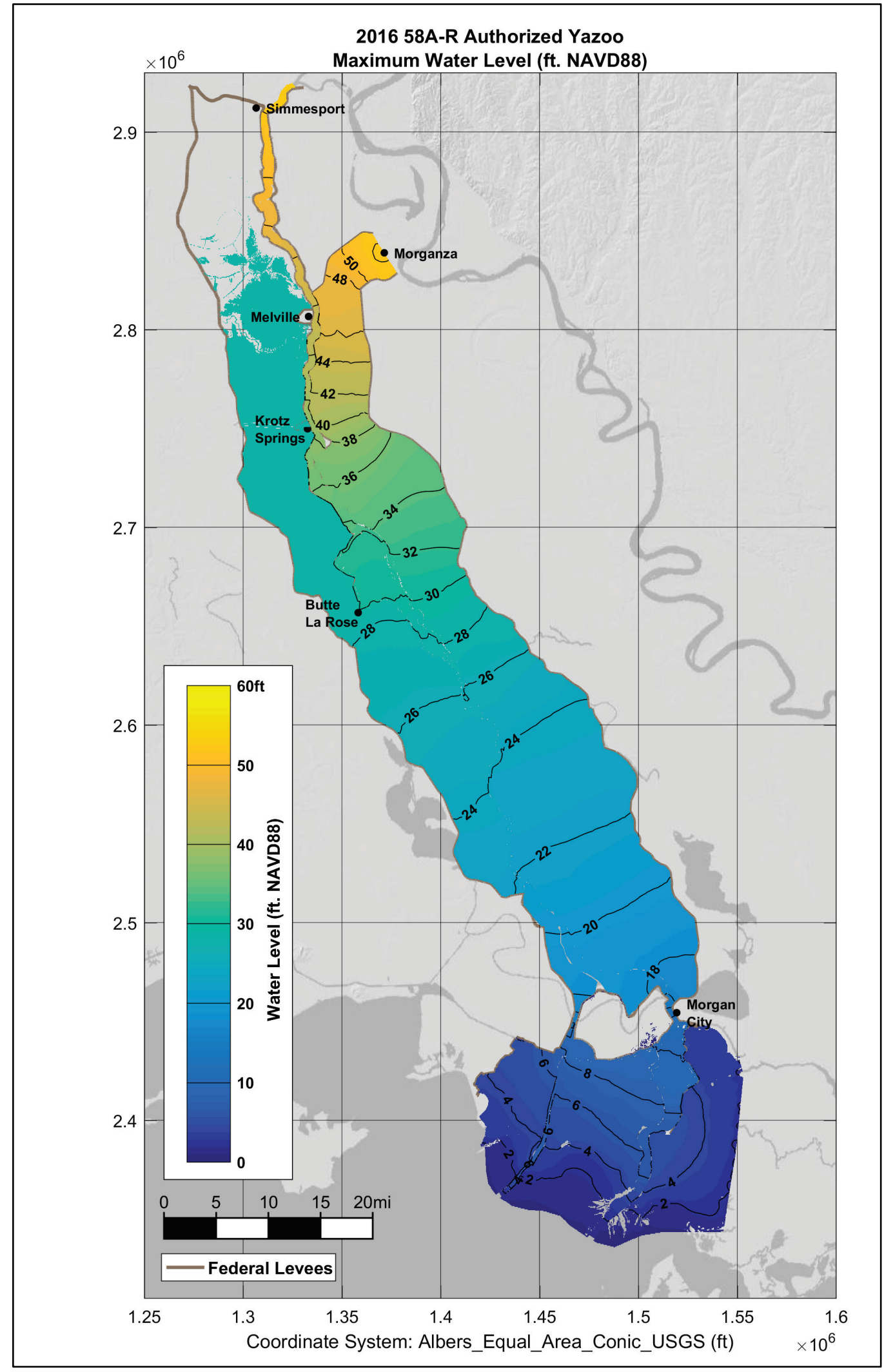


Figure 115. Maximum water surface elevation of the 2016 58A-R Existing Yazoo Plan.

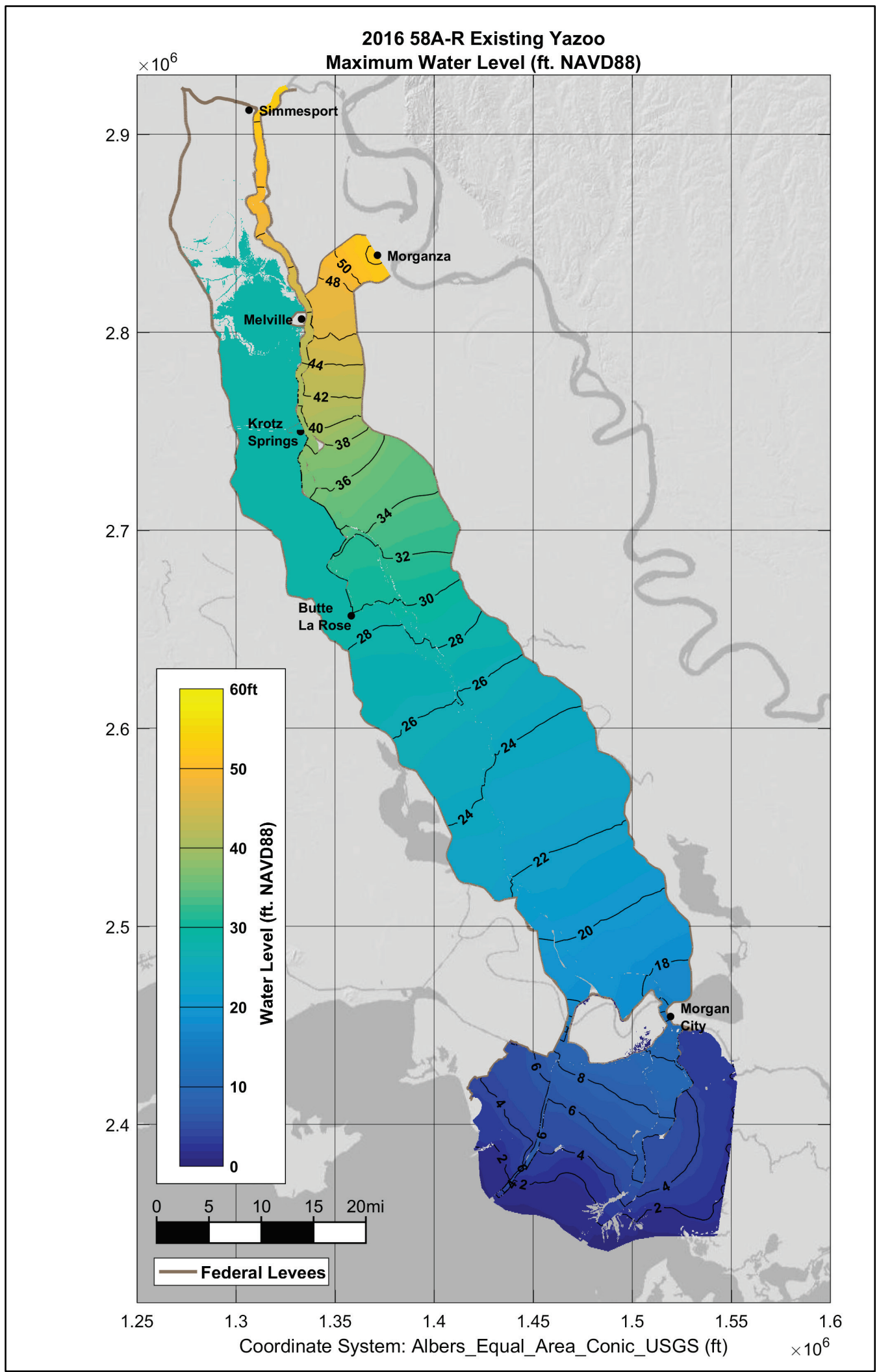


Figure 116. Maximum water surface elevation of the 2016 Concept Plan.

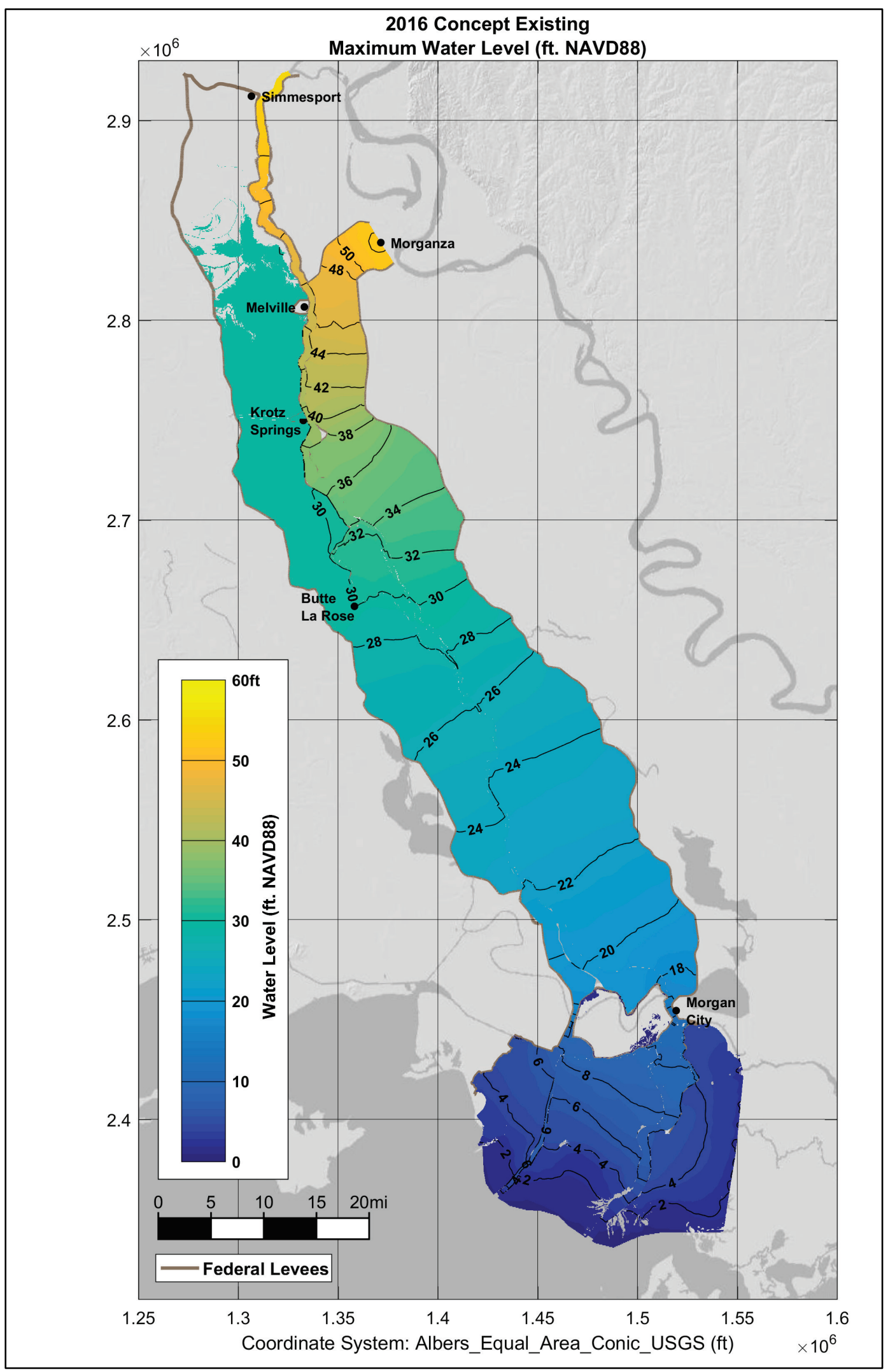


Table 34. Summary of hypothetical event maximum water surface elevations for existing conditions.

\begin{tabular}{|l|l|l|c|c|c|}
\hline \multicolumn{1}{|c|}{ River } & \multicolumn{1}{|c|}{ Station Name } & RAS Station & $\begin{array}{c}\text { 2016 58A-R } \\
\text { Authorized Yazoo }\end{array}$ & $\begin{array}{c}\text { 2016 58A-R } \\
\text { Existing Yazoo }\end{array}$ & $\begin{array}{c}\text { Concept } \\
\text { Existing }\end{array}$ \\
\hline Atchafalaya & Simmesport & $\begin{array}{l}\text { Atch } 7 \\
732010.6\end{array}$ & 52.18 & 52.47 & 53.83 \\
\hline Atchafalaya & Melville & $\begin{array}{l}\text { Atch 7 } \\
608311.8\end{array}$ & 43.49 & 43.72 & 44.74 \\
\hline Atchafalaya & Krotz Springs & $\begin{array}{l}\text { Atch 7 } \\
561101.4\end{array}$ & 40.05 & 40.22 & 41.02 \\
\hline Atchafalaya & $\begin{array}{l}\text { Whiskey Bay Pilot } \\
\text { Channel }\end{array}$ & $\begin{array}{l}\text { Atch Split } \\
125437.1\end{array}$ & 32.87 & 32.95 & 33.4 \\
\hline Atchafalaya & Butte La Rose & $\begin{array}{l}\text { Atch Split } \\
76965.38\end{array}$ & 29.83 & 29.9 & 30.36 \\
\hline Atchafalaya & $\begin{array}{l}\text { Chicot Pass near } \\
\text { Myette Point }\end{array}$ & $\begin{array}{l}\text { Atch 5 } \\
256773\end{array}$ & 21.6 & 21.68 & 22.24 \\
\hline Atchafalaya & Six Mile Lake & $\begin{array}{l}\text { Wax Lake 2 } \\
130064.4\end{array}$ & 19.06 & 19.12 & 19.68 \\
\hline Atchafalaya & Morgan City & $\begin{array}{l}\text { Atch 4 } \\
138318.5\end{array}$ & 11.56 & 11.62 & 11.91 \\
\hline $\begin{array}{l}\text { Wax Lake } \\
\text { Outlet }\end{array}$ & Calumet & $\begin{array}{l}\text { Wax Lake 2 } \\
99864.52\end{array}$ & 14.92 & 14.97 & 15.43 \\
\hline $\begin{array}{l}\text { Wax Lake } \\
\text { Outlet }\end{array}$ & Crewboat Channel & $\begin{array}{l}\text { Wax Lake 1 } \\
38069.36\end{array}$ & 6.77 & 6.78 & 6.8 \\
\hline Atchafalaya & Avoca Island Cutoff & $\begin{array}{l}\text { Atch 1 } \\
68558.72\end{array}$ & 6.69 & 6.73 & 6.85 \\
\hline
\end{tabular}

\subsubsection{Downstream boundary sensitivity test}

To evaluate the effects of the selected downstream stage boundary $(0.9 \mathrm{ft}$ NAVD88), a sensitivity test was conducted with a raised mean gulf elevation. The 2016 Concept Plan was simulated with an artificially raised downstream boundary to $3.3 \mathrm{ft}$. The results show that the raised mean Gulf elevation does not have a significant effect on the calculated profile. Figure 117 displays a comparison of the Concept Plan with a 0.9 and $3.3 \mathrm{ft}$ downstream boundary stage. The effects of the downstream boundary do not extend above Wax Lake Delta. 
Figure 117. Comparison of existing condition Concept Plan with downstream boundary set to 0.9 and $3.3 \mathrm{ft} \mathrm{NAVD88.}$

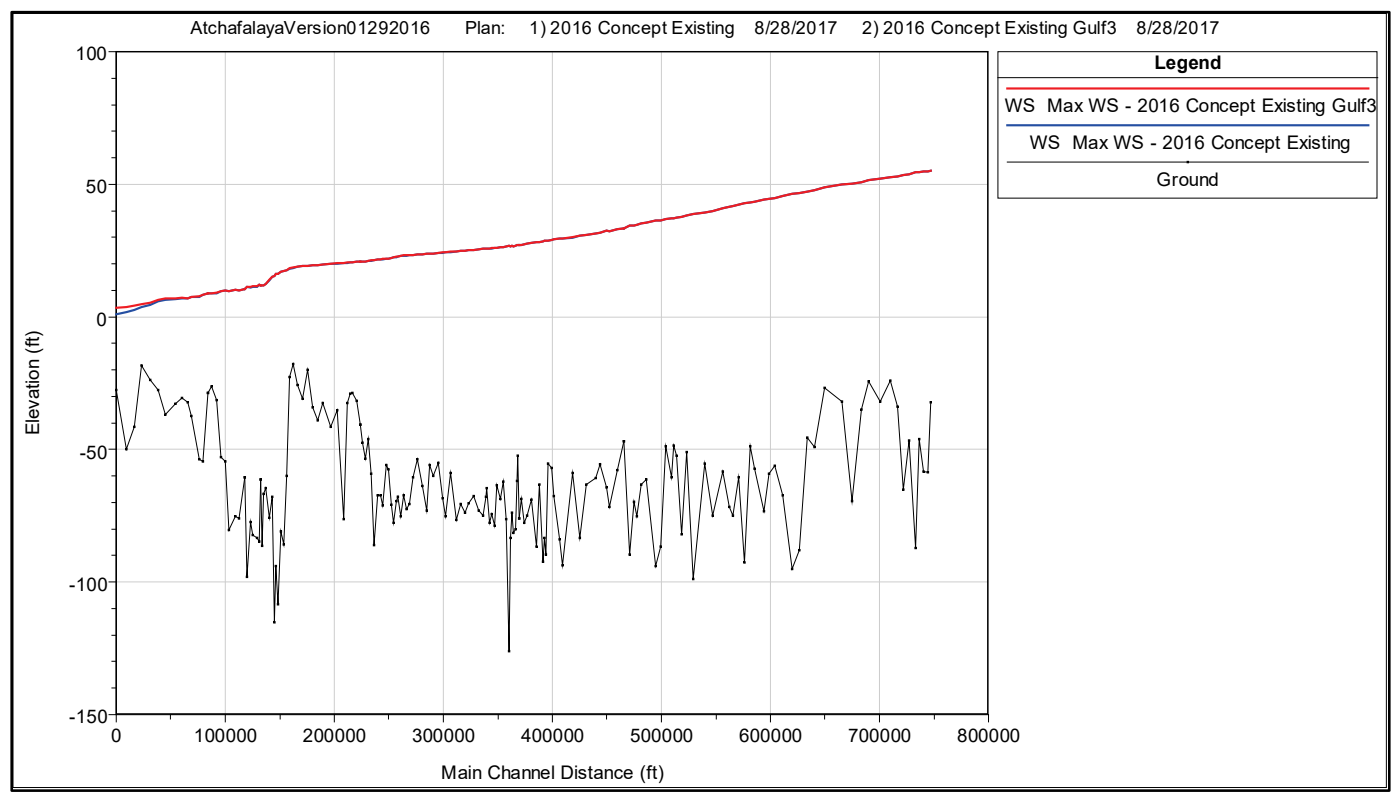

\subsubsection{Future condition geometry}

To account for future condition bed changes within the basin, a HEC-6T model was developed to simulate scour and deposition over a 50-year time period. Table 35 contains the total bed change applied to the various reaches of the HEC-RAS model. The fourth column of Table 35 represents the bed change caused by 50 years of sedimentation, approximately 2016 to 2066. The fifth column is the change from that point (2066 numbers) to the peak of the PDF event. The bed change in the fifth column is caused by the hydrograph of the PDF event itself. Since the HEC-RAS model is using a fixed-bed geometry, it was necessary to include an estimate of the bed changes that happen during the flood. The two bed change values are added together to get the expected bed change from 2016 to the peak of a PDF event occurring in the year 2067. Reaches that are not listed (Gulf Intracoastal Waterway and A21-99), were not simulated in the 6T model, so no bed change was applied to the model in these areas. A Matlab script was developed to modify the geometry file and apply the bed change to each cross section. Figure 118 displays a future condition cross section in the Atchafalaya River with a $+9.5 \mathrm{ft}$ bed adjustment. Figure 119 displays a cross section with the $-11.5 \mathrm{ft}$ bed adjustment. The Matlab script was set to only modify bathymetry between the banks. No changes were made to the elevations of overbank areas, including the terrain applied to the $2 \mathrm{D}$ areas. 


\subsubsection{Future condition simulations}

Three plans were simulated using the future condition geometry:

1. 2016 58A-R Existing Yazoo Future

2. 2016 58A-R Authorized Yazoo Future

3. 2016 Concept Future.

The results of each future condition plan were compared to the corresponding existing condition simulation. Figure 120, Figure 121, and Figure 122 show the water surface elevation profiles for the existing and future condition scenarios. In general, the trend in water surface elevation change appears to be somewhat counterintuitive. The future condition water level increases near the Gulf due to sea level rise. Near Morgan City, the water level actually decreases in the future condition, most likely because the cross sections downstream were lowered $11.5 \mathrm{ft}$. Figure 123 through Figure 127 display the existing and future condition water level time series at Simmesport, Mellville, Krotz Springs, Butte La Rose, and Calumet. Table 36 contains the maximum water surface elevations at various locations for the 58A-R Existing, 58A-R Authorized, and Concept hypothetical events for future conditions.

Table 35. Future condition bed change adjustments.

\begin{tabular}{|l|c|c|c|c|c|}
\hline \multicolumn{1}{|c|}{ River } & $\begin{array}{c}\text { Upstream } \\
\text { XS }\end{array}$ & Downstream XS & $\begin{array}{c}\text { Bed Adjustment } \\
\text { from 10/1/2010 } \\
\text { to 10/1/2066 } \\
\text { (ft) }\end{array}$ & $\begin{array}{c}\text { Bed Adjustment from } \\
\text { 10/1/2066 to the } \\
\text { Peak of the PDF (ft) }\end{array}$ & $\begin{array}{c}\text { Total Bed } \\
\text { Adjustment } \\
\text { Applied to } \\
\text { Model (ft) }\end{array}$ \\
\hline Atch & 18957.01 & 2719.914 & 1 & -4 & -3 \\
\hline Atch & 25881.71 & 25881.71 & 2.7 & 0 & 2.7 \\
\hline Atch & 41382.14 & 33563.18 & 2.8 & 0 & 2.8 \\
\hline Atch & 57287.42 & 47666.67 & 2.8 & -4.5 & -1.7 \\
\hline Atch & 63075.32 & 63075.32 & 8.2 & -4.5 & 3.7 \\
\hline Atch & 94485.92 & 68558.72 & 4.8 & -4.5 & 0.3 \\
\hline Atch & 120513.6 & 98835.9 & 5 & -12.5 & -7.5 \\
\hline Atch & 125947 & 123105.8 & 5 & -25.5 & -20.5 \\
\hline Atch & 134315.2 & 128249.9 & 5.7 & -25.5 & -19.8 \\
\hline Atch & 143623.7 & 135620.3 & 0 & -9 & -9 \\
\hline Atch & 156948.7 & 146057.3 & 6 & -16.5 & -10.5 \\
\hline Atch & 162338.7 & 159741.5 & 6 & -0.5 & 5.5 \\
\hline Atch & 227227.7 & 165558.3 & 10.5 & -0.5 & 10 \\
\hline WaxLake & 8237.124 & 1445.184 & 0 & 0 & 0 \\
\hline WaxLake & 32561.78 & 26764.01 & 0.5 & -6.5 & -6 \\
\hline
\end{tabular}




\begin{tabular}{|l|c|c|c|c|c|}
\hline \multicolumn{1}{|c|}{ River } & $\begin{array}{c}\text { Upstream } \\
\text { XS }\end{array}$ & Downstream XS & $\begin{array}{c}\text { Bed Adjustment } \\
\text { from 10/1/2010 } \\
\text { to 10/1/2066 } \\
\text { (ft) }\end{array}$ & $\begin{array}{c}\text { Bed Adjustment from } \\
\text { 10/1/2066 to the } \\
\text { Peak of the PDF (ft) }\end{array}$ & $\begin{array}{c}\text { Total Bed } \\
\text { Adjustment } \\
\text { Applied to } \\
\text { Model (ft) }\end{array}$ \\
\hline WaxLake & 38069.36 & 38069.36 & -5.3 & -2.5 & -7.8 \\
\hline WaxLake & 48692.56 & 41565 & -5.3 & -1 & -6.3 \\
\hline WaxLake & 79657 & 56100.93 & -5.3 & 0 & -5.3 \\
\hline WaxLake & 97192.81 & 81922.72 & 0 & 0 & 0 \\
\hline WaxLake & 99864.52 & 99864.52 & -4 & 0 & -4 \\
\hline WaxLake & 112305.5 & 104402.8 & -10 & 0 & -10 \\
\hline WaxLake & 155746 & 113545.4 & -0.7 & 0 & -0.7 \\
\hline Atch & 243947.4 & 230375.6 & 8.2 & 0 & 8.2 \\
\hline Atch & 306553.2 & 246498.7 & 6.8 & 0 & 6.8 \\
\hline Atch & 398154.3 & 310726.6 & 4 & 0 & 4 \\
\hline AtchSplit & 28319.64 & 2874.749 & 4 & 0 & 8 \\
\hline Atch & 470193.8 & 400592.8 & 4 & 4 & 2 \\
\hline AtchSplit & 125437.1 & 33140.38 & 2 & 0 & 2 \\
\hline Atch & 751747.4 & 475518.4 & 3.5 & -1.5 & 4 \\
\hline
\end{tabular}

Figure 118. Future condition cross section with accretion.

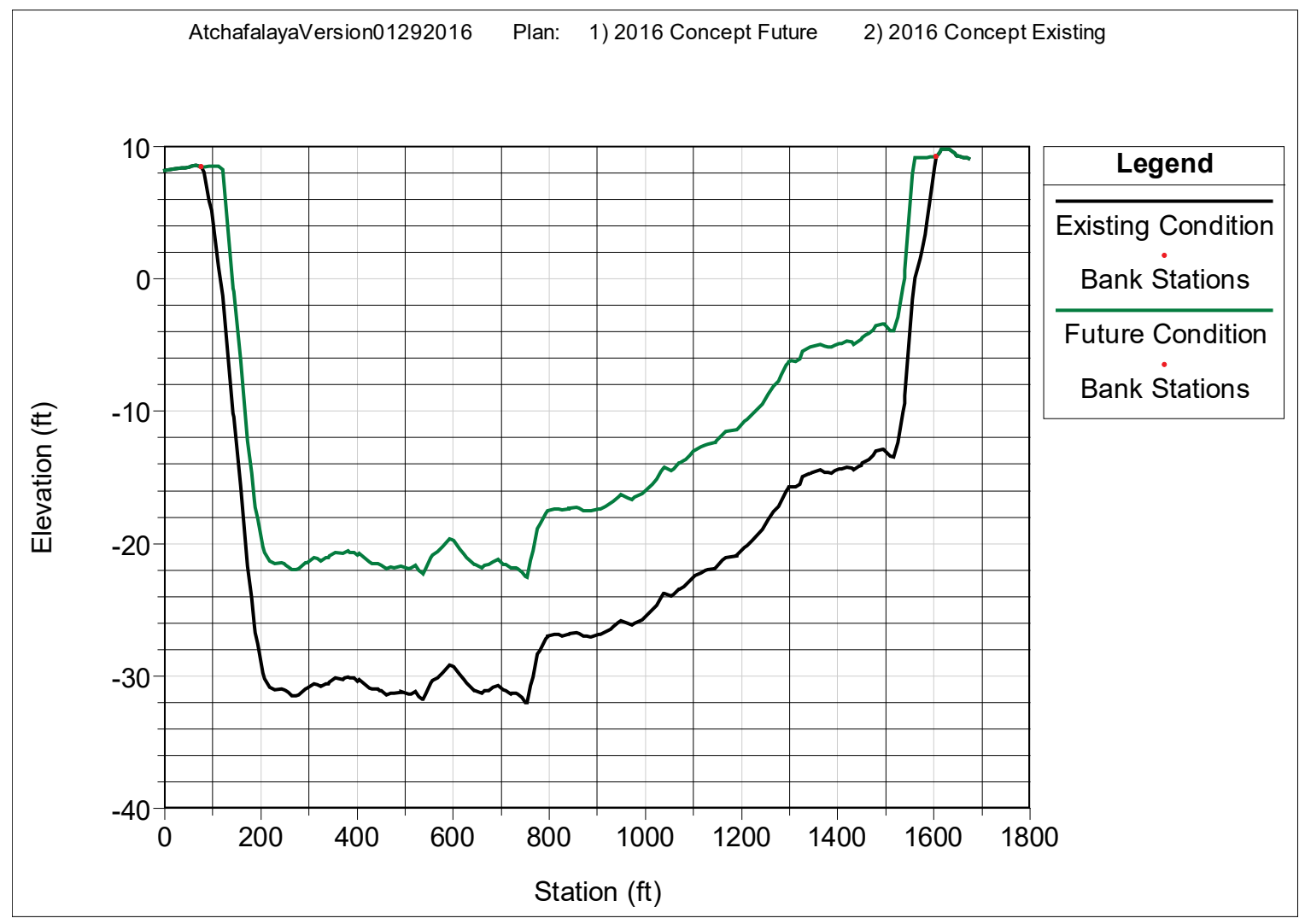


Figure 119. Future condition cross section with scour.

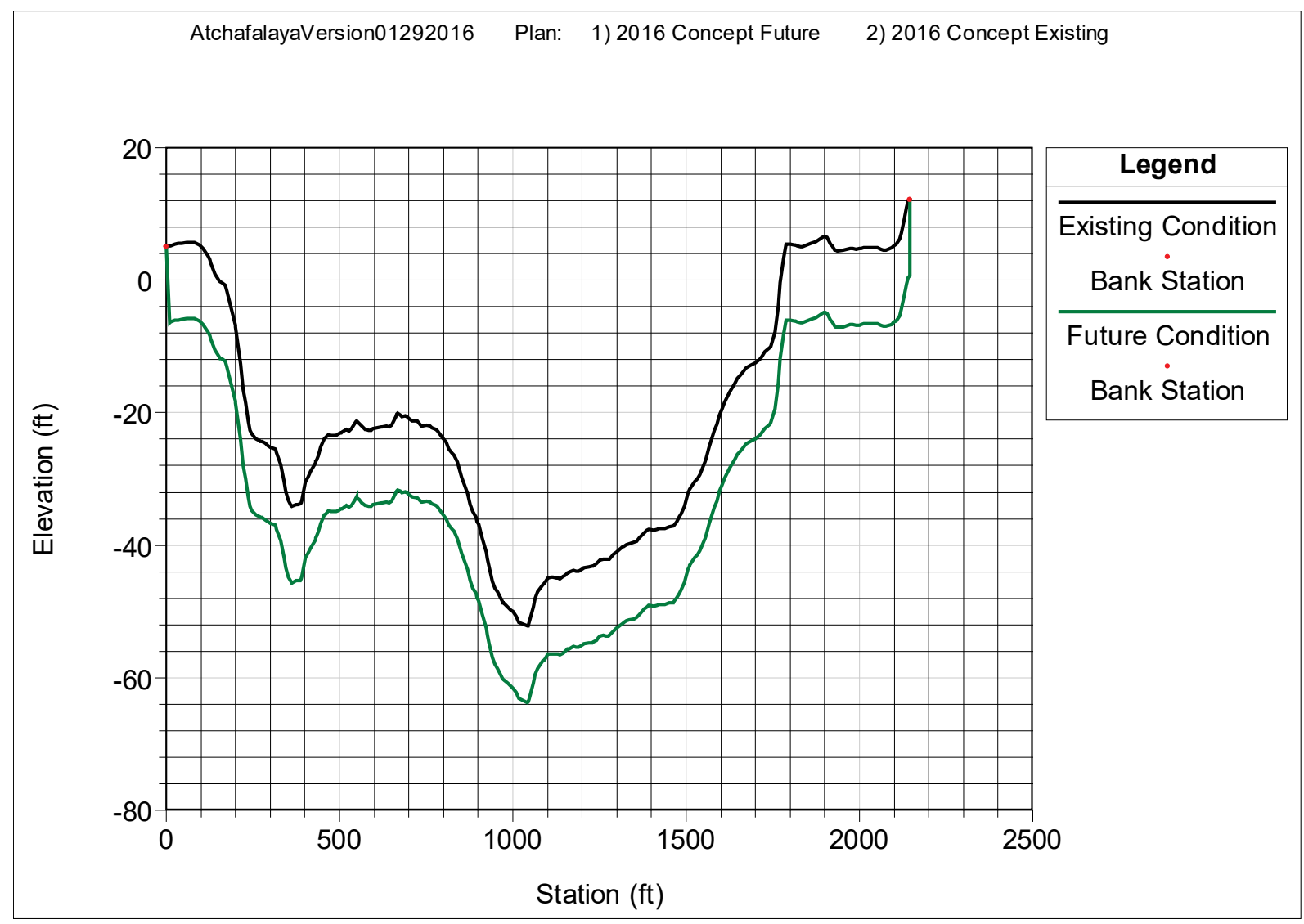


Figure 120. Comparison of existing and future condition bed change and peak water surface for the 58 A-R Authorized Yazoo Plan.

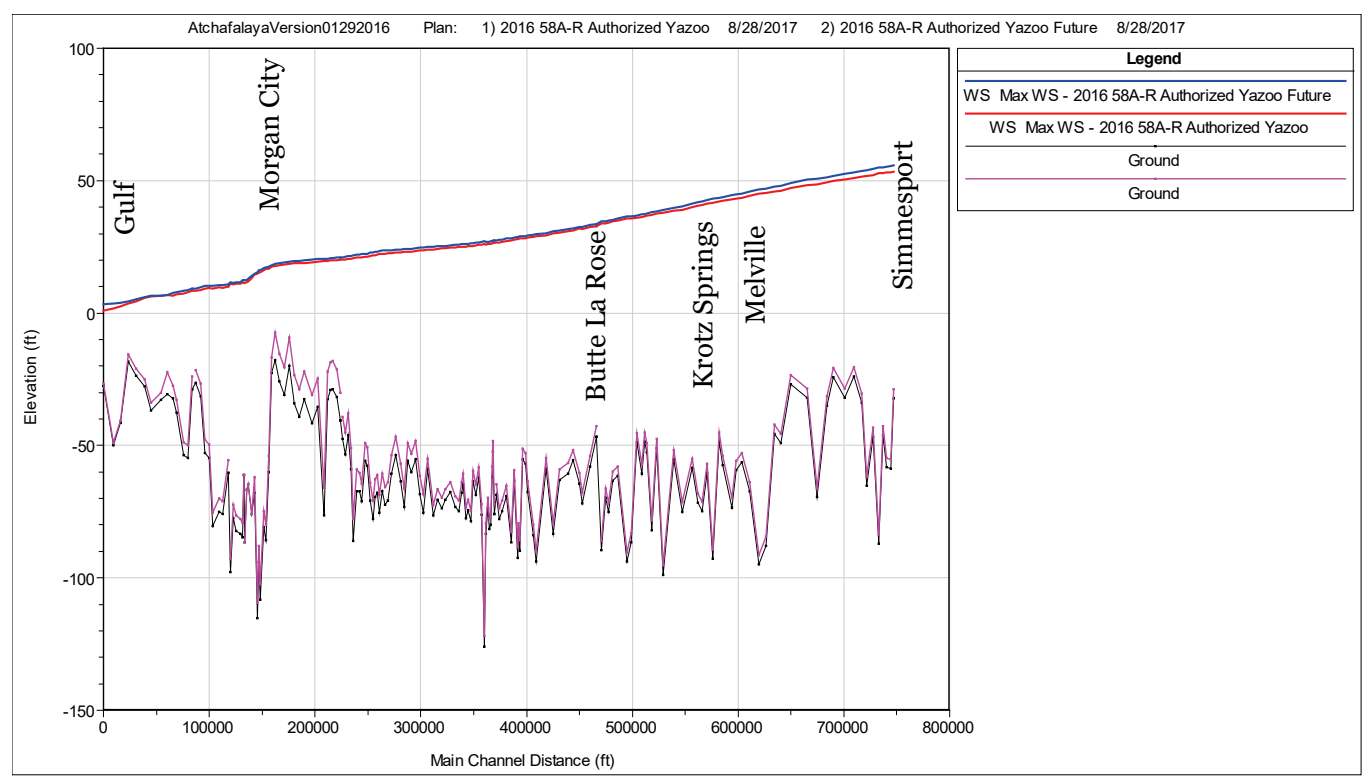

Figure 121. Comparison of existing and future condition bed change and peak water surface for the 58 A-R Existing Yazoo Plan.

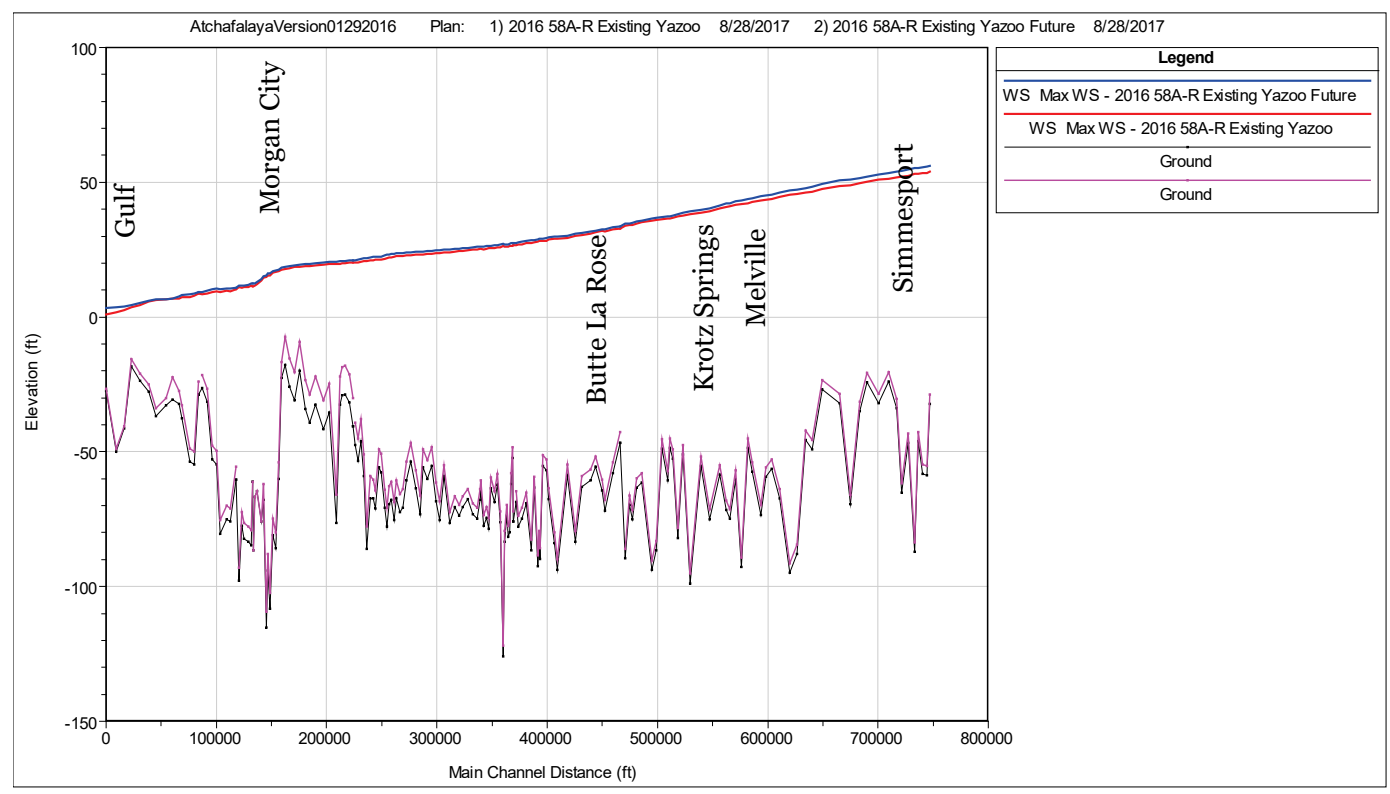


Figure 122. Comparison of existing and future condition bed change and peak water surface for the Concept Plan.

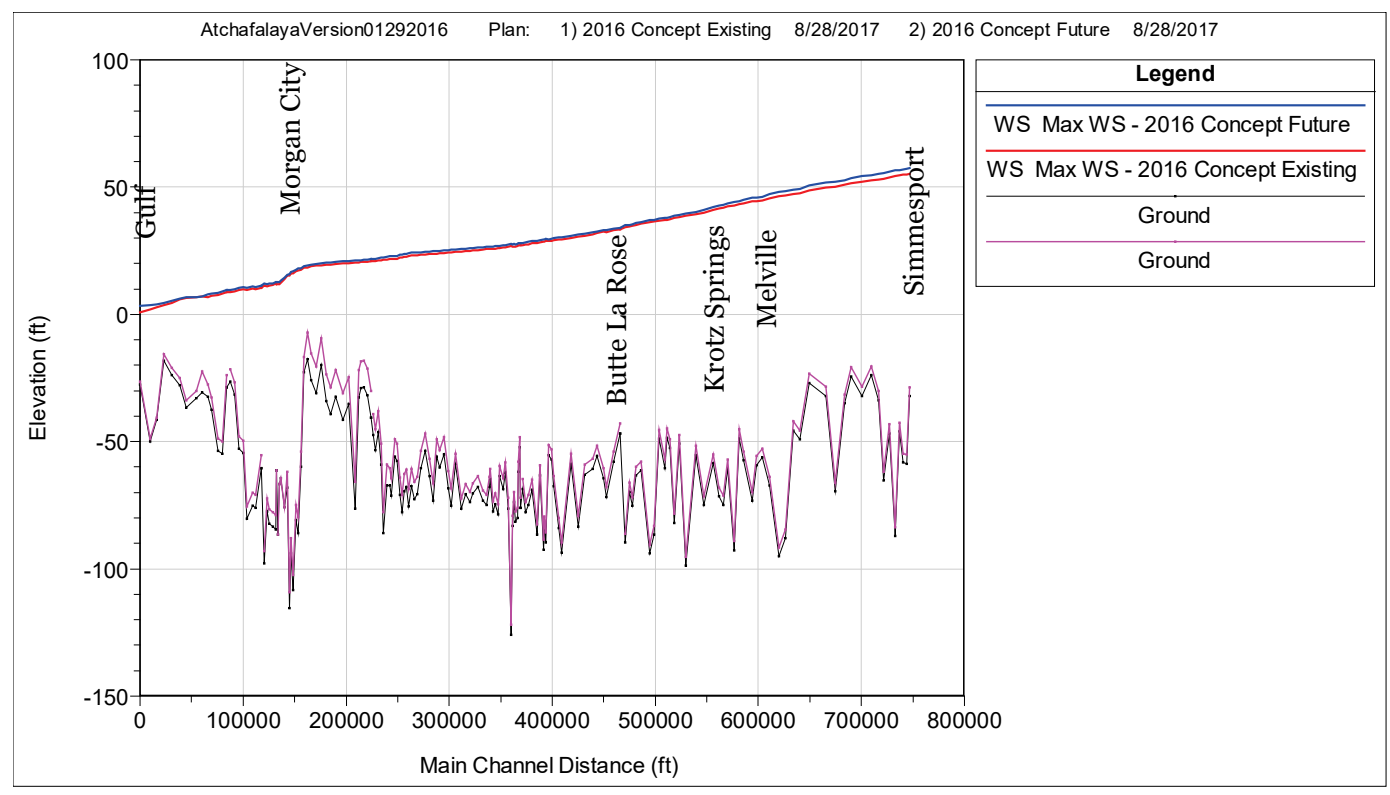

Figure 123. 58A-R modeled stages at Simmesport, LA.

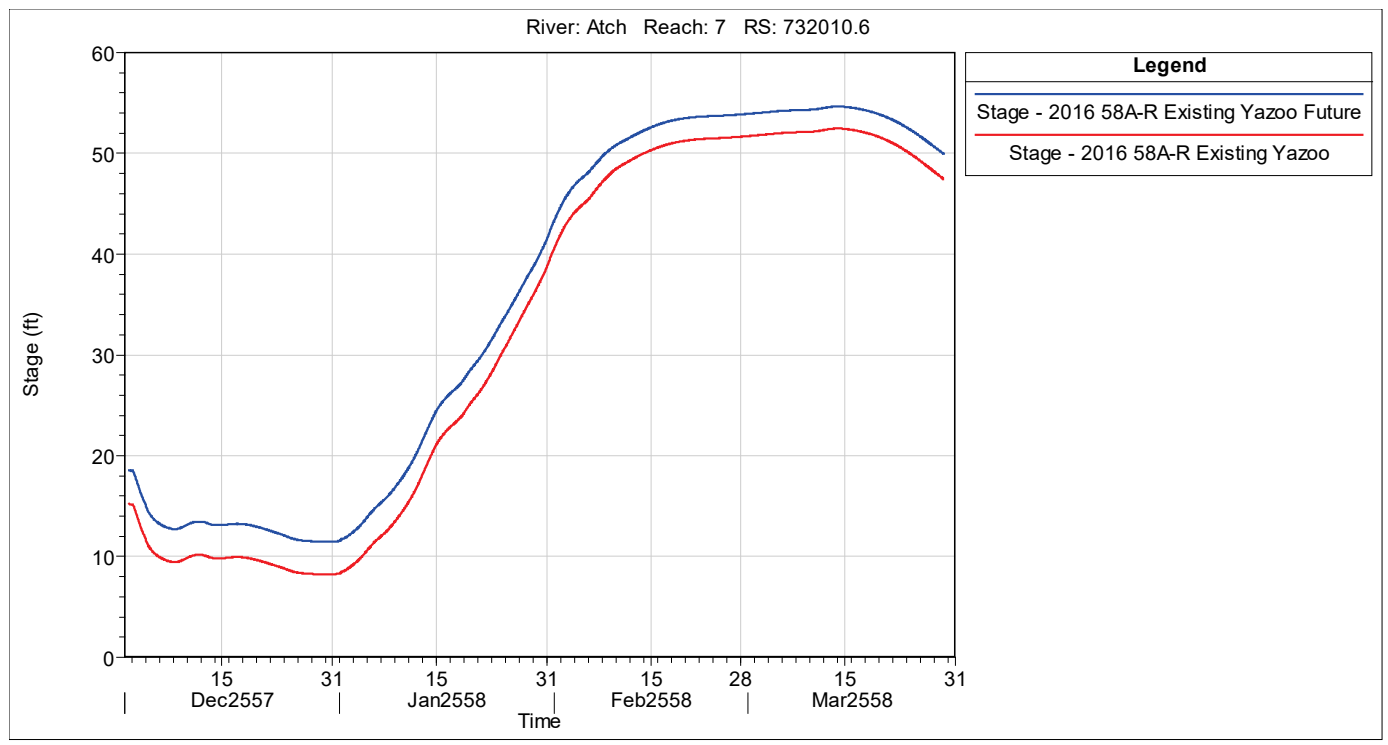


Figure 124. 58A-R modeled stages at Mellville, LA.

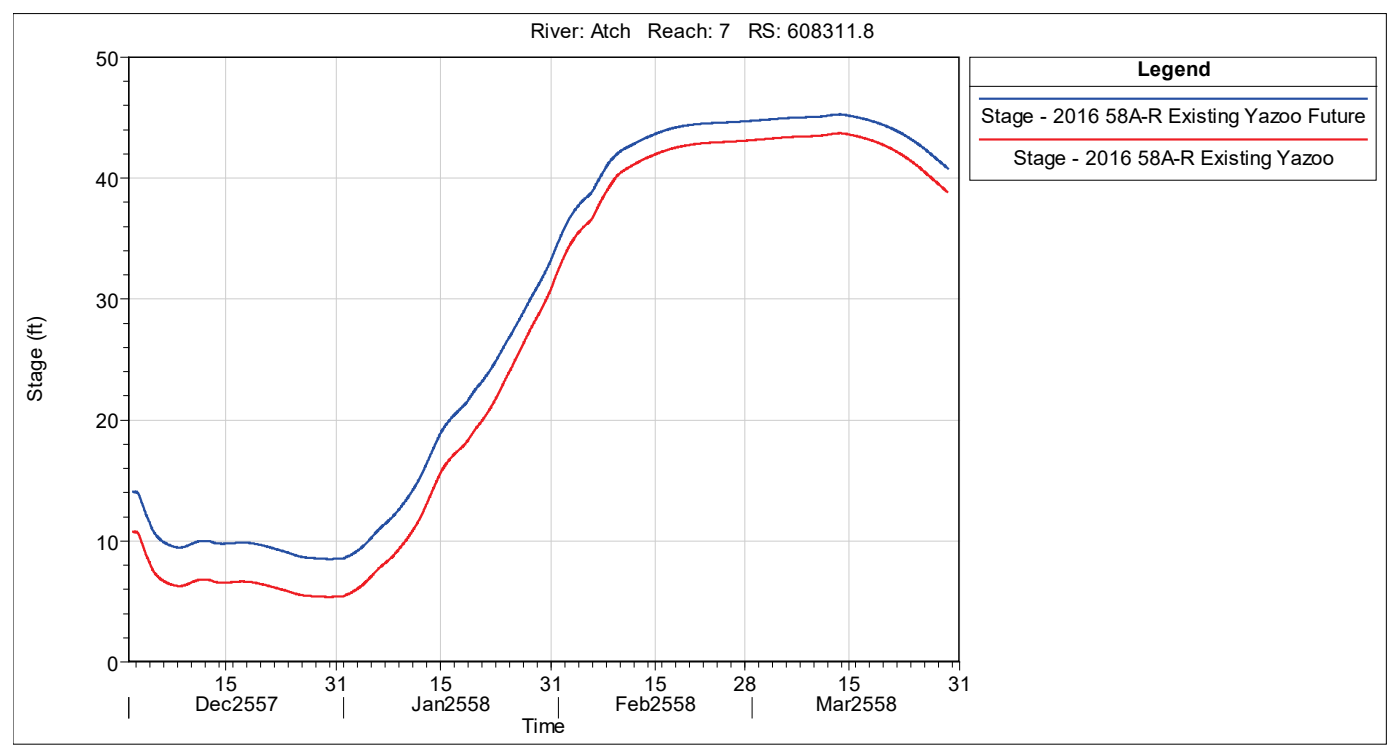

Figure 125. 58A-R modeled stages at Krotz Springs, LA.

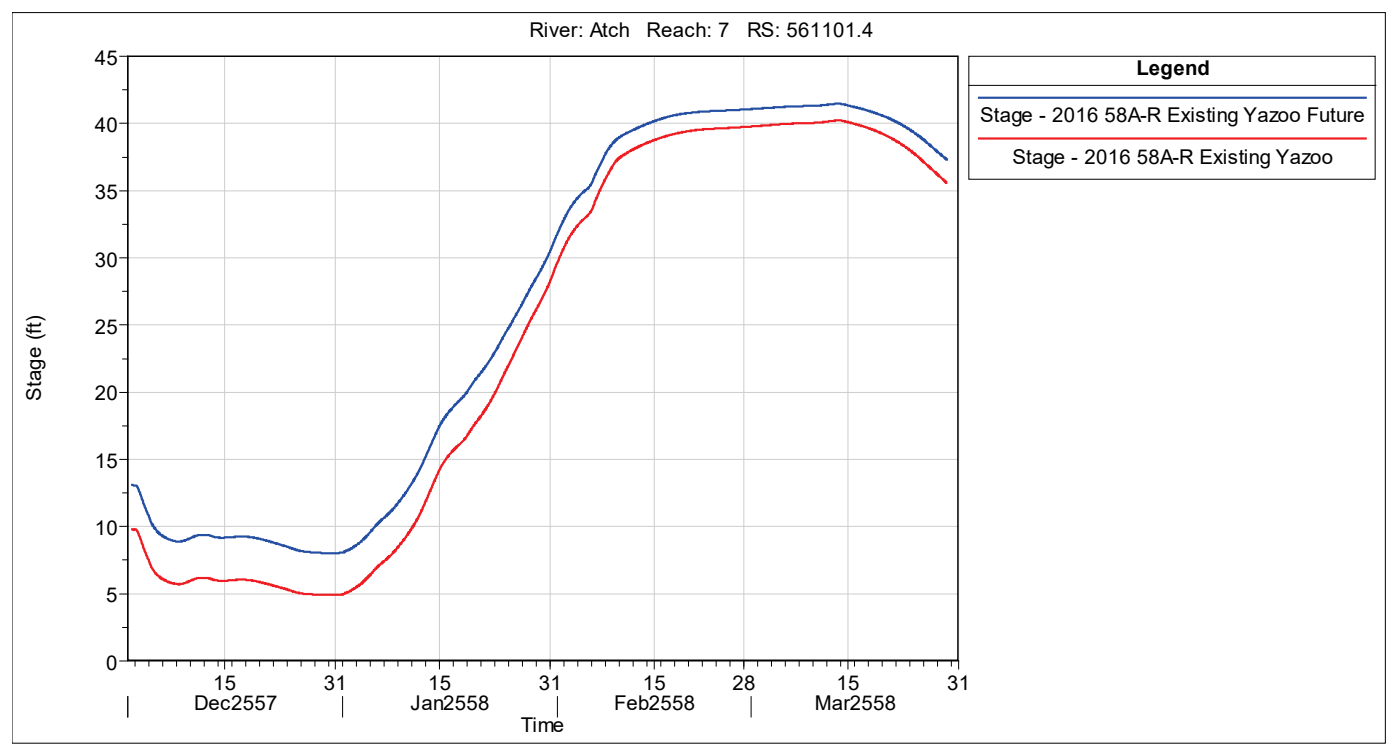


Figure 126. 58A-R modeled stages at Butte La Rose.

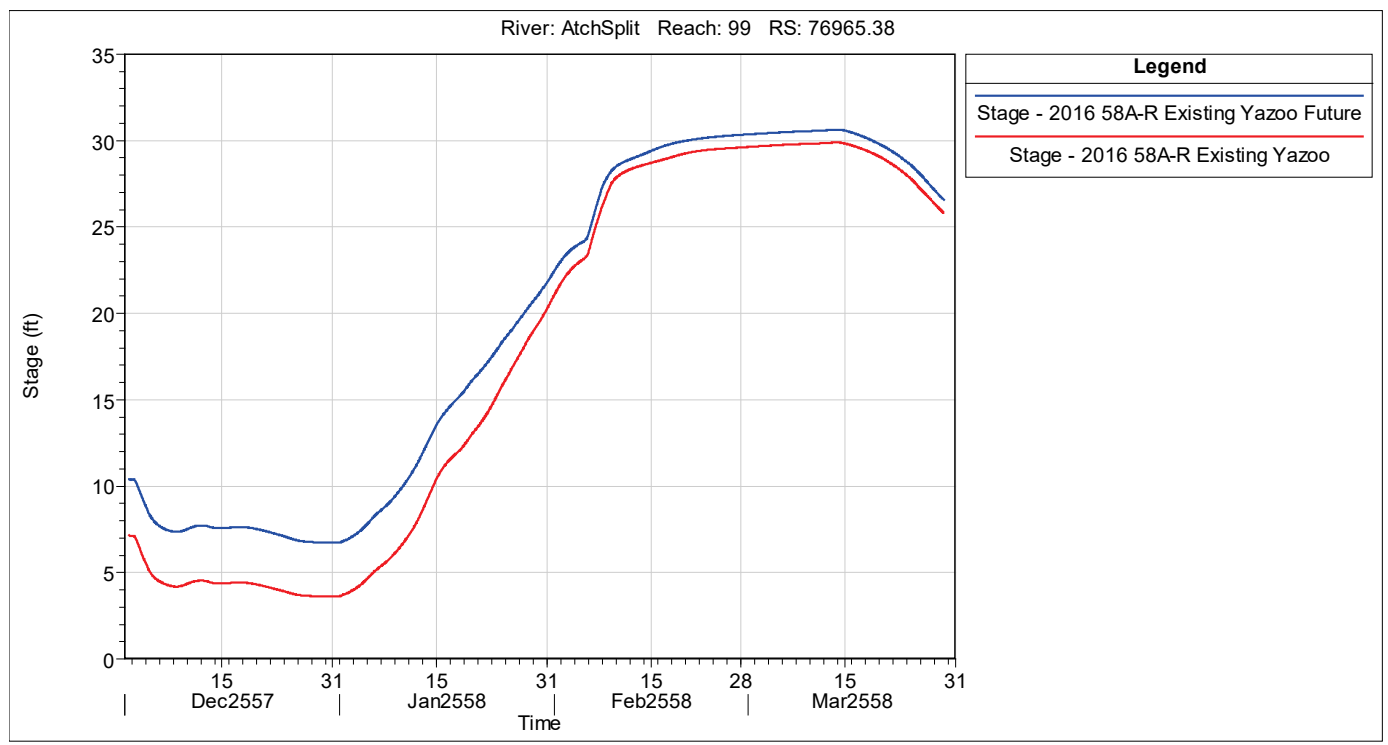

Figure 127. 58A-R modeled stages at Calumet.

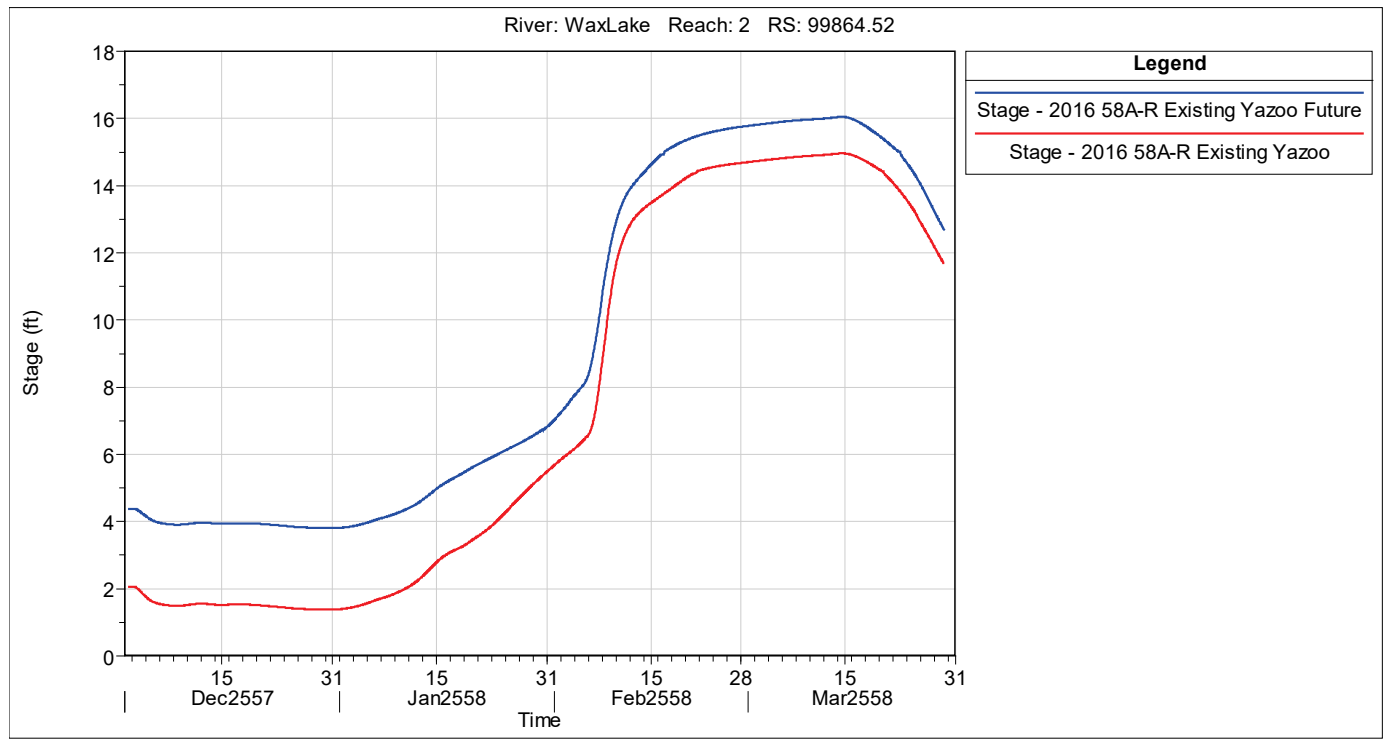


Table 36. Summary of hypothetical maximum water surface elevations for future conditions.

\begin{tabular}{|c|c|c|c|c|c|}
\hline River & Station Name & RAS Station & $\begin{array}{l}\text { 58A-R Authorized } \\
\text { Yazoo Future }\end{array}$ & $\begin{array}{l}\text { 58A-R Existing } \\
\text { Yazoo Future }\end{array}$ & $\begin{array}{l}\text { Concept } \\
\text { Future }\end{array}$ \\
\hline Atchafalaya & Simmesport & $\begin{array}{l}\text { Atch } 7 \\
732010.6\end{array}$ & 54.38 & 54.66 & 55.95 \\
\hline Atchafalaya & Melville & $\begin{array}{l}\text { Atch } 7 \\
608311.8\end{array}$ & 45.06 & 45.28 & 46.2 \\
\hline Atchafalaya & Krotz Springs & \begin{tabular}{|l} 
Atch 7 \\
561101.4
\end{tabular} & 41.32 & 41.47 & 42.15 \\
\hline Atchafalaya & $\begin{array}{l}\text { Whiskey Bay Pilot } \\
\text { Channel }\end{array}$ & $\begin{array}{l}\text { Atch Split } \\
125437.1\end{array}$ & 34.38 & 34.4 & 34.44 \\
\hline Atchafalaya & Butte La Rose & $\begin{array}{l}\text { Atch Split } \\
76965.38\end{array}$ & 30.64 & 30.66 & 31.2 \\
\hline Atchafalaya & $\begin{array}{l}\text { Chicot Pass near } \\
\text { Myette Point }\end{array}$ & $\begin{array}{l}\text { Atch } 5 \\
256773\end{array}$ & 22.84 & 22.91 & 23.45 \\
\hline Atchafalaya & Six Mile Lake & $\begin{array}{l}\text { Wax Lake } 2 \\
130064.4\end{array}$ & 19.95 & 20.03 & 20.58 \\
\hline Atchafalaya & Morgan City & $\begin{array}{l}\text { Atch } 4 \\
138318.5\end{array}$ & 12.45 & 12.49 & 12.81 \\
\hline $\begin{array}{l}\text { Wax Lake } \\
\text { Outlet }\end{array}$ & Calumet & $\begin{array}{l}\text { Wax Lake } 2 \\
99864.52\end{array}$ & 15.98 & 16.05 & 16.52 \\
\hline $\begin{array}{l}\text { Wax Lake } \\
\text { Outlet }\end{array}$ & Crewboat Channel & $\begin{array}{l}\text { Wax Lake } 1 \\
38069.36\end{array}$ & 6.9 & 6.9 & 6.91 \\
\hline Atchafalaya & Avoca Island Cutoff & $\begin{array}{l}\text { Atch 1 } \\
68558.72\end{array}$ & 7.62 & 7.64 & 7.79 \\
\hline
\end{tabular}

\subsection{Comparison to 2010 flowline analysis}

In 2010, a separate flowline analysis was conducted for the Atchafalaya River. The purpose of this section is to compare the results from the 2010 analysis to the current (2016) analysis. Table 37 shows some of the significant changes to methodology for the older and newer studies. A comparison was made between the official 2010 flowline water levels and the latest 201658 A-R water levels ${ }^{1}$. Figure 128 displays the comparison between 2010 and 2016 water levels. In general, the newer values are significantly lower.

Changes to the methodology are one reason for the decrease in values. In addition to modeling differences, channel surveys in recent years have

\footnotetext{
1 The comparison analysis between 2010 and 2016 results was performed in response to comments received after the independent external peer review phase of this assessment.
} 
consistently shown wide-spread scouring, or channel lowering, in the Upper Atchafalaya River. In the Lower Atchafalaya Basin, there has been a long trend of accretion occurring in the river channel and in the floodplain areas. This filling has caused the stage-flow relationships to increase for all flow regimes. From an uncertainty perspective, both 2010 and 2016 HEC-RAS models calibrated well to large-scale flood events. However, the PDF event is much larger than anything that is observed in the historical record. The uncertainty of the modeling is higher for extreme floods since there is no way to validate the response of the models for events that have not happened.

Table 37. Comparison of 2010 and 2016 Atchafalaya flowline analyses.

\begin{tabular}{|l|l|l|}
\hline & 2010 Flowline Analysis & $\begin{array}{l}\text { 2016 Flowline Analysis } \\
\text { (2016 58 A-R) }\end{array}$ \\
\hline Geometry & RAS 4.0 1D, AdH model & RAS 5.0.3 1D/2D \\
\hline \multirow{2}{*}{ Flows } & Steady State & Unsteady \\
\cline { 2 - 3 } & $\begin{array}{l}930,000 \text { Simmesport 630,000 } \\
\text { Morganza Includes West } \\
\text { Floodway }\end{array}$ & $\begin{array}{l}886,440 \text { peak Simmesport } \\
600,000 \text { peak Morganza No } \\
\text { west floodway }\end{array}$ \\
\hline $\begin{array}{l}\text { Downstream } \\
\text { Boundary }\end{array}$ & AdH with 5 ft gulf elevation & $0.9 \mathrm{ft}$ gulf elevation \\
\hline Calibration & $\begin{array}{l}1997(\sim 630,000 \text { cfs at } \\
\text { Simmesport) }\end{array}$ & $\begin{array}{l}2011(\sim 700,000 \text { cfs at } \\
\text { Simmesport })\end{array}$ \\
\hline Verification & 1998,2005 & 2002,2008 \\
\hline
\end{tabular}


Figure 128. Difference between 2010 and 2016 peak flood profiles.

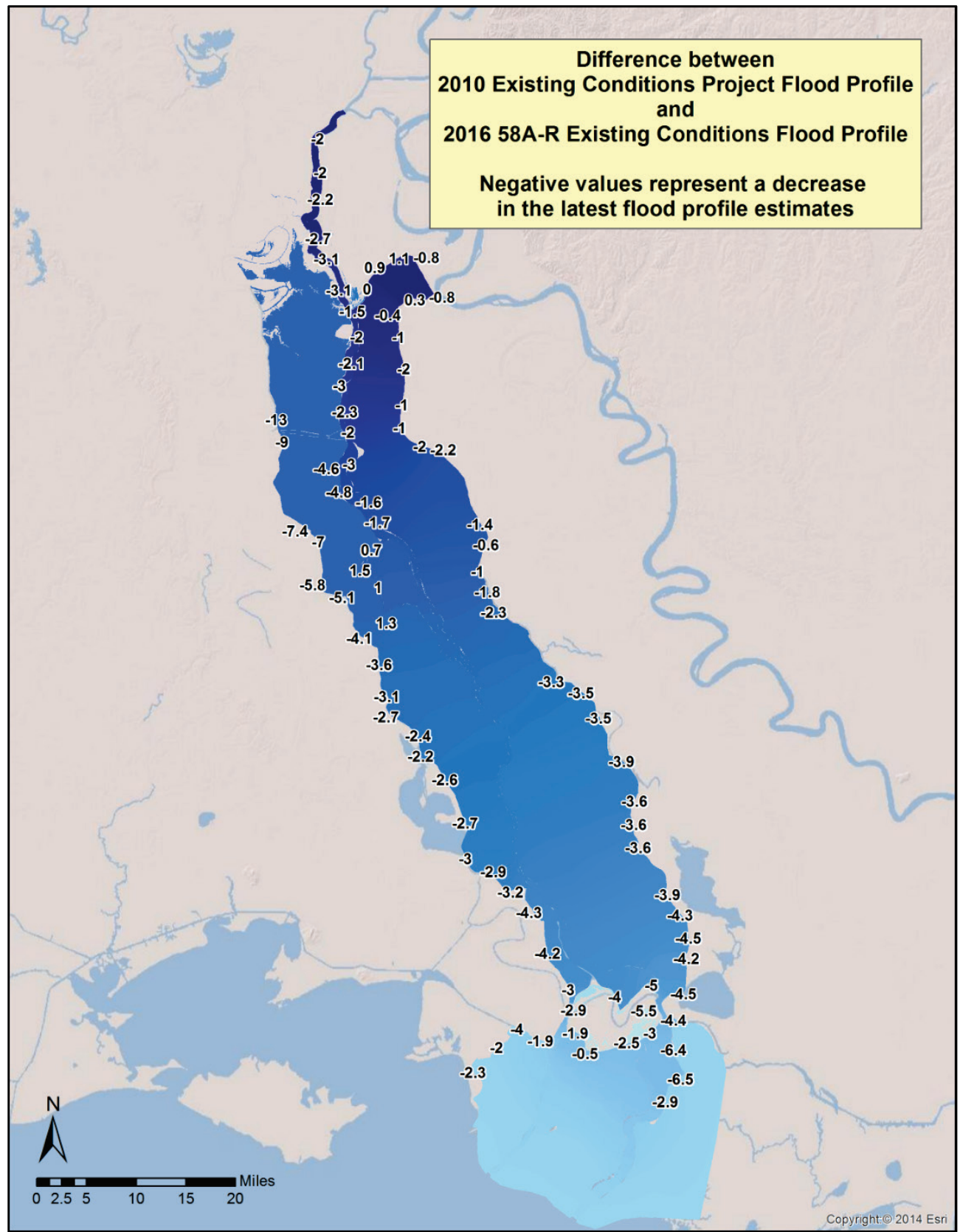

\subsection{Summary and path forward}

The Atchafalaya River HEC-RAS model has been used to evaluate a series of past floods including the 2002, 2008, and 2011 events. The model was also applied to evaluate hypothetical design events. In addition to these tasks, the model was also used during the 2016 flood to forecast stages within the basin. Additionally, the model was used to evaluate changes to the authorized 70/30 flow distribution at the ORCC. The model will be useful for a variety of future uses. 


\section{Summary}

An unsteady flow Hydrologic Engineering Center - River Analysis System (HEC-RAS) model was developed for the Mississippi River from Chester, IL, to Venice, LA (RAS stations 1163 to 15.07), by combining the individual Memphis District, Vicksburg District, and New Orleans District models. The model was calibrated to the 2011 Mississippi River flood event and validated to the 2002 and 2008 high flow events. The purpose of the modeling effort was to capture the behavior of the Mississippi River during large events. The model developed for this effort performs well in terms of both timing and magnitude of the peak events in each simulation when compared with gage observations.

This model was then used to simulate the Project Design Flood (PDF) event. The historic PDF simulations used the previous hydrographs developed from the 1955 hydrology as inflow boundary conditions to the HEC-RAS model. These simulations resulted in very similar flows occurring throughout the river as was reported previously (USACE 1978), but the stages showed some differences, primarily due to geomorphic channel changes that have occurred since the 1970s. The new PDF simulations used the new hydrograph flows developed within this assessment as inflow boundary conditions to the HEC-RAS model. New Hypo PDF HEC-RAS simulations were performed for the 58A, 52A, 56, and 63 storm events. The 58A storm event produced the highest maximum water surface elevations throughout the river from Cairo, IL, to Venice, LA.

The peak flows of the new hydrology results were higher and occurred sooner than the hydrology results developed in 1955. The New Hypo 58A$\mathrm{R}$ PDF simulations generally resulted in higher peak stages throughout the Mississippi River HEC-RAS model. Many water surface elevations were approximately $4 \mathrm{ft}$ higher in the 58A-R Authorized Yazoo simulation than the Refined 1973 Flowline Study water surfaces, converted to NAVD88. Locations with the greatest differences between the Refined 1973 Flowline Study and the 58A-R Authorized Yazoo results were just upstream of Memphis and near Baton Rouge.

Four backwater areas of the Mississippi River and the operation of Old River Control Complex (ORCC) were adjusted within the Concept Plan to lower flows within the Mississippi River. Through the optimization of the backwater areas and the operation of ORCC, peak flows were reduced 
to the Refined 1973 PDF flood flows for areas below ORCC. This scenario was based solely on whether it was technically possible within the HECRAS model to reduce the flows to the Refined 1973 PDF levels and does not take into consideration increased inundation, potential consequences, costs, environmental impacts, or what, if any, authorization change would be required.

Future sea level rise was incorporated into the downstream boundary conditions of the HEC-RAS model in order to estimate its impact 50 years from now. There was an increase in peak water surface elevations in the lower few hundred miles of the river. 


\section{References}

Adam, T., S. Chen, R. Davis, T. Schade, and D. Lee. 2010. “The Ohio River Community HEC-RAS Model.” In Proceedings, ASCE EWRI Congress 201O, Challenges of Change, Providence, RI.

Biedenharn, D. S., M. A. Allison, C. D. Little, C. R. Thorne, and C. C. Watson. 2017. Large-Scale Geomorphic Change in the Mississippi River from St. Louis, MO, to Donaldsonville, LA, as Revealed by Specific Gage Records. MRG\&P Report No. 10. Vicksburg, MS: U.S. Army Engineer Research and Development Center. http://dx.doi.org/10.21079/11681/22744.

Colby, B. R., and C. H. Scott. 1965. Effect of Water Temperature on the Discharge of Bed Materials. Geological Survey Professional Paper 462-G. Washington DC: U.S. Government Printing Office. https: $/ /$ www.google.com/url?sa $=t \& r c t=j \& q=\& e s r c=s \&$ source=web\&cd=1\&cad=rja\&uact=8\&ve $\mathrm{d}=0$ ahUKEwihtZqWuPPYAhWLKMAKHeNaAx8QFggnMAA\&url=https\%3A\%2F\%2Fpubs. usgs.gov\%2 Fpp\%2F0462g\%2Freport.pdf\&usg=AOvVaw2AHnltygZXRaZTxCQ3iChv.

Driessen, T. L. A., and M. van Ledden. 2013. "The Large-Scale Impact of Climate Change to Mississippi Flood Hazard in New Orleans." Drinking Water Engineering and Science 6: 81-87. https://doi.org/10.5194/dwes-6-81-2013.

Homer, C. G., J. A. Dewitz, L. Yang, S. Jin, P. Danielson, G. Xian, J. Coulston, N. D. Herold, J. D. Wickham, and K. Megown. 2015. "Completion of the 2011 National Land Cover Database for the Conterminous United States-Representing a Decade of Land Cover Change Information." Photogrammetric Engineering and Remote Sensing 81(5): 345-354.

https://cfpub.epa.gov/si/si_public_file_download.cfm?p_download_id=525722.

Lopez, John, Theryn Henkel, Ezra Boyd, Paul Conner, Megan Milliken, Andrew Baker, Kristian Gustavson, and Luis Martinez. 2013. Bohemia Spillway in Southeastern Louisiana: History, General Description, and 2011 Hydrographic Surveys. Lake Pontchartrain Basin Foundation. http://saveourlake.org/wp-content/uploads/PDFDocuments/our-coast/Bohemia/Bohemia\%20Report_March2013.pdf.

National Oceanic and Atmospheric Administration (NOAA). 2013. Digital Coast Data Access Viewer. Custom processing of USGS Atchafalaya 2 LiDAR. Charleston, SC: NOAA Office for Coastal Management. https://coast.noaa.gov/dataviewer.

Sharp, Jeremy A., Charles D. Little, Gary L. Brown, Thad C. Pratt, Ronald E. Heath, Lisa C. Hubbard, Fred Pinkard, S. Keith Martin, Nathan Dwayne Clifton, David W. Perkey, and Naveen B. Ganesh. 2013. West Bay Sediment Diversion Effects. ERDC/CHL TR-13-15. Vicksburg, MS: U.S. Army Research and Development Center. http://hdl.handle.net/11681/7733.

U.S. Army Corps of Engineers (USACE). 1955. Mississippi River Project Flood Study, Memorandum Report No. 1. Office of the President, Mississippi River Commission. Vicksburg, MS: Mississippi River Commission. 
USACE. 1957. Mississippi River and Tributaries Project-Volume II Annex C-Project Design Flood Study. House Document No. 308 of the 88th Congress, $2^{\text {nd }}$ Session. Vicksburg, MS: Mississippi River Commission.

USACE. 1978. Refined 1973 MR\&T Project Flood Flowline. Vicksburg, MS: U.S. Army Engineer District, Vicksburg.

USACE. 1999. Water Control Manual, Bonnet Carre Spillway. U.S. Army Engineer District, New Orleans.

USACE. 2000. Water Control Manual, Morganza Floodway. U.S. Army Engineer District, New Orleans.

USACE. 2010. HEC-RAS, River Analysis System, Version 4.1.o. Accessed 7 February 2015. at http://www.hec.usace.army.mil/software/hec-ras/downloads.aspx.

USACE. 2012a. MR\&T 2011 Post Flood Report: Documenting the 2011 Flood, the Corps' Response, and the Performance of the MR\&T System. http://www.mvd.usace.army.mil/Missions/Flood-Risk-Management/Regional-Flood-RiskManagement-Program/MR-T-Post-Flood-Report/.

USACE. 2012b. HEC Geo-RAS 10.2 for ArcGIS 10.2. Accessed 12 February 2015 at http://www.hec.usace.army.mil/software/hec-georas/downloads.aspx.

USACE. 2012c. MR\&T 2011 Post Flood Report: Documenting the Project Manager for Water Control; Morganza Control Structures, Mississippi River \& Tributaries Project; Lower Mississippi River Basin, Louisiana. U.S. Army Engineer District, New Orleans.

USACE. 2013. Incorporating Sea Level Change in Civil Works Programs. ER 1100-28162. Washington, DC: U.S. Army Corps of Engineers. http://www.publications.usace.army.mil/Portals/76/Publications/EngineerRegulations/ER_110 0-2-8162.pdf?ver=2014-02-12-131510-113.

USACE. 2014. Morganza Floodway Interim Water Control Manual Proposed Clarifications to the Standing Instructions. U.S. Army Engineer District, New Orleans.

http://www.mvn.usace.army.mil/Portals/56/docs/MRT/MorganzaInterimWCM StandingInstructionsSimplifiedFINAL.pdf.

USACE. 2015. HEC-RAS, River Analysis System, versions 4.2 beta and 5.0 beta. Limited release from HEC. http://www.hec. usace.army.mil/contact/.

USACE. 2018a. Mississippi River and Tributaries Flowline Assessment Main Report. MRG\&P Report No. 24; Volume 1. Vicksburg, MS: U.S. Army Engineer Research and Development Center.

U.S. Army Corps of Engineers. 2018b. Mississippi River and Tributaries Flowline Evaluation of Project Flood Hydrology. MRG\&P Report No. 24; Volume 2. Vicksburg, MS: U.S. Army Engineer Research and Development Center.

USACE. 2018c. Mississippi River and Tributaries Flowline Assessment: Mississippi River Sedimentation Report. MRG\&P Report No. 24; Volume 4. Vicksburg, MS: U.S. Army Engineer Research and Development Center. 
USACE. 2018d. Mississippi River and Tributaries Flowline Assessment: Atchafalaya River Sedimentation Model Report. MRG\&P Report No. 24; Volume 5. Vicksburg, MS: U.S. Army Engineer Research and Development Center.

USACE. 2018e. Corpscon Version 6.o. Army Geospatial Center, Alexandria, VA. Accessed 26 January. http://www.agc.army.mil/Missions/Corpscon.aspx. (downloaded 8 February 2015).

U.S. Congress. 1954. House of Representatives. Mississippi River and Tributaries with Respect to Old River Control. $83^{\text {rd }}$ Congress, $2^{\text {nd }}$ session, July 9, 1954. House Document 478.

U.S. Congress. 1964. House of Representatives. Mississippi River and Tributaries Project. $88^{\text {th }}$ Congress, $2^{\text {nd }}$ session, 21 May 1964. House Document 308.

Zou, Lei, Joshua Kent, Nina S. N. Lam, Heng Cai, Yi Qiang, and Kenan Li. 2015. "Evaluating Land Subsidence Rates and Their Implications for Land Loss in the Lower Mississippi River Basin.” Water 8(1): 10. 


\section{Appendix A: Memphis District (MVM) Model}

\section{A.1 Background}

The initial Memphis District model development employed the Hydrologic Engineering Center (HEC), River Analysis System (RAS) (version 4.1.0 [USACE 2010] as well as version 4.2.0 Beta and version 5.o Beta; since that time, there was an official release of HEC-RAS version 5.0.1) hydraulic modeling software. The unsteady hydraulic model was constructed by using an older version of the model and improving on that but was enhanced and updated from an older version of a RAS model that was being used in the basin and referred to as the Ohio River Community Model (Adam et al. 2010). A mini-model version of the ORCM was used during the 2011 Mississippi River flood by the NWS) with the support of the Hydrologic Engineering Center (HEC) in an attempt to forecast river stages and the activation of the Bird's Point-New Madrid Floodway. The mini-model had upstream extents of Chester, IL, on the Mississippi River and Smithland, KY, on the Ohio River. The downstream boundary was Caruthersville, MO, which is located approximately 110 river miles downstream of the confluence of the Mississippi and Ohio Rivers. The mini-model was updated significantly by the MVM and extended downstream to Vicksburg, MS, to include the major tributaries that either contribute significant flow or experience a considerable backwater effect during high flood events. Inflows due to precipitation within the MVM model limits were estimated using NWS hydrologic models and further routed in the hydraulic model.

The 2D RAS models of the BPNMF and the confluence of the Arkansas, White, and Mississippi Rivers were constructed for this effort due to the complexity of those locations. These models were calibrated and refined using the most advanced features available in RAS version 4.2.0 beta and RAS version 5.o Beta (release 22 March 2015). A schematic of the MVM hydraulic model is shown in Figure 129. 
Figure 129. Chester, IL/Smithland, KY, to Vicksburg, MS (MVM) hydraulic model schematic.

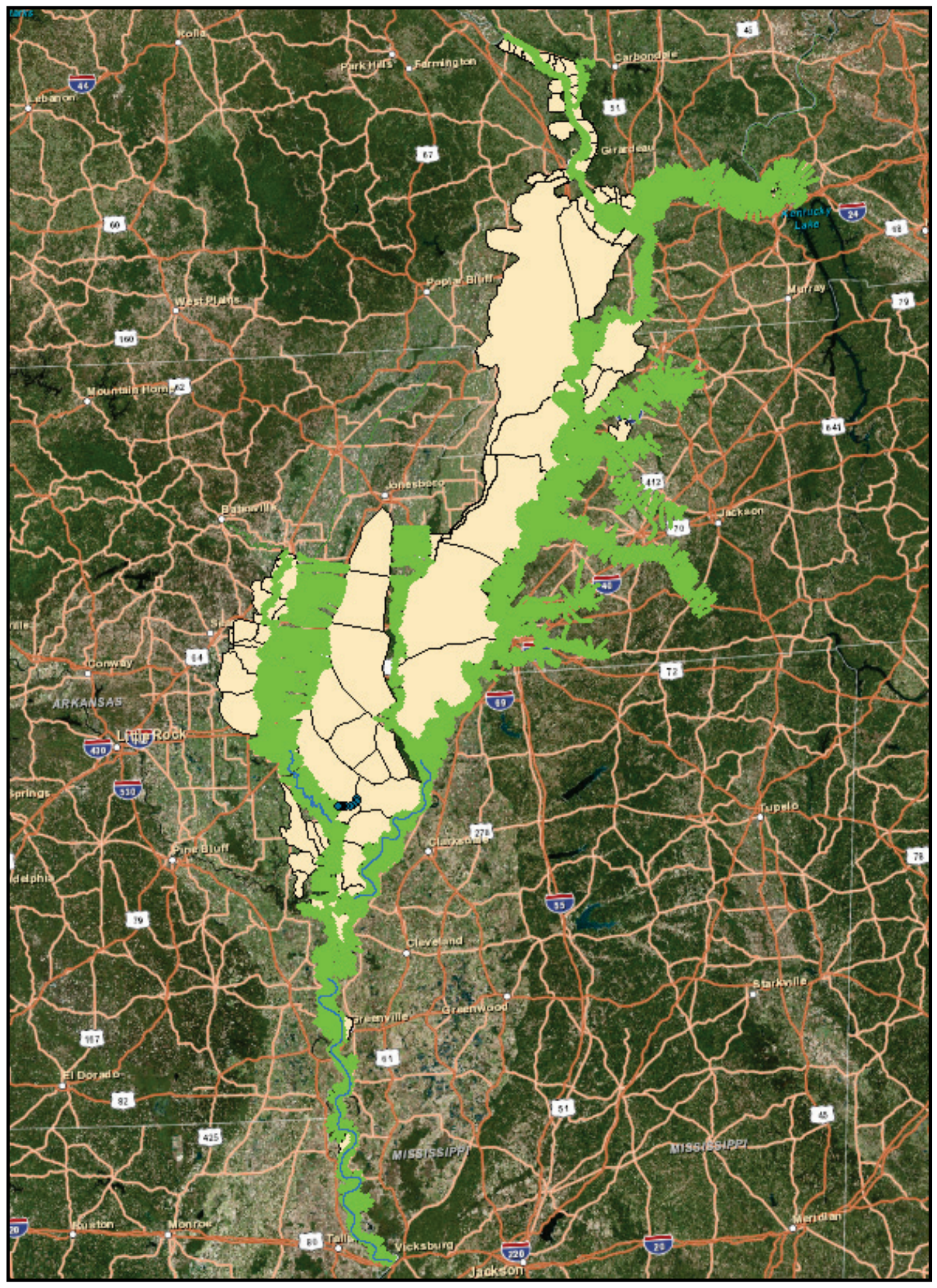




\section{A.2 Data compilation}

For the external (edges of the hydraulic model domain) and internal (locations with measured data within the interior of the model domain) boundaries of the MVM model, flow and stage data were obtained from the United States Geological Survey (USGS), the USACE, and the NWS. Data used for the MVM model setup are shown in Table 38. The NWS computes data in Coordinated Universal Time (UTC) while many of the district offices report data in their respective time zones, typically Central Standard Time (CST) in this case. These data were compiled, converted, and stored in HEC-DSS databases in both UTC and CST. The vertical datum used for the model is the NAVD88. The elevations of many of the gages have been tied to the NAVD88 datum by surveying. For most of the gages that have not been surveyed and related to NAVD88, Corpscon6 software (http://www.agc.army.mil/Missions/Corpscon.aspx, 8 February 2015) was used to convert the elevation of the gage in the National Geodetic Vertical Datum of 1929 (NGVD29) to NAVD88.

Many points within the model with a significant contribution of flow are monitored by gages managed by either the USACE or the USGS. Most realtime stage gages also provide flow data by using multiple flow measurements across a wide range of stages to develop the stage-flow rating curve, but some gages are simply staff gages read daily. Because 2011 included some of the highest water levels in modern times, the number of flow measurements at these high stages was limited, and therefore the rating curves used to compute flow from observed stage are subject to some uncertainty. For example, flow measurements at Smithland, KY, on the Ohio River (main contributor of flow for the 2011 event) were scarce during the 2011 event. For the past decade, there have only been approximately 10 or so measurements above 400,000 cfs (2011 peaks were over 1,000,000 cfs). Two contributing lakes just downstream of Smithland, KY, were releasing record amounts of water as well. The Smithland rating curve did not account for the backwater influence of these lakes while all were at such high magnitudes because the situation had not previously been observed. To calculate the flow at Smithland, KY, the stage hydrograph was set as the boundary condition. The results were compared to downstream gages with computed flow as well as USGS measurement points until a reasonable flow hydrograph for Smithland was computed. 
Other published flow discrepancies worth noting are between the ratings maintained by the USGS and USACE. Separate ratings in the same locations are maintained by each entity for different purposes. The USGS ratings took precedent over USACE when available. The USGS typically has more data than USACE to support their historical flows and corrects the data as time progresses as more measurements are taken. USACE oftentimes has a different rating for real-time operations. The USGS waits to get a sufficient number of measurements to make shifts to the respective ratings and then edits the historical flows, whereas the USACE operates in real time and is forced to make shifts based on fewer measurements.

Table 39 lists the gages with flow data used for calibration. The NWS forecasts flows using their hydrologic models that were used to retroactively compute observed meteorological conditions to supplement as local or total flow contribution data where needed. These forecasts include total routed flows at the boundaries of the hydraulic model and intermediate local basin inflows. The parameter "Total Flow" refers to data that are fully routed (including upstream basins) whereas "Lateral Flow" is the data that are just the local contribution for that basin. The parameter "Inflow" describes data at the model boundaries used for calibration.

Table 38. Flow data used for the MVM model setup.

\begin{tabular}{|l|l|l|c|l|l|}
\hline \multicolumn{7}{|c|}{ Main Inflows to the Model } \\
\hline River & Reach & Station Name & RAS Station & Parameter & Entity \\
\hline Arkansas River & Arkansas River & LD03 & 28.07 & Inflow & USACE \\
\hline Big Muddy & Reach-1 & Murphysboro & 34.87 & Inflow & USACE \\
\hline Cache River & Cache River & CR113 & 116.44 & Inflow & USACE \\
\hline Cumberland River & Cumberland River & BARK2 & 29.36 & Total Flow & NWS \\
\hline Forked Deer & North Fork & FN111 & 20.00 & Inflow & USACE \\
\hline Forked Deer & South Fork & FS105 & 38.68 & Inflow & USACE \\
\hline Forked Deer & South Fork & HLST1 & 8.59 & Lateral Flow & NWS \\
\hline Hatchie River & Hatchie River & HA116 & 149.62 & Inflow & USACE \\
\hline Hatchie River & Hatchie River & RLTT1 & 38.46 & Lateral Flow & NWS \\
\hline Loosahatchie & Loosahatchie & Arlington & 35.24 & Inflow & USGS \\
\hline Loosahatchie & Loosahatchie & BRNT1 & 22.55 & Lateral Flow & NWS \\
\hline Mississippi & Upper Miss & Chester, MO & 110.40 & Inflow & USGS \\
\hline Mississippi & Below Big Muddy & CPGM7 & 52.15 & Lateral Flow & NWS \\
\hline
\end{tabular}




\begin{tabular}{|c|c|c|c|c|c|}
\hline \multicolumn{6}{|c|}{ Main Inflows to the Model } \\
\hline River & Reach & Station Name & RAS Station & Parameter & Entity \\
\hline Mississippi & Below Cairo & WKLK2 & 972.56 & Lateral Flow & NWS \\
\hline Mississippi & Below Cairo & NMDM7 & 908.52 & Lateral Flow & NWS \\
\hline Mississippi & Below Obion & OBOT1 & 835.27 & Lateral Flow & NWS \\
\hline Mississippi & Below Wolf & MEMT1 & 749.01 & Lateral Flow & NWS \\
\hline Mississippi & Below St. Fran & HEEA4 & 676.42 & Lateral Flow & NWS \\
\hline Mississippi & Below White & ROSM6 & 602.06 & Lateral Flow & NWS \\
\hline Mississippi & Below Arkansas & ARSA4 & 564.00 & Lateral Flow & NWS \\
\hline Mississippi & Below Arkansas & Vicksburg & 443.73 & Stage & USACE \\
\hline Nonconnah Cr & Nonconnah $\mathrm{Cr}$ & HEEA4 & 25.64 & Total Flow & NWS \\
\hline Obion & Reach_1 & BOGT1 & 34.16 & Lateral Flow & NWS \\
\hline Obion & Reach_1 & OBNT1 & 72.10 & Total Flow & NWS \\
\hline Ohio River & Lower SOHS & Smithland & -919.00 & Inflow & USACE \\
\hline Ohio River & $\mathrm{OHS}$ & CIRI2 & -979.68 & Lateral Flow & NWS \\
\hline Ohio River & $\mathrm{OHS}$ & PAHK2 & -934.18 & Lateral Flow & NWS \\
\hline St. Francis & Above SS & SB111 & 82.47 & Inflow & USACE \\
\hline St. Francis & Below SS & MSNA4 & 37.70 & Lateral Flow & NWS \\
\hline Straight Slough & Straight Slough & MSNA4 & 30.82 & Inflow & NWS \\
\hline Tennessee River & Tennessee River & KYDK2 & 18.21 & Total Flow & NWS \\
\hline White River & White River & Newport & 258.94 & Inflow & USACE \\
\hline White River & White River & AUGA4 & 204.34 & Lateral Flow & NWS \\
\hline White River & White River & Dewey & 177.51 & Lateral Flow & USGS \\
\hline White River & White River & GEOA4 & 169.52 & Lateral Flow & NWS \\
\hline White River & White River & DSCA4 & 145.72 & Lateral Flow & NWS \\
\hline White River & Below Cache & CLDA4 & 100.05 & Lateral Flow & NWS \\
\hline Wolf River & Wolf River & ROST1 & 46.40 & Total Flow & NWS \\
\hline Wolf River & Wolf River & GERT1 & 19.46 & Lateral Flow & NWS \\
\hline
\end{tabular}

GIS data were necessary for the creation of the hydraulic model. The HEC Geo-RAS 10.2 for ArcGIS 10.2 (U.S. Army Corps of Engineers 2012b) was used to translate the vector and raster data into HEC-RAS geometry. The projection and datum for the terrain model were USGS Albers Equal Area and NAVD88 (feet), respectively. The terrain model associated with the MVM geometry was created from sets of bathymetric data and laser imaging detection and ranging (lidar) or DEM datasets obtained during 
2006 and 2009. The use of data obtained in various years was unavoidable due to the model boundaries extending into other USACE District areas of responsibility. However, all of the terrain data used for the model were from time periods prior to 2011.

Post-2011 flood surveys and after-action reports were used to help determine final breach sizes or areas of overtopping and to gain a general knowledge of the flood history. Levees and floodwalls identified in the National Levee Database were included in the model. The BPNMF operated during 2011 consisted of three levee breaches by use of explosive material. Multiple overtopping and breaches occurred in the Len Small Levee upstream of the confluence of the Mississippi and Ohio Rivers. A large bank failure on the left descending bank of the Mississippi River near Tiptonville, TN, allowed flow to convey drastically in the overbank bypassing nearly 20 river miles. No major overtopping or breaches occurred during the 2002 and 2008 events.

Table 39. Data used for the MVM model calibration.

\begin{tabular}{|c|c|c|c|c|}
\hline River & Reach & Station Name & $\begin{array}{c}\text { RAS } \\
\text { Station }\end{array}$ & Calibration Parameter \\
\hline Arkansas River & Arkansas River & D02 & 28.07 & Observed Elevation \\
\hline Big Muddy & Reach-1 & Murphysboro & 34.87 & Observed Elevation \\
\hline Big Muddy & Reach-1 & Sand Ridge & 26.97 & Observed Elevation \\
\hline Cache River & Cache River & CR113 & 80.53 & Observed Elevation \\
\hline Cache River & Cache River & CR114 & 19.01 & Observed Elevation \\
\hline $\begin{array}{l}\text { Cumberland } \\
\text { River }\end{array}$ & $\begin{array}{l}\text { Cumberland } \\
\text { River }\end{array}$ & Barkley Dam & 29.36 & Observed Flow \\
\hline Forked Deer & North Fork & FN111 & 5.38 & Observed Elevation \\
\hline Forked Deer & South Fork & Owl City & 28.69 & Observed Elevation \\
\hline Forked Deer & South Fork & FS111 & 8.59 & Observed Elevation \\
\hline Forked Deer & South Fork & FS112 & 3.42 & Observed Elevation \\
\hline Hatchie River & Hatchie River & Bolivar & 139.89 & Observed Elevation \\
\hline Hatchie River & Hatchie River & HA115 & 72.55 & Observed Elevation \\
\hline Hatchie River & Hatchie River & HA116 & 38.46 & Observed Elevation \\
\hline Hatchie River & Hatchie River & Rialto & 38.46 & Observed Flow \\
\hline Loosahatchie & Loosahatchie & Arlington & 30.643 & Observed Elevation \\
\hline Mississippi & Below Arkansas & Arkansas City & 563.01 & Observed Elevation \\
\hline
\end{tabular}




\begin{tabular}{|c|c|c|c|c|}
\hline River & Reach & Station Name & $\begin{array}{c}\text { RAS } \\
\text { Station }\end{array}$ & Calibration Parameter \\
\hline Mississippi & Below Cairo & MS111 & 972.56 & Observed Elevation \\
\hline Mississippi & Below Cairo & MS113 & 942.45 & Observed Elevation \\
\hline Mississippi & Below Cairo & MS115 & 908.52 & Observed Elevation \\
\hline Mississippi & Below Cairo & MS114 & 926.21 & Observed Elevation \\
\hline Mississippi & Below Cairo & MS116 & 891.54 & Observed Elevation \\
\hline Mississippi & Below Cairo & MS117 & 863.96 & Observed Elevation \\
\hline Mississippi & Below Cairo & MS118 & 849.27 & Observed Elevation \\
\hline Mississippi & $\begin{array}{l}\text { Below } \\
\text { Nonconnah }\end{array}$ & MS130 & 712.80 & Observed Elevation \\
\hline Mississippi & Below Obion & MS119 & 835.92 & Observed Elevation \\
\hline Mississippi & Below Obion & MS121 & 798.58 & Observed Elevation \\
\hline Mississippi & Below White & MS136 & 602.06 & Observed Elevation \\
\hline Mississippi & Below Wolf & MS125 & 750.92 & Observed Elevation \\
\hline Mississippi & Below Wolf & MS126 & 749.01 & Observed Elevation \\
\hline Mississippi & Below Wolf & MS128 & 742.67 & Observed Elevation \\
\hline Mississippi & Upper Miss & Chester, MO & 110.40 & Observed Elevation \\
\hline Mississippi & Upper Miss & $\begin{array}{l}\text { Cape Girardeau, } \\
\text { MO }\end{array}$ & 52.15 & Observed Elevation \\
\hline Mississippi & Upper Miss & Thebes & 43.70 & Observed Elevation \\
\hline Mississippi & Upper Miss & Price Landing & 29.92 & Observed Elevation \\
\hline Mississippi & Upper Miss & Bird's Point & 2.00 & Observed Elevation \\
\hline Mississippi & Below Cairo & MS113 & 942.45 & Observed FLow \\
\hline Mississippi & Below St. Francis & MS133 & 676.42 & Observed Flow \\
\hline Mississippi & Below Wolf & MS126 & 749.01 & Observed Flow \\
\hline Mississippi & Upper Miss & Thebes & 43.70 & Observed Flow \\
\hline Obion River & Reach_1 & HWY 51 & 52.65 & Observed Elevation \\
\hline Obion River & Reach_1 & OB113 & 34.16 & Observed Elevation \\
\hline Obion River & Reach_2 & OB114 & 20.87 & Observed Elevation \\
\hline Obion River & Reach_1 & HWY 51 & 52.65 & Observed Flow \\
\hline Ohio River & Lower SOHS & Smithland & -919.00 & Observed Elevation \\
\hline Ohio River & $\mathrm{OHS}$ & Paducah, KY & -934.18 & Observed Elevation \\
\hline Ohio River & $\mathrm{OHS}$ & Metropolis & -944.10 & Observed Elevation \\
\hline Ohio River & $\mathrm{OHS}$ & Grand Chain, IL & -962.61 & Observed Elevation \\
\hline
\end{tabular}




\begin{tabular}{|c|c|c|c|c|}
\hline River & Reach & Station Name & $\begin{array}{c}\text { RAS } \\
\text { Station }\end{array}$ & Calibration Parameter \\
\hline Ohio River & $\mathrm{OHS}$ & Cairo, IL & -979.68 & Observed Elevation \\
\hline Ohio River & $\mathrm{OHS}$ & Metropolis & -944.10 & Observed Flow \\
\hline St. Francis & Below SS & SB111 & 58.27 & Observed Elevation \\
\hline St. Francis & Below SS & SF133 & 37.70 & Observed Elevation \\
\hline St. Francis & Below SS & SF135 & 19.26 & Observed Elevation \\
\hline Tennessee River & Tennessee River & Kentucky Dam & 18.21 & Observed Flow \\
\hline White River & White River & Augusta & 204.34 & Observed Elevation \\
\hline White River & White River & WR113 & 169.52 & Observed Elevation \\
\hline White River & White River & WR114 & 145.72 & Observed Elevation \\
\hline White River & White River & WR115 & 124.33 & Observed Elevation \\
\hline White River & Below Cache & WR116 & 100.12 & Observed Elevation \\
\hline White River & Below Cache & WR117 & 92.42 & Observed Elevation \\
\hline White River & Below Cache & WR118 & 56.63 & Observed Elevation \\
\hline White River & Below Cache & WR121 & 34.42 & Observed Elevation \\
\hline White River & Below Cache & MP Lock\&Dam HW & 0.00 & Observed Elevation \\
\hline White River & Below Cache & MP Lock\&Dam TW & -1.00 & Observed Elevation \\
\hline White River & White River & Augusta & 204.34 & Observed Flow \\
\hline White River & White River & Georgetown & 169.52 & Observed Flow \\
\hline White River & White River & Devalls Bluff & 124.33 & Observed Flow \\
\hline White River & White River & Newport & 258.94 & Observed Elevation \\
\hline Wolf River & Wolf River & Germantown, TN & 19.46 & Observed Elevation \\
\hline Wolf River & Wolf River & Rossville, TN & 42.64 & Observed Elevation \\
\hline Wolf River & Wolf River & $\begin{array}{l}\text { Hollywood St, } \\
\text { Memphis }\end{array}$ & 5.87 & Observed Elevation \\
\hline Wolf River & Wolf River & WF111 & 10.59 & Observed Elevation \\
\hline Wolf River & Wolf River & Germantown, TN & 19.46 & Observed Flow \\
\hline
\end{tabular}

\section{A.3 Model setup and calibration}

Gaining an understanding of how the flow data and geometric data function in the model for a variety of flood events is a critical modeling setup and calibration task. Correcting flow data or modifying the geometric data was considered part of the calibration process. Determining the locations and elevations of lateral structures and 
corresponding weir coefficients, the storage area volumes and layouts, ineffective flow areas, levee points, and Manning's $n$-values were the other key tasks in calibrating the MVM model. No seasonal roughness changes were implemented in the MVM model.

Slight changes in the flow ratings as a result of a change in cross-sectional geometry of the river cannot be appropriately captured in the model. The current hydraulic model does not incorporate sediment transport, so the cross-section geometry is static throughout the simulations. The variations in cross-sectional area are assumed to be insignificant overall, and precedence was given to the more recent flow data. Many years of data were simulated by the model, and the general trends for the range of flows were used for calibration. However, emphasis was placed on recent high flow years in 2002, 2008, and 2011.

The only location where flow data were modified from a published dataset was at Smithland, KY, on the Ohio River. Separate documentation (USACE 2018b) is available that documents the process in more detail as well as the communication procedure with the relevant agencies. As discussed previously, the USGS rating had few high flow measurements at Smithland. The following lists the procedure used for correcting the USGS flow data:

1. Computed Smithland flow with HEC-RAS using a Stage Hydrograph as the input variable.

2. Determined Manning's $n$-values on Ohio River that will produce reasonable peak flows for the events as compared to actual measurements and downstream flow gages.

3. Calibrated to an event or range of flows on nearby, influencing gages using the flow output from \#2.

4. Repeated Step 1 with new geometry for a refined hydrograph.

5. Continued calibrating stages until the change in flow at Smithland is negligible for the range of events, and flows globally are reasonable for the events as compared to actual measurements as well as downstream flow gages.

6. Digitized the computed flow values to transition with the USGS values at lower levels, which were considered to be accurate. 
Because of the multiple backwater influences at Smithland, a single-value, theoretical backwater rating curve was insufficient over the full range of flows. A stage hydrograph was set as the boundary condition in the HEC-RAS model, which allows the model to compute the flow at every time step. The modification of the Manning's $n$-values on the Ohio River and immediately downstream has a dramatic impact on the flows computed by the model. These Manning's $n$-values were modified until an acceptable replication of the downstream flow hydrographs at Hickman, Memphis, Helena, and Arkansas City was achieved. Next, Manning's $n$-values were adjusted to calibrate the gages to elevations that impact flow at Smithland (e.g., Paducah, Metropolis, Cairo, Bird's Point New Madrid Floodway, Price Landing, Hickman, and New Madrid). Adjusting these Manning's $n$-values resulted in a new flow hydrograph being computed at Smithland. This procedure was done multiple times until stages were calibrated and flows were reasonable on the Ohio River and gages downstream.

After a quality check on the published flow data, calibration to a range of flows began initially by changing Manning's $n$-values, working upstream to downstream. The 2002, 2008, and 2011 events were the target events used to calibrate the model. Although the 2011 event was the most recent and highest event, 2008 was used for calibration of some of the areas of great complexity. For example, in 2011 there were four major breaches between Cairo and Caruthersville (three of the breaches were intentional for operation of the BPNMF). The unintentional breach was not a breach of a project levee. Since none of the four breaches occurred during the 2008 event, the 2008 event was used to help isolate variables unique to the cross-section geometry. In general, comprehensive data from 2002 to 2011 were used to determine elevation trends for the different levels of flow, with emphasis on the more recent events. Modifying the Manning's $n$-values was an iterative process conducted by analyzing the trends of flow versus the difference between computed elevations and observed elevations (residuals).

Because of the complex nature of the Mississippi River, adoption of a single Manning's $n$-value representing the channel for all levels of flow was not practical. A 0.03 value for the channel was the initial trial Manning's $n$-value. The initial value was changed to best represent in-channel conditions unique to a particular cross section. These modified values were then varied with flow by a series of multipliers. For example, if the 
model residuals were showing that computed elevations were too low for flow ranges of 200,000 to $300,000 \mathrm{cfs}$, a multiplier greater than 1.0 was used on the Manning's $n$-values for a series of cross sections delineated for a particular gage during that flow range. An automated roughness feature within HEC-RAS was used to help determine reasonable multipliers to correct a high or low trend at the various flow rates. The automated roughness calibration feature was used as a time-saving feature and not used exclusively in all locations. The automated roughness feature determines the trends of the residuals with flow rates and iteratively determines the multiplier needed to minimize the difference between the computed and observed elevations. The output of this feature was a series of multipliers for the different reaches for the range of flows. These data were adjusted by the modeler to provide smoother transitions.

After the in-channel flows at the gages were reasonably calibrated, calibration to higher, out-of-bank flows began. The automated roughness feature did not work as well for higher flows as the geometric features, breaches, and hydrodynamics become more complex, but Manning's $n$-values were still varied at higher flow rates by the modeler. At higher flow rates, more effort was necessary to represent the conveyance in the cross sections. This became apparent as the computed elevations began to lag in time and magnitude. To represent the conveyance in a given cross section, the cross section had to be delineated horizontally by Manning's $n$-values and schematic changes to the model were necessary.

The larger geometric or schematic changes to the model as a part of the calibration process generally were related to storage areas and lateral structures within the MR\&T levee system that represented breaches that occurred or areas where large overbanks existed in the original cross sections. Storage areas within the MR\&T levee system were only used if an obvious high-elevation restriction existed. Most of these areas are partially bound by spur levees jutting out almost perpendicular to the path of overbank flow. In the majority of circumstances, water backs up into these areas and does not actively convey downstream; therefore, storage areas were deemed appropriate. The profiles of the lateral structures that control the flow of water into the storage areas were often cut from elevations with little difference in elevation on either side of the structure. The weir coefficients were set to low values (typically 0.1 to 0.7 ). These lower values best represented the flow into or out of these areas but also tend to be 
more numerically stable. Higher weir coefficients were used to simulate some of the breaches that occurred during the 2011 calibration event.

In the 1D model, most of the situations that occur are not ideal lateral weirs; variables such as angle of entry and how the tailwater for the weir is being computed are additional considerations when choosing a weir coefficient. For example, a storage area will tend to underestimate the tailwater (when not in a backwater situation) for some of the breaches that occurred during the 2011 event. When a storage area is not in a backwater situation and a breach upstream occurs, a lower weir coefficient is sometimes more appropriate to keep too much volume from escaping the river side. Another example occurs when the lateral weir is more perpendicular to flow and functions more like an inline weir-in this case a larger weir coefficient was used in that type of situation. Table 40 and Figure 130 below describe the breaches in the calibration model as well as their respective parameters. 
Table 40. List of breaches and their parameters in the MVM model

\begin{tabular}{|c|c|c|c|c|c|c|c|c|}
\hline River & Reach & Station & $\begin{array}{c}\text { Weir } \\
\text { Coefficient }\end{array}$ & $\begin{array}{l}\text { Development } \\
\text { Time (hr) }\end{array}$ & Progression & $\begin{array}{l}\text { Vertical/Horizontal } \\
\text { Growth Ratio }\end{array}$ & $\begin{array}{l}\text { Start } \\
\text { Date/Time }\end{array}$ & Remarks \\
\hline Mississippi & $\begin{array}{l}\text { Below } \\
\text { Big } \\
\text { Muddy }\end{array}$ & 28.580 & 2.00 & 24.00 & $\begin{array}{l}\text { Half Sine } \\
\text { Wave }\end{array}$ & 1.000 & $\begin{array}{l}\text { 02 May } 2011 \\
1900\end{array}$ & \multirow{3}{*}{$\begin{array}{l}\text { All parameters were estimated } \\
\text { based on post survey data or the } \\
\text { process of calibration to the nearest } \\
\text { gages. The tail water side of these } \\
\text { breaches is still the Mississippi River } \\
\text { and is modeled by long cross } \\
\text { sections. These sections will } \\
\text { overestimate the tailwater elevation } \\
\text { prior to a breach and underestimate } \\
\text { the elevation at the peak flow of the } \\
\text { breach. The dynamics of the breach } \\
\text { and response simply cannot be } \\
\text { captured in this } 1 D \text { method. } \\
\text { Coefficients of } 2 \text { are actually } \\
\text { probably higher than what one } \\
\text { would calculate if one measured all } \\
\text { the data as it happened, but using } \\
\text { the values seemed to drop the water } \\
\text { surface at a rate that was } \\
\text { comparable to what happened in } \\
2011 \text {. A higher coefficient was used } \\
\text { to account for the overestimation of } \\
\text { the tailwater. }\end{array}$} \\
\hline Mississippi & $\begin{array}{l}\text { Below } \\
\text { Big } \\
\text { Muddy }\end{array}$ & 25.959 & 2.00 & 24.00 & $\begin{array}{l}\text { Half Sine } \\
\text { Wave }\end{array}$ & 1.000 & $\begin{array}{l}\text { O2 May } 2011 \\
1900\end{array}$ & \\
\hline Mississippi & $\begin{array}{l}\text { Below } \\
\text { Big } \\
\text { Muddy }\end{array}$ & 25.390 & 2.00 & 24.00 & $\begin{array}{l}\text { Half Sine } \\
\text { Wave }\end{array}$ & 1.000 & $\begin{array}{l}\text { O2 May } 2011 \\
1900\end{array}$ & \\
\hline
\end{tabular}




\begin{tabular}{|c|c|c|c|c|c|c|c|c|}
\hline River & Reach & Station & $\begin{array}{c}\text { Weir } \\
\text { Coefficient }\end{array}$ & $\begin{array}{l}\text { Development } \\
\text { Time (hr) }\end{array}$ & Progression & $\begin{array}{l}\text { Vertical/Horizontal } \\
\text { Growth Ratio }\end{array}$ & $\begin{array}{l}\text { Start } \\
\text { Date/Time }\end{array}$ & Remarks \\
\hline Mississippi & $\begin{array}{l}\text { Below } \\
\text { Cairo }\end{array}$ & 937.020 & 0.85 & 12.00 & Linear & 0.200 & $\begin{array}{l}05 \text { May } 2011 \\
1334\end{array}$ & $\begin{array}{l}\text { This location represents the } \\
\text { inflow/outflow crevasse \#1. This } \\
\text { breach was not activated as } \\
\text { designed. The explosives fluffed the } \\
\text { material more than removing it. Very } \\
\text { little flow went into or out of this } \\
\text { breach. Elevation gages near this } \\
\text { breach compare well to the } \\
\text { computed. The momentum of the } \\
\text { river is also not directed at this } \\
\text { structure. }\end{array}$ \\
\hline Mississippi & $\begin{array}{l}\text { Below } \\
\text { Cairo }\end{array}$ & 913.070 & 2.60 & 24.00 & $\begin{array}{l}\text { BPNM } \\
\text { Activation } \\
\text { Progression }\end{array}$ & 0.004 & $\begin{array}{l}03 \text { May } 2011 \\
1135\end{array}$ & $\begin{array}{l}\text { This location represents the } \\
\text { inflow/outflow crevasse \#2. It is the } \\
\text { main method for the floodway } \\
\text { waters to reenter the Mississippi } \\
\text { river. It functions more like an inline } \\
\text { structure weir than a true lateral, } \\
\text { which is why the coefficient needed } \\
\text { to be higher (2.6) compared to the } \\
\text { inflow and inflow/outflow \#1. }\end{array}$ \\
\hline
\end{tabular}




\begin{tabular}{|c|c|c|c|c|c|c|c|c|}
\hline River & Reach & Station & $\begin{array}{c}\text { Weir } \\
\text { Coefficient }\end{array}$ & $\begin{array}{l}\text { Development } \\
\text { Time (hr) }\end{array}$ & Progression & $\begin{array}{l}\text { Vertical/Horizontal } \\
\text { Growth Ratio }\end{array}$ & $\begin{array}{l}\text { Start } \\
\text { Date/Time }\end{array}$ & Remarks \\
\hline Mississippi & $\begin{array}{l}\text { Below } \\
\text { Cairo }\end{array}$ & 888.640 & 2.20 & 84.00 & Linear & 1.00 & $\begin{array}{l}29 \text { Apr } 2011 \\
1300\end{array}$ & $\begin{array}{l}\text { This location represents the failure } \\
\text { of the Merriwether-Cherokee } \\
\text { revetment and the Sheep's Ridge } \\
\text { Road spur levee. The timing was } \\
\text { determined based on the gage } \\
\text { response at Tiptonville as little data } \\
\text { were available on when the breach } \\
\text { began. The revetment failed initially; } \\
\text { then the spur levee failed after that. } \\
\text { These two features are } \\
\text { approximately } 1,000 \mathrm{ft} \text { apart. The } \\
\text { breach occurred where the river } \\
\text { begins to turn (momentum is more } \\
\text { in line with the structure than lateral } \\
\text { to it); this is why the coefficient is so } \\
\text { large. An estimated } 40 \% \text { of the } \\
\text { Mississippi River flows were moving } \\
\text { through this breach. This structure } \\
\text { and area were modeled extensively } \\
\text { with a multidimensional model, and } \\
\text { the RAS computations are } \\
\text { comparable to that model. }\end{array}$ \\
\hline Mississippi & $\begin{array}{l}\text { Below } \\
\text { Cairo }\end{array}$ & 883.010 & 1.10 & 48.00 & Linear & 1.00 & $\begin{array}{l}29 \text { Apr } 2011 \\
1300\end{array}$ & $\begin{array}{l}\text { This location is a private spur levee } \\
\text { that is directly across from the } \\
\text { Merriwether-Cherokee breach. Little } \\
\text { to no data exist on when/how large } \\
\text { the breach actually was. Parameters } \\
\text { were estimated based on many } \\
\text { iterative runs with all the breaches } \\
\text { in the area and by taking } \\
\text { measurements from aerial imagery. }\end{array}$ \\
\hline
\end{tabular}


Figure 130. BPNMF breach activation progression.

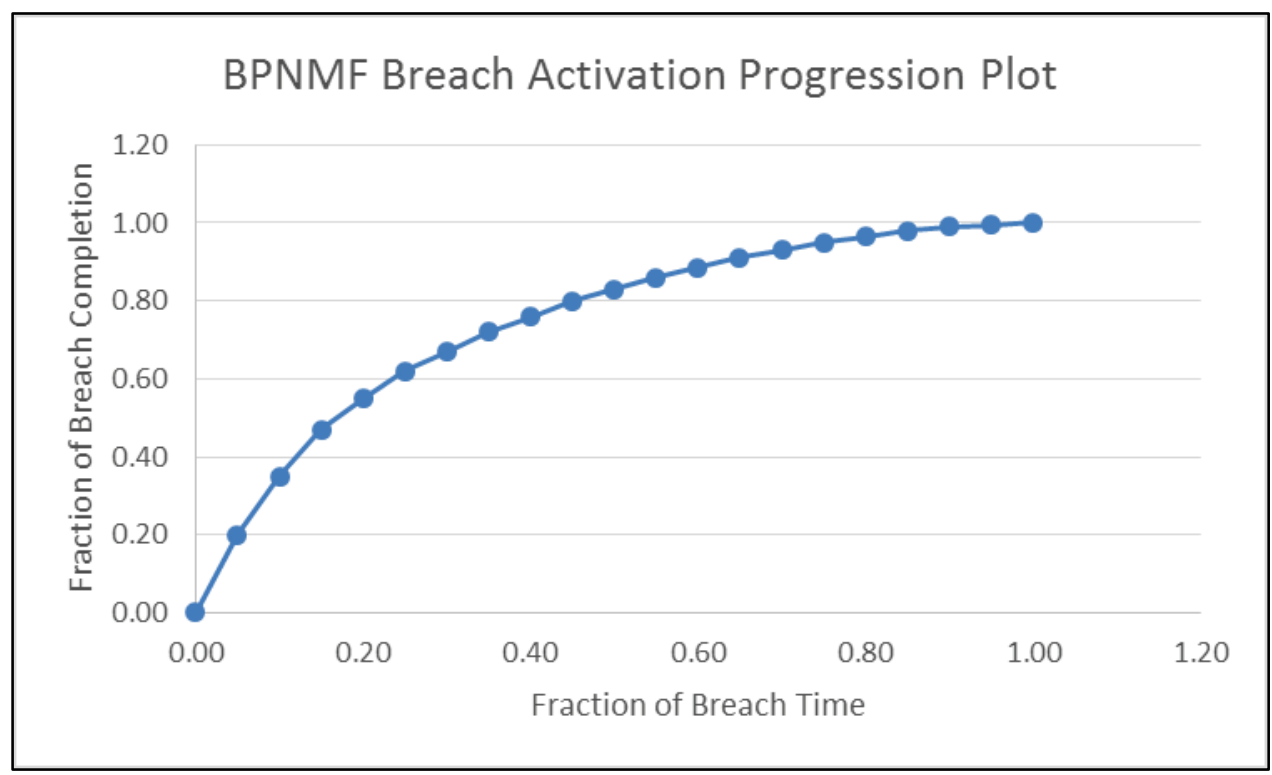

Large Manning's $n$-values such as 0.2 or 0.3 were used at the fringes of the cross sections to reduce the conveyance of this volume downstream. Manning's $n$-values this high are not listed in any hydraulic textbook strictly for describing roughness, but the complex hydrodynamics actually taking place cannot be modeled otherwise in a $1 \mathrm{D}$ model. The energy losses occurring transversely and vertically have to be accounted for, in addition to the standard longitudinal losses, to obtain the correct timing of calculated elevations at the main stem gages. Using these high Manning's $n$-values, as well as varying the Manning's $n$-value with flow rates, most of the events could be calibrated satisfactorily. For cases of unusually high flow or events that had a long duration at levels that caused water to oscillate into and out of the channel, additional levee points and ineffective areas were necessary for the model to compute accurate elevations without significantly delaying the timing of the peaks. Due to $1 \mathrm{D}$ limitations of HEC-RAS, the super-elevation of the water surface cannot be modeled; however, the conveyances within the cross sections were reasonably modified to compute a close approximation to the observed elevations near the time they occurred. Much effort was spent attempting to calibrate to the events temporally and spatially. Aerial photography and the terrain model helped to define the overbank conveyances.

For the overbank flow areas of great complexity, such as the BPNMF and the confluence of the Arkansas, White, and Mississippi Rivers, the 2D component of HEC-RAS was used. Figure 131 shows the Bird's Point-New Madrid Floodway 2D layout and Figure 132 shows the Arkansas, White, 
Mississippi River confluence layout. The cell size used for BPNMF was 500 $\mathrm{ft}$, and the cell size used for the Arkansas, White, and Mississippi Rivers confluence was $1000 \mathrm{ft}$. Manning's $n$-values were spatially assigned to the cells using land use datasets for the BPNMF area, and a Manning's $n$-value of 0.15 was used for the Arkansas, White, and Mississippi Rivers confluence area, since it is a densely wooded area.

Figure 131. BPNMF 2D flow area.

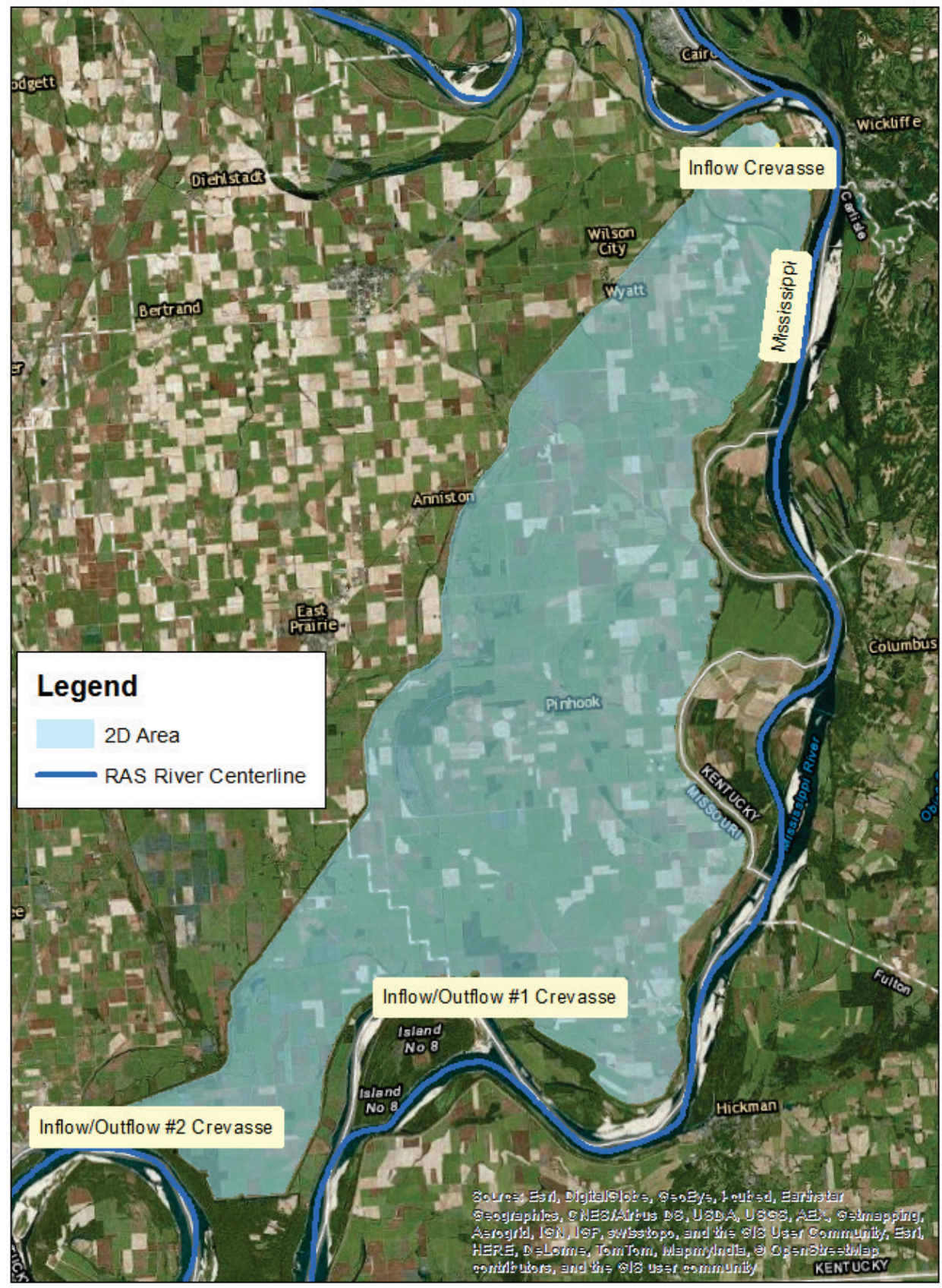


Figure 132. Arkansas, White, and Mississippi Rivers confluence 2D flow area.

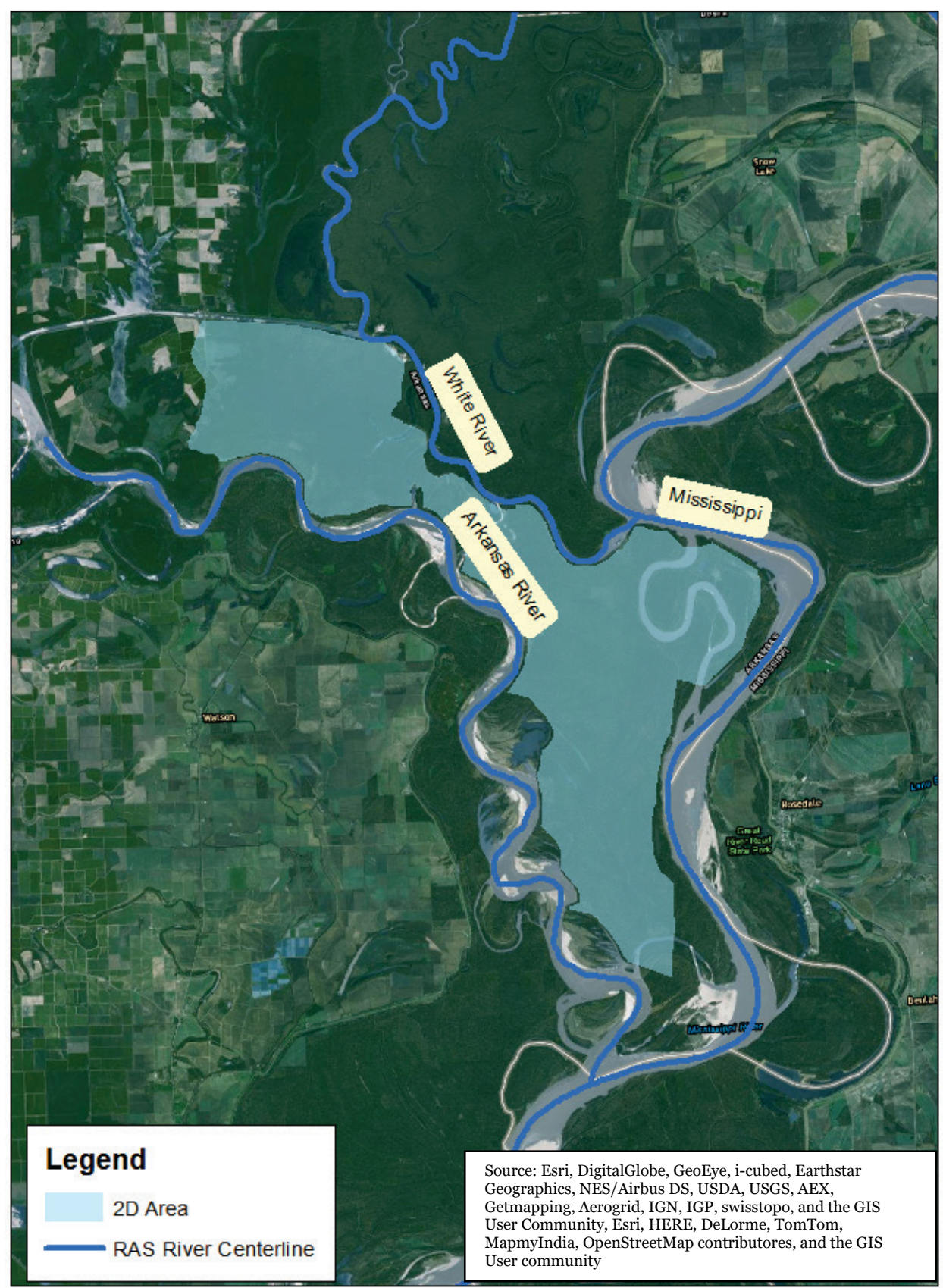

\section{A.3.1 Considerations and limitations}

1. A comprehensive National Levee Database representation of levee heights and floodwalls in the model is not available; however, the missing features were not considered critical to the calibration of the model.

2. Calibration at the lower flows of the model is limited. Flows coming out of the Ohio River are computed based on how HEC-RAS computes flow through the locks and dams. These instantaneous decisions made by the 
software do not properly reflect the human element during low flow conditions. However, the general flow trend is captured and is considered to be an accurate method as well as an accurate estimate.

3. Calibration of the model was completed by using historic published flow data as well as NWS simulated historic local contributions. However, the model is intended to simulate using strictly NWS data. There exists a disjoint between using NWS flows at the external boundaries for forecasting or otherwise and having a calibration completed using the published flow data. As meetings between USACE and the River Forecast Centers occur, USACE is asking that the River Forecast Centers provide some archived simulations to document and rectify, if necessary, the disjoint at these boundaries for a range of flows.

4. The DEM used for model setup is derived from the bathymetry of the channel prior to the 2011 Mississippi River flood that presumably changed the shape of many of the cross sections.

5. The calibration to the 2011 event at the Tiptonville gage was not completed in great detail because of the difficulty modeling the breach at Merriwether-Cherokee. A detailed HEC-RAS 2D model was completed outside this project, and an Adaptive Hydraulics (AdH) model is currently being produced for this area. These models provide an amount of detail that is outside the scope of this initial calibration. The hydrodynamics of the breach that occurred in 2011 will not be necessary for this assessment because it was unique to the one event, but modification of the current geometry will be necessary to represent the current conditions of the spur levee.

6. The White River reach of the model is limited in its calibration, specifically in regard to the timing of flows. The White River is sinuous and has minimal slope. The overbank elevations for the model were cut from 10-meter DEM. The sinuosity of the White River is difficult to accurately capture in one dimension. HEC-RAS is limited to a channel length and right and left overbank lengths. Delineating these lengths to represent a full range of flows is challenging.

7. Only a portion of the overbanks of the confluence of the Arkansas, White, and Mississippi Rivers was modeled in RAS 2D to meet the single Manning's $n$-value assumption in the current version of the software. A larger 2D area (including the channels) would more accurately represent the hydrodynamics once the multiple Manning's $n$-value capability becomes available, but time constraints on the project may have an impact. 


\section{A.4 Results}

The calibration of the MVM hydraulic model focused on the 2002, 2008, and 2011 events primarily, but continuous data from 2002 through 2011 were run through the model as well. In general, gages that recorded hourly stage data were used for a detailed calibration analysis, but intermediate gages with daily data, high water marks, or staff gages with intermittent data were also used for refinement of the model. Table 41 lists results for each of the three primary events. Table 42 lists results from the 10-year simulation from 2002 to 2011. In Table 41, results are listed for locations along the Mississippi River from Chester, IL, downstream to Arkansas City, AR. For each event and location, the accuracy of the model is described by listing the percentage of calculated stages within 0.5 and 1.0 $\mathrm{ft}$ of the observed data, in addition to the absolute value of the mean error. Also, the difference in peak elevations between calculated and observed stages is listed. For all three events, the model is generally more accurate at the upstream end than at the downstream end. The absolute values of the mean error and differences at peaks are less than $2.0 \mathrm{ft}$ and typically less than $1.0 \mathrm{ft}$.

Table 41. MVM calibration results for 2002, 2008, and 2011.

\begin{tabular}{|c|c|c|c|c|c|c|c|c|c|c|c|c|}
\hline & \multicolumn{4}{|c|}{2002 Event } & \multicolumn{4}{|c|}{2008 Event } & \multicolumn{4}{|c|}{2011 Event } \\
\hline Gage & 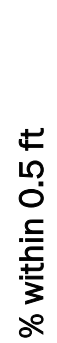 & 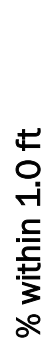 & 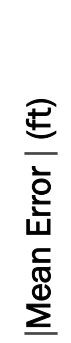 & 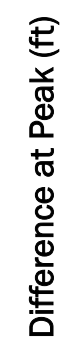 & 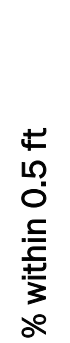 & 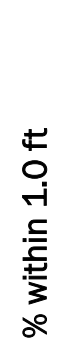 & 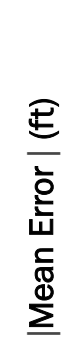 & 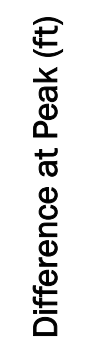 & 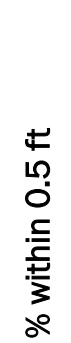 & 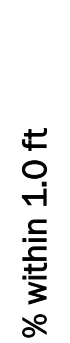 & 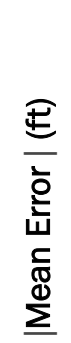 & 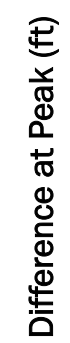 \\
\hline Chester & 82 & 99 & 0.29 & 0.32 & 81 & 94 & 0.32 & -0.1 & 77 & 99 & 0.35 & 0.03 \\
\hline Red Rock & 52 & 93 & 0.50 & -0.05 & 63 & 88 & 0.49 & -0.2 & 46 & 86 & 0.56 & 0.04 \\
\hline Grand Tower & 76 & 88 & 0.41 & -1.25 & 70 & 93 & 0.39 & 0.45 & 73 & 98 & 0.39 & -0.01 \\
\hline $\begin{array}{l}\text { Moccasin } \\
\text { Springs }\end{array}$ & 22 & 77 & 0.81 & -1.21 & 37 & 50 & 1.30 & 0.7 & N/A & N/A & N/A & $\mathrm{N} / \mathrm{A}$ \\
\hline Cape Girardeau & 54 & 93 & 0.52 & -1 & 57 & 92 & 0.53 & 0.19 & 65 & 99 & 0.37 & -0.08 \\
\hline Thebes & 32 & 82 & 0.68 & -1 & 74 & 92 & 0.39 & -0.04 & 75 & 96 & 0.35 & -0.22 \\
\hline Commerce & 42 & 85 & 0.62 & -1.05 & $\mathrm{~N} / \mathrm{A}$ & $\mathrm{N} / \mathrm{A}$ & $\mathrm{N} / \mathrm{A}$ & $\mathrm{N} / \mathrm{A}$ & $\mathrm{N} / \mathrm{A}$ & $\mathrm{N} / \mathrm{A}$ & $\mathrm{N} / \mathrm{A}$ & $\mathrm{N} / \mathrm{A}$ \\
\hline Price Landing & 26 & 75 & 0.73 & -0.05 & 51 & 88 & 0.56 & -0.42 & 60 & 91 & 0.43 & 0.37 \\
\hline $\begin{array}{l}\text { Thompson } \\
\text { Landing }\end{array}$ & 56 & 81 & 0.57 & -0.29 & 54 & 83 & 0.62 & -0.95 & N/A & N/A & N/A & $\mathrm{N} / \mathrm{A}$ \\
\hline Bird's Point & 61 & 89 & 0.49 & -0.68 & 47 & 78 & 0.66 & -0.56 & 60 & 84 & 0.49 & -0.32 \\
\hline
\end{tabular}




\begin{tabular}{|c|c|c|c|c|c|c|c|c|c|c|c|c|}
\hline & \multicolumn{4}{|c|}{2002 Event } & \multicolumn{4}{|c|}{2008 Event } & \multicolumn{4}{|c|}{2011 Event } \\
\hline Gage & $\begin{array}{l}4 \\
10 \\
0 \\
.5 \\
5 \\
5 \\
\frac{5}{3} \\
0 \\
0\end{array}$ & $\begin{array}{l} \pm \\
0 \\
\text { i } \\
.5 \\
\frac{1}{5} \\
\frac{7}{3} \\
\text { o } \\
\end{array}$ & 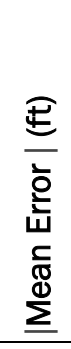 & 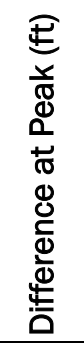 & 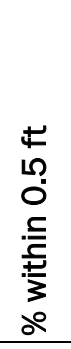 & 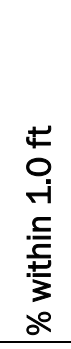 & 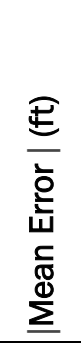 & 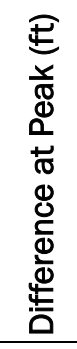 & $\begin{array}{l} \pm \\
10 \\
0 \\
0 \\
.5 \\
\frac{1}{3} \\
30 \\
0\end{array}$ & 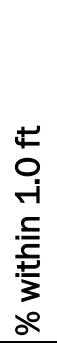 & 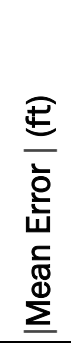 & 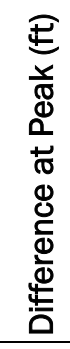 \\
\hline Smithland & 39 & 65 & 0.90 & 0.03 & 30 & 59 & 1.03 & 0.01 & 34 & 56 & 1.05 & -0.99 \\
\hline Paducah & 38 & 66 & 0.86 & 0.09 & 38 & 56 & 1.06 & 0.22 & 32 & 61 & 1.00 & -0.46 \\
\hline Metropolis & N/A & N/A & N/A & N/A & $\mathrm{N} / \mathrm{A}$ & N/A & $\mathrm{N} / \mathrm{A}$ & $\mathrm{N} / \mathrm{A}$ & 34 & 61 & 0.97 & 0.31 \\
\hline Grand Chain & 43 & 64 & 1.25 & 0.03 & 28 & 42 & 1.84 & 0.19 & 44 & 69 & 0.76 & 0.02 \\
\hline Cairo & 58 & 88 & 0.52 & -0.37 & 31 & 56 & 0.97 & 0.07 & 38 & 71 & 0.68 & 0 \\
\hline Hickman & 30 & 68 & 0.81 & -0.96 & 58 & 87 & 0.52 & -0.32 & 60 & 87 & 0.48 & -0.62 \\
\hline New Madrid & 49 & 84 & 0.61 & -0.83 & 58 & 90 & 0.50 & -0.23 & 51 & 84 & 0.60 & 0.36 \\
\hline Tiptonville & 53 & 86 & 0.57 & -1.03 & 51 & 83 & 0.60 & -0.46 & 60 & 81 & 0.55 & 1.01 \\
\hline Caruthersville & 59 & 91 & 0.48 & -1.1 & 65 & 92 & 0.47 & -0.67 & 64 & 90 & 0.48 & 0.06 \\
\hline Osceola & 59 & 80 & 0.61 & -0.55 & 58 & 81 & 0.57 & -0.11 & 34 & 74 & 0.76 & 0.14 \\
\hline Memphis & 24 & 54 & 0.96 & -0.55 & 50 & 84 & 0.59 & -0.34 & 54 & 78 & 0.65 & 0.08 \\
\hline Helena & 24 & 54 & 1.06 & -0.57 & 41 & 72 & 0.81 & -0.74 & 40 & 69 & 0.89 & 0.01 \\
\hline $\begin{array}{l}\text { Montgomery } \\
\text { Point }\end{array}$ & N/A & N/A & $\mathrm{N} / \mathrm{A}$ & N/A & 21 & 38 & 1.63 & 0.19 & 15 & 35 & 1.64 & -0.64 \\
\hline Arkansas City & 32 & 60 & 1.10 & 0.91 & 25 & 51 & 1.30 & 1.19 & 20 & 44 & 1.18 & 0.13 \\
\hline
\end{tabular}

In Table 42, results are listed for locations along the Mississippi River from Chester, IL, downstream to Arkansas City, AR. The percentage of the availability of observed data for the 2002-2011 simulation period is listed. For each event and location, the accuracy of the model is described by listing the percentage of calculated stages within 0.5 and $1.0 \mathrm{ft}$ of the observed data, as well as the average error. For the continuous simulation, the general tendency is for the model to perform better at the upstream end of the model domain. Average errors are less than $2.0 \mathrm{ft}$ and typically less than $1.0 \mathrm{ft}$. 
Table 42. MVM calibration results for the 2002-2011 hourly simulation.

\begin{tabular}{|c|c|c|c|c|}
\hline Gage & $\begin{array}{l}\% \text { of Observed } \\
\text { Data Available }\end{array}$ & $\%$ within $0.5 \mathrm{ft}$ & $\%$ within $1.0 \mathrm{ft}$ & |Mean Error | (ft) \\
\hline Chester & 100 & 83 & 98 & 0.31 \\
\hline Red Rock & 64 & 69 & 93 & 0.47 \\
\hline GrandTower & 89 & 75 & 95 & 0.39 \\
\hline $\begin{array}{l}\text { Moccasin } \\
\text { Springs }\end{array}$ & 69 & 59 & 84 & 0.71 \\
\hline $\begin{array}{l}\text { Cape } \\
\text { Girardeau }\end{array}$ & 100 & 74 & 95 & 0.44 \\
\hline Thebes & 97 & 61 & 89 & 0.48 \\
\hline Commerce & 60 & 54 & 80 & 0.85 \\
\hline Price Landing & 98 & 51 & 83 & 0.57 \\
\hline $\begin{array}{l}\text { Thompson } \\
\text { Landing }\end{array}$ & 74 & 51 & 77 & 0.48 \\
\hline Bird's Point & 97 & 47 & 75 & 0.58 \\
\hline Smithland & 98 & 39 & 64 & 0.97 \\
\hline Paducah & 100 & 41 & 68 & 0.94 \\
\hline Metropolis & 23 & 66 & 87 & 0.32 \\
\hline Grand Chain & 99 & 39 & 60 & 1.24 \\
\hline Cairo & 100 & 36 & 61 & 0.77 \\
\hline Hickman & 100 & 56 & 84 & 0.58 \\
\hline New Madrid & 100 & 60 & 89 & 0.54 \\
\hline Tiptonville & 98 & 56 & 85 & 0.56 \\
\hline Caruthersville & 100 & 63 & 91 & 0.47 \\
\hline Osceola & 96 & 60 & 86 & 0.61 \\
\hline Memphis & 78 & 52 & 81 & 0.69 \\
\hline Helena & 83 & 41 & 74 & 0.87 \\
\hline $\begin{array}{l}\text { Montgomery } \\
\text { Point }\end{array}$ & 72 & 19 & 34 & 1.09 \\
\hline Arkansas City & 83 & 33 & 61 & 1.13 \\
\hline
\end{tabular}

\section{A.5 Two-dimensional (2D) storage areas}

The BPNM was modeled in HEC-RAS as a 2D area. The underlying terrain dataset was a $4 \mathrm{ft} \mathrm{LiDAR}$ grid, and Manning's $n$-values were associated with the USGS Land Use Dataset. The grid cells for the 2D area were $500 \mathrm{ft} \times 500 \mathrm{ft}$. Due to the limitations of time and the capabilities in HEC-RAS at the time of model construction, a detailed delineation of the interior was not completed. Although improvements could be made with 
newer HEC-RAS versions, the large amounts of flow entering the floodway during activation allowed for calibration to still be completed.

The overbank area between the confluence of the Arkansas, White, and Mississippi Rivers was modeled as a 2D area. The underlying terrain dataset was $30 \mathrm{ft}$ lidar grid. The grid cells for the 2D area were $500 \mathrm{ft} \times 500 \mathrm{ft}$. The area does a better job of computing volumes into and out of this area from the three different rivers than simply using a storage area. This is evident from the nearby gages at the mouth of the White River as well as at Dam Number 2 on the Arkansas River. No calibration data for the interior of the $2 \mathrm{D}$ area was available.

The BPNM Floodway was activated in 2011. Activation consisted of three breaches by explosives. The Inflow Crevasse was breached on 2 May 2011 at 21:04 CST. The design breach length is 11,099 ft, but during 2011 activation, approximately 9,400 ft was breached. The Inflow/Outflow \#1 Crevasse was breached on 5 May 2011 at 13:34 CST. The design breach is $5,500 \mathrm{ft}$, but due to a lack of explosive material available, only approximately $690 \mathrm{ft}$ was breaching during 2011. The Inflow/Outflow \#2 Crevasse was breached on 3 May 2011 at 11:35 CST. The design breach is $5,500 \mathrm{ft}$, but approximately 4,100 $\mathrm{ft}$ was breached during the 2011 event. Figure 133 below shows these breach locations.

Figure 133. BPNMF breach locations.

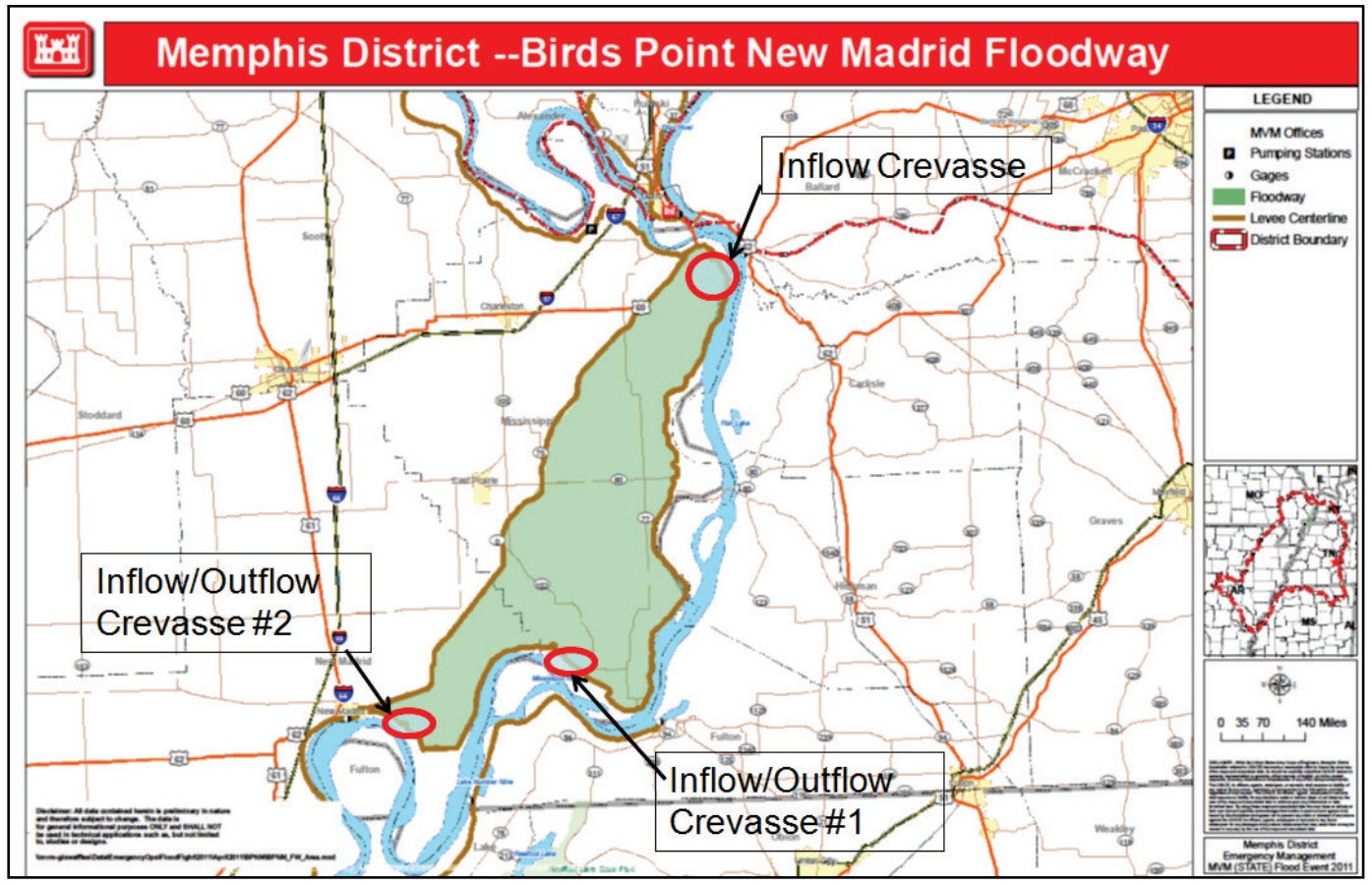


The USGS set up gages within the floodway before activation. Figure 134 through Figure 138 show the locations of these gages and a few examples of the comparison to the modeled computations.

Figure 134. USGS gage locations during 2011 activation.

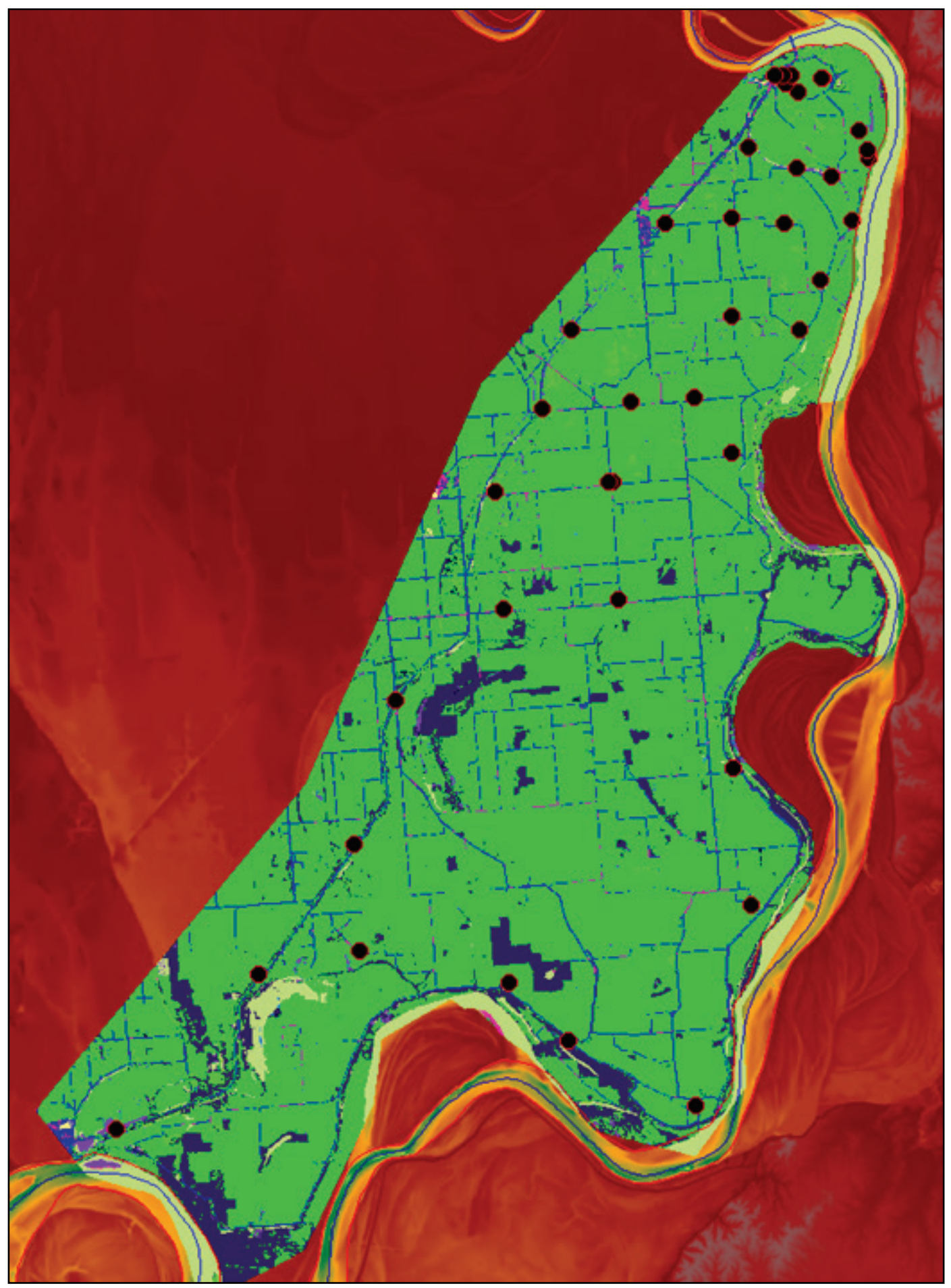


Figure 135. Elevation hydrograph near Inflow Crevasse.

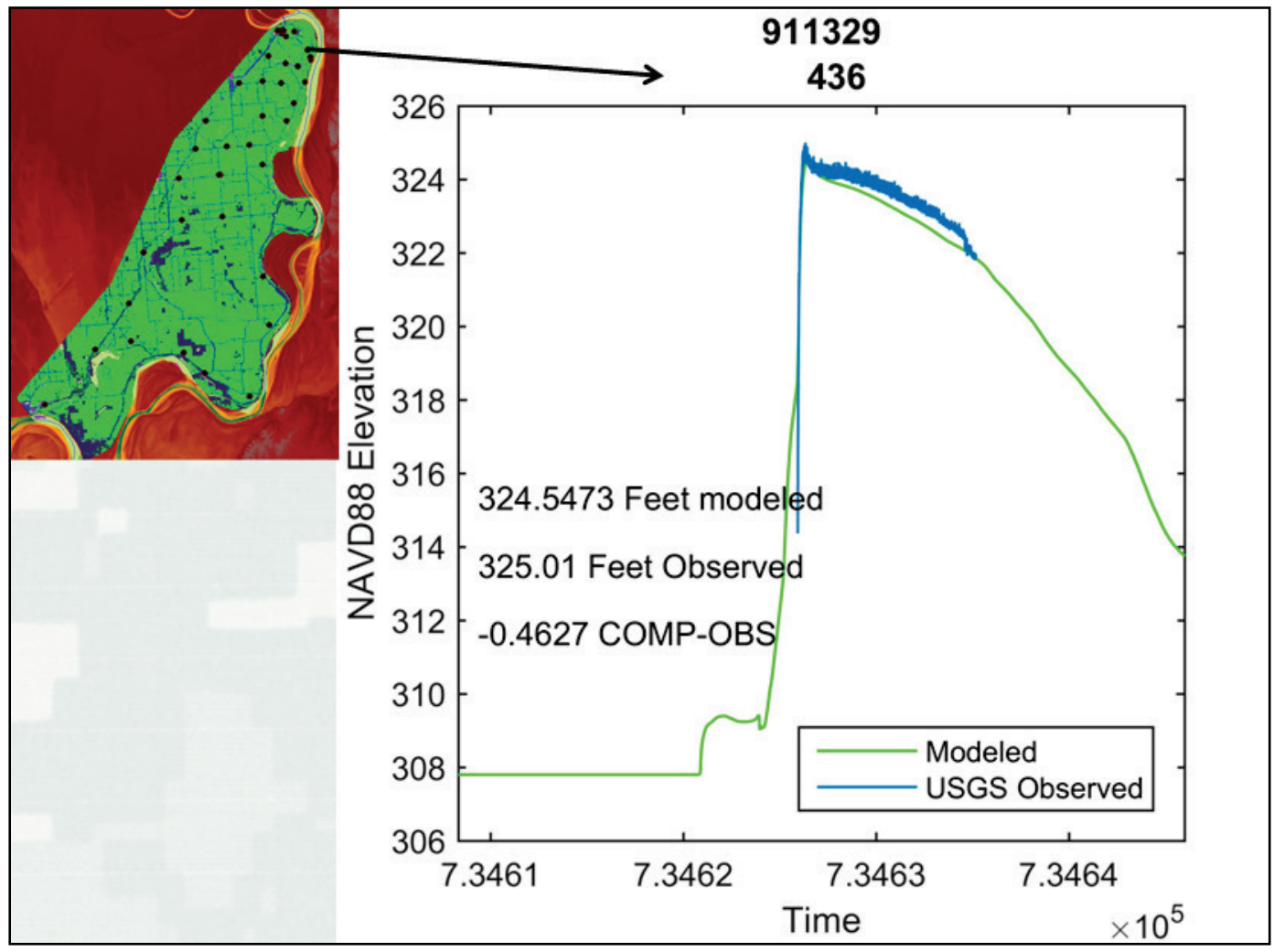

Figure 136. Elevation hydrograph near Inflow/Outflow \#1 Crevasse.

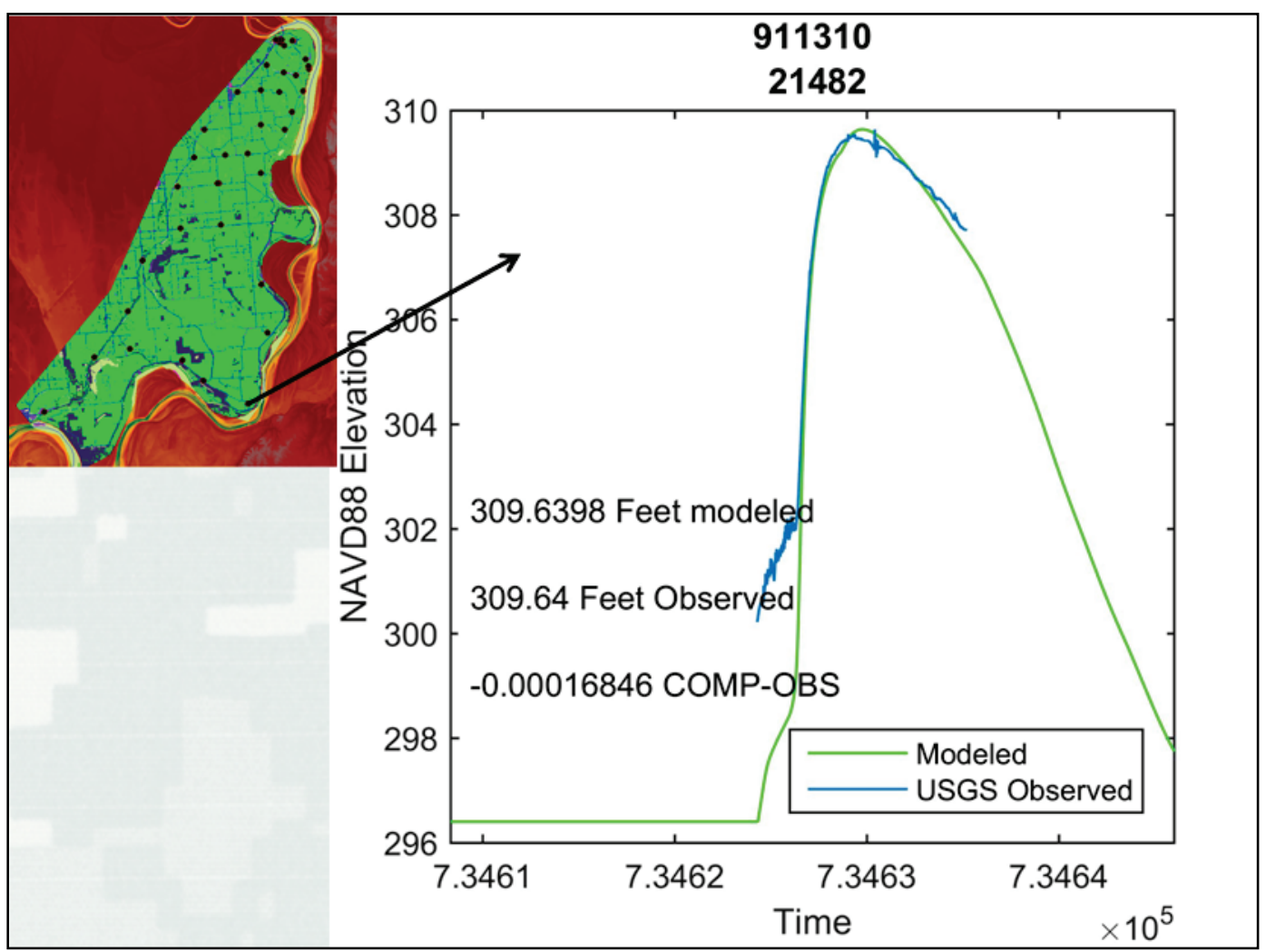


Figure 137. Elevation hydrograph near Inflow/Outflow \#2 Crevasse.

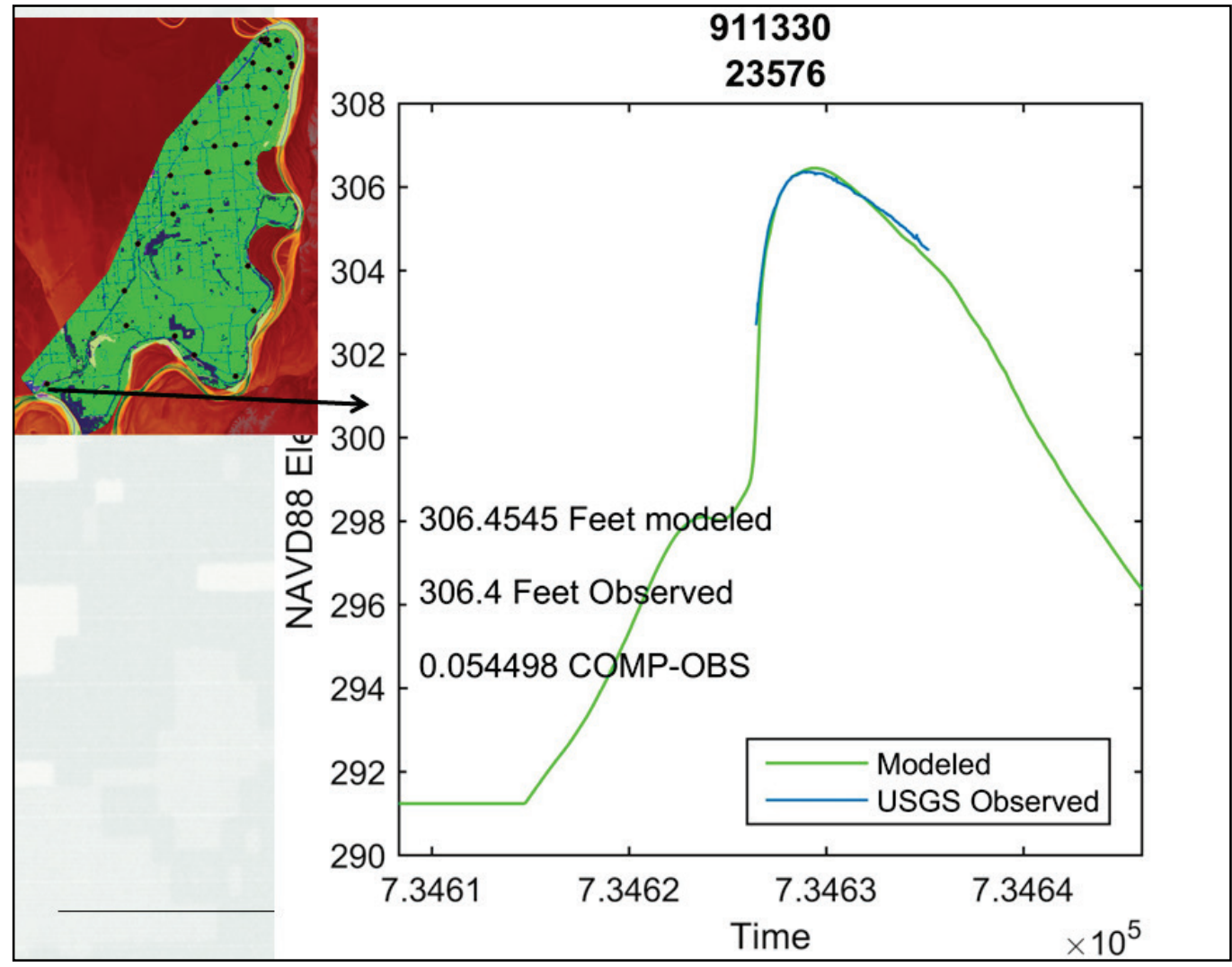

Figure 138. Elevation hydrograph near center of floodway.

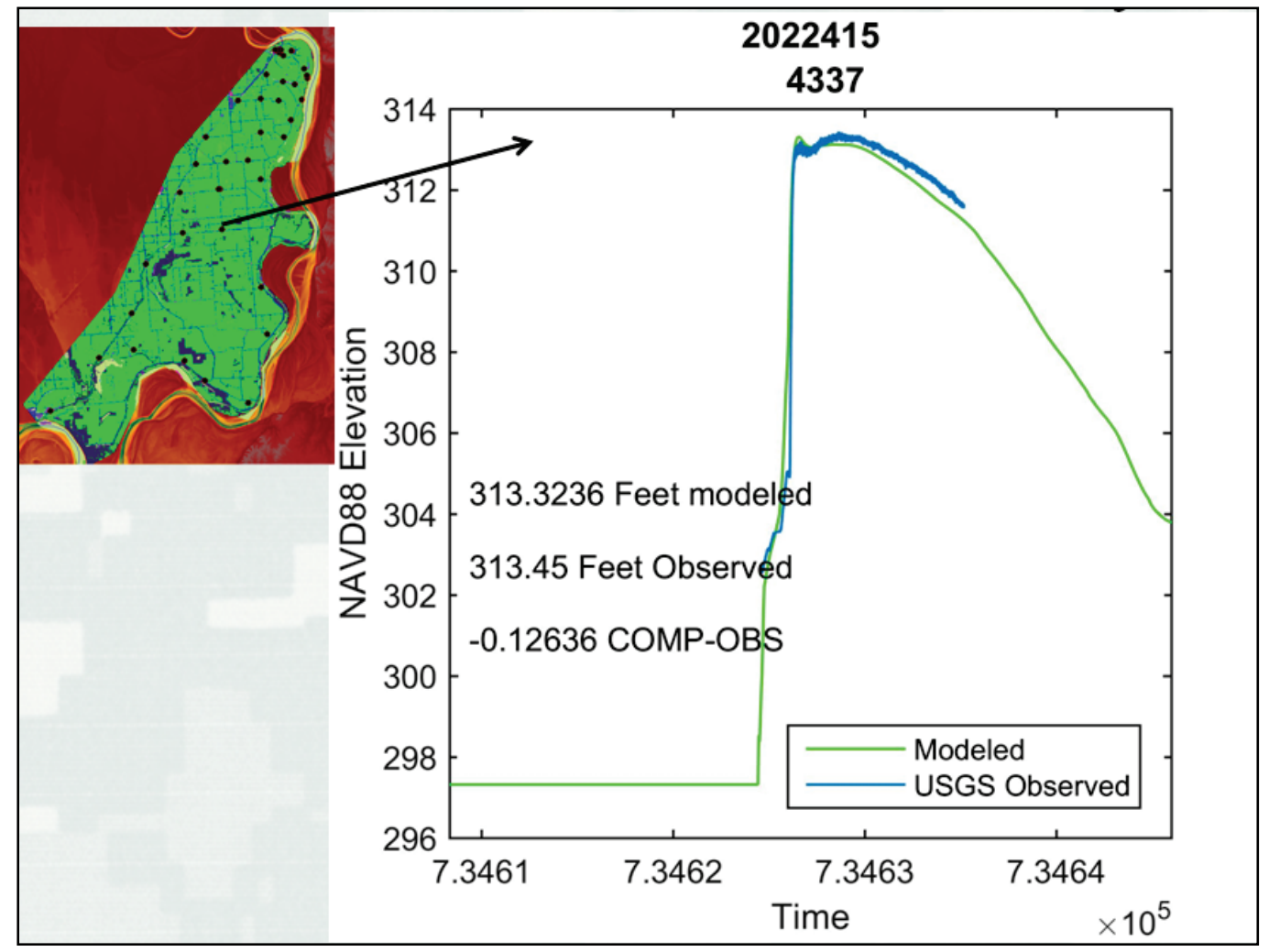




\section{A.6 2D summary}

The calibration of this portion of the model, for a range of flows for multiple events, indicates that the methods and assumptions applied for calibration are reasonable and can be applied to evaluate a PDF. Additional areas of refinement were noted from the calibration process. Prior to the PDF simulation, the BPNMF needs to be calibrated in two dimensions, which may have implications on the mainstem that will need to be evaluated. The Arkansas/White 2D area will also need to be extended for the PDF event to capture more of that complexity. Both of these features and capabilities are available in version 5 of the RAS software and will be added to the combined model to improve calibration prior to the PDF simulations.

\section{A.7 Conclusion}

The MVM model has been calibrated and validated for all three events: 2002, 2008, and 2011. The model is generally more accurate at the upstream end than at the downstream end. The absolute values of the mean error and differences at peaks are less than $2.0 \mathrm{ft}$ and typically less than 1.o ft. The 2D areas within the model have also been calibrated. 


\section{Appendix B: Vicksburg District (MVK) Model}

\section{B.1 Background}

The MVK utilized the HED-RAS (version 4.2.0; unpublished) unsteady hydraulic modeling software. The HEC-RAS model was constructed with the intent of adequately simulating the full range of flows that occurred during three separate high-flow years: 2002, 2008, and 2011. The model domain includes the mainstem Mississippi River, the Yazoo River, the Yazoo River Backwater area, the Red River Backwater area, reaches of the Red River, Ouachita-Black River, several smaller tributary channels, and numerous storage areas that help convey and/or store floodwater until downstream conditions allow the floodwater to recede. The HEC-RAS model is configured such that the mainstem Mississippi River is connected to the Red River Backwater area, which in turn is connected to the Atchafalaya River by the ORCC diversion channel. The ORCC requires daily regulation by the MVN to achieve a distribution of approximately $70 \%$ of the water continuing in the Mississippi River and 30\% being diverted into the Atchafalaya River. Since this area has a significant influence on the Red River Backwater area, the three structures and diversion channel were included in the MVK HEC-RAS model. A schematic of the MVK model is shown in Figure 139.

A section of the Red River Backwater area, located south of the Red River and west of the Old River diversion channel, was added to the model to better represent the topography of the backwater area. During the calibration process, it was determined that the backwater area created more instability in the model than other areas due to the location where the two channels (Red River and ORCC diversion) converged. Large amounts of floodwater moved into and out of this area; therefore, several structures such as small low flow structures and bridges were removed from the geometry file. Since the primary function of the area is to store floodwater, the inundated bridges and low flow structures did not affect the movement of the floodwater. 
Figure 139. Rosedale, MS, to St. Francisville, LA, (MVK) hydraulic model schematic.

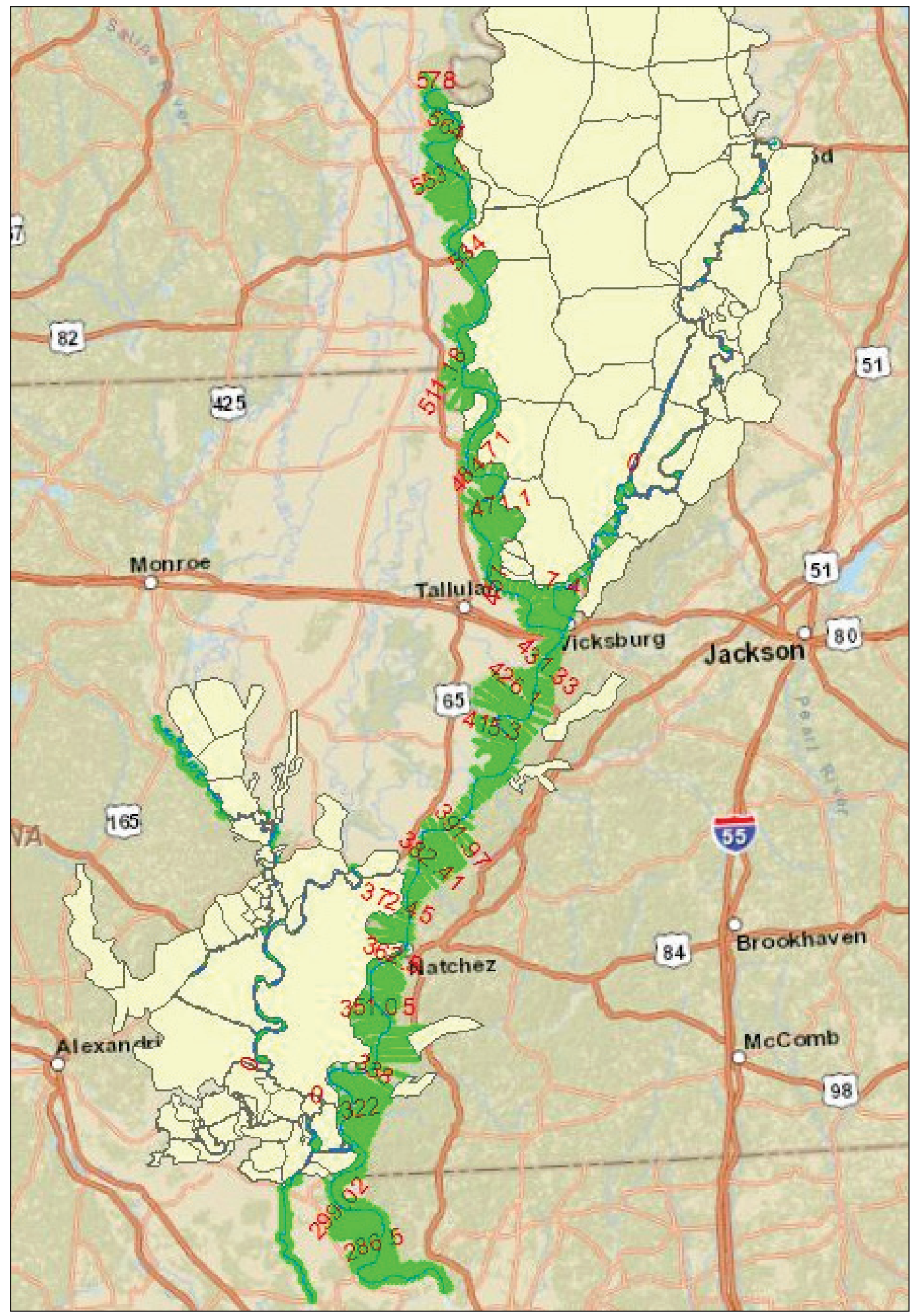




\section{B.2 Data compilation}

For the external and internal boundaries of the unsteady flow HEC-RAS model, flow and stage data were obtained from the USACE. The vertical datum being used for the model is the NAVD88. The elevations of many of the gages have been tied to the NAVD88 datum by surveying. For gages that have not been surveyed and related to NAVD88, Corpscon6 software (http://www.agc.army.mil/Missions/Corpscon.aspx, 8 February 2015) was used to convert the elevation of the gage in the NGVD29 to NAVD88.

Within the model domain, more stage data were available than flow data. Some areas had flow measurements that were taken near the crest of the 2011 flood that proved invaluable in determining the magnitude and direction of the floodwaters in the Red River backwater area. Table 43 lists the flow data used for setting up the MVK model, and Table 44 lists the gages with flow and stage data used in the calibration process.

Table 43. Flow data used for the MVK model setup.

\begin{tabular}{|c|c|c|c|c|}
\hline \multicolumn{5}{|c|}{ Main Inflows to the Model } \\
\hline River & Location & HEC-RAS Station(mile) & Parameter & Entity \\
\hline Mississippi & Flow from MVM model & 581.02 & Inflow & USACE \\
\hline Yazoo & Greenwood & 167.64 & Inflow & USACE \\
\hline Ouachita & Columbia Lock & 116.7 & Inflow & USACE \\
\hline Red & Lock and Dam 1 & 8.71 & Inflow & USACE \\
\hline \multicolumn{5}{|c|}{ Flows Diverted from Mississippi River to the Atchafalaya River } \\
\hline River & Location & $\begin{array}{c}\text { HEC-RAS } \\
\text { Station(mile) }\end{array}$ & Parameter & Entity \\
\hline Mississippi & $\begin{array}{l}\text { Flow from Mississippi } \\
\text { River to Old River } \\
\text { through Hydropower }\end{array}$ & 321.03 & Lateral Flow & USACE \\
\hline Mississippi & $\begin{array}{l}\text { Flow from Mississippi } \\
\text { River to Old River } \\
\text { through Low Sill } \\
\text { structure }\end{array}$ & 319.16 & Lateral Flow & USACE \\
\hline Mississippi & $\begin{array}{l}\text { Flow from Mississippi } \\
\text { River to Old River } \\
\text { through Auxiliary } \\
\text { structure }\end{array}$ & 317.98 & Lateral Flow & USACE \\
\hline $\begin{array}{l}\text { Old River } \\
\text { Outflow }\end{array}$ & $\begin{array}{l}\text { Flow from Auxiliary } \\
\text { Structure to Old River } \\
\text { diversion channel }\end{array}$ & 10.1 & Lateral Flow & USACE \\
\hline
\end{tabular}




\begin{tabular}{|l|l|c|l|l|}
\hline $\begin{array}{l}\text { Old River } \\
\text { Outflow }\end{array}$ & $\begin{array}{l}\text { Flow from Low Sill } \\
\text { Structure to Old River } \\
\text { diversion channel }\end{array}$ & 0.45 & Lateral Flow & USACE \\
\hline $\begin{array}{l}\text { Old River } \\
\text { Outflow }\end{array}$ & $\begin{array}{l}\text { Flow from HydroPower } \\
\text { to Old River diversion } \\
\text { channel }\end{array}$ & 19.39 & Lateral Flow & USACE \\
\hline \multicolumn{4}{|c|}{ Minor Flows for Model Stability } \\
\hline Boeuf & R1 & 10.95 & Inflow & USACE \\
\hline $\begin{array}{l}\text { Coulee Des } \\
\text { Grues }\end{array}$ & 1 & 5.47 & Inflow & USACE \\
\hline Dummy & 1 & 0.04 & Inflow & USACE \\
\hline Little River & R1 & 20.96 & Lateral Flow & USACE \\
\hline Old River1 & 1 & 0.44 & Inflow & USACE \\
\hline Old River6 & 1 & 0.12 & Inflow & USACE \\
\hline Tensas & R1 & 30.74 & Inflow & USACE \\
\hline
\end{tabular}

Table 44. Gages used to calibrate the MVK model.

\begin{tabular}{|l|l|c|}
\hline River & Location & $\begin{array}{c}\text { RAS } \\
\text { Station }\end{array}$ \\
\hline Mississippi & Arkansas city & 562.18 \\
\hline Mississippi & Vicksburg & 442.16 \\
\hline Mississippi & Natchez & 368.44 \\
\hline Black River & ACME & 0.2 \\
\hline Red River & Madam Lee & 15.35 \\
\hline Ouachita River & Columbia Lock and Dam & 116.1 \\
\hline
\end{tabular}

HEC Geo-RAS 10.2 for ArcGIS 10.2 (USACE 2012b) was used to translate the vector and raster data into HEC-RAS geometry. The projection and datum for the terrain model were USGS Albers Equal Area and NAVD88 (feet), respectively. The DEM for the MVK HEC-RAS model was derived from a 2006 lidar survey. The area extended from levee to levee or levee to high ground. The 2010 hydrographic surveys were augmented with the 2006 lidar data to build a terrain model of the total length of the Mississippi River within the MVK area of responsibility. Cross sections were then cut along the mainstem Mississippi River at an approximate spacing of one cross section per mile. 


\section{B.3 Model setup and calibration}

During the 2011 Mississippi River flood, the MVK used a HEC-RAS model of the Mississippi River constructed using hydrographic survey data and approximated overbank areas from 1990. It was possible to approximate the flood crest using the model; however, when attempting to calibrate the model, it could not be adjusted to match the crest elevation while achieving the proper timing of the flood crest. Therefore, only the peak of the crest was calibrated. For the current assessment, more recent surveys, newer overbank terrain, and additional hydraulic data have enabled the HEC-RAS model to be calibrated and useful over the full range of flows. The upper end of the Vicksburg model stops at $2011 \mathrm{RM} 581$. This point on the Mississippi River coincides with the mouth of the Arkansas River. The Arkansas City gage is located at RM 562.18 and is used to check the stages and flow in the model. The lower end of the model extends several miles downstream from the RRL, LA, gage.

For calibration, the HEC-RAS model was split into two parts (the mainstem Mississippi River and the Red River Backwater). Once the two parts were calibrated independently, they were combined. At present, there are three structures being used to divert flow from the Mississippi River into the Atchafalaya River. These three structures are the Sidney Murray Hydropower structure (RM 321.03), the Low Sill Structure (RM 319.16), and the Auxiliary Structure (RM 317.98). These flows are removed from the Mississippi River using lateral structures. During the phase of combining the MVK and MVN models, the ORCC structure was added to the model for future emergency use.

The calibration method used in-channel and overbank roughness coefficients (Manning's $n$-values) generated from a previous steady-state HEC-RAS model for the initial run. The Manning's $n$-values were then adjusted within appropriate tolerances to minimize the difference between measured stage and measured flow and model-generated stage and modelgenerated flow. Initially, the in-channel and overbank Manning's $n$-values were adjusted to match the highest 2011 flood peak. Subsequently, flow roughness factors were applied, resulting in peak stages and timing that more accurately matched the measured data. However, even though the stage, flow, and timing matched the measured data reasonably-well, it was noted that during the early and late part of the year, the computed stages were higher than the observed stages for the hydrographs even with the changes that had corrected the May 2011 flood peak. The timing was 
slightly off for these earlier year hydrographs. This condition is shown below in the plot of the Vicksburg gage (Figure 140).

There have been multiple studies of the ability of a river such as the Mississippi River to move flood flow down the river more efficiently during the colder water period than during the warmer water period (USACE 1978; Colby and Scott 1965). This was identified during the Refined 1973 Flowline Study for the Mississippi River and shown in the MVK Refined 1973 Flowline Report (USACE 1978). There are different opinions as to why this occurs; however, it has been shown in previous studies and observations of flow data that this does occur in the MVK. To show this effect on the stages and flood water movement, an adjustment was made using the option in HEC-RAS that allows adjustments in roughness based on the season. The seasonal roughness factor was adjusted for the first quarter and fourth quarter of the year. The model was then run with and without the seasonal roughness factors to determine the amount of change in stage that occurred, due to seasonal change, on stages during the passage of the flood. Hydrographs of computed versus measured data are shown for four different gages in Figure 140 to Figure 143 for January-December 2011. These figures demonstrate that using flow roughness factors and seasonal adjustments in roughness resulted in the best fit of the hydrograph and the timing alignment. 
Figure 140. 2011 Vicksburg gage calibration, (a) without seasonal roughness and (b) with seasonal roughness.

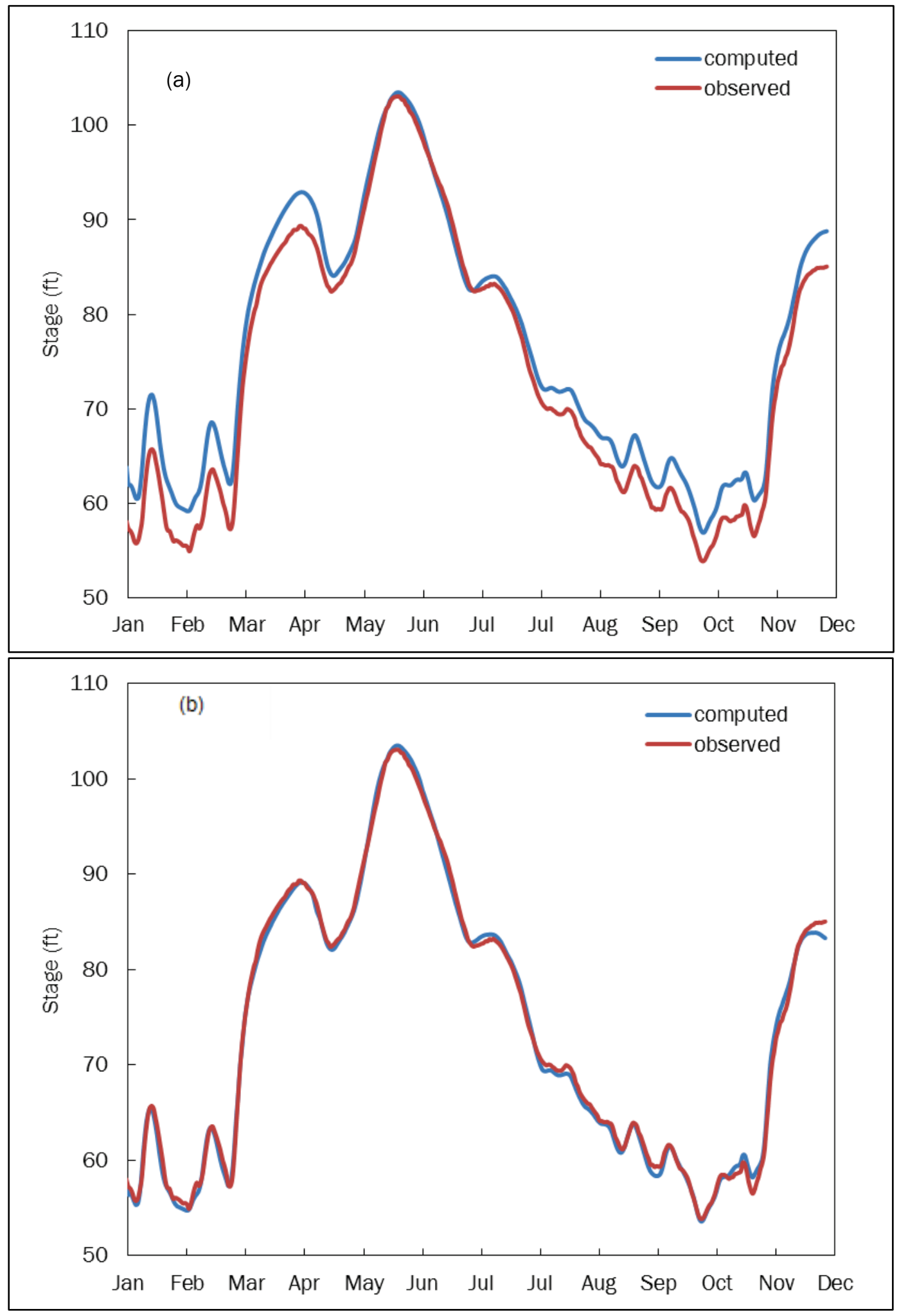


Figure 141. 2011 Arkansas City gage calibration, (a) without seasonal roughness and (b) with seasonal roughness.

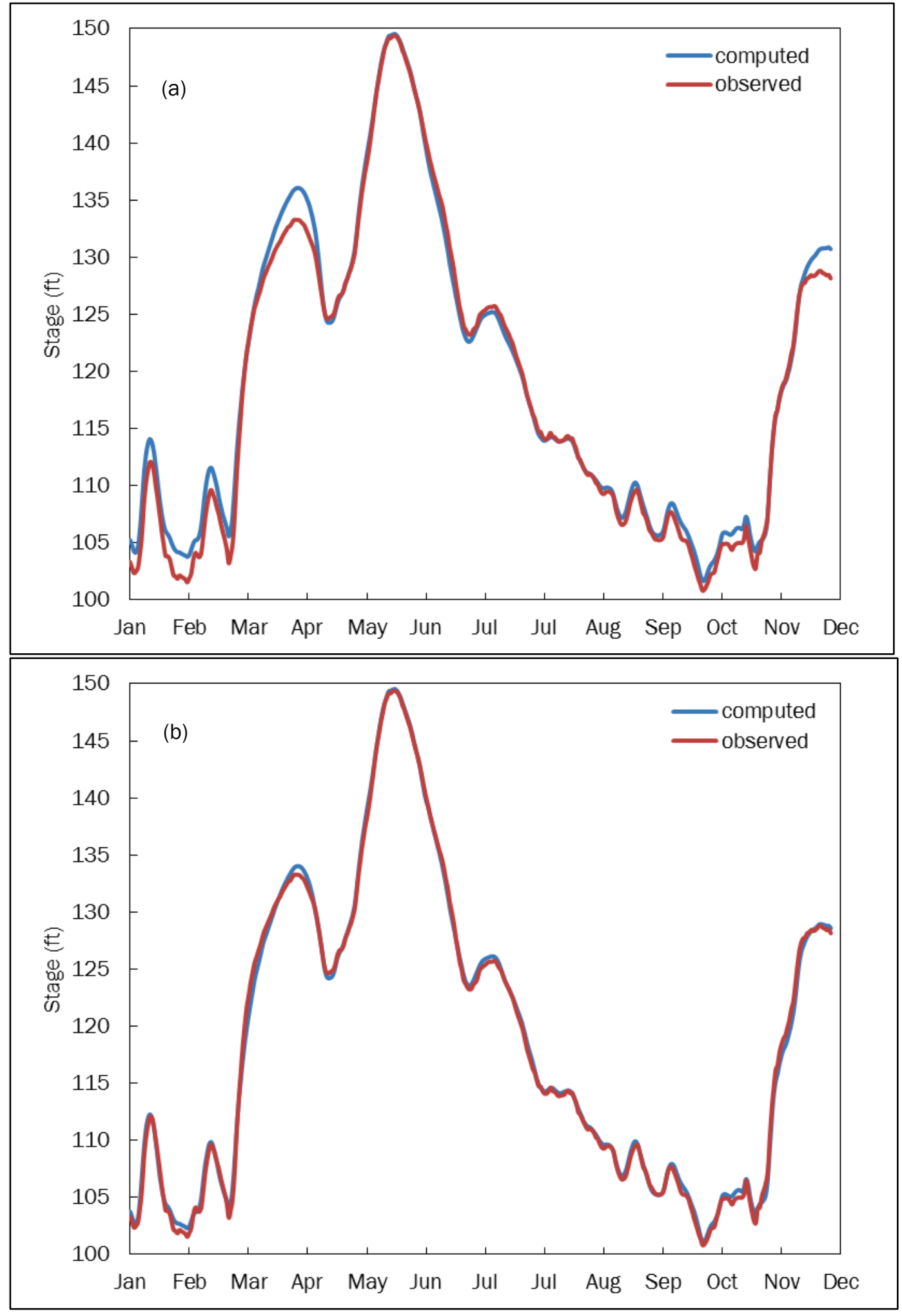


Figure 142. 2011 Greenville gage calibration, (a) without seasonal roughness and (b) with seasonal roughness.

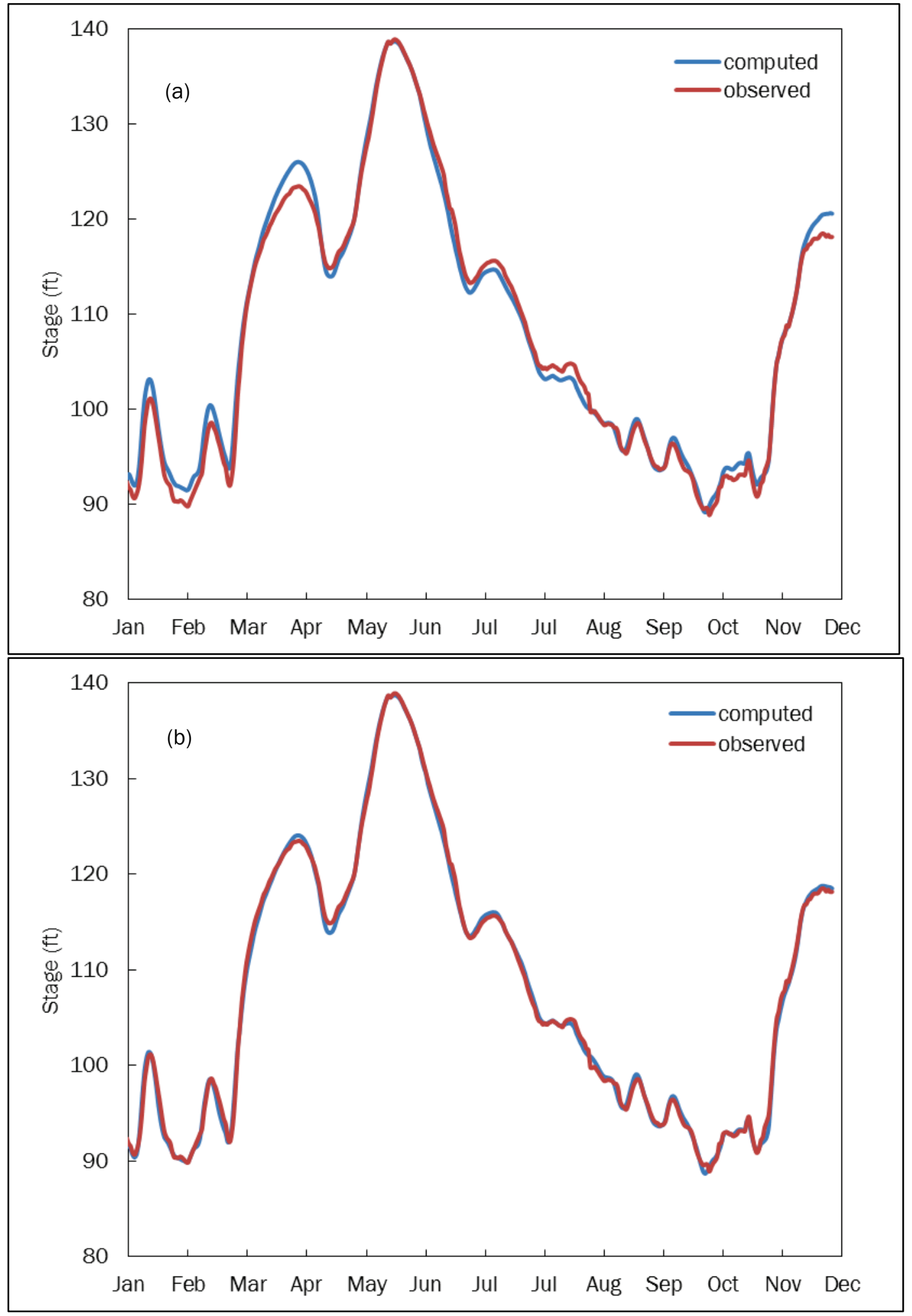


Figure 143. 2011 Lake Providence gage calibration, (a) without seasonal roughness and (b) with seasonal roughness.

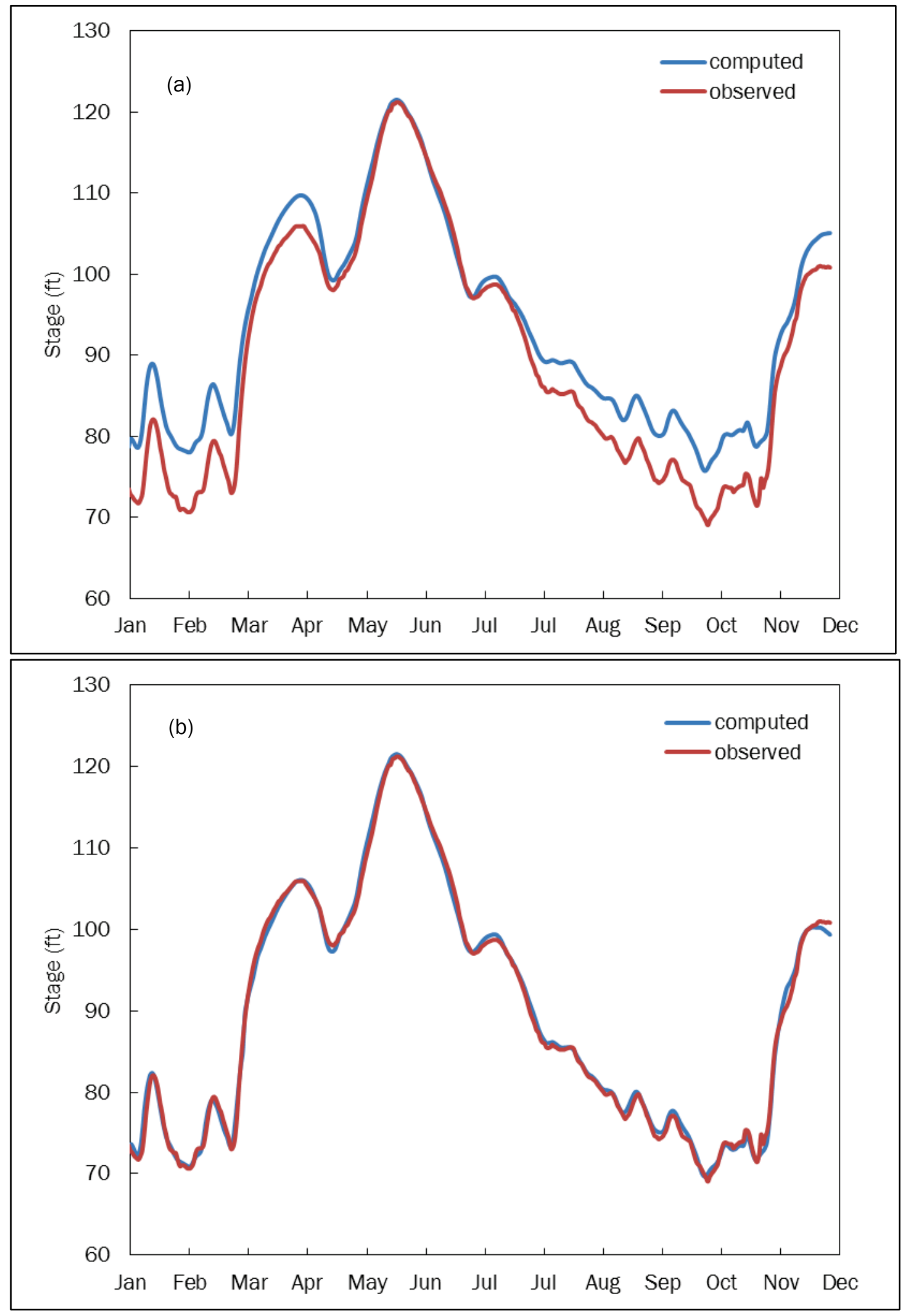




\section{B.4 Considerations and limitations}

There were some discrepancies in measured flow data, possibly from the measured flows not capturing all the water at the gage, such as at the Arkansas River gage where some of the overbank flow was missed. Another problem occurred at the Vicksburg gage with the timing and magnitude of the peak flood flow. The measured peak flow at Vicksburg occurred just before the measured peak flow occurred at the Arkansas City gage (approximately 118 miles upstream of the Vicksburg gage). This was noted during the calibration process, and while the measured peak flow could not be rectified, it was felt that based on the stage measurements at the gage and the flow measures at the other gages, the model stages and flows were within an acceptable tolerance.

\section{B.5 Results}

The 2011 Mississippi River flood presented a calibration challenge due to the problems associated with the measured flows at the three main gaging stations in the MVK. Challenges also existed in the large amount of overbank flood water that was stored and moved in and out of the storage areas as well as the failure of a frontline levee that protected an area known as Wilson Point located downstream from the Greenville, MS, gage.

The initial failure of the frontline levee at Wilson Point occurred on the upstream part of the levee, then on the downstream part of the levee from interior floodwater re-entering the Mississippi River. The model showed an appropriate dip in the water surface at the Greenville, MS, gage as the result of the levee failure. The model showed that while the Mississippi River flow at the time of failure was reduced, the river flow adjusted as the flood hydrograph increased. The observed flow data at the Vicksburg gage indicated no loss in peak flow, and this was also observed in the model.

The Red River Backwater area was the most difficult to calibrate due to the large amount of floodwater that was removed from the Mississippi River and temporarily stored in the backwater storage areas rather than moving downstream through the Atchafalaya River. The floodwater moving into the backwater areas resulted in the different river flows to reverse in several of the streams including the Red River and the Black River. 
The calibration of the MVK hydraulic model was concentrated on the 2011 event, but 2002 and 2008 events were also run through the model. In general, gages that recorded daily stage data were used for calibration. Table 45 lists results for each of the three primary events. Results are listed for locations along the Mississippi River from Arkansas City to Natchez. For each event and location, the accuracy of the model is described by listing the percentage of calculated stages within 0.5 and 1.0 $\mathrm{ft}$ of the observed data, as well as the average error. Also, the difference in peak elevations between calculated and observed stages is listed. For all three events, the model generally performed better at the upstream end.

Table 45. MVK calibration results for 2002, 2008, and 2011.

\begin{tabular}{|c|c|c|c|c|c|c|c|c|c|c|c|c|}
\hline & \multicolumn{4}{|c|}{2002 Event } & \multicolumn{4}{|c|}{2008 Event } & \multicolumn{4}{|c|}{2011 Event } \\
\hline $\begin{array}{l}\text { Gage } \\
\text { (RAS Station) }\end{array}$ & 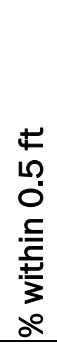 & 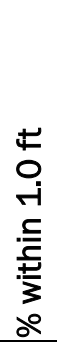 & 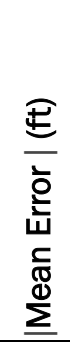 & 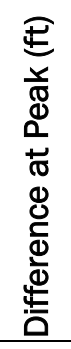 & $\begin{array}{l}+5 \\
10 \\
0 \\
.5 \\
\frac{1}{5} \\
\frac{1}{3} \\
0 \\
0\end{array}$ & 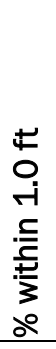 & 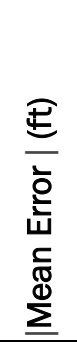 & 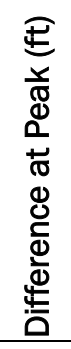 & 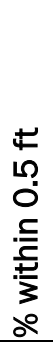 & 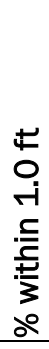 & 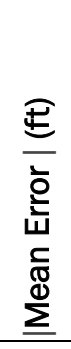 & 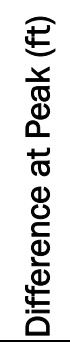 \\
\hline $\begin{array}{l}\text { Arkansas City } \\
(562.18)\end{array}$ & 22 & 45 & 1.13 & 1.14 & 63 & 94 & 0.44 & 0.60 & 71 & 95 & 0.39 & 0.16 \\
\hline Greenville (539.13) & 51 & 84 & 0.73 & 1.06 & 41 & 73 & 0.77 & 0.27 & 67 & 96 & 0.43 & 0.22 \\
\hline $\begin{array}{l}\text { Lake Providence } \\
(494.47)\end{array}$ & 12 & 25 & 2.21 & 1.37 & 34 & 62 & 1.02 & 0.47 & 49 & 91 & 0.59 & 0.32 \\
\hline Vicksburg (442.16) & 15 & 40 & 1.77 & 1.76 & 27 & 58 & 1.12 & 1.34 & 49 & 94 & 0.56 & 0.47 \\
\hline Natchez (368.44) & 5 & 15 & 3.07 & 3.76 & 10 & 25 & 2.46 & 4.69 & 54 & 80 & 0.62 & 0.00 \\
\hline
\end{tabular}

\section{B.6 Conclusion}

The calibration of the MVK reach of the model is best for 2011; however, it is adequate for a range of flows for multiple events. Additional analysis was conducted prior to the combined model validation to further investigate how this model and the other two models can most effectively use seasonal roughness information in the calibration. Currently, only the MVK uses seasonal roughness for calibration. The backwater areas, which included all or parts of the Yazoo River, Red River, Black River, and Little River, presented unique problems that may need to be revisited with 2D areas similar to those used in the MVM model. 


\section{Appendix C: New Orleans District (MVN) Model}

\section{C.1 Background}

The MVN model development utilized the HEC-RAS version 4.1.o, version 4.2.o Beta, version 5.o Beta, and version 5.0.1 at various stages. The model for the current assessment was developed from a RAS model utilized during the 2011 Mississippi River flood. The upstream boundary of the MVN model is located at RM 311.2 (1962 river miles), Tarbert Landing, LA. The downstream boundary is located at RM 10.51 (1962 river miles), Venice, LA, above the Head of Passes (AHP). This domain includes major river control structures like the Morganza Floodway and Bonnet Carré Spillway as well as man-made fresh-water and sediment diversions such as the Davis Pond Fresh Water Diversion, the Caernarvon Freshwater Diversion, Bohemia Spillway, Fort St. Phillip Diversion, and Baptiste Collette Diversion. There are also many other smaller natural outlets along the reach of the Lower Mississippi River downstream of New Orleans. There are no major hydrologic inflows within the New Orleans segment. There are only several very minor storage areas and no backwater areas contained within the segment. In general, the New Orleans main stem segment contains very little storage.

A schematic of the hydraulic model domain is shown in Figure 144. Crosssection spacing of approximately 200 to $8,600 \mathrm{ft}$ apart was utilized. The average spacing was approximately $3,400 \mathrm{ft}$. There were no bridges or inline structures included in the segment. 
Figure 144. Tarbert Landing, LA, to Venice, LA (MVN), hydraulic model schematic.

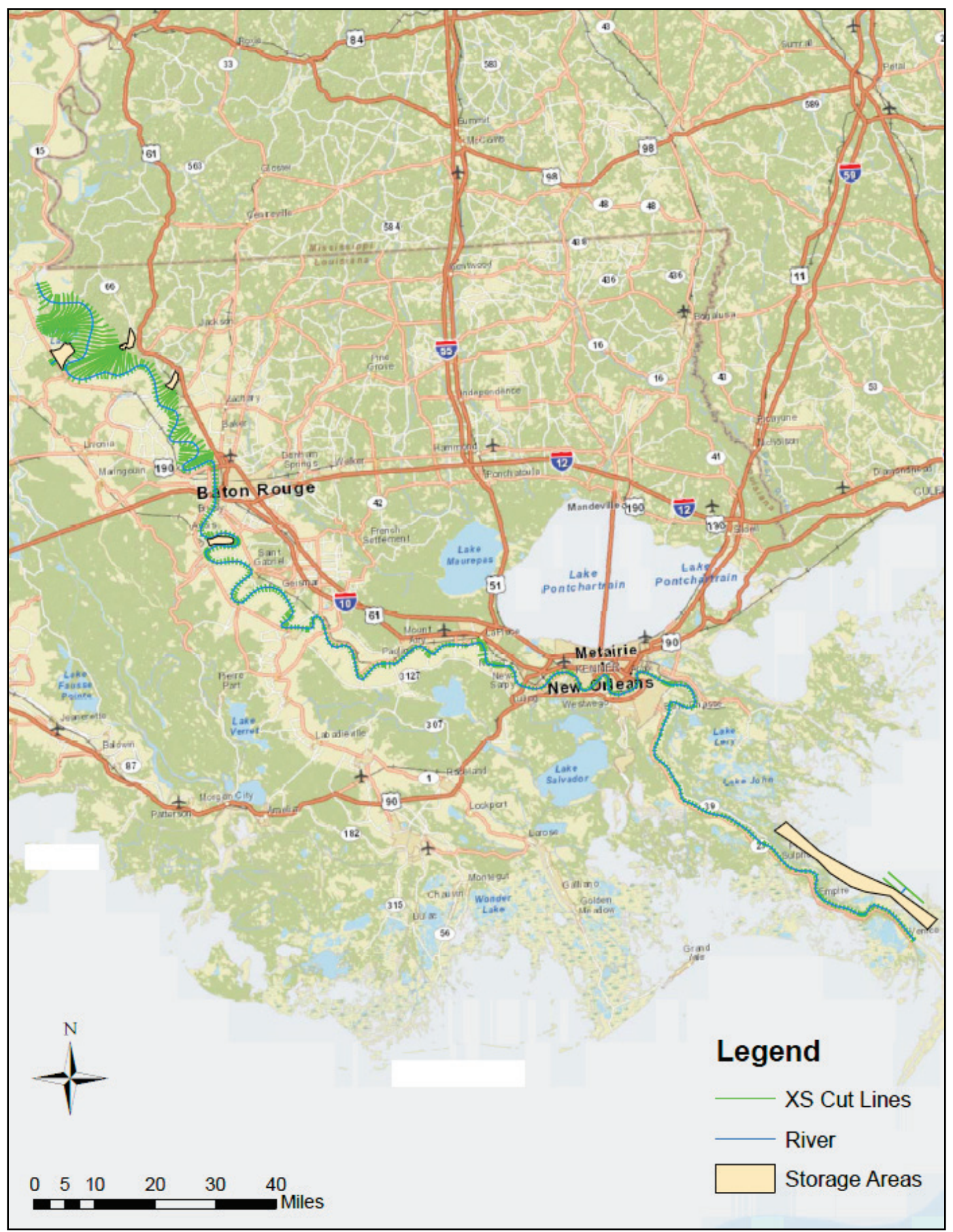

The MVN segment is located in the Southeast Louisiana region. In contrast to the Memphis and Vicksburg model regions, Southeast Louisiana is influenced by subsidence and sea level rise. For this reason, elevations in the MVN model are referenced to a particular epoch of the NAVD 88 datum (e.g., NAVD 88 2004.65). For the southern-most stretches of the river (below Baton Rouge), there can be a high degree of variation in stage 
readings between various epochs (up to $1 \mathrm{ft}$ or slightly more between consecutive epochs). Going upstream from the Venice area, the variation between epochs begins to lessen, since subsidence impacts gradually tapers down when going upstream. NAVD 882009.55 and NAVD 882004.65 are considered functionally equivalent upriver of New Orleans. Subsidence rates for South Louisiana are shown in Figure 145 (Zou et al. 2015). As observed, subsidence in the Venice area near the downstream model boundary is most severe, on the order of 29 millimeters/year on average. As noted in the main report, it is important for the epochs to be continually updated to use the model to accurately calculate flowline profiles in the future for this segment of the river.

Figure 145. Subsidence rates in South Louisiana.

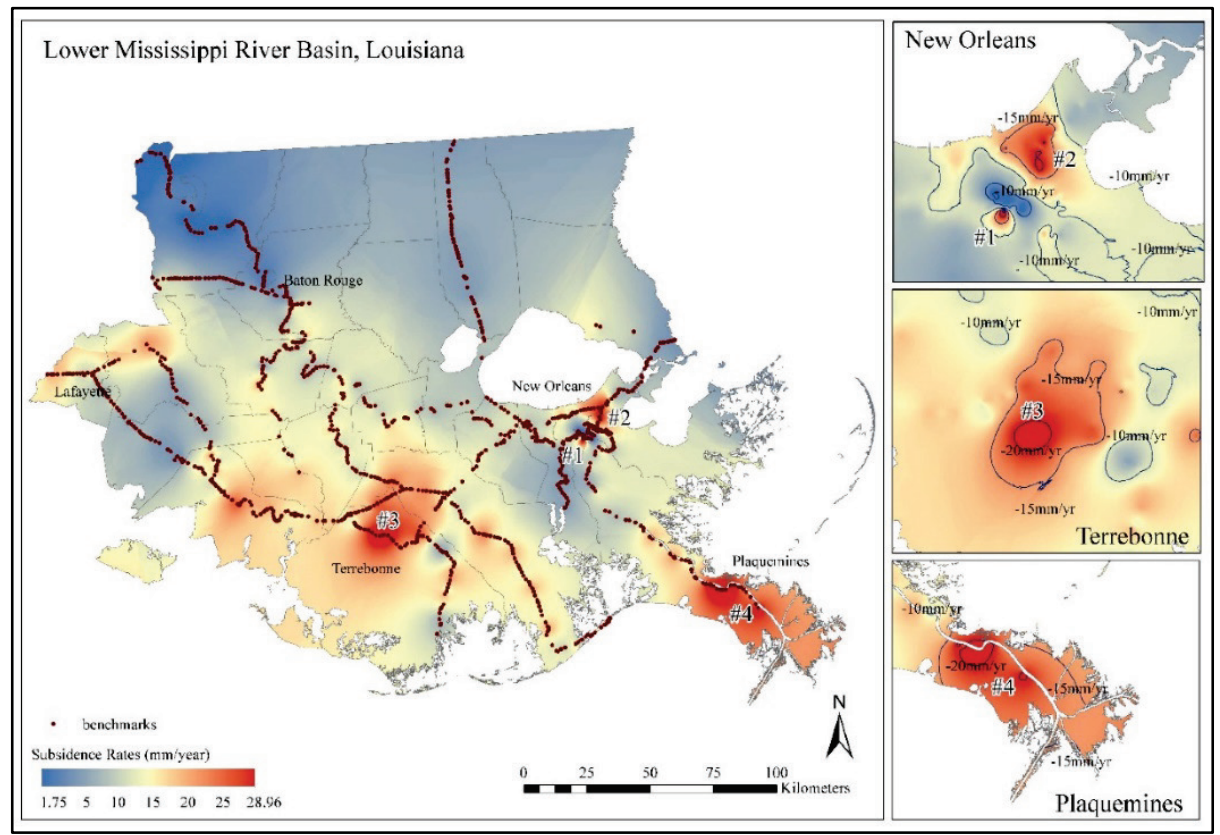

\section{C.2 Data compilation}

For the external and internal boundaries of the unsteady flow HEC-RAS model, flow and stage data were obtained from the USGS and the USACE. Due to subsidence in the southern segment of the river, Corpscon could not be used to convert between various datums. Surveys to tie the gages to NAVD 88 2004.65, the vertical datum used for the geometry and gage data, were needed for the gages that are referenced to a prior NAVD88 epoch, NGVD 29, or an arbitrary datum. Table 46 lists gage conversions for MVN gages. Table 47 lists the gages that were used, the agency responsible for the operation and management of each gage, the station name, and whether the gage reports stage and/or flow data. USGS gages at 
Baton Rouge (USGS gage \# 07374000) and Belle Chasse (USGS gage \# 07374525) record flow and stage data.

The Tarbert Landing, LA, gage was the only USACE flow gage used in the calibration (USACE gage \# O1100Q). For the Tarbert Landing gage, a flow reading based on a stage and stage/discharge rating curve is recorded daily. When the river is below flood stage at Tarbert, flow measurements are typically made twice per week to check the accuracy of the rating; however, the rating is checked more frequently when the river is in flood stage.

Table 46. MVN gage conversions.

\begin{tabular}{|c|c|c|c|c|c|c|c|c|c|}
\hline \multirow{2}{*}{$\begin{array}{l}\text { Location } \\
\text { (Gage ID) }\end{array}$} & \multicolumn{3}{|c|}{ Current Gage Zero } & \multicolumn{3}{|c|}{ NAVD88 Conversion(s) } & \multicolumn{3}{|c|}{ NGVD29 Conversion } \\
\hline & Datum & Epoch & Date & Value & Date & Epoch & Value & Date & Epoch \\
\hline \multirow{2}{*}{$\begin{array}{l}\text { Mississippi } \\
\text { River at RRL } \\
\text { (01120) }\end{array}$} & \multirow{2}{*}{ NGVD29 } & \multirow{2}{*}{1976} & \multirow{2}{*}{ Pre 1997} & -0.29 & $4 / 27 / 10$ & 2004.65 & \multirow{2}{*}{\multicolumn{3}{|c|}{ N/A }} \\
\hline & & & & -0.56 & $4 / 27 / 10$ & OPUS 2010 \# & & & \\
\hline $\begin{array}{l}\text { Mississippi } \\
\text { River near St } \\
\text { Francisville } \\
\text { (01145) }\end{array}$ & NAVD88 & $\begin{array}{l}\text { OPUS } \\
2010\end{array}$ & $8 / 24 / 10$ & -0.87 & $5 / 3 / 10$ & OPUS $2010 \#$ & & JNKNOV & /N * \\
\hline \multirow{2}{*}{$\begin{array}{l}\text { Mississippi } \\
\text { River at } \\
\text { Baton Rouge } \\
(01160)\end{array}$} & \multirow[b]{2}{*}{ NGVD29 } & \multirow[b]{2}{*}{1983} & \multirow[b]{2}{*}{ Pre 1997} & -0.37 & $5 / 5 / 10$ & 2004.65 & \multirow{2}{*}{\multicolumn{3}{|c|}{$\mathrm{N} / \mathrm{A}$}} \\
\hline & & & & -0.77 & $5 / 5 / 10$ & OPUS 2010 \# & & & \\
\hline \multirow{2}{*}{$\begin{array}{l}\text { Mississippi } \\
\text { River at } \\
\text { Donaldsonville } \\
\text { (01220) }\end{array}$} & \multirow[b]{2}{*}{ NGVD29 } & \multirow[b]{2}{*}{1983} & \multirow[b]{2}{*}{ Pre 1997} & -0.82 & $5 / 6 / 10$ & 2004.65 & \multirow{2}{*}{\multicolumn{3}{|c|}{ N/A }} \\
\hline & & & & -0.88 & $5 / 6 / 10$ & OPUS 2010 \# & & & \\
\hline \multirow{2}{*}{$\begin{array}{l}\text { Mississippi } \\
\text { River at } \\
\text { Reserve } \\
(01260)\end{array}$} & \multirow[b]{2}{*}{ NGVD29 } & \multirow[b]{2}{*}{1983} & \multirow[b]{2}{*}{ Pre 1997} & -0.70 & $5 / 5 / 10$ & 2004.65 & \multirow{2}{*}{\multicolumn{3}{|c|}{$\mathrm{N} / \mathrm{A}$}} \\
\hline & & & & -0.85 & $5 / 5 / 10$ & OPUS 2010 \# & & & \\
\hline \multirow{2}{*}{$\begin{array}{l}\text { Mississippi } \\
\text { River at Bonne } \\
\text { Carre - North of } \\
\text { Spillway } \\
(01275)\end{array}$} & \multirow[b]{2}{*}{ NGVD29 } & \multirow[b]{2}{*}{1983} & \multirow[b]{2}{*}{ Pre 1997} & -0.72 & $4 / 7 / 10$ & 2004.65 & \multirow{2}{*}{\multicolumn{3}{|c|}{$\mathrm{N} / \mathrm{A}$}} \\
\hline & & & & -0.68 & $4 / 7 / 10$ & OPUS 2010 \# & & & \\
\hline \multirow{2}{*}{$\begin{array}{l}\text { Mississippi } \\
\text { River at Bonnet } \\
\text { Carre (01280) }\end{array}$} & \multirow{2}{*}{ NGVD29 } & \multirow{2}{*}{1983} & \multirow{2}{*}{ Pre 1997} & -0.80 & $4 / 7 / 10$ & 2004.65 & \multirow{2}{*}{\multicolumn{3}{|c|}{$\mathrm{N} / \mathrm{A}$}} \\
\hline & & & & -0.70 & $4 / 7 / 10$ & OPUS 2010 \# & & & \\
\hline \multirow{2}{*}{$\begin{array}{l}\text { Mississippi } \\
\text { River at New } \\
\text { Orleans- } \\
\text { Carrollton } \\
(01300)\end{array}$} & \multirow[b]{2}{*}{ NGVD29 } & & & -0.79 & $8 / 24 / 10$ & 2004.65 & & & \\
\hline & & 1983 & Pre 1997 & -0.82 & $10 / 2 / 14$ & 2009.55 \# & & N/A & \\
\hline
\end{tabular}




\begin{tabular}{|c|c|c|c|c|c|c|c|c|c|}
\hline \multirow{2}{*}{$\begin{array}{l}\text { Location } \\
\text { (Gage ID) }\end{array}$} & \multicolumn{3}{|c|}{ Current Gage Zero } & \multicolumn{3}{|c|}{ NAVD88 Conversion(s) } & \multicolumn{3}{|c|}{ NGVD29 Conversion } \\
\hline & Datum & Epoch & Date & Value & Date & Epoch & Value & Date & Epoch \\
\hline \multirow{2}{*}{$\begin{array}{l}\text { Mississippi } \\
\text { River at Harvey } \\
\text { Lock } \\
(01320)\end{array}$} & \multirow{2}{*}{ NGVD29 } & \multirow{2}{*}{1983} & \multirow{2}{*}{ Pre 1997} & -0.79 & $\begin{array}{l}6 / 20 / 0 \\
7\end{array}$ & 2004.65 & \multirow{2}{*}{\multicolumn{3}{|c|}{ N/A }} \\
\hline & & & & -0.83 & $\begin{array}{l}11 / 12 / \\
14\end{array}$ & $2009.55 \#$ & & & \\
\hline $\begin{array}{l}\text { Mississippi } \\
\text { River at IHNC } \\
\text { Lock } \\
(01340)\end{array}$ & NAVD88 & $\begin{array}{l}2004 . \\
65\end{array}$ & $\begin{array}{l}10 / 15 / 0 \\
8\end{array}$ & -0.11 & $\begin{array}{l}10 / 16 / 1 \\
4\end{array}$ & 2009.55 & 0.97 & $\begin{array}{l}10 / 1 \\
5 / 08\end{array}$ & 1983 \\
\hline $\begin{array}{l}\text { Mississippi } \\
\text { River at Algiers } \\
\text { Lock } \\
(01380)\end{array}$ & NAVD88 & $\begin{array}{l}2004 . \\
65\end{array}$ & $\begin{array}{l}11 / 28 / 0 \\
7\end{array}$ & -0.06 & $\begin{array}{l}9 / 30 / 1 \\
4\end{array}$ & $2009.55 \#$ & 0.64 & $\begin{array}{l}9 / 19 \\
/ 07\end{array}$ & 1983 \\
\hline \multirow{2}{*}{$\begin{array}{l}\text { Mississippi } \\
\text { River at Alliance } \\
(01390)\end{array}$} & \multirow{2}{*}{$\begin{array}{l}\text { Gage } \\
\text { Datum } \\
\star \star\end{array}$} & \multirow{2}{*}{ N/A } & \multirow{2}{*}{ 7/1/08 } & -0.14 & $\begin{array}{l}11 / 27 / 0 \\
7\end{array}$ & 2004.65 & \multirow{2}{*}{0.57} & \multirow{2}{*}{$\begin{array}{l}11 / 2 \\
7 / 07\end{array}$} & \multirow{2}{*}{1983} \\
\hline & & & & 0.00 & $\begin{array}{l}10 / 9 / 1 \\
3\end{array}$ & $2009.55 \#$ & & & \\
\hline \multirow{2}{*}{$\begin{array}{l}\text { Mississippi } \\
\text { River at West } \\
\text { Pointe a la } \\
\text { Hache } \\
(01400)\end{array}$} & \multirow{2}{*}{$\begin{array}{l}\text { Gage } \\
\text { Datum } \\
* * *\end{array}$} & \multirow[b]{2}{*}{ N/A } & \multirow{2}{*}{$8 / 11 / 10$} & 0.10 & $\begin{array}{l}8 / 11 / 1 \\
0\end{array}$ & 2004.65 & \multirow{2}{*}{$\begin{array}{l}0.84 \\
* * * *\end{array}$} & \multirow{2}{*}{$\begin{array}{l}5 / 9 / \\
13\end{array}$} & \multirow[b]{2}{*}{1983} \\
\hline & & & & -0.21 & $\begin{array}{l}10 / 8 / 1 \\
3\end{array}$ & $2009.55 \#$ & & & \\
\hline $\begin{array}{l}\text { Mississippi } \\
\text { River at Empire } \\
\text { (01440) }\end{array}$ & NAVD88 & $\begin{array}{l}2004 . \\
65\end{array}$ & $\begin{array}{l}11 / 29 / 0 \\
5\end{array}$ & -0.64 & $\begin{array}{l}10 / 1 / 1 \\
3\end{array}$ & $2009.55 \#$ & $\begin{array}{l}-0.73 \\
* * * *\end{array}$ & $\begin{array}{l}4 / 24 \\
/ 14\end{array}$ & 1984 \\
\hline \multirow{2}{*}{$\begin{array}{l}\text { Mississippi } \\
\text { River at Venice } \\
(01480)\end{array}$} & \multirow{2}{*}{ NGVD } & \multirow{2}{*}{1983} & \multirow{2}{*}{ Pre 1997} & -0.58 & $\begin{array}{l}11 / 27 / 0 \\
7\end{array}$ & 2004.65 & \multirow{2}{*}{ N/A } & & \\
\hline & & & & -1.60 & $\begin{array}{l}10 / 2 / 1 \\
3\end{array}$ & $2009.55 \#$ & & & \\
\hline
\end{tabular}

\section{NOTES}

N/A: information not available.

* Gage re-established in new location in 2009 , no prior history.

** 01390 - Gage was set to invalid elevation of NAVD88 (2004.65) on 7/1/2008; conversion to true elevation of NAVD88 (2005.65) was back calculated to 2007 survey. NAVD88 (2004.65) to NGVD29 (1983) conversion is $+0.71 \mathrm{ft}$.

*** 01400 - Gage was set to NAVD88 (2004.65) on 9/24/2006 and was later considered gage datum 8/11/2010. Prior to Hurricane Katrina, gage was set to NGVD29.

$\star * * *$ Estimated conversion based on local Permanent Benchmark. 
Table 47. Flow and stage data used for MVN model setup.

\begin{tabular}{|l|l|c|l|l|}
\hline River & Station Name & RAS Station & Parameter & Entity \\
\hline Mississippi & Tarbert Landing & 316.37 & Flow & USACE \\
\hline Mississippi & RRL & 307.48 & Stage & USACE \\
\hline Mississippi & St. Francisville & 265.42 & Stage & USACE \\
\hline Mississippi & Baton Rouge & 232.49 & Stage/Flow & USGS \\
\hline Mississippi & Donaldsonville & 177.45 & Stage & USACE \\
\hline Mississippi & Reserve & 142.1 & Stage & USACE \\
\hline Mississippi & Bonnet Carré North & 134.3 & Stage & USACE \\
\hline Mississippi & Bonnet Carré South & 131.27 & Stage & USACE \\
\hline Mississippi & Carrollton & 106.96 & Stage & USACE \\
\hline Mississippi & Harvey Lock & 102.35 & Stage & USACE \\
\hline Mississippi & IHNC Lock & 92.96 & Stage & USACE \\
\hline Mississippi & Algiers Lock & 92.75 & Stage & USACE \\
\hline Mississippi & Belle Chasse & 80.20 & Stage/Flow & USGS \\
\hline Mississippi & Alliance & 66.85 & Stage & USACE \\
\hline Mississippi & West Pointe a la Hache & 53.22 & Stage & USACE \\
\hline Mississippi & Empire & 33.79 & Stage & USACE \\
\hline Mississippi & Venice & 15.07 & Stage & USACE \\
\hline
\end{tabular}

Digitization of Geographic Information System (GIS) data was necessary for the creation of the hydraulic model. HEC Geo-RAS 10.2 for ArcGIS 10.2 (USACE 2012b) was used to digitize the geometry into vector and raster data, then transfer that data into the HEC-RAS geometrical elements (1D cross sections, lateral structures, etc.). The horizontal projection for the terrain model is the USGS Contiguous Albers Equal Area and NAVD88 (2004.65), respectfully. Hydrographic surveys from 20042005 were used to develop the channel cross-sectional data. The channel surveys were taken from bank to bank. The overbank areas were extracted from lidar data. The lidar data were collected either during or around the year 2001 timeframe.

\section{C.3 Model setup and calibration}

The calibration of the model was a multi-step process. Year 2011, which included the record Mississippi River flood event, was used for calibration. Years 2002 and 2008, which also included high flow events, were used for validation. The main parameters adjusted during calibration were 
Manning's $n$-values, Manning's $n$-flow roughness factor tables, Manning's $n$-seasonal roughness factor tables, and lateral structure coefficients.

Ineffective flow areas were set in cross sections after examining aerial imagery and lidar data to determine where flow would not likely occur, such as for overbank areas where buildings or other barriers would obstruct flow. For floodplain areas where there was tree vegetation but no obstructions, higher Manning's $n$-values were used instead of ineffective flow areas. Several small 1D storage areas were added as lateral storage near RRL to represent overbank areas that are not part of the cross sections that would get inundated for large flows. Storage curves (elevation versus volume relationship) for these areas were formulated using the lidar data. These storage areas were connected to the main channel by lateral structures.

Flows through the Morganza Flood Control Structure and the Bonnet Carré Spillway were represented in the model as negative lateral inflow hydrographs as part of the unsteady flow file. These floodways were modeled in this manner because observed measurements from historical events were available, which allowed for a more accurate calibration and validation. This was beneficial since the Bonnet Carre was operated above the normal capacity of 250,000 cfs during the 2011 flood. Five other boundaries representing diversions, spillways, and natural river outlets in the Lower Mississippi River were also included in the MVN segmentDavis Pond Fresh-Water Diversion Structure, the Caernarvon Freshwater Diversion Structure, the Bohemia Spillway, the Fort Saint Phillip Natural Diversion, and the Baptiste Collette Natural Diversion. These five diversions were modeled using rating curves developed based on either design criteria, water control specifications, or measured data. The major diversions in the lower river, the Bohemia Spillway, Fort St. Phillip Diversion, and Baptiste Collette Diversion along with other minor outlets, are depicted in Figure 146. 
Figure 146. Diversions and outlets (in blue) - lower river.

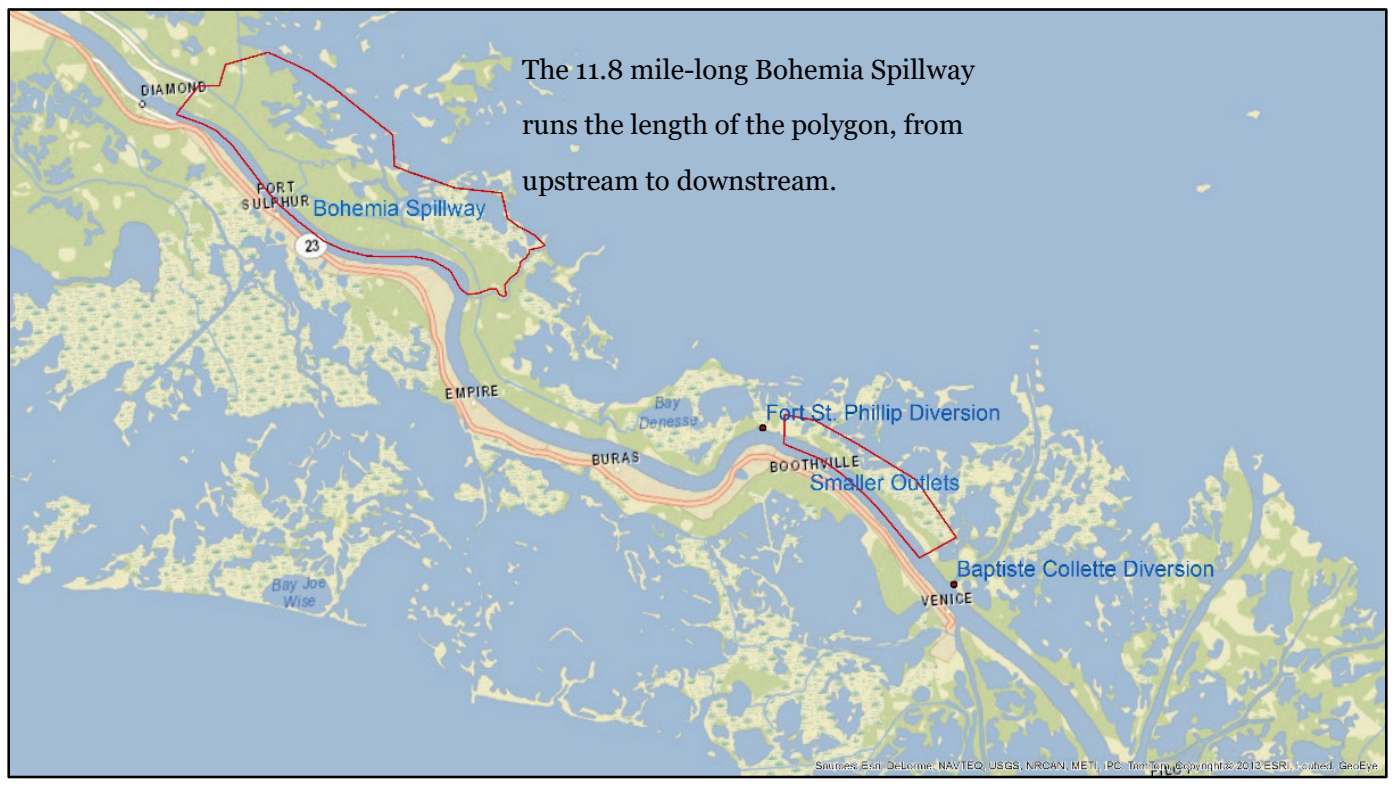

Flow measurements taken in the field of the river and of the various diversions were used in the calibration effort. In taking actual measurements of the river's flow between Belle Chasse and Venice, there is a relatively high degree of uncertainty in determining the volume of flow leaving the river, especially from the smaller outlets, at the various points. The indirect approach that is typically used, and that was used for measurements used in this study, is to calculate the diverted flow as the difference in Mississippi River flow between points upstream and downstream of the diversion location. Conversely, more confidence is derived for other diversions where point flow is measured at the outlet.

Also decreasing confidence in the measured data for the lower river is not only the relatively short period of record but also the lengthy intervals of measurement of the data. Flow measurement data at the various outlets are collected, on average, several times per year. Flow measurements along this reach date back to just December of 2003. Geomorphological change is consistent in the Venice area, and data just a few years old may no longer be as representative as when it was recorded.

To calibrate and verify the model, rating curves (diverted flow vs. Mississippi River flow) developed from the flow measurements were formulated with the intention that the developed curves must be able to accommodate the flows for the PDF events, which are higher than the 2011 
flood, along with any other observed readings. Therefore, the calculated ratings for these outlets and diversions were extrapolated.

The Davis Pond and Caernarvon Diversions are minor diversions, with flows of approximately 4,500 cfs and 6,000 cfs, respectively, for the 1,250,000 cfs current PDF flow. The Davis Pond Freshwater Diversion Structure rating curves were based on the HEC-6T Mississippi River sedimentation model developed by Copeland (USACE 2018c). The Caernarvon Freshwater Diversion rating curve was derived from water control specifications. Caernarvon diverts 6,000 cfs of flow at a 1,250,000 cfs Mississippi River flow. Both the Davis Pond and Caernarvon Diversion rating curves were incorporated into lateral structure rating curves in the HEC-RAS geometry.

The Bohemia diversion, at 11.8 miles long, diverts approximately 60,000 cfs of peak flow. A non-linear regression curve was developed based on an indepth study completed by the Lake Ponchartrain Basin Foundation (LPBF). Field flow data were not available to produce a rating curve for Bohemia, so the modeling team conducted research to try and determine the most reliable source of information. The modeling team ultimately selected the LPBF study for the rating curve data because it was based on the most extensive effort in trying to accurately determine flow through the spillway (Lopez et al. 2013). However, one drawback from the study is that the Bohemia flow is based on stages from the Carrollton stage gage (USACE gage \# 01300) approximately 60 miles upstream of Bohemia. However, it was concluded that the breath of the analysis overweighed this drawback.

The Fort St. Phillip (FSP) Diversion is located approximately 10 river miles north of Venice. Approximately $10 \%$ of the river's volume directly upstream of FSP is diverted there. For FSP, the aforementioned indirect method of calculating diverted flow as the difference in river flow at points upstream and downstream of the diversion was used. A rating curve to model the flow through the FSP Diversion was developed based on measurements taken at Ostrica Lock and at Venice by the MVN between December 2012 and August 2016. Between these two measurement points is Fort St. Phillip. The flow through the diversion was considered as the flow difference between the two measurement points. Smaller outlets on the river are also included between the two points. Consequently, this allowed the flow out of the smaller outlets to also be included in the Fort St. Phillip curve. A linear regression rating curve was developed and 
extrapolated to include higher flows than the measured flows to properly model the 2016 PDF event. Various other types of regression curves were examined, but the modeling team concluded that the linear curve best fits the observed data, especially for the higher flows. For the curve, the Fort St. Phillip flow is based on the Mississippi River flow at Ostrica Lock several miles upstream.

The Baptiste Collette Diversion, located directly upstream of the Venice gage, is also a major diversion that redirects, on average, approximately $10 \%$ of the river flow at the diversion point. A non-linear regression curve that extends high enough to handle 2016 PDF flows was developed using Baptist Collette flows measured by MVN between 2004 and 2012.

The rating curves for the Bohemia, Fort St. Phillip, and Baptiste Collette Diversions are incorporated by script in the unsteady flow file. This was necessary since the diversion flows were dependent on conditions not directly upstream of the diversion. If the flows were dependent on directly upstream, then the rating curves could have been incorporated into the lateral structure in the HEC-RAS geometry, similar to Davis Pond and Caernarvon.

There is an extensive floodplain area on the left descending bank downstream of the Eastbank Mississippi River Levee, with an upstream terminus at Pointe a la Hache and extending downstream to the mouth of the river. This overbank area was modeled as lateral structures, with weir coefficients set to 0.5. The lateral structures were needed so that overflow is allowed to be conveyed out of the river during very high flood events, when water would overtop the banks and extend across the floodplain. A synthetic storage area, entitled "Lake Borgne," is located in the model between the Venice gage (RAS station 15.07) upstream to the Pointe a La Hache gage (RAS station 53.22) at the southern terminus of the east bank levee where the river floodplain expands and is joined by the Gulf of Mexico. The storage area was connected to the river by the lateral structures representing the overbanks. The purpose of the storage area was two-fold: (1) to adequately simulate the storage provided by the marshy areas alongside the river, and (2) to allow for tidal interchange between the river and Lake Borgne across the overbank lateral structures. A large dummy channel was connected to the storage area for use as an external boundary since HEC-RAS does not allow a storage area to be used for this type of boundary. 
So that the model would not be unnecessarily complex in regards to the amount of geometrical elements, flow diversion through the navigation locks was not included in the model. There are six locks located within the MVN model. A simple calculation was made to determine the amount of unaccounted-for flow. The calculation consisted of six $1,200 \mathrm{ft} \times 80 \mathrm{ft}$ locks at $30 \mathrm{ft}$ of head on each, with two lockages per hour, which is approximately 10,000 cfs.

Once the flows were validated, the initial Manning's $n$-values were selected. A Manning's $n$-value of 0.03 was initially used for the channel, and 0.17 for the overbanks. Next, to accurately calculate the volume and phase of discharges at the Baton Rouge and Belle Chasse gages, using the data from the 2011 event, the positions of ineffective storage areas were modified, and Manning's $n$-values within the overbanks were revised. The most difficulty existed in trying to obtain modeled discharges comparable to those observed at the Baton Rouge gage. Although the model accounted for the volume passing Baton Rouge well, depending on the event, the model either lagged or preceded the flood hydrograph by several days.

After the calculated discharge hydrographs were adjusted to reasonable values, the calibration was completed in sections between each set of gages by further adjusting Manning's $n$-values. The Manning's $n$-values in the channel were adjusted to between 0.022 and 0.032 , while the overbank Manning's $n$-values were adjusted between 0.06 and 0.12 . Gradually increasing Manning's $n$-values were used moving upstream in the system in order to produce a reasonably calibrated model. Flow roughness values (multipliers) for the $n$-values were adjusted to be between 0.63 and 1.5 .

After storage and Manning's $n$-values were calibrated to 2011, data from the 2002 and 2008 events were used for validation. For the 2008 event, the Tarbert Landing flow, used as the upstream boundary, needed adjustment because the flow hydrograph at Baton Rouge had a higher volume of water passing for the event, and the model stages were correspondingly higher than observed for this event in the upper reaches. Most of this volume difference is at the peak of the hydrographs. The flow measurements at Tarbert Landing were higher than the modeled flow during the flood peak in 2008. 


\section{C.4 Considerations and limitations}

The following section lists considerations and limitations of the MVN model and recommendations for future updates.

1. The model does not accurately represent post-2011 flood channel bathymetry. Geometric updates would be helpful to represent existing conditions in future updates. The New Orleans portion of the model is more susceptible to geomorphologic changes than the Memphis and MVK portions of the model, as the sediment grain size is smaller in New Orleans than in those districts.

2. As aforementioned, there is some degree of uncertainty in the amount of flow leaving the river near Venice since the geomorphology is very dynamic and the accuracy of measurements may change within time. Also, the most severe flood on record is 2011, which is below the severity of the New Hypo 58A-R event. Although statistical methods were utilized to address this, there is uncertainty of the accuracy of the model for the New Hypo 58A-R and any other flow events higher than 2011 flows.

3. The large areas of overbank storage are difficult to approximate with a 1D model. A 2D model should be developed in the future to represent these areas better, especially in the Venice area. The sparsity of geometrical data in that area prevented the completion of a 2D model for this effort.

\section{C.5 Results}

The calibration of the MVN hydraulic model focused primarily on the 2002, 2008, and 2011 high-flow events. Figure 147 through Figure 151 are the calibration plots, upstream to downstream. Table 48 lists results for each of the three high-flow events. For each event and location, the accuracy of the model is described by listing the percentage of calculated stages within 0.5 and $1.0 \mathrm{ft}$ of the observed data, as well as the average error. Also listed is the difference in peak elevations between calculated and observed stages. 
Figure 147. 2011 RRL gage calibration.

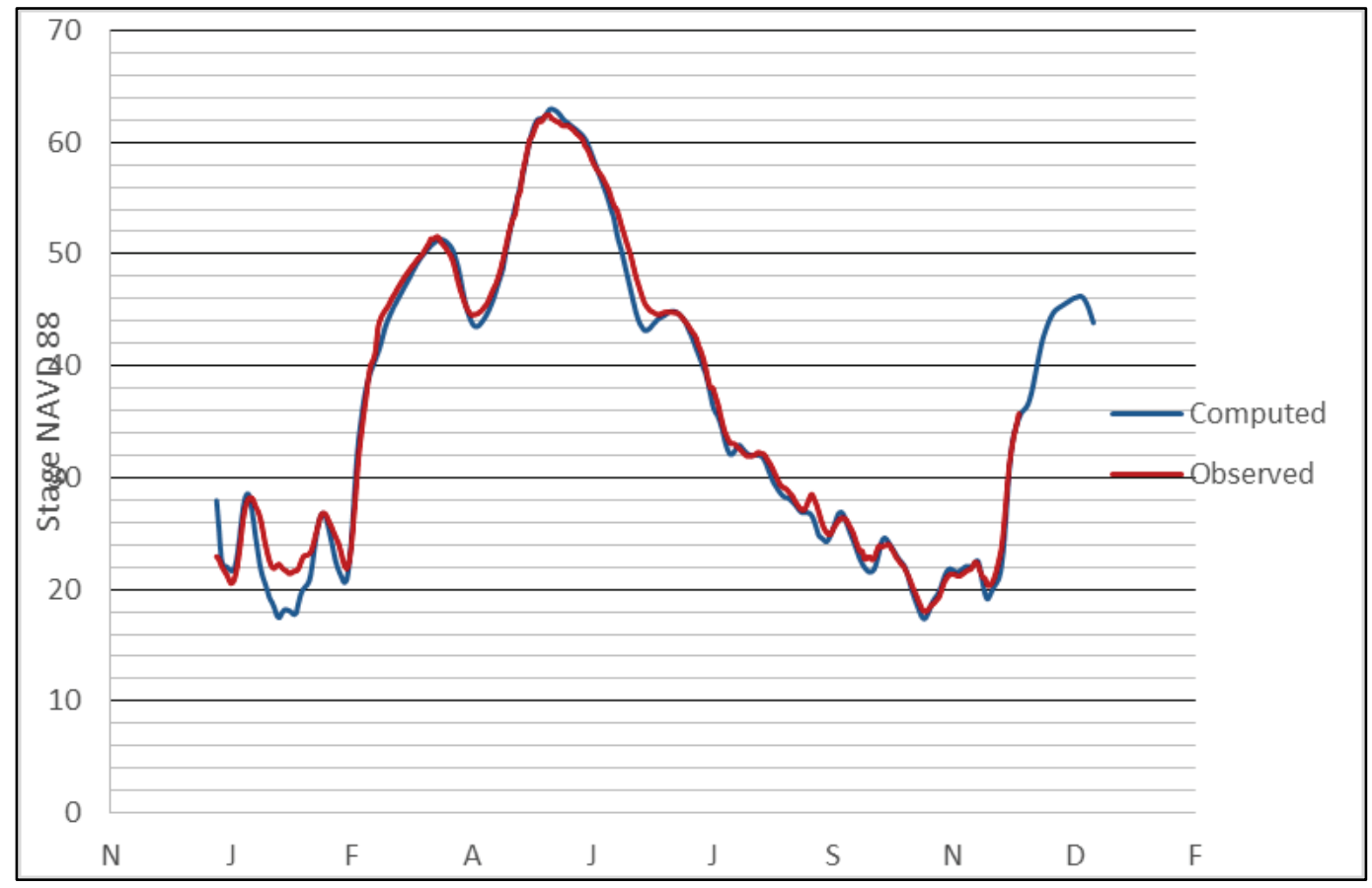

Figure 148. 2011 Baton Rouge gage calibration.

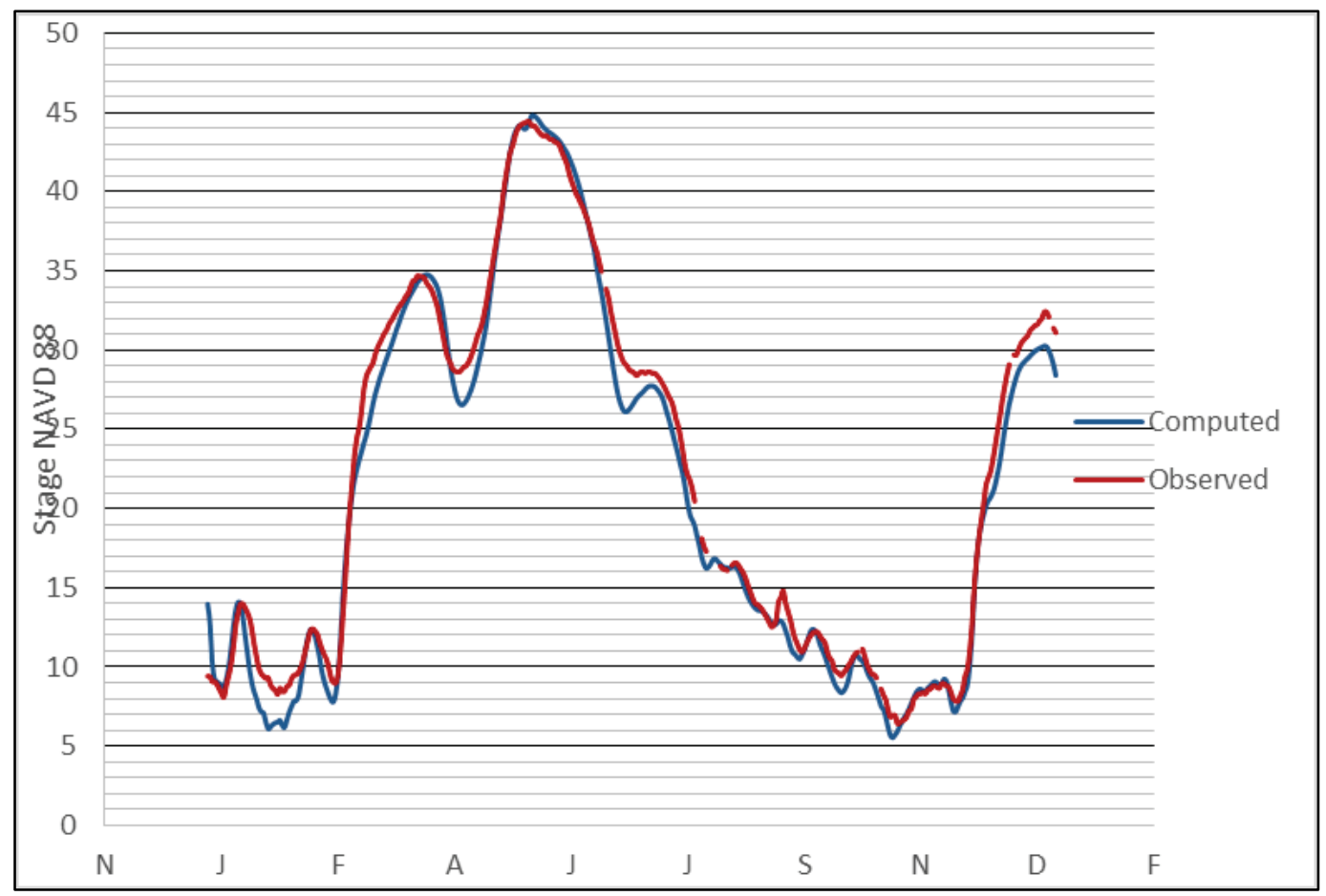


Figure 149. 2011 Donaldsonville gage calibration.

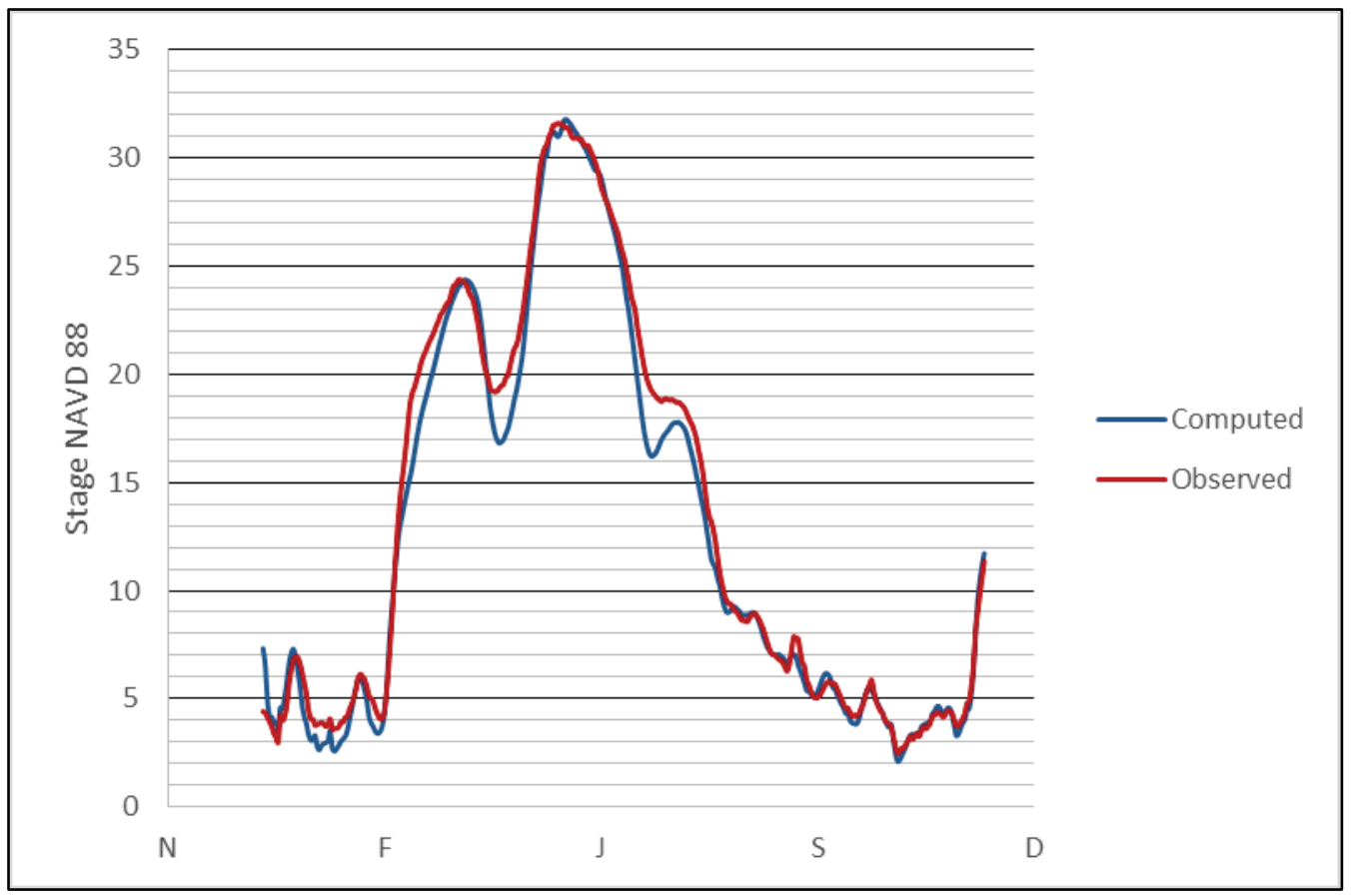

Figure 150. 2011 Carrollton gage calibration.

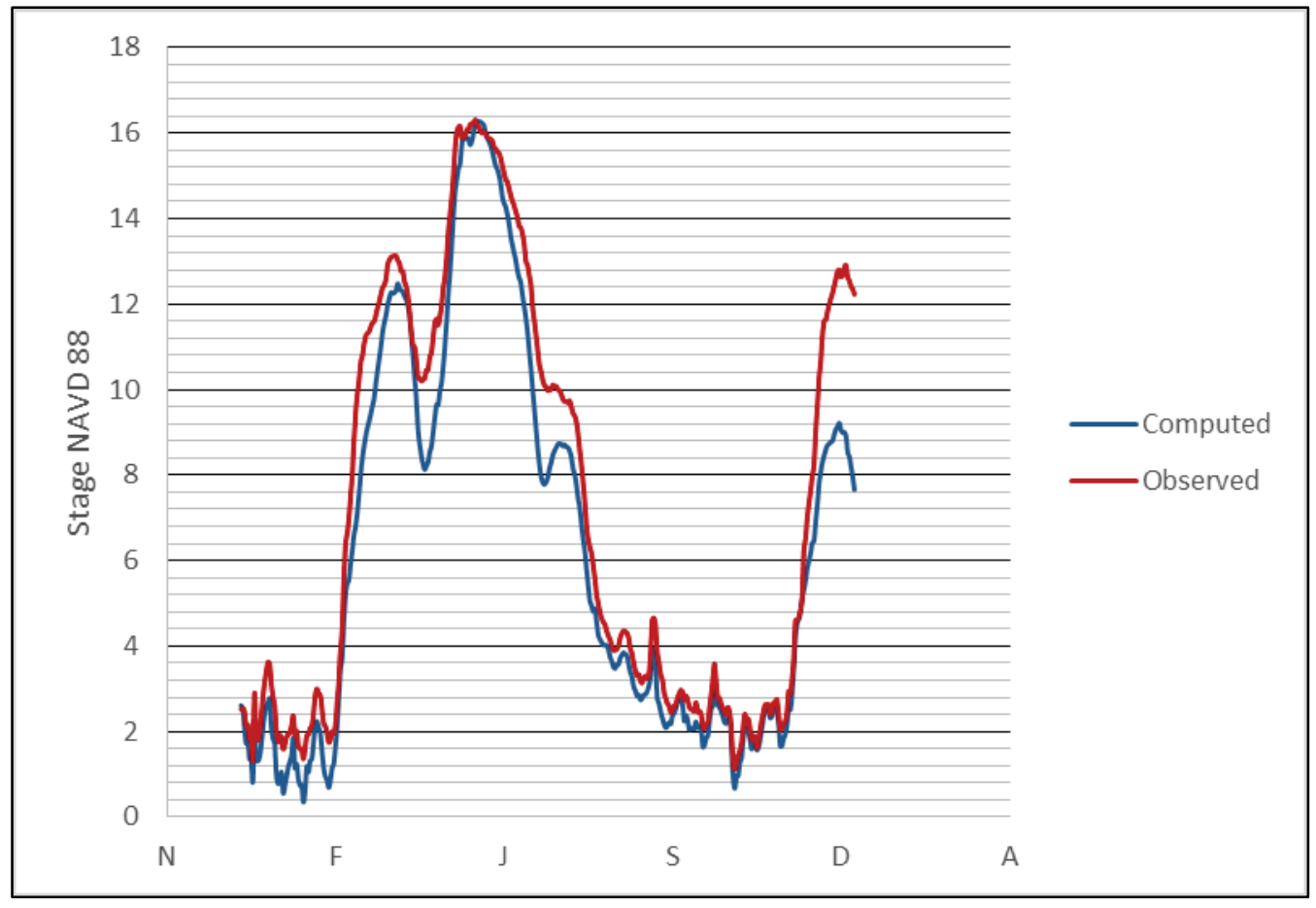


Figure 151. 2011 Pointe a la Hache gage calibration.

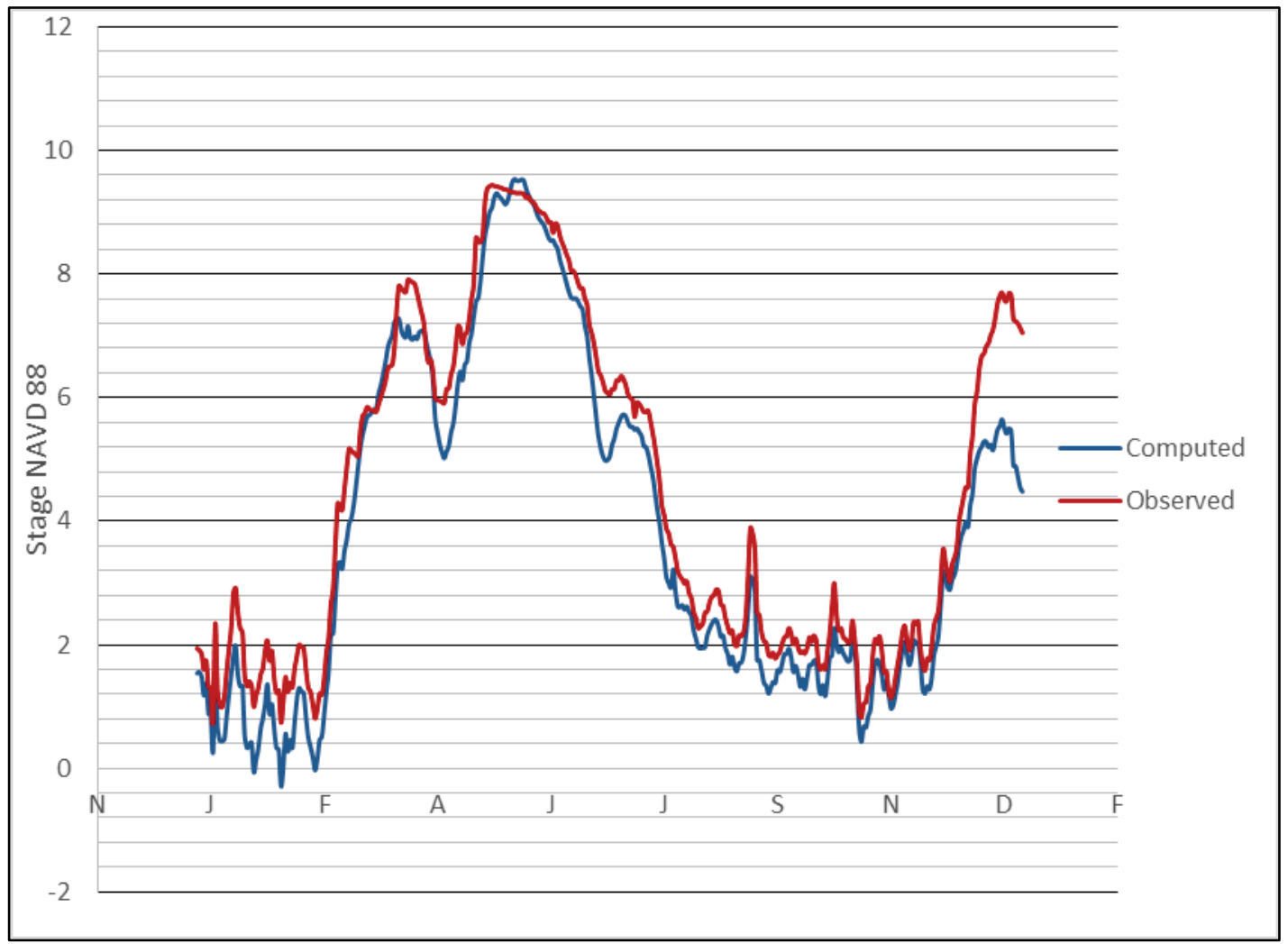

Table 48. MVN calibration results for 2002, 2008, and 2011 (n/a values indicate that data were not available at the gage for that time period).

\begin{tabular}{|c|c|c|c|c|c|c|c|c|c|c|c|c|}
\hline & \multicolumn{4}{|c|}{2002 Event } & \multicolumn{4}{|c|}{2008 Event } & \multicolumn{4}{|c|}{2011 Event } \\
\hline Gage & 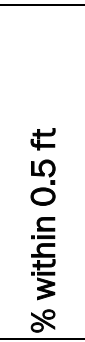 & 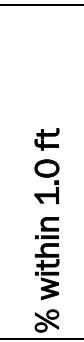 & 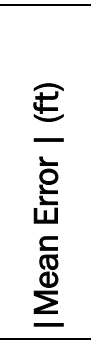 & 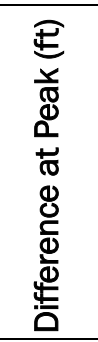 & 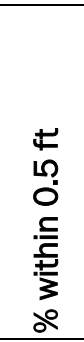 & 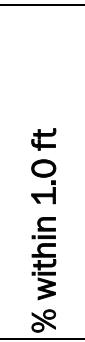 & 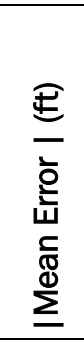 & 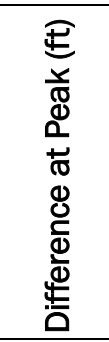 & 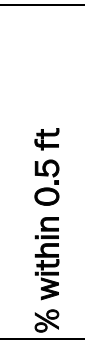 & 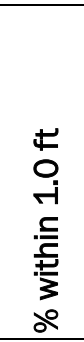 & 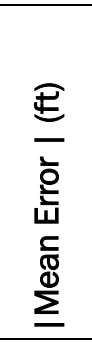 & 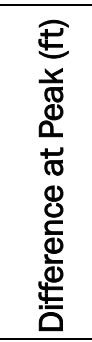 \\
\hline RRL & $2 \%$ & $4 \%$ & 4.41 & 4.88 & $23 \%$ & $41 \%$ & 1.96 & -1.15 & $41 \%$ & $69 \%$ & 0.95 & 0.56 \\
\hline St. Francisville & $\mathrm{n} / \mathrm{a}$ & $\mathrm{n} / \mathrm{a}$ & $\mathrm{n} / \mathrm{a}$ & $\mathrm{n} / \mathrm{a}$ & $\mathrm{n} / \mathrm{a}$ & $\mathrm{n} / \mathrm{a}$ & $\mathrm{n} / \mathrm{a}$ & $\mathrm{n} / \mathrm{a}$ & $33 \%$ & $53 \%$ & 1.06 & 0.33 \\
\hline Baton Rouge & $3 \%$ & $6 \%$ & 3.58 & 5.05 & $30 \%$ & $45 \%$ & 1.46 & -0.24 & $32 \%$ & $53 \%$ & 1.12 & 0.36 \\
\hline Donaldsonville & $13 \%$ & $23 \%$ & 2.1 & 3.22 & $18 \%$ & $44 \%$ & 1.60 & -0.72 & $51 \%$ & $72 \%$ & 0.80 & 0.18 \\
\hline Reserve & $15 \%$ & $28 \%$ & 1.71 & 2.65 & $25 \%$ & $48 \%$ & 1.34 & -0.46 & $42 \%$ & $67 \%$ & 0.84 & -0.2 \\
\hline $\begin{array}{l}\text { Bonnet Carré } \\
\text { North }\end{array}$ & $\mathrm{n} / \mathrm{a}$ & $\mathrm{n} / \mathrm{a}$ & $\mathrm{n} / \mathrm{a}$ & $\mathrm{n} / \mathrm{a}$ & $\mathrm{n} / \mathrm{a}$ & $\mathrm{n} / \mathrm{a}$ & $\mathrm{n} / \mathrm{a}$ & $\mathrm{n} / \mathrm{a}$ & $48 \%$ & $69 \%$ & 0.70 & 0.03 \\
\hline $\begin{array}{l}\text { Bonnet Carré } \\
\text { South }\end{array}$ & $7 \%$ & $16 \%$ & 2.19 & 3.55 & $41 \%$ & $72 \%$ & 0.84 & 0.93 & $35 \%$ & $65 \%$ & 0.97 & 0.09 \\
\hline Carrollton & $17 \%$ & $42 \%$ & 1.32 & 2.60 & $26 \%$ & $55 \%$ & 1.09 & -0.09 & $38 \%$ & $63 \%$ & 1.00 & -0.02 \\
\hline
\end{tabular}




\begin{tabular}{|c|c|c|c|c|c|c|c|c|c|c|c|c|}
\hline & \multicolumn{4}{|c|}{2002 Event } & \multicolumn{4}{|c|}{2008 Event } & \multicolumn{4}{|c|}{2011 Event } \\
\hline Gage & $\begin{array}{l}+5 \\
10 \\
0 \\
0 \\
\frac{.}{5} \\
3 \\
3 \\
0 \\
0\end{array}$ & 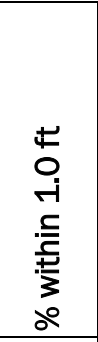 & 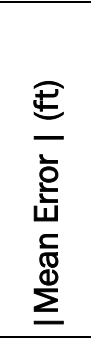 & 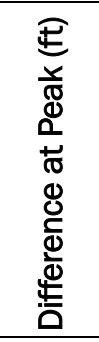 & $\begin{array}{l}\frac{1}{10} \\
10 \\
0 \\
.5 \\
\frac{5}{5} \\
3 \\
0 \\
0 \\
0\end{array}$ & 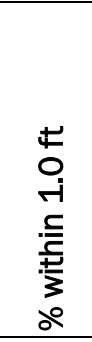 & 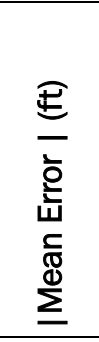 & 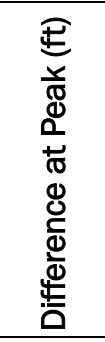 & $\begin{array}{l} \pm \\
10 \\
0 \\
0 \\
\frac{.}{E} \\
\frac{7}{3} \\
00 \\
0\end{array}$ & 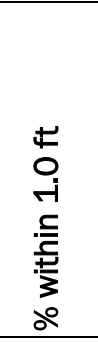 & 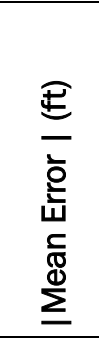 & 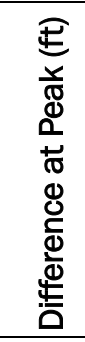 \\
\hline Harvey Lock & $\mathrm{n} / \mathrm{a}$ & $\mathrm{n} / \mathrm{a}$ & $\mathrm{n} / \mathrm{a}$ & $\mathrm{n} / \mathrm{a}$ & $\mathrm{n} / \mathrm{a}$ & $n / a$ & $\mathrm{n} / \mathrm{a}$ & $\mathrm{n} / \mathrm{a}$ & $53 \%$ & $89 \%$ & 0.60 & 0.1 \\
\hline IHNC Lock & $30 \%$ & $72 \%$ & .79 & 1.54 & $\mathrm{n} / \mathrm{a}$ & $\mathrm{n} / \mathrm{a}$ & $\mathrm{n} / \mathrm{a}$ & $\mathrm{n} / \mathrm{a}$ & $53 \%$ & $89 \%$ & 0.60 & 0.1 \\
\hline Algiers Lock & $49 \%$ & $92 \%$ & .56 & 1.04 & $57 \%$ & $90 \%$ & 0.51 & -0.01 & $62 \%$ & $86 \%$ & 0.53 & 0.2 \\
\hline Alliance & $\mathrm{n} / \mathrm{a}$ & $\mathrm{n} / \mathrm{a}$ & $\mathrm{n} / \mathrm{a}$ & $\mathrm{n} / \mathrm{a}$ & $\mathrm{n} / \mathrm{a}$ & $\mathrm{n} / \mathrm{a}$ & $\mathrm{n} / \mathrm{a}$ & $\mathrm{n} / \mathrm{a}$ & $\mathrm{n} / \mathrm{a}$ & $\mathrm{n} / \mathrm{a}$ & $\mathrm{n} / \mathrm{a}$ & $\mathrm{n} / \mathrm{a}$ \\
\hline $\begin{array}{l}\text { W. Pointe a la } \\
\text { Hache }\end{array}$ & $2 \%$ & $4 \%$ & 4.41 & 4.88 & $23 \%$ & $41 \%$ & 1.96 & -1.15 & $41 \%$ & $69 \%$ & 0.95 & 0.56 \\
\hline Empire & $n / a$ & $\mathrm{n} / \mathrm{a}$ & $n / a$ & $\mathrm{n} / \mathrm{a}$ & $\mathrm{n} / \mathrm{a}$ & $\mathrm{n} / \mathrm{a}$ & $\mathrm{n} / \mathrm{a}$ & $\mathrm{n} / \mathrm{a}$ & $33 \%$ & $53 \%$ & 1.06 & 0.33 \\
\hline
\end{tabular}

After completing the phase of calibration in which actual observed data were used for the Venice boundary to perform simulations, each calibration and verification simulation (2011, 2008, and 2002) was re-run using the identical rating curve that was developed for the PDF simulations. These simulations were run to determine if using the rating curve would produce drastically different results in regards to comparing the simulated vs. observed stages. Also of interest was how far any differences propagated upstream. Figure 152 through Figure 159 depict the comparisons at various gages for the events. It was observed from the simulations that the differences are largest at the Venice boundary and gradually taper off going upstream until the differences are virtually nonexistent at Carrollton. The largest differences were observed during low flows (under $600,000 \mathrm{cfs}$ ) for which the difference in the stages from using the observed data vs. rating curve boundary was in the range of 1.5 to $2 \mathrm{ft}$ at Venice for the 2011 calibration. However, it was noted that the differences lessen as the flow increases. For example, the stage was roughly $0.7 \mathrm{ft}$. higher when using the rating curve boundary for the peak yearly flow of the 2011 calibration at Venice and $0.4 \mathrm{ft}$. higher for the 2008 yearly peak. Since the flowline is based on flows that are higher than the 2011 calibration (meaning that the differences introduced by the curve would be even less than these simulations), it was concluded that using the rating curve boundary would not drastically impact the flowline. 
Figure 152. 2011 Venice stage comparisons with actual gage data vs. rating curve used for Venice boundary.

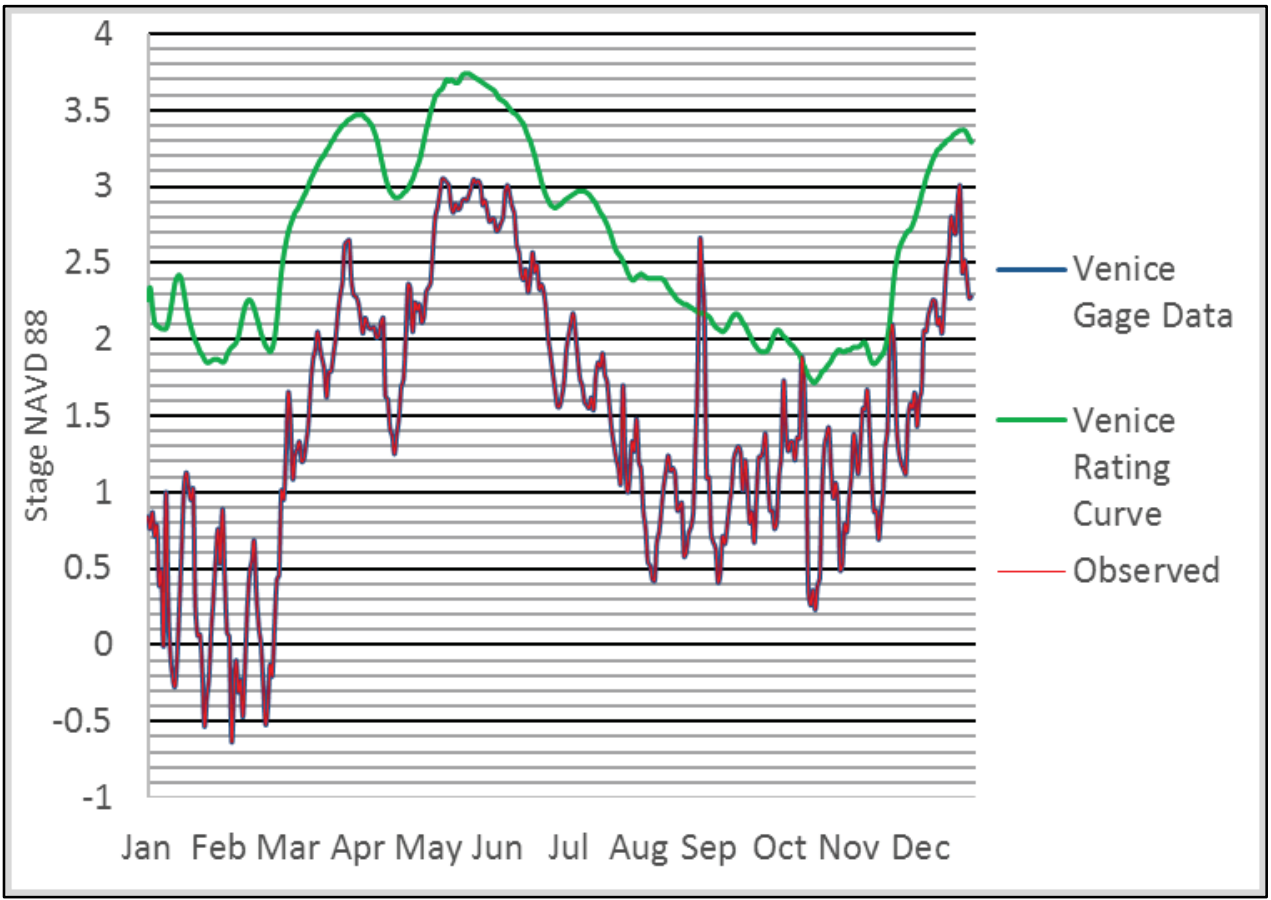

Figure 153. 2011 Empire stage comparisons with actual gage data vs. rating curve used for Venice boundary.

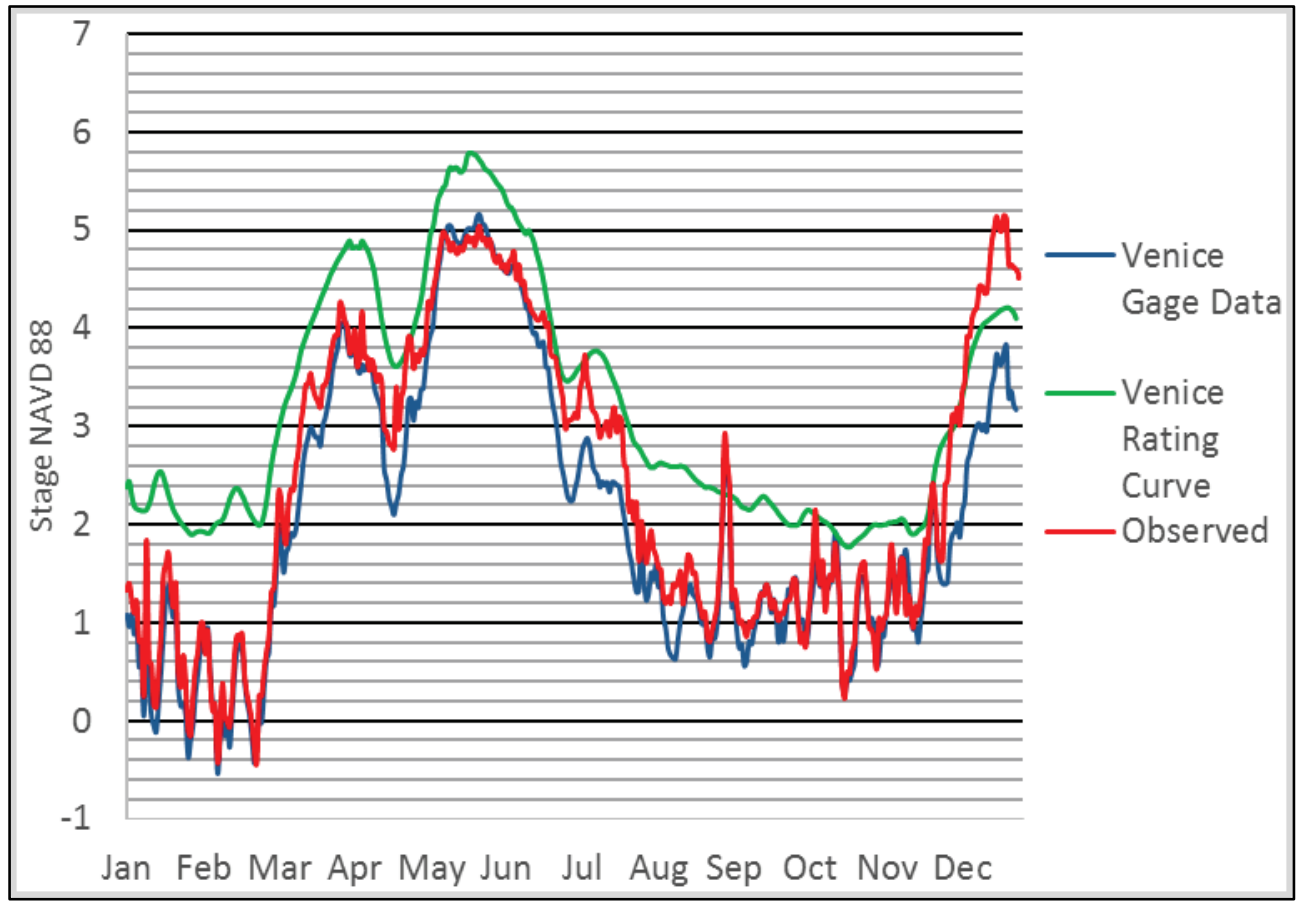


Figure 154. 2011 Carrollton stage comparisons with actual gage data vs. rating curve used for Venice boundary.

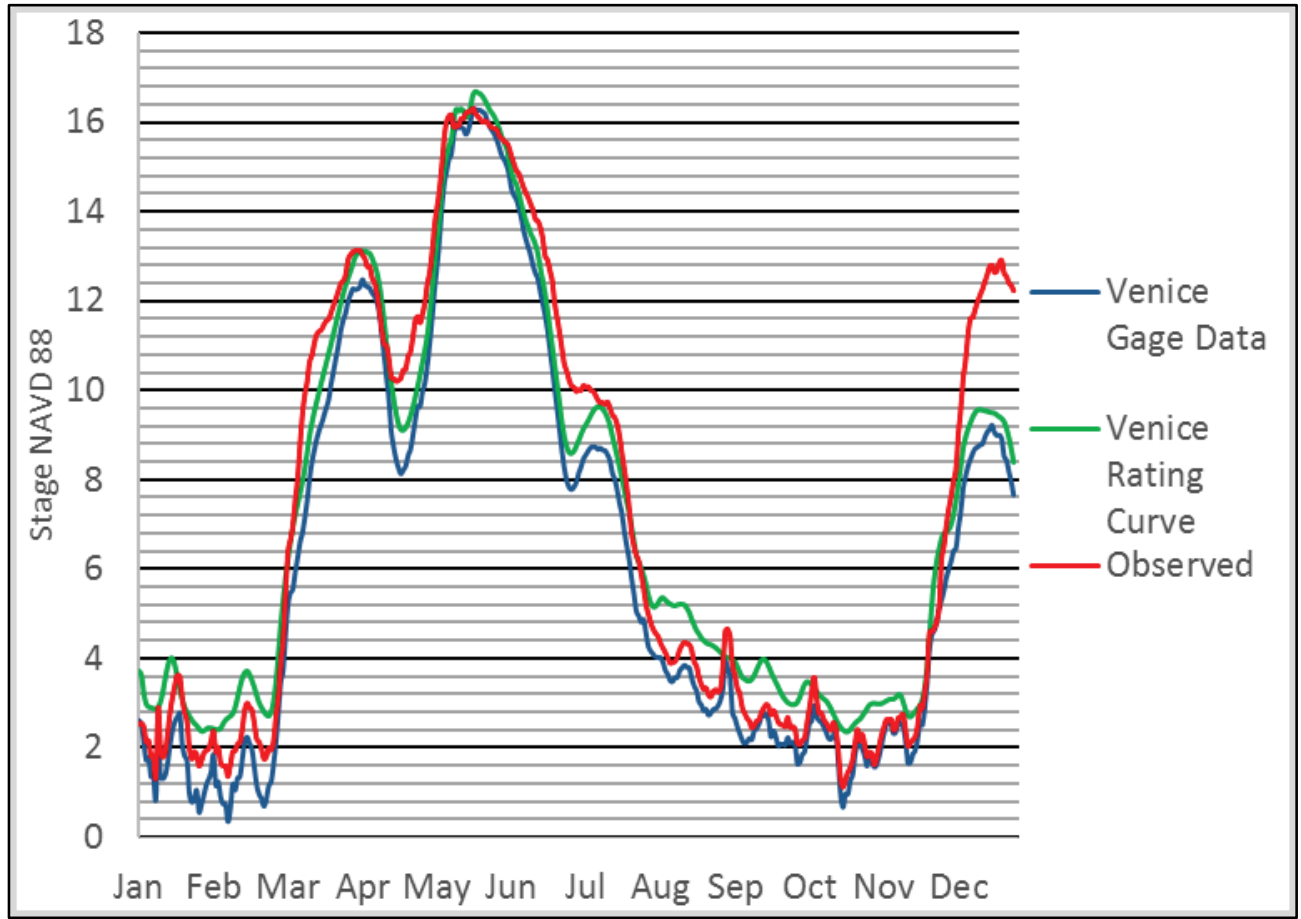

Figure 155. 2011 Baton Rouge stage comparisons with actual gage data vs. rating curve used for Venice boundary.

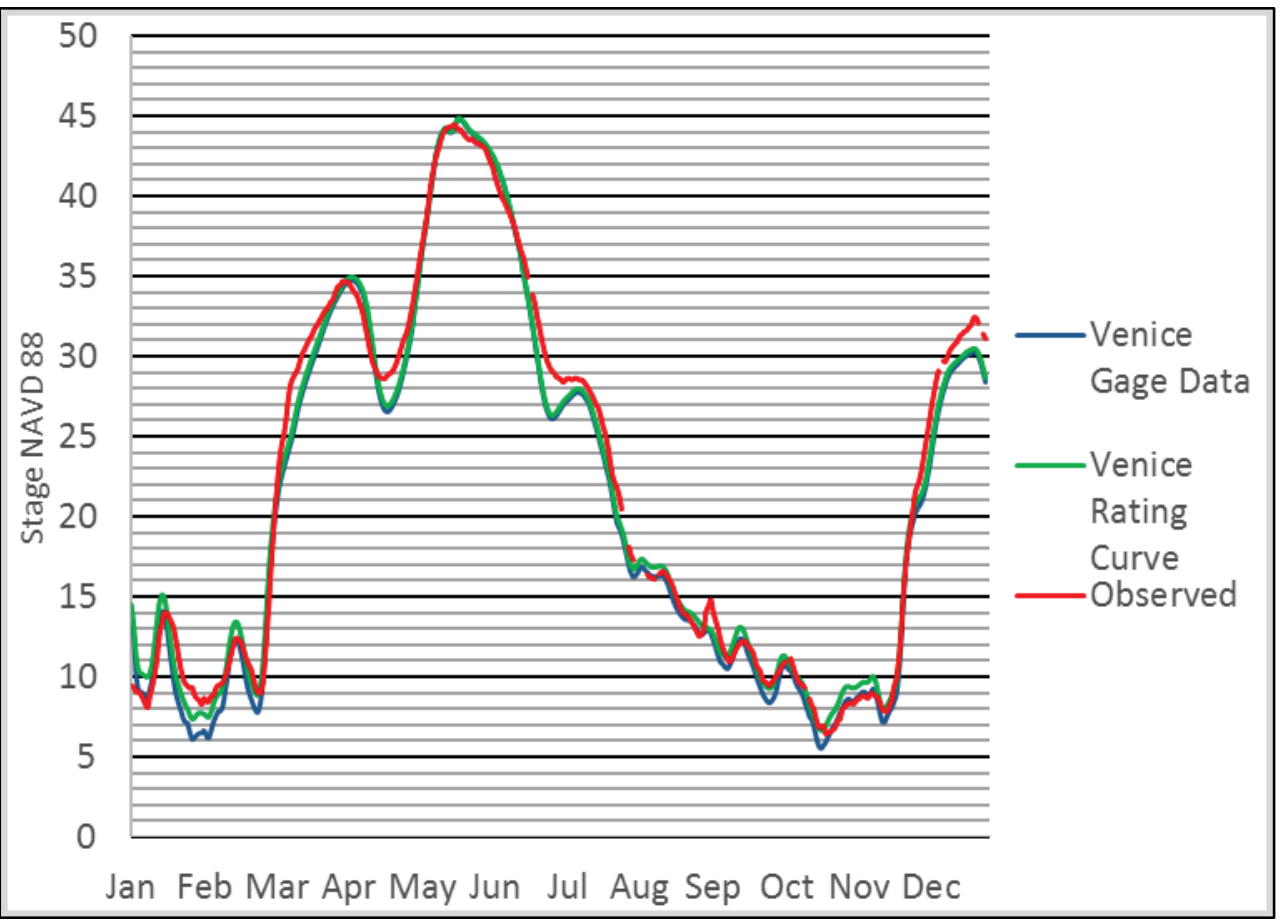


Figure 156. 2008 Venice stage comparisons with actual gage data vs. rating curve used for Venice boundary.

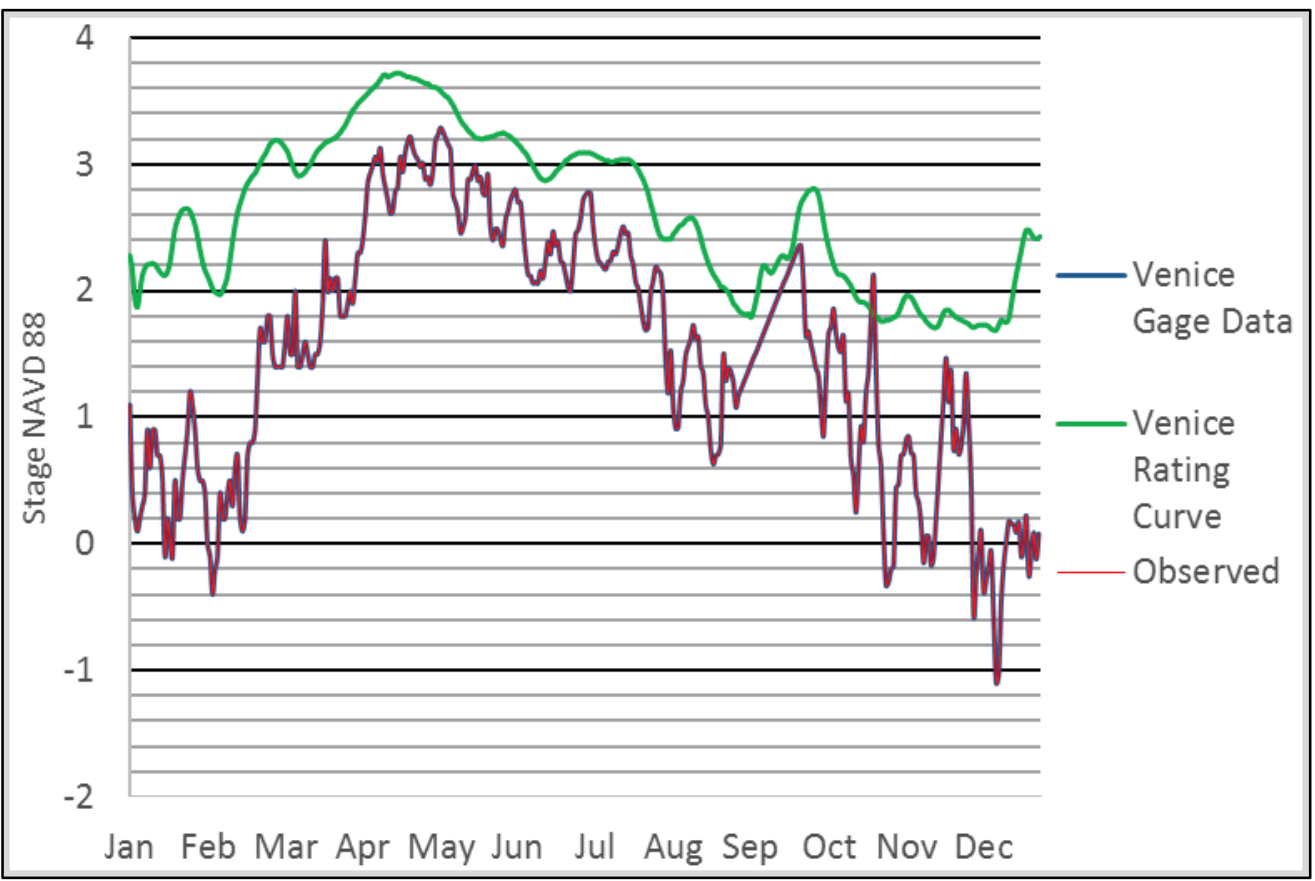

Figure 157. 2008 Carrollton stage comparisons with actual gage data vs. rating curve used for Venice boundary.

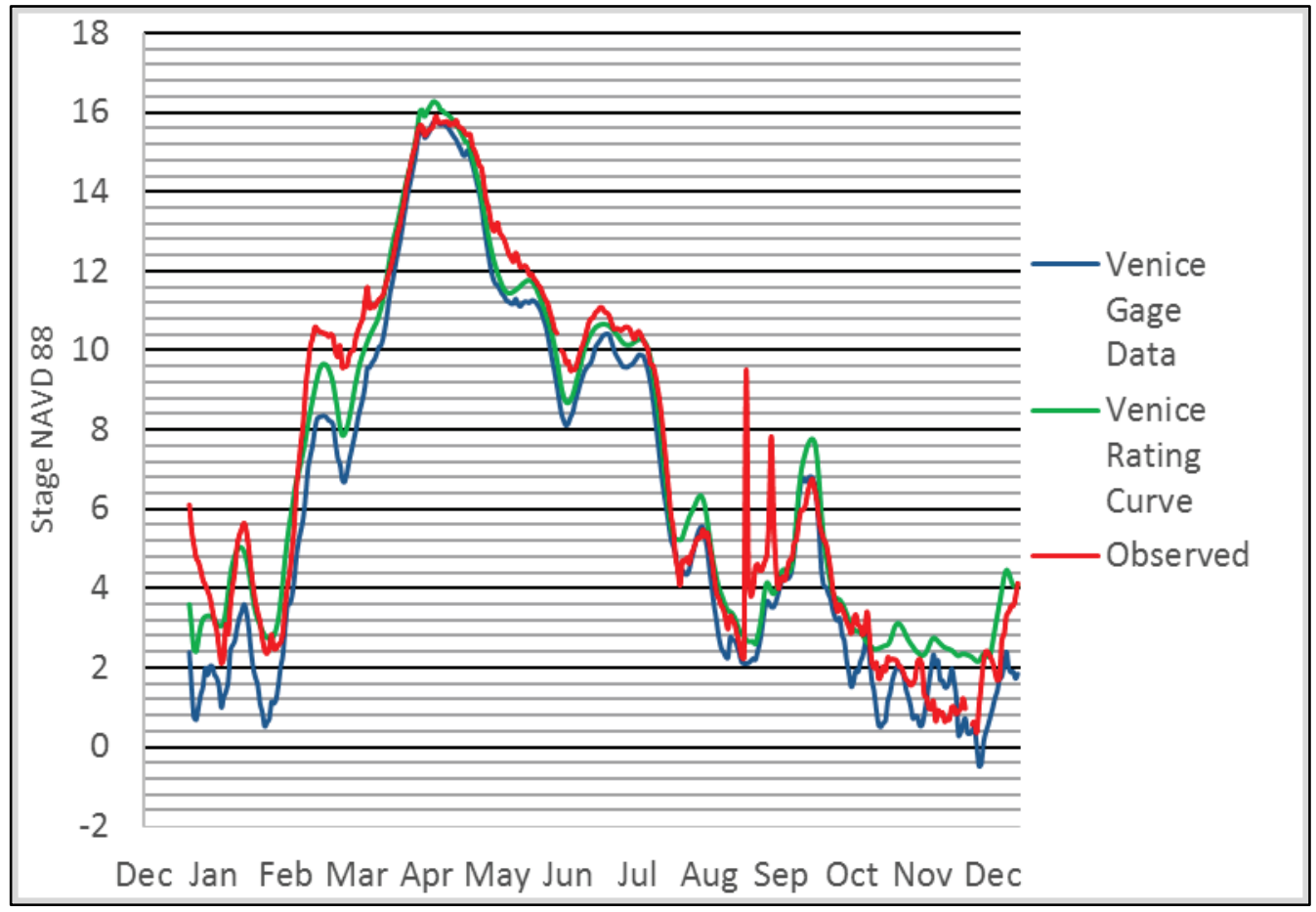


Figure 158. 2008 Baton Rouge stage comparisons with actual gage data vs. rating curve used for Venice boundary.

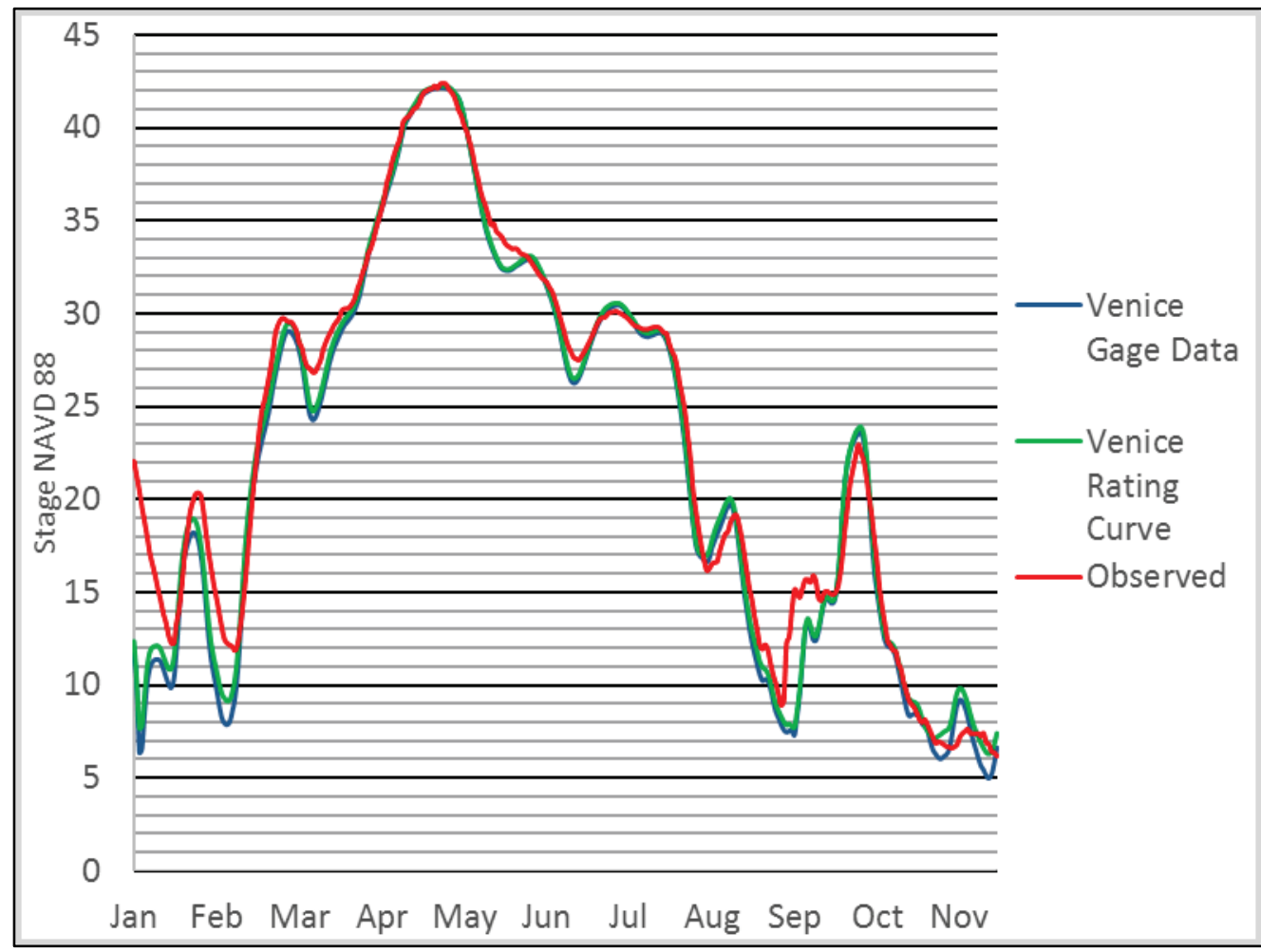

Figure 159. 2002 Venice stage comparisons with actual gage data vs. rating curve used for Venice boundary.

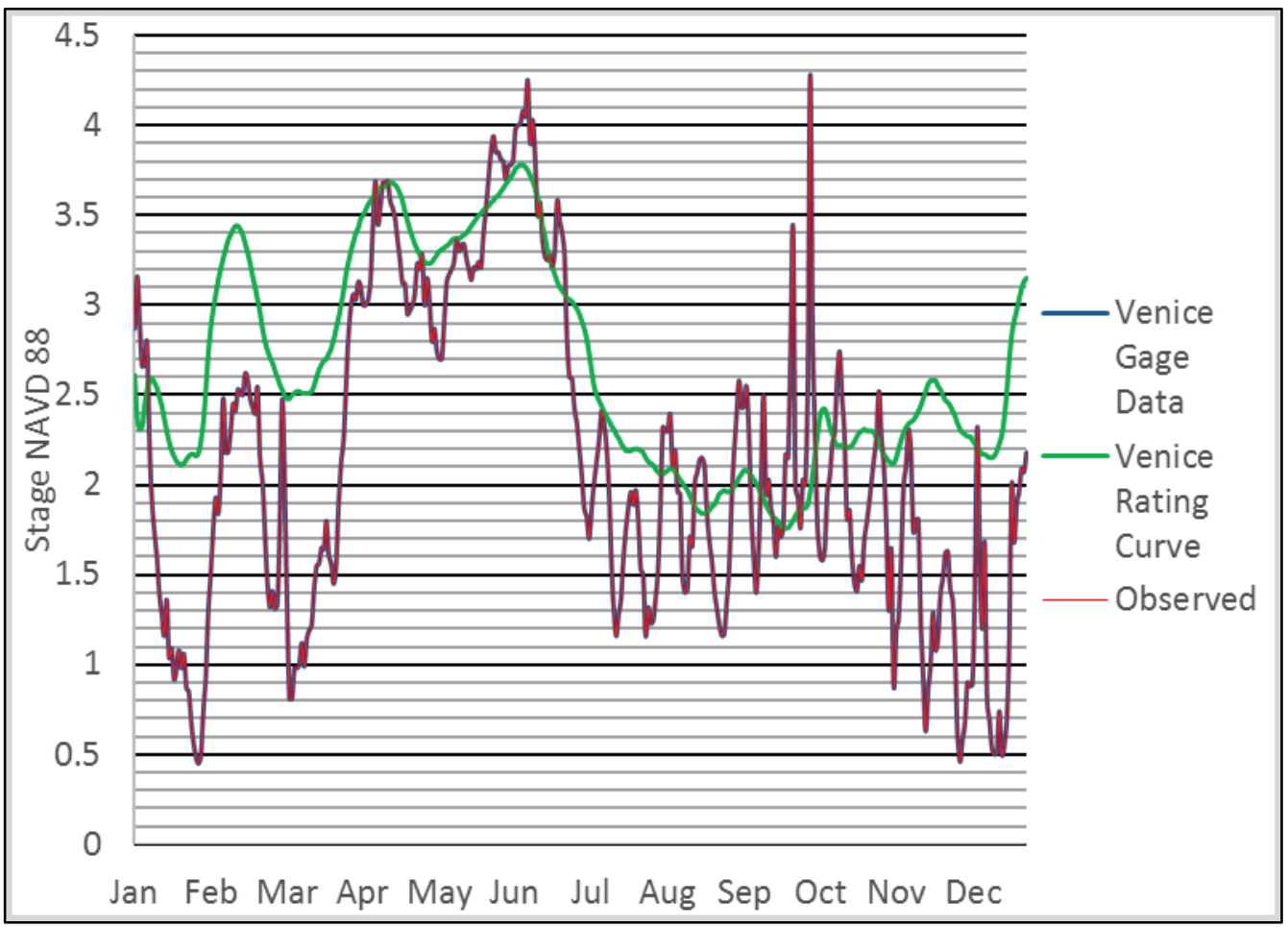




\section{C.6 Future sea level rise adjustments}

To adjust the model boundaries to simulate PDF events considering future conditions, adjustments were made to the rating curve used as the downstream boundary at Venice, LA. Since Venice is 10.5 river miles AHP, an analysis was performed to check the relationship in stages between Venice and the Gulf of Mexico to determine what percentage of sea level rise in the Gulf of Mexico should be applied to Venice. A stage-stage correlation was used to assess this relationship.

The Southwest Pass at East Jetty (01670) gage was used to represent stages in the Gulf of Mexico near the mouth of the Mississippi River. A stage-discharge plot was created to assess whether this gage is influenced by river discharge (Figure 160). The results show that while there appears to be some influence, approximately $5 \%$ of the variance in stage can be attributed to Mississippi River discharge while an increase in discharge of 1 million cfs would be expected to raise stages by only $1.5 \mathrm{ft}$. For an analysis restricted to high flow conditions, this was deemed to be an effectively insignificant influence.

Figure 160. Influence of Mississippi River discharge on stage at Southwest Pass.

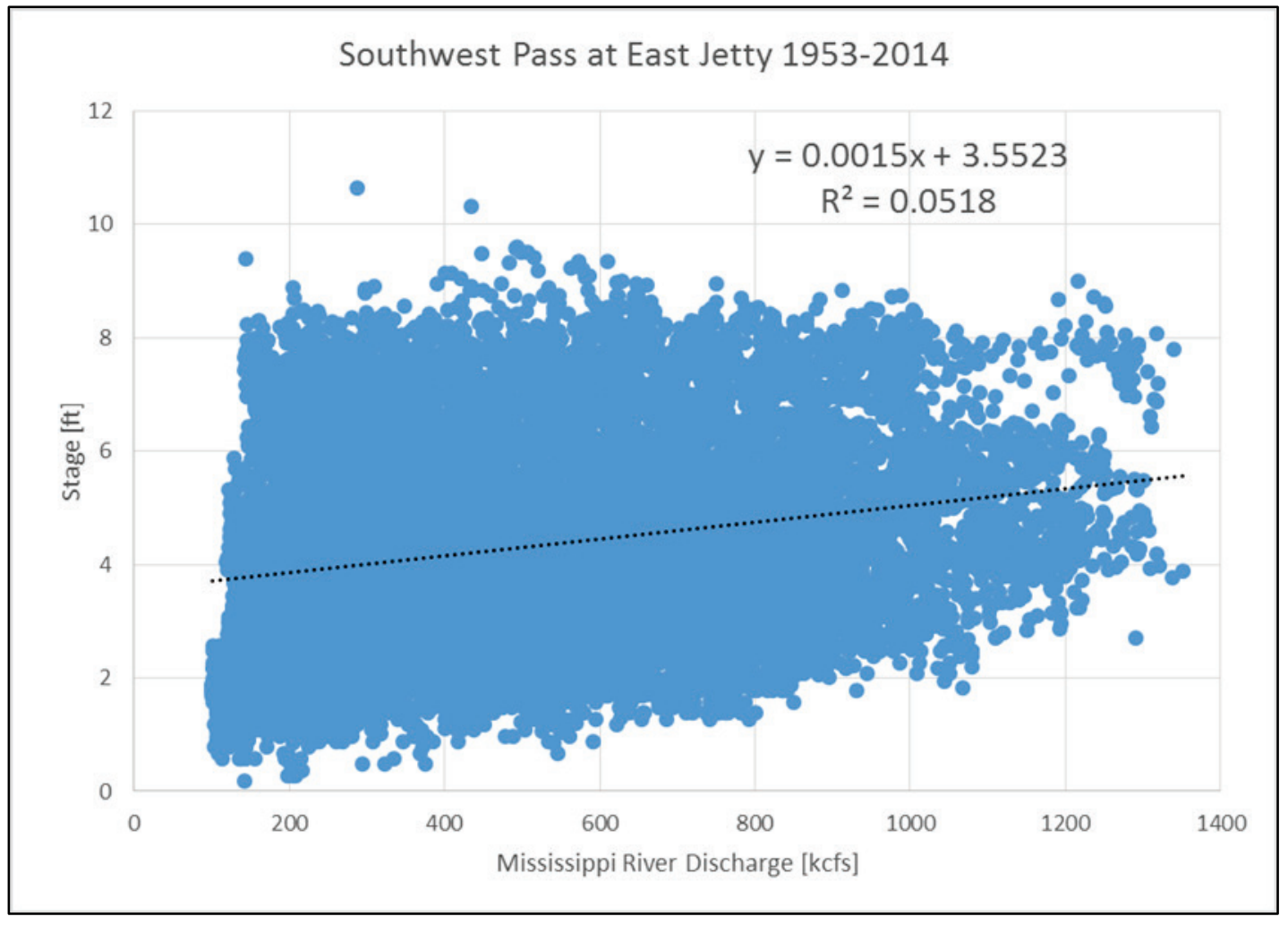


The stage correlation between Southwest Pass and Venice was restricted to the time period between 1954 (when daily data records began for both gages) and June of 2015, when the gages were shifted to NAVD88 datum. Additionally, the analysis was restricted to times when the Mississippi River discharge (measured at Tarbert Landing) was above 1.25 million cfs, which corresponds roughly to the conditions that create PDF conditions below the Bonnet Carré Spillway. The analysis was performed using raw stage data from each gage, which includes the effects of gage shifts that were formerly performed in an attempt to counteract the effects of subsidence (this practice has since been discontinued). These shifts were not necessarily performed simultaneously at each gage, so another analysis was performed in which the gage shifts were removed to create a continuous record in a consistent datum. This approach has the advantage of consistency in the reference plane but includes historical relative sea level rise at the two gages, which are not equal in rate.

The results of both analyses are shown in Figure 161 and indicate that for every increment of stage change at Southwest Pass, stages at Venice change by $43 \%-51 \%$ of that increment (during periods of high river flow).

Figure 161. Venice stage vs. Southwest Pass stage during high river flow conditions.

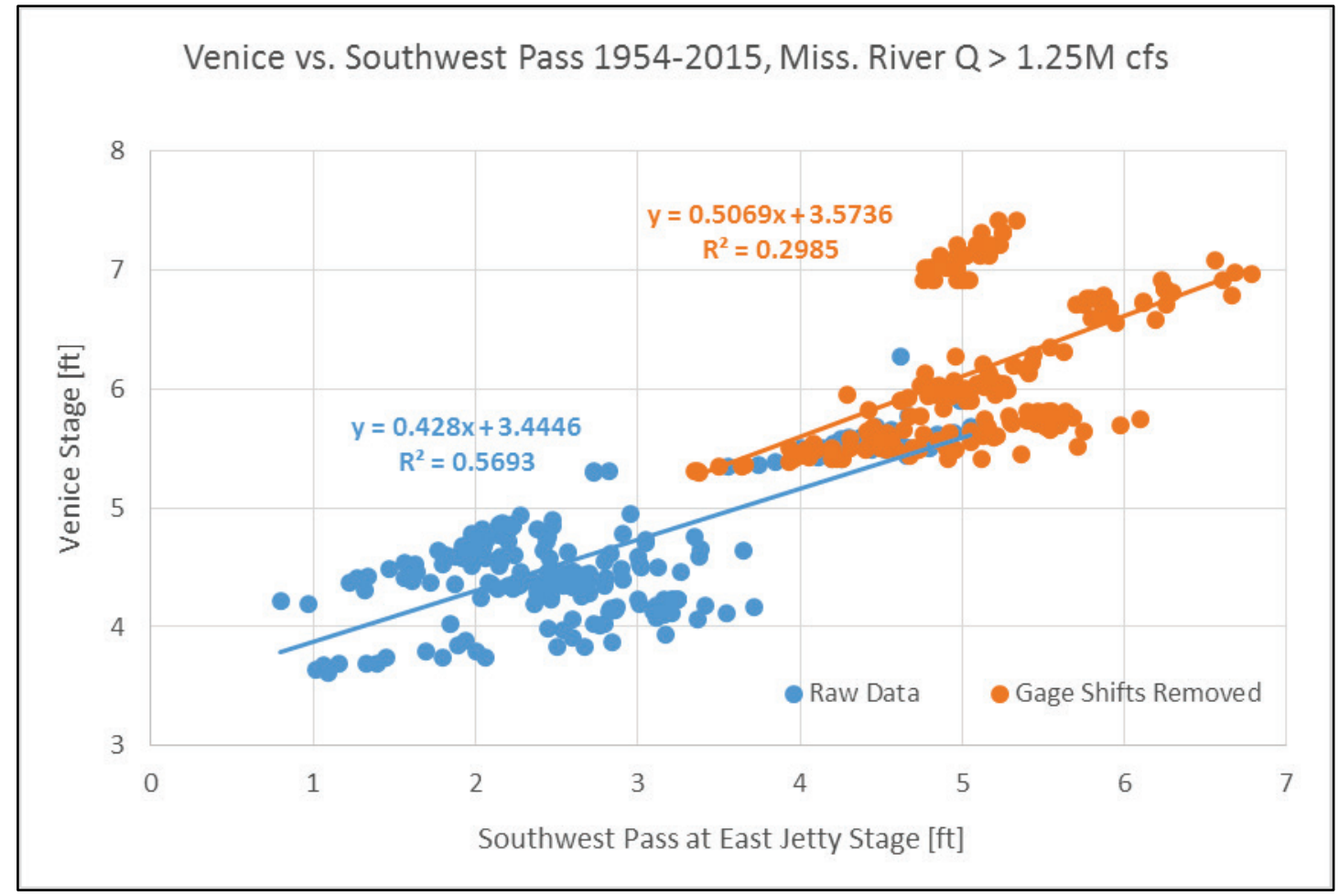


These results show that in general, Venice responds to tidal effects approximately $45 \%$ of what occurs in the Gulf of Mexico. This percentage is even lower with higher Mississippi River flows. These conclusions were used in making adjustments to the Venice rating curve for future conditions.

\section{C.7 Conclusions}

The MVN reach of the unsteady HEC-RAS model calculates peak stages within an acceptable threshold. Higher residuals in the calibration are mainly concentrated amongst the lower flows and the less recent floods. It is suspected that geomorphological changes are most responsible for the large residuals for the 2002 year. The largest sources of uncertainty are the boundary condition flows at Tarbert Landing and the amount of flow leaving the river through miscellaneous diversions and other miscellaneous outlets. However, the model can satisfactorily calculate water surface elevations for large events. 


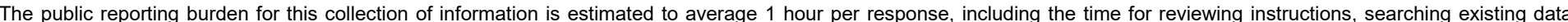

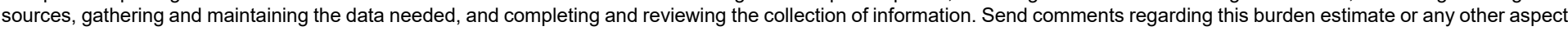

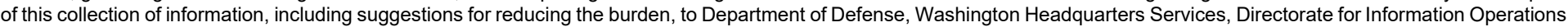

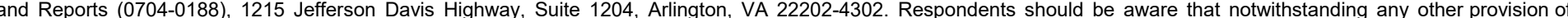
law, no person shall be subject to any penalty for failing to comply with a collection of information if it does not display a currently valid OMB control number.

PLEASE DO NOT RETURN YOUR FORM TO THE ABOVE ADDRESS.

\begin{tabular}{|l|l|l|l} 
1. REPORT DATE & 2. REPORT TYPE & 3. DATES COVERED (FrOm - TO)
\end{tabular}

December 2018

Final Report

\section{TITLE AND SUBTITLE}

5a. CONTRACT NUMBER

Mississippi River and Tributaries Flowline Assessment Hydraulics Report

5b. GRANT NUMBER

5c. PROGRAM ELEMENT NUMBER

5d. PROJECT NUMBER

6. AUTHOR(S)

449963

Taylor, David A. Ramirez, Matthew S. Dircksen, Robert Gambill

5e. TASK NUMBER

5f. WORK UNIT NUMBER

7. PERFORMING ORGANIZATION NAME(S) AND ADDRESS(ES) (see reverse)

8. PERFORMING ORGANIZATION REPORT NUMBER

MRG\&P Report No. 24; Volume 3

10. SPONSOR/MONITOR'S ACRONYM(S)

USACE MVD

11. SPONSOR/MONITOR'S REPORT NUMBER(S)

\section{DISTRIBUTION/AVAILABILITY STATEMENT}

Approved for public release; distribution is unlimited.

\section{SUPPLEMENTARY NOTES}

\section{ABSTRACT}

This report documents the development of the model for the Mississippi River and Tributaries Flowline Assessment using the Hydrologic Engineering Center - River Analysis System model (unsteady, version 5.0.1) completed by the U.S. Army Engineer District, Memphis; the U.S. Army Engineer District, Vicksburg; the U.S. Army Engineer District, New Orleans; and the U.S. Army Engineer Research and Development Center, Vicksburg, MS. The 2011 Mississippi River flood was chosen as the primary event for calibration, and the model performance was checked for 2002 and 2008, two other recent high-flow events. The model from this effort was used for two simulations of historic project design flows (PDFs), here labeled "Historic PDF - Existing Yazoo" and "Historic PDF - Authorized Yazoo." The combined model was also used for 10 new hypothetical project design flows. Additionally, the model was used for one alternative scenario, labeled "Concept Plan." Future sea level rise was also implemented with the Concept Plan and the New Hypo 58A-R PDF simulations.

\section{SUBJECT TERMS}

Flood control-Mississippi River, Hydraulic models, Hydrologic models, Mississippi River Watershed, Water levels

16. SECURITY CLASSIFICATION OF:

\begin{tabular}{|l|l|l|l|}
\hline a. REPORT & b. ABSTRACT & c. THIS PAGE & ABSTRACT \\
Unclassified & Unclassified & Unclassified & SAR \\
& & & \\
\end{tabular}

18. NUMBER OF PAGES

238 19a. NAME OF RESPONSIBLE PERSON

James Lewis

19b. TELEPHONE NUMBER (Include area code) 601-634-3895 
7. PERFORMING ORGANIZATION NAME(S) AND ADDRESS(ES) (continued)

Coastal and Hydraulics Laboratory

U.S. Army Engineer Research and Development Center 3909 Halls Ferry Road

Vicksburg, MS 39180-6199

U.S. Army Engineer District, Little Rock

700 West Capitol Avenue

Little Rock, AR 72201-3221

U.S. Army Engineer District, Vicksburg

4155 Clay Street

Vicksburg, MS 39183

U.S. Army Engineer District, New Orleans

7400 Leake Avenue

New Orleans, LA 70118

U.S. Army Engineer District, Memphis

167 North Main Street

Memphis, TN 38103-1894 